


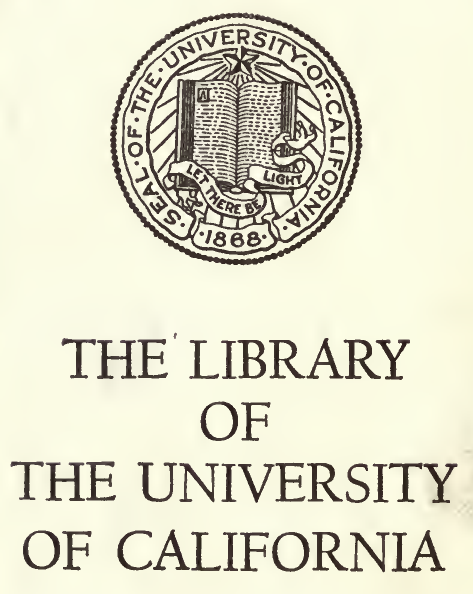

PRESENTED BY

PROF. CHARLES A. KOFOID AND MRS. PRUDENCE W. KOFOID 


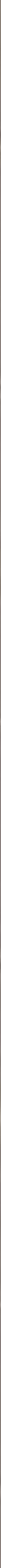


114 




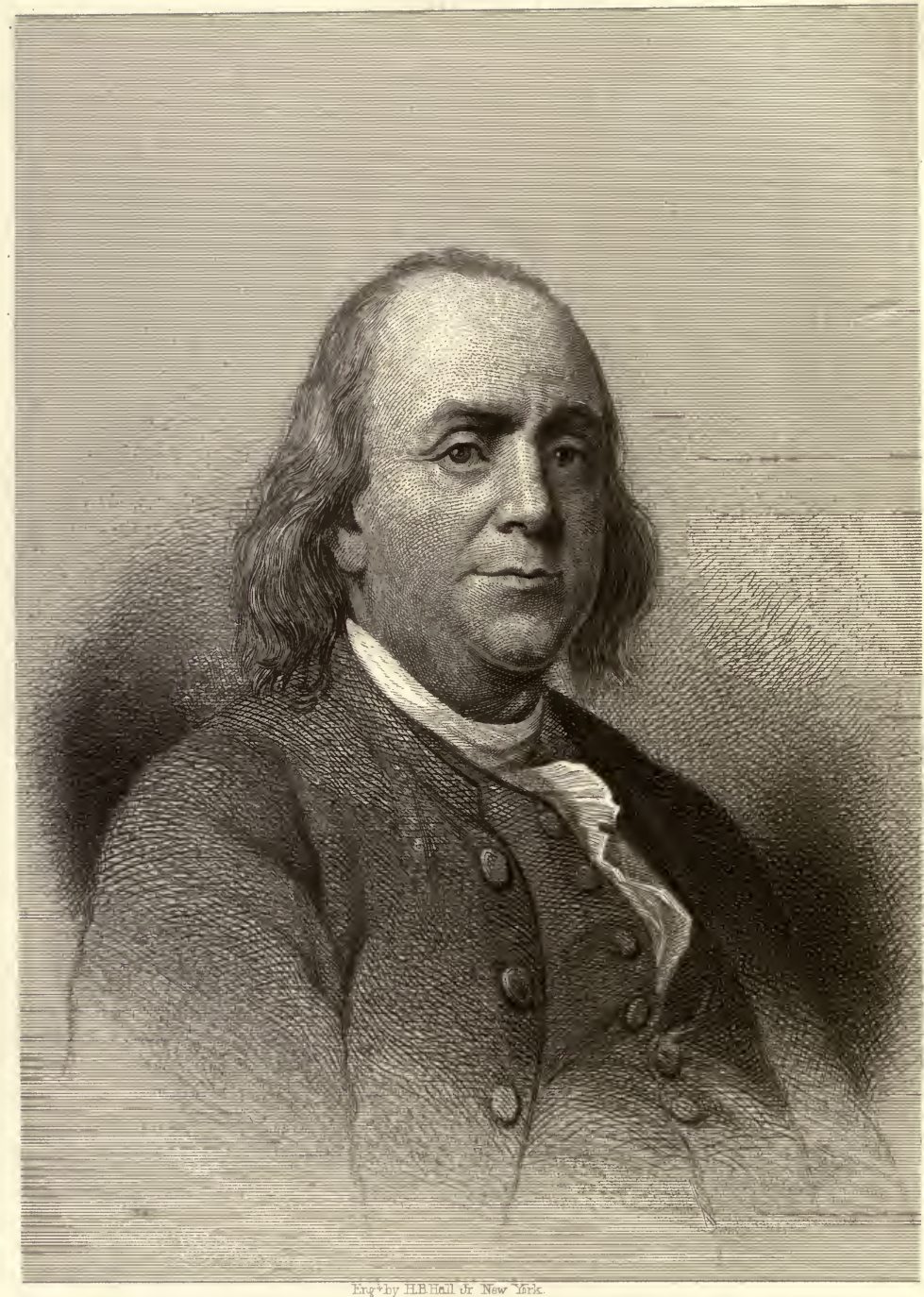

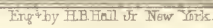

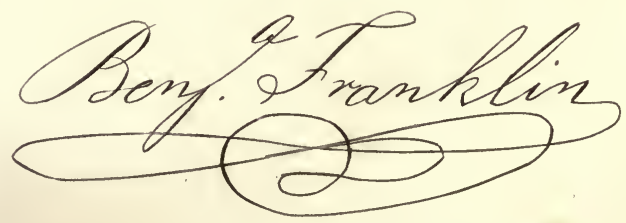




\title{
PIONEERS OF
}

\section{SCIENCE IN AMERICA}

Fketches of their $\mathfrak{L i n e s}$ and Icientific Volork

\author{
REPRINTED WITH ADDITIONS \\ FROM THE POPULAR SCIENCE MONTHLY
}

\author{
EDITED AND REVISED BY \\ WILLIAM JAY YOUMANS, M. D.
}

WITH PORTRAITS

NEW YORK

D. APPLETON AND COMPANY

$1896 \checkmark$ 
Copyright, 1896 , By D. APPLETON AND COMPANY. 


\section{Q/4 167}

\section{P R E F A C E.}

THE development of science during the last hundred years, with its multiplied and ever-increasing contributions to the welfare of man, is justly looked upon as the beginning of one of the most marvellous periods of progress in the history of the race. Though we are still in the early stages of this advance, its effects are already abundantly apparent. It has revolutionized the industries of the civilized world, has given us new and more intimate commercial relations, has swept away traditional educational standards, and by its stimulating influence is redirecting and extending the movement of human thought.

In this country the men who took a prominent part in the initiation of these wonderful changes were comparatively few, while the disadvantages they had to contend with were many and serious. Scattered over a large extent of undeveloped territory, unable to secure the benefits of co-operation, poor in pocket, and generally lacking the sympathy when they did not meet the active opposition of their fellow-men, the work they did as teachers and original investigators forms one of the most creditable chapters of our early history, and unquestionably paved the way for those later scientific achievements of which as a nation we may well be proud. Surely the careers of these men are quite as worthy the contemplation of both young and old as are the doings of heroes of carnage and political strife.

The purpose of the present volume is to point out, though without any pretensions to completeness, the character and scope of the work of these interesting scientific worthies, and to give the reader, briefly in each instance, such accounts of the men as will enable him to appreciate something of their personal characteristics, and to know and admire their en- 
thusiastic love of Nature, which carried them over every obstacle in the pursuit of their chosen study.

Nearly all of the biographies appeared originally in the Popular Science Monthly, in which magazine such accounts have long been considered by many of its readers one of its most interesting features. The accompanying portraits, as will be seen, are in every instance well authenticated. In collecting the materials for the Monthly no effort was spared to reach the most trustworthy sources of information. Surviving relatives when accessible, the records of educational institutions, public documents, and published biographies in the few cases where these existed, were freely consulted, especial care being taken to verify names, dates, and other important facts. The accuracy thus secured in the first instance has been made more perfect by a thorough revision of the matter for this volume.

The number of biographies included in the book is limited to fifty. Of course it is not claimed that these comprise all the names in American science that are entitled to a like distinction; but beginning with the time of Franklin, prior to which we have found no record of the systematic pursuit of science by any one in this country, the plan has been to present the various personages in the order of their birth, making the list as complete as possible as far as it went. This brings it down to about the year I810, the working period of many of those included thus falling within the present century. Should the book be found of sufficient interest to warrant the venture, a second volume on a similar plan may follow.

I am indebted to Mr. W. H. Larrabee for the preparation of the sketch which opens the volume. This involved a long and painstaking search through a very considerable literature, and so far as I know it is the first systematic account of what Franklin did in science that has appeared. My acknowledgments are also due to Mr. F. A. Fernald for valuable aid in the work of revision and in seeing the book through the press.

W. J. Y.

New YoRk, January 12, 1896. 


\section{CONTENTS.}

\section{Benjamin Franklin}

Portrait after the picture in pastel by Joseph S. Duplessis, I783.

\section{John AND William BARTRAM}

Portrait of William Bartram after an engraving in The Cabinet of

Natural History and American Rural Sports, Philadelphia, 1832.

John Winthrop

Portrait after a painting by Copley belonging to his family.

DAvid RitTenhouse

Portrait after a painting by C. W. Peale.

Gotthilf Heinrich ERnst Muhlenberg . . . . . 58

Portrait after a painting belonging to his family.

Samuel Latham Mitchill . . . . . . . . . $7 \mathbf{I}$

Portrait after an engraving loaned by Dr. Henry Carrington Bolton, a kinsman.

BenJamin SMith BARTon

Portrait after an engraving in the Biography of him by W. P. C. Barton.

Alexander Wilson .

Portrait after a steel engraving by W. J. Alais in Wilson's Poems and Literary Prose.

David Hosack .

Portrait after a painting belonging to Columbia College.

Amos Eaton

Portrait after a steel engraving by A. H. Ritchie.

Gerard Troost

Portrait after a painting in the Hall of the Academy of Natural Sciences of Philadelphia.

Charles Alexandre Lesueur 
John James Audubon

Portrait after a painting by George P. A. Healy, belonging to the Boston Society of Natural History.

Lewis David von Schweinitz

Portrait after a miniature belonging to his family.

ROBERT HARE .

Portrait after a painting belonging to Mr. Frederick Prime.

Constantine Samuel Rafinesque.

Portrait after an engraving in his Analyse de la Nature.

James Pollard Espy

Portrait after a painting in the Smithsonian Institution.

\section{Thomas NutTall}

Portrait after a daguerreotype formerly belonging to Dr. Asa Gray.

Thomas SAY

Portrait after a lithograph in the Hall of the Academy of Sciences of Philadelphia.

William Cranch Bond.

Portrait after an engraving in the Annals of Harvard College Observatory, Volume VII.

Samuel Finley Breese Morse

Portrait from a photograph.

Denison Olmsted

Portrait after a steel engraving by A. H. Ritchie in the New Englander for August, 1859.

ISAAC LEA.

Portrait after an etching by S. J. Ferris.

LARDNER VANUXEM .

Portrait from a photograph loaned by his daughter.

Elisha Mitchell • • • • • • • • • • 279

Portrait after an engraving loaned by Dr. Henry Carrington Bolton, a kinsman.

EDWARD HitchCock

Portrait from a photograph furnished by his son.

HENRY Rowe ScHoolcraft

Portrait after an engraving loaned by Gen. James Grant Wilson.

Samuel Luther Dana . . . . • • • • • . 3II

Portrait from an albertype in a memorial pamphlet on the Dana family.

ZADOC THOMPSON

Portrait from a photograph procured by Prof. G. H. Perkins, of the University of Vermont.

Portrait after a painting belonging to Columbia College.

George Catlin

Portrait after a miniature by Watkins, of London. 
PAGE

Ebenezer Emmons . . . . . . . . . . . . 347

Portrait from a photograph loaned by his son.

JOSEPH HENRY • • • • • . . . . . . . 354

Portrait from a photograph.

James Blythe Rogers • • • • • • • • • 368

Portrait from a photograph loaned by his daughter-in-law.

JoHn ERICSSON .

Portrait from a photograph by M. B. Brady, Washington.

Timothy Aвbott Conrad • • . . . . . . . 385

Portrait from a photograph made by his nephew, Dr. Charles Conrad Abbott.

William Starling Sullivant

Portrait after an ambrotype.

William Williams Mather . . . . . . . . . 402

Portrait from a photograph furnished by his son.

\section{William BARTon Rogers}

Portrait made under the direction of Mrs. Rogers.

Charies Upham Shepard . . . . . . . . . . 4 49

Portrait from a photograph furnished by his son.

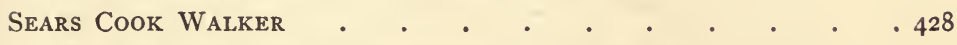

Portrait from a photograph furnished by his brother.

Alexander Dallas Bache . . . . . . . . . 436

Portrait from a photograph by F. Gutekunst, Philaḑelphia.

JAMES HENRy COFFin

Portrait from a photograph by F. Gutekunst, Philadelphia.

Leo LesquereuX . • . . . . . . . . . 458

Portrait from a photograph by Baker, Columbus, O.

Matthew Fontaine Maury . . . . . . . . . 464

Portrait after a photograph taken in $187 \mathrm{I}$ by Miley \& Co., Lexington, Va.

Jean Louis Rodolphe Agassiz . . . . . . . . . 475

Portrait after a steel engraving by C. H. Jeens in Volume II of the Life and Correspondence of Agassiz.

Arnold Henry Guyot . . . . . . . . . 492

Portrait from a photograph by Pach Bros., New York and Princeton.

David Dale Owen . . . . . . . . . . . . 500

Portrait from a photograph loaned by his son. 
ILLUSTRATIONS IN THE TEXT.

FIG.

I. Bartram's House in 1887

2. Cypress Tree in Bartram Park

3. Nether Stone of John Bartram's Cider Mill .

4. The Dana House. First Observatory of Harvard College

5. Prof. Morse's First Telegraph Instrument 


\section{PIONEERS OF SCIENCE IN AMERICA.}

\section{BENJAMIN FRANKLIN.}

$$
\text { I 706-I 791. }
$$

No man in the eighteenth century gained a wider fame, or one which has been less modified by the hundred years that have intervened, than Benjamin Franklin. We might be led to believe at first thought that the extraordinary repute into which he rose was relative, and that the world's appreciation of him, and particularly the feeling of his own countrymen, was exaggerated by the surprise that the colonies, then so young and primitive, should have produced so able and versatile a man. But this would be an incorrect view. Franklin's fame was a tribute to his real eminence. The more his life and achievements are studied the more clearly does it appear that Franklin's greatness was of the whole world and would have been as prominent in any age; and that in any group of leaders of progress, from whatever time or nation they might be selected, he would find his place near the head.

Franklin's history is so universally familiar that more than a mere reference in this sketch to such of the personal and political events of his life as constitute the staple of most of the biographies of him would be superfluous. Giving the briefest summary of the principal dates, our account will be devoted to that part of his work which contributed to the advancement of science.

Benjamin Franklin was born in Boston, January I 7, I706, "the youngest son of the youngest son for five generations," the fifteenth child of his father and the eighth of his mother, who was a second wife, out of a family of seventeen. His father was a Nonconformist emigrant from England, out of an 
honourable family of the working class, "a man of strength and prudence of character." His mother was the daughter of Peter Folger, author of a volume of poems, A Looking Glass for the Times, asserting liberty of conscience.

Franklin's earlier years were spent in the soap and candle factory of his father till the age of twelve, when he became an apprentice in the printing office of his brother James, and began to cultivate his literary tastes and write for publication. On account of disagreements with his brother he stole away from Boston and went to Philadelphia in 1723 , and there met that curious series of adventures the story of which has been, and continues to be, so entertaining to American youth. Here, too, his active life, so far as it directly affected the world, began.

Franklin tells us in his autobiography that his father took great pains to train his children to habits of honesty and industry. One of the earliest lessons he taught the boy-it was in the affair of appropriating the building stones to make a fishing wharf-was, when he pleaded the usefulness of the work, to convince him that nothing was useful which was not honest. This father "was skilled a little in music," both with the voice and on the violin, had a mechanical genius, and was handy on occasion in the use of other trades than his own; "but his great excellence lay in a sound understanding and solid judgment in prudential matters, both in private and public affairs"; and he was frequently visited for consultation in matters of both kinds. "At the table he liked to have, as often as he could, some sensible friend or neighbour to converse with, and always took care to start some ingenious or useful topic for discourse, which might tend to improve the minds of his children. By this means he turned our attention to what was good, just, and prudent in the conduct of life." The father had intended to devote the boy, "as the tithe of his sons," to the service of the Church, and was encouraged in this design by his early readiness in learning to read, and the opinion of his friends, who discerned signs of scholarly promise in him; but, in view of the expense of a college education, "and the mean living many so educated were afterward able to obtain," changed his first intention and took him from the grammar school, where he had been preparing, and sent him to a school for writing and arithmetic. Franklin "acquired fair 
writing pretty well," but failed in arithmetic. Then he was placed in the chandler's shop, and gained the rest of his education there, in the printing office, and in practical life.

Having developed a strong taste for reading, Franklin eagerly devoured such books as came within his reach. $\mathrm{He}$ adopted a vegetable diet and applied the money he saved thereby to the purchase of books, while he devoted the time he could gain from his meals to reading. His collection of books was a miscellaneous one, but it included some works, like The Spectator and others of its kind, that were remarkable for the graces of their style, and some that were quickening to thought. Perceiving the defects in his own style as a writer, he undertook to cultivate it systematically.

The printer Keimer, Franklin's employer in Philadelphia, loved argument and engaged in many disputations with his journeyman. Franklin practised himself in the Socratic method of discussion, and had much amusement, with great advantage to himself in self-discipline, in drawing the old printer unawares into quandaries by leading questions, begetting difficulties and contradictions, till he became accustomed, before answering even common questions, to ask, "What do you intend to infer from that ?"

On his return from a visit to England in 1726, Franklin formed a club or debating society among his friends, called the Junto, and drew up its rules. Every member of this association was required in turn to produce one or more queries on some point of morals, politics, or natural philosophy for discussion by the company; and once in three months to read an essay of his own writing, on any subject he might select. The debates were expected to be conducted in the sincere spirit of inquiry after truth, without fondness for dispute, desire of victory, expression of positiveness in opinion, or direct contradiction. Applicants for admission to this society were asked a list of questions intended to determine that they were catholic in spirit or free from bigotry or strong prepossession, culminating in the interrogatory, "Do you love truth for truth's sake, and will you endeavour impartially to find and receive it yourself, and communicate it to others?"

A selection from the questions discussed in the Junto was made by Dr. William Smith from a record which came into his possession at the time the American Philosophical Society was instituted. They indicate a desire for the real increase of 
knowledge among the members that may very well have borne fruit later in the formation of the larger and more learned body, of which the Junto was the forerunner, if not the direct parent. Certain of these questions pertain to the nature of sound-is it an entity or a body? to the origin of vapours; the extent of the domain of self-interest; the best form of government and the first; whether one form of government can suit all mankind; the reason for the tides being higher in the Bay of Fundy than in the Delaware; the safety of paper money; knowledge of happiness; the utilization of the lakes; the cause of smoky chimneys; why candle flames are spiral; and subjects relating to metaphysics and human nature.

Franklin's plan for the members of the Junto to bring their books together and form a library for common consultation did not work well in practice, and was given up after the end of the first year; but the idea of the collection kept a-working in Franklin's mind, and he started a subscription for a public library. The institution was chartered and became, Franklin says, "the mother of all the North American subscription libraries . . . a great thing itself, and continually increasing." * Of its immediate results, Franklin relates that it "soon manifested its utility, was imitated by other towns and in other provinces. The libraries were augmented by donations; reading became fashionable; and our people, having no public amusements to divert their attention from study, became better acquainted with books, and in a few years were observed by strangers to be better instructed and more intelligent than people of the same rank generally are in other countries." To Franklin the library afforded the means of improvement by constant study, for which he set apart an hour or two each day, and thus, he says, supplied in some degree the lack of the learned education which his father had once intended for him.

The inscribed tablet on the front of the building of the library bears record that it was instituted at the instance of Benjamin Franklin. Thomas Penn, presenting the library with an air pump in 1738 , accredited the Library Company with being "the first that encouraged knowledge and learning in the Province of Pennsylvania." "The praise is not ill deserved," says Duyckinck, as at the time of the foundation of the library

* The Philadelphia Library, on Fifth Street, facing the State House Square. 
"there was not even a good bookstore accessible nearer than Boston."

In the scheme for the formation of the American Philosophical Society, which was drawn up in 1743 and brought forward in that or the following year, Franklin observed that the hardest drudgery of the early settlement of the colonies having been performed, there were many persons in every province in circumstances that set them at ease and afforded them leisure to cultivate the fine arts and improve the common stock of knowledge. "To such of those who are men' of speculation many hints must from time to time arise, many observations occur, which if well examined, pursued, and improved, might produce discoveries to the advantage of some or all the British plantations, or to the benefit of mankind in general." As a remedy for the wide separation of such persons, whereby many useful particulars might remain uncommunicated, die with the discoverers, and be lost to mankind, it was suggested that one society be formed of virtuosi or ingenious men, residing in the several colonies, who should maintain constant correspondence; Philadelphia to be its headquarters, because it was the most central place; and that there should be always at least seven members-a physician, a mechanician, a geographer, and a general natural philosopher-who should meet once a month or oftener, to exchange communications with one another, take care and notice of the papers of correspondence, and distribute copies of communications of value to more distant members in order to get their opinions upon them. Among the subjects to which the society should give attention were included the recognised branches of science and the useful arts, and "all philosophical experiments that let light into the nature of things, tend to increase the power of man over matter, and multiply the conveniences and pleasures of life." The plan also made provision for correspondence with the Royal Society of London and the Dublin Society; for the distribution of quarterly abstracts of proceedings; and for the publication of annual collections of experiments, discoveries, and improvements. On the $5^{\text {th }}$ of April, I744, Franklin wrote to Cadwallader Colden " that the society, so far as it relates to Philadelphia, is actually formed, and has had several meetings, to mutual satisfaction." Its meetings were kept up for about ten years and then discontinued. Another society, called at first the Junto, was formed 
in $175^{\circ}$, consisting, it is supposed, of members of the old Junto. It enlarged its scope and its name in 1766 , and again in 1768 , and became "the American Society, held at Philadelphia, for Promoting Useful Knowledge." Franklin was made its president. The original American Philosophical Society was resuscitated in 1767 by six of the old members, to whom others were afterward added. In January, 1769, the two societies were united as the Ameriean Philosophical Society and Franklin was elected president, after an exciting contest with the Hon. James Hamilton, president of the original society of that name. $\mathrm{He}$ continued to be president till his death in $\mathbf{r} 79 \mathrm{I}$.

Franklin's useful activity as a citizen was visible everywhere during his life in Philadelphia. A paper on fires, which he read in the Junto and published in 1736 , gave rise to a project for forming a fire company. Some thirty persons were found to engage in the scheme. This act was the suggestion for the formation of other fire companies.

When applied to for a subscription for the establishment of a hospital he was told, to enlist his more active interest in the scheme, that the people would not take hold unless he was in it. $\mathrm{He}$ secured a charter and a grant for the institution from the Legislature. Of his agency and course in this matter he characteristically observes: "I do not remember any of my political manœuvres the success of which gave me at the time more pleasure, or wherein, after thinking of it, I more easily excused myself for having made some use of cunning."

Again we find him pioneering in the improvement of the street pavements. He had the street around Jersey Market paved, and contracted with a man to keep it swept. A general awakening on the subject followed, paving was done all over the city, and shortly became the object of a law. Subsequently, on one of his visits to England, he published plans for cleaning the streets of London and Westminster. The first street lamps set up in Philadelphia were dim and smoky. Franklin inquired into the causes of the inefficiency of their light, and found that they were closed at the bottom so as to cut off the draught. By his direction the bottom was opened; the form of the lamp was changed from a globe to a lantern of four flat panes, with a funnel above to draw up the smoke. This form of lamp prevailed in our cities till recently, and may still be found in many towns where gas lights are used. 
Having published propositions relating to the education of youth in Pennsylvania, Franklin started a subscription for an academy that was opened in 1749 . He was a member of the building committee of the institution and of the board of trustees. It was incorporated as " the College, Academy, and Charitable School of Philadelphia " in $\mathbf{I} 755$; its funds were increased by contributions from Great Britain; land was granted to it by the proprietaries and other land was added by the Assembly; and the institution grew into the University of Pennsylvania.

In 1742 Franklin invented the Franklin stove, with provision for warming the fresh air on its entering. The merits and advantages of this new method of warming rooms, which was claimed also to be superior in economy to the former methods, were set forth in detail in his pamphlet on "The Newinvented Pennsylvania Freplaces." Franklin made a present of the model of the stove to his friend Robert Grace, who, being the proprietor of an iron furnace, found the casting of them profitable. Governor Thomas was so pleased with Franklin's description of the stoves that he offered him a patent upon them; but this Franklin declined from a principle which he says had ever weighed upon him on such occasions"that as we enjoy great advantages from the inventions of others, we should be glad of an opportunity to serve others by an invention of ours; and this we should do freely and generously." An ironmonger of London, having made some small changes in the stove, "which rather hurt its operation," patented it and made a little fortune out of it. "And this," says Franklin, "is not the only instance of patents taken out for my inventions by others, though not always with the same success, which I never contested, having no desire to profit by patents myself, and hating disputes."

In time Franklin yielded to his taste for investigation and public discussions and retired from private business, flattering himself, as he said, that by the sufficient though moderate fortune he had acquired he had secured leisure during the rest of his life for philosophical studies and amusements. But the public, he complained, now considering him a man of leisure, laid hold of him for their purposes, every part of the civil government, and almost at the same time, imposing some duty upon him. 
One of the schemes from which he evidently anticipated much enjoyment was the pursuit of his electrical experiments, for which he purchased the apparatus of Dr. Spence, who had come from England to lecture here. Franklin had met Dr. Spence, then recently come over from Scotland, in Boston, in 1746 , and was shown some experiments which, though imperfectly performed, were novel, and equally surprising and pleasing to him. Soon afterward the Library Company received from $\mathrm{Mr}$. Peter Collinson, of the Royal Society, an account of the new German experiments in electricity, with a glass tube and directions for using it. Franklin at once improved the opportunity to repeat the experiments he had witnessed in Boston. He also practised upon others accounts of which had been received from England, and added new ones. So many persons were attracted to his house to see the wonders he could perform that he was in danger of being overworked; so he had a number of the tubes blown and distributed among his friends, who were thus enabled to divide with him the burden of entertaining the sightseers. A Mr. Kinnersley, being out of business, was furnished with instruments of a little finer make, and charged with two lectures prepared by Franklin, "in which the experiments were ranged in such order and accompanied by such explanations in such method as that the foregoing should assist in comprehending the following"; and he proceeded to show the experiments for money. In return for Mr. Collinson's favours, Franklin sent him accounts of his experiments, which were read in the Royal Society, but were not thought there "worth so much notice as to be printed in the Transactions." "One paper," says Franklin, "which I wrote for Mr. Kinnersley, on the sameness of lightning with electricity, I sent to Dr. Mitchell, an acquaintance of mine and one of the members also of that society, who wrote to me that it had been read but was laughed at by the connoisseurs. The papers, however, being shown to Dr. Fothergill, he thought them of too much value to be stifled, and advised the printing of them. Mr. Collinson then gave them to Mr. Cave for publication in his Gentleman's Magazine, but he chose to print them separately in a pamphlet, and Dr. Fothergill wrote the preface. Cave, it seems, judged rightly for his profit, for by the additions that arrived afterward they swelled to a quarto volume ... and cost him nothing for copy money. It was 
some time, however, before the papers were much taken notice of in England. A copy of them happening to fall into the hands of the Count de Buffon ... he prevailed with M. Dolibaud to translate them into French, and they were printed in Paris. The publication offended the Abbé Nollet, preceptor in natural philosophy to the royal family, and an able experimenter who had formed and published a theory of electricity which then had general vogue. He could not at first believe that such a work came from America, and said it must have been fabricated by his enemies in Paris to decry his system. Afterward, having been assured that there really existed such a person as Franklin in Philadelphia, which he had doubted, he wrote and published a volume of letters, chiefly addressed to me, and denying the validity of my experiments and of the positions deduced from them." Franklin thought at first of answering the abbé, but he reflected that every one might repeat and verify the experiments, and that he was not obliged to defend observations offered as conjectures and not dogmatically, and that a controversy would not be worth while. The abbé was refuted by M. le Roy, of the Royal Academy of Sciences. Franklin's book was translated into other languages, and the doctrine it contained was by degrees universally adopted by philosophers.

A sudden and general celebrity was given to the book by the success of one of the experiments proposed in it, in the hands of MM. Dolibaud and De Lor at Marly, for drawing lightning from the clouds. This engaged public attention everywhere. M. De Lor's repetitions of the "Philadelphia experiment," having been performed before the king and court, was visited by all the curious of Paris. Franklin was greatly pleased, and soon afterward made a similar one-his famous kite experiment-in Philadelphia.

Dr. Wright, an English physician, then in Paris, took up Franklin's case and wrote to a friend in the Royal Society, which had neglected the philosopher, concerning the high estate to which his experiments had risen among the learned abroad, and expressing wonder that so little notice was taken of them in England. Dr. Watson drew up an account of these and others of Franklin's papers, and it was printed in the Transactions. Some of the members of the Royal Society themselves drew lightning from the clouds, and in the end 
Franklin was unanimously elected a member of that learned body without application from him; and in recognition, as it were, of the honour conferred upon the society rather than upon him by the connection, he was excused from making the customary payment.

Franklin's literary work was a part and a product of his unceasing activity. Always doing or observing, he was always thinking and learning; and what he thought and learned he was ready to communicate at once to some one of his numerous correspondents who would be interested by it or might derive advantage from it. When his observations had borne fruit in some discovery or practicable scheme, he embodied the result in some essay or paper, which likewise, most usually, took the form of a letter to a friend. The spirit of the hour, as Mr. G. Brown Goode well said at the American Philosophical Society's commemoration of the centennial of Franklin's death, was his constant inspiration, "and his writings were a legitimate result, the natural outgrowth of his activity in all matters of public concern. Admirable in themselves, their chief interest is nevertheless due to the fact that they form so complete a record of the deeds and the personal character of their author. Though he was a voluminous writer, and one of the great masters of English expression, Franklin wrote habitually with à single eye to immediate practical results. He never posed for posterity."

One of the most salient features of his scientific writings is the broadness of his interests in that field. Nothing that could conduce to the advancement of knowledge or to the promotion of the well-being of men-for which knowledge was to be valned-escaped his attention. He was most deeply interested in matters that concerned health and comfort; domestic economy, the art of getting along, of making life easier and more profitable, of saving and of improving what one had, followed; related to this was interest in the introduction to his countrymen of new products and additional sources of rerenue, concerning which there are many letters; and from these he went into all the fields of pure science in which the thought of the day busied itself. If the subject were not one on which he had himself experimented or a scheme on which he had some definite plan, he could discuss the observations of others and present speculations which were always sagacious respecting 
the nature and causes of phenomena; though, in view of the primitive condition of scientific knowledge in his day, it would be too much to expect that they should always be correct. They were, however, usually in advance of what was known.

His outline of the subjects which he thought should come within the range of the discussions of the American Philosophical Society gives only a partial summary of the matters in which he ultimately became interested. It embraces all newly discovered plants, herbs, trees, roots, their virtues, uses, etc.; methods of propagating them, and making such as are useful, but particular to some plantations, more general; improvements of vegetable juices, such as ciders, wines, etc.; methods of curing or preventing diseases; all new-discovered fossils in different countries, as mines, minerals, and quarries; new and useful improvements in any branch of mathematics; new discoveries in chemistry, such as improvements in distillation, brewing, and assaying of ores; new mechanical inventions for saving labor, as mills and carriages, and for raising and conveying of waters, draining of meadows, etc.; all new arts, trades, and manufactures that may be proposed or thought of ; surveys, maps, and charts of particular parts of the seacoasts or inland countries; course and junction of rivers and great roads, situation of lakes and mountains, nature of the soil and productions; new methods of improving the breed of useful animals; introducing other sorts from foreign countries; new improvements in planting, gardening, and clearing land; and all philosophical experiments that let light into the nature of things, tend to increase the power of man over matter, and multiply the conveniences or pleasures of life.

The most important among Franklin's contributions to science were his experiments in electricity, which culminated in the demonstration that lightning is an electrical phenomenon, and in the introduction of lightning rods as a means of protecting buildings. We have already referred to the beginning of these experiments. They were continued through Franklin's life, and were the subject of frequent correspondence between him and such of his friends as were interested in "philosophy," as he called it. In this correspondence a variety of methods of experimenting and many novel experiences were described. The investigators constructed their own machinesfrictional machines-and with them made new demonstrations of 
the properties and powers of frictional electricity, now familiar, but in those days original and startling discoveries. The brilliancy of these experiments, said Dr. J. W. Holland, of Jefferson Medical College, at the centennial commemoration, "depended mainly on Franklin's discovery that the electricity of the Leyden jar was stored up on the glass, and that by increasing the extent of excited surface the energy was proportionately multiplied. The power thus obtained made it appear highly probable that the difference between the spark and the lightning flash was one of degree"-as was ultimately proved. "In a hundred years," Dr. Holland adds, "but little has been added to what Franklin revealed concerning the electricity of friction." In a paper read before the Royal Academy of Sciences at Paris, in $\mathrm{x} 779$, Franklin gave an explanation of the aurora borealis as a phenomenon of atmospheric electricity which still holds good as to its general principles, although the details have been modified by recent discoveries; but he does not seem to have grasped the connection between electricity and magnetism, for, in a letter written in 1773 to M. Dubourg, in Paris, he gives it as his "real opinion that these two powers of Nature have no real affinity with others, and that the apparent production of magnetism [by electricity] is purely accidental "; and he gives ten points in explanation and proof of this view.

The next most important of Franklin's labours in the field of practical science is represented, perhaps, by his invention of a stove and his study of the causes and cure of smoky chimneys. The Franklin stove was not merely the portable open grate or fireplace with which the name is usually associated, but was a philosophically constructed heating apparatus, based upon a careful study of the properties of warm air and the diffusion of heat, and embodied the principles which have since been applied in endless variety in the construction of stoves of every shape and of hot-air warming apparatus. He further devised a stove in which all the smoke was turned to account and operated as fuel in heating the rooms, which, when tried, answered even beyond his expectations. His studies of smoky chimneys furnished a remedy for what was in his day one of the most crying miseries of domestic life. Connected with this subject is that of ventilation to which he gave much attention; and he is credited with being the first person who observed that respiration communi- 
cated a noxious quality to the air, and that the atmosphere was poisoned by effluvia emitted from the body.

Franklin's interest in matters of health and sanitation is further illustrated in the provision made in his will in behalf of a water supply for Philadelphia; in his experiments in ventilation and his efforts to improve our means of keeping ourselves warm; and by frequent references in his letters to matters of health. He had very definite ideas in regard to disease and its cause, which in many points went against the medical theories of the day. Some of these were emphatically expressed in his paper on colds. In a letter on the treatment of hospital patients * he recommended light covering and abundance of fresh air, declared that the idea that perspiration was better under thick clothes was fallacious; and expressed himself convinced from certain experiments of what he had before suspected, that "the opinion of perspiration being checked by cold is an error, as well as that of rheum being occasioned by cold. But this is heresy here, and perhaps may be so with you. I only whisper it, and expect you will keep my secret. Our physicians have discovered that fresh air is good for people in the smallpox and other fevers. I hope in time they will find out that it does no harm to people in health."

With singular prevision of what science was to develop, Franklin wrote to Priestley in $\mathbf{7 7 4}$, almost at the date of the birth of modern chemistry: "That the vegetable creation should restore the air which is spoiled by the animal part of it looks like a rational system, and seems to be of a piece with the rest. We knew before that putrid animal substances were converted into sweet vegetable when mixed with the earth and applied as manure; and now it seems that the same putrid substances, mixed with the air, have the same effect. The strong thriving state of your mint in putrid air seems to show that the air is mended by taking something from it, and not by adding to it." To this he added-another heresy in those times-that he did not believe the woods were unhealthy.

Another prophecy is embodied in Franklin's views on the progress of storms. He ventured the theory in $1747 \dagger$ that though the course of the wind in storms is from northeast to

* To Mr. Leroy, from London, 1773.

† In a letter to Jared Eliot. 
southwest, the course of the storm is from southwest to northeast_-" that is, the air is in violent motion in Virginia before it moves in Connecticut, and in Connecticut before it moves at Cape Sable." In 1760 he wrote:* "Our northeast storms begin in point of time in the southwest parts-that is to say, the air in Georgia, the furthest of our colonies to the southwest, begins to move southwesterly before the air of Carolina, which is the next colony northeastward; the air of Carolina has the same motion before the air of Virginia, which lies still more northeastward; and so on, northeasterly through Pennsylvania, New York, New England, etc."

Concerning the origin of springs Franklin wrote to Jared Eliot, in 1747 , agreeing in his view "that most springs arise from rains, dews, or ponds on higher grounds; yet possibly some, that break out near the tops of high, hollow mountains, may proceed from the abyss, or from water in the caverns of the earth, rarefied by its internal heat, and raised in vapour, till the cold region near the tops of such mountains condenses the vapour into water again, which comes forth as springs, and rides down on the outside of the mountains as it ascended on the inside."

The mention of mountains suggested an observation that the great Appalachian Mountains "show in many places, even the highest parts of them, strata of seashells; in some places the marks of them are in the solid rocks. It is certainly the wreck of the world we live in! I have specimens of these seashell rocks, broken off near the tops of the mountains, brought and deposited in our library as curiosities. If you have not seen the like, I will send you a piece." An observation is mentioned of "the bluff side or end of a mountain which appeared striped from top to bottom," divided by Nature, as Mr. Walker had told him, into pillars, of which he would be glad to have a partial account from his correspondent. It was somewhere near New Haven.

The calming effect of oil on waves attracted his attention. Describing some of his experiments to Dr. Brownrigg, he wrote that one circumstance in them struck him with particular surprise. This was "the sudden, wide, and forcible spreading of a drop of oil on the face of the water, which I do not know that

* In a letter to Alexander Small. 
anybody has hitherto considered. When put on water it spreads many feet around, becoming so thin as to produce the prismatic colours for a considerable space, and beyond them so much thinner as to be invisible, except as to its effect in smoothing the waves at a much greater distance. It seems as if a mutual $r \in$ pulsion between its particles took place as soon as it touched the water, and a repulsion so strong as to act on other bodies swimming on the surface, ... forcing them to recede every way from the drop as from a centre, leaving a large clear space. The quantity of this force, and the distance to which it will operate, I have not yet ascertained; but I think it is a curious inquiry, and I wish to understand whence it arises." The continued study of this subject has given rise to many curious observations, and has thrown considerable light on the property of surface tension of liquids.

The nature of inflammable and uninflammable gases was not yet understood, although Priestley was engaged, with his coworkers, in Europe, in the experiments by which it was finally elucidated; and to him Franklin wrote, in 1774 , as a contribution to the list of phenomena to be accounted for, concerning a river in New Jersey, that on stirring the bottom bubbles arose which could be set on fire; and he related an experiment made upon this river by the Rev. Dr. Finley, president of the college at Princeton. "The discoveries," he added, "you have lately made of the manner in which inflammable air is in some cases produced, may throw light on this experiment, and explain its succeeding in some cases and not in others." In another letter to Priestley, Franklin illustrated the pleasant relations he enjoyed with that philosopher, and manifests his sympathy with his work by saying: "I find that you have set all the philosophers of Europe at work upon fixed air; and it is with great pleasure that I observe how high you stand in their opinion, for I enjoy my friends' fame as my own."

How far Franklin and the world were still, however, from understanding the true nature of chemical heat-producing processes, is shown in a curious speculation in his handwriting found among the papers of Cadwallader Colden, in which the heat of the blood and the cold and hot fits of some fevers were explained by supposing that the heat is a matter of friction, not of the liquid blood, for liquids have no friction, and water cannot be warmed by shaking it, but by friction of 
the solid parts of the blood, and that produced by the distention and contraction of the arteries, the resultant heat from which is communicated to the blood. To account for the cold, he supposed the blood to become so viscid that it could not pass through the minute vessels at the extremities through which it flowed freely when duly fluid; hence, it bringing no more heat to them, they grow cold.

Franklin's views concerning the nature of fire and of heat in general appear to have been partly in harmony with the theory of phlogiston then current, and partly a vague conception of the undulatory theory, with its ethereal medium. They are further given in a letter written to Benjamin Vaughn, in 1784 , in which he said that he had long been of the opinion that fire exists everywhere as in the state of a subtle fluid; that too much of the fluid in our flesh gives us the sensation we call heat; too little, cold; its vibrations, light; that all solid and fluid substances which are inflammable have been composed of it; their dissolution in returning to their original fluid state we call fire. This subtle fluid is attracted by plants and animals in their growth, and consolidated; is attracted by other substances, thermometers, etc., variously; has a particular affinity with water, and will quit many other bodies to attach itself to water, and go off with it in evaporation.

To David Rittenhouse thus he wrote, in the same year, that universal space, as far as we know of it, seems to be filled with a subtle fluid, whose motion or vibration is called light. This fluid may possibly be the same with that which, being attracted by and entering into other more solid matter, dilates the substance by separating the constituent particles, and so rendering some solids fluid and maintaining the fluidity of others.

Franklin's speculations as to the origin of the globe are given in a letter to the Abbé Sonleire, which was read as a paper before the American Philosophical Society, September 22, 1782. In it he supposes that all the elements in separable particles being originally mixed in confusion and occupying a great space, they would (as soon as the Almighty fiat ordained gravity, or the mutual attraction of certain parts and the mutual repulsion of others, to exist) all move to their common centre; and the air being a fluid whose parts repel each other, though drawn to the common centre by this gravity, would be densest toward the centre and rarer as more remote; consequently all 
matters lighter than the central parts of that air, and immersed in it, would recede from their centre, and rise till they arrived at that region of the air which was of the same specific gravity with themselves, when they would rest, while other matter mixed with the lighter air would descend, and the two meeting would form the shell of the first earth, leaving the upper atmosphere nearly clear. The original movement of the parts toward that common centre would naturally form a whirl then, which would continue upon the turning of the new-formed globe upon its axis, and the greatest diameter of the shell would be in its equator. If by any accident afterward the axis should be changed, the dense internal fluid, by altering its form, must burst the shell and throw all its substance into the confusion in which we find it-whereby the upturning and mingling of strata so often found are explained.

A paper in the Memoirs of the Literary and Philosophical Society of Manchester, England, contains some meteorological speculations and conjectures. It supposes a region high in the air over most countries where frost exists continually. The mass of the earth to the depth perhaps of thirty feet retains its heat for some time. Hence the first snows are melted and the beginning of the winter is slow. The cold of the winter of I $783-' 84$ was attributed, in accordance with this theory, to the fogs that prevailed in the preceding summer, which prevented the land being warmed as much as usual.

A letter from M. de Saussure, the eminent Alpine geologist, found among Franklin's papers, exhibits Franklin as interested in the experiment for determining the density of the earth by measuring the attraction of a mountain. 'The letter, in answer to a proposition on the subject from the Royal Society, mentions the difficulty of performing the experiment in Switzerland, on account of the confusion of the attractions of surrounding mountains, and suggests that it be tried on some high, isolated peak.

The alleged finding of some toads inclosed in solid stones at Passy, near Paris, suggested a curious speculation as to the way in which they could have lived under such conditions. "It is observed," Franklin said, "that animals who perspire but little can live long without food, such as tortoises, whose flesh is covered with a thick shell, and snakes, who are covered with scales which are of so close a substance as scarcely to admit 
the passage of perspirable matter through them. Animals that have open pores all over the surface of their bodies and live in air which takes off continually the perspirable part of their substance naturally require a continual supply of food to maintain their health. Toads shut up in solid stone, which prevents their losing anything of their substance, may perhaps for that reason need no supply, and being guarded against all accidents and all the inclemencies of the air and changes of seasons are, it seems, subject to no diseases, and become, as it were, immortal."

The length of the time that dead bodies will retain infection after sepulture is discussed in one of the letters, ${ }^{*}$ and cases are cited of smallpox caught from bodies thirty years dead; fever from an Egyptian mummy; cold from a mummy of Teneriffe three hundred years old; and fevers mentioned in a newspaper account resulting in fifteen funerals, from the bodies of persons who had died of the plague one hundred years before.

The early experiments with balloons were observed with interest by Franklin. He was hopeful but not sanguine as to the outcome, and he wrote, in 1784 , that the beginning of the art of flying would be a new epoch. The construction and manner of filling balloons were improving daily. Remarking that some of the artists had lately gone to England, he suggested to his correspondent: "It will be well for you philosophers to obtain from them what they know, or you will be behindhand, which in mechanical operations is unusual for Englishmen." He, however, discouraged one of his friends from attempting to cross from France to England in a balloon, telling him that means had not yet been found to keep a balloon up more than two hours. He saw the embryo of a steamboat, of which more than one notice occurs, and which he introduced to the attention of Dr. Ingenhousz in 1788 , speaking of it as a boat moved by a steam engine, that "rows itself against the tide in a river-and it is apprehended that its construction may be so simplified and improved as to become generally useful."

Franklin observed that the same convexity of glass in spectacles through which a man sees clearest and best at the proper distance for reading is not the best for greater distances, and for a long time used two pairs of spectacles, which he changed

* To Félix Vicq d’Agyr. 
according to the use he wished to make of them. He finally hit upon a more convenient plan and had his glasses cut, and "half of each kind associated in the same circle," the upper semicircle of one kind and the lower of the other, so that he was able to wear the same spectacles constantly, having, as he said, "only to move my eyes up or down as I want to see distinctly far or near, the proper glasses being always ready." He wore these glasses with great comfort, and maintained that he was even able to understand French better by their help; for when at table he could observe what he was eating with one set of the glasses and look with the other into the faces of the friends who spoke to him, reading the sounds which his foreign ears heard only imperfectly, in the movements of their lips.

There is hardly a subject of knowledge, art, life, and economy that is not touched upon and illuminated in Franklin's letters. We find in them observations concerning the prevailing views of life and death as not showing sufficient understanding; a mode of rendering meat tender by electricity; supplies of saltpetre and gunpowder for the war, with a wish that pikes might be introduced, and bows and arrows, for the use of which six reasons are given; M. Volta's experiments and the length of time for which the electric force may be kept in the Leyden vial; true science and its progress; the discovery of the great use of trees in producing wholesome air; a slowly sensitive hygrometer, suggested by such incidents as the shrinking in America so as to be tight, and the swelling in Europe so as to afford ample room, of a mahogany magnet box and a telescope box; the Indian languages; the antiquity of the mariner's compass; the route by which the Phœnicians came to America, if they did come; Lavoisier's experiment of melting platinum in fine charcoal blown upon by dephlogisticated air; a comet seen in Gibraltar, concerning which data from Herschel are enclosed to Rittenhouse; the spots on the sun; the temperature of the water of the ocean; the civil service, in which the theory is declared to Henry Lawrence that every place of honour should be made a place of burden: "The malady [of government] consists in the enormous salaries, emoluments, and patronage of great offices"; the logographic mode of printing; thanks to Lavoisier for his Nomenclature Chimique; a collection of songs and music of American composition, "the first of the kind that has appeared here"; a 
remedy for moderate deafness by putting the thumb and fingers behind the ear, pressing outward and enlarging it, as it were, by the hollow of the hand, which he had tried with satisfaction; Noah Webster's labours on the English language, with a plea for its purity and approval of a scheme for a reformed alphabet; an instrument for taking books down from shelves; the distillation of fresh from salt water, with a theory that the skin has imbibing as well as discharging pores, and we might drink by sitting or lying in the water, even in salt water; the discovery of an ancient sepulchre, perhaps of a Scythian king, on the frontiers of Russia; improvements in navigation, of which he had made careful studies during his long voyages across the ocean, and on which he has observations respecting sails, cables, models, power at sea, the course of the Gulf Stream, precautions, and general reflections on the subject, relating to which a paper was read to the American Philosophical Society in 1785 ; the evil effects of lead on the human system, to which, although they had been known for years, not much attention seems to have been paid; building houses with reference to safety against fire; the Deluge as a possible result of the internal fluidity of the earth; the wonderful discoveries made by Herschel and "the indefatigable ingenuity by which he has been enabled to make them"; and on the merits of the Greek and Latin languages for general instruction, the time spent in learning which, he thought, might be better employed in the education suitable for such a country as ours.

Among Franklin's economical papers is one on the nature and necessity of a paper currency, in which the sound principles are declared that "money as bullion or as land is valuable by so much labour as it costs to procure that bullion or that land; money as a currency has an additional value by so much time and labour as it saves in the exchange of commodities." In his letter on customs duties he squarely avows the principle of freedom of commerce, but apologizes for the tariff imposed by the colonies on the ground of their necessity to raise money to pay their debt, and that by the most convenient means. "We are not ignorant," he wrote to M. de Veilard, "that the duties paid at the custom-house on the importation of foreign goods are finally reimbursed by the consumer, but we impose them as the easiest way of levying a tax from those consumers"; and to M. Dupont de Némours, "You appear to 
be possessed of a truth which few governments are possessed of-that A must take some of B's produce, otherwise B will not be able to pay for what he would take of A."

The reprint of Franklin's scientific writings by Sparks includes sixty-three papers on electricity, and one hundred and fifty-seven on philosophical subjects, making in all two hundred and twenty letters, filling eight hundred and eighty pages.

Franklin was made a Foreign Associate in the French Academy of Sciences in 1772 , and was esteemed in France during his residence there as one of the foremost men of the time. In I 782 the Academy of Sciences, Letters, and Arts of Padua expressed a desire, through Chevalier Deprin, to add Franklin's name to its list of members. Its diploma recited that the particular act of electing into a learned society persons who had been zealous in promoting the increase of all kinds of knowledge was "properly but an acknowledgment of the original titles of their relationship. Among them, Dr. Franklin, having distinguished himself eminently, and having rendered himself equally memorable in natural philosophy and in politics, the Academy . . . considers it to be honouring themselves when they number him among the twenty-four strangers who, by the constitution, are to be associated into their body."

In 1784 he was elected a member of the Spanish Royal Academy of Sciences, and the publication of a Spanish translation of some of his writings was announced. A few days afterward the Count de Capomenes wrote him from Madrid: "Nature, which you have profoundly studied, is indebted to you for investigating and explaining phenomena which wise men had not before been able to understand; and the great American philosopher, at the same time he discovers these phenomena, suggests useful methods for guarding against their dangers."

The feelings of his own countrymen toward him were equally enthusiastic. When he came home, in 1785 , from his long service abroad, the Provost of the University of Pennsylvania addressed him, recognising him as the projector of the institution, and acknowledging that " not contented with enriching the world with the most important discoveries in natural philosophy, your benevolence and liberality of sentiment early engaged you to make provision for exciting a spirit of inquiry into the nicest operations of Nature, for exalting and refining the 
genius of America by the propagation of useful learning, and for qualifying many of her sons to make that illustrious figure which has commanded the esteem and admiration of the most polished nations of Europe." The address of the American Philosophical Society welcomed him to his native country, for which he had done the most essential service, and to the presidential chair, his occupation of which added to the institution much lustre in the eyes of all the world. "Sir," the address continues, "it reflects honour on philosophy when one distinguished for his deep investigations and many valuable improvements in it, is known to be equally distinguished for his philanthropy, patriotism, and liberal attachment to the rights of human nature."

Franklin's death was announced in the French National Assembly, June I4, I790, by Mirabeau, who said: "The genius that gave freedom to America, and shed torrents of light upon Europe, is returned to the bosom of the Divinity. The sage whom two worlds claim; the man, disputed by the history of the sciences and the history of empires, holds, most undoubtedly, an elevated rank among the human species." Then, having spoken of the month's mourning recommended by our Congress, and suggested that a similar recognition would be proper in France, the orator added: "Antiquity would have elevated altars to that mortal who, for the advantage of the human race, embracing both heaven and earth in his vast and extensive hand, knew how to subdue thunder and tyranny. Enlightened and free, Europe at least owes its remembrance and its regret to one of the greatest men who has ever served the cause of philosophy and of liberty." His motion that the Assembly wear mourning for three days was seconded by La Rochefoucauld and Lafayette, and adopted by acclamation; and a letter of condolence was addressed to the Congress of the United States. In r79I a street in Paris was named Franklin, in perpetual remembrance of his long sojourn there.

It would be hard to imagine a more pleasing picture of the quiet closing of an honoured and useful life than is given of him by the Rev. Manasseh Cutler, who found him in July, I 787 , sitting in his garden surrounded by his grandchildren and a few friends, interested in a two-headed snake, a device for showing the circulation of the blood, a copying press, his book-handling apparatus, and an immense volume on botany; 
and in the letters to friends in which he touches upon his advancing age and the prospect of death. He had always avoided controversy in defence of his philosophical opinions, trusting that if they were right time and experience would support them, and if wrong they ought to be refuted and rejected. Although he had a few enemies in England and at home, as an American and because of what he had done for America, he was able to thank God that there were not in the whole world any who were his enemies as a man; for by His grace through a long life he had been enabled so to conduct himself that there did not exist a human being who could justly say, "Ben Franklin has wronged me." 


\section{JOHN BARTRAM,}

I699-I777, AND

\section{WILLIAM BARTRAM,}

$$
\text { I 739-1823. }
$$

DURING the century which preceded the American Revolution the science of the colonies, like their commerce, was tributary to that of the Old World. Fabulous reports in regard to the natural resources of America had been brought home by European voyagers, and the cultivators of all sciences and arts were looking to that vast unexplored region for products which should increase the knowledge of the naturalist, the resources of the physician and the agriculturist, the profits of the merchant, and the enjoyment of the man of leisure. The function of those colonists who inclined to natural history was that of explorers and collectors, and among the earliest and most notable of these American collectors were the subjects of this sketch.

The grandfather of the elder Bartram, also named John, came from Derbyshire, England, to Pennsylvania in 1682 . He brought his wife, three sons, and one daughter, and settled near Darby, in Delaware (then Chester) County. The third son, William, was the only one who married, his wife being Elizabeth, daughter of James Hunt. Both families belonged to the Society of Friends. The children of William were John (the botanist), James, William, and a daughter who died young. The second William went to North Carolina and settled near Cape Fear; John and James remained in Pennsylvania.

The date of John Bartram's birth was March 23, 1699. But little is on record concerning his early years. Like the majority of boys in the colonies, he was brought up to a farming life, and his education was only such as the country schools of the time afforded. After reaching adult years he studied Latin 

a little, so as to be able to pick out the descriptions of plants in the Latin works of European botanists. In a sketch of John Bartram, written by his son William, it is stated that he had an inclination to the study of physic and surgery and did much toward relieving the ailments of his poor neighbours. In January, r723, he married Mary, daughter of Richard Morris, of Chester Meeting, by whom he had two sons-Richard, who

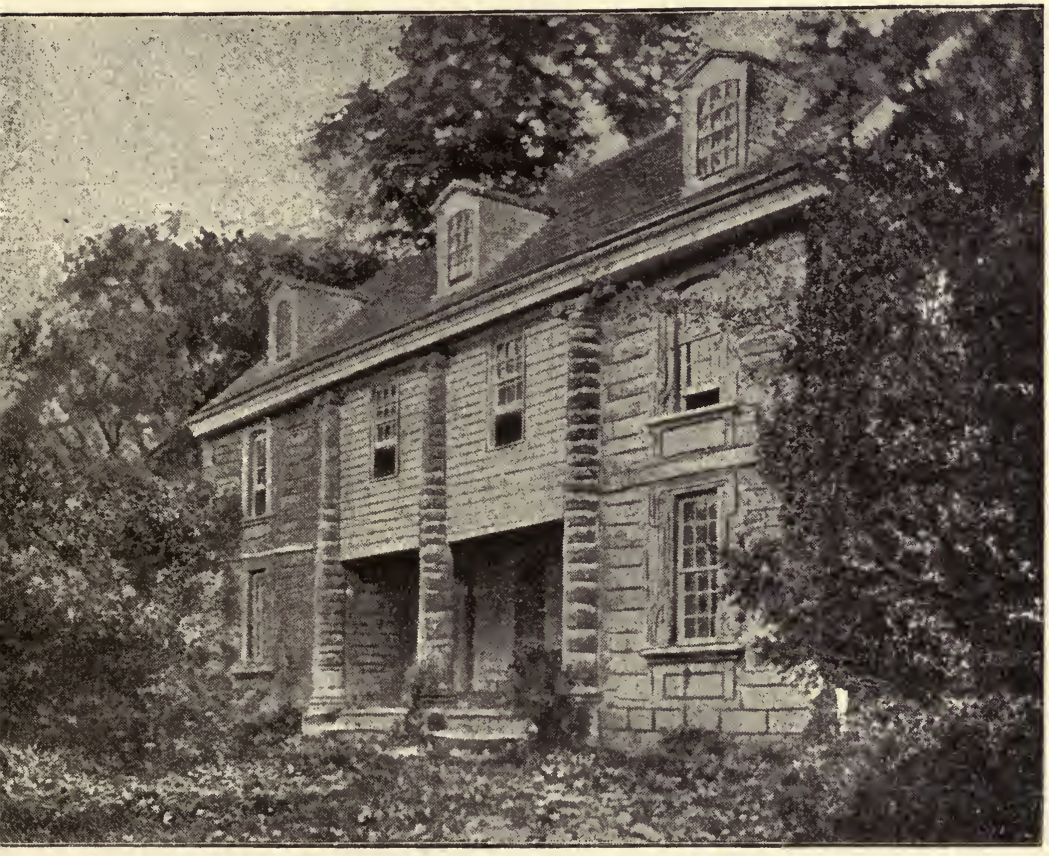

Fig. I.-BARTRAM'S HOUSE IN 1887 **

died young; and Isaac, who lived to old age. His wife Mary died in 1727 , and in September, 1729 , he married Ann Mendenhall, of Concord Meeting, who survived him. John and Ann Bartram had nine children, five boys and four girls. Of these the third son was William, he and his twin sister, Elizabeth, being born February 9, I739. The ground on which John Bartram laid out the first botanic garden in America was on

\footnotetext{
* The pictures in the text are from photographs furnished by Mr. Thomas Meehan.
} 
the west bank of the Schuylkill River, at Kingsessing, near Gray's Ferry (now within the limits of Philadelphia), and was bought by him September 30, 1728. "Here he built with his own hands," says William, "a large and comfortable house of hewn stone, and laid out a garden containing about five acres." A view of this house, which is still standing, is given herewith. The year of its erection is shown by a stone in the wall on which is cut "John * ANN BARTRAm, I73I." Another inscription on a stone over the front window of his study reads :

\section{“' 'Tis God alone, Almighty Lord, The Holy One, by me adored.}

“JohN BARTRAM, I770."

That the building was a labour of love is attested by the care bestowed upon the carved stonework around the windows and doors and the pillar under the porch. John Bartram must have been a good stonecutter and mason, for this is one of four stone houses that he built in his lifetime.

Nearly all the extant information concerning the lives of the two Bartrams has been embodied in the Memorial of John Bartram, by William Darlington, published in $\mathbf{1} 849$. This volume contains the sketch of John Bartram by his son William, with some additions by the editor, and over four hundred pages of correspondence. About a fourth of these letters are from his friend Peter Collinson; the others are from eminent botanists in Europe and America, and from Bartram to these various correspondents. Darlington also reprinted a sketch of John Bartram, which appeared in the Letters from an American Farmer, by J. Hector St. John, published in London soon after Bartram's death. The "letter" describing Bartram purports to be written by a Russian traveller, who is evidently a myth, although in all important respects the account represents the botanist as he was. As to how Bartram's interest in botany was aroused, the "Russian gentleman" has a very pretty story, telling of a sudden awakening after the botanist had married; but Bartram himself is better authority, and he writes to Collinson, May I, I 764 , "I had always since ten years old a great inclination to plants, and knew all that I once observed by sight, though not their proper names, having no person nor books to instruct me."

He was encouraged to study systematically by James Logan 
(founder of the Loganian Library, in Philadelphia), who gave him several botanical works. In order that his explorations, begun at his own expense, might be extended, Bartram's friends prompted him to seek the patronage of some wealthy and influential person in the mother country. Accordingly, a quantity of his specimens and a record of some of his observations were sent to Peter Collinson, a Quaker merchant in England, who was greatly interested in horticulture. Bartram's consignment secured his interest, and led to a correspondence, which lasted nearly fifty years. The first letter in Darlington's collection is from Collinson, under the date January 20, 1734-'35, and refers to letters from Bartram of the preceding November; hence this correspondence probably began when Bartram was about thirty-five years of age. In his early letters Collinson makes many inquiries about American plants and requests for specimens. He sends Bartram seeds, roots, cuttings of trees, vegetables, and flowering plants cultivated in England, packages of paper in which to preserve specimens, and gives him directions for collecting and drying plants. From time to time he sends presents of cloth and other articles for the use of the botanist or his family. For Bartram's "improvement in the knowledge of plants" he early offers, if duplicate collections are sent, to "get them named by our most knowing botanists, and then return them again, which will improve thee more than books." In this way the learning of Dillenius, Gronovius, and other eminent men was brought to the aid of the humble colonist. Collinson obtained for Bartram many orders for seeds and roots of American plants, and early secured for him the patronage of Lord Petre, whose gardens and hothouses were probably the most extensive in the kingdom. This noble amateur ordered quantities of seeds from time to time, and when Bartram asked for a yearly allowance to enable him to extend his explorations, Lord Petre agreed to contribute ten guineas toward it. As much more was obtained from the Duke of Richmond and Philip Miller, and the twenty guineas were paid each year till $\mathrm{I}_{742}$, when Lord Petre died. The first expedition that Bartram made with this assistance was an exploration of the Schuylkill River. He transmitted his journal of the trip and a map of the river to his patrons, and with both of these Collinson reported Lord Petre to be much pleased.

Besides plants, Collinson asks Bartram at various times to 
send insects, birds, and their eggs and nests, terrapin and other turtles, snakes, shells, wasps' and hornets' nests, and fossils, which last were then regarded as "evidences of the Deluge." "My inclination and fondness to natural productions of all kinds," he writes, "is agreeable to the old proverb, "Like the parson's barn-refuses nothing." " During the second year of his allowance Bartram complains that it does not recompense him for his labours, and he also finds fault with Collinson for giving him seeds and cuttings that he has already, and for not having answered some of his letters. Collinson, in a businesslike reply, shows that Bartram's complaints are due to his ignorance of commercial affairs, the difficulty of transatlantic communication, and to his exceeding the commissions of his patrons-whereupon the botanist promptly apologizes.

In 1738 Bartram made a journey of five weeks through Maryland and Virginia to Williamsburg, then up the James River, and over the Blue Ridge Mountains, travelling in all about eleven hundred miles. Most of his expeditions were made without any scientific companion. "Our Americans," he writes to a correspondent, "have very little taste for these amusements. I can't find one that will bear the fatigue to accompany me in my peregrinations."

In an undated letter, written probably in 1739 , to Colonel Byrd, of Virginia, Bartram reports that he had been making "microscopical observations upon the male and female parts in vegetables." He had also made, he says, "several successful experiments of joining several species of the same genus, whereby I have obtained curious mixed colours in flowers, never known before." To this he adds: "I hope by these practical observations to open a gate into a very large field of experimental knowledge, which, if judiciously improved, may be a considerable addition to the beauty of the florist's garden." It was in this "field of experimental knowledge"-namely, cross fertilization - that Darwin afterward won a share of his fame. Bartram evidently discussed this subject with Collinson, for the latter writes in 1742 : "That some variegations may be occasioned by insects is certain; but then these are only annual, and cease with the year." Permanent variegations, he says, are produced by budding - a sort of inoculation.

That Bartram had a hostility to superstition, tempered with much considerateness for persons, is shown by a letter in which 
he tells of a visit to Dr. Witt, of Germantown, another of Collinson's correspondents. He says: "When we are upon the topic of astrology, magic, and mystic divinity, I am apt to be a little troublesome, by inquiring into the foundation and reasonableness of these notions-which, thee knows, will not bear to be searched and examined into: though $I$ handle these fancies with more tenderness with him than I should with many others that are so superstitiously inclined."

One of the botanists whom Collinson had enlisted in identifying Bartram's specimens was Prof. Dillenius, of Oxford, and in $\mathbf{1} 740$ Collinson writes for some mosses for him, saying, " $\mathrm{He}$ defers completing his work till he sees what comes from thee, Clayton, and Dr. Mitchell." In the same year a list of specimens which had been named by Dr. J. F. Gronovius, of Leyden, was returned, and contained this entry: "Cortusa sive Verbasci, Fl. Virg., pp. 74, 75. This being a new genus, may be called BARTRAmia." The name Bartramia is now borne by a different plant-a moss growing in the Berkshire Hills of Massachusetts.

Bartram's correspondence with Gronovius began about I 743, and extends over a dozen years or more. Gronovius writes at length, very appreciatively, and makes many requests. $\mathrm{He}$ sends his books as they appear, and before the publication of his Index Lapidæ, sends a transcript of the passage, in Latin, in which he is to give Bartram credit for his finds of fossils.

Among the European scientists whom Collinson made acquainted with Bartram's work was Sir Hans Sloane, physician and naturalist, who succeeded Newton as President of the Royal Society. At his request Bartram sends him, in $174 \mathrm{I}$, some "petrified representations of seashells." The next year Sloane sends to Bartram a silver cup inscribed:

“The gift of $\mathrm{S}^{\mathrm{r}}$ Hans Sloane, Bart.

To his Frd John Bartram.

Anno r742."

A figure of this cup is given by Darlington. Sloane also sent Bartram his Natural History of Jamaica, in two ponderous folio volumes.

About this time a correspondence began between Bartram and Dr. John Fothergill, a wealthy physician and naturalist, who, like Sloane, had first received some of Bartram's specimens from Collinson. Dr. Fothergill wishes to know what 
mineral springs there are in America, and Bartram sends him what information he has and can get from others.

Bartram also exchanged letters with Philip Miller, author of the Gardener's Dictionary ; with George Edwards, who in $\mathbf{I} 766$ sends his book, containing descriptions of birds that the Pennsylvanian had sent him; with Prof. John Hope, of Edinburgh; and with the ablest observers of Nature in the colonies, among whom were Dr. John Mitchell, Rev. Jared Eliot, John Clayton, Cadwallader Colden, and Dr. Alexander Garden.

In 744 he writes, "Dr. Gronovius hath sent me his Index Lapidæ, and Linnæus the second edition of his Characteres. Plantarum, with a very loving letter desiring my correspondence, and to furnish him with some natural curiosities of our country." The same year he sends to England his Journal of the Five Nations and the Lake Ontario, describing a journey he had made the preceding fall. It contained an account of the "soil, productions, mountains, and lakes" of those parts of Pennsylvania and New York through which the route lay; and gave the proceedings of a great assembly of Indian chiefs held to treat with the agent of the Province of Pennsylvania, whom Bartram accompanied. This journal was afterward published in London.

The visit of Peter Kalm to America took place in 1748 to I 75 I. He travelled through Canada, New York, Pennsylvania, and adjoining provinces; made the acquaintance of the Gray's Ferry botanist, and obtained much assistance from him. It has been alleged that Kalm took to himself the credit of some discoveries which rightfully belonged to Bartram. This would not be suspected from reading Kalm's Travels, in which he gives Bartram a page and a half of hearty commendation, saying among other things: "We owe to him the knowledge of many scarce plants, which he first found, and which were never known before. ... I likewise owe him many things, for he possessed that great quality of communicating everything he knew. I shall, therefore, in the sequel frequently mention this gentleman." On nearly every one of the next twenty pages credit is given to Bartram for information.

In 175 Benjamin Franklin and D. Hall published at Philadelphia an American edition of Dr. Thomas Short's Medicina Britannica, "with a Preface by Mr. John Bartram, Botanist, of Pennsylvania, and his Notes throughout the work;... and 
an Appendix, containing a description of a number of Plants peculiar to America, their uses, virtues, etc." The notes told

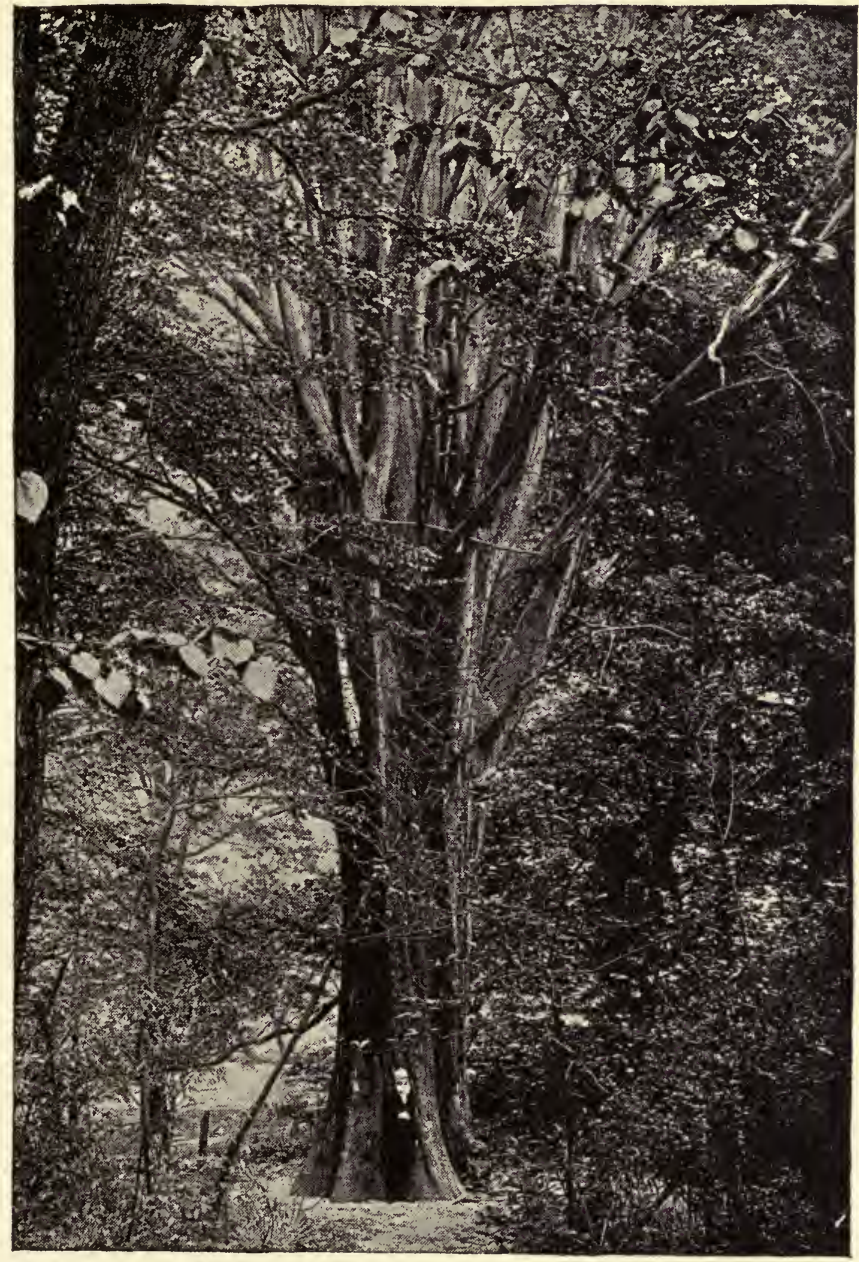

Fig. 2.-Cypress Tree in Bartram Park.

Circumference at base, 27 feet 6 inches.

where the plants were found in America, and how they differed from the English varieties.

John Bartram's son William begins to figure in his father's correspondence when about fifteen years old. At that time Bartram sent some of William's drawings of natural objects to 
Collinson, and took him on a trip to the Catskills. In 1755 Bartram writes: "I design to set Billy to draw all our turtles with remarks, as he has time, which is only on Seventh days in the afternoon, and First-day mornings; for he is constantly kept to school to learn Latin and French." This attention to the languages indicates that Bartram was determined that his son should not suffer from the lack of knowledge by which his own reading of works on natural history had been limited. William was then attending the old college in Philadelphia.

The same passage shows also that Bartram's ideas about Sunday occupations was somewhat unusual for that generation, and in fact it is stated that he was excommunicated by his brother Quakers about this time for his independent religious views. The question of an occupation for William now came up, and in the letter just quoted his father asks Collinson's advice in the matter. "My son William," he writes, "is just turned of sixteen. It is now time to propose some way for him to get his living by. I don't want him to be what is commonly called a gentleman. I want to put him to some business by which he may, with care and industry, get a temperate, reasonable living. I am afraid that botany and drawing will not afford him one, and hard labour don't agree with him. I have designed several years to put him to a doctor, to learn physic and surgery; but that will take him from his drawing, which he takes particular delight in. Pray, my dear friend Peter, let me have thy opinion about it." Franklin offered to teach William the printing trade, but Bartram was not quite satisfied with the prospects for printers in Pennsylvania, and Franklin then suggested engraving. But William became neither printer nor engraver. At the age of eighteen he was placed with a Philadelphia merchant, Mr. Child, where he remained about four years.

Bartram's science was largely practical. He wrote to Dr. Alexander Garden, of Charleston, in r 755, suggesting a series of borings on a large scale, to search for valuable mineral products. He gives as another reason the satisfaction to be derived from knowing the composition of the earth, and adds, "By this method we may compose a curious subterranean. map." "This scheme of John Bartram's," says Darlington"if original with him-would indicate that he had formed a pretty good notion of the nature and importance of a geo- 
logical survey and map, more than half a century before such undertakings were attempted in our country, or even thought of by those whose province it was to authorize them."

Bartram was evidently much interested in geological subjects; thus, in $175^{6}$ he writes, "My dear worthy friend, thee can't bang me out of the notion that limestone and marble were originally mud, impregnated by a marine salt, which I take to be the original of all our terrestrial soils."

In 1760 he makes a trip through the Carolinas, his Journal of which he wrote out and sent to England. The following summer, William, then twenty-two years old, went to North Carolina and set up as a trader at Cape Fear, where his uncle William had settled when a young man. That year John Bartram makes a journey to Pittsburg and some way down the Ohio River, keeping a journal, as usual, which is sent to his English friends. Nearly all of these trips were made in autumn, so as to get ripe seeds of desirable trees and plants.

Bartram had too tender a feeling toward animal life to be much of a zoölogist. He says on this score: "As for the animals and insects, it is very few that I touch of choice, and most with uneasiness. Neither can I behold any of them, that have not done me a manifest injury, in their agonizing mortal pains without pity. I also am of opinion that the creatures commonly called brutes possess higher qualifications, and more exalted ideas, than our traditional mystery-mongers are willing to allow them." His ideas concerning animal psychology were thus clearly in advance of his time.

The war with France, known to Americans as the French and Indian War, resulted in extending the British possessions in America as far west as the Mississippi River. Immediately a desire was expressed in England for a thorough exploration of this great accession of territory. Bartram writes in 1763 that this could not be made without great danger from the Indians. His own expeditions had been very short during the hostilities. The late war had shown the colonists what atrocities the savages were capable of, and the prevailing feelings toward the red men had become dread and hatred. "Many years past in our most peaceable times," writes Bartram, "far beyond the mountains, as I was walking in a path with an Indian guide, hired for two dollars, an Indian man met me and pulled off my hat in a great passion, and chawed it all round- 
I suppose to show me that they would eat me if I came in that country again." In two other letters he declares that the only way to make peace with the Indians "is to bang them stoutly." The question arises whether the combative disposition of the botanist thus revealed might not have been one of the reasons for his exclusion from the Society of Friends.

In 1764 Bartram sends to England his Journal to Carolina and New River. In this year, one Young, of Pennsylvania, managed to gain the favour of the new king, George III, by sending him some American plants, and obtained sudden preferment. It was said that all the plants had been sent to England before-many of them by Bartram. The friends of our botanist, feeling that he was much more deserving of such favour, urged him to send some specimens to the king, which he does through Collinson, desiring that he may be given a commission for botanical exploration in the Floridas. April 9, 1765, Collinson writes, "My repeated solicitations have not been in vain," and reports that the king has appointed Bartram his botanist for the Floridas, with a salary of fifty pounds a year. This appointment continued till the death of the botanist, twelve years after. Bartram accordingly made an expedition in the South the next fall. He was then sixty-six years old; and, although his eagerness for exploring was undiminished, he felt the need of a companion on this trip, and got William tc go with him, the latter closing out his not very successful business at Cape Fear in order to do so. In his sketch of his father, William states that he had been ordered to search for the sources of the river San Juan (St. John's), and that he ascended the river its whole length, nearly four hundred miles, by one bank, and descended by the other. He explored and made a survey of both the main stream and its branches and connected lakes, and made a draught showing widths, depths, and distances. He also noted the lay of the land, quality of the soil, the vegetable and animal productions, etc. His report was approved by the governor of the province, and was sent to the Board of Trade and Plantations in England, by which it was ordered published "for the benefit of the new colony." Bartram collected a fine lot of plants, fossils, and other objects of interest on this trip, which were forwarded to the king, who was reported to be much pleased with them. His journal is still extant, in a volume with an Account of East Florida, by 
William Stork, published in England. It is evident from this production that the botanist was not a ready writer. His observations are minute and sagacious, and his language is simple, but his sentences are loosely strung out, and the record is the barest statement of facts. His Journal tn the Five Nations, however, is much more readable.

William seems to have been much taken with Florida, and accordingly his father helped to establish him as an indigoplanter on the St. John's River. After about a year of disastrous experience he returned to his father's home and went to work on a farm in the vicinity. Collinson had been watching for an opening for William in England, but so far nothing had come of it. The next year he writes that the Duchess of Portland, a "great virtuoso in shells and all marine productions," had just dined at his house, and, having seen William's drawings, "she desires to bestow twenty guineas on his performances for a trial." The kind of objects she wants drawn are told. The same month, July I8, r768, Collinson writes to William that he had also secured an order from Dr. Fothergill for drawings of shells, turtles, terrapin, etc. This was probably the last letter of Collinson to the Bartrams, as he died on the $\mathrm{r}$ Ith of the following month. During his long friendship with John Bartram the two men had never met.

William now began to send drawings and descriptions to Dr. Fothergill from time to time. In $\mathrm{I}_{772}$ he began explorations in the Floridas, Carolina, and Georgia, the expense of which for nearly five years was borne by Dr. Fothergill, and to him William's collections and drawings were turned over. William made many contributions to the natural history of the country through which he travelled, and in r79r published his Travels through North and South Carolina, Georgia, East and West Florida, together with an account of the Creek, Cherokee, Choctaw, and other tribes of Indians which he visited. His opinion of the red men is much more favourable than that of his father. The volume contains many engravings of plants and birds from the author's own drawings. Of this book Coleridge said: "The latest book of travels I know written in the spirit of the old travellers is Bartram's account of his tour in the Floridas. It is a work of high merit every way."

Among the influential friends of the elder Bartram was Benjamin Franklin. While in England Franklin writes to him 
and sends him seeds of garden vegetables at various times; and when the Revolution had stopped Bartram's sending seeds to England for sale, Franklin offers to sell them for him in France.

Among the testimonials to his botanical achievements that Bartram received was a gold medal, weighing 487 grains, from a society in Edinburgh, founded in 1764 , for obtaining seeds of useful trees and shrubs from other countries. This medal is inscribed, "To Mr. John Bartram, from a Society of Gentlemen at Edinburgh, I772"; and on the reverse, "MERENTI," in a wreath. The medal is figured in Darlington's Memorials, and when that book was published was in the possession of a Mrs. Jones, a descendant of the botanist. April 26, i769, the Royal Academy of Sciences, of Stockholm, on the proposal of Professor Bergius, elected Bartram to membership. Another honour that he received from the same country was a letter from Queen Ulrica, and with this may be mentioned the opinion passed upon him by Linnæus, who called Bartram the greatest natural botanist in the world. Bartram was one of the original members of the American Philosophical Society, and contributed many papers to its Transactions.

The closing years of John Bartram's life were the opening years of the Revolution. He was living when independence -was declared in the neighbouring city of Philadelphia, but died the following year, September 22, 1777, at the age of seventyeight. A granddaughter, who remembered him distinctly, has stated that he was exceedingly agitated by the approach of the British army after the battle of Brandywine, and that his days were probably shortened in consequence. The royal troops had been ravaging the country, and he was apprehensive lest they should lay waste his darling garden.

His son William describes him as "a man of modest and gentle manners, frank, cheerful, and of great good nature; a lover of justice, truth, and charity.... During the whole course of his life there was not a single instance of his engaging in a litigious contest with any of his neighbours or others. $\mathrm{He}$ zealously testified against slavery, and, that his philanthropic precepts on this subject might have their due weight and force, he gave liberty to a most valuable male slave, then in the prime of his life, who had been bred up in the family almost from infancy." He was of an active temperament, and 
often expressed the wish that he might not live to be helpless. This desire was gratified, for he died after only a short illness.

No picture of him is known to exist. In regard to his physical appearance William states: "His stature was rather above the middle size, and upright. His visage was long, and his countenance expressive of a degree of dignity with a happy mixture of animation and sensibility." Concerning Bartram's ability as a naturalist there are enthusiastic opinions extant in letters by Franklin, Collinson, Colden, and others well qualified to judge.

William Bartram, after the death of his father, continued in the pursuit of natural history. The Botanic Garden was inherited by his brother John, who took William into a partnership which lasted many years. After this arrangement terminated, William continued to assist his brother till the death of the latter, in 1812 . The garden then descended to John's daughter Anne, the wife of Colonel Robert Carr, in whose family William resided from that time until his death. He was never married. In $\mathbf{I}_{782}$ William Bartram was elected Professor of Botany in the University of Pennsylvania, but declined the position on account of ill health. He became a member of the American Philosophical Society in 1786 , and was elected to other learned societies in both Europe and America. He was an ingenious mechanic, and, as before intimated, was skilful in drawing and painting. Most of the illustrations in Prof. Barton's Elements of Botany were from his drawings. His botanical labours brought to light many interesting plants not previously known. But this was not his only field. He made the most complete and correct list of American birds before Wilson's Ornithology, and, in fact, his encouragement and assistance were largely instrumental in making that work possible. Among William Bartram's scientific correspondents were the Rev. Henry Muhlenberg and F. A. Michaux, to whom he furnished seeds. A manuscript diary kept by him, which was presented to the Academy of Natural Sciences of Philadelphia in 1885 , by Mr. Thomas Meehan, is rich in ornithological, botanical, and meteorological notes, also records of personal experiences, all of which are of great interest. His death occurred suddenly from the rupture of a blood vessel in the lungs, July 22,1823 , in the eighty-fifth year of his age. Besides his Travels, William Bartram was the 
author of Anecdotes of a Crow and Description of Certhia. In I789 he wrote Observatio on the Creek and Cherokee Indians, which was published in $185 \mathrm{r}$, in the Transactions of the American Ethnological Society, Vol. III. Our portrait of him is from an engraving which formed the frontispiece to the second volume of the Cabinet of Natural History and American Rural Sports, published in Philadelphia in $183^{2}$ by J. \& T. Dougherty. Concerning its authenticity the statement is made in the accompanying biographical sketch that " the portrait is a

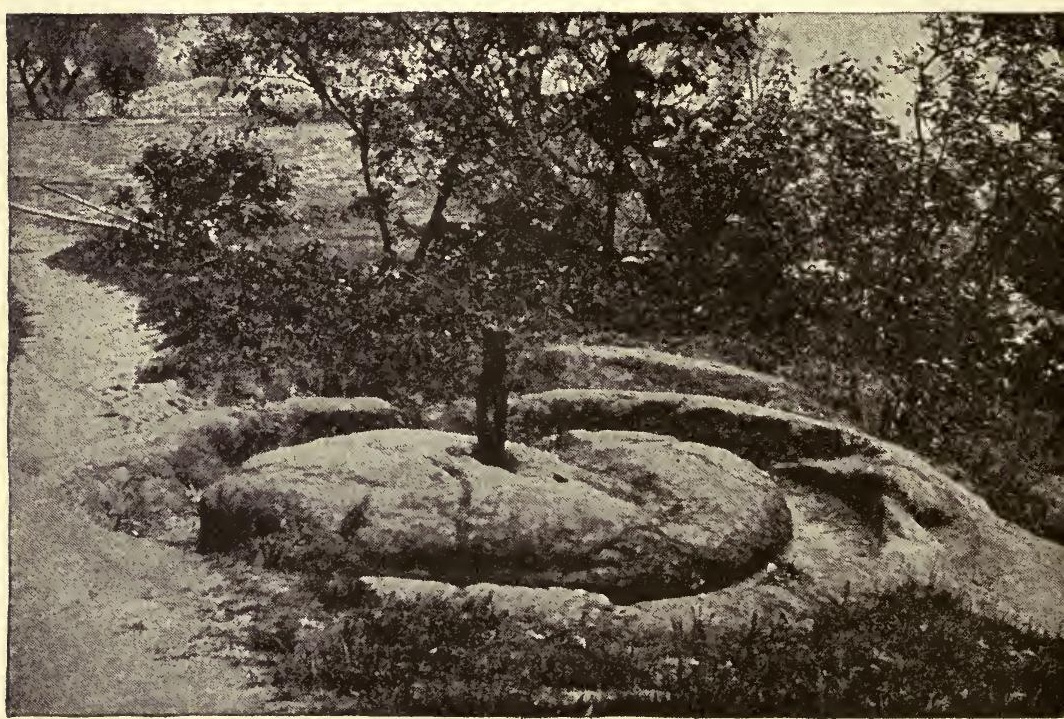

Fig. 3.-Nether Stone of John Bartram's Cider Mill.

correct likeness of Mr. Bartram, and the only engraved one ever given to the American public." It will be observed that the date of the publication of this portrait was only nine years after William Bartram's death.

In the old stone house the great fireplace has been filled up, although but few other changes have been made. The building is full of curious turns and cubby-holes. Connected with a cupboard in the sitting room is a recess running behind the chimney, which furnished a safe depository in winter for specimens that frost could injure. Back of the sitting room, in the wing of the building, is an apartment with large windows looking toward the south, which was the botanist's conserva- 
tory. Here were reared such pepots as could not stand a Pennsylvania winter-gathered in Fic tha or the Carolinas, or sent from Europe. In the grounds close to the river is a great imbedded rock, hewn flat, in which is cut a wide, deep groove. This is the nether stone of John Bartram's cider mill. The Botanic Garden remained in the possession of Colonel Carr till about $185^{\circ}$, when it became the property of Mr. A. M. Eastwick. This gentleman had derived much pleasure from visiting it as a boy, and was resolved to preserve it without the sacrifice of a tree or a shrub. In I853 a Handbook of Ornamental Trees, by Mr. Thomas Meehan, was published, the main purpose of which, as stated in its preface, was to describe the trees then in the Bartram garden. After Mr. Eastwick's death, the fate of the garden was for some time dubious. His executors saw no duty but to get as much money out of the estate as possible. About 1880 Prof. C. S. Sargent, of Harvard University, obtained the promise of a private subscription to buy the old garden, and a price was agreed upon, but the executors withdrew from the agreement. In $1882 \mathrm{Mr}$. Thomas Meehan became a member of the Common Council of Philadelphia and at once introduced a scheme for small parks for the city, in which the Bartram place was included. Repeated re-elections enabled him to follow the matter up, and finally, in the spring of $189 \mathrm{I}$, the city took possession of the property, and put a superintendent in charge of it. The great gale of September, 1875 , and some fifteen years of neglect had had their effect among the trees, but many planted by the botanist's own hands yet remain. It should be a source of gratification to all cultivators of science that this relic of the beginnings of botany in America is now assured of preservation. 


\title{
JOHN WINTHROP.
}

\author{
I 7 I 4-I 779 .
}

THE name of Winthrop has always been an honoured one in New England, in the domain of public affairs, and one member of the family, at least, has placed it high on the rolls of science. Several of the Winthrops of colonial times were cultivators of the sciences, but none employed such high talents so exclusively in this field of activity as did the subject of the present sketch.

John Winthrop, one of many Johns in that family, was born in Boston, December 8, 17r4. His family history is a part of the history of Massachusetts. His father, Judge Adam Winthrop, was a great-grandson of the first Governor of the Massachusetts Bay Colony; a graduate of Harvard; chief justice of the Court of Common Pleas; colonel of the Boston regiment; and a lay member of the Provincial Council. John Winthrop was graduated from Harvard College in $173^{2}$. Six years later, being then twenty-four years old, he was elected to the Hollis professorship of Mathematics and Natural Philosophy by the corporation of the college. The choice being submitted to the overseers of the college, that body appointed a committee " to examine the professor-elect as to his knowledge of the mathematics," which soon reported favourably. Certain of the overseers, who were especially anxious to protect the college from any possible contamination of heresy or schism, tried to have a committee appointed "to examine Mr. Winthrop about his principles of religion." This matter was debated at several meetings, but finally voted down, and Winthrop's election was thereupon approved. He was formally inaugurated, as was then the custom, January 2, 1738-'39. The ceremonies included two Latin orations, the reading of the rules to govern the professor, prescribed by the founder of the 


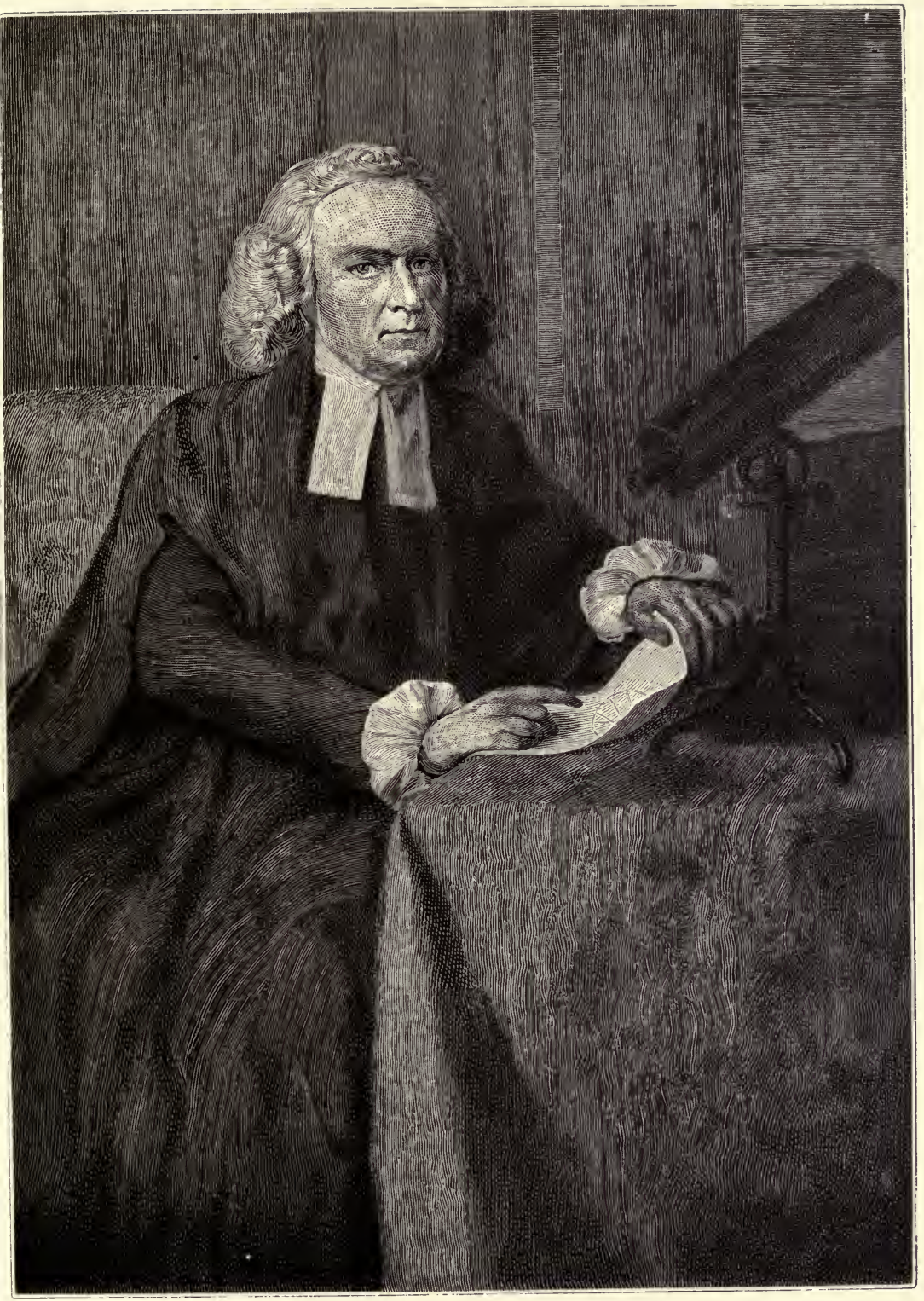

JOHN WINTHROP. 

professorship, and the singing of a psalm, after which came a dinner.

Soon after entering upon his professorship, in 1740 , Winthrop observed a transit of Mercury over the sun, and sent a report of his observations to the Royal Society. This paper was printed in the society's Transactions, and was favourably mentioned in the Memoirs of the French Academy. Prof. Winthrop was thanked by the society, and was asked to continue his communication. Winthrop was now launched upon a long and useful career, during which he was held in high esteem as a teacher of science at home, while his investigations won him much credit abroad. There is sufficient evidence as to his success as an instructor to justify the words of President Quincy, who, in his History of Harvard University, says of Winthrop: "The zeal, activity, and talent with which he applied himself to the advancement of these sciences [i. e., physics and astronomy] justified the expectations which his early promise had raised. As a lecturer he was skilful and attractive, and during forty years he fulfilled the duties of the professor's chair to universal acceptance." Many of his papers on astronomical subjects are to be found in the volumes issued by the Royal Society during his lifetime, among these being an essay on comets, in Latin, entitled Cogitate de Cometis, which he transmitted to the society in 1765 , on the occasion of his becoming a member of that body.

On November 18, 1755, an earthquake occurred which terrified the superstitious people of all New England, who regarded it as a direct expression of the wrath of God. To calm the popular terror, Prof. Winthrop read a public lecture on the earthquake in the college chapel. He accounted for such disturbances as being produced by the expansive action of heat upon vapours contained in underground cavities, and argued ably in support of this theory. $\mathrm{He}$ also stated that earthquakes had occurred at intervals in New England from the time the first settlers landed, but that not a single life had ever been lost, nor had any great damage ever been done by them. In conclusion, he maintained that earthquakes are "neither objections against the order of Providence nor tokens of God's displeasure, according to the views of skeptical or superstitious minds, but that they are the necessary consequences of general laws." This lecture was published by 
request of the college authorities, and an account of the earthquake which Winthrop sent to the Royal Society was also printed.

At that time lightning rods had been invented about three years, and a Boston minister published an essay in which he suggested that the use of Franklin's "iron points" might have caused the earthquake by drawing the electric fluid from the clouds and concentrating it on that part of the earth. This led Prof. Winthrop to add an appendix to his lecture in which he defends the discoveries of his friend Franklin, and shows the unreasonableness of attributing the earthquake to the action of the rods. He concludes with the hope that he has "fully vindicated the character of those innocent and injured iron points." Some years after, in 1770 , he seized another opportunity to defend Franklin's invention, by publishing an essay against the notion that there was great impiety in using lightning rods, since they prevented the "tokens of Divine displeasure" from "doing their full execution." Under date of October 26, I770, he writes to Franklin, who was then in London, acknowledging the execution of several commissions concerning books and instruments, and says in regard to the rods : "I have on all occasions encouraged them in this country, and have the satisfaction to find that it has not been without effect. A little piece I inserted in our newspapers last summer induced the people of Waltham (a town a few miles from hence) to fix rods upon their steeple, which had just before been much shattered and set on fire by lightning." *

Prof. Winthrop had a clearer understanding of earthquake movements than the generality of scientific men of his time, and was one of the earliest, if not the first, to apply computation to these phenomena. The chimney of his house was thirtytwo feet high, and, observing that bricks were thrown from it so that they fell thirty feet from its foot, he calculated the speed of their motion and found it to be twenty-one feet a second. He perceived also the resemblance between the vibrations of the earth and those of the strings of a musical instrument.

The fullest published account of the scientific work of Prof. Winthrop is contained in the chapter on Boston and Science,

* Massachusetts Historical Society's Proceedings, vol. xv, p. I3. 
contributed to the Memorial History of Boston by Prof. Joseph Lovering, who for over fifty years occupied the same professorship that Winthrop held. "Prof. Winthrop was fortunate," says Prof. Lovering, "in living at a time when he could be a witness of three celestial occurrences of transcendent importance to the progress of astronomy-namely, the first predicted return of Halley's comet in I 759, after an absence of twenty-seven years, and the transits of Venus across the sun in I $76 \mathrm{I}$ and $\mathrm{I769}$. In $\mathrm{r} 759$ the accuracy of astronomical prediction was on its trial, and months before the time of the expected visit astronomers were at their posts and looking; but they were all anticipated by a Saxon peasant, who first saw the comet on December 25, 1758. Winthrop saw it on April 3, r759." He delivered two lectures on comets at this time, which were printed the same year, and reprinted in $18 \mathrm{r}$. Prof. Winthrop also observed the comets of 1769 and of 1770 , "one remarkable for its brilliancy and the other for the disturbances which Jupiter inflicted upon its orbit," and contributed accounts of the phenomena to the Boston newspapers.

Like the earthquake already mentioned, the comet of $\mathbf{1 7 5 9}$ aroused considerable popular apprehension, and the following passage from one of Winthrop's lectures, in which he essayed to calm this feeling, will serve as a good sample of his style: "It may not be unseasonable to remark, for a conclusion, that as, on the one hand, it argues a temerity unworthy a philosophic mind, to explode every apprehension of danger from comets, as if it were impossible that any damage could ever be occasioned by any of them, because some idle and superstitious fancies have in times of ignorance prevailed concerning them; so on the other, to be thrown into a panic whenever a comet appears, on account of the ill effects which some few of these bodies might possibly produce, if they were not under a proper direction, betrays a weakness equally unbecoming a reasonable being."

The transits of Venus, which were not to occur again until I 874 and 1882 , were precious opportunities for astronomical work, and preparations were widely made to take advantage of them. The governor of the province, Francis Bernard, was interested in the matter by Prof. Winthrop, and sent a message to the House of Representatives, stating that the King of England had sent "a Man-of-War with Mathematicians to be 
stationed in different Parts of the East Indies, etc.," to observe the transit; that the French king and other powers had taken similar action, the comparison of observations taken in different parts of the earth being important; that Prof. Winthrop had offered to go to Newfoundland for the same purpose; and he therefore recommended that the House furnish the professor transportation on the province sloop, which would be sent to Penobscot a little before the time of the transit. The House of Representatives immediately passed a vote in accordance with this suggestion.

The sloop with Prof. Winthrop on board sailed from Boston May 9th, and reached St. John's thirteen days later. The professor took with him the college instruments and two members of the senior class. Some difficulty was met with in finding a suitable station, but at last a position was taken on a considerable elevation, which was afterward named Venus Hill. The work of setting up the clock and other instruments was made arduous by persecution from swarms of bloodthirsty insects, which had possession of the hill. June 6th was the day of the transit, and the weather proved favourable. In every part of America except Labrador the phenomenon began before sunrise. At St. John's the sun rose at $4 \mathrm{~h}$. $18 \mathrm{~m}$., with Venus upon its disk, from which the planet passed off at $5 \mathrm{~h} .6 \mathrm{~m}$. On his return Prof. Winthrop published an account of his voyage and his observations.

When the transit of June $3, \mathrm{r} 769$, was approaching he delivered two lectures on the coming phenomenon, which were published. Dr. Maskelyne, then astronomer royal of England, desired that Prof. Winthrop should go to the neighbourhood of Lake Superior, where the whole of this transit would be visible, but his health would not admit of this. Accordingly, he saw only the beginning of the passage, as at Cambridge the sun set before it was finished. Prof. Winthrop observed the transit of Mercury January $20, \mathrm{I}_{7} 6_{3}$, and prepared an account of it for the Memoirs of the American Academy of Sciences (vol. i, p. 57), of which society he was one of the founders.

As a mathematician and astronomer Prof. Winthrop had no equal in the American colonies, and his fellowship of the Royal Society, together with the degree of LL. D. which he received from the University of Edinburgh in 1771 , attests his reputation in the mother country. Prof. Lovering states that 
his views of the nature of heat were greatly in advance of the science of his day. His scholarship, moreover, was not limited to his specialty. He wrote Latin with purity and elegance, studied the Scriptures critically in their original languages, and was well versed in the tongues of modern Europe. "He is, perhaps," says Quincy, "better entitled to the character of a universal scholar than any individual of his time in this country." Rev. Charles Chauncy, D. D., in A Sketch of Eminent Men in New England, written in I768, says: "Mr. Winthrop, Hollisian professor, I have been very free and intimate with. $\mathrm{He}$ is by far the greatest man at the college in Cambridge. Had he been of a pushing genius and a disposition to make a figure in the world, he might have done it to his own honour, as well as the honour of the college." *

The office of a professor in Harvard College during the last century was not a lucrative one. The salaries obtained were fluctuating and always small. From about the middle of the century the Professor of Mathematics and Physics received $£ 80$ a year. In reply to inquiries made by a committee of the Provincial Legislature, Winthrop wrote a letter in which he stated that his salary had been far from adequate, and that he had run in debt for the support of his family.

Prof. Winthrop married, August 22, 1746, Rebecca, daughter of James Townsend, of Boston, and by this marriage had five sons. His wife died after seven years, and he married again in 1756. His second wife was Hannah, daughter of Thomas Fayerweather, and widow of Farr Tolman, of Boston. She was the well-known correspondent of Mrs. John Adams.

Four of Prof. Winthrop's sons lived to adult age. Of these John became a merchant in Boston and was a member of the Massachusetts Legislature. Adam was a sea captain, and was lost at sea in 1774. James was Librarian of Harvard College, a Judge of the Court of Common Pleas, and one of the founders of the Massachusetts Historical Society. He was in the battle of Bunker Hill and was wounded. William was an active member of several learned societies.

The first vacancy in the presidency of Harvard College that occurred during Prof. Winthrop's professorship was made by the death of President Holyoke in June, 1769. Winthrop

* Massachusetts Historical Society's Collections, Series I, vol. x, p. I59. 
presided at commencement that year, and had he been a few years younger (he was then fifty-five) would doubtless have become president of the college. In a letter to Mr. Thomas Hollis, in England, under date of July זо, ז769, Dr. Andrew Eliot, a member of the corporation, remarks: "It is difficult to find one every way qualified to undertake such a task. Mr. Winthrop, Hollis Professor of Mathematics, will probably be the successor to Mr. Holyoke. His learning and abilities are unquestionable. He is older than we could wish, and is frequently taken off from business by bodily infirmities." The office was tendered to Prof. Winthrop, but he declined it. In I774, when the chair was again vacant, it was offered to Winthrop a second time, and again declined.

The tide of discontent with the mother country was now running high in the colonies, and Winthrop was clearly identified with the patriot cause. The Massachusetts Historical Society's Collections (Series V, vol. iv) contain a correspondence between the professor and John Adams. The letters cover a period within which occurred the battle of Bunker Hill, the evacuation of Boston, and the Declaration of Independence; and they show that Winthrop had a thorough understanding of public affairs, a fearless patriotism, and an eager desire for American independence. In 1773 he was elected to the Governor's Council, but, together with two other members, all having been opponents of the Government, he was negatived by Governor Gage, in compliance with a special mandate from the English ministry. Prof. Winthrop was chosen a delegate to the Provincial Congress in 1774 , and in 1775 was finally admitted to a seat in the Council. About this time he was appointed Judge of Probate for Middlesex County, and held the office for the remaining years of his life. His death occurred in Cambridge, before the Revolutionary struggle was decided, on May 3, I779.

The portrait which accompanies this sketch has been engraved from a photograph, furnished by Mr. Robert C. Winthrop, of a painting by Copley, which belonged to the late Colonel John Winthrop, of Louisiana, a great-grandson of the professor, and his last descendant in the male line. 



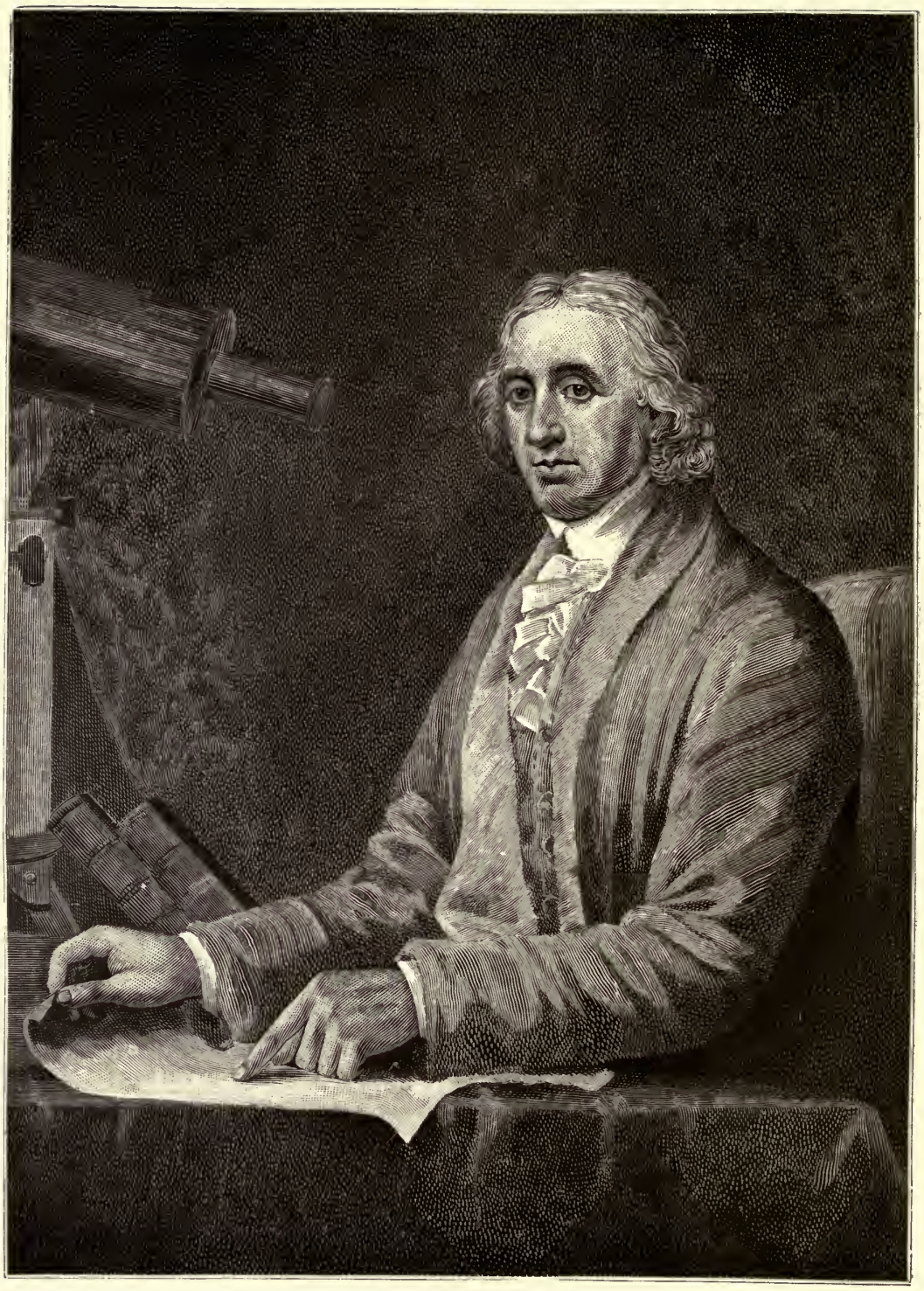

DAVID RITTENHOUSE. 


\section{DAVID RITTENHOUSE.}

$$
\text { I } 732-1796 .
$$

"As a citizen of Pennsylvania," says William Barton, in the preface to his Memoirs of the Life of David Rittenhouse; "as an inestimable public and private character; as a distinguished son of science, of great probity and extensive usefulness in society-in all these points of view, the history of Dr. Rittenhouse may be contemplated as holding a relationship with almost every object connected with science and art in his day that could in any way contribute to the wellbeing of mankind in general and his native country in particular." He, in fact, acquired a fame in the period of the infancy of American science, the nature and extent of which can hardly be realized in this day; and his gifts, then regarded as extraordinary, were always freely placed at the service of the public.

David Rittenhouse was born in Roxborough Township, near Germantown, Pa., April 8, r732, and died in Philadelphia, June 26, I796. He was descended from a family of papermakers residing at Arnheim, Guelderland. His great-grandfather, Wilhelm Rittinghuysen, came from Holland with his family in 1687 -'88; he was the first Mennonite minister in Pennsylvania; and established the first paper mill in this country, at the spot where David was born. David's grandfather, Nicholas, continued in the hereditary industry of his family, and his father, Matthias, was brought up in it. Matthias Rittenhouse, in 1727 , married Elizabeth, daughter of Evan William, a native of Wales. Barton, who was her grandson, credits her with "a cheerful temper," and "a mind uncommonly vigorous and comprehensive," but states she had received very little education, owing to her having been left an orphan at an early age.

David was the third child and the eldest of four sons in a 
family of ten children. When he was a few months old, his father quit paper-making and went to farming at Norriton, about twenty miles from Philadelphia. David was early put to work on the farm, and was ploughing at fourteen years of age. An uncle dying had left him a chest of tools and a few books on arithmetic and geometry, with some manuscript mathematical calculations. These furnished palatable food to his mind, and his biographers tell of his having covered the handle of his plough and the fences around the field with his workings of the problems which they set before him. As the uncle mentioned above was his mother's brother, it is inferred that he inherited his genius from his mother's side. His mechanical talent was shown in his construction of a complete water wheel in miniature when eight years old, a wooden clock when seventeen, and a clock with metallic works at a later age. His father was not disposed at first to favour the youth's tastes, but eventually he furnished him with money enough to buy a set of clock-making tools; and David built a workshop at Norriton, where he carried on the clock-making business for several years. $\mathrm{He}$ at the same time pursued his studies so diligently that he impaired his constitution, and contracted an internal pain that afflicted him all his life. Astronomy appeared to be his favourite study; and he was interested in optics and mechanical science. He discovered himself, independently, the method of fluxions, of which, in his imperfect knowledge of what Newton and Leibnitz had done, he believed himself to be the originator; and mastered the English translation by Motte of Newton's Principia.

The acquaintance which he formed in $175 \mathrm{I}$ with Thomas Barton, who afterward married his sister, had an important influence in shaping his career. Rittenhouse, according to William Barton, "possessed a sublime native genius; which, however, was yet but very imperfectly cultivated for want of indispensable means of extending the bounds of natural knowledge." Barton had enjoyed these means, and had acquired the reputation of being a man of learning. He found Rittenhouse's society profitable, and Rittenhouse found his equally so. Barton aided Rittenhouse greatly by helping him to the books he needed. Partly through his instrumentality a circulating library was established at Norriton; and he bought books for Rittenhouse when he went to Europe. 
The life of Rittenhouse came near being cut short in 1756 by a discharge of lightning which struck a poplar tree growing before his father's door. David was standing between the tree and the house and suffered a severe shock.

Mr. Rittenhouse was called upon in 1763 to determine the initial of the boundary line between Pennsylvania and Maryland, his particular duty being defined to be to ascertain and fix the "circle to be drawn at twelve miles' distance from New Castle, northward and westward, with the beginning of the fortieth degree of north latitude," etc. The work was an arduous one, and involved going through a number of tedious and intricate calculations. It was performed in a satisfactory manner-for which acknowledgment was made in the shape of extra compensation-and with instruments largely of Rittenhouse's own making; and his observations were accepted without change by the official astronomers, Mason and Dixon, when they took charge of the work. He was afterward appointed to a similar work in 1769 , by the commission to settle the boundary between New York and Pennsylvania. Among his scientific studies at this period were the investigation of variations in the oscillations of the pendulum under changes of temperature, with the device of a plan for compensation, and the construction of what he called a metalline thermometer. This instrument was so made-on the principle of the expansion and contraction of metals under variations of temperature-that the degrees of heat and cold were indicated by the movements of an index moving along a graduated semicircle. It was adapted, in form and size, to be carried in the pocket. He discussed the compressibility of water in the light of an experiment that had been reported to the Royal Society, and observed, in a letter to Mr. Barton, that, although the experiment did not please him, he did not doubt the fact; for, "if the particles of water were in actual contact, it would be difficult to conceive how any body could much exceed it in specific gravity; yet we find that gold does, more than eighteen times." We find him also at this time ( 1767 ) indulging in some amusing speculations on the possibility of a man moving the world. Some one having published the result of calculations he had made respecting the fulfilment of Archimedes's famous dictum on the subject, Mr. Rittenhouse gave the result of his own computations, which was 
that "the force wherewith a man acts when he lifts a weight of two hundred pounds, if applied without intermission for the space of one hundred and five years, is sufficient, without any machinery, to move the earth one inch in that time; and it must, from the velocity received by that force alone, continue forever after to move at the rate of one inch in fifty years." The first calculator had computed that twenty-seven billions of years would be required to accomplish the movement.

Rittenhouse married, February 20, I766, Eleanor, daughter of Bernard Colston, by whom he had two daughters.

Mr. Rittenhouse's reputation as an astronomer became conspicuous, and his name, according to Mr. Barton, acquired a celebrity even in the Old World, "of which his early but now much-increased fame in his native country was a sure presage." A great bound was given to his fame by his construction of an orrery, or apparatus for illustrating the planetary motions, and by the conspicuous part which he took in the observations of the transit of Venus of 1769 .

The design of the orrery is indicated in the correspondence with Mr. Barton in ${ }_{7} 67$, in the course of which Mr. Rittenhouse says: "I did not design a machine which should give the ignorant in astronomy a just view of the solar system; but would rather astonish the skilful and curious examiner by a most accurate correspondence between the situations and motions of our little representatives of the heavenly bodies and the situations and motions of those bodies themselves. I would have my orrery really useful by making it capable of informing us truly of astronomical phenomena for any particular point of time, which I do not find that any orrery yet made can do."

This instrument was bought before it was finished for Princeton College. The trustees of the College of Philadelphia had also been bargaining for it, and were disappointed over the turn the affair had taken. Mr. Rittenhouse had made a saving clause in his bargain in favour of the College of Philadelphia, in agreement with which he began another orrery for that institution. "This," he said, "I am not sorry for, since the making of the second will be but an amusement compared with the first; and who knows but that the rest of the colonies may catch the contagion?" The 
sum of two hundred pounds was obtained toward paying for the instrument by means of lectures on astronomy delivered by Rittenhouse's friend, the Rev. Dr. Smith, Provost of the College of Philadelphia, concerning which the Rev. Dr. Peters wrote, "The doctor in his introductory lecture was honoured with the principal men of all denominations, who swallowed every word he said with the pleasure that attends the eating of the choicest viands, and in the close, when he came to mention the orrery, he overexcelled his very self." The members of the Assembly of Pennsylvania took a view of the orrery, and, "being of the opinion that it greatly exceeds all others hitherto constructed, in demonstrating the true Situations of the celestial Bodies, their Magnitudes, Motions, Distances, Periods, Eclipses, and Order, upon the principles of the Newtonian System," voted the constructor three hundred pounds in consideration of his mathematical genius and mechanical abilities, and appointed a committee to agree with him for a new orrery for the use of the public. This purpose was not carried out. Mr. Rittenhouse became engaged in public enterprises, which occupied his time till the beginning of the Revolution, when all other interests were suspended.

The praises which were bestowed upon Mr. Rittenhouse for his orrery were extravagant, and seem now even absurd; but nothing, perhaps, can more clearly illustrate the infantine condition of American science at the time.

Mr. Barton, by way of emphasizing the assertion that the skill and accuracy he displayed in the construction of his mathematical and astronomical instruments were not surpassed by similar works of the most celebrated British mathematicians, remarks that "his profoundness in, astronomical science and his wonderful ingenuity, manifested in the construction of his orrery, leave him without a rival in the twofold character of an astronomer and mechanic." Dr. Jedediah Morse, in his Geography ( 1789 ), noticing some of the more prominent productions of scientific ingenuity and skill in America, observed that "every combination of machinery may be expected from a country a native son of which, reaching this inestimable object in its highest point, has epitomized the motions of the spheres that roll throughout the universe." Mr. Thomas Penn, of London, was surprised that the instrument could have been 
executed in Pennsylvania. Joel Barlow wrote, in the Vision of Columbus :

"See the sage Rittenhouse, with ardent eye, Lift the long tube and pierce the starry sky; Clear in his view the circling systems roll, And broader splendours gild the central pole;

He marks what laws th' eccentric wand'rers bind, Copies Creation in his forming mind, And bids beneath his hand in semblance rise, With mimic orbs, the labours of the skies."

Thomas Jefferson, successor of Mr. Rittenhouse as President of the American Philosophical Society, wrote, in his Notes on Virginia, in refutation of the Abbe Reynal's assertion that America had "not produced one able mathematician, one man of genius in a single art or science": "We have supposed $\mathrm{Mr}$. Rittenhouse second to no astronomer living; that in genius he must be the first, because he is self-taught. As an artist he has exhibited as great a proof of mechanical genius as the world has ever produced. He has not, indeed, made a world; but he has by imitation approached nearer its Maker than any man who has lived from the creation to this day."

A committee of thirteen persons was appointed by the American Philosophical Society early in 1769 to view the transit of Venus, which was to occur on the $3 \mathrm{~d}$ of June-a phenomenon which had been scientifically observed only twice before. This committee was divided into three, for observation at three stations-Philadelphia, Mr. Rittenhouse's home at Norriton, and the lighthouse near Cape Henlopen. Three other observers were associated with Mr. Rittenhouse at Norriton. An observatory was furnished, and the preparations and calculations preliminary to taking the observations were made by Mr. Rittenhouse. Some instruments were bought for the other stations. For Norriton a reflecting telescope was furnished by $\mathrm{Mr}$. Maskelyne, astronomer royal at Greenwich, which was afterward given to the Philadelphia College; an astronomical quadrant by the Earl of Stirling, of East Jersey; and an equal-altitude instrument, a transit telescope, and a timepiece were made by Mr. Rittenhouse. The results of the observations were communicated to the American Philosophical Society, and a report of them was furnished to Mr. Maskelyne, who declared that they seemed excellent and complete, and 
did honour to the gentlemen who made them and to those who promoted the undertaking. The whole affair, in fact, gave the observers great credit abroad, and was regarded as promising well for the future of American science. The importance of the observation may be judged from the fact that it furnished one of the elements for verifying the great astronomical unit - the earth's distance from the sun.

On the $9^{\text {th }}$ of November following this observation a transit of Mercury-the fourth ever witnessed-was observed at Norriton by Mr. Rittenhouse and his fellow-astronomers, and a report on the subject was filed with the Philosophical Society. Shortly after this the difference of the meridians of Norriton and Philadelphia was determined by a committee, of which Mr. Rittenhouse was one, at the request of Mr. Maskelyne, who wished to connect the observations of the longitude of Norriton with those made by Messrs. Mason and Dixon in the course of measuring the degree of latitude.

About this time a scheme was started by Dr. Smith to induce Mr. Rittenhouse to remove to Philadelphia. Recommending him for appointment as a trustee of the Loan Office, then before the Assembly, Mr. Smith represented to the Speaker that he "ought to be encouraged to come to town, to take a lead in a manufacture, optical and mathematical, which never had been attempted in America, and drew thousands of pounds to England for instruments, often ill finished; and it would redound to the honour of Philadelphia to take a lead in this, and of the Assembly to encourage it." The proposition was received enthusiastically, and the whole house rose to vote for Mr. Rittenhouse, one of the members exclaiming, "Our name is legion for this vote." The Assembly adjourned, however, without passing the bill, although Mr. Rittenhouse was afterward appointed to the position for which he was named in it. He removed to Philadelphia, on his own account, in the fall of 1770 . The next scientific investigation in which he appears to have been engaged was the observation of the comet of 1770 , of which he calculated the elements, and communicated the results to the American Philosophical Society. We afterward find him, with several other gentlemen, making experiments on the electric eel for the purpose of ascertaining the origin of the shock which the animal emits on being touched. 
From this time on, Rittenhouse was to a considerable extent engaged in works in the service of the public, to some of which he was called in consequence of his scientific ability and mechanical skill, to others commended by his character as a citizen and his integrity. He was given charge of the State House clock; appointed to survey the lands between the Susquehanna and Delaware Rivers; to superintend the improvement of the Schuylkill; and to determine the northwestern extremity of the boundary between New York and Pennsylvania.

In 1775 the American Philosophical Society presented to the Pennsylvania Assembly a plan for the erection of an observatory under State control, with Mr. Rittenhouse as "public astronomical observer"; describing him as "a gentleman whose abilities, speculative as well as practical, would do honour to any country. . . Under his auspices the work could now be undertaken with the greatest advantages; and others may be bred up by him, to prosecute it in future times; but, if the present opportunity is neglected, perhaps whole centuries may not afford another. To rescue such a man from the drudgery of manual labour, and give him an occasion of indulging the bent of his genius with advantage to his country, is an honour which crowned heads might glory in; but it is an honour also, which it is hoped, in the case of a native, Pennsylvania would not yield to the greatest prince or people on earth." The Revolution came on, and the scheme was not carried out.

In view of that crisis, $\mathrm{Mr}$. Rittenhouse was commissioned to prepare moulds and have iron clock weights cast, to be exchanged with the people for their leaden ones; as engineer to the Committee of Safety, to arrange for casting cannon; to view a site for the erection of a Continental powder mill; to conduct experiments for rifling cannon and musket balls; to devise a method of fastening a chain for the protection of the river; to superintend the manufacture of saltpetre, and to locate a magazine for military stores. He was a member of the Committee of Safety in April, its vice-president in August, and its presiding officer in November, 1776 . In the same year he was a member of the Assembly from Philadelphia, and a member of the first Constitutional Convention of Pennsylvania; a member of the Board of War; and one of the 
Council of Safety, which had absolute powers. He was the first State Treasurer of Pennsylvania, from 1777 to 1789 , when he declined to serve any longer. He was the first Director of the United States Mint, serving for three years from $179^{2}$; and was called upon on several occasions to serve on commissions for the adjustment of boundaries. In connection with these public employments we find a curious letter from Mr. Jefferson to Mr. Rittenhouse, written in 1778 , protesting against his wasting his abilities on affairs of state. "I am satisfied," he says, "that there is an order of geniuses above that obligation [to conduct government], and therefore exempt from it. No one can conceive that Nature ever intended to throw away a Newton upon the occupations of a crown. It would have been a prodigality for which even the conduct of Providence might have been arraigned had he been by birth annexed to what was so far below him. ... I doubt not there are in your country many persons equal to the task of conducting government; but you should consider that the world has but one Rittenhouse, and that it never had one before."

Mr. Rittenhouse was Professor of Astronomy in the University of Pennsylvania from 1779 till $\mathbf{I} 782$, and was a trustee of the institution, continuing in that office after its reorganization in I791. He was made one of the secretaries of the American Philosophical Society in $177 \mathrm{I}$; became its vice-president in I 786 ; and succeeded Benjamin Franklin as president, on his death in 1790. He was elected a Fellow of the American Academy of Arts and Sciences in 1782 , and an Honorary Fellow of the Royal Society in 1795 . He received degrees from the College of Philadelphia, William and Mary College, and Princeton College.

He was tall and slender, quick in gait, had a countenance "indicative of intelligence, complacency, and goodness," and a disposition and manners that secured him friends and kept them. He bore testimony against the slave trade, and sympathized with the original motives of the French Revolution to such an extent that he assisted in the organization of the Democratic Society, and was made its president-but this was before the excesses of the Revolution were committed. While he might be called self-educated, he was not, as Mr. Barton shows, wholly without assistance in pursuing his studies, al- 
though some writers had mistakenly affirmed this, but that assistance was small. Dr. Rush asserted, in the eulogy he pronounced upon him, that the eminence he attained was to be ascribed "chiefly to his having escaped the pernicious influence of monkish learning upon his mind in early life"; otherwise, "instead of revolving through life in a planetary orbit," he might have spent his time "in composing syllogisms, or in measuring the feet of Greek and Latin poetry." $\mathrm{He}$ understood the German and Low Dutch languages, acquired a reading knowledge of French, and "overcame in a great degree the difficulties of the Latin tongue." $\mathrm{He}$ was a firm believer in the Christian religion, though he was not attached to any church. That speculative disquisitions were of little interest to him is shown by his remark concerning a conversation with a clerical gentleman, that it was "not, perhaps, greatly to the satisfaction of either of us; for he appears to be a mystical philosopher, and I, you know, care not a farthing for anything but sober certainty in philosophy." He published but little, because, as his biographer believes, he was too busy with work to give his time to the composition of formal papers. The list of his contributions to the American Philosophical Society includes twenty-two titles of papers relating to his orrery; the transits of Venus and Mercury; the comet of 1770; a method of deducing the true time of the sun's passing the meridian; the difference of longitude between the observations of Norriton and Philadelphia; an explanation of an optical deception; experiments on magnetism; a remarkable meteor seen in 1779 ; a comet observed in 1784 ; a new method of placing the meridian mark; an optical problem; astronomical observations (on the Georgium Sidus and a transit of Mercury) ; an account of several houses struck with lightning; another account of the effects of a stroke of lightning; several astronomical observations described in a single

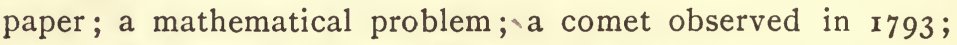
the improvement of time-keepers; the expansion of wood by heat; a problem in logarithms; and the mode of determining the true place of a planet in an elliptical orbit -his last paper, read February 5, I796. To these is added his oration on "Astronomy," delivered before the American Philosophical Society, on the 24th of February, I775, and inscribed "To the delegates of the thirteen 
United Colonies." In this oration, three years before the announcement of Mayer's discovery of the proper motion of certain stars, and six years before Herschel's discovery of Uranus, the author put forth the suggestion, which has since proved a presage, that the fixed stars, and particularly the Milky Way, would afford fruitful fields of observation. 


\section{GOTTHILF HEINRICH ERNST MUHLENBERG.}

$$
\text { I753-1815. }
$$

THE late Prof. J. M. Maisch, in his memorial oration on Muhlenberg as a Botanist,* laid stress upon the frequency with which his name is met in works of descriptive botany as that of the person who first recognized as separate and scientifically designated some particular genus or species. Waiving all considerations of credit for priority or of personal fame, the leading aim in all Muhlenberg's botanical work seems to have been to assure the precise and accurate definition of the plant with which he was for the moment dealing.

Names of the Muhlenberg family are conspicuous in the history of this country. Its founder in America, Pastor Heinrich Melchior Mühlenberg, who came to Philadelphia by way of Charleston, S. C., in $\mathrm{I}_{742}$, was known as the patriarch of the Lutheran Church in the United States. His eldest son, Johann Peter Gabriel, also a minister in his earlier life, was a major-general in the Revolutionary War, Vice-President of Pennsylvania, for six years a member of the House of Representatives of the United States, a United States Senator, and an officer of the revenue. Another son, Friedrich August, who also began his career in the pulpit, was a member of the Continental Congress, a member and Speaker of the Pennsylvania Legislature, and a member of the House of Representatives of the first four Congresses, during two of which he was Speaker.

The third son, Gotthilf Heinrich Ernst Muhlenberg, the subject of the present sketch, was born in New Providence,

* Delivered before the Pioneerverein of Philadelphia, May 6, 1886, and published in Dr. Fr. Hoffmann's Pharmaceutische Rundschau, June, I886; also separately. It is the principal source whence we have drawn the matter of this sketch. 




GOTTHILF H. E. MUHLENBERG. 

Montgomery County, Pa., November I7, I753, and died in Lancaster, $\mathrm{Pa}$., May 23, 1815 . He attended schools in his native place and in Philadelphia, whither his family removed in 1761 . At the age of ten years he was sent with his elder brothers to Halle, in order to finish his academic studies and to prepare for the ministry. Arrived in Holland, the brothers proceeded directly to Halle, while young Henry set out in the care of an attendant for Einbeck, his father's native place, where many of his relatives still lived. Deserted on the journey by the man to whose protection he had been confided, this boy, left without money in a strange land, bravely pushed forward on foot and thus finally reached his destination. After his visit to Einbeck he entered a school in Halle, in which he continued about six years. He spent a longer time in the higher classes than was necessary, awaiting the age at which he could be admitted to the university. This he entered in 1769 , but remained in attendance only about a year. He returned to Pennsylvania in 1770 , and was ordained by the synod of his church and appointed assistant to his father in the pastoral work "at Philadelphia, Barren Hill, and on the Raritan." In 1774 he was called to be the third preacher in Philadelphia. The prominence of his brothers in the Revolutionary councils exposed him to dangers from the British, as they approached the scene of his labours, and he was twice obliged to leave the city, in 1776 and 1777 . On the second occasion he escaped with difficulty, disguised as an Indian. In the course of the war the property which belonged to his wife was sacrificed, and a large portion of his own estate was lost in the Loan Office. Yet he was constantly active with voice and pen in urging his fellow-citizens to stand up in defence of their common country. In 1780 he became pastor of the Lutheran church at Lancaster, where he spent the rest of his life. Mr. Muhlenberg was married, in 1774 , to Catherine, daughter of Philip Hall, of Philadelphia. He had two sons; one of them, Henry Augustus, won a high reputation, first as clergyman, and afterward in public affairs. The other son, Frederick Augustus, became an able physician in Lancaster, $\mathrm{Pa}$.

His work in botany began during his residence in the country following his flight from Philadelphia. He resumed the study earnestly after his return to the city, and became 
deeply interested in the less conspicuous flowering plants and the cryptogams. Botanists had not been idle in the study of North American plants. The field of the present Middle Atlantic States had been explored with considerable energy before Muhlenberg's time. New species of plants had been discovered and additional information had been gained concerning species already known. The scientific value of these observations, attested by the herbariums which still exist, and by what Muhlenberg furnished for publication, is enhanced and interest is added to them by a careful perusal of Muhlenberg's correspondence, a part of which he kept and is now preserved by the Historical Society of Pennsylvania. These letters-some from European naturalists and others from American-were written in the last sixteen years of the eighteenth century and the first and part of the second decades of the nineteenth, and are often annotated with Muhlenberg's remarks. Of his own letters only a few copies are present, chiefly those which he wrote between I79I and 1794 to Dr. Manasseh Cutler, of Ipswich, Mass. Further, a number of letters from various students, together with notebooks, botanical notices, descriptions, and outlines in Muhlenberg's handwriting are in the possession of his descendants, or have been handed over by them to scientific societies; while in the works of Pursh (I8I4), Schecut (I806), Le Conte (I8II), and Bigelow (I8I4) is incorporated matter borrowed from the results of his researches.

The notebooks bear witness to the earnestness with which Muhlenberg took up and pursued his botanical studies from the beginning. During the year 1778 may be found numerous descriptions of plants like that of Eupatorium purpureum, trumpetseed or gravel root; to which are added such notes as "is probably Eupatorium (altissimum)." Doubtful remarks of the kind abound. "It is probably Actea?" "It may be Azalea?" "Perhaps it is Convallaria?" It is evident from such notes that Muhlenberg had not advanced far in acquaintance with the wild plants in the summer of 1778 . In the same year he seems to have drawn up a plan of studies by the systematic execution of which he could hardly fail to acquire the desired knowledge.

It was not long before Muhlenberg became engaged in correspondence with other botanists. Dr. Johann David 
Schöpf, an officer of the Hessian troops stationed in New York during the Revolutionary War, who traveled through the Eastern States to Florida, after the conclusion of peace, in search of medicinal plants, became acquainted with Muhlenberg and was assisted by him. After his return to Germany he was the occasion of a correspondence between Muhlenberg and Prof. Schreber, of Erlangen, and this was followed by exchanges of letters with other eminent botanists in Germany, England, France, and Sweden, as well as with Americans.

Like a true naturalist, Muhlenberg continued to exercise the greatest care and thoroughness in observation and research. A botanical excursion and note book of 1785 contains the following plan of work:

"This year I shall again keep a calendar of all plants as I may observe them, especially when in bloom. When I am quite certain, I shall set down only the Linnæan name; when not quite certain, I shall make a full description. Especially shall I try to complete the descriptions of 1789 in those kinds of plants in which many species are most exact. As I very carefully explored this region last year, I shall this year visit other regions, namely: I. The mountains on the Susquehanna, in May and July. 2. The mountains called Chestnut Mountains, also twice, etc. I must further call upon apothecaries and take other pains to learn the officinal plants, their virtues and their common names. I must this year pay particular attention to the seeds, and especially to describe all herbs as completely and exactly as possible, especially when I am not wholly certain. I shall give particular attention to those of which there are many species, such as asclepias, convolvulus, serratula, aster, solidago, and all the ferns. . . . The seed vessels and seeds are very important for the genus and species, and I must therefore give careful attention to them." $\mathrm{He}$ also indicates here as one of his purposes, besides the native plants, to observe all the exotics, whether they need protection in winter or are completely acclimated.

In the spring of $\mathrm{r} 79 \mathrm{I}$ he was able to inform Dr. Cutler that he had collected more than eleven hundred different plants in a circuit of about three miles from Lancaster, and that he was devoting himself to the collection of material concerning their medicinal and economic applications. In a later letter, November $8, \mathbf{1 7 9 1}$, he wrote: "If the medicinal application seems to 
be sufficiently confirmed from different sides, and agrees with the character of the plant, I either try it on myself or commend it to my friends. I raise most of the grasses in my garden, and experiment how often they can be cut, and whether they are readily eaten by horses or cattle." These grasses numbered at the beginning of 1798 one hundred and fifty-six species, including many introduced ones, and among them were a large number of new species and at least one new genus. This collecting and testing of grasses is mentioned in other letters. An exchange seems to have been arranged with Prof. Schreber, of American plants for foreign grasses; and, besides mosses, grasses of New England were obtained from Dr. Cutler, especially such as grew near the sea.

Some of these notes on the medicinal properties of plants, Muhlenberg says, were furnished to Dr. Schöpf for use in his contemplated work on American Materia Medica. Although the author of that work, which was published in 1787 , acknowledged indebtedness for information to several other American botanists, he does not give Muhlenberg's name-a most ungrateful omission. A similar case occurred in connection with an American book. When Muhlenberg first saw a copy of Bigelow's Medical Botany, he could not help remarking to his son, after looking through it, "This gentleman has appropriated to himself all my explanations, without making any acknowledgment." But he never called public attention to this, and there were other such trespasses which were also let pass unnoticed.

In July, I785, Muhlenberg communicated to the American Philosophical Society an outline of a Flora Lancastriensis containing the results of his own observations on the plants and their habits. At the same time he presented a manuscript Calendar of Flowers. In February, 1791, he communicated the Index Flora Lancastriensis. This was published in the third volume of the first series of the Transactions of the society. It is arranged according to the Linnæan system, and contains four hundred and fifty-four genera with nearly eleven hundred species, including both wild and cultivated plants. Of the naming of these plants, Muhlenberg remarked in a note: "When I found no name in Linnæus's system, I took a name from other recently published works, or from the letters of Dr. Schreber, with whom I kept up a correspondence. When I found no name in this way, I was obliged to give one myself 
and to add to it N. S., till better information came from more capable botanists." The cryptogamous plants are represented in this index by twenty-five genera with one hundred and twenty-five species. The work, as its name implies, consists merely of the enumeration of the species observed, without description or indication of their habits or uses. A supplement to this Index, presented to the American Philosophical Society in September, 1796 , and published in the fourth volume of its Transactions, contained forty-four additional genera with sixty-two species of phanerogams, of which nine were hitherto unknown species of grasses; while the cryptogams were further represented by two hundred and twenty-six additional species, belonging to twenty-nine genera.

Muhlenberg perceived very early in his botanical studies how great confusion was likely to arise if names were conferred upon plants supposed to be new, without considering whether they might not have been previously identified and named by others. We have already described the painstaking care he took in his own notes to find the correct names of his specimens. While he was critical of the work of others, he was always ready to recognise their merit, and to make allowance for their imperfections. He wrote to Dr. Cutler of his work on the Useful Plants of New England that, although the author regarded it as immature, "it was of great use to me, and I was very much pleased with it. Every beginning will be imperfect, especially in a new country, and I have not yet read any botanical work without errors. Even Linnæus's works, which were prepared with so much industry, are full of them." In another place he wrote: "Herr Aiton,* in my opinion, makes too many species out of varieties; for instance, his asters and golden-rods. We must expect such things when descriptions are made from specimens taken from a garden instead of from their natural habitats, where plants grow numerously and in various soils." Other criticisms of similar tenor may be taken from his letters, all made from the point of view of exactness in identification and description.

Freedom from self-glorification and from solicitude for the recognition of his work are patent in all his writings and transactions. When Dr. Barton announced, in $\mathrm{r} 79 \mathrm{r}$, his illustrated

* In his Hortus Kewensis, I789. 
Flora of Pennsylvania as in preparation, Muhlenberg concluded that as that author had seen his manuscripts and herbarium, it would not be necessary for him to publish anything except a few additional notes which he might make during the year, and a Floral Calendar. "Excuse my enthusiasm for science," he wrote to Dr. Cutler, in 1792, "which has given me so many pleasant hours, and which, I know, has been cultivated by you with great success. Botany needs your co-operation, and when you have prepared a full table, please leave a few fragments for me." It was this readiness to give credit to the merit of others, combined with his clear vision of the confusion that threatened to arise from the continuance of planless labours, that decided him as early as 1785 to bring out a plan for common labour in making up the Flora of North America. He came to the Philosophical Society again in I790 or I79I with this plan. "I repeat," he writes, "my formerly expressed desire that a number of my learned countrymen should unite in botanical investigation and send in their floras to the society for revision and publication, so that by combination of the floras of the different States we may obtain a flora of the United States which shall rest on good and definite observation." While this plan was not carried into execution through the medium of the American Philosophical Society, Muhlenberg again and again returned to it in his extensive correspondence. Thus he wrote: "Others should do the same (that is, search out the flora of the neighbourhood of their homes), and, after collecting material for a dozen years, let a Flora of North America be written." Further, "I first sent in a sketch, and in 1790 an index of all the plants that grow here, in the expectation that my botanical friends would join in working up the floras of their several States, so that in about ten years a more general work might be undertaken." And in another place: "If the botanists continue to proceed in the way they are going, in a few years all will be confusion. In order to be sure, we should confer with one another. For this purpose I have printed my Index before publishing full descriptions." A letter to Dr. Cutler, of November I2, I792, goes more into particulars; it reads: "You have made the beginning of a Flora of New England, and all friends of botany wish that you would go on and complete the work. Let each of our American botanists do something, and the 
wealth of America would soon be recognised. Michaux should do South Carolina and Georgia; Kromsch, North Carolina; Greenway, Virginia and Maryland; Barton, New Jersey, Delaware, and the lower parts of Pennsylvania; Bartram, Marshall, and Muhlenberg, each his neighbourhood; Mitchell, New York; and you, with the Northern botanists, your States. How much might then be accomplished! If, then, one of our younger associates-Dr. Barton, for instance, whose specialty it is-would combine the different floras into one, how pleasant it would be for the botanical world! I have written to nearly all the persons named above, and hope to receive their concurrence. Let me know your views about it." Dr. Cutler gave the scheme his unreserved approval.

This plan was not carried out. Instead of it, André Michaux worked the combined collections of his eleven years' travels in the United States, through the French botanist Richard, into a Flora of North America, and it appeared in Paris in 1803 , one year after the author's death in Madagascar.

The publication of this flora did not change Muhlenberg's view of the necessity of comparative work in co-operation, and in order to bring it a step nearer he decided in 1809 to write a catalogue of the then known native and naturalized plants of North America (Catalogus Plantarum America Septentrionalis, huc usque cognitarum indigenarum et cicurum), the printing of which was finished after nearly nine months of work, at the end of July, r8r3. While Michaux had described about fifteen hundred flowering plants and ferns, Muhlenberg was able ten years later to exhibit more than double the number of species, and besides these to add, from specimens mostly collected in Pennsylvania, I 75 mosses, 39 liverworts, 32 algæ, I 76 lichens, and 305 fungi, in all 727 species. The Composite comprised in Michaux 193 species, in Muhlenberg 4ro.

Muhlenberg conscientiously named not only the books which he had used in the determination of his collected plants, but also the twenty-eight correspondents in different parts of the United States who had assisted him in his researches by sending plants or seeds. The work gives, besides the botanical and English names, only the numbers of the several parts of the flower, the color of the corolla, the character of the fruit, the locality, and the time of flowering, all as briefly as possible. 
At the same time a complete description of the plants growing around Lancaster had been ready to print for years; likewise a complete description of all the other North American plants which Muhlenberg had himself seen and arranged in his herbarium. These descriptions were consequently based entirely on his own knowledge, and had, therefore, especial value. Unfortunately, they have not been published.

A part of one of these works, comprising the grasses, was printed in 1817 , two years after the author's death, under the title Descriptio uberior Graminum (Fuller Description of Grasses). This manuscript was presented by Zaccheus Collins, a friend of Muhlenberg, to the American Philosophical Society in $183 \mathrm{r}$.

The valuable herbarium, for which Muhlenberg collected and sorted for a full third of a century, was bought by a number of his friends for a little more than five hundred dollars, and was presented to the American Philosophical Society in February, 1818. It was then in good condition, but has, unfortunately, not been well taken care of, and has become so decayed as to have little if any more than historical value.

In considering the question of the importance to science of these labours of a whole lifetime, we should think first of the greater clearness which they led to in the descriptive botany of North America. Although Muhlenberg printed but little, and although he often lost the claim to priority through being anticipated in publication by less reserved botanists, yet we find in Gray's Manual of the Botany of the Northern United States about one hundred species and varieties which were first established as such by him, and besides them a nearly equal number which were either assigned afterward to other genera, or with which, on the principle of priority in publication, the names given by other botanists were retained. This is really an admirable result, considering the zeal of collectors and hunters before and during Muhlenberg's time, and the limited extent of the field which he was able personally to examine. His services have also been freely recognised by later botanists. A golden-rod was given by Torrey and Gray the name Solidago Muhlenbergii; Grisebach named a centaury Erythrea Muhlenbergii; a small willow was called by Barratt Salix Muhlenbergii; and Gray gave the name Muhlenbergii to a species of reed or sedge. Two mosses of the genera Phascum and 
Funaria were named after Muhlenberg by Schwartz; two lichens of the genera Umbilicaria and Gyrophora by Acharius; and a fungus of the genus Dothidea by Elliott.

About half of the plant-names given by Muhlenberg which are now recognised belong to the reeds and the grasses, Cyperacea and Graminea, in the study of which he was supported by Schreber. One of the first new genera of grasses observed by him, to which belong seven species in the Northern floral region of the United States, and a still larger number of other species in the other States and Territories, was given the name Muhlenbergia by Schreber. At least five species of this genus, which have not become domiciled east of the Mississippi, are known in Colorado.

It is recorded by one who knew him, in Sprague's Annals of the American Pulpit, that "in person Dr. Muhlenberg was of medium stature, of a florid complexion, of a robust frame, and great physical strength. There are various traditions, some of them amusing enough, illustrative of this latter quality. On one occasion when a beggar had obtruded himself into his study, and had begun to take on insolent airs, the doctor took him up and removed him from the premises with perfect ease, greatly to the amusement of those who were looking in. $\mathrm{He}$ was a great pedestrian, and often walked from Lancaster to Philadelphia, a distance of sixty miles, without suffering from fatigue." His grandson, Frederick A. Muhlenberg, for many years professor in the University of Pennsylvania, gives the following statement as to what manner of man he was:

"His private journal is now before me, and the variety of subjects in it which engaged his reflections is remarkable, and shows the inquiring character of his mind and his power of accurate discrimination. Here are found, for instance, carefully prepared descriptions of plants, birds, minerals, or other objects of Nature, which he had met with in his walks, and the uses to which they might be applied for the benefit of himself or others. Here he gives his decision upon the medicinal properties of plants or the value of the inks made out of their juices, and there records an attempt of his, and a successful one, as early as the year 1779 , to make molasses from cornstalks. In other parts of the journal we meet with observations on the weather, such as thunderstorms, dark days, remarkable 
snows, and other natural phenomena; and two of such meteorological memoranda met my eye in running over the pages of the volume, which may be of interest, one in reference to the winter of 1780 , the other to that of 1786 . The former he designates the 'cold' winter, and remarks that in February the snow was three feet deep where there was no drift, and, where drifted, from five to seven; and in the other year two feet in depth. Besides these there were also discussions of the bankrupt laws of Congress, several remarkable dreams, articles in opposition to the theatre and public dancing, poetic effusions, and pious meditations.

"His knowledge of medicine was considerable; and he was in the habit of prescribing for his people and distributing to them the medicines of the Halle Institute, which he regularly ordered to be sent to him. In his journal are given at length accounts of the diseases and treatment of the different members of his own family when visited with sickness.

"His habits of life were simple. He was temperate in eating and drinking. His wife always carved at table and supplied his plate, and he was accustomed to ask her if he had eaten a sufficiency and to submit to her judgment in the matter; and a favourite dessert of his was a roasted potato, with a little butter and salt. When he drank anything spirituous he usually mingled a wineglass of wine with a quart of water. In his dress he also meekly submitted to the wishes and judgment of his wife.

"He was very fond of music, and played with taste, having a preference for that which was sad and plaintive rather than lively.

"His early entrance upon the arduous duties of the ministry at seventeen years of age, together with his subsequent intense studies in literature and science, had a serious influence in causing frequent attacks of vertigo and acute pains in his head. One remarkable incident in his life, due no doubt to this protracted mental activity, is worthy of record for its psychological interest. About ten years before his sudden death from apoplexy he lost, after an attack of serious illness, all his knowledge, and he began study a second time with the alphabet, syllabication, and reading under the instruction of his daughter. After having thus learned to read a second time, one day 
while his daughter was teaching him the Lord's Prayer, all his former acquisitions, like a sudden effulgence, returned to him in their completeness, and he laboured successfully in the ministry for the ten subsequent years. Such instances of disordered mental action are few in number."

This review of Muhlenberg's botanical work would not be complete without special mention of his scientific correspondence, his personal intercourse with naturalists, and the honours he received. Among his foreign correspondents were Dillenius, Hedwig, Hoffmann, Persoon, Pursh, Smith, Schöpf, Schreber, Sturm, Willdenow, William Aiton, of Kew; Batsch, the mycologist; Palisot de Beauvoir in Paris, and Dr. Thibaud in Montpellier; Christian Ludwig Schkuhr, of Wittenberg, an eminent cryptogamist ; Professor and Medical Counsellor Heinrich Adolph Schrader, of Göttingen; Kurt Sprengel, professor of medicine and botanist at Halle; and Prof. Olof Swartz, one of Linnæus's most eminent pupils. Among the twenty-eight home correspondents mentioned by Muhlenberg in the preface to his catalogue are the Rev. Christian Denke, of Nazareth, $\mathrm{Pa}$; ; the Rev. Samuel Kramph, of North Carolina; the Moravian bishop Jacob Van Vleck, and Dr. Christopher Müller, of Harmony, Pa. One of the most valued was Dr. Baldwin, of South Carolina, and Muhlenberg's letters to him have been published by William Darlington, in a volume entitled Baldwiniana. All or nearly all these correspondents were entertained by him in his home at Lancaster, which was open to all students of plants, and was usually visited by them when they came to Philadelphia. Alexander von Humboldt and Aimé Bonpland sought him there on their return from their long sojourn in Spanish America; and Humboldt's letter acknowledging his hospitality is the last which that master in science wrote in America.

Learned societies and institutions likewise covered him with their honours. The University of Pennsylvania gave him the degree of Master of Arts in $1780^{\circ}$; Princeton College, that of Doctor of Divinity in 1787 . He was elected a member of the American Philosophical Society on January 22, 1785, along with Joseph Priestley and James Madison. Of other societies he received diplomas: from the Imperial Academy of Erlangen, I79r ; the Society of Friends of Natural History, Berlin, I798; the Westphalian Natural History Society, 1798; the Phyto- 
graphic Society of Göttingen, 1802 ; the Physical Society of Göttingen, 1802 ; the Linnæan Society of Philadelphia, 1809; the Academy of Natural Sciences of Philadelphia, I8I4; the Society for the Promotion of the Useful Arts, Albany, N. Y., 1815; the Physiographical Society of Lund, Sweden, I815; and the New York Historical Society, April 12, I815.

Introducing the description of a Muhlenbergia in the second volume of his work on the Grasses, Prof. Schreber referred to Dr. Muhlenberg as having, "through the discovery of numerous new species and in other ways, rendered immortal service to the natural history of North America, and especially to the knowledge of the plants of Pennsylvania and the other United States." 



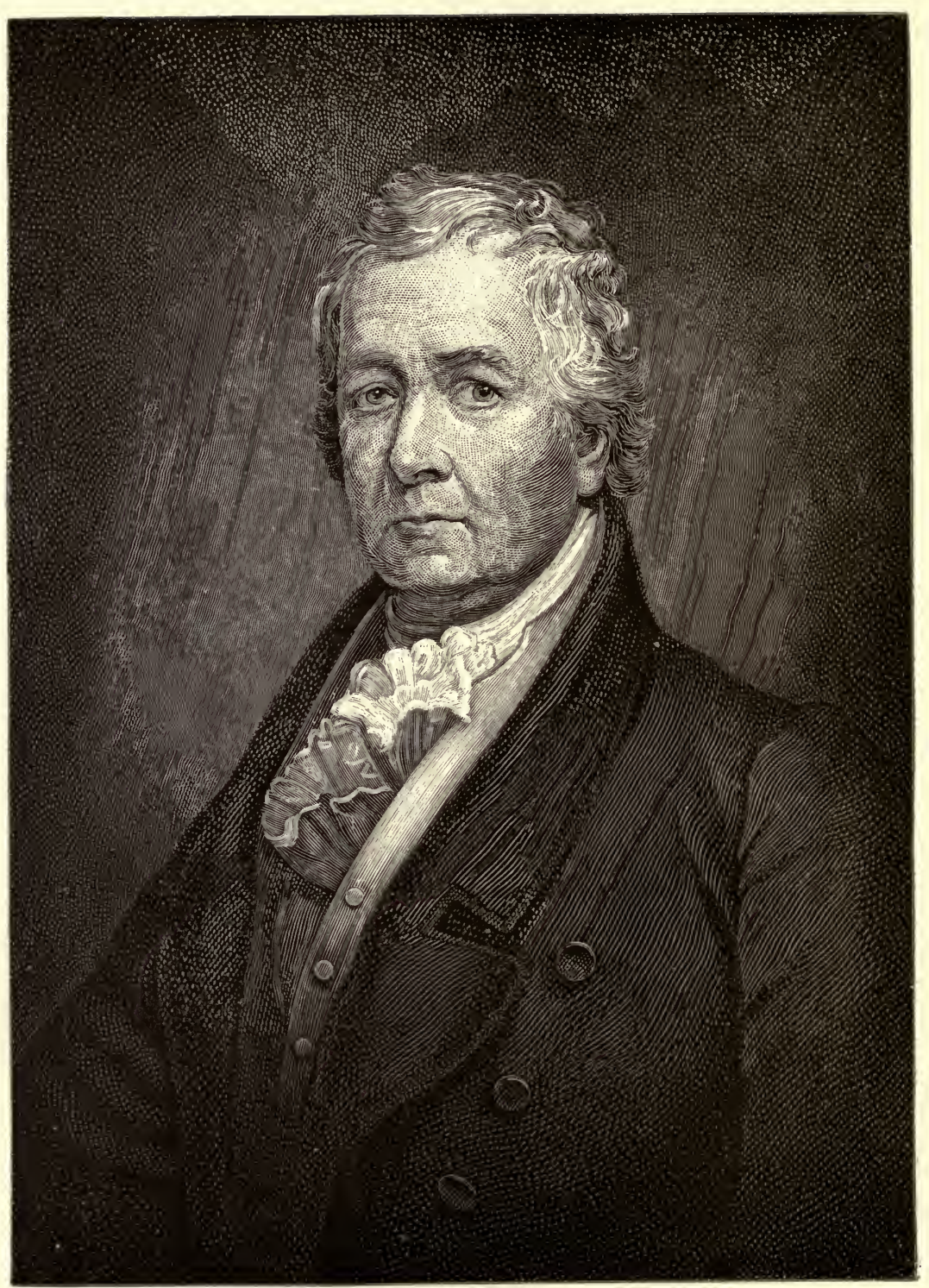

SAMUEL LATHAM MITCHILL. 


\section{SAMUEL LATHAM MITCHILL.}

$$
\text { I 764-I } 83 \text { I. }
$$

The name and fame of Dr. Samuel L. Mitchill have, in the absence of a complete biography, become to a considerable extent a tradition, known to few except students; yet, during the first quarter of this century, he was one of the most conspicuous figures in the literary and scientific life of the United States. He is called by Dr. J. W. Francis "the Nestor of American science," and "the pioneer philosopher in the promotion of natural science and medicine in America." He was a man of various attainments, and proved himself at home in many fields-in medicine, science, letters, politics, and social life.

Samuel Latham Mitchill was born in Hempstead, Long Island, August 20, 1764 , and died in the city of New York, September 7, I831. He was the third son of Robert Mitchill, an industrious farmer and member of the Society of Friends, and was remarkable for his habits of observation and reflection. His father seems to have taken less interest in his early instruction than his maternal uncle, Dr. Samuel Latham, of North Hempstead, who assisted him to obtain a good classical education. He afterward studied medicine with Dr. Latham; then with Dr. Samuel Bard, of New York; and in 1783 went to complete his studies in the University of Edinburgh, whence he was graduated in $\mathbf{I} 786$. He there enjoyed rare advantages of intellectual society, and had among his contemporaries at the university such illustrious men as Sir James Mackintosh and Thomas Addis Emmet, Dr. Caspar Wistar, Richard S. Kissam, the surgeon; and William Hammersley, afterward a professor in Columbia College. After graduation, and before returning home, he made a pedestrian tour through a part of England. In $\mathbf{1 7 8 7}$, after his return to America, he visited Saratoga Springs while it was surrounded by the forest, and 
ascertained experimentally that the gas escaping from the water was "fixed air, with the power to extinguish flame, destroy the life of breathing animals, etc." $\mathrm{He}$ is found in I 788 recording his walking with congenial companions "in the very grand procession for celebrating the adoption of the Constitution of the United States." He began the study of law with the Hon. Robert Yates, Chief Justice of the State of New York, and was shortly afterward appointed one of the commissioners to treat with the Five Nations for the cession of the "Great Western District" to the State of New York, He attended the council at Fort Stanwix, witnessed the deed, and received names from the Oneidas and Onondagas.

In 1790 Dr. Mitchill was chosen a representative from Queens County in the New York Legislature. In the next year he exerted himself to form the North Hempstead Library Association and Library. In 1792 he was appointed Professor of Chemistry, Natural History, and Philosophy in Columbia College, where, while dissenting from some of the principles of the French chemist, he introduced, for the first time in the United States, the chemical nomenclature devised by Lavoisier. His dissent from Lavoisier led to a controversy with Dr. Priestley, at the end of which the two disputants found themselves on a footing of mutual esteem and warm personal friendship. He records himself in 1794 as having exhibited at full length, in a printed essay, the actual state of learning in Columbia College. At about this time, too, he was co-operating with Chancellor Livingston and Simeon De Witt in the establishment of the Society for the Promotion of Agriculture, Manufactures, and the Useful Arts, before which he delivered his first public address. Having executed a commission from this society for that work, he made a detailed report, in 1796 , of geological and mineralogical observations on the banks of the Hudson, for coal, etc.- - a performance which, he mentions, was respectfully quoted by Count Volney. This was the first work of the kind undertaken in the United States, and the report helped to secure a wide European as well as American reputation for the author. Referring to it, Dr. J. W. Francis says, " He may fairly be pronounced the pioneer investigator of geological science among us, preceding McClure by several years." The report was published in the Medical Repository, a quarterly magazine begun in 1797 by Dr. Mitchill, with Drs. 
Edward Miller and Elihu H. Smith, and continued by Dr. Mitchill for more than sixteen years.

After his marriage, in I 799, to Mrs. Catharine Cock, which brought him the enjoyment of an ample fortune, Dr. Mitchill was able to devote himself entirely to scientific and public occupations. Among the scientific works with which he accredits himself during the few years succeeding this event is the publication of a chart of chemical nomenclature, with an explanatory memoir, in which he contended that metals in their malleable and ductile state are compounds of a base with hydrogen (phlogiston), as in their calciform state they consist of a base with oxygen; and that in several there is an intermediate condition in which there is no union either with hydrogen or oxygen. And he extended the same doctrine to the greater part of inflammable bodies. In 1802 he records a correspondence with Albert Gallatin, Secretary of the Treasury, on a project for illuminating the lighthouses of the United States with inflammable air. In 1806 he wrote the introduction to the American edition of Assalini's Observations on the Plague, Dysentery, and Ophthalmy of Egypt; and in the ensuing winter translated from the Latin Lancisi's book on the noxious exhalations of marshes at Washington-a work which was afterward printed in the Medical Repository. As a member of the Legislature, he supported, in the face of ridicule and opposition, the act of 1798 giving Livingston and Fulton the exclusive right to navigate the waters of New York by steam. $\mathrm{He}$ performed, with Fulton, in August, 1807 , the first voyage in a steamboat. He was again chosen to the Assembly in 1797 as one of the representatives from the city and county of New York for a term of service which he marked as distinguished by his introduction of a motion relative to the fourth commandment, requiring citizens to labour on the six days as well as to refrain from labour on the seventh day. In $180 \mathrm{r}$ he was elected to the national House of Representatives, as member from the district consisting of the counties of Kings and Richmond and the city and county of New York. He was appointed to the Senate in 1804 , to fill the vacancy caused by the resignation of John Armstrong, and after the expiration of his term there, in I809, served in the House again till 18 I3. A bright picture of his life in Washington is given in the letters written by him to his wife during his term of service. They are full of the life, 
the politics, and the society of the capital, and the telling of the incidents is made more attractive by the writer's always lively humour.

The lines of Dr. Mitchill's work in Congress are indicated by various notes in his letters and in the record which he has left of Memorable Events and Occurrences in his life. During his first term he was a member of committees of the House on Commerce and Manufactures, the Naturalization Laws, the protection of American seamen and commerce against the Tripolitan corsairs, Naval Affairs, memorials concerning perpetual motion, patent rights, the Mint, and French spoliations. He laboured in the Senate for the adoption of improved quarantine laws, "and was strenuous," says Dr. Francis, "to lessen the duty on the importation of rags, in order to render the manufacture of paper cheaper, the better to aid the diffusion of knowledge by printing." In December, I8I I, he brought up for adoption by the House of Representatives a report favourable to the "nascent nations" of Spanish America, and "full of good wishes toward them in their exertions to become free and independent." In connection with the War of I 812 he acted as a commissioner under the Navy Department in constructing a floating battery or heavy vessel of war, to defend the seacoast and harbours of the United States; and in I 8 I 4 he was found labouring jointly with his patriotic neighbours, "with mattock and shovel, in the trenches for several days, to erect fortifications against the enemy."

National and social matters did not absorb Dr. Mitchill's attention in Washington to the exclusion of his interest in scientific inquiries. Curious speculations and remarks appear in his letters about phenomena which came under his observation. In one letter, he wishes his wife to inform him exactly at what hour a certain storm began. "I wish to know," he said, "exactly when the storm began in New York, as it is connected with other facts tending to a theory of the atmospheric motions in winter." Another letter, forwarding a specimen of the Mitchella repens, explains why no plant had been named after him. Prof. Willdenow, of Berlin, had intended to give his name to some plant, but found it already appropriated by this partridge berry, which was named by Linnæus in honour of John Mitchell, of Virginia. He was more fortunate, according to Dr. Francis, in the matter of 
fish. "He was the delight," says this biographer, "of a meeting of naturalists. The seed he sowed gave origin and growth to a mighty crop of those disciples of natural science. He was emphatically our great living ichthyologist. The fishermen and fishmongers were perpetually bringing him new specimens. They adopted his name for our excellent fish, the striped bass, and designated it the Perca Mitchilli."

$\mathrm{He}$ writes concerning a conversation he had with Captain Lewis, the explorer, about the burning plains up the Missouri, where the burning strata of coal underlying the plains produced such intense heat as to form lava, slag, and, pumicestone by the same process that forms those volcanic substances in the burning mountains of other countries. December 30,1807 , he congratulates his wife on the account in one of her letters of the meteoric stones that fell to the earth in Connecticut, which arrived at a most convenient time, having preceded all the letters to the Connecticut delegation, and even outrun the newspapers. Dr. Mitchill also during this period visited Upper Canada, and described the mineralogy of Niagara Falls; wrote a history of West Point and the Military Academy; and visited Harper's Ferry and described the geology and scenery of that spot, which had been eulogized for its sublimity by Jefferson in his Notes on Virginia. Dr. Mitchill retired from his professorship in Columbia College on his election to Congress, in I80I. In 1807 , when the College of Physicians and Surgeons of the City of New York was organized, he was chosen its first Professor of Chemistry, but declined the position, preferring his public duties. In 1808 , however, he accepted a professorship of Natural History; and in 1820 , on the reorganization of the faculty, became Professor of Botany and Materia Medica. Difficulties occurred with the Board of Trustees in 1828 , and the whole faculty of the college resigned. Among other works for the advancement of science and learning mentioned in his record are his action with Drs. Hosack and Hugh Williamson in laying the foundation of a Literary and Philosophical Society in New York, in 1815 ; the reading to the society of a narrative of the earthquakes of the United States and in foreign parts, during I8II, I8I2, and 1813; co-operation in a petition to the Common Council of New York for the grant of the building in the North Park for the purposes of Literature, Science, and Arts; the delivery, in 
connection with a curious case by which the town was stirred, of a public lecture on the Somnium, or dream, as a state different both from wakefulness and sleep; an excursion with friends to the region watered by the Wallkill, where the party disinterred a mammoth; participation in an excursion to the Neversink Hills, near Sandy Hook, where a dangerous mistake in their altitude, which had been supposed to be six hundred feet, was corrected, and the real height was found to be only half as great, or three hundred feet; acting as vice-president of the District Convention which met at Philadelphia for preparing a National Pharmacopœia; and co-operation with Samuel Wood and Garrett K. Lawrence in recommending the willow-leaved meadow-sweet (Spirca salicifolia) " as an admirable article for refreshment and health, and as a substitute for the tea of China." A description and classification of one hundred and sixty-six species of fish, chiefly found in the fresh and salt waters adjacent to the city of New York, which he offered to the Literary and Philosophical Society at one of its earlier meetings, was the nucleus of what is regarded as his chief work. He mentions in his record more than forty additional species described in Bigelow and Holly's Magazine, and several more in the Journal of the Academy of Sciences of Philadelphia. An elaborate History of the Botanical Writers of America by him is to be found in the collections of the New York Historical Society. Of his literary and scientific work as a whole, in fact, it is well said in the Cyclopædia of American Literature that numerous papers by him are included in the Transactions of the many learned societies of Europe and America of which he was a member; and he was often called upon, at the anniversaries of the societies of his own city, to appear as their orator. "His multifarious productions are consequently scattered over a number of publications and collections of pamphlets, and are somewhat overshadowed by the reputation of the learned bodies with which they are connected. They have fallen, to some extent, into an unmerited oblivion." He had committed his manuscripts to his brotherin-law, the late Dr. Samuel Akerly, as the friend most competent to write his biography, and the work was begun, when the papers were destroyed by the burning of the house in which they were deposited. Had Dr. Akerly not been thus prevented from completing this work, and had he been able to 
present Dr. Mitchill's life and writings in substantial form, the subject of our sketch would doubtless have received the credit to which he was entitled, and have been made to appear as one of the most vigorous leaders of early American science.

The scientific items in Dr. Mitchill's record are continued with mention of the introductory lecture to the College of Physicians, etc., on the life and writings of their late president, Samuel Bard, r82r; a philosophical discourse in St. Stephen's Chapel, Bowery, to the class formed in that congregation for cultivating the natural and physical sciences, r822; a discourse on the Life and Writings of Linnæus, at Prince's Botanical Gardens, Flushing, on the anniversary of the Swede's birthday in 1823; and the publication of a catalogue of the geological articles and organic remains which he presented to the museum of the Lyceum. In 1823 he appears as performing, after the Venetian example, on an invitation from Albany and a mission from New York, the ceremony of marrying the Lakes to the Ocean, at Albany, "on the day of the unprecedented gathering of the people to witness the scene of connecting the Western and Northern Canals with the Hudson "; and again, two years afterward, as a member of a committee for celebrating the completion of the Western Canal, when, in the vicinity of Sandy Hook, he pronounced an address "on the introduction of the Lady of the Lake to the estate of her spouse the Lord of the Ocean." This, according to Dr. Francis, was the proudest day of his life. He also acted on a committee, in I 824, to receive funds in aid of the efforts of the Greeks to achieve their independence.

Dr. Francis says, summing up his work, and quoting at least a part of the estimate from the book, Old New York, that "the universal praise which Dr. Mitchill enjoyed in almost every part of the globe where science is cultivated, during a long life, is demonstrative that his merits were of a high order. ... His knowledge was diversified and extensive, if not profound. His first scientific paper was an essay on Evaporation. His mineralogical survey of New York, in I797, gave Volney many hints; his analysis of the Saratoga waters enhanced the importance of those mineral springs. . . . His ingenious theory of the doctrine of septon and septic acid gave origin to many papers and impulse to Sir Humphry Davy's vast discoveries; his doctrines on pestilence awakened inquiry from every class 
of observers throughout the Union; his expositions of a theory of the earth and solar system captivated minds of the highest qualities. His speculations on the phosphorescence of the waters of the ocean, on the fecundity of fish, on the decortication of fruit trees, on the anatomy and physiology of the shark, swelled the mystery of his diversified knowledge.... His researches on the ethnological characteristics of the red men of America betrayed the benevolence of his nature and his generous spirit. ... He increased our knowledge of the vegetable materia medica of the United States, and wrote largely on the subject.... He largely seconded the views of Judge Peters on gypsum as a fertilizer. . . His letters to Tilloch, of London, on the progress of his mind in the investigation of septic acid-oxygenated azote-is curious as a physiological document.... He was associated with Griscom, Eddy, Colden, Gerard, and Wood in the establishment of the Institution for the Deaf and Dumb; and, with Eddy and Hosack, may be classed with the first in this city, in respect to time, who held converse with the afflicted mute by means of signs."

It would be difficult, says an article in Harper's Magazine for April, 1879, for those who never saw Dr. Mitchill, "to conceive the deference paid to his learning and judgment. His knowledge of the physical sciences, his varied and intimate acquaintance with classical literature, both ancient and modern, his attainments in history and political science, his practical acquaintance with public affairs, and his remarkable affinity with the common and useful arts, caused him to be looked upon as a fountain of learning always ready to pour forth abundant streams of knowledge to every thirsty applicant. A witty friend once said of him, "Tap the doctor at any time, he will flow.' Accordingly, the merits of all inventions, discoveries, projects, arts, sciences, literary subjects and schemes, new books and publications, professional cases, acts of charity or public spirit, and a multitude of other things, used to be submitted to his critical opinion. If he had not been one of the most polite and amiable of men, he could hardly have borne the demands thus made upon his time and patience." Dr. Francis relates that, being present at his funeral, he stayed till all but the sexton had gone, and then asked, unrecognised by him, whom he had just buried. "A great character," the man answered, "one who knew all things on the earth and in the waters of the great 
deep." Dr. Francis is also authority for the story that when the purchase of the Elgin Botanic Garden by the constituted authorities was argued at the Capitol, "he won the attention of the members by a speech of several hours' length, in which he gave a history of gardens and the necessity for them. . . . With his botanical Latinity occasionally interspersed, he probably appeared more learned than ever. Van Horn, a Western member, was dumfounded at the Linnæan phraseology, and declared such knowledge to be too deep for human powers to fathom."

As described by Dr. Francis, Dr. Mitchill's appearance before his class in the instruction room was that of an earnest instructor, ready to impart the stores of his accumulated wisdom for the benefit of his pupils, while his oral disquisitions were perpetually enlivened with novel and ingenious observations. Chemistry, which first engaged his capacious mind, was rendered the more captivating by his endeavours to improve the nomenclature of the French savants, and to render the science subservient to the useful purposes of agriculture, art, and hygiene. In treating of the materia medica, he delighted to dwell on the riches of our native products for the art of healing, and he sustained an enormous correspondence throughout the land, in order to add to his own practical observations the experience of the competent, the better to prefer the claims of our indigenous products.

Many of Dr. Mitchill's scientific papers were published in the London Philosophical Magazine, New York Medical Repository, American Medical and Philosophical Register, New York Medical and Physical Journal, American Mineralogical Journal, and Transactions of the Philosophical Society of Philadelphia ; and he supplied several other periodicals, both abroad and at home, with the results of his cogitations.

Dr. Mitchill was the author of a few verses, and of prose essays or addresses of an order of humorous trifling, much affected at the time, of which the lighter works of Irving and Paulding furnish the most conspicuous examples, and with which Halleck's verses are in sympathy. One of his favourite topics was a proposition to give a new name-Fredon or Fredonia-to the United States, after which the people should be called Fredes or Fredonians, and their relations Fredish or Fredonian. The subject was taken up and discussed in the 
New York Historical Society, but has long since been forgotten.

His social and domestic character, according to the writer in Harper's Magazine, was unusually amiable and attractive, and marked by many amusing peculiarities. He had great fondness for young people, and a rare power of inspiring them with the love of knowledge. His home was pleasant and unpretending, "and the numerous celebrities who used to resort to his salon were entertained with cordial but simple hospitality." His house was a perfect museum of curiosities, and Mrs. Mitchill used to be troubled by the disorder they occasioned. As pertinent to this nuisance, the story of the anteater's skin was told. At first the skin was an object of great interest. Then it became dingy and dusty, and was remanded to the garret. In two or three years more it became old and motheaten, and Mrs. Mitchill and the servant, not wishing to worry the doctor, had it secretly carried off and thrown into the street. Dr. Mitchill, taking his regular walk the next morning, came upon a group of boys curiously looking at some unusual object, which proved to be the ant-eater's skin. He joined them, and, after giving them a full scientific lecture on the ant-eater, said he had a skin like this one at home, and would be glad to have another-and bought it from them for fifty cents. No further attempts were made to get rid of it. 



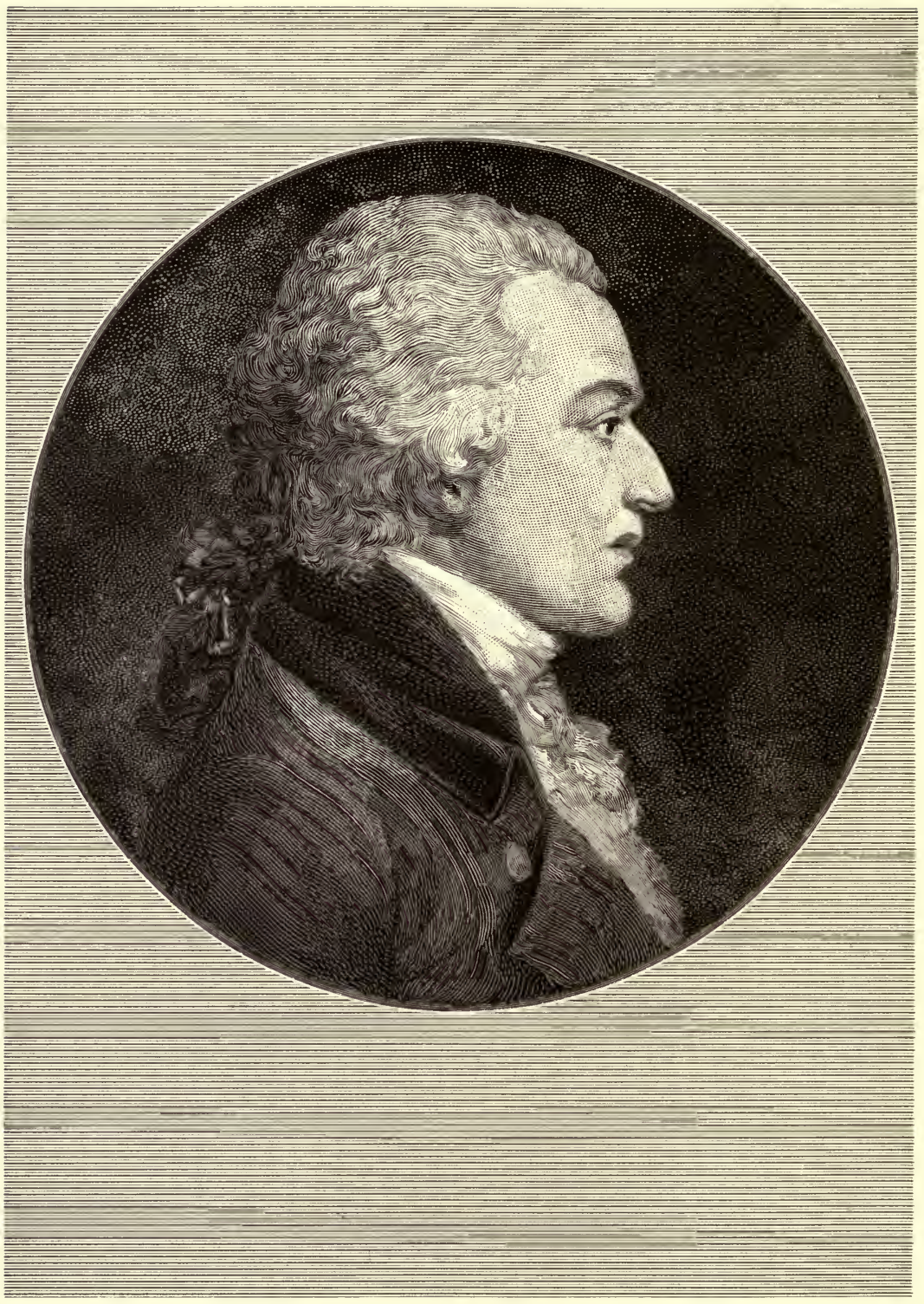

BENJAMIN SMITH BARTON. 


\section{BENJAMIN SMITH BARTON.}

$$
\text { I 766-I } 8 \text { I } 5 \text {. }
$$

OF the three professions formerly distinguished as "learned," that of medicine is the only one connected with natural science. Hence it is not surprising that, in the times when scientific research could seldom be pursued except as an avocation, it was frequently joined to his vocation by the physician. The history of medicine in the Old World is adorned with the names of many profound students of Nature, and in America the name of Dr. Barton stands at the head of a considerable list of eminent investigators who either followed or at least entered upon the medical profession.

Benjamin Smith Barton was one of the younger children of the Rev. Thomas Barton, an Episcopal clergyman, and was born at Lancaster, Pa., February ro, 1766. His mother was a sister of David Rittenhouse, the astronomer. He received, therefore, a double inheritance of intellectual ability, but the benefits of parental care and training were lost to him at an early age. His mother died when he was eight years old, and his father when he was fourteen. Early in the fall of $1778 \mathrm{Mr}$. Thomas Barton had left Pennsylvania, intending to go to Europe, but was taken sick before he could conveniently set sail, and died without returning to his home, May 25, I780, at the age of fifty years.

Before leaving Lancaster Mr. Barton had placed his younger children in the care of a friend in the country near by, where they remained until after their father's death. During this period young Benjamin devoted much of his time to reading, showing considerable fondness for the subject of civil history. Being a studious boy, he naturally took less interest than boys generally do in athletic sports. His predilection for natural history, especially for botany, appeared early, and very likely had received some encouragement from his father, who is 
known to have been a student of Nature. In a note to his Observations on the Desiderata of Natural History Dr. Barton speaks of the "fine collection of North American minerals, which was made by my father near forty years ago, at a time when he paid more attention to this part of natural history than, so far as I know, any other person in the (then) colonies." It appears also that the Rev. Thomas Barton was a member of the American Philosophical Society, and corresponded with Linnæus on botanical subjects.

Young Benjamin early displayed a notable talent for drawing, and afterward became also remarkably skilful in etching. His artistic ability was of great service to him in sketching objects of Nature and in criticising the illustrations prepared by others for his books. He is said to have maintained that " no man could become a nice, discriminating, and eminent botanist without possessing that acumen in perception of proportion, colour, harmony of design, and obscure differences in the objects of the vegetable world which alone belong to the eye of a painter." He insisted on strict accuracy in details that even most careful naturalists would disregard. To mention an extreme instance of his exactness, he had every protuberance on the back, tail, and legs of a horned lizard counted, and required the precise number found to be represented in the drawing made for him.

In the spring of 1780 Benjamin, with one of his brothers, was placed in an academy at York, Pa., where he remained nearly two years, pursuing a course of classical study. When he was sixteen years of age, his elder brother, who was living in Philadelphia, took him into his family, where he remained about four years. During this period he attended for a time the College of Philadelphia, and afterward, at the beginning of his eighteenth year, took up the study of medicine under Dr. William Shippen.

In the summer of 1785 he accompanied the commission, of which his uncle, Mr. Rittenhouse, was a member, that was engaged in running the western boundary line of Pennsylvania. Young Barton was absent from Philadelphia five months, and it was on this expedition that he gained his first acquaintance with the Indians and began his researches into their medicines and pathology, their general customs and history, which received a share of his attention for the rest of his life. 
In order to obtain a thorough medical training it was at that time necessary to go abroad. Accordingly, young Barton repaired to Edinburgh in the autumn of $\mathrm{x} 786$, where he studied for two years, with the exception of a few months spent in London. Having become a member of the Royal Medical Society at Edinburgh, he won the Harveian prize of that association for a dissertation on the Hyoscyamus niger of Linnæus (black henbane). Barton's first book was issued while he was in London, in the early part of $\mathbf{r}_{787}$. It was a little pamphlet, entitled Observations on some Parts of Natural History: to which is prefixed an Account of some Considerable Vestiges of an Ancient Date, which have been Discovered in Different Parts of North America. Considering his youth-he was only twenty-one years of age-and the fact that he was afflicted with ill health when he wrote it, this production is very creditable; but it contained some ill-founded theories and other crudities that he readily and candidly acknowledged only a few months later. For a number of reasons-among them the failure of two professors to show him courtesies that he had reason to expect-he left Edinburgh and took his degree at Göttingen, returning to America toward the close of the year 1789 . He began to practise his profession in Philadelphia, where his knowledge of science soon caused him to be looked upon as one of the rising young men of the day.

The trustees of the College of Philadelphia having instituted a professorship of natural history and botany, appointed Dr. Barton, then only twenty-four years of age, to the chair. This appointment was confirmed in the following year, when the college united with the University of Pennsylvania, and was held by him for the rest of his life. Dr. Barton thus became the first instructor in natural history in Philadelphia, and probably was the first in any American college. Five years later the professorship of materia medica in the University became vacant, and this chair also was assigned to Dr. Barton and was held by him until he succeeded to that of Dr. Rush. On January 28, r798, he received an appointment as one of the physicians of the Pennsylvania Hospital, which position he held for the rest of his life. Dr. Barton was a man of high ambition, and being deeply impressed by the well-deserved fame of Prof. Rush, spared no exertions to equal it. When the latter died, he very naturally desired to obtain his professorship, and 
his application was followed in a few months by his appointment.

Dr. Barton had been from early life subject to hæmorrhages and to attacks of gout-his period of illness while a student at Edinburgh was due to these causes-and he had further weakened his health by too great application to his scientific and professional labours. He had sustained a severe hæmorrhage just before undertaking the labour of preparing for his new position. He had delivered but two courses of lectures on the practice of medicine when his increasing ill health decided him to try the effect of a sea voyage. He accordingly sailed for France in the spring of $181_{5}$, and returned in November of that year, but without gaining the benefit hoped for. Hydrothorax came on soon after he landed in New York, and it was three weeks before he was able to reach home. His condition became rapidly worse, and on the morning of December 19, I815, he was found dead in bed.

Only three days before his death he wrote a memoir on a genus of plants which had been named in honour of him, and requested his nephew, Dr. W. P. C. Barton, to make a drawing to accompany it. The latter did so, and read the memoir at the next meeting of the American Philosophical Society. Dr. Barton was elected to this society January 16,1789 , before his return from his medical studies abroad, and had been one of its vice-presidents since January I, I802. The printed Transactions of the Society afford abundant evidence of his activity as a member and as a man of science. For three years in succession, beginning with 1797 , he was chosen to deliver the annual oration.

In his youth Dr. Barton had suffered the discomforts and hindrances of poverty and the persecutions of those who bore him ill will. But it was not many years before the income from his lectures and his books had lifted him above the influence of want.

Being prevented by his professional engagements from making explorations in search of plants and other objects of natural history, he employed others to collect for him, advancing his favourite sciences by this means. Frederick Pursh, in his Flora America Septentrionalis (London, 1814), describes an excursion that he was enabled to take by the aid of Prof. Barton. Starting in the beginning of 1805 , he went along the 
mountain chain of Virginia and the Carolinas, and returned through the coast lands, reaching Philadelphia late in the autumn. Similar assistance was extended to Thomas Nuttall, "whose zeal and services," to use the words of Dr. Barton, "have contributed essentially to extend our knowledge of the northwestern and western flora of North America, and to whom the work of Frederick Pursh is under infinite obligations." Pursh himself gives due credit for Nuttall's contributions. A genus of plants (resembling cactus), first described by them, was named Bartonia, in honour of "their mutual friend Dr. B. S. Barton." In a paper written by Dr. Barton, a few days before his death, he says of Nuttall:

"I became acquainted with this young Englishman in Philadelphia several years ago; and observing in him an ardent attachment to and some knowledge of botany, I omitted no opportunity of fostering his zeal, and of endeavouring to extend his knowledge. He had constant access to my house, and the benefit of my botanical books.

"In I810 I proposed to Mr. Nuttall the undertaking of an expedition entirely at my own expense and under my immediate direction, to explore the botany, etc., of the northern and northwestern parts of the United States and the adjoining British territories." Dr. Barton further relates that Nuttall set out on this journey in April, i8ro, but he deviated from the route which had been pointed out to him, having been prevailed upon to ascend the Missouri with other travellers, whose objects were principally traffic. Returning, he reached St. Louis in the autumn of I8Ir. "In the latter end of the year I8I I, Mr. Nuttall returned to England by the way of New Orleans. Previously to his departure he transmitted to me a number of the dried specimens and seeds which he had collected." It was on this trip that Nuttall found two species of the genus that he named Bartonia, descriptions and specimens of which he furnished to his patron.

Among the early printed works of Dr. Barton was a Memoir concerning the Fascinating Faculty which has been ascribed to the Rattlesnake and other North American Serpents, published in 1796 . He issued a supplement to this memoir four years later, and a new edition in 1814 . The original paper had been read before the American Philosophical Society. He also undertook a work on the materia medica of the United States, 
issuing an opening part in 1798 , a second part in 1804 , and an edition of the two combined in 1810 . His most important publication was his Elements of Botany, a work of 508 pages, octavo, illustrated with thirty plates, which first appeared in two volumes in 1803 . A second edition of the first volume was issued in 1812 , and of the second volume in 1814 , with forty plates. After the author's death, Dr. William P. C. Barton published, in 1836 , a revised edition in one volume, condensed by omitting the quotations from Latin and English poets, certain tabular views that had become antiquated, and the index. To this edition is prefixed a biographical sketch, prepared by Dr. W. P. C. Barton at the request of the Philadelphia Medical Society, of which Dr. B. S. Barton had been president from February, I809, till he died, and read before that society February 24, 1816. The Elements of Botany was republished in London, and was translated into Russian.

Another considerable work was his New Views of the Origin of the Tribes and Nations of America, which appeared in 1798 . Other subjects on which he published more or less fully were the natural history of Pennsylvania, the disease of goittre, the generation of the opossum, the principal desiderata in natural history (read before the Philadelphia Linnæan Society), Siren lacertina, the hellbender, the bite of the rattlesnake, the honeybee, the jerboa, and the stimulant effects of camphor upon vegetables. He issued also the first part, sixty-four pages, of a work on paleontology, entitled Archaologia Americance Telluris Collectanea et Specimina. In the preface to this fragment he says, "I at one time, indeed for some years together, flattered myself that I should have found leisure to have devoted a considerable portion of my life to the study of organic geology," but adds that his recent succession to the chair of Dr. Rush would prevent any extensive or systematic attention to this subject. An ardent thirst for literary fame, which was present in Prof. Barton throughout his life, made him an indefatigable student and writer. Several ambitious undertakings were left unfinished by him. The following three papers that he had read before the American Philosophical Society remained unpublished at his death: a eulogy on Dr. Priestley, with whom Dr. Barton had been acquainted; a geographical view of the trees and shrubs of North America; and a memoir (which gained the Magellanic premium), concerning a con- 
siderable number of pernicious insects of the United States. Prof. E. A. W. Zimmerman, of Brunswick, translated into German and published the memoir on the fascinating faculty of serpents and that on the bite of the rattlesnake.

In 1797 Dr. Barton married a daughter of Mr. Edward Pennington, of Philadelphia, who, with their only children, a son and a daughter, survived him. He named his son after Mr. Thomas Pennant, an English naturalist and author of Arctic Zoölogy, with whom he became acquainted while a medical student.

Dr. Barton was extremely cautious about accepting human testimony in matters of science, and in one of his publications he declares that "credulity is the most injurious feature in the character of the naturalist as well as that of the historian. Its influence in one individual is often felt and propagated through many ages. Unfortunately, too, it has been the vice of naturalists, or those who have touched on questions relative to natural history."

In a general description of Prof. Barton his nephew says: "As a medical teacher he was eloquent, instructive, and when occasion called for it quite pathetic. His voice was good, though attenuated, penetrating, and sometimes rather sharp-his enunciation clear and distinct-his pronunciation constrained, and his emphasis, owing to his remarkable kind of punctuation, and a desire to be perspicuously understood, was studied, forced, and often inappropriate. In his lectures his diction was cacophonous and unpleasant.

"As a writer he is ingenious, rich in facts, profound in research, and always abounding in useful information. $\mathrm{He}$ wanted, however, in a great degree, a talent for generalizing Hence his various works are characterized by an egregious want of method or perspicuous arrangement. His style, it must be confessed, is always diffuse, inelegant, and frequently tautological. As he never corrected what he once wrote, or at least but rarely, these defects in his composition were the natural consequences of his vehemence in writing. His punctuation is truly remarkable, and, for a man of his discernment and extensive reading, singularly incorrect.

"As a physician, he discovered a mind quick in discriminating disease, skilful in the application of appropriate remedies, 
though he certainly was a very cautious if not timid practitioner. No man read more extensively on the subject of diseases-in fact he was deeply versed in pathological knowledge derived from book As, however, his medical practice was never very extensive, his practical observations delivered in his lectures were strikingly marked with the evidences of overweening caution. Hence he recommended to his pupils, and always employed himself, unusually small doses of medicine. He was, however, in the main, an observing and intelligent practitioner, and was remarkably assiduous in his attentions and soothing in his behaviour to his patients.

"In figure he was tall and exceedingly well formed; in middle life he might be considered as having been handsome. His physiognomy was strongly expressive of intelligence, and his eye was remarkably fine and penetrating.

"In temperament he was irritable and even choleric. His spirits were irregular, his manners consequently variable, impetuous, vehement. These repeated vacillations between equanimity and depression were generally owing to the sudden and repeated attacks of his continual earthly companion-irregular gout.

"In familiar conversation he was often elegant, remarkably facetious, but never witty.

"As a parent he was kind, tender, and indulgent to a fault.

"He possessed some high virtues; among the most elevated of them was his unaffected love of country. Indeed, his patriotic feelings were not only strong, but frequently expressed with unreserved warmth."

A sketch of Barton, extracted from that by his nephew, was published in The Portfolio for April, I8I6 (Philadelphia), and in an editorial note prefixed to it occurs this statement: "Our estimate, too, of the character of the deceased is somewhat different from that which has been formed by the author of this 'Sketch.' Dr. Barton was a very industrious man in the pursuit of science, and though we do not think that he has contributed much to enlarge its bounds, we are willing to believe that his collections will facilitate the labours of the student, to whom he has left a laudable example of active diligence and unwearied perseverance." 
Dr. Barton was in correspondence with many prominent naturalists and physicians both at home and abroad. He established an enviable foreign reputation, as is attested by his membership in the Imperial Society of Naturalists of Moscow, the Linnæan Society of London, the Society of Antiquaries of Scotland, the Danish Royal Society of Sciences; and the Royal Danish Medical Society. 


\section{ALEXANDER WILSON.}

$$
\text { I 766-I } 8 \text { I } 3 \text {. }
$$

A PECULIAR interest attaches to the lives and labours of pioneers. The circumstances which led to the discovery of a new continent, the first application of one of the forces of $\mathrm{Na}$ ture to the services of man, the making of the first instrument for viewing the stars, and the first description of the animals, plants, or physical features of a country, always have eager readers. Then, too, the personality of a man who has the courage and originality to set forth into an untrodden field is generally picturesque and inspiring. All these claims to attention are possessed by the pioneer American ornithologist.

Alexander Wilson was born on the 6th of July, I766, at Paisley, in Renfrewshire, which lies just south of the river Clyde. His father, Alexander Wilson, was a weaver, and reached the age of eighty-eight years, dying in 1816 . During the latter part of his life, at any rate, the father was rated as a most exemplary citizen, but there is a glamour of "moonshine" about his early manhood, in the sense that, when not occupied with tending the loom, he operated a "wee still," from which trickled good Scotch whisky that was consumed without paying tribute to the tax-collector. This has naturally been denied, but not with entire success. His wife was a Mary McNab, of a strictly pious character, and with the beauty that frequently accompanies a tendency to consumption. Of this disease she died when young Alexander, who was one of three children, was ten years old.

Like many devout Scottish folk, the parents of "Alick," especially his mother, cherished the ambition that their boy should "wag his head i' the puppit yet," but his genius did not lie in the direction of the ministerial office. He attended the Grammar School of Paisley, but his schooling must have been interrupted and of no great amount, for much of his boyhood was otherwise occupied, and his deficiencies in grammar, spell- 


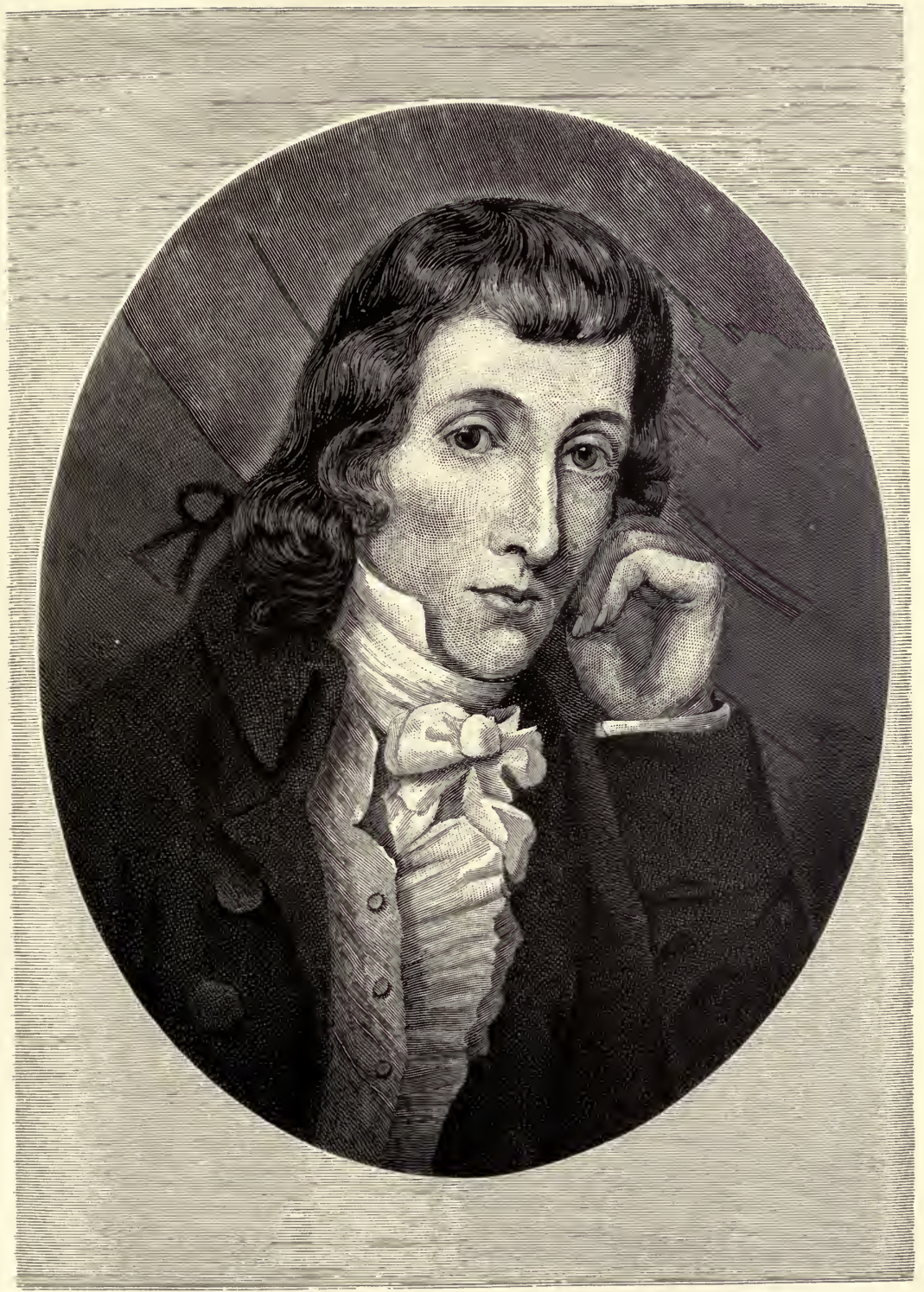

ALEXANDER WILSON. 

ing, etc., clung to him till manhood. $\mathrm{He}$ is known to have struggled with his backwardness in arithmetic after emigrating to America. His handwriting was called excellent, and his language was simple and idiomatic. The taste for reading, which he early developed, largely made up for his scanty schooling. At one time he was sent to be a herd on a farm called Bakerfield, not far from Paisley, where he remained probably not more than a single summer. It is said that "he was a very careless herd, letting the kye transgress on the corn, being very often busied with some book."

In his thirteenth year he was bound apprentice as a weaver, for three years, to his brother-in-law, William Duncan. Having served out his time in 1782 , he continued a weaver "by constraint, not willingly," for four years, living part of the time under his father's roof in Paisley and in Lochwinnoch, and finally with his brother-in-law at Queensferry. His taste was for outdoor life, and he had inherited a feeble constitution from his mother, so that the loom was irksome to him both mentally and physically. During this period young Wilson began to contribute verses to the local newspapers. His best piece, however, Watty and Meg, was published in $\mathrm{I}_{792}$, as a penny chap-book, without his name, and was ascribed to Robert Burns. The latter, who lived not far away, and was but six years older, strengthened the compliment by avowing that he should have been glad to be its author. Wilson's descriptive pieces are interesting, from the evidence they give of his natural fondness for the woods and fields.

After a while Duncan decided to "travel" as a peddler through the eastern districts of Scotland, and invited Alexander to accompany him. Accordingly, the two abandoned the loom and entered upon their new occupation. The Scotch peddler of that time was generally a man of shrewdness and common sense, probably resembling the best type of our own departed Yankee peddler, and was generally respected by the common people, but often suspected and despised by the wealthier. This occupation, although it delivered Wilson from the confinement of the weaving room, was not all sunshine. It involved trials and rebuffs, which to a man, as Grosart* calls

* The Poems and Literary Prose of Alexander Wilson, edited with memorial introduction, essay, etc., by the Rev. Alexander B. Grosart, two vols., Paisley, I876. 
him, "of sensitive, strangely refined if also in elements as strangely coarsened temperament," must have been hardly borne. His Journal as a Pedlar, several poems bearing on his experiences of the road, and his earlier letters give a realizing sense of the lights and shadows of this kind of life. In addition to his trading, he solicited subscriptions for a volume of poems, which he published in 1790 .

In a short time he dropped the pack and returned to his hated trade of weaving. Being in ill health and sorely oppressed by poverty, he was at this period much given to despondency. Yet he had a humour which enabled him at times to joke about his necessities. He had a gift of satire, also, which got him into some trouble, but which was the cause of his taking the first step in the path that led to fame. Industrial affairs in Great Britain at that time were greatly unsettled. Many of the Paisley weavers were unemployed, and capital and labour were arrayed against each other. Some of the turbulent spirits among his fellow-weavers induced the enthusiastic young Wilson to use his talent for verse-making to abuse the capitalists. Several poems of his, portraying in no flattering light certain local petty tyrants, were adjudged libellous, and Wilson, who manfully acknowledged their authorship, was fined heavily and condemned to burn the poems in public. Being unable to pay the fine, he was sent to jail.

In this hour of gloom, Wilson's eyes were turned to the New World. Attracted by the chances for winning his way open to a free man in a new country, he determined to emigrate. Accordingly, he and his nephew, William Duncan, sailed from Belfast Loch, Friday, May 23, I794, and after a voyage of over seven weeks landed at Newcastle, Delaware. Wilson was then twenty-eight years old. He and young Duncan went first to Wilmington, and from there to Philadelphia, looking for employment at weaving. At the latter place, he writes in his first letter home to his father and step-mother, "we made a more vigorous search than ever for weavers, and found, to our astonishment, that, though the city contains between forty and fifty thousand people, there is not twenty weavers among the whole, and these had no conveniences for journeymen, nor seemed to wish for any, so, after we had spent every farthing we had, and saw no hopes of anything being done that way, we took the first offer of employment we could 
find, and have continued so since." This employment was in the shop of a copper-plate printer. The above-quoted letter was a long and very newsy one, and contains Wilson's first observation of the feathered creatures that were to make his fame. He writes: "As we passed through the woods on our way to Philadelphia, I did not observe one bird such as those in Scotland, but all much richer in colour. We saw a great number of squirrels, snakes about a yard long, and some red birds, several of which I shot for our curiosity."

Wilson remained in his first found employment but a few weeks. After that he worked at his trade of weaving at a place ten miles north of Philadelphia, and for a short time in Virginia. In $\mathbf{7} 795$ he tramped through northern New Jersey as a peddler. He had been in America but little over a year when he took up school-teaching, and at this occupation he succeeded remarkably well, although it gave him only a scanty income. He first opened a school at Frankford, but soon gave it up to become master of the school at Milestown, in Philadelphia County, where he taught for nearly six years. His own education had been limited; so, after he began to teach, he had to study diligently to make up his deficiencies. He advanced so far in mathematics that he was enabled to take occasional employment as a surveyor.

After leaving Milestown he taught for a while at Bloomfield, N. J., but found this place disagreeable; and he was at the same time burdened with a trouble, only dimly revealed in his letters, but in which one of the Milestown young ladies figured. He became very despondent, and even thought of returning to Scotland. It was not long before he obtained a school at Kingsessing, near Gray's Ferry, on the Schuylkill. His removal to this place was attended with important results, He became acquainted with William Bartram, who lived at the famous garden of his father, not far away, and with Alexander Lawson, the engraver, both of whom became his steadfast friends. Bartram lent him books, among them the works of Catesby and Edwards. In the parts of these works relating to American birds, Wilson's own acquaintance with the birds was enough to show him an exasperating number of errors, false theories, and caricatured figures. During the early part of his life at this place Wilson was so despondent that Lawson at one time feared for his reason, and advised him to give up poetry 
and his flute, which seemed to increase his melancholy, and to take up drawing. This accomplishment does not seem to have come very naturally to him, for he made a failure of the landscapes and human figures which Lawson set before him. Still, the statement of an American writer that he was "without any previously suspected aptitude" is denied by Mr. Grosart, who adds that drawings by him before he left Scotland are preserved in the Paisley Museum with the collection of Wilson's manuscripts. Bartram and his niece, Miss Nancy, started him again on easier subjects-first flowers, and then birds, with which he made encouraging success.

It is in a letter to one of his Scottish biographers, his old friend in Paisley, Mr. Thomas Crichton, under date of June I, I 803 , that Wilson's determination to study the birds of America is earliest recorded. "Close application to the duties of my profession," he writes, "which I have followed since November, I795, has deeply injured my constitution, the more so that my rambling disposition was the worst calculated of any one's in the world for the austere regularity of a teacher's life. I have had many pursuits since I left Scotland-mathematics, the German language, music, drawing, etc., and I am now about to make a collection of all our finest birds." At first he devoted only leisure hours to the birds, and his figures "were chiefly coloured by candle-light," but he soon began to make longer and longer expeditions. In October, I804, he set out with two companions, on foot, to visit Niagara. From there he went through the lake region of central New York, visiting his sister and her children, who were living on a farm that Wilson and his nephew William had bought together. $\mathrm{He}$ made his way home down the Mohawk Valley to Albany, and thence by boat to New York. In this journey, occupying two months, he traversed over twelve hundred miles. Winter overtook him in the midst of it, so that the latter part of it was made "through deep snows and almost uninhabited forests; over stupendous mountains and down dangerous rivers." The trip seems to have benefited both his health and spirits, for in his account of it, written to Bartram, he expresses eagerness for wider explorations and new discoveries. "With no family to enchain my affections, no ties but those of friendship, and the most ardent love of my adopted country; with a constitution which hardens amid fatigues, and a disposition sociable 
and open, which can find itself at home by an Indian fire in the depth of the woods, as well as in the best apartment of the civilized [world], I have at present a real design of becoming a traveller. But I am miserably deficient in many acquirements absolutely necessary for such a character. Botany, mineralogy, and drawing I most ardently wish to be instructed in, and with these I should fear nothing." How oblivious to matters of detail his enthusiasm made him can be judged, Ord* remarks, from the fact that at this time Wilson's available cash amounted to seventy-five cents.

Two of the birds which he shot in New York, one being the Canada jay, were unknown to Wilson's associates. He made careful drawings of them, and got Mr. Bartram to send them to President Jefferson, whom Wilson much admired. The President, who was quite an amateur naturalist, replied with a very appreciative letter, in which he put Wilson on the track of a certain sweet-singing and very unapproachable bird. He had "followed it for miles without ever, but once, getting a good view of it," and had for twenty years tried to get a specimen, without success. "After many inquiries and unwearied research," says Ord, "it turned out that this invisible musician was no other than the wood robin, a bird which, if sought for in those places which it affects, may be seen every hour of the day." The next summer Wilson announced to Bartram his determination to make a collection of drawings of the birds of Pennsylvania, and sent him twenty-eight for criticism. The scope of his undertaking was extended, within a few months, so as to include the whole United States. He had planned an expedition down the Ohio and Mississippi Rivers for the summer of 1806 with Bartram; but the latter, who was nearly seventy years old, gave up the idea. Wilson, who had heard that explorers were to be sent by the Government up the Red and Arkansas Rivers, through the recently acquired Territory of Louisiana, then offered himself to President Jefferson for this service, "Mr. Wilson," says Ord, "was particularly anxious to accompany Pike, who commenced his journey from the cantonment on the Missouri, for the sources of the Arkansas, etc., on the I $5^{\text {th }}$ of July, I806." But no reply was made to his application.

* Life of Alexander Wilson, by George Ord, in volume ix of the American Ornithology. 
About this time he was engaged by the publishers, Messrs. Bradford and Inskeep, as assistant editor for the revision of Rees's New Cyclopædia, on "a generous salary," namely, nine hundred dollars a year. He now gave up school-keeping, which had been his calling for ten years. While in this position he made known his plans for the American Ornithology to Bradford, who readily agreed to undertake its publication. A prospectus was immediately issued, and a year later, in September, I808, the first volume of the work appeared. In the fall of that year Wilson made a trip through New England, "in search of birds and subscribers." On the way from Philadelphia he stopped at Princeton to show his work to the college professors. $\mathrm{He}$ expected to get some valuable information on American birds from the Professor of Natural History, "but," he writes, "I soon found, to my astonishment, that he scarcely knew a sparrow from a woodpecker." Wherever he showed his book to college professors, and other literary men, the highest praise was lavished upon it, but subscriptions were not so freely forthcoming, the price, one hundred and twenty dollars, being a serious obstacle. He wrote from Albany, on his way home, that he had obtained only forty-one subscribers. One of the less intelligent personages, whose favour he had sought, was the then Governor of New York-Daniel D. Tompkins. This magnate, as Wilson informs us, "turned over a few pages, looked at a picture or two, asked me my price, and, while in the act of closing the book, added, 'I would not give a hundred dollars for all the birds you intend to describe, even had I them alive." "

$\mathrm{He}$ soon set off again on a trip through Baltimore, Washington (where he was received "very kindly" by Jefferson), and other Southern cities, and when he reached home had in all two hundred and fifty subscribers. In the South he shot several new birds. It was now deemed advisable to add three hundred impressions of Volume $I$ to the two hundred first struck off, and the second volume started with an edition of five hundred copies. His undertaking had already won him "reputation and respect," but the pecuniary return was still doubtful.

Volume II of the Ornithology was ready in 1810 , and in February of that year Wilson set out on another hunt for new specimens of the feathered tribes and those rarer birds-sub- 
scribers. His varied adventures on these expeditions, and his impressions of the people and places that he visited, are delightfully recorded in the letters which Mr. Grosart collected.

At Hanover, $\mathrm{Pa}$., he met a judge who condemned his work because "it was not within the reach of the commonality, and therefore inconsistent with our republican institutions." Wilson turned the tables on this learned man by showing that the judge's elegant three-story brick house was open to the same objection; and then in a more serious vein pointed out to him the benefit which a young, rising nation can derive from science, "till he began to show such symptoms of intellect as to seem ashamed of what he said." From Pittsburg Wilson made his way in a skiff down the Ohio over seven hundred miles, nearly to Louisville, stopping at the important towns on the way.

At Louisville one of the persons on whom he called was Audubon, then thirty years old and engaged in business. Audubon has left an account of this meeting, in which he thus describes Wilson's physical appearance: "How well do I remember him as he walked up to me! His long, rather hooked nose, the keenness of his eyes, and his prominent cheek bones stamped his countenance with a peculiar character. .... His stature was not above the middle size." Audubon claims that he was about to subscribe for the Ornithology, but a complimentary reference to his own knowledge of birds, spoken in French by his partner, checked him. "Vanity and the encomium of my friend prevented me from subscribing," he writes, and to this he adds that he lent some of his drawings to Wilson, and hunted with him, obtaining some birds which the latter had never seen before. Audubon states also that being in Philadelphia some time afterward he called on Wilson, who received him with civility, but did not speak of birds or drawings. Against this story must be set the following extract from Wilson's diary published in the ninth volume of the Ornithology: "March 23d, I bade adieu to Louisville, to which place I had four letters of recommendation, and was taught to expect much of everything there; but neither received one act of civility from those to whom I was recommended, one subscriber, nor one new bird; though I delivered my letters, ransacked the woods repeatedly, and visited all the characters likely to subscribe. Science or literature has not one friend in this place." "We must take Audubon's account," says his 
own biographer, Robert Buchanan, "cum grano salis," while Grosart, eager in defence of Wilson, does not hesitate to call it "a tissue of lies," except his admission that vanity kept him from subscribing to Wilson's work.

Turning southward, Wilson crossed Kentucky to Tennessee, and proceeded through the Chickasaw and Choctaw countries to Natchez, and thence went to New Orleans.

By persistent labour the successive volumes of the Ornithology were issued up to the seventh, which appeared in the spring of 1813 . On the 6th of July in that year he wrote: "I am myself far from being in good health. Intense application to study has hurt me much. My eighth volume is now in the press and will be published in November. One volume more will complete the whole." But he was not to see the appearance of even the eighth volume. The unremitting labour of that summer, carried on in the city, where even his tramps with his gun were cut off, so reduced his strength that he succumbed to an attack of his old enemy the dysentery and died, August 23, 1813, at the age of forty-seven. The immediate cause of the attack was his swimming a river in pursuit of a rare bird that he caught sight of while visiting a friend.

Wilson died unmarried, although in his letters he condemns celibacy, and shows that he was not indifferent to female companionship. In fact, he was to have married a Miss Miller, whom he made one of his executors. George Ord, who had accompanied Wilson on some of his trips, was made a coexecutor, and completed the publication of the Qrnithology, prefixing to the last volume a life of the author. The original edition of Wilson's great work is now rare. It comprises nine thin folio volumes, about eleven by fourteen inches in size. Several birds are figured on each plate-the smallest ones of life size, the others reduced. An edition in three volumes, including the birds afterward described by Prince Bonaparte, was issued in $1829-36$, ${ }^{*}$ and another in four volumes, edited by Prof. Robert Jameson, in 1831 .

Wilson was no compiler; he took his facts from his own observations, or the accounts of those who had known the birds for a lifetime. He had, further, as Grosart says, a "magnet-

* American Ornithology, by Alexander Wilson and Prince Charles Lucien Bona parte. Edited, with a Life of Wilson, by Sir William Jardine, Bart. 
ical sympathy with the birds whereby his descriptions of their looks and ways and faculties take the colouring of so many little biographies of personal friends."

Sir William Jardine says of Wilson: "He was the first who truly studied the birds of North America in their natural abodes, and from real observations; and his work will ever remain an ever-to-be-admired testimony of enthusiasm and perseverance-one certainly unrivalled in descriptions; and if some plates and illustrations may vie with it in finer workmanship or pictorial splendour, few, indeed, can rival it in fidelity and truth of delineation." 


\section{DAVID HOSACK.}

$$
\text { I 769-1 } 835 \text {. }
$$

IN the early part of the nineteenth century no citizen of New York was held in higher honour than was De Witt Clinton. Closely associated with Clinton in the leadership of the civic life of the day, but holding rigidly aloof from politics, was Dr. Hosack. "It was not infrequently remarked by our citizens," said his pupil and associate, John W. Francis, "that Clinton, Hosack, and Hobart were the tripod on which our city stood." Dr. Hosack was one of the founders of the New York Historical Society and its president from I 820 to I 828 . He was also instrumental in founding an art society, was prominent in various scientific, literary, and humane undertakings, and, if his lead had been followed, New York would have today a botanic garden equal to any in a European metropolis.

David Hosack was the eldest of seven children, and was born August 3I, I769, in the house of his maternal grandfather, No. 44 Frankfort Street, New York. His father, Alexander Hosack, was a native of Morayshire (Elgin), Scotland. Having entered the British army, he was, at the age of twentyone, serving as an officer in the artillery. He came to America in the force under General Sir Jeffrey Amherst, and was at the retaking of Louisburg. April I, I768, he married in New York Jane, daughter of Francis Arden. Her father's family came from England, while that of her mother belonged to that valuable contingent of Huguenot citizens which America received as a consequence of the revocation of the Edict of Nantes.

Young David, after receiving the ordinary elements of education, was placed at fourteen or fifteen years of age in the academy of the Rev. Dr. Alexander McWhorter, of Newark, N. J., where he pursued the study of Latin and other usual branches and began to learn Greek. But as Dr. Peter Wilson, 


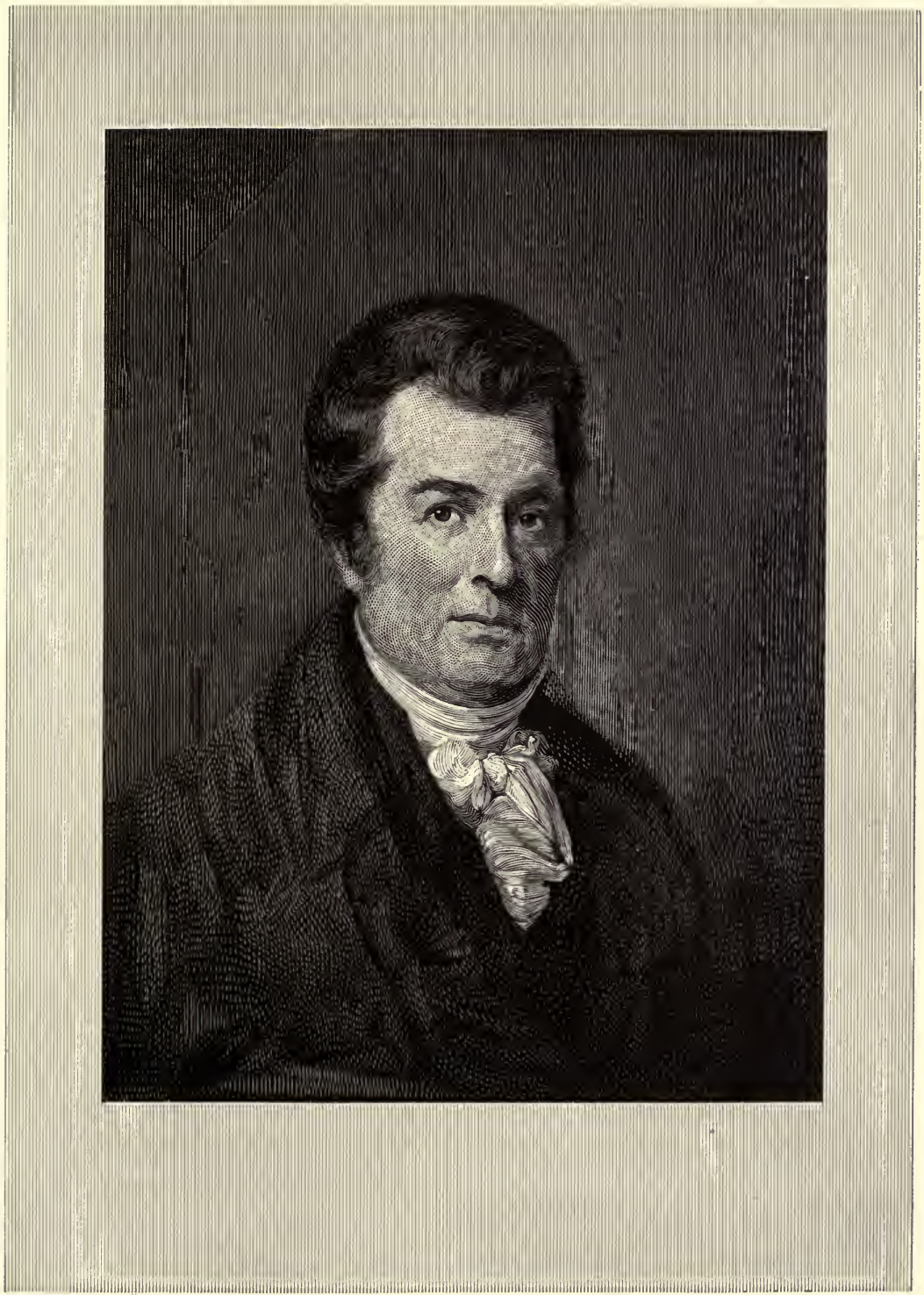

DAVID HOSACK. 

of Hackensack, was a more distinguished teacher of that language than Dr. McWhorter, David was transferred to his academy in 1785. The next year he entered Columbia College, remaining in that institution until the middle of his junior year. $\mathrm{He}$ had also private tutors in the classics and the French language. In the beginning of the junior year, finding his time not fully occupied, he took up the study of medicine as a private pupil under Dr. Richard Bayley. "He had scarcely begun his studies," writes his son," "before the celebrated 'Doctors' Mob' occurred, which threatened serious results to those concerned; it arose in consequence of the imprudence of some of the students carelessly pursuing dissection in the building upon the site since occupied as the New York Hospital. This mob caused many of the professors to absent themselves from the city and others to seek shelter in the city jail. Mr. Hosack, with the rest of the students interested, learning that the mob had seized upon and demolished the anatomical preparations found in the lecture room above referred to, repaired immediately to Columbia College, $\nmid$ with the view of saving such specimens as were to be found in that institution. Before reaching the college, however, and when on his way in Park Place, he was knocked down by a stone striking him on the head; he would in all probability have been killed had it not been for the protection he received from the neighbour of his father, Mr. Mount, who was passing at the time and took care of him."

In the fall of 1788 young Hosack entered the senior class of the College of New Jersey at Princeton in order that he might the sooner complete his collegiate course and devote his whole attention to the study of medicine, to which he had become ardently attached. "Having finished my course at Princeton," he says in some memoranda that he left for the benefit of his children, "I returned to New York and resumed my favourite medical studies, to which I now gave my undivided attention, availing myself of every advantage which the city at that time presented. I attended the lectures on anatomy and

* Dr. Alexander E. Hosack, in a biography contributed to the Lives of Eminent American Physicians and Surgeons of the Nineteenth Century, edited by Samuel D. Gross, M. D. From this biography most of the facts for the present article have been drawn.

t Then in College Place. 
physiology delivered by Dr. Wright Post, those on chemistry and practice of physic, by Dr. Nicholas Romayne, and the valuable course on midwifery and the diseases of women and children, by Dr. Bard. I also attended the practice of physic and surgery at the almshouse, which then offered the only means of clinical instruction in this city; they were, however, very ample, the house being daily visited by Dr. Post, Dr. William Moore, Dr. Romayne, and Dr. Benjamin Kissam."

There was then no institution in New York empowered to grant the degree in medicine, the medical faculty of Columbia, formerly King's College, having been broken up by the Revolution. So after a year of private study Hosack proceeded to Philadelphia and enrolled at the medical school of the University of Pennsylvania, where Drs. Shippen, Rush, Kuhn, and Wistar were then among the professors, and in the summer of the succeeding year obtained his medical degree. In the same year he married at Princeton Miss Catharine Warner, a young lady of great worth, to whom he had become attached while pursuing his collegiate studies.

By the advice of Dr. Rush and others whom he consulted Dr. Hosack settled first at Alexandria, Va., which place he believed was to be the capital of the United States. The practice that he acquired here, although considerable was not satisfactory to him, and after a year's residence he returned to New York. He now determined to supplement his medical studies abroad. "Observing the distinction," to quote his own words, "which our citizens at that time made between those physicians who had been educated at home, and those who had had additional instruction from the universities of Europe, and knowing how little property I had reason to expect from my parents, I found that my chief dependence was upon my own industry and increasing attention to the profession I had chosen as the means of my subsistence: my ambition to excel in my profession did not suffer me to remain insensible under such distinction. Although it was painful for me to think of leaving my family, consisting then of a wife and child, I accordingly suggested to my father the propriety of my making a visit to Europe, and of attending the medical schools of Edinburgh and London. $\mathrm{He}$ at once, with his characteristic liberality, acquiesced in my views and wishes. In August, 
I792, leaving my family to the care of my parents, I took passage for Liverpool."

After spending a few days in Liverpool he proceeded to Edinburgh, where he attended the medical lectures at the university during the following winter. In the spring, after a visit to his father's birthplace, where he met two uncles and other relatives, and to some other places in Scotland, he repaired to the metropolis and entered as a pupil of St. Bartholomew's Hospital. He also frequently visited other hospitals when any important surgical operations were performed, surgery being the favourite subject of his pursuit; he nevertheless did not neglect the collateral branches of medical science.

It was during this stay abroad that his interest in botany sprang up. "Having," as he says, "upon one occasionwhile walking in the garden of Prof. Hamilton, at Blandford, in the neighbourhood of Edinburgh-been very much mortified by my ignorance of botany, with which his other guests were familiarly conversant, I had resolved at that time, whenever an opportunity might offer, to acquire a knowledge of that department of science. Such an opportunity was now presented, and I eagerly availed myself of it. The late Mr. William Curtis, author of the Flora Londinensis, had at that time just completed his botanic garden at Brompton, which was arranged in such a manner as to render it most instructive to those desirous of becoming acquainted with this ornamental and useful branch of a medical education. Although $\mathrm{Mr}$. Curtis had for some time ceased to give lectures on botany, he very kindly undertook, at my solicitation, to instruct me in the elements of botanical science. For this purpose I visited the botanical garden daily throughout the summer, spending several hours in examining the various genera and species to be found in that establishment. I also had the benefit once a week of accompanying him in an excursion to the different parts of the country in the vicinity of London. Dr. William Babbington, Dr. Thornton, Dr. (now Sir) Smith Gibbs, Dr. Hunter, of New York, the Hon. Mr. Greville, and myself composed the class in these instructive botanical excursions, in the summer of $\mathrm{r} 793$.

"By Mr. Dickson, of Covent Garden, the celebrated cryptogamist, the 'maximus in minimis,' as Mr. Curtis has very properly and facetiously denominated him, I was also initiated into 
the secrets of the cryptogamic class of plants. In the spring of $\mathrm{r} 794 \mathrm{I}$ also attended the public lectures of botany delivered by the President of the Linnæan Society, Dr. (now Sir) James Edward Smith; and by the kindness of the same gentleman I had access to the Linnæan Herbarium. I spent several hours daily for four months examining the various genera and the most important species contained in that extensive collection. Notwithstanding my attention to botany, I was not unmindful of the other departments of medicine." The acquaintance thus begun with Sir James Edward Smith ripened into an affectionate friendship, and a correspondence was begun that ended only with Smith's life.

In the course of the winter of I793-'94 Dr. Hosack embodied certain Observations on Vision in a paper which he communicated to the Royal Society. It was published in the society's 'Transactions for 1794, and brought him, after due examination by a committee, the thanks of the society. A theory was in some vogue at the time that the power of accommodation in the eye resided in the crystalline lens. Hosack maintained the opposing theory, that it depended upon the external muscles. His paper contained many original views, and its statements were supported by experiments that he had made upon himself and others.

He returned to New York in $\mathrm{I} 794$ by the ship Mohawk, the passage lasting fifty-three days. On the voyage typhus fever made its appearance and became very general, particularly among the steerage passengers. Dr. Hosack being the only physician on board, was called upon to attend the stricken ones, and was wonderfully successful, not losing a single case. His services were duly appreciated by all, as was evinced by the unsolicited vote of thanks published in the daily papers when the ship reached port.

Taking up his residence in New York city, Dr. Hosack at the age of twenty-five years began again the practice of his profession under the most favourable auspices. Mr. Thomas Law, who had been a fellow-passenger on the Mohawk, introduced him to many of his acquaintances, among whom were General Hamilton and Colonel Burr. He soon became the family physician to these distinguished persons. In 795 he was appointed Professor of Botany in Columbia College, for which position his diligent application to this science in Lon- 
don had admirably fitted him. At the end of his first course he published a syllabus of his lectures, afterward inserted in his Medical Essays. In 1795, also, the yellow fever reached New York, and the violence of the epidemic afforded ample opportunity to young medical men to distinguish themselves. Dr. Hosack at this time attracted the especial attention of Dr. Samuel Bard, one of his former preceptors, who soon after took him into partnership. This was a preparatory step to Dr. Bard's retiring from the profession, which he did three or four years later, leaving Dr. Hosack in the enjoyment of an extensive and profitable practice.

Having lost his infant son during his absence in England and his wife not long after his return, Dr. Hosack married, Decmber 21, I797, Mary, daughter of James and Mary Darragh Eddy, of Philadelphia. By this marriage he had nine children.

Upon the death, in $\mathbf{I 7 9 7}$, of Dr. William Pitt Smith, his chair of Materia Medica in Columbia College was assigned to Dr. Hosack, in addition to the one of Botany already held by the latter. He continued to fill these two professorships until I807, when the College of Physicians and Surgeons of the State of New York was established, in which he was chosen Professor of Surgery and Midwifery. He soon, however, relinquished this chair for that of the Theory and Practice of Physic and Clinical Medicine. The Analectic Magazine for I 8 I 4 contained a notice of an introductory lecture given in the last-named chair, which had been published. It says that, after an opening statement on another matter, "Dr. Hosack proceeds to point out what he deems the proper method of cultivating the science of medicine. He recommends the inductive system of philosophizing as the only sure means of acquiring correct methods in science, and enforces the same by the celebrated examples of Bacon, Boyle, and Newton in physics, of Reid, Bentley, and Stewart in metaphysics, and of Hippocrates, Sydenham, and Boerhaave in medicine."

Meanwhile Dr. Hosack had become prominently known for his success in the treatment of yellow fever, which had visited New York in four successive summers, beginning with I 795, and afterward in $1803,1805,1819$, and 1822 . On many occasions, when disease suspected to be yellow fever broke out, he was called upon by the Board of Health of New York for a report 
as to its real nature, for if the fears of his fellow-citizens were groundless his statement would be sure to allay them.

Of Dr. Hosack in the professorial chair, Dr. Minturn Post, one of his pupils, has said: "In no respect was Dr. Hosack more remarkable than as a lecturer; gifted with a commanding person and a piercing eye, of an ardent temperament and of strong convictions, his manner of treating the various subjects connected with his professorship was at once bold, impressive, and eloquent. . . His great object was to direct the student to the importance of the subject under examination, to lead him by his eloquence, and to rivet his attention by his earnestness, and no man ever succeeded better as a public lecturer in attaining these results. ... Dr. Hosack was gifted with a fine, sonorous voice, great play of expression, and a remarkable vivacity of manner-qualities which, being as it were contagious, begat in his youthful auditory a kindred sympathy." In closing his account above quoted Dr. Post remarks: "He lived in memorable times, before the great men of the Revolution had passed away; had seen and conversed with the most eminent of the age; had listened to the inspired song of Burns, tuned to sweet cadence, from his own lips; was intimate with Rush, and Gregory, and Sir Joseph Banks, and was the friend of Clinton and Hamilton." The friendship of Hamilton was probably won for the most part by his success in saving the life of a son of the general sick with scarlet fever, whose case for a time was deemed hopeless. This friendship was conspicuous on every occasion, and was terminated only on that day when Dr. Hosack accompanied Hamilton across the Hudson River to his fatal duel with Colonel Burr.

Dr. Hosack is often mentioned as one of the leading promoters of science of his time. "His love of botanical science," says his son, "induced him to found the Elgin * Botanic Garden, which he did at his own individual expense, as early as I80I. It was situated about three and a half miles from the city of New York. It consisted of about twenty acres of land on the middle road. $\nmid$ It was selected from its varied soil as

\footnotetext{
* So named after the village in Scotland where his father was born.

+ The location is given in Mrs. Lamb's History of New York as lying between Fifth and Sixth Avenues and stretching from Forty-seventh to Fiftyfirst Streets.
} 
peculiarly adapted to the cultivation of the different vegetable productions. The grounds were skilfully laid out and planted with some of the most rare and beautiful of our forest trees. An extensive and ornamental conservatory was erected for the cultivation of tropical and greenhouse plants, as well as those devoted to medical purposes, more especially those of our own country.

"At this time there were under cultivation nearly fifteen hundred species of American plants, besides a considerable number of rare and valuable exotics. To this collection additions were made from time to time from various parts of Europe as well as from the East and West Indies. It was the intention of the founder of this beautiful garden, had his means been more ample, to devote it to the sciences generally, more especially those of zoölogy and mineralogy. This, however, he was compelled from want of fortune to relinquish, hoping that the State of New York would at some future day be induced to carry out the plan as suggested by him similar in all respects to that of the Garden of Plants in Paris; but in this he was disappointed. The State purchased the garden from him, but, like many other public works unconnected with politics, it was suffered to go to ruin. While it was in his possession it afforded him many a pleasant hour of recreation, and served to abstract him from the cares and anxieties of an arduous profession." Frederick Pursh, author of the Flora Septentrionalis, was for several years curator of this garden.

A jail society, which had existed in New York to supply provisions to prisoners for debt, was developed by Hosack into the Humane Society, with broader aims and means. The City Dispensary received no less his care and attention. He vigorously advocated a separate hospital building for contagious diseases, the strict enforcement of quarantine regulations, the substitution of stone piers for wooden ones, and urged that the city's sewers should discharge at the outer ends of the piers instead of at the bulkhead line.

His friends often wondered that Dr. Hosack found time to contribute so much as he did to the literature of his profession. At an early period he began the publication of the Medical and Philosophical Register, a quarterly journal, in which Dr. John W. Francis was associated with him. He afterward published three volumes of his Medical Essays, containing occa- 
sional addresses, introductory lectures to his regular courses, many practical papers on medical subjects, etc. He also published an extensive appendix to a work on the Practice of Medicine, by Dr. Thomas, of Salisbury, England. Adopting the nosological arrangement as a system best calculated to illustrate diseases, he was induced to prepare a work on that subject, which ran through several editions.

Botany was not the only branch of science in which he became interested while abroad. To quote from a sketch of his life by a friend: " $\mathrm{He}$ attended in the winter of $\mathrm{I} 793-$ '94 the first course of lectures on mineralogy that was delivered in London by Schmeisser, a pupil of Werner. With this additional knowledge of mineralogy, which Dr. Hosack had begun to study at Edinburgh, he continued to augment the cabinet of minerals which he had commenced in Scotland. This collection was brought by him to the United States, and was, we believe, the first cabinet that crossed the Atlantic; it was afterward deposited in Princeton College, in rooms appropriated by the trustees, but fitted up at the expense of the donor, similar to those at the Ecole des Mines at Paris. To render this donation immediately useful, it was accompanied by a collection of the most important works on mineralogy."

Having a large circle of friends and acquaintances, and being fond of company, Dr. Hosack used to set apart his Saturday evenings for entertaining them. "Surrounded by his large and costly library, his house was the resort of the learned and enlightened from every part of the world. No traveller from abroad rested satisfied without a personal interview with him; and, at his evening soirée, the literati, the philosopher, and the statesman, the skilful in natural science, and the explorer of new regions, the archæologist and the theologue met together, participators in the recreation of familiar intercourse." Many a distinguished American and many a foreign visitor, coming with a letter from somẹ European friend of Hosack, has left on record his delightful experience in a visit to the doctor, either at his city house or his place in the country.

Of the scientific honours most prized by Americans in his day-membership in European societies-Dr. Hosack had a goodly share. He also received the honour of having a genus of plants named for him. The various species of Hosackia, 
of which there are some thirty, are herbs and shrubs growing in the Southern and Southwestern States and in Mexico.

His second wife having died, Dr. Hosack married Mrs. Magdalena Coster, widow of the Holland merchant, Henry A. Coster. Some time after this event he retired from his profession and spent the rest of his life, except the winter months, on the beautiful estate at Hyde Park, on the banks of the Hudson, which he had owned for a number of years. Here he devoted himself to agriculture and to growing plants of botanical interest. "He carried with him," his son remarks, "the same ardour and zeal which had been so characteristic of him in his professional career. He introduced into the country many of the finest breeds of cattle, sheep, and swine, which he imported at great expense from abroad. The grounds were cultivated in the best possible manner, and the most esteemed fruits and vegetable productions of the country were made to thrive in the greatest luxury possible."

In the autumn of 1835 Dr. Hosack removed as usual to his city residence, and a few weeks after was seized with apoplexy which terminated his existence. One morning in December he went out and did some business errands, and on his return home found he was paralyzed in his right arm. His speech was also affected. He received immediate attention from his son, Dr. A. E. Hosack, and later from several of his professional friends. But their efforts were of no avail. His symptoms became worse, and four days after the attack, on December $22 \mathrm{~d}$, he passed away. His body was placed in the family vault in the marble cemetery in Second Street.

One of the surest ways in which an eminent man can cause his influence to live after him is in training up younger men to lives of usefulness. This Dr. Hosack was constantly doing. "I can scarcely recollect the time," says his son, "when he was without some such protégé." At one time it was the son of a New York carpenter, who, unfortunately, fell a victim to his devotion to yellow-fever patients in the epidemic of 1798 . At another it was a young Frenchman, who, without means, had come to America to study its flora, his family having been forced to leave France on account of the Revolution there. Dr. Hosack took him into his family and educated him as a physician. He returned to France and became eminent as a botanist. This was Prof. Delile, who accompanied Napoleon 
to Egypt as the botanist of his corps de savants, and was afterward superintendent of the Jardin des Plantes at Montpellier. Among Dr. Hosack's regular pupils at the College of Physicians and Surgeons was John Torrey, and many other students who heard his lectures at the medical school or at Columbia College had whatever of inclination toward botany they possessed greatly quickened by the enthusiasm and eloquence of Dr. Hosack. 



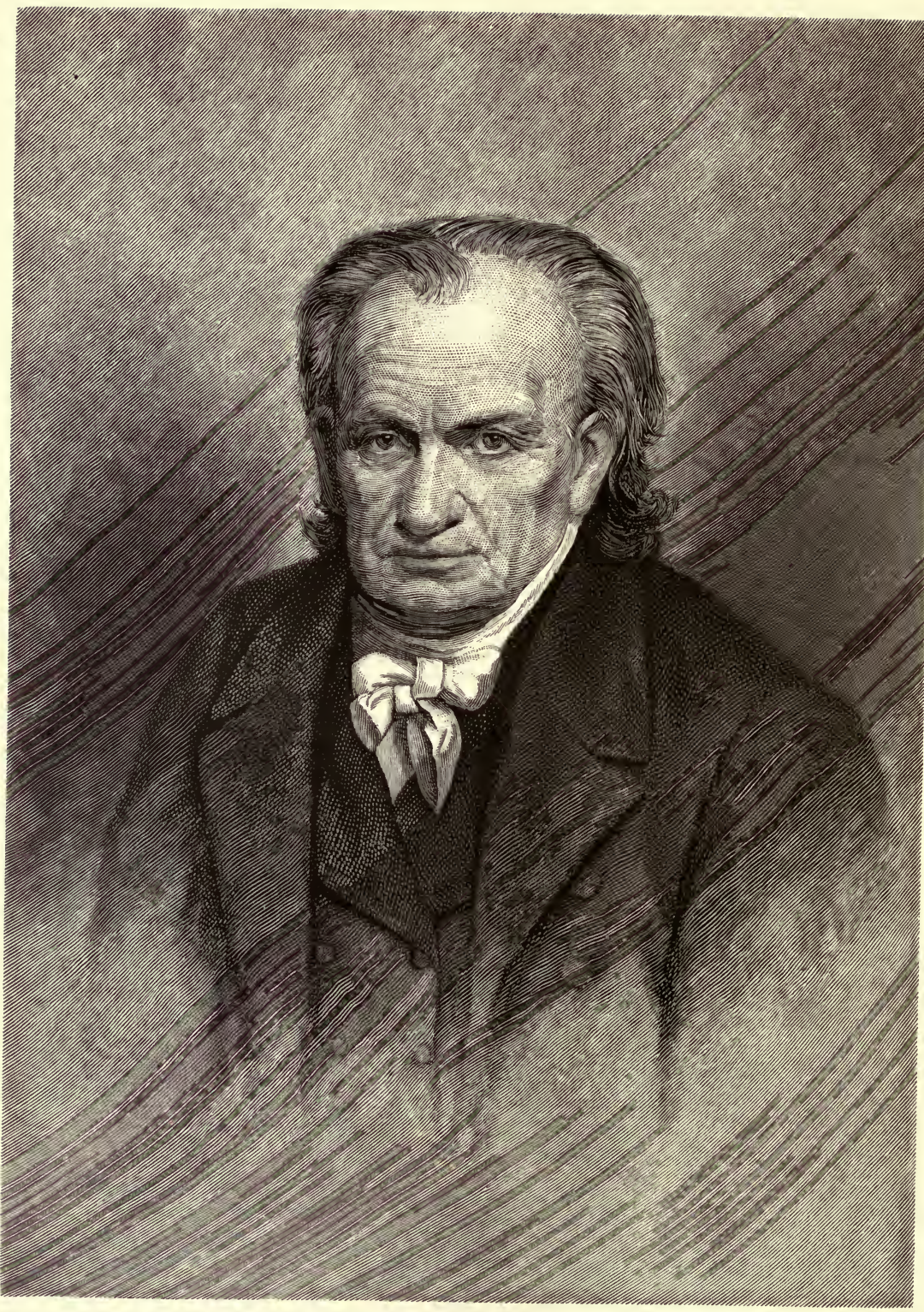

AMOS EATON. 


\section{AMOS EATON.}

$$
\text { I } 776-1842 \text {. }
$$

Prof. Amos Eaton was prominent among those who cultivated science in the earlier half of this century, who laboured to popularize the study and make it accessible to the masses. American geology and botany owe much to him. His books on those subjects have two special merits-they were among the first published in which a systematic treatment for America was attempted, and they were written throughout in a language that all could read.

Amos Eaton was born in Chatham, Columbia County, N. Y., May $17, x 776$, and died in Troy, N. Y., May 6, r842. His father, Captain Abel Eaton, was a farmer in comfortable circumstances, and of the best standing as a citizen. The family was descended from a John Eaton, who came from Dover in Eng-

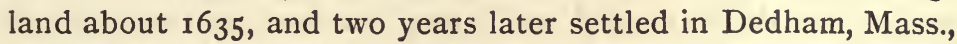
where descendants of the elder line still reside. The scholastic tendencies which determined the character of his career appear to have shown themselves at an early age, for we find that in I790, when Amos was only fourteen years old, he was appointed to make a Fourth-of-July oration, and acquitted himself acceptably in the effort. Serving as a chain bearer in the surveying of some land, he acquired a taste for that business. $\mathrm{He}$ had no instruments, and, in order to obtain them, he arranged with a blacksmith to "blow and strike" for him by day, in return for which the blacksmith should help him make instruments at night. After several weeks' work, a needle, magnetized from kitchen tongs, and a working chain were turned out. A compass case was made out of the bottom of an old pewter plate, well smoothed, polished, and graduated; and the young man, at sixteen years of age, was ready to do little jobs of surveying.

He fitted himself for college with the Rev. Dr. David Pot- 
ter, of Spencertown ; entered Williams College, and was graduated thence in I799, with a high standing in science. On October r6th of the same year he married, at Chatham, Polly, daughter of Malachi and Mary (McCall) Thomas, who died three years later, leaving him a son. He prepared himself for the legal profession, studying law with the Hon. Elisha Williams, of Spencertown, and the Hon. Josiah Ogden, of New York. An association which he formed in New York with Dr. David Hosack and Dr. Samuel L. Mitchill, the most distinguished scientific men in the city at the time, marked another determinative point in his career; for, under their instruction, he became interested in the natural sciences, and particularly in botany. So earnest did he become in these studies that, having borrowed Kirwan's Mineralogy, he made a manuscript copy of the whole work. Having been admittd to the bar of the Supreme Court of New York, he settled in Catskill as a lawyer and land agent, and continued his studies in science. At this place he began, in $18 \mathrm{ro}$, a course of popular lectures on botany, which is believed to have been the first attempted in the United States. In connection with the lectures he compiled a small elementary treatise. Dr. Hosack commended him as being the first in the field with this course, saying, "You have adopted the true system of education, and very properly address yourself to the memory."

Finding that his taste for the incidents of legal practice was diminishing, and his interest in science was growing upon him, Mr. Eaton resolved to abandon the law and devote himself to the more congenial pursuit. He removed to New Haven in I $81_{5}$, and there placed himself under the tuition of Prof. Silliman, who was lecturing on chemistry, geology, and mineralogy: He enjoyed the advantage of Prof. Silliman's library and of that of Prof. Ives, in which works on botany and materia medica were prominent, and was a diligent student of the college cabinet of minerals. Having become well grounded in the sciences he took up his abode near Williams College, where he gave courses of lectures to volunteer classes of the students on botany, mineralogy, and geology, and awakened a permanent interest in the natural sciences. An interesting description of his personality at this time, when he was in his prime, is given by Prof. Albert Hopkins, who speaks of him as "of striking personage, a large form, somewhat portly and dignified, though 
entirely free from what is commonly called starch. His face was highly intellectual, the forehead high and somewhat retreating, locality strongly marked, and the organs of observation and compassion well developed. His hair was black, and, being combed back, rendered his fine physiognomy still more striking." In the same year the first edition was published of Prof. Eaton's Manual of Botany, a work the appearance of which, according to Dr. Lewis C. Beck, gave an i mpulse to the study of botany in New England and New York, which had been hampered by the want of a manual in English. The only descriptive work previous to this one was that of Pursch, in which the descriptions were in Latin. The Manual was added to and became fuller, in successive editions, till the eighth edition, published in 1840 , was a large octavo volume of 625 pages, known as the North American Botany of Profs. Eaton and Wright, and contained descriptions of 5,267 species of plants.

From Williams College the lectures were extended, in the shape of courses, with practical instructions to classes, to the larger towns of New England and New York. Prof. Eaton was greatly aided in this enterprise by the patronage and encouragement he had received from the faculty and students of Williams College, and the fame he derived from his lectures there; and he made an acknowledgment of this fact in dedicating the second edition of his botany to the president and professors, when he said, "The science of botany is indebted to you for its first introduction into the interior of the North. ern States, and I am indebted to you for a passport into the scientific world." In the course of two or three years, says Prof. H. B. Nason, to whose Biographical Record of the Rensselaer Polytechnic Institute we are most largely indebted for the material for this sketch, "Prof. Eaton diffused a great amount of knowledge on the subjects of his lectures; and so far excited the curiosity and enthusiasm of many young students that there sprang up, as a result of his labours, an army of botanists and geologists." The late Prof. Albert Hopkins, of Williams College, accrediting Prof. Eaton with being one of the first to popularize science in the Northern States, mentioned as among his special qualifications for the task an easy flow of language, a popular address, and a generous enthusiasm in matters of science, which easily communicated itself to his pupils. $\mathrm{He}$ 
adds: "Prof. Eaton was among the first in this country to study Nature in the field with his classes. In pursuance of this idea, he used to make an annual excursion with Rensselaer School, sometimes leading these expeditions in person, at others deputing some competent teacher to take the lead. The cause of natural history in Williams College owes, undoubtedly, a good deal to Prof. Eaton. I think his zeal in the department of botany led Prof. Dewey to direct his discriminating mind to the study of plants, a study which he pursued further than Prof. Eaton had done in certain lines. . . . At this time, also, Dr. Emmons took the field. In fact, natural history came on with the spring tide, and has never lost the impulse since." While at Albany, in 1818 , on the invitation of Governor Clinton, delivering a course of lectures before the members of the Legislature of New York, Prof. Eaton became acquainted with many leading men of the State, and interested them in geology and its application by means of surveys to agriculture. Here was planted the idea which eventually fructified in that great work, The Natural History of New York. In the same year Prof. Eaton published his Index to the Geology of the Northern States, which has been pronounced "the first attempt at a general arrangement of geological strata in North America." Although under the undeveloped condition of geology at the time, with the defective knowledge even among its advanced students, this book could not fail to contain many statements now known to be errors, it must be recognised as a creditable and valuable effort. An interesting view of the conditions of geology at the time and of the method of study is given in a letter which Prof. Eaton wrote to Mr. Henry R. Schoolcraft, in 1820 , while preparing a second volume of his Index. In it he said: "I have written the whole over anew, and extended it to about two hundred and fifty pages, r 2 mo. I have taken great pains to collect facts in this district during the two years since my first edition was published, but I am rather deficient in my knowledge of secondary and alluvial formations. I wish to trouble you with a few inquiries on that subject. From what knowledge I have been able to obtain in that department, I am inclined to arrange the secondary class thus: Breccia, compact, or shell limestone; gypsum, secondary sandstone. I leave much, also, for peculiar local formations. A gentleman presented specimens to the Troy Ly- 
ceum, from Illinois, of gypsum and secondary sandstone, and informed me that the latter overlaid the former in regular structure. Myron Holly and others have given me similar specimens, which they represent as being similarly situated, from localities in the western part of this State. This secondary sandstone is sometimes more or less calcareous. I believe it is used for a cement by the canal company, which hardens under water. Will you do me the favour to settle this question? On your way to Detroit you may perhaps, without material inconvenience, collect facts of importance to me in reference to secondary and alluvial formations. Anything transmitted to me by the middle of April on these subjects will be in season, because I shall not have printed all the transition part before that time. Have you any knowledge of the strata constituting the Rocky Mountains? Is it primitive, or is it graywacke, like Catskill Mountains? I have said in a note that after you and Dr. E. James set foot upon it we shall no longer be ignorant of it. I intend to kindle a blaze of geological zeal before you return. I have adapted the style of my index to the capacity of ladies, plough-joggers, and mechanics."

Prof. Eaton also delivered lectures at Lenox Academy and the Medical College at Castleton, Vt., where he was appointed Professor of Natural History in 1820 . He gave lectures and practical instructions in Troy, and thus laid the foundation for the establishment there, as a direct result of his work, of the Lyceum of Natural History; and it is said that in the fall of I818 Troy could boast of a more extensive collection of American geological specimens than could be found at any other literary institution in this country. The geological and agricultural survey of Albany and Rensselaer Counties, made in 1820 and 1821 , by Prof. Eaton and Drs. T. Romeyn and Lewis C. Beck, at the expense of the Hon. Stephen Van Rensselaer, is believed to have been the beginning of such surveys in this country, and was described by Prof. Silliman, in his Journal, as a novel attempt. Next was a geological survey by Prof. Eaton, also at the instance of Mr. Van Rensselaer, of the district adjoining the Erie Canal, the result of which was published in 1824 , in a report of one hundred and sixty pages, with a profile section of rock formations, from the Atlantic Ocean, across Massachusetts and New York, to Lake Erie. 
Governor Seward said of this work, in the Introduction to the Natural History of the State of New York, that it "marked an era in the progress of geology in this country. It is in some respects inaccurate, but it must be remembered that its talented and indefatigable author was without a guide in exploring the older formations, and that he described rocks which no geologist had at that time attempted to classify. Rocks were then classified chiefly by their mineralogical characters, and the aid which the science has since learned to derive from fossils in determining the chronology and classification of rocks was scarcely known here, and had only just begun to be appreciated in Europe. We are indebted, nevertheless, to Prof. Eaton for the commencement of that independence of European classification which has been found indispensable in describing the New York system. . . . Prof. Eaton enumerated nearly all the rocks in western New York, in their order of succession, and his enumeration has, with one or two exceptions, proved correct. It is a matter of surprise that he recognised, at so early a period, the old red sandstone on the Catskill Mountains, a discovery the reality of which has since been proved by fossil tests."

In 1824 Prof. Eaton was placed at the head, as "Senior Professor," of the School of Science founded by the Hon. Stephen Van Rensselaer at Troy, N. Y., then called the Rensselaer School, now the Rensselaer Polytechnic Institute. $\mathrm{He}$ spent the remainder of his life in this position. He introduced and developed here a system of instruction in which the students were made experimenters and workers, and, in place of recitations, delivered lectures to one another. The success of this method was such that some one or other of its features were introduced into other schools.

Summarizing his career in brief, Prof. Nason says, in his biography: "In developing the botany and geology of the Northern States, Prof. Eaton rightfully ranks among the pioneers of the new era of the natural sciences in this country. His efforts in various departments of natural history were a rich gift to New England, New York, and even to the whole country, for which the country owes him a debt of gratitude. Many of his pupils have been for years among the most justly distinguished scientific men of the country. As an educator and an active labourer in the general cause of natural history 
in America, his memory will long be cherished. The history of natural science on this continent can never be faithfully written without giving the name of Amos Eaton an honourable place. It was he, more than any other individual in the United States, who, finding the natural sciences in the hands of the learned few, by means of popular lectures, simplified textbooks, and practical instruction, threw them broadcast to the many. He aimed at a general diffusion of the natural sciences, and nobly and successfully did he accomplish his mission."

Prof. Eaton is described as having been a kind and courteous gentleman, whose vast acquirements and simple habits were pleasantly characterized by Mrs. Emma Willard's designation of him as "the Republican Philosopher." In 1803 he married Sally, a daughter of Eleazar and Tryphena (Beebe) Cady, and sister of Daniel Cady, afterward Judge of the Court of Appeals of New York. She bore him five sons. After her death he was again married, October 20, 1816, to Anne, daughter of Lewis and Lydia (Woodin) Bradley, by whom he had three sons and two daughters. She having died, he married, August 5,1827 , Alice, daughter of Benjamin and Alice (Smith) Johnson, who bore him one son, and survived him about four years. Three of his sons adopted scientific pursuits or cultivated scientific tastes. One, Hezekiah Hulbert Eaton, was Assistant Professor of Chemistry in Transylvania University, but died when only twenty-three years old. Major General Amos B. Eaton was an officer of the United States Army, and interested in science. A daughter, Sara C. Eaton, was a teacher of natural sciences and the modern languages in a young woman's seminary at Monticello, Ill. A grandson, Daniel Cady Eaton, has been Professor of Botany in Yale College since 1864 .

The list of Prof. Eaton's books includes an Elementary Treatise on Botany, I8ro; Manual of Botany, I8I7 ; Botanical Dictionary, 1817 ; Botanical Exercises, 1820 ; Botanical Grammar and Dictionary, I828; Chemical Notebook, I82 i ; Chemical Instructor, I822; Zoölogical Syllabus and Notebook, 1822; Cuvier's Grand Division, I822; Art without Science, I800; Philosophical Instructor, 1824; Directions for Surveying and Engineering, 1838 ; Index to the Geology of the Northern States, 1818; Geological and Agricultural Survey of 
the County of Albany, N. Y., I820; Geological Nomenclature of North America, I822; Geological and Agricultural Survey of the District adjoining the Erie Canal, 1824; Geological Text-Books, prepared for Popular Lectures on North American Geology, 1830; and Geological Text-Book, for the Troy class, I84I. 



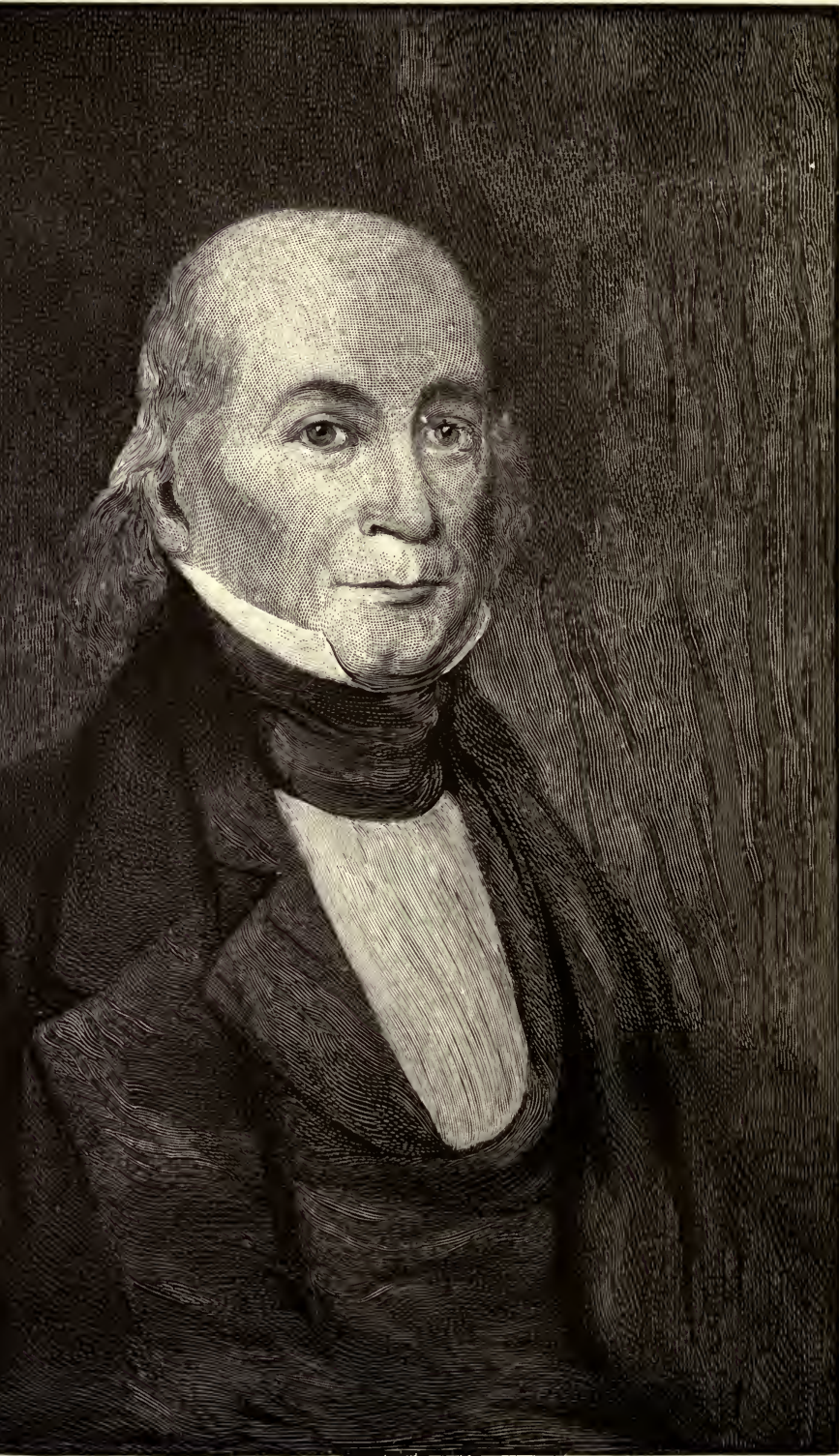

GERARD TROOST. 


\section{GERARD TROOST.}

$$
\text { I 776-1850. }
$$

Gerard Troost, one of the founders and first President of the Academy of Natural Sciences of Philadelphia, was born at Bois-le-Duc, Holland, March 5, 1776, and died in Nashville, Tenn., August 14, 1850. His parents were Anna Cornelia (Van Heeck) and Everhard Joseph Troost. He attended the Universities of Leyden and Amsterdam, devoting special attention to chemistry, geology, and natural history; received the degree of Doctor of Medicine from the University of Leyden, and that of Master in Pharmacy, in I80I, from the University of Amsterdam. He practised his art for a short time at Amsterdam and the Hague; served in the army as a private soldier, and at another time as an officer of the first class in the medical department; and during these periods of service was wounded in the thigh and in the head. In 1807 he went to Paris, under the patronage of Louis Napoleon, King of Holland, to pursue his studies, and then he became the pupil and associate of the Abbé René Just Haüy, author of the famous system of crystallography. For this distinguished and most excellent man he ever cherished a filial, grateful, and affectionate respect. One of the last letters written by the illustrious Haüy was to Troost with a presentation copy of his great work. While in Paris he translated into the Dutch language one of the earlier works of Alexander von Humboldt; The Aspects of Nature. This service brought him the cordial thanks of the author, with whom he maintained a friendly correspondence to the last.

Dr. Troost travelled in France, Italy, Germany, and Switzerland, and collected a valuable cabinet of minerals, which was purchased by the King of Holland. In I 809 this king appointed Troost to accompany, in a scientific capacity, a naval expedition to Java. He was captured by an English privateer 
and confined for some time; returned to Paris; and'then made his way to La Rochelle. He took passage from a northern port, beyond French jurisdiction, in an American vessel, for New York, whence he hoped to reach the East Indies under the protection of our flag. This vessel was captured by a French privateer and Troost was kept a prisoner till the French became aware of his true name and character, when he was released. He went at once to Paris. In March, I8ro, he was elected a correspondent of the Museum of Natural History of Paris. A few days afterward he was allowed to embark again on an American vessel for Philadelphia. The turn of political events in Europe, among which was the abdication of Louis Napoleon as King of Holland and the surrender of Java to England, caused him to abandon his contemplated visit to the East Indies and to remain in the United States.

His decision to remain here may have been partly due to his forming the acquaintance of Miss Margaret Tage, of Philadelphia, whom he married on the I4th of January, I8Ir. They had two children-Caroline, who married Mr. A. G. Stein, a civil engineer, and went with her husband to live in Mobile. The second child was Louis, who became a civil engineer, and removed to Mobile, where he resided until his death. Mrs. Troost died in 1819 , when Louis was little more than a year old. The facts here given in regard to the parentage and marriage of Dr. Troost and the birth of his children are derived from the record in an old family Bible, kindly transcribed by his grandson, Mr. Louis Stein, of Mobile. The entries are in Latin, and presumably in Dr. Troost's own hand. Dr. Troost married a second wife, a Mrs. O'Riley, who by admirable housekeeping greatly aided him in the conduct of his affairs. There were no children by this marriage.

A brother of Dr. Troost, Dr. Benoit Troost, came to the United States, and was living at Kansas, Mo., when Gerard Troost died.

In 1812 Dr. Troost participated in the foundation of the Academy of Natural Sciences in Philadelphia and became its first president. Of the origin of this society, Dr. W. S. W. Ruschenberger, from whose account we derive much of the material of this sketch, says there were some young persons in Philadelphia disposed to study the laws of creation. Occupied with their business during the day, they were accustomed to 
converse concerning natural phenomena when they met in the evening, without appointment, at the ordinary places of resort. They very often met at the apothecary's shop of John Speakman, of whom Thomas Say was subsequently the business partner, at the corner of Market and Second Streets. At one of these meetings Mr. Speakman suggested that if the young men could be induced to meet at stated times, where they would be secure from interruption, to communicate to one another what they might learn about the phenomena of Nature, they would derive more pleasure and profit than from desultory and irregular conversation. The suggestion was seconded by Jacob Gilliams, and a meeting was appointed for the next Saturday evening at Mr. Speakman's house, for the young men and such of their friends as might be interested in the matter: Six persons were present at the meeting, January 25, I8 1 2 : Dr. Gerard Troost, Dr. Camillus Macmahon Mann, Jacob Gilliams, John Shinn, Jr., Nicholas Parmentier, and John Speakman, host. The meeting was described in the minutes as "a meeting of gentlemen, friends of science and of rational disposal of leisure moments"; and it was agreed that the exclusive object of the society should be the cultivation of natural science. For the furtherance of this purpose all matters of politics and religion were rigorously excluded, even allusions to them being forbidden. It was perhaps from this determination, Dr. Ruschenberger suggests, that "the erroneous notion sprang, which, according to tradition, prevailed with some, that the object of the institution was to favour religious infidelity." The constitution of the society was agreed upon on the I 7 th of March, and the name Academy of Natural Sciences was adopted on the 2 Ist of that month, which date was established as that of the beginning of the institution. On that day, too, the members agreed "to contribute to the formation of a museum of natural history, a library of works of science, a chemical experimental laboratory, an experimental philosophical apparatus, and every other desirable appendage or convenience for the illustration and advancement of natural knowledge, and for the common benefit of all the individuals who may be admitted members of our institution." Among the first donors of minerals were Dr. Troost, Mr. Isaac Lea, Dr. Hays, and Mr. S. Hazard. When the small room, I2I North Second Street, hired about the ist of April, was occupied, the 
members came foward with their gifts to serve as the nucleus of the museum and library. Among them was Dr. Troost, with some artificial crystals, prepared by himself. On the occasion of the election of officers, May 7, 1812, Dr. Troost was chosen president. He held this office five years, or till $18 \mathrm{I} 7$, when he resigned and was succeeded by William Maclure. On the 15 th of August, 1812 , the collection of minerals previously purchased from Dr. Seybert by Mr. Speakman came formally into the possession of the society, which formed a kind of joint-stock company to pay for it and hold it. Soon after this, Dr. Troost delivered a course of lectures on mineralogy before the academy.

During his residence in Philadelphia Dr. Troost was engaged in manufactures of various kinds. In 1815 or 1816 he began the manufacture of alum on the Magothy River, Cape Sable, Maryland, establishing the first alum works in the United States. Owing to the failure of the proprietors, he suffered great pecuniary loss. The War of I8I 2 with Great Britain had stimulated manufactures, and its termination was disastrous to many enterprising men. In $182 \mathrm{I}$ he was appointed Professor of Mineralogy in the Philadelphia Museum, where he delivered lectures on the subject. He was also appointed about the same time first Professor of Chemistry in the College of Pharmacy, Philadelphia, a position which he resigned, after having delivered one course of lectures, in the surceeding year. During this period he also made geological excursions into New Jersey, New York, and elsewhere.

In I825 Dr. Troost, with Maclure, Say, and Lesueur, joined Robert Owen in the formation of the Communistic Society at New Harmony, Ind. After remaining there two years, he removed to Nashville, Tenn., in 1827 . In 1828 he was elected, at the instance of President Lindsley, Professor of Chemistry, Geology, and Mineralogy in the University of Nashville. In a historical sketch, published in the catalogue of $185^{\circ}$, is a table of the longest terms of official service of instructors. It is headed by President Lindsley, twenty-six years; and next in length of service comes Prof. Troost, from February 9, I 828, to August I4, I850, twenty-two years and a half.

In I $_{3} \mathrm{I}$ he was appointed State Geologist of Tennessee, an office which he held till it was abolished in 1839 . The record of his work in this department is preserved in his reports. 
The first and second reports were not published. The third report, made in 1835 , contains the results of the geologist's investigations respecting the extent of the coal formations in the State. "I have ascertained," it says, "that the places in which coal may be expected belong exclusively and entirely to that group of mountains which are known by the name of Cumberland Mountains, and are composed of Walden's Ridge, Crab Orchard Mountain, Brimstone Mountain, and some other subordinate ridges of the same system." The breadth of the formation was greatest near the northern limit of the State, and in one part the coal was represented as deposited in horizontal strata of great extent. The report also deals largely with marl, iron, and soils, and concludes with the words: "In a scientific point of view, my labours have been very advantageous. I have been very fortunate in obtaining organic remains which were unknown, and which eventually will show how far our strata correspond with those on the old continent. I have discovered parts of the American or gigantic mastodon hitherto unknown."

The fourth report, of 1837 , relates to the Ocoee district, comprising a part of the mountain region near the North Carolina boundary, which Prof. Troost was directed by the State Legislature to explore. It begins with an exposition of the principles of geology and their application to the general structure of the district under view, for the information of the people; an admirable specimen of exact scientific writing adapted to popular comprehension, explicit, lucid in style, and showing familiarity with the subject. The character of the region is depicted in a few words: "Commencing our reconnaissance at the most northern extremity of the district, I found the rocks at Tallassee, on the Tennessee River, entirely composed of grauwacke, alternating here and there with limestone; this is the case everywhere along the Tennessee River, where I was able to approach and examine them, to the Smoky Mountain, which forms the southeastern limit of the district, and separates Tennessee from North Carolina. It is almost impossible to penetrate any distance in this wild and mountainous country; and the apparent confusion of the rocks, which seem at some places heaped up without order, and changing at small distances, makes the geological survey hazardous and extremely difficult." The author calls attention to 
tin of the Geological Society of France, a memoir on the organic remains and fossils of Tennessee; and in Silliman's American Journal of Science and the Arts, articles on Amber at Cape Sable, Maryland; Minerals of Missouri; Coral Regions of Tennessee; Analysis of a Meteorite from Tennessee; Meteoric Iron from Tennessee and Alabama; A Shower of Red Matter in Tennessee; Three Varieties of Meteoric Iron; Meteoric Iron of Murfreesboro, Tenn.; and Krausite and Cacorene in Tennessee. His last writing, forwarded to the Smithsonian Institution for publication only a few weeks before his death, was a monograph on the rare and hitherto undescribed encrinites of Tennessee, with accurate and beautiful drawings, from specimens in the doctor's cabinet.

He gathered a collection of about fourteen thousand mineralogical and more than five thousand geological specimens, besides a large number of shells, and relics from Indian mounds, constituting what was at the time considered the finest cabinet belonging to a single person in the United States. This cabinet was sold in 1874 by his heirs to the Louisville (Ky.) Public Library for twenty thousand dollars. His specimens in comparative anatomy, zoölogy, and botany were disposed of before his death. Besides the Philadelphia Academy, he was a member of the American Philosophical Society, the Geological Society of Pennsylvania, the Geological Society of France, and of other scientific bodies in America and Europe.

A minute adopted by the Board of Trustees of the University of Nashville, on the occasion of the death of Prof. Troost, relates that, "born and liberally educated in Holland, he early manifested a zealous devotion to natural history and chemistry, more especially to the then infant sciences of geology and mineralogy. With a view to the more successful pursuit of his favourite studies he visited Paris, and was for several years the pupil of the celebrated Haüy. He removed to the United States about forty years ago, and in due time became an American citizen. His entire life was consecrated to geology and the kindred sciences, with what ability and success his published writings and his well-earned reputation at home and abroad may eloquently testify. As a professor in this university during the last twenty-two years and a State geologist of Tennessee for the most part of that period, he won the confidence and respect of the community by invaluable service in 
both capacities, as well as by the unaffected modesty, kindness, and uniform courtesy of his deportment toward all men. In the various relations and stations of life, public and private, he was without reproach and above suspicion. Beloved, trusted, honoured, venerated by all those most intimately connected or associated with him, he could not make an enemyhe had none."

The last official act of Dr. Lindsley before retiring from the presidency of the university was to pronounce a discourse on the life and character of Troost, from which many of the facts in this account are derived.

A son of President Lindsley, Prof. J. Berrien Lindsley, M. D., who was Dr. Troost's favourite and most trusted pupil, thus writes of him: "The doctor was, in all respects, of most lovable character. From my early boyhood until his death I knew him intimately, and admired and revered him. He was universally esteemed. From the University of Nashville he received throughout his long professional career one thousand dollars per annum for three lectures weekly to the senior class; from the State five hundred, and, for a short period, one thousand dollars per annum for three months' geological explorations. He lived very frugally and sent large sums to Europe for rare and choice mineral specimens. He dealt largely with Hewland, of London, and with Krautz, of Bonn. The latter told me, in $185^{2}$, that Dr. Troost was one of his most liberal customers."

In a letter to President Lindsley, replying to one which had informed him of Troost's death, Dr. Charles T. Jackson, of Boston, wrote: "It was my good fortune to become somewhat intimately acquainted with Dr. Troost in 1825 , while travelling in company with him and the late distinguished geologists and naturalists, Maclure, Say, and Lesueur, during their scientific excursions through the counties of Sussex, N. J., and Orange, N. Y., and I was struck with the unaffected simplicity of his manners, and his uniform kindness and courtesy, as well as his prompt and scientific recognition of the minerals and rocks which it was our object to examine. He was an accurate and scientific mineralogist, and very correct crystallographer, remembering with the most remarkable fidelity the exact angles of known crystals of minerals, so that he readily distinguished rare and remarkable forms." 


\title{
CHARLES ALEXANDRE LESUEUR.
}

\author{
I $778-1846$.
}

Among the early naturalists in America, not the least deserving of commemoration was the artist, traveller, and naturalist who was "the first to study the ichthyology of the Great American Lakes." He travelled widely in Pennsylvania, New York, and New England from i 817 to 1828 . He had won a high reputation in France as an artist. As a naturalist he had voyaged for over three years with Péron. He was a careful and faithful observer, and, according to accounts, a man of most genial and attractive character.

Charles Alexandre Lesueur was born at Havre-de-Grâce, France, on New Year's Day of 1778 . His father, Jean Baptiste Denis Lesueur, who was an officer of the admiralty, bestowed upon his son such education as his limited means allowed, there being several other children that equally claimed his paternal care. In French schools the elements of drawing were even then taught, and young Charles early developed a strong bent toward this art. At the end of his school days the productions of his pencil displayed the skill and finish of a master.

Toward the close of the eighteenth century the Institute of France conceived a project for a government expedition of discovery and scientific observation in the southern parts of the Eastern hemisphere. The idea found favour with Bonaparte, who was then First Consul, and was duly carried out. Two corvettes, named Le Géographe and Le Naturaliste, were equipped in the port of Havre, officers and crews were carefully selected from the best material in the navy, and a scientific corps of twenty-three members was organized. This body comprised four astronomers and hydrographers, three botanists, five zoloögists, two mineralogists, four artists, and five gardeners. There was great competition for places in both the naval and the scientific departments of the expedition. It had been in- 


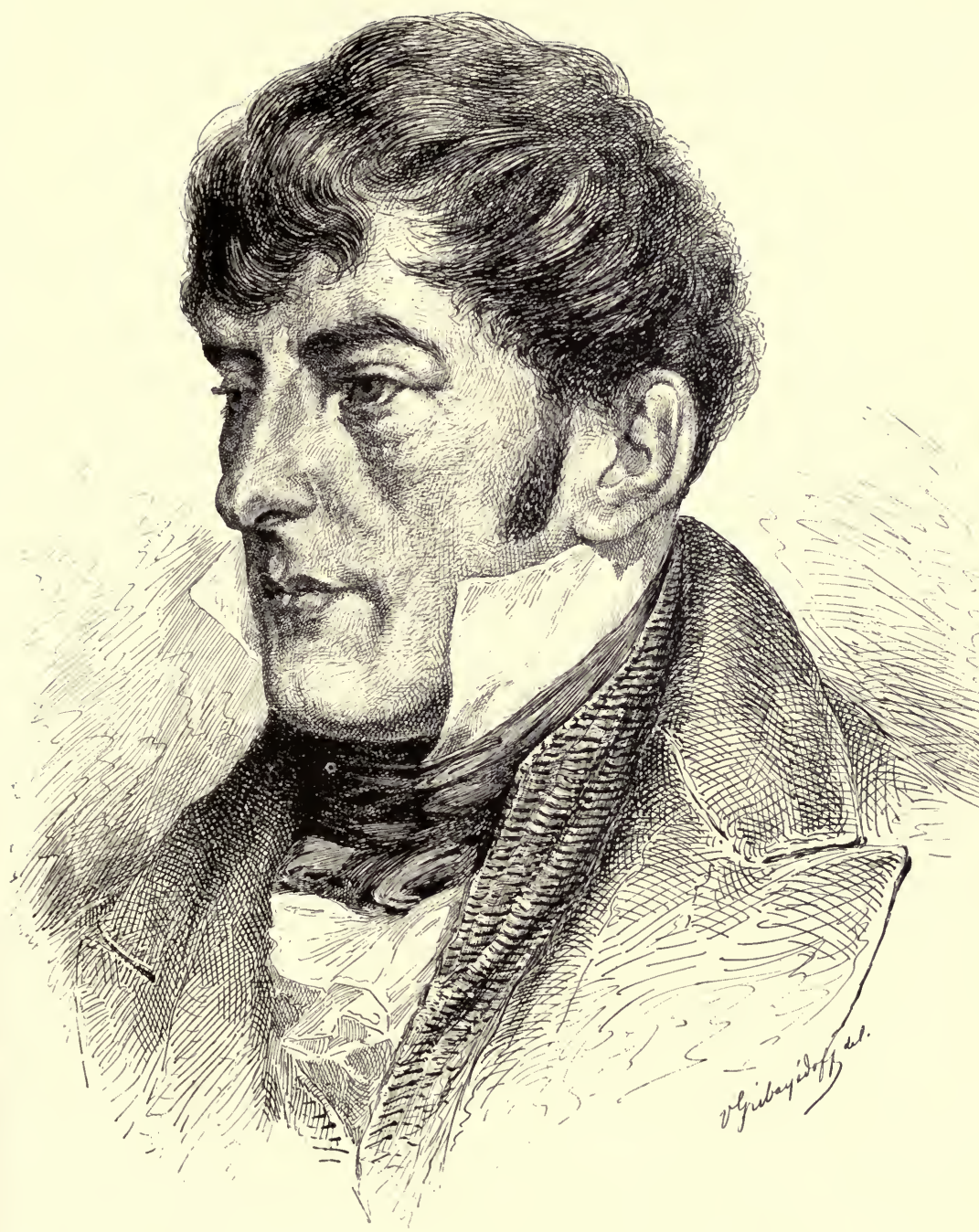

CHARLES ALEXANDRE LESUEUR. 

tended to have only four zoloögists. The fifth was François Péron, a young physician, who made a place for himself after the staff was complete by pointing out the desirability of adding a medical naturalist, who should make researches upon the natural history of the human race, or anthropology. Lesueur caught the prevailing fever and succeeded in joining the expedition by enlisting on board Le Géographe as an aide canonnier according to one authority, or a novice-timonier (helmsman's apprentice) according to another. A detailed account of this voyage is given by George Ord, in the memoir of Lesueur read by him before the American Philosophical Society in 1849 . The two vessels set sail October I9, I800, touched at the Canaries, and after following around the coast of Africa reached the Ile de France, now Mauritius, east of Madagascar, on March I5, I80I. Long before the ship reached this port the talent of young Lesueur for drawing and painting had become known. When the artists of the scientific corps saw the masterly manner in which he had depicted some of the mollusks, and soft zoöphytes taken in the early part of the voyage, they declared him worthy of a place in their department. The commander in chief, Nicholas Baudin, accordingly released him from the humble position he occupied among the crew, gave him similar accommodations to those enjoyed by the other artists, and for occupation set him at work illustrating the private journal which the commander kept. This journal, aside from Lesueur's illustrations, was worthless. Lesueur had made the acquaintance of Péron, who was only three years older than he, and for the rest of the voyage these two young men worked zealously together.

The commander had by this time proved himself both incompetent and dishonest. Instead of standing from the Canaries across the ocean to near Brazil, and from there to the Cape of Good Hope, thus taking advantage of the trade winds, he attempted to follow down the coast, and experienced calms and baffling winds, which caused much loss of time. At Mauritius upward of eighty boxes and trunks, among whose contents, it was alleged, were quantities of the wines, liquors, and medicines belonging to the ship, were put on shore in charge of the commander's secretary, who soon opened a shop for the sale of these goods. Seven of the scientific corps decided to go no further. These were Bissy, an astronomer; André Mi- 
chaux, and Delisse, botanists; Bory de Saint-Vincent, zoölogist; Milbert, Lebrun, and Garnier, artists. Forty of the best seamen had deserted, and several of the officers remained on the island. Many of those who left the ships had the excuse of illness, but their chief reason was a sense of insecurity with such a commander. Worse was to follow, for in the subsequent part of the cruise the work of the scientific exploring parties was hampered by the rigid discipline of the commander and the inadequate supplies of food and arms which he furnished to them, while sickness and death afflicted both the crew and the scientific corps because of his neglect of well-known sanitary measures 'and the scant allowance of water, stimulants, and sometimes food, prescribed by him.

After a stay of six weeks at Mauritius the expedition proceeded to Australia. While exploring this coast the ships became separated in a gale. The Géographe then visited $\mathrm{De}$ Witt's Land and went next to Timor, where she was rejoined by her consort. On this island, while pursuing a troop of monkeys among the rocks which obstructed the course of the River Coepang, Lesueur was bitten in the heel by a venomous reptile. He was alone, at some distance from the town, but by placing a ligature around the limb he was able to reach the quarters of the surgeon general and obtain treatment, which saved his life.

Although the climate of Timor is very unhealthful to Europeans, a stay of eighty-four days was made there. As a result dysentery made frightful havoc among the crew, while among the scientists the chief gardener died at the island, two zoölogists, a mineralogist, and another gardener only a short time after leaving it. The ships at length set sail for Tasmania, which was explored together with part of the southern coast of Australia. The horrors of scurvy had succeeded the dysentery. A long stop was made at Sydney to care for the sick and replenish supplies. The Naturaliste was sent home from here and a small schooner was bought to accompany the Gégraphe. Five months were spent in further explorations of Tasmania and neighbouring islands, and another stay of a month was made at Timor, but dysentery caused a hurried departure. The ship being in need of supplies which could not be procured in the vicinity, and the commander suffering from hemorrhage, the 
course was laid for Mauritịs, where Baudin died six weeks after reaching Port Louis.

After a stay of four months at Mauritius the Gégraphe set sail for the Cape of Good Hope, homeward bound. At that port Péron, now the only remaining zoölogist of the expedition, with the aid of Lesueur, made a careful investigation of an anatomical peculiarity of the Bushman women-a fold of skin called the apron-of which Lesueur made four careful drawings. From the Cape the ship proceeded directly to France, entering the port of Lorient, March 25, 1804, after an absence of upward of three years and five months.

Knowledge of Captain Baudin's misconduct and of the consequent disintegration of the scientific corps had predisposed the Government and the Institute to regard the expedition as a failure, so that Péron and Lesueur met with rather a cold reception. They secured, however, a committee to examine the collections brought home by the Naturaliste and Gégraphe, from whose comprehensive report, made June 9, I806, the following summary is drawn:

"Of the five zoölogists appointed by the Government, two remained at the Isle de France. Two others perished at the commencement of the second campaign, by diseases contracted at Timor. Péron alone was left; but supported by his invigorated ardour, and the efforts of his coadjutor Lesueur, a zoölogical collection was made, the extent and importance of which become more and more manifest. It is composed of more than one hundred thousand specimens of animals, several of which will constitute new genera; and the new species, according to the report of the professors of the museum, are upward of twenty-five hundred. If we call to mind that the second voyage of Cook, fruitful as were its discoveries, made known not more than two hundred and fifty new species, and that all the united voyages of Carteret, Wallis, Furneaux, Mears, and even Vancouver, did not produce as great a number, it results that Péron and Lesueur alone have discovered more new animals than all the travelling naturalists of modern days."

After commending Péron's descriptions, the report proceeds :

"A description, nevertheless, how complete soever it may be, can never give a sufficiently just idea of those singular 
forms, which have no precise term of comparison in objects previously known. Correct figures alone can supply the imperfection of language. Here the labours of which it is our duty to render an account acquire a new interest. Fifteen hundred drawings or paintings, executed by Mr. Lesueur with extreme precision, reproduce the principal objects which were collected by his careful industry and that of his friend. All these drawings, either made from living animals or recent specimens, form the most complete and the most precious series of the kind that we have any knowledge of."

Of Lesueur's share in the work the report says further: "You have seen, by what we have said of the labours of Lesueur, that he was almost everywhere an associate in those of Péron. The natural history of man is not less indebted to him. All the details of the existence of the natives have been designed by him with the most scrupulous accuracy. All their musical instruments, those of war, of hunting, of fishing; their domestic utensils; all the peculiarities of their clothing, of their ornaments, of their habitations, of their tombs-in a word, all that their rude ingenuity has been able to accomplish, is found united in the productions of this skilful and indefatigable artist. The principal sites of the coasts explored by the expedition; different views of the town of Sydney, the capital of the English colony of New South Wales, its plan, etc., give to the Atlas of the History of the Voyage, edited by his friend, a new character of importance."

The Government now provided for the publication of a history of the voyage, under the editorship of Péron, with an atlas by Lesueur. The first volume of the Voyage de Découvertes aux Terres Australes appeared in 1807. When only part of the chapters of the second volume were finished, Péron was compelled by ill health to give up the work, and he died in December, I8ro. Lesueur, to whom he had bequeathed all his manuscripts, shrank from the task of going on with the history, but the second volume was completed by Captain Louis Freycinet, one of the naval officers of the expedition, and finally published in 1816 . An account of the voyage prepared by Lesueur's father was also published.

After Péron's death Lesueur was no longer contented in France. He desired to visit other scenes, but was restrained by the fact that his father, now aged, was in need of his assist- 
ance. At length an opportunity was afforded him to gratify his desire for travelling without inconvenience of a pecuniary nature. Mr. William Maclure, formerly of Philadelphia, but then residing in Paris, was intending to go to the United States by the way of the West Indies, and offered to take Lesueur as a travelling companion. The offer was gladly accepted, and they left France in the autumn of 1815 . A large number of the West India islands were visited in the following winter, enabling Lesueur to gather a rich harvest of marine creatures, and the travellers reached the United States late in the spring of I8I6. After a tour through New York, Connecticut, Rhode Island, Massachusetts, New Jersey, Pennsylvania, and Maryland, they settled down in Philadelphia.

Lesueur found many agreeable associates in the United States. His reputation had preceded him, and he was quickly elected a member of the American Philosophieal Society. Scme months later he was elected into the Acadeny of Natural Sciences, of which Mr. Maclure was now president, and took a large part in gaining a high scientific standing for that rising institution. Philadelphia was Lesueur's residence for nine years. The teaching of drawing and painting was his profession, and the time that he could devote to science was employed in preparing materials for a contemplated systematic work on the fishes of North America. Needing a literary coadjutor for this undertaking, whom he never found, the work was not written.

When the famous socialistic colony was established by Robert Owen, at New Harmony, Ind., Lesueur was one of its members. He came down from Pittsburg in the famous "boatload of knowledge" with which the colony was intellectually equipped. It was not his own choice, but a sense of duty-to gratify the wishes of his patron, Mr. Maclure-that induced him to leave his agreeable surroundings in Philadelphia for the crude, experimental social conditions of the colony in the West. During his stay at New Harmony, Lesueur made considerable collections and many drawings, some of which are still preserved, and others have been published in the Journals of the Academy at Philadelphia. A most spirited portrait of the old Governor Vigo is still extant. An account of the drop-curtain painted by Lesueur for the old theatre in New Harmony mentions that a rattlesnake and the Falls of Niagara were repre- 
sented on it, as two natural features most characteristically American.

After the failure of the New Harmony colony, Lesueur continued to reside at the settlement for several years, the companionship of Thomas Say largely reconciling him to his surroundings, and its loss at Say's death, in 1834, being keenly felt. Three years later Lesueur sailed from New Orleans for France, where, according to Swainson, he earned a precarious livelihood as a teacher of painting.

Fortunately this sketch can be enriched by the most valuable of original documents concerning Lesueur. This is a personal letter from the late Prof. Richard Owen, whose early life was spent at New Harmony, to Prof. Jordan, his successor in the chair of Biology in the University of Indiana.

Prof. Owen writes as follows under date of December 14, I 886 :

"Charles A. Lesueur was, when I knew him in 1828 , about fifty to fifty-five years of age, tall, rather spare in muscle, but hardy and enduring. He permitted his beard to grow, which at that time was quite unusual; hence he sometimes platted it and tucked it almost out of sight when he went from home. In New Harmony he usually went barenecked, often bareheaded, and in summer occasionally barefooted, or at least without socks. His hair had been dark, but was sprinkled (as well as his beard) with gray. His manner and movements were quick; his fondness for natural history (as it was then called) led him to hunt and fish a good deal.

"In summer he was fond of swimming in the Wabash, and I frequently accompanied him. He instructed me how to feel with my feet for Unios and other shells as we waded sometimes up to our necks in the river or ponds, searching to add to our collections. When he went fishing with others he always exchanged his fine common fishes for the smallest and to them most indifferent-looking, when he recognised some new species or even variety. This item I have from Mr. Sampson, who is well acquainted with the fish of the Wabash, but who confesses he could see no difference in many caught until Mr. Lesueur, who at once detected that difference, had pointed it out.

"He was temperate and active in all his habits, smoking being the only objectionable habit in which he indulged. His temper was quick and used to call out an occasional "God 
bless my soul!" the only approach to anything like irritation that he evinced; he was very kind-hearted.

"In conversation with Agassiz about Mr. Lesueur, the great Swiss ichthyologist paid a high compliment to Lesueur's acquirements in that department, considering him then (as I inferred) the next best to himself at that time in the United States. He was, however, I judge, remarkably conversant with other branches of biology, inasmuch as nearly all the magnificent drawings he had made when left in New Holland (as it was then called) were mammals, chiefly the ornithorhynchus, echidna, and other rare animals. In showing his drawings he generally offered a lens, that you might see every hair distinctly delineated.

"He was a magnificent artist, good alike in drawing and colouring. I have some of his sketches yet, in which, when I was taking drawing lessons from him, he showed me how to outline, for instance, the skeleton of the human figure, then to add the muscular system, then the clothing, drapery, etc. We usually took views from Nature. Although so minute in details of fine paintings, he was equally good in large scenery. For many years we had here the scenes he painted for a Thespian Society of this place, where, amid the forest trees, he had squirrels, birds, etc. Being fond of hunting, he had made to order by a native gunsmith, who was quite a genius, a doublebarrel piece, one a rifle, the other a smoothbore. Gillson, the gunsmith, made the barrels, bored the rifle, made the stock, and an admirable lock; the stock was inlaid with silver and engraved by the same skilful hand, bearing Lesueur's name and an appropriate device. I do not remember exactly the price, but think it was about a hundred dollars.

"In consequence of his having been with La Pérouse (until, fortunately for his life, he was left to work up the animals of Australia), the French Government gave him a pension, which he drew annually, until they notified him that, unless he returned and gave his time and talents to his native country (France), the pension would be withheld.* He went at a time when I was absent, and those who here knew him well have

* This statement evidently contains an error. The pension was probably given for his services in conjunction with Péron, as he was too young to have gone on the ill-fated expedition commanded by La Pérouse.-W. J. Y. 
forgotten the date. He became curator of the museum at Havre, and then, after some years, died and was buried there. The exact date of his death those there have also forgotten.

"When he came to New Harmony during the social experiment he was directly from the West Indies, and brought a young lad and a child, both of whom subsequently married, but both are now dead. It was from their relatives that I expected to get dates, but failed.

"When the 'Preliminary Society' (at New Harmony) resolved itself into the (I) Educational, (2) Agricultural, and (3) Commercial Societies, Mr. Lesueur joined the first, and I have in my box of valuable papers a deed of a lot (for the purpose of erecting a foundry), executed by the Educational Society, and signed by my father-in-law, Mr. Neef, and his family, Drs. Troost, C. A. Lesueur, William Phiquepal, and a number of others.

"Some of the relatives of those who came with him think there was a notice in some public journal of his death, etc., but I never saw it. I just recall two incidents :

"When we were together, going sketching, I think, we found and killed a large blacksnake, uncommonly distended. Mr. Lesueur, when we reached home, used a large syringe and injected water into the stomach, from which he then stripped four young rabbits. Another time we obtained a female opossum, and he very deftly dissected it and showed me the young adhering to the small teats in the pouch or marsupium."

Lesueur's scientific work was done chiefly in America, and it ranked with the best of its kind at the time. His most important memoir was a monograph of the suckers, a group of American fishes constituting his genus Catostomus, each species being represented by a clever and accurate figure-drawing and engraving being both by the hand of Lesueur. In 1878 Prof. David Starr Jordan spoke of this paper as "an excellent one, comparing favourably with most that has since been written on the group." Other valuable papers were on certain blennies, rays, and flying fishes, accounts of new species from the West Indies, and descriptions of tortoises and other reptiles.

The Royal Society's Catalogue of Scientific Papers contains the titles of nine papers of which Lesueur was joint author with François Péron. These appeared in 1809 and 1810 in 
French scientific serials and deal with jellyfishes and some other marine animals. Lesueur was joint author with Anselme G. Desmarest of two papers on certain molluscs and sea mosses in 1814 and 1815 . The papers of which he was sole author number forty-three. They begin in 1813 with a memoir on several new species of mollusks and radiates, published in the Journal de Physique. The first six were written before he came to America, and he picked up material for the seventh on his way over. It deals with three new sluglike molluscs, and is entitled Characters of a New Genus (Firoloida) and Descriptions of Three New Species upon which it is Formed; Discovered in the Atlantic Ocean, in the Months of March and April, 1816, lat. $22^{\circ} 9^{\prime}$. It appeared in Volume I of the Journal of the Academy of Natural Sciences of Philadelphia, in I8I 7 . Dr. Ruschenberger relates, in his Notice of the Academy, that in the first year of the Journal, "Mr. Ord, anxious to forward the publication, translated or rather prepared the papers of $M$. Lesueur from materials furnished by him, as that gentleman, who immigrated from France in 1816 , possessed very little knowledge of the English language." The last three of the list appeared in Paris in 1827,1831 , and 1839 respectively. Two are on certain tortoises, the other is an observation on a bite of a viper. Three other papers, written while he was in this country, were published in Paris; the rest appeared in the Journal of the Philadelphia Academy, except one in the Transactions of the American Philosophical Society. He evidently restricted himself quite closely to the fishes and other aquatic animals, though with an occasional excursion among the reptiles. Péron and Lesueur had intended to publish an elaborate work on the Meduse, after the history of the Voyage to Terra Australis was completed. The death of the former checked the project, but Lesueur issued a prospectus of the work, with specimen plates engraved and coloured after his beautiful drawings. It is probable that the necessarily great cost of such a publication prevented the plan from being carried out.

His descriptions are clear, exact, and honest. His drawings are not accurate only, but spirited. They are works of art rather than mechanical representations. With less range of learning than Rafinesque and some other contemporaries, Lesueur had, what Rafinesque had not, sound sense and faithful- 
ness in the study of details. In America he was perhaps the first of that school of systematic zoölogy which regards no fact as so unimportant that it need not be correctly ascertained and stated-a method of work with which has been rightly associated the name of Prof. Spencer F. Baird. This attention to accuracy in detail marks the so-called "Bairdian epoch" in vertebrate zoölogy.

When Lesueur left France for America, Ord relates, he placed all his disposable means, including his pension, in the hands of his father. The latter dying four years later, these affairs were entrusted to an attorney, "it being his intention to create a fund, to which he might have recourse in case of need. It does not appear that he gave himself much concern with respect to this agency, and on his return.to Paris he had the mortification to find that the agent had betrayed his confidence by appropriating to the use of his own family the entire fund, which amounted to the sum of forty thousand francs! The feelings of Lesueur were sorely tried at this event, and the wrong was the more galling, as it was perpetrated under the guise of friendship. Notwithstanding this heavy loss, at a time of life, too, when the infirmities of age began to be felt, he had still a remnant left, the produce of his industry, which modicum he shared with a brother whose necessities were greater than his own."

In the latter part of $1838 \mathrm{Mr}$. George Ord visited him in Paris, whither he had brought a valuable collection of specimens of natural history from the United States, and all the drawings and manuscripts resulting from his various travels. "Perhaps no individual then living," said Mr. Ord in his memoir, "possessed a greater fund of materials for works of the highest interest in natural history-materials destined in a great measure, it is feared, to be useless, for the want of that mind which alone could direct their application."

"Some time in the year 1843 ," Ord continues, "the project of founding a museum of natural history in the city of Havre was set on foot, and Mr. Lesueur, who had taken a great interest in the measure, was looked to as one eminently capable of filling an important office in an establishment which was indebted to his personal exertions for much of its favour with the community. In 1845 he was chosen curator of the museum, and he removed to Havre in order to superintend the building, 
which was advancing toward completion." In May, 1846 , he wrote to Ord: "I am occupied at this time in arranging the collections of our cabinet. As my presence is now essential, I have taken a small country house not far from Havre. It is situated in a quiet valley, a short distance from the sea, which is visible from our windows. Should you return to France you must come and stay with us." He was not destined to enjoy these congenial surroundings for long. On December I2, I846, he died, after an illness of only a day or two. His burial place is the Church of St. Adresse, in a little valley at the base of Cape la Hève. 


\section{BENJAMIN SILLIMAN, THE ELDER.}

$$
\text { I 779-1864. }
$$

THE name of Professor Silliman is intimately connected with the progress of science in the United States during the former half of this century. In fact, his long life, his unbroken connection of over half a century with Yale College, and his founding of the American Journal of Science, make him probably the best-known figure of the period.

Benjamin Silliman was born in North Stratford (now Trumbull), Connecticut, on the 8th of August, I779. The home of his family was at Fairfield, a few miles distant, on Long Island Sound. But the Revolutionary War was then at its height, his father had recently been taken out of his house at midnight by a British and Tory raiding party, and his mother had sought safety with friends. His earliest American ancestor on the father's side, Daniel Silliman, was believed to have been an emigrant from Holland, but there are reasons for presuming that he belonged to an Italian Protestant family that took refuge in Switzerland, and one of whose members afterward came to America, possibly sojourning for a short time in Holland. His grandfather, Ebenezer Silliman, was a graduate from Yale College, a Judge of the Superior Court of the colony, a member of the Governor's Council, and influential in public affairs. His father, Gold Selleck Silliman, was grad-

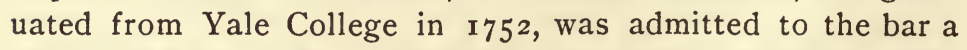
few years later, and soon became prosecuting attorney of his county. When the Revolution broke out he was a colonel of cavalry in the local militia. At the head of his regiment he joined the forces under Washington at New York, was in the battles of Long Island and White Plains, and enjoyed the confidence of his chief. He was made a brigadier general of Connecticut troops and charged with the defence of the southwestern frontier of that colony. His activity in resisting the incur- 


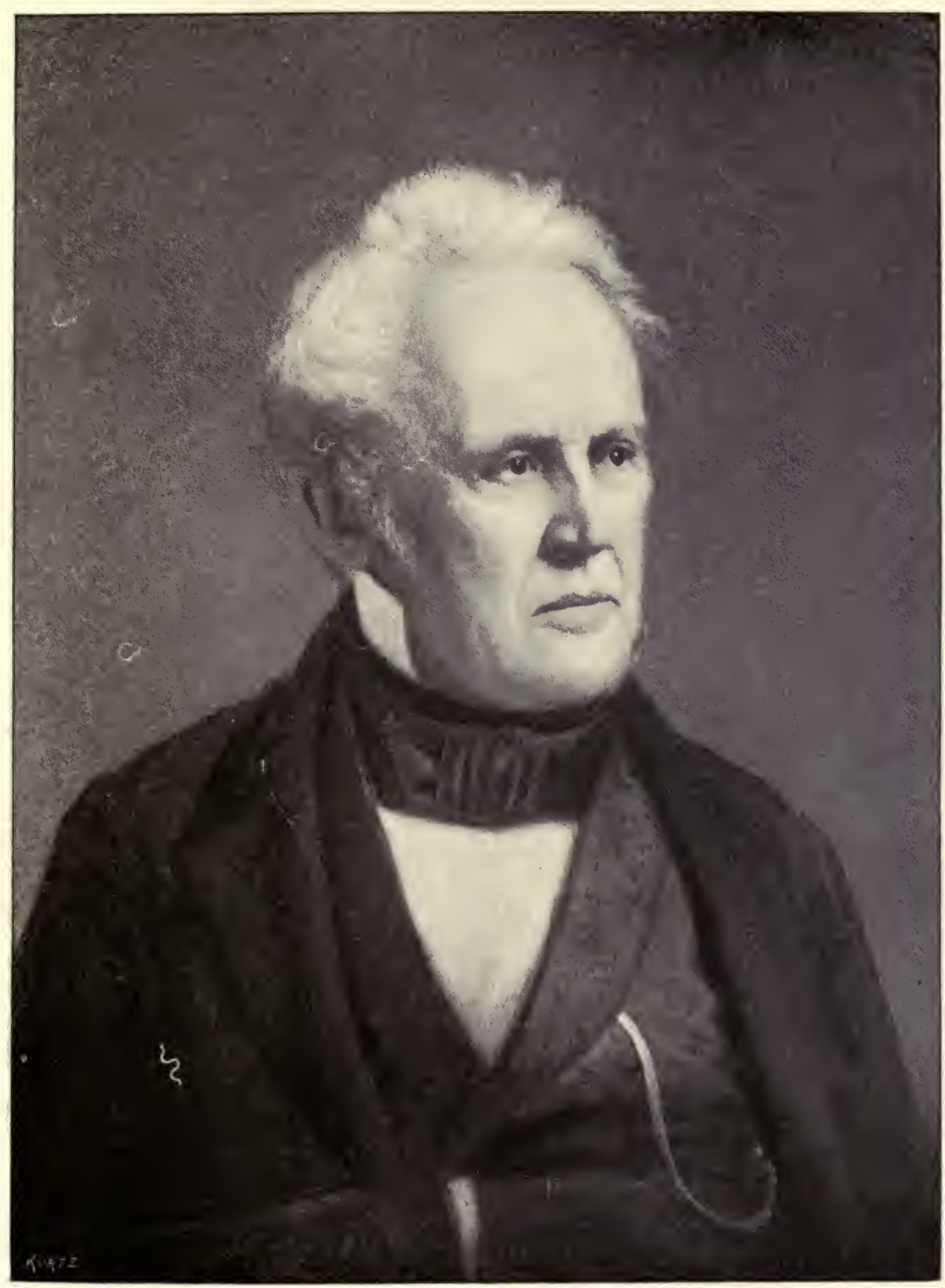

BENJAMIN SILLIMAN. 

sions of the British led to the secret expedition which succeeded in capturing him. He was held a prisoner nearly a year. General Silliman died in $\mathbf{r} 790$.

Benjamin's mother, Mary Fish, was descended from John Alden and Priscilla Mullins, of the Mayflower. She was the eldest daughter of Rev. Joseph Fish, of North Stonington. She had been married to Rev. John Noyes, of New Haven, and at the time of her second marriage had three children living. Mr. Silliman had also been married before and had a son, William.

In the recollections of his relatives and his early years, written out by Benjamin Silliman near the close of his life, he describes his father as a gentleman of the old school and a decidedly religious man, but without austerity or bigotry. All of his large household, including negro domestics and hired white people, were expected to attend, so far as practicable, daily prayers, and public worship on Sunday. For conveyance to church they had usually half a dozen horses and two chaises, and the horses under the saddle frequently carried two. "My brother and I," he writes, "were sometimes instructed to take each of us one of the daughters of our clergyman, the Rev. Mr. Eliot, who had more girls than horses; and we were at an age when the jeers of our school-fellows made this a rather embarrassing duty."

After attending for a time the public schools of his neighbourhood, Benjamin prepared for college under the tuition of his pastor, the Rev. Andrew Eliot, and entered Yale College at the age of thirteen years, the youngest but one in his class. As to his college career his biographer, Prof. George P. Fisher, writes :

"Mr. Silliman exhibited in his college essays and debates, as well as in the letters written by him in that period, both a maturity of thought and a correctness of style hardly to be expected in one so young. He was fond of writing verses, and acquired no mean facility in versification. His closing piece at graduation was a poem, as was also the piece which he delivered on taking the master's degree. He does not appear to have shown an exclusive predilection for any one department of knowledge, but attained to a highly respectable proficiency in all. He speaks of himself as having been unusually fond of rhetorical and poetical studies, but as also 
taking delight in geometry, and being strongly interested in natural phenomena. His reading, as far as it went beyond the requirements of the curriculum, was chiefly in history and English literature."

Only once in his college course, it is believed, did young Silliman expose himself to an academic penalty or censure. One day in his Freshman year the thirteen-year-old lad gave a kick to a stray football in the college yard, and for this offence against ancient decorum was fined a sixpence by President Stiles, who happened to be an eyewitness. This incident drew upon him some banter from Mr. Eliot and other friends at home, who were much amused that "Sober Ben," as they were wont to style him, should be so unlucky as to fall into the hands of the law.

Owing to a severe wound in the foot from an axe, which was unskilfully treated, the youth was obliged to be absent from college during portions of his senior year. After graduating he was still a sufferer from this hurt, and unable to sustain continuous intellectual labour. Partly for this reason and partly because his mother needed his aid, he spent the next year at home. For lack of a guiding hand the farm lands left by his father had largely run to waste, and he devoted himself to reclaiming them. He went into the fields with the labourers and was almost entirely cut off from the society of cultivated young men, which he had enjoyed for the preceding four years. "In this situation," says Prof. Fisher, "uncertain as he was respecting his career in the future, and oppressed with nervous infirmity, it is not strange that he became for a while a prey to gloomy thoughts and apprehensions." Another year brought with it improved health and a more congenial occupation, which soon restored his cheerfulness. He took charge of a select school in Wethersfield for the greater part of the year I 798, and in October of that year, having decided to adopt the legal profession, he entered the law office of the Hon. Simeon Baldwin, in New Haven, whence, after completing his three years' course in law, he was admitted to the bar in 1802 . While still a law student-in September, 1799-and when he had just reached the age of twenty, he was appointed a tutor in Yale College.

Up to this time classical instruction had received the predominant share of attention at Yale College; "theological, 
ethical, and metaphysical subjects were much cultivated, and logic was also a prominent topic"; mathematics was appreciated; much interest had been aroused in astronomy; physics was less cared for, and chemistry had been "scarcely mentioned." Mr. Silliman was considering a proposition to settle down at the practice of the law in Georgia, when in July, r8or, President Dwight informed him that the corporation of the college had several years before resolved to establish a professorship of chemistry and natural history as soon as the funds would admit of it. The time had come when the resolution could be carried into effect, but it was impossible to find in this country a man properly qualified to discharge the duties of the office, while there were reasons that made the appointment of a foreigner inexpedient. The president saw no way but to select a suitable young man at home, and give him time to qualify himself for the professorship; and he had fixed upon Mr. Silliman as the person whom he would propose to the corporation. Mr. Silliman was inclined from the first to consider the offer favourably, because, as he has recorded in his Reminiscences, "the study of Nature appeared very attractive. In her works there is no falsehood, although there are mysteries to unveil, which is a very interesting achievement. Everything in Nature is straightforward and consistent. There are no polluting influences; all the associations with these pursuits are elevated and virtuous, and point toward the infinite Creator." The professorship was instituted in 1802 , with a provision that such time as might be agreed upon should be given the professor-elect to decide whether he would accept the appointment, and Mr. Silliman was chosen professor. Philadelphia then "presented more advantages in science than any other place in the country," and he went there first. Here he enjoyed the instruction, with experiments, of Dr. James Woodhouse, of the Medical College, and had as a fellow-boarder Robert Hare, who had just perfected his oxyhydrogen blowpipe, and was much occupied with the subject, and enlisted his new friend in his service. He also attended the lectures of Dr. Barton on botany and of Dr. Caspar Wistar on anatomy and surgery, and met Dr. Priestley at the house of the latter. He received valuable suggestions from Dr. Maclean, of Princeton, whom he visited in his transits to and from Philadelphia; and thus he learned to regard the eminent pro- 
fessor as his earliest master in chemistry, and Princeton as his first starting-point in that pursuit, although he had not an opportunity to attend any lectures there. Having attended two winters in Philadelphia, he returned to New Haven and began to write his lectures. His first lecture was delivered April 4, I 804 , when he was twenty-four and a half years old, to a class which included, among other men who afterward became distinguished, John C. Calhoun, Bishop Gadsden; and John Pierpont; the subject was the history and progress, nature and objects, of chemistry. Four lectures were given in a weeksixty in the course-and some notices of mineralogy were included.

In the meantime the corporation of the college had voted to spend ten thousand dollars in Europe during the ensuing year, in the purchase of books and philosophical and chemicąl apparatus. Prof. Silliman applied for the privilege of going as purchasing agent, suggesting that his salary, which would be continued, and the agent's commission would pay his expenses, and he would at the same time have an opportunity of improving in his profession. His proposition was accepted; armed with a multitude of letters of introduction, the general effect of which he found to be equivalent to an order-"Sir: Please to give the bearer a dinner, and charge the same to yours," etc.-he spent a year in Europe. He performed experiments with Frederick Accum, the German chemist, and attended the lectures of Dr. George Pearson on chemistry, materia medica, and therapeutics, in London; heard Drs. Hope, Gregory, and Murray, in chemistry and geology; subscribed to Dr. Munroe's and attended Dr. Barclay's courses in anatomy, at Edinburgh; visited the Continent, and made the acquaintance of the most eminent scientific men of the day. Geological science at that time, he says, in his Reminiscences, "did not exist among us, except in the minds of a very few individuals, and instruction was not attainable in any public institutions." In Edinburgh there were learned and eloquent geologists and lecturers, and ardent and successful explorers, and the contest between the Wernerians and the Huttonians was at its height. Prof. Silliman was interested in the discussion, and, giving his attention to the subject, reached a standard of attainment in geology which he believed he could not have gained at home. He read 
the arguments on both sides, and came to the conclusion on which geologists are generally now tacitly agreed, that "both theories were founded in truth, and that the crust of the earth had been formed and greatly modified by the combined, or sometimes antagonistic and conflicting, powers of fire and water."

Prof. Silliman had already attended to the care of the modest collections of minerals belonging to the college. There were a few metallic ores which had been named by Dr. Adam Seybert, of Philadelphia; a small collection which Dr. Semper had brought from England, containing some beautiful specimens, particularly in the lime family; and his own collections made in the mines of Derbyshire and Cornwall, in England, and local specimens obtained in his rambles among the trap-rocks of the Scottish capital, with a purchased suite of Italian polished marbles, all of which "when arranged, labelled, and described in illustration of the mineral portion of the chemical lectures, served to awaken an interest in the subject of mineralogy, and to produce both aspirations and hopes looking toward a collection which should by and by deserve the name of a cabinet." One of the first things to be done after returning home was to study the geology of the vicinity of New Haven, in the light of the knowledge that had been gained in Edinburgh. The result of this survey was a report, printed in the first volume of the Transactions of the Connecticut Academy of Arts and Sciences, in which an attentive reperusal by the author fifty-two years afterward suggested very few alterations and disclosed no important errors. The cabinet of Mr. Benjamin D. Perkins was shortly afterward purchased for a thousand dollars, and in 18 ro the splendid cabinet of Colonel George Gibbs was deposited in the college. The latter cabinet, which attracted visitors from all parts of the country, was bought fifteen years afterward. While Prof. Silliman was engaged in arranging it, the Rev Dr. Ely accosted him: "Why, dominie, is there not danger that with these physical attractions you will overtop the Latin and the Greek?" Prof. Silliman replied: "Sir, let the literary gentlemen push and sustain their departments. It is my duty to give full effect to the sciences committed to my care."

An American Journal of Mineralogy had been started by Dr. Archibald Bruce, of New York, in I8Io, but it was suspended after the publication of four numbers. Prof. Silliman, 
at the suggestion of Colonel Gibbs, and with the approbation of Dr. Bruce, started, in 1818 , a journal intended to include the entire circle of the physical sciences and their applications. This was Silliman's (now the American) Journal of Science, which is still continued under the direction of the grandson of its founder.

The courses of popular lectures on scientific subjects which were conducted by Prof. Silliman in the different cities of the United States, originated in 1808 , when a course in chemistry for ladies and gentlemen was proposed to him, and gladly assented to, as a scheme in the interest of scientific progress. A class of about forty-five persons was formed, and listened to the instruction given them apparently with complete satisfaction, for it appeared afterward, the lecturer remarks, in speaking of the matter, that the course "turned on female hinges," and "sentiment lubricated the joints. ... It was my province to explain the affinities of matter, and I had not advanced far in my pleasing duties before I discovered that moral affinities, also moving without my intervention, were playing an important part." One of the affinities involved the professor, and his marriage to one of his hearers, Miss Harriet Trumbull, daughter of the second Governor Trumbull, followed in the course of the next year. Many years afterward he was invited to deliver a course in Hartford-the first out of New Haven; then followed courses in Lowell, Boston (where "the Orthodox and Unitarian influence was united in his favour," and where he returned to lecture in several successive years afterward), other New England towns, and New York. In I 843 he lectured in Pittsburg, where he received most "vivid demonstrations of kind and gratified feelings"; the next year in Baltimore, where he found that "people who came for once, stayed"; and afterward in Baltimore again, Mobile, New Orleans, Natchez, at Washington before the Smithsonian Institution, and in St. Louis. The calls to lecture continued actively through twenty-three years, from 1834 to 1857 . In summing up the results of these courses, Prof. Silliman expressed a feeling of satisfactory assurance that he had popularized science; that at no period of his life had his efforts been more useful, both to his country and his family; and that there was no part of his professional career which he reflected upon with more satisfaction. 
He was accustomed to explain the success of his lectures, and the uninterrupted interest they attracted, by stating that he always prepared them "with all possible care, and arranged every experiment and illustration so as to insure success. Then I could stand before the largest audience without anxiety or embarrassment; could, without manuscript, clearly state and explain my subject, and, when the proof became necessary, I could perform the experiments successfully and even beautifully, and exhibit the specimens which some other truth demanded, to insure conviction."

In 1830 Prof. Silliman made a visit of exploration to the valley of Wyoming, in Pennsylvania, and its coal formations, where he examined some hundred mines and localities of coal, extending through forty miles in length; in $183^{2-} 33$ he was engaged, under a commission from the General Government, in a scientific examination on the subject of the culture and manufacture of sugar; and in 1836 he made a tour of investigation among the gold mines of Virginia.

In 1840 an association of geologists was formed in Philadelphia for the purpose of promoting the progress of their science and its applications in this country, and Prof. Silliman was chosen its first president. This society was in time succeeded by the "American Association of Geologists and Naturalists," and the latter eventually became the "American Association for the Advancement of Science."

In 1849 Prof. Silliman, having reached the age of seventy years, tendered a resignation of his professorship, to take effect at the end of the ensuing academic year. The corporation, only half accepting his resignation, requested him to continue his lectures in the department of mineralogy and geology, should his life and health be spared. Later, at the request of the corporation, he reconsidered his resignation, and continued in the full occupation of his professorship till 1853 , when, "wishing to go out before he should be compelled by infirmity, and to march out of the camp with colours flying," he retired finally. "Thus," he remarks in his journal, after referring to the public notices that were taken of his retirement during commencement week, "I have finished my regular connection with Yale College, after having been almost fifty-four years an officer of the institution-three years a tutor, fiftyone a professor, and almost fifty a lecturer. ... I seem to 
have attended my own academic funeral, and many were the mourners on the occasion." The corporation requested him to continue as a professor emeritus, with the right to vote in the academical and medical faculties. His professorship was divided, and he had the satisfaction of seeing his son placed in the chair of Chemistry, and his son-in-law, Prof. James D. Dana, in that of Geology and Mineralogy. The name of Silliman was given to both chairs.

Prof. Silliman was still to continue a prominent figure before the public, kept so by other events than those connected with science and the affairs of the college. A few months after his resignation the Kansas-Nebraska controversy rose to its height, and the Republican party was born amid the convulsions it excited. Prof. Silliman had always abhorred slavery, and he saw in these disputes great moral issues, and the question of the equal rights of citizens of all the States to settle in the Territories and defend themselves there. His active interest in these matters, and the works by which he showed it, called out bitter partisan reprobation, and this in turn invoked eloquent and deserved eulogies of his pure character and his attainments in science from Senators Foster and Dixon in the United States Senate.

Prof. Silliman kept even pace with the progress of science and scientific ideas as they were developed through all his career, and let his religious faith shine at the same time with a light of even brilliancy. The possibility that there was a conflict or could be a conflict does not seem even to have occurred to him. From his earliest college days, piety and a firm devotion in religious faith seem to have formed a prominent side of his character; yet he never hesitated to accept the most startling discovery, when it proved deserving acceptance. "Now, at eighty-two and a half years of age," he says, March I, I862, "I can truly declare that, in the study and exhibition of science to my pupils and my fellow-men, I have never forgotten to give all the honour and glory to the infinite Creator, happy if I might be the honoured interpreter of a portion of his works, and of the beautiful structure and beneficent laws discovered therein by the labours of many illustrious predecessors. For this I claim no merit. It is the result to which right reason and sound philosophy, as well as religion, would naturally lead. While I have never concealed my con- 
victions on these subjects, nor hesitated to declare them on all proper occasions, I have also declared my belief that while natural religion stands as the basis of revelation, consisting as it does of the facts and laws which form the domain of science, science has never revealed a system of mercy commensurate with the moral wants of man. In Nature, in God's creation, we discover only laws-laws of undeviating strictness, and sure penalties annexed for their violation. There is associated with natural laws no system of mercy; that dispensation is not revealed in Nature, and is contained in the Scriptures alone. With the double view just presented, I feel that Science and Religion may walk hand in hand." "For his own part," says Prof. Fisher, from whose rich biography we have drawn freely in the composition of this sketch, "he felt that the Bible was a revelation from God. ... Not being in the habit of resorting to the Scriptures for information in physical science, he had valued its early pages for the pure and sublime theism which they inculcated. ... Nor did he deem it necessary to suppose that the author of Genesis, however instructed by a higher light, was himself cognizant of the truths of geology, especially the truth of the great antiquity of the globe, and the length of time consumed in the geological changes." The idea of the length of geological time, as presented in his lectures, was novel to the majority of his auditors, and evidently shocked the prejudices of many of them, but he maintained it with vigour, and generally left a good impression regarding it in the end. Concerning the opponents of these ideas among the clergy, he wrote to Dr. Hitchcock in 1837: "I believe, with you, if they were masters of our subject, they would think as we do. Some of them are candid and forbearing; others find no insuperable difficulties; others are silent because they feel that they do not understand the matter; but a few are loud, confident, and uncharitable, while it is obvious they know not whereof they affirm, . . . but I see a strong purpose on the part of some to hold no terms with geology, and to insist upon the literal and limited understanding of the history; but they will find themselves deserted, for the matter will in time come right." Of a particular attack on the geological theory he wrote to Prof. Hitchcock: "You and I know that any attempt to impair geological evidence, or to reconcile it with the popular view of time, must be abortive. 
No matter how violent or bitter our assailant may be, doubtless he will be more so in proportion to his ignorance of geology and to the strength of his prejudices."

Mrs. Silliman died in January, I850, and Prof. Silliman was married a second time, in the following year, to Mrs. Sarah I. Webb, of Woodstock, Connecticut. He had nine children, of whom one son and four daughters lived to adult age. The son was Prof. Benjamin Silliman, the younger, and the daughters were Maria Trumbull, who married John B. Church; Faith Wadsworth, who married Prof. O. P. Hubbard; Henrietta Frances, the wife of Prof. James D. Dana; and Julia, who married Rev. Edward W. Gilman. Prof. Silliman's death was supposed to be due to an affection of the heart, apparently induced by a neuralgic attack which he incurred from attending a meeting on behalf of the Sanitary Commission, on the $1^{\text {th }}$ of November, 1864. He was confined to the house for several days, but seemed afterward to recover, and made several calls in the neighbourhood; but on the $24^{\text {th }}$ - Thanksgiving dayhe died, instantly and without a struggle, just as he had remarked that he might perhaps go out to church.

Prof. Silliman, says Prof. Fisher, would have been the last to claim that he had that rare insight of genius which divines the secrets of Nature. His whole turn was more practical than speculative. "His perceptions were quick, his judgment sound, and all his mental operations were marked by good sense." His qualities "well fitted him for his peculiar work, and that was to collect and diffuse scientific truth. ... Nor is he without merit as an investigator, although his distinction does not lie here. He was never very careful to claim for himself the credit of scientific discovery. At the same time, he took delight in bringing honour to the discoveries of others." He prepared an edition of Henry's Chemistry, which appeared in 1808 , with the modest announcement, "To which are added notes by a professor in this country." While this work was going through the press, a remarkable meteor passed over New England (December, 1807), and exploded over Weston, Connecticut, where several stones fell to the ground. He visited the scene, and, besides publishing a popular account of the facts in the Connecticut Herald, made them the subject of a scientific examination and report before the Philosophical Society of Philadelphia, which was afterward 
republished in the Memoirs of the Connecticut Academy of Arts and Sciences, and read before the Philosophical Society of London and the Academy of Sciences in Paris. His two visits to Europe (the second one was in $185 \mathrm{I}$ ) were followed by books of travels, both of which were received with great satisfaction, while the earlier one (I8ro) was highly commended, abroad as well as at home, as one of the best works of its class. He was the first to obtain potassium in this country, and the first to notice and record the effect of a powerful battery in volatilizing carbon and transferring it from the positive to the negative pole in a state of vapour. An account of his experiments with the oxyhydrogen blowpipe was published in the Memoirs of the Connecticut Academy of Arts and Sciences in $\mathrm{r}_{8} \mathrm{r}_{3}$. He published an account of a journey between Hartford and Quebec in I 820, an edition of Bakewell's Geology in 1829 , and a text-book on chemistry, in two volumes, in 1830. It was largely through his influence that the Scientific School, started by the younger Prof. Silliman in 1842 , which was afterward endowed by the gentleman whose name it bears as the Sheffield Scientific School, was adopted by the college as one of its departments, in 1846 and 1847 . Prof. Silliman was for many years in regular correspondence with the most eminent scientific men of Europe, among whom may be named Berzelius, Robert Bakewell, Humboldt, Carl Ritter, Lyell, Sir R. I. Murchison, Richard Owen, Daubeny, Herschel, ana Dr. Mantell. Some of these he never knew personally, but was brought into communication with them through a common interest in science. 


\section{JOHN JAMES AUDUBON.}

$$
\text { I } 780-1851 \text {. }
$$

When Audubon's fame was just beginning, "Christopher North" (Prof. Wilson, of the University of Edinburgh, and editor of Blackwood's Magazine) wrote, under the form of a dialogue between himself and the Ettrick Shepherd (James Hogg, the poet), as follows:*

"North. What a pity, James, that you were not in Edinburgh in time to see my friend Audubon's exhibition!

"Shepherd. An exhibition o' what?

"North. Of birds painted to the life. Almost the whole American ornithology, true to Nature as if the creatures were in their native haunts in the forests, or on the seashores. Not stiff and staring like stuffed specimens, but in every imaginable characteristic attitude, perched, wading, or a-wing-not a feather, smooth or ruffled, out of its place-every song, chirp, chatter, or cry made audible by the power of genius.

"Shepherd. Where got he sae weel acquaint wi' a' the tribes-for do they not herd in swamps and woods where man's foot intrudes not-and the wilderness is guarded by the rattlesnake, fearsome watchman, wi' nae ither bouets than his ain fiery eyne?

"North. For upward of twenty years the enthusiastic Audubon lived in the remotest woods, journeying to and fro on foot thousands of miles-or sailing on great rivers, great as any seas-with his unerring rifle, slaughtering only to embalm his prey by an art of his own, in form and hue unchanged, unchangeable-and now, for the sum of one shilling, may anybody that chooses it behold the images of all the splendid and gorgeous birds of that continent.

\footnotetext{
* Noctes Ambrosianæ (Blackwood's Magazine), No. XXX, January, 1827.
} 


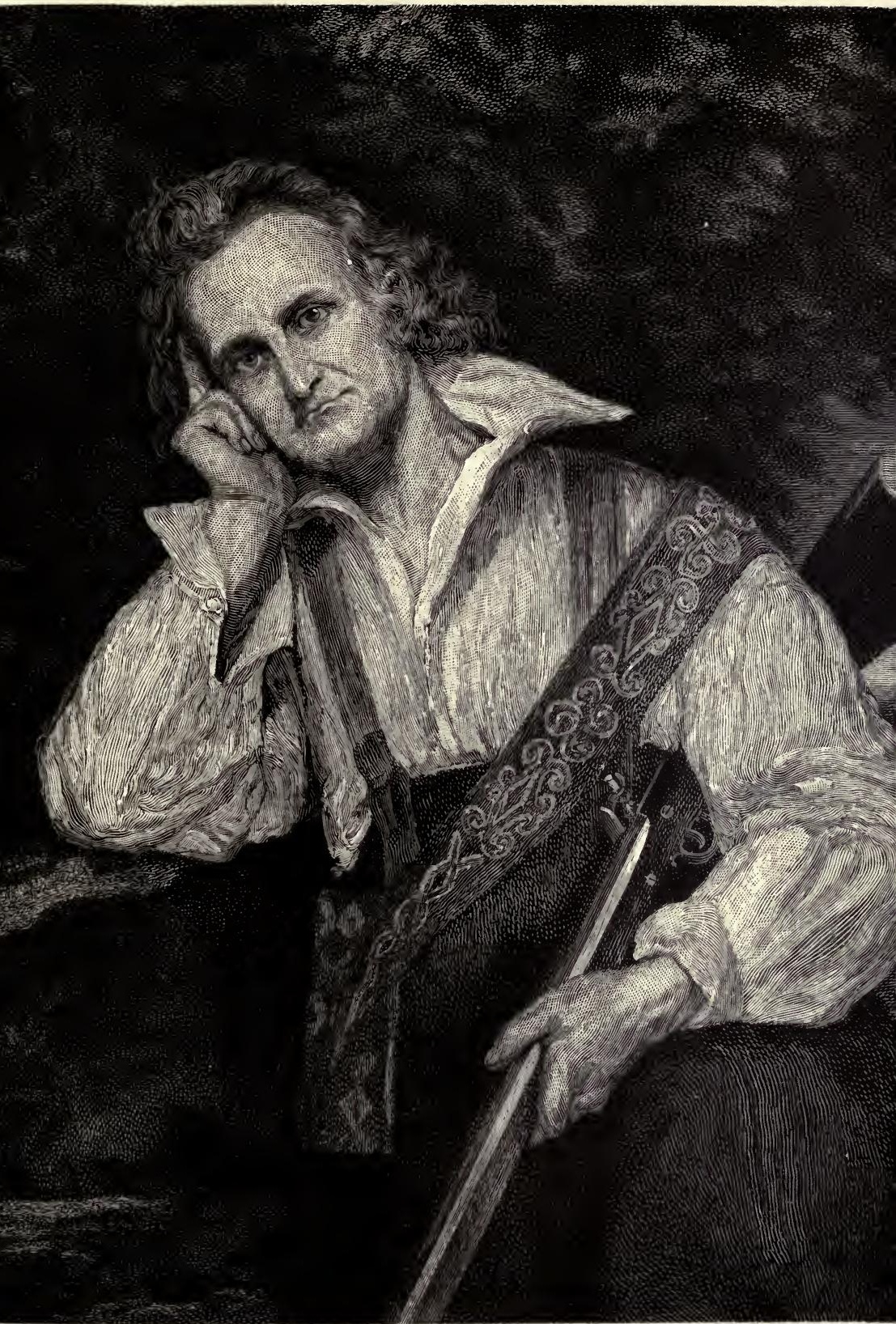

\section{J. J. AUDUBON.}



"Shepherd. Where's the exhibition now ?

"North. At Glasgow, I believe-where I have no doubt it will attract thousands of delighted spectators. I must get the friend who gave a glance over Selby's Ornithology to tell the world at large more of Audubon. $\mathrm{He}$ is the greatest artist in his own walk that ever lived, and can not fail to reap the reward of his genius and perseverance and adventurous zeal in his own beautiful branch of natural history, both in fame and fortune."

John James Audubon was born near New Orleans, May 4, I 780, and died at the present Audubon Park, New York city, January $27, \mathrm{r} 85 \mathrm{I}$. His father, the son of a fisherman of La Vendée, was a French naval officer, who rose to the rank of admiral and came to America with Rochambeau and De Grasse, was present at the siege of Yorktown, and became an enthusiastic American himself. He had purchased a plantation in Louisiana, then a French province, while the American Revolution was still in progress. A few years later he removed to Santo Domingo, where his wife * was murdered in an uprising of the blacks. He then returned to Louisiana, where he married a lady of that colony, of Spanish descent, named Anne Moynette, and not long after took his family to France. The son imbibed a love of Nature at an extremely early age. This was probably strengthened by his short residence on the West Indian plantation, and was not repressed, but mastered the situation when he was taken to France to be educated. It is recorded of him that he was accustomed to amuse himself when a mere child by trying to draw the birds he saw around him; and that, his crude efforts not being satisfactory, he used to make a bonfire of them at each birthday. His father desired him to be qualified for some occupation connected with the navy or with engineering, and having bought an estate near Nantes, left him there in charge of his stepmother to be taught mathematics, drawing, geography, fencing, and music. His drawing master was the celebrated artist David, who set him to drawing "horses' heads and the limbs of giants," but he preferred birds, and improved such opportunities as he could get to exercise himself upon them, and spent much of

* Little is known about the naturalist's mother. It is thought that she was a Mlle. La Forêt. 
his time in excursions into the woods, collecting specimens, and making drawings of them. The real supervision of his operations was with his indulgent stepmother, who gave him ample scope for the exercise of his own tastes. When Audubon's father returned from sea he was astonished at the large collection his son had made, and then asked what progress he had made in his other studies. The reply not being satisfactory, he took the youth in hand himself, and kept him for a year in the close study of mathematics. But every opportunity for natural history rambles was still improved.

Either at this time or during a later stay of a year at Nantes, young Audubon is credited with having made a hundred drawings of European birds. Three specimens of these works have come into the hands of Dr. R. W. Shufeldt, who has described them in The Auk. They are all drawn in a combination of crayon and water colours, on a thin kind of drawing paper; are numbered 44,77 , and 96 , and represent the magpie, the coot, and the green woodpecker. The earliest of the sketches is the magpie, represented as of life-size and standing on the ground. "The execution is quite crude, though the naturalist 'sticks out' in it, for, notwithstanding the somewhat awkward position the bird is in, there is life in it." The second picture, that of a coot, "is a marked improvement on the magpie. Far more pains have been taken with the feet, legs, bill, and eye, though little has been gained in the natural attitude of the bird. . . . Except very faintly in the wing, no attempt has been made to individualize the feathers, the entire body being of a dead black, worked in either by burned cork or crayon." Dr. Shufeldt also remarks that, "as is usually the case among juvenile artists, both this bird and the magpie are represented upon direct lateral view, and no evidence has yet appeared to hint to us of the wonderful power Audubon eventually came to possess in figuring his. birds in their every attitude." The green woodpecker "is a wonderful improvement, in every particular, upon both of the others. The details of the plumage and other structures are brought out with great delicacy, and refinement of touch; while the attitude of the bird, an old male, is even better than many of those published in his famous work. The colours are soft, and have been so handled as to lend to the plumage a very flossy and natural appearance, while the old trunk, upon the side of 
which the bird is represented, presents several evidences of an increase of the power to paint such objects."

When about seventeen or eighteen years old, young Audubon returned to the United States. Since he had no inclination to the art of war, for which he had been intended, his father, willing to gratify his now decided tastes, settled him upon a farm, Mill Grove, which he owned near Philadelphia, at the mouth of Perkiomen Creek. Here he had full opportunity for the gratification of his huntsman's and naturalist's inclination, and improved it so industriously that he appeared to be good for little else. Desiring to form a matrimonial engagement with Lucy Bakewell, he was advised by the father of the young lady to go into business, and he accordingly entered the employment of a firm in New York; but even here it was the study of Nature and not trade that engaged his attention. "For a period of twenty years," he confesses in the biographical preface to his Birds, "my life was a series of vicissitudes. I tried various branches of commerce, but they all proved unprofitable, doubtless because my whole mind was ever filled with my passion for rambling and admiring those objects of Nature from which alone I received the purest gratification." It is in connection with the relation of the story of a hurricane, while he was living at Henderson, Ky., years after his Philadelphia experiences, that he says that, just before the breaking out of the awful storm, his thoughts were, "for once, at least, in the course of my life, entirely engaged in commercial speculations." $\mathrm{He}$ soon gave up his New York engagement, and shortly afterward formed a partnership with Ferdinand Rosier to go into trade at Louisville, Kentucky. His settlement at this place having been determined upon, he was married to Miss Bakewell in April, I808. This lady was a descendant of the Peverils of the Peak, one of whom has given name to one of Sir Walter Scott's novels, and was a relative of the famous British geologist Bakewell. She proved a congenial wife to the naturalist, and gave him valuable aid while he had his great work under way, by helping him to pay the expenses of his enterprise out of the fruits of her own industry. The farm at Mill Grove was sold, a stock of goods was purchased with the proceeds, and Audubon removed with his wife to Louisville, making the journey down the Ohio River in a flatboat, with two rowers. At Louisville, 
again, he left business to his partner, and occupied himself with natural history and his drawings.

In 1810 he was visited at his store by Alexander Wilson, who came to solicit subscriptions to his Ornithology. He was about to sign the list, when his partner suggested to him, in French, that he could make better drawings than Wilson, and probably knew as much about American birds as he. Wilson understood the remark, and asked Audubon if he had any drawings of birds. Audubon exhibited what he had, and, to Wilson's question if he intended to publish his work, replied that he had never thought of it. The two naturalists seem to have spent some time together. Audubon, it is stated, explored the woods with Wilson, lent him his drawings, and aided him in various ways; although Wilson entered in his notes against Louisville that "science or literature had not one friend in the place."

As might be expected, the business at Louisville was not prosperous. After four years, marked by two removals to secure better success, the partnership was dissolved, and Audubon removed to Henderson, Kentucky, in 1812. Another business adventure, entered into with his brother-in-law in New Orleans, failed. Only natural history prospered with him. A very large proportion of his work in this line, which bore so noble and so abundant fruit in later years, was done during his residence in Henderson. Aiming to represent the birds which he drew in position as far as possible, he adopted ingenious devices to secure correct views of them as they looked in Nature. Those which he had to shoot he would afterward set up and support in natural attitudes, while he painted them; others he would view, with their actual surroundings, through a telescope. Audubon's father died about 1812, leaving to him the estate in France and seventeen thousand dollars, which had been deposited with a merchant in Richmond, Virginia. "Audubon, however, took no steps to obtain possession of his estate in France, and in after-years, when his sons had grown up, sent one of them to France for the purpose of legally transferring the property to his own sister Rosa." Before Audubon was able to obtain the money from the merchant in Richmond, the latter died insolvent; and so no benefit accrued to the naturalist from either part of his legacy. 
By this failure of his expectations and other disasters, Audubon was compelled to work for a living. He took up the drawing of crayon portraits with much success, and seemed to get a new start in life. In a short time he received an invitation to become a curator of the museum at Cincinnati, and for the preparation of birds received a liberal remuneration. In conjunction with this situation he opened a drawing school in the same city, and obtained from this employment additional emolument sufficient to support his family comfortably. His teaching succeeded well until several of his pupils started on their own account. The work at the museum having been finished, Audubon fell back upon his portrait painting and such resources as his genius could command. Applying for assistance to an old friend whom he had helped into business, the ungrateful wretch declared he would do nothing for his benefactor, and further added that he would not even recommend one who had such wandering habits. On more occasions than this his genius for discovery was made an argument against him.

In October, 1820 , Audubon left Cincinnati, and sailed down the Ohio in company with Captain Cumming, a civil engineer, who had been appointed to make a survey of the Mississippi River. He was provided with letters of introduction from General Harrison and Henry Clay, and intended a long ornithological excursion through Mississippi, Alabama, and Florida, up Red River, and down the Arkansas. At Bayou Sara, in the following June, he accepted an engagement with Mrs. Perrie to teach her daughter drawing during the summer months at sixty dollars a month. Mrs. Perrie's real aim is supposed to have been to provide for Audubon an opportunity to carry on his pursuits under the guise of an employment which would be congenial and not interfere with his work. Later in the year he was invited to join another artist in painting a panorama of New Orleans. But, he wrote in his journal, "My birds, my beloved birds of America, occupy all my time, and nearly all my thoughts, and I do not wish to see any other perspective than the last specimen of those drawings."

For the first two months of 1822 it is written by his wife in her Life, "The records of Audubon's life are sparse and imperfect, on account of his inability to purchase a book to write his journal in!" The one at last obtained was made of thin, 
poor paper, and the records entered are rather in keeping with his financial difficulties. It took all his means at this time to supply his family with the necessaries of life; and in order to obtain money to educate the children, his wife undertook the duties of a situation in which she had charge of and educated the children of a Mr. Brand. They afterward removed to Natchez, where Audubon drew and taught drawing in the college at Washington, Mississippi, and Mrs. Audubon taught; and then to Bayou Sara, Louisiana, where Mrs. Audubon established a school, with the proceeds of which she was enabled to aid materially in the publication of the Birds, and Audubon assisted her by teaching music and dancing. A member of one of the families, in which Mrs. Audubon was a governess during this period, has furnished Dr. Shufeldt with a childhood's reminiscence of the naturalist. "He was with us," she says, "eight months, but during the greater part of the time was wandering all over the State, walking almost the entire time; no insect, worm, reptile, bird, or animal escaped his notice. He would make a collection, return home and draw his crayon sketches, when his son John would stuff the birds and such animals as he wished to preserve."

In the spring of 1824 , Audubon, with two hundred drawings, representing about a thousand birds, went to Philadelphia in order to obtain help to complete his ornithological work. $\mathrm{He}$ was soon satisfied, it is said in Mrs. Audubon's Life, that the venture would be successful. Having purchased a new suit of clothes and dressed himself with extreme neatness, he called upon Dr. Mease, an old friend, and was introduced by him to several artists, who paid him pleasant attentions. $\mathrm{He}$ was also introduced to Prince Canino, son of Lucien Bonaparte, "who examined my birds," Audubon writes, "and was complimentary in his praises. He was at the time engaged on a volume of American birds, which was soon to be published; but this did not prevent him from admiring another naturalist's work.-April 12 th. Met the prince at Dr. Mease's, and he expressed a wish to examine my drawings more particularly. I found him very gentlemanly. He called in his carriage and took me to Peale, the artist, who was drawing specimens of birds for his work; but from want of knowledge of the habits of birds in a wild state, he represented them as if seated for a portrait, instead of their own lively, animated 
ways when seeking their natural food or pleasure. Other notable persons called to see my drawings, and encouraged me with their remarks. The Prince Canino introduced me to the Academy of Arts and Sciences, and pronounced my birds superb and worthy of a pupil of David. I formed the acquaintance of Lesueur, the zoölogist and artist, who was greatly delighted with my drawings." Audubon was engaged by Prince Canino to superintend his drawings intended for publication; but his terms being much dearer than Alexander Wilson's, he was asked to discontinue his work. "I had now," he writes, "determined to go to Europe with my 'treasures,' since I was assured nothing so fine in the way of ornithological representations existed. I worked incessantly to complete my series of drawings. On inquiry, I found Sully and Lesueur made a poor living by their brush. I had some pupils offered at a dollar per lesson; but I found the citizens unwilling to pay for art, although they affected to patronize it. I exhibited my drawings for a week, but found the show did not pay, and so determined to remove myself."

Thus, notwithstanding the pleasant social aspect of his reception in Philadelphia, he does not appear to have been encouraged in its material promise; and he met with a misfortune which would have depressed the spirits of the bravest and most sanguine. His plates, the fruit of years of labour and of almost exclusive preoccupation during the whole time, were destroyed in a single night by rats. He went to work at once, however, to restore his drawings, and did so. Mr. McMurtrie, the conchologist, advised him to take his drawings to England. Prince Canino advised him to go to France. He proceeded to New York, having left Philadelphia "free from debt and free from anxiety about the future." In New York he visited the museum and "found the specimens of stuffed birds set up in unnatural and constrained attitudes. This appears to be the universal practice, and the world owes to me the adoption of the plan of drawings from animated nature. Wilson is the only one who has in any tolerable degree adopted my plan."

The prospect for having his drawings published in New York did not appear very encouraging, although it seemed more hopeful than it had been in Philadelphia. He visited the Lyceum, and his portfolio was examined by the members 
of the Institute, among whom, he writes, "I felt awkward and uncomfortable. After living among such people I felt clouded and depressed; remember that I have done nothing, and fear that I may die unknown. I feel I am strange to all but the birds of America. In a few days $I$ shall be in the woods and quite forgotten." On the next day: "My spirits low, and I long for the woods again; but the prospect of becoming known prompts me to remain another day." He was invited by the artist, Vanderlyn, to sit for a portrait of General Jackson, whom his figure was thought to resemble considerably.

From New York he proceeded up the Hudson and into the lake region, visiting Niagara, but not crossing over to Goat Island on account of the low state of his finances; then returned by way of Erie, Pittsburg, and the rivers, to his home in Bayou Sara. His wife was receiving an income of nearly three thousand dollars a year from her labours in teaching, and he took charge of a class in dancing by which he cleared two thousand dollars; and with this capital and his wife's savings he was now able to foresee a successful issue to his great ornithological work.

He had determined upon going to England, where, although he knew no one, he hoped that he might find a way to get his plates engraved. He sailed from New Orleans in May, I826, and arrived in Liverpool on the 20 th of July. He exhibited his pictures, with satisfaction to his visitors at Liverpool and Manchester, to their admiration at Edinburgh. He made friends of Herschel, Sir Walter Scott, and "Christopher North," who has left the record of his warm admiration for the man and his work in two of his essays, and of Cuvier, Humboldt, and Saint-Hilaire in France. He resolved to go on with the publication of his works, although his friends advised him that the risk was too great to venture upon. In 1827 he issued the prospectus of The Birds of America, to be published in numbers of five folio plates each, the whole to be included in four volumes, and to be sold for one thousand dollars a copy. The entire cost of the work would exceed one hundred thousand dollars; yet when the prospectus was published he had not money enough to pay for getting out the first number. With the aid of Sir Thomas Lawrence he sold some pictures, and was enabled to carry himself over this difficulty; and this led the way to his finding a regular means of support while his 
enterprise was going on, by painting. He visited Paris in I 828, canvassing for subscribers, and experienced an admiration from illustrious men parallel with that which had greeted him in England. But he does not appear to have appreciated the money value of this admiration as highly as what he found in England, for he wrote: "France is poor, indeed! This day I have attended the Royal Academy of Sciences, and had my plates examined by about one hundred persons. 'Fine, very fine,' issued from many mouths; but they said, also, 'What a work! what a price! who can pay it?' I recollected that I had thirty subscribers at Manchester, and mentioned it. They stared and seemed surprised; but acknowledged that England, the little island of England, alone was able to support poor Audubon.... Now it is that I plainly see how happy, or lucky, it was in me not to have come to France first; for if I had, my work now would not have had even a beginning. It would have perished like a flower in October; and I should have returned to my woods, without the hope of leaving behind that eternal fame which my ambition, industry, and perseverance long to enjoy." Baron Cuvier was requested by the Academy of Sciences to make a verbal report on Audubon's Birds, and he responded, describing the work "as the most magnificent monument which has yet been erected to ornithology." The author, having returned to his own country after his schooling in France, "thought he could not make a better use of his talents than by representing the most brilliant productions of that hemisphere. The accurate observation necessary for such representation as he wished to make soon rendered him a naturalist. ... Formerly the European naturalists were obliged to make known to America the riches she possessed; but now Mitchell, Harlan, and Bonaparte give back with interest to Europe what America had received. Wilson's history of the Birds of the United States equals in elegance our most beautiful works on ornithology. If that of Mr. Audubon should be completed, we shall be obliged to acknowledge that America, in magnificence of execution, has surpassed the Old World."

After spending the winter in London, Audubon returned to the United States in April, I829, and made his way to his home in Louisiana, which he reached in November, his journey having been interrupted by excursions in quest of birds to 
Little Egg Harbor, New Jersey, and the "Great Pine Swamp" in Northumberland County, Pennsylvania. His book, in the meantime, was going steadily on, and the first volume was published in London in 1830 . It contained one hundred plates, representing ninety-nine species of birds, with every figure of the colour and size of life. The whole work was completed in four volumes, in 1839. It contained four hundred and thirty-five plates, representing one thousand and sixty-five distinct specimens of birds-all, from the eagle to the humming-bird, of the size of life. Again, after three months at home, spent in hunting and drawing, he visited England in I830, where he found that he had been elected a Fellow of the Royal Society of London, and on the 6th of May took his seat in the great hall, and paid his entrance fee of fifty pounds, "though I felt myself that I had not the qualifications to entitle me to such an honour." He was shortly afterward joined by his wife, who accompanied him in his journeys to get new subscribers. In $183 \mathrm{I}$, anticipating another tour of observation and study in the South, he visited Washington, to get letters of introduction to the commanders of frontier posts and officers along his route. All received him in the kindest manner. The winter of $183^{1-} \mathbf{3}^{2}$ was spent in East Florida, in what Audubon called a rather unprofitable expedition, but which furnished the material for several striking "episodes," as his accounts of the events have been designated.

In his subsequent journey Audubon visited the coast of Maine, accompanied by his family. According to Dr. Griswold's account, ${ }^{*}$ although no reference to the circumstance is made in Mrs. Audubon's Life, the cholera then prevailing in the country, he was taken sick in Boston and detained there for some time. Aside from his illness, his experience in Boston must have been of the most grateful character, for he wrote of it, "Although I have been happy in forming many valuable friendships in various parts of the world, all dearly cherished by me, the outpouring of kindness which I experienced in Boston far exceeded all that I have ever met with." With these kindnesses he associated the names of the men who lent to the Boston of that time its peculiar lustre. Continuing his journey, he explored the forests of Maine and New

* Prose Writers of America, p. 189. 
Brunswick and the shores of the Bay of Funday, and then went by schooner to the Gulf of St. Lawrence, the Magdalen Islands, and the coast of Labrador; and in the latter part of the season visited Newfoundland and Nova Scotia. In the ensuing spring, after nearly three years of travel and research, he went for the third time to England, where, and in Edinburgh, he lived a year and a half. As soon as the first volume of the Birds was published, Audubon began his Ornithological Biographies, to accompany it; a work which, besides descriptions of the birds, contained reminiscences of personal adventure, with delineations of scenery and character. It was completed in five volumes (183I-'39). It has a literary and historical value apart from that which the accounts of the birds give it, in that it presents in language warm from his having been a part of the scenes, a virgin past of our country, and its forests and prairies, which can never be restored or so well described again. In the scientific part of this work he had the valuable co-operation of $\mathrm{Mr}$. William McGillivray, of Edinburgh. Having spent the winter of $1836-37$ at Charleston, with excursions to the Sea Islands, Savannah, and Florida, Audubon, in the spring of 1837 , sailed in a revenue cutter for explorations in the Gulf of Mexico, of which he has left sketches of scenes in the Louisiana bayous, and in Texas. In I 838 he returned to Edinburgh, where he spent several months in preparing the fourth and fifth volumes of the Ornithological Biographies and in finishing the drawings for the Birds.

In 1839 Audubon came back to the United States for the last time, bought an estate on the banks of the Hudson River, which he called Minniesland-now Audubon Park, in the city of New York-and engaged in the preparation of an edition of the Birds in volumes of a reduced size. In this edition the matter was classified, a feature which had not been found practicable in the method of publication of the original edition. He had also had in hand for some time a book on the Quadrupeds of America, for which he, his sons, Victor Gifford and John Woodhouse Audubon, and the father-in-law of his sons, the Rev. John Bachman, of Charleston, South Carolina, had gathered much material. Mr. Bachman took the same relation to this book that $\mathrm{Mr}$. McGillivray had taken to the Ornithological Biographies. A trip to the Rocky Mountains had been planned in connection with this work, but 
on account of his age Audubon was induced to give it up, after having gone as far as the Yellowstone River. The first volume of the Quadrupeds, which was largely the work of his collaborators, was published in 1846 , and the last volume in I854, after Audubon's death. During the last four years of his life, Audubon became weak in mind, and not able to do any regular work. "The interval of about three years," says Mrs. Audubon, "which passed between the time of Audubon's return from the West and the period when his mind began to fail, was a short and sweet twilight to his adventurous career. His habits were simple. Rising almost with the sun, he proceeded to the woods to view his feathered favourites till the hour at which the family usually breakfasted, except when he had drawing to do, when he sat closely to his work. After breakfast he drew till noon, and then took a long walk. At nine in the evening he generally retired.... He was very fond of his grandchildren, and used often to take them on his knees and sing to them amusing French songs that he had learned in France when he was a boy. ... After r 848 the naturalist's mind entirêly failed him, and during the last years of his life his eye lost its brightness, and he had to be led to his daily walks by the hand of a servant."

The body of Audubon was placed in a vault in Trinity Cemetery, which adjoins Audubon Park on the south side. In I 885 Prof. Thomas Egleston, finding the vault much out of repair, undertook to have it put in better order. He induced the corporation of Trinity Church to remove it to a more prominent site, and interested the New York Academy of Sciences in raising a subscription for a monument. The project was successful, and on April 26, r893, the monument was unveiled. It consists of a Runic cross of blue stone eighteen feet in height, standing upon a blue-stone die, which rests upon a granite base. The total height is twenty-five feet. There is a fine bas-relief bust of Audubon on one side of the die and an inscription fills the other. The cross is ornamented with carvings of birds and quadrupeds described in his works.

Various estimates of Audubon's character and work, and accounts of his appearance have been given us, all to his praise. Dr. Griswold says, in his Prose Writers of America, that his highest claim to admiration "is founded upon his drawings in natural history, in which he has exhibited a per- 
fection never before attempted. In all our climates-in the clear atmosphere, by the dashing waters, amid the grand old forests, with their peculiar and many-tinted foliage, by him first made known to art-he has represented our feathered tribes, building their nests and fostering their young; poised on the tip of the spray and hovering over the sedgy margin of the lake; flying in the clouds in quest of prey, or from pursuit; in love, enraged, indeed, in all the varieties of their motion and repose, and modes of life so perfectly, that all other works of the kind are to his as stuffed skins to the living birds. But he has also indisputable claims to a respectable rank as a man of letters. Some of his written pictures of birds, so graceful, clearly defined, and brilliantly coloured, are scarcely inferior to the productions of his pencil. ... From the beginning he surrendered himself entirely to his favourite pursuit, and has been intent to learn everything from the prime teacher Nature. His style as well as his knowledge is a fruit of his experience." His personal appearance, as a reference to his portrait will show must have been the case, was calculated to impress a visitor. $\mathrm{He}$ is described as having been tall and commanding in person, with a countenance which, from the sharp glance of his eye and the outline of his features, "suggested a resemblance to the eagle." $\mathrm{He}$ is believed, from his own account, to have been somewhat of a dandy while living at Mill Grove. "It was one of my fancies," he says, "to be ridiculously fond of dress; to hunt in black satin breeches; wear pumps when shooting, and dress in the finest ruffled shirts I could obtain from France." When on his hunting tours, as he records in the relation of a visit to Niagara, he would allow himself to get into the plight of the poorer class of Indians, and worse, from not having, like them, plucked his beard or trimmed his hair in any way. "Had Hogarth been living, and there, when I arrived, he could not have found a fitter subject for a Robinson Crusoe. My beard covered my neck in front, my hair fell much lower at my back; the leather dress which I wore had for months stood in need of repair; a large knife hung at my side; a rusty tin box, containing my drawings and colours, and wrapped up in a wornout blanket that had served me for a bed, was buckled to my shoulders. To every one I must bave seemed immersed in the depths of poverty, perhaps of despair." Some explanation 
was needed to convince the landlord of the hotel that he was a suitable subject for entertainment, but it seems to have been satisfactory. Christopher North says of him in the Noctes Ambrosianæ, as he appeared at Edinburgh: "The man himself is just what you would expect from his productions; full of fine enthusiasm and intelligence, most interesting in his looks and manners, a perfect gentleman, and esteemed by all who know him for the simplicity and frankness of his nature."

In an address delivered on the unveiling of the monument to Audubon, Prof. Thomas Egleston has said of him: "He was a woodsman, not a scientific naturalist, according to the ideas prevalent to-day. He loved to go into the forests and watch the creatures that dwelt among the leafy lanes and thickets; to study the birds in their time of love-making, nesting, and migration, and to draw their forms upon the canvas. But of books he was no student; of the intricate scientific details of his mighty subject he was unconcerned and indifferent; sufficient for him it was to learn where and how his feathered friends lived and moved, and to produce their portraits." 



\section{LEWIS DAVID VON SCHWEINITZ.}

$$
\text { I } 780-1834 \text {. }
$$

DURING colonial times in America, and even down into the present century, science advanced over a much-obstructed path. Not having then attained to its present power and esteem, there were but few of its votaries whose whole time and best energies it could command. The explorations by which the animals, plants, and minerals of the vast Western continent were made known to science were accomplished in large part by naturalists who either followed some other vocation as a means of livelihood, or were mainly occupied by some other career to which they felt more strongly bound. Franklin was a printer and later a statesman, being an electrician only at odd times; John Bartram was a farmer; Mitchill, Hosack, and Barton were physicians; while Muhlenberg and the subject of this article were clergymen.

Lewis David von Schweinitz was born, February 13, r780, at Bethlehem, Pa., then a Moravian Church settlement which had been founded by his family in $\mathrm{r} 74 \mathrm{r}$. His father, Baron Hans Christian Alexander von Schweinitz, came from an ancient and distinguished family residing on the ancestral estate called Leuba in the present limits of Saxony. That he was a man of stable character may be inferred from the fact that he performed the responsible duties of a treasurer general for the Moravian Church in America. The mother of Lewis was Dorothea Elizabeth, daughter of Baron (afterward Bishop) John de Watteville, and Benigna, daughter of Lewis Nicholas, Count Zinzendorf. It was to Zinzendorf and Watteville that the renewal and resuscitation of the ancient church of the Unitas Fratrum, or Moravian Brethren, in the eighteenth century was mainly due. In I 722 two families of the Brethren crossed the frontier of Moravia by night and made their way to the estate of Count Zinzendorf in Saxony. Here they were 
joined by others, and in a few years the town of Herrnhut was built by the colonists. Zinzendorf took an interest in this settlement from the start, became a bishop in the church, and devoted his life to its service. The efforts of the Brethren were early turned toward foreign missions, and it was in furtherance of mission work that Zinzendorf and Watteville came to America and founded the first Moravian settlements in this country.

Being so closely connected with the refounders of an ancient denomination, the parents of Lewis naturally looked forward to his becoming an able promoter of the interests of their church. He was their eldest son, of a decidedly intellectual temperament and an enthusiastic disposition, and when in early boyhood he developed the habit of addressing short speeches and little sermons to the family circle, his future seemed to be definitely marked out.

When a little more than seven years old, Lewis was placed in the academy of the Moravian community at Nazareth Hall, where he remained eleven years. Young Lewis received his first impulse toward scientific study when on a visit to this school with his grandfather, Bishop de Watteville, before he entered it as a pupil. Seeing a specimen of the Lichen digitatus lying on a table, the child examined it with interest, and was told its name and something about its physiology. From that moment he was wont to date his interest in the vegetable kingdom. After entering the school he received some instruction in the elements of botany. A partial flora of Nazareth and vicinity, made while he was at this institution, which remained among his manuscripts at his death, is evidence that this study took immediate hold upon the mind of the youth. During his school days his powers of language and his vein of satirical humour were occasionally manifested in poetical effusions. While still a pupil and not yet eighteen years of age he assisted in teaching some of the younger classes. Lewis had three brothers and two sisters, none of whom ever turned to scientific pursuits.

In I798 Hans von Schweinitz was called to Germany and took his family with him. Lewis was removed from the Nazareth seminary and after the family reached Germany was entered as a student in the theological institution at Niesky, in what was then known as the province of Lusatia, in Silesia. 
Here he made the acquaintance of Prof. J. B. de Albertini, who became his fast friend and his fellow-worker in botanical investigations. After completing his course as a student he became a teacher in the academy. His leisure at Niesky was occupied in the pursuit of his favourite science, in general reading and study, and in writing for the literary journals of the time. In his Memoir of von Schweinitz, read before the Academy of Natural Sciences of Philadelphia, Walter R. Johnson says of his literary activity at this time, "Scarcely any important topic in the wide field of science escaped his notice, and especially did the constitution and management of the affairs of his social and religious fraternity call forth from his pen many able and spirited articles."

The first published botanical work of von Schweinitz appeared in 1805 , when he was twenty-five years of age. From the beginning of his residence at Niesky he had given especial attention to the fungi, previously little studied. The association with Albertini had continued and the discoveries of the two friends in this field had been so many as to warrant the publication of a volume of about four hundred pages on the fungi of Lusatia embodying the results of their united efforts. It was written in Latin, as was still the custom for scientific works in Europe, and the twelve plates, containing figures of ninety-three new species, with which it was illustrated, were drawn and engraved by von Schweinitz's own hands. In this work the authors creditably refrained from the then too common practice of giving new names to the already known plants included in their descriptions. They were convinced that natural history had been grievously burdened by the accumulation and confusion of synonyms, many of which promoted no other purpose than an unworthy ambition.

Soon after this Mr. von Schweinitz began to preach, and in r 807 was called to the Moravian settlement at Gnadenberg, not far from Niesky. "Considered as literary performances," says Johnson, in the memoir already cited, "his sermons were characterized by the utmost simplicity, both in style and delivery, and were addressed more to the heart than to the head. His discourses were invariably practical, not argumentativeexperimental, not speculative." It was now the time of $\mathrm{Na}$ poleon's continental wars, and troops were quartered at Gnadenburg. The inhabitants found the presence of the soldiery 
irksome, but the happy disposition and winning deportment of the young pastor had much influence in preventing collisions. The next year he was invited to Gnadau, in Saxony, where he remained four years, performing the duties of his clerical office and teaching the boys of the community who were destined for learned professions.

In I8I 2 Mr. von Schweinitz, being then thirty-two years of age, was appointed general agent of the Moravian Church in the southern United States. Before starting for this country he married, at Niesky, Louiza Amelia Le Doux, who belonged to a French family residing at Stettin. The continental system of Napoleon rendering direct communication with the United States extremely hazardous, Mr. von Schweinitz and his wife were compelled to go through Denmark to Sweden and embark there. The trouble of making this roundabout journey was, as it chanced, not without its compensation. The travellers were obliged to make a stay of some length at Kiel, in Holstein, during which von Schweinitz formed an enjoyable acquaintance with several of the professors in the university there. His attainments, moreover, so impressed the authorities of this seat of learning that they conferred upon him the honorary degree of Doctor of Philosophy. When, at length, the voyage was begun the United States had declared war with England and the sea swarmed with privateers. The passage abounded with thrilling adventures and providential escapes. While still in European waters the vessel fell in with a French privateer and narrowly avoided capture by taking refuge under the guns of a Danish fort. A fierce cannonade between the Danes and the Frenchman followed, many of the balls passing over and through the ship. Later it was actually captured by a British frigate, but escaped in the darkness and fog of a stormy night. Much tempestuous weather was met with, and the climax came in a terrible storm which dismasted the vessel. Nevertheless, it finally entered port in safety, being the only one of fifteen or twenty American vessels sailing from Sweden on the same day that ever reached America.

The principal church settlement of the district to which von Schweinitz had been assigned was at Salem, N. C., and there he took up his residence. Although not a native of North Carolina, he had a strong predilection for that State, having often heard his father and grandfather speak of their 
visits to its early settlements. His official duties were very arduous. He was a member of the governing board of the Moravian Churches in North Carolina, a trustee of the Salem Female Academy, the administrator of the very large landed estates owned by the church in the State, and he frequently preached in Salem and other places. Yet he found time to continue his botanical researches, which he could now carry on in a dominion, scientifically speaking, all his own. On one of his exploring trips he discovered among the Sauraton Mountains, in Stokes County, a most beautiful waterfall, which still bears his name. Among his scientific correspondents at this time were Dr. Reichenbach, of Dresden; Kunze, of Leipsic; Major Le Conte, United States Army; Blumenbach, of Göttingen; Elliott, of South Carolina; Schwaegrichen, of Leipsic; and Hooker, of England. The first fruit of his botanical work in the South was a synopsis of the fungi of North Carolina, written in Latin, which was given to the world in 1818 through the Society of Naturalists at Leipsic, under the editorial care of Dr. D. F. Schwaegrichen. Among the thirteen hundred and seventy-three species described in this synopsis, there are three hundred and fifteen that were new to science. In the same year his duties required him to attend a synod of his religious brethren at Herrnhut. On his way he visited England, France, and Holland, and established correspondences which were of great value to him after he returned to America and began the formation of a regular herbarium. In I82I von Schweinitz published at Raleigh, N. C., a pamphlet containing descriptions of seventy-six species of Hepatica (liverworts), among them being nine discovered by him. In the same year he contributed to the American Journal of Science, then in its fifth volume, a Monograph on the Genus Viola, in which five new species were described. This was a valuable paper, and was often cited by European botanists. In it he made the interesting statement that among the thirty species of violets then known in America there was not one exactly like any of the twenty European species.

During his residence at Salem, von Schweinitz had been offered the presidency of the University of North Carolina. The acceptance of this honourable position would have necessitated giving up his service in the Moravian Church, and so, feeling that the Brethren had the best claim upon his energies, 
he declined it. At the beginning of the year 1822 he removed to Pennsylvania, and took up his residence in his native village of Bethlehem. Here he undertook the charge of the Moravian girls' seminary at that place, and the secular office of general agent for the Brethren was retained. His botanical studies were not suffered to languish. "The beautiful slopes and valleys about Bethlehem and Nazareth," says Johnson, "the romantic banks of the Delaware, and the precipitous rocks of the Lehigh, all yielded up to him a tribute of their hitherto unexplored treasures. The high estimation set upon his works by men of science had procured his election as an honorary member in several societies devoted to natural history, both in Europe and America. His correspondence increased, and the formation of his herbarium advanced with great rapidity." About this time Major Long's expedition to the sources of the St. Peter's River, in the Northwest Territory, returned. It had been arranged that the plants collected on this trip by Thomas Say should be described by Nuttall. The work was begun by this naturalist, but he was obliged to go to Europe, and was prevented from returning in season to do any more. The plants were accordingly put in the hands of von Schweinitz, who described them most acceptably.

Toward the end of 1823 the then well-known botanist communicated to the Lyceum of Natural History (now the Academy of Natural Sciences), of New York, a key or analytical table for determining the American species of Carex-the largest genus of the sedges. This production, though small in bulk, could result only from ample knowledge and exact discrimination. In 1824 the American Journal of Science published a short paper by him on the rarer plants of Easton, $\mathrm{Pa}$. There was another synod at Herrnhut this year which it was necessary for him to attend, and, having a Monograph of the North American Carices about completed, he put the manuscript, together with a large collection of specimens, into the hands of Dr. Torrey, in order that the monograph might be communicated to the Lyceum of Natural History in his absence. He gave full liberty for making any additions or alterations warranted by Dr. Torrey's later discoveries. When he found, on returning, that his editor had made important additions to the number of species described, von Schweinitz, with characteristic conscientiousness, requested that the paper 
should be published as their joint production, saying that "the judicious and elaborate amendments he has proposed, and the mass of new and valuable matter he has added, entitle Dr. Torrey to a participation in the authorship of the work." The whole number of species described was one hundred and thirteen, of which six were new. This and the analytical table of the Carices were both printed in the first volume of the Annals of the Lyceum. In his absence a paper in which he described fifteen new American species of Spharia, one of the largest genera of fungi, was communicated to the Academy of Natural Sciences of Philadelphia, and appeared in vol. $v$ of its Journal.

Von Schweinitz was absent till near the end of 1825 . After his return he resumed his labours as general agent for the Brethren; the charge of the school, however, had been given up some time before. The great work to which he now devoted his attention was a Synopsis of North American Fungi. $\mathrm{He}$ had intended this for publication in one of the European journals, but was induced to present it, in 1831, to the American Philosophical Society of Philadelphia. In this work three thousand and ninety-eight species, belonging to two hundred and forty-six genera, were described, of which twelve hundred and three species and seven genera had been discovered by the author. If to these discoveries we add those made by von Schweinitz in other orders of plants, we have a total of nearly fourteen hundred new species added to botanic science by the talents and industry of a single observer. The whole number of species known at his death was estimated at sixty thousand.

Until he was about fifty years of age his health had been excellent. But the various and increasing cares of his official position finally had their effect. The sedentary work involved in writing a dissertation on the affairs of his community, which prevented for a time his usual out-of-door exercise, was the immediate cause of a severe cough and other alarming symptoms of decline. His spirits, which had been uniformly cheerful, became depressed. A journey to the West to establish a branch community of the United Brethren in Indiana was temporarily beneficial, but his system was undermined and the progress of disease could not be stayed. On February 8, 1834, came the end of what his memoirist calls "a life of various, constant, and unobtrusive usefulness."

A widow and four sons survived him. All the sons entered 
the Moravian ministry. The eldest, Emil Adolphus de Schweinitz, was born in Salem, N. C., in 1816 . He filled various ecclesiastical offices in Pennsylvania and North Carolina, was made a bishop in 1874 , and died in 1879 . The second son, Robert, was born in Salem, in 1819 . He has filled various charges and was for many years president of the executive board of the American Moravian Church. Since his retirement from the active ministry he has been general treasurer of the Church and of its Foreign Mission Department. The third son, Edmund Alexander, was born in Bethlehem in 1825 , and died there in 1887 . He also became a bishop, and was the author of several books on the history and polity of the Unitas Fratrum. In 1856 he established a weekly journal for the Moravians in America, which he edited for ten years. His life was one of great activity and usefulness. Bernard, the youngest son, was born at Bethlehem, in 1828 , and died at the age of twenty-six years, being at the time in charge of a church on Staten Island. During the latter years of the father's life he used de in place of zon in his name, and the sons have always used the new form.

Von Schweinitz was of high stature, erect carriage, and robust habit. The accompanying portrait is a copy of a miniature painted some years before his death, and consequently represents him in the prime of life. He had an unusually amiable and attractive disposition, which made him a general favourite with high and low. His conversational powers were of a high order, and contributed much to an ease of intercourse which was an important factor of his usefulness. Humour, anecdote, and repartee were always at his command, while the varied and exciting scenes through which he had passed and the prominent personages with whom he had come in contact furnished him an inexhaustible fund of interesting reminiscences. Strange to say, considering his German extraction, he was devoid of any appreciation for music. $\mathrm{He}$ spoke and wrote in English, German, French, and Latin, and was also acquainted with Greek.

A notable feature of his scientific work was its systematic character. Evidence of this is furnished by the synoptical tables attached to his several monographs, and by the fact that the analytical table of the Carices was one of his productions. The cryptogams had for him an attraction that they do not 
have for many. We owe most of our knowledge of this series of plants to German, Danish, and Swedish investigators. Knowledge that may not be read by him who runs but must be delved for, as is the case with that relating to the fungi and their near allies, seems to have an especial attraction for Northern minds.

Among his well-deserved honours was the naming after him of Schweinitzia odorata (sweet pinesap), by Stephen Elliott. This is a small plant, found from Maryland southward, and bears a spike of flesh-coloured flowers which exhale the odour of violets.

A general characterization of the botanist's work can not be given better than in the following words of Walter R. Johnson :

"When we consider the extreme difficulty of the particular departments of botany to which Mr. Schweinitz devoted his chief attention, the prodigious number of facts which he has accumulated, the vast amount of minute and delicate investigation demanded by the nature of the objects of his study, the labour of preparing for the press the materials which he had brought together; when we recollect that, with the exception of Dr. Muhlenburg, of Lancaster, no American botanist had ventured far upon this wide and unexplored dominion of $\mathrm{Na}$ ture, and when we remember that this science was his relaxation, not his profession-his occasional pursuit, not his daily duty-we are forcibly struck with the high order of his talents for the pursuit of physical science, and can not but regret that more of his time and energies could not have been devoted to this favourite occupation."

Von Schweinitz bequeathed his collection of plants to the Academy of Natural Sciences of Philadelphia. It comprised twenty-three thousand species of phanerogams and many thousand cryptogams. A large portion of the specimens were from the most remote parts of the world, having been obtained by exchange with American and European explorers. They included the "Baldwin collection" from Florida, Brazil, and La Plata, which von Schweinitz had bought, and in which he had found three thousand species not before in his herbarium. The examination and arrangement of these plants had been one of his last scientific labours. 


\section{ROBERT HARE.}

$$
\text { I } 78 \mathrm{I}-1858 \text {. }
$$

THE name of Robert Hare, said the American Journal of Science at the time of his death, "has for more than half a century been familiar to men of science as a chemical philosopher, and to the cultivators of the useful arts throughout the civilized world." Dr. Hare was born in Philadelphia, January 7 , I78I, and died in the same place, May I5 $_{5}$ I858. His father, the proprietor of a large brewery in Philadelphia, was an Englishman of strong mind, occupying a prominent position in society, and enjoying the confidence of his fellow-citizens. The management of this concern shortly fell into the hands of the son. He was soon drawn away from it, however, by the strength of his predilection for scientific pursuits; and before he was twenty years old he was enrolled as an attendant of the course of lectures on chemistry and physics in Philadelphia, and became a member of the Chemical Society of that city. There he found Priestley, Sybert, and Woodhouse among his associates. To this society he communicated in I80I a description of the oxyhydrogen blowpipe, which was then called the hydrostatic blowpipe, and which Prof. Silliman, who had been engaged with him in 1802 and 1803 in a series of experiments with the instrument, afterward called the compound blowpipe. On his return from Philadelphia, in $\mathbf{r} 803$, Prof. Silliman constructed for Yale College the first pneumatic trough combining Dr. Hare's invention; an apparatus which was afterward figured and described by Dr. Hare in his memoir on the Fusion of Strontia and the Volatilization of Platinum-a paper which was republished in London and in the Annales de Chimie. This apparatus, according to Prof. Silliman, was the earliest and most remarkable of Dr. Hare's original contributions to science. It revealed to the chemical student a source of artificial 


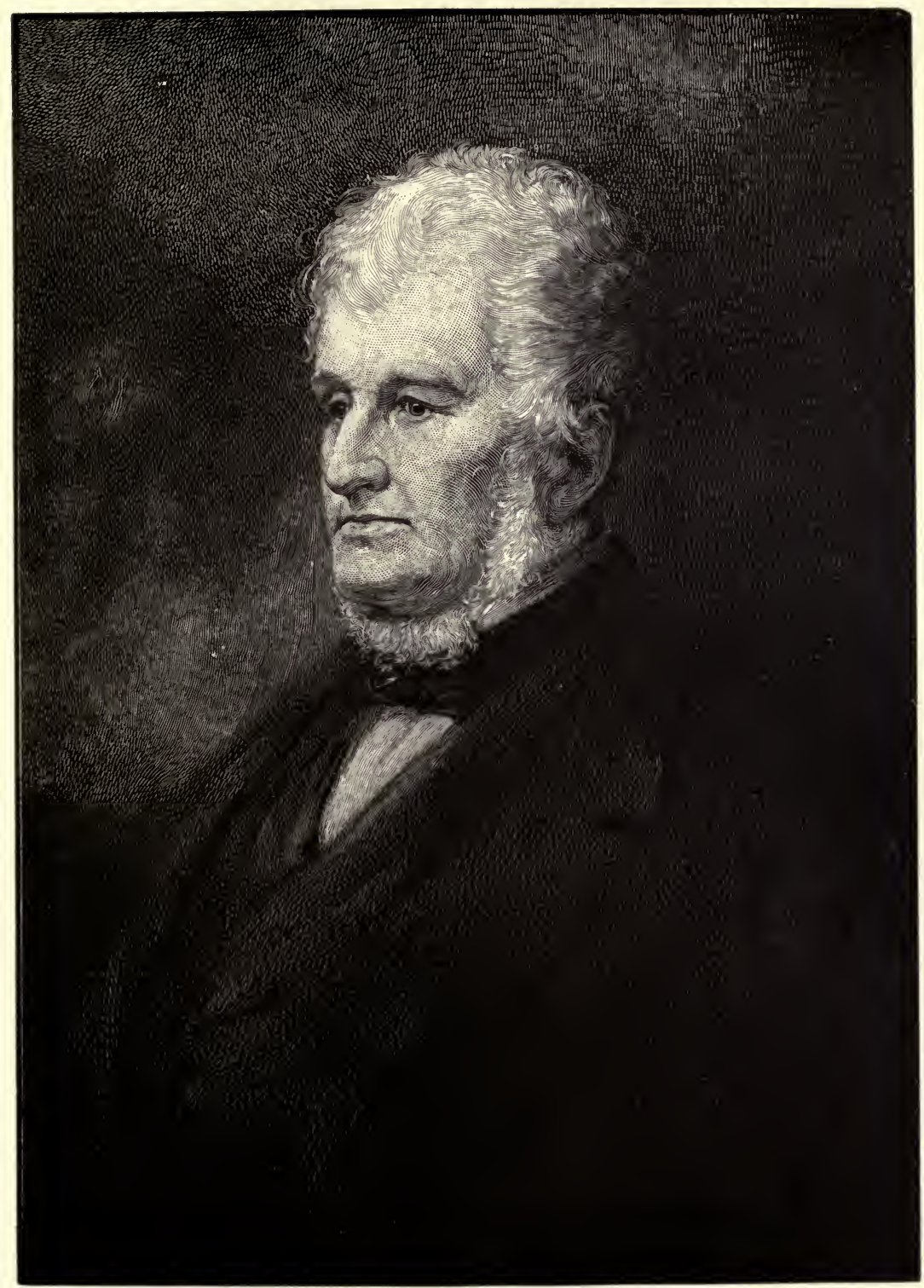

ROBERT HARE. 

power far transcending anything he had ever known before; and this, though the facts on which it was based were not unknown.

Lavoisier had directed a jet of oxygen on charcoal and had burned the elements of water together; but even he, and in the face of these experiments, had failed to comprehend the power of this heating apparatus, and it was left for the acumen of Hare to demonstrate it and make it practically applicable. The author of the biography in the American Journal of Science says of it, "In our view, Dr. Hare's merit as a scientific philosopher is more clearly established upon this discovery than upon any other of the numerous contributions he has made to science." Dr. Hare's original experiments were repeated in $\mathrm{r} 802$ and $\mathrm{r} 803$ in the presence of Dr. Priestley and Messrs. Silliman, Woodhouse, and others. In recognition of the discovery, Dr. Hare received the Rumford medal from the American Academy of Science at Boston. An attempt was afterward made, in 1819 , by Dr. Clarke, of Edinburgh, to rob him of the credit of this discovery; and though he showed that the oxhydrogen apparatus had been before the public several years, no attention was paid to his protests. The calcium and Drummond lights also furnish instances of most important applications of Dr. Hare's invention, in which no reference is made to him. He himself led the way to these devices by consţructing an apparatus on a gigantic scale, with large vessels of wrought iron, capable of sustaining the pressure of the Fairmount Water Works, with which he was able to fuse at one operation nearly two pounds of platinum, with a resultant production of metal greatly purified.

$\mathrm{He}$ devoted much labour and skill to the construction of new and improved forms of the voltaic pile; "and it is easy to show," Prof. Silliman says, "that owing to his zeal and skill in this department of physics American chemists were enabled to employ with distinguished success the intense powers of extended series of voltaic couples long in advance of the general use of similar contrivances in Europe."

In 18 r6 Dr. Hare constructed an instrument called the calorimeter, in which great extent of surface was obtained by combining many large plates of zinc and copper into one series, 
and plunging the whole at once into a tank of dilute acid. Great magnetic and heating effects were obtained with this instrument, and it was many years before any other voltaic apparatus was constructed in which the movement of so great a volume of heat was attained with so low a projectile or intensive force. By it large rods of iron or platinum were ignited and fused with splendid exhibitions, while the intensity of the current was so low that hardly a visible spark could be made to pass by it through poles of carbon. The magnetic effects were afterward shown by Prof. Henry to be attainable from a single cell, if combined with suitable conductors. Instead of Cruikshank's cumbrous battery of alternating zinc and copper plates, which Davy used in the experiments that resulted in the discovery of the metallic bases of the alkalies, Hare found a way of obtaining a corresponding amount of surface and its resultant power with a single roll of metal, and in 1820 introduced the deflagrator, in which any series, however extended, could be instantaneously brought into action or rendered passive at pleasure. This apparatus consists of a large sheet of copper having several hundred square feet of surface and a similar one of zinc, separated by a piece of felt or cloth saturated with acidulated water, and then rolled up in the form of a cylinder. Faraday bore testimony, in his Experimental Researches, to the merit of this invention when, in 1835 , he acknowledged that, having worked exhaustively to perfect the voltaic battery, finding that Hare had anticipated him many years before, and had accomplished all that he had attempted, he at once adopted his instruments, as embodying the best results then possible.

With one of Hare's deflagrators, Prof. Silliman, in 1823 , first demonstrated the volatilization and fusion of carbon, a result then considered so extraordinary that it was a considerable time before it was fully credited. It was with these batteries that the first application of voltaic electricity to blasting under water was made in 1831 in experiments conducted under Dr. Hare's direction.

Dr. Hare was also distinguished in chemistry as the author of a process for denarcotizing laudanum, and of a method for detecting minute quantities of opium in solution. He was interested, too, in the discussions of philosophical chemistry, as was most notably shown in the earnestness with which he con- 
tested what he conceived were the errors of the salt radical theory.

He made studies in meteorology, and had a theory of whirlwinds and storms founded on an electrical hypothesis, which he opposed to the rotary theory of W. C. Redfield. At the second meeting of the American Association for the Advancement of Science he explained his own views on this subject, while he controverted those of Mr. Redfield. This gentleman was present and heard his remarks, but made no reply then. He was not a speaker, and did not address the public except in writing.

In 1818 Dr. Hare was chosen Professor of Chemistry and Natural Philosophy in William and Mary College, and in the same year was made Professor of Chemistry in the medical department of the University of Pennsylvania. He held the latter position till 1847 . His teachings were marked by the originality of his experiments and the extent and variety of the apparatus he employed. He spared no labour or expense in his operations, and, being a handy mechanician, he was able to bestow much ingenuity in the construction of novel devices for experiment and illustration. $\mathrm{He}$ accumulated instruments and material with astonishing profusion. To these he added graphic illustrations and lucid descriptions to make his lectures intelligible and interesting. When he resigned his professorship, he gave all the apparatus he had accumulated to the Smithsonian Institution.

He was a man of literary tastes, fond of poetry, and himself wrote verses occasionally. $\mathrm{He}$ also sometimes wrote articles on the political and financial questions of the day, and contributed moral essays to The Portfolio, under the signature of "Eldred Grayson."

In person he had a robust frame, a large head, and an imposing figure and presence.

In his family and among his friends, according to Prof. Silliman, he was very kind, and his feelings were generous, amiable, and genial; yet, in the absence of mind occasioned by his habitual abstraction, and when absorbed in thought, his manner was occasionally abrupt. With his keen and active mind, conversation would sometimes seem to awaken him from an intellectual reverie. He had great colloquial pow- 
ers, but to give them full effect it was necessary that they should be aroused by a great and interesting subject, and the effect was heightened by the injection of antagonism. $\mathrm{He}$ would then discourse with commanding ability, and his hearers were generally as ready to listen as he to speak. $\mathrm{He}$ was a man of unbounded rectitude, a faithful friend, and a lover of his country and its best interests, without thought of personal emolument or political advancement. He was a voluminous scientific writer. For many years his contributions to the American Journal of Science were more numerous than those of any other correspondent. The full list of them includes about one hundred and fifty articles, in forty-eight volumes of that journal, the record of the titles of which occupies five columns in the General Index of the first fifty volumes. Besides notices of the various substances he discovered or experimented with, and descriptions of apparatus, we find among these articles some that touch the principles of chemical and physical philosophy-as on the nature of acids and salts; concerning Faraday's views on atoms; on chemical nomenclature, a subject which is also discussed in a letter to Berzelius; on some inferences from the phenomena of the spark in Thompson's work on heat and electricity; on the error that electric - machines must communicate with the earth; on a new theory of galvanism; on the cause of heat; a reply to Prof. D. Olmsted's views on the materiality of heat; Reply to Matter is Heavy, as demonstrated by W. Whewell; on meteorological topics-storms of the Atlantic coast; reviews of Redfield's theory of storms and of Dove's essay on storms; an account of a storm or tornado in Rhode Island, August, 1838 , "and others"; on Causes of Storm, Tornado, and Waterspout; among accounts of experiments and new methods-blasting rocks by galvanic ignition; apparatus for producing ebullition by cold; process for fulminating powder, consisting of cyanogen and calcium; mode of obtaining the specific gravity of gases; analysis of gaseous mixtures; method of dividing glass by friction; and apparatus for decomposition and recomposition of water. He was also author of a Brief View of the Policy and Resources of the United States (I8ro); Chemical Apparatus and Manipulations (1836); Compendium of the Course of Chemical Instruction in the Medical Department of the University of Pennsylvania (1840); Memoir on the Ex- 
plosiveness of Nitre (1850); and Spiritualism Scientifically Demonstrated (1855).

He was a member of the American Academy of Arts and Sciences and of the American Philosophical Society, and was one of the few life-members of the Smithsonian Institution. He received the honorary degree of M. D. from Yale in 1806 and from Havard in 1816 . 


\section{CONSTANTINE SAMUEL RAFINESQUE.}

$$
1783-1840 \text {. }
$$

IT is now more than seventy years since the most learned of our early naturalists, and the most persistent of travellers, crossed the Falls of the Ohio and stood on Indiana soil. $\mathrm{He}$ came on foot, with a notebook in one hand and a hickory stick in the other, and his capacious pockets were full of wild flowers, shells, and toads. He wore "a long, loose coat of yellow nankeen, stained yellower by the clay of the roads, and variegated by the juices of plants." In all respects of dress, manners, and appearance he would be described by the modern name of "tramp." Nevertheless, no more remarkable figure has ever appeared in the annals of America or in the annals of science. To the writer it has always possessed a peculiar interest; and so, for a few moments, I wish to call up before you the figure of Rafinesque, with his yellow nankeen coat, "his sharp, tanned face, and his bundle of plants, under which a peddler would groan," before it recedes into oblivion.

Constantine Samuel Rafinesque was born in Constantinople on the $22 \mathrm{~d}$ of October, in the year 1783 . His father was a French merchant from Marseilles, doing business in Constantinople, and his mother was a German woman, born in Greece, of the family name of Schmaltz. Rafinesque himself, son of a Franco-Turkish father and a Græco-German mother, was an American. Before he was a year old his lifelong travels began, his parents visiting ports of Asia and Africa on their way to Marseilles. As a result of this trip we have the discovery, afterward characteristically announced by him to the world, that "infants are not subject to seasickness." At Marseilles his future career was determined for him; or in his own language: "It was among the flowers and fruits of that delight ful region that I first began to enjoy life, and I became a botanist. Afterward the first prize I received in school was a 


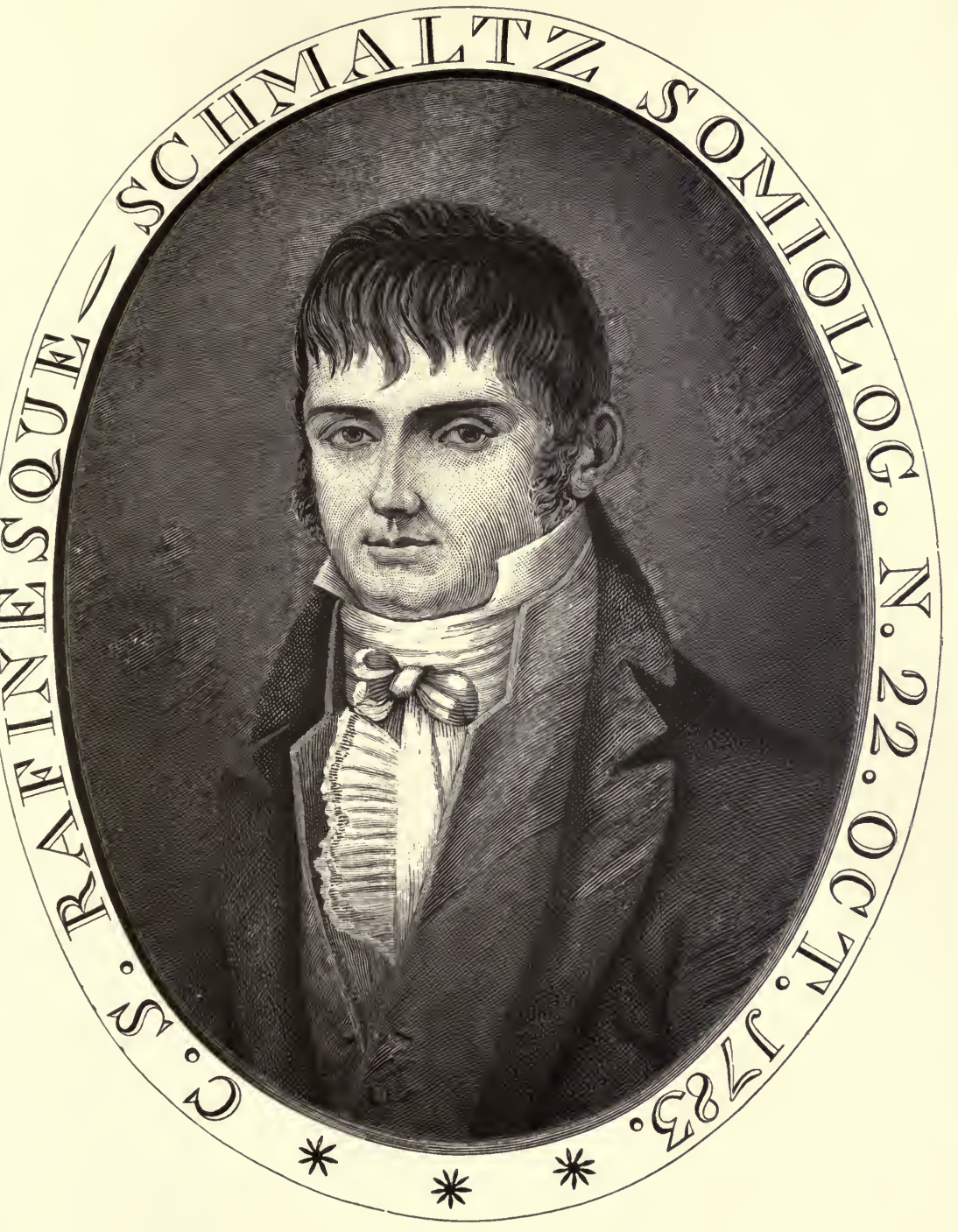

CONSTANTINE SAMUEL RAFINESQUE. 

book of animals, and I became a zoölogist and a naturalist. My early voyage made me a traveller. Thus, some accidents or early events have an influence on our fate through life, or unfold our inclinations." *

Rafinesque read books of travel, those of Captain Cook, Le Vaillant, and Pallas especially; and his soul was fired with the desire "to be a great traveller like them. . . . And I became such," he adds tersely. At the age of eleven he had begun a herbarium, and had learned to read the Latin in which scientific books of the last century were written. "I never was in a regular college," he says, "nor lost my time in the dead languages ; but $I$ spent it in reading alone, and by reading ten times more than is read in the schools. I have undertaken to read the Latin and Greek, as well as the Hebrew, Sanskrit, Chinese, and fifty other languages, as I felt the need or inclination to study them." At the age of twelve he published his first scientific paper, Notes on the Apennines, as seen from the back of a mule on a journey from Leghorn to Genoa. Rafinesque was now old enough to choose his calling in life. He decided to become a merchant; for, said he, "commerce and travel are linked." At this time came the first outbreaks of the French Revolution, when the peasants of Provence began to dream of "castles on fire and castles combustible"; so Rafinesque's prudent father sent his money out of France and his two sons, Constantine and Anthony, to America.

In Philadelphia, it is said, "No one knew where he came from, no one knew where he went on his return." According to his own story, Constantine Rafinesque became a merchant's clerk, and his spare time was devoted to the study of botany. He tried also to study the birds; but he says, "The first bird I shot was a poor chickadee, whose death appeared a cruelty, and I never became much of a hunter." During his vacations Rafinesque travelled on foot over parts of Pennsylvania and Virginia. He visited President Jefferson, who, he tells us, asked him to call again. In 1805 , receiving an offer of business in Sicily, Rafinesque returned to Europe. He spent ten years in Sicily-the land, as he sums it

* This and most of the other verbal quotations in this paper are taken from an Autobiography of Rafinesque, of which a copy exists in the Library of Congress. A few quotations have been somewhat abridged. 
up, "of fruitful soil, delightful climate, excellent productions, perfidious men, and deceitful women." His will, published fifty years after his death, gives a key to this statement. The deceitful woman was his wife, Josephine Vaccaro, and the perfidious man, the actor Giovanni Pizzalour, with whom she ran away when Rafinesque left Sicily to resume his American travels.

It was in Sicily that Rafinesque discovered the medicinal squill, which, aided by the equally medicinal paregoric, was once the great specific for all childish ailments. $\mathrm{He}$ commenced gathering this in large quantities for shipment to England and Russia. The Sicilians thought that he was using it as a dyestuff; "and this," said he, "I let them believe." Nearly two hundred pounds had been shipped by him before the secret of the trade was discovered, since which time the Sicilians have prosecuted the business on their own account. He began to turn his attention to the animals of the sea, and here arose his passion for ichthyology. The red-shirted Sicilian fishermen used to bring to him the strange creatures which came in their nets. In 1810 he published two works on the fishes of Sicily, and for our knowledge of very many of the Mediterranean fishes we are indebted to these Sicilian papers of Rafinesque. It is unfortunately true, however, that very little of real gain to science has come through this knowledge. Rafinesque's descriptions in these works are so brief, so hasty, and so often drawn from memory, that later naturalists have been put to great trouble in trying to make them out. A peculiar, restless, impatient enthusiasm is characteristic of all his writings - the ardour of the explorer without the patience of the investigator.*

In Sicily, Rafinesque was visited by the English ornithologist William Swainson. Swainson seems to have been a great admirer of "the eccentric naturalist," as he called him. Of him Rafinesque says: "Swainson often went with me to the mountains. He carried a butterfly net to catch insects with, and was taken for a crazy man or a wizard. As he hardly

* Dr. Elliott Coues has wittily suggested that as the words "grotesque," "picturesque," and the like are used to designate literary styles, the adjective " rafinesque" may be similarly employed for work like that of the author now under consideration. 
spoke Italian, I had once to save him from being stoned out of a field where he was thought to seek a treasure buried by the Greeks." Rafinesque now invented a new way of distilling brandy. He established a brandy distillery, where, said he, "I made a very good brandy, equal to any made in Spain, without ever tasting a drop of it, since I hate all strong liquors. This prevented me from relishing this new employment, and so I gave it up after a time."

Finally, disgust with the Sicilians and fear of the French wars caused Rafinesque, who was, as he says, "a peaceful man," to look again toward the United States. In 1815 he sailed again for America, with all his worldly goods, including his reams of unpublished manuscripts, his bushels of shells, and a multitude of drawings of objects in natural history. According to his own account, the extent of his collections at that time was enormous, and from the great number of scattered treatises on all manner of subjects which he published in later years, whenever he could get them printed, it is fair to suppose that his pile of manuscripts was equally great. A considerable number of his notebooks, and of papers for which, fortunately for scientific nomenclature, he failed to find a publisher, are now preserved in the United States National Museum. These manuscripts are remarkable for two things-the beauty of the quaint French penmanship and the badness of the accompanying drawings. His numerous notebooks, written in French, represent each the observations of a busy summer; and these observations, for the most part unchecked by the comparison of specimens, he prepared for the press during the winter. To this manner of working, perhaps unavoidable in his case, many of Rafinesque's errors and blunders are certainly due. In one of these notebooks I find, among a series of notes in French, the following remarkable observation in English: "The girls at Fort Edzeard eat clay!" In another place I find a list of the new genera of fishes in Cuvier's Règne Animal (1817), which were known to him. Many of these are designated as synonymous with genera proposed by Rafinesque in his Caratteri in 1810 . With this list is the remark that these genera of Cuvier are identical with such and such genera "proposed by me in 1810 , but don't you tell it!"

Rafinesque was six months on the ocean in the second voyage to America. Finally, just as the ship was en tering Long 
Island Sound, the pilot let her drift against one of the rocks which lie outside the harbour of New London. The vessel filled and sank, giving the passengers barely time to escape with their lives. "I reached New London at midnight," say's Rafinesque, "in a most deplorable situation. I had lost everything-my fortune, my share in the cargo, my collections and labours of twenty years past, my books, my manuscripts, and even my clothes-all I possessed, except some scattered funds and some little insurance money. Some hearts of stone have since dared to doubt of these facts, or rejoice at my losses. Yes, I have found men vile enough to laugh without shame at my misfortunes instead of condoling with me. But I have met also with friends who have deplored my loss and helped me in need." It was after this shipwreck that his wife deserted him, preferring a comedian to a madman, and taking with her his only daughter, Emily, who became a singer in a Sicilian opera.

I shall pass rapidly over Rafinesque's career until his settlement in Kentucky. He travelled widely in America-in the summer always on foot. "Horses were offered me," he said, "but I never liked riding them, and dismounting for every flower. Horses do not suit botanists." He now came westward, following the course of the Ohio, and exploring for the first time the botany of the country. He came to Indiana, and for a short time was associated with the community then lately established by Owen and Maclure at New Harmony, on the Wabash. Though the New Harmony experiment was a failure, as all communities must be in which the drone and the worker alike have access to the honey cells, yet the debt due it from American science is very great. Although far in the backwoods, and in the long-notorious county of Posey, New Harmony was for a time fairly to be called the centre of American science; and even after half a century has gone by, its rolls bear few names brighter than those of Thomas Say, David Dale Owen, and Charles Alexander Lesueur.

Rafinesque soon left New Harmony, and became Professor of Natural History and the Modern Languages in Transylvania University at Lexington, Kentucky. He was, I believe, the first teacher of natural history in the West, and his experiences were those of most pioneers. They would not give him at Lexington the degree of Master of Arts, he says, "because I had not studied Greek in a college, although I knew more lan- 
guages than all the American colleges united. But it was granted at last; but that of Doctor of Medicine was not granted, because I would not superintend anatomical dissections." He continues :

"Mr. Holley, the president of the university, despised and hated the natural sciences, and wished to drive me out altogether. To evince his hatred against science and its discoveries he had broken open my rooms in my absence, given one to the students, and thrown all my effects, books, and collections into the other. He had deprived me of my situation as librarian, and tried to turn me out of the college. I took lodgings in town, and carried there all my effects, leaving the college with curses both on it and Holley, which reached them both soon after; for Holley died of yellow fever in New Orleans, and the college burned with all its contents."

In one of his summer trips Rafinesque became acquainted with Audubon, who was then painting birds and keeping a little "grocery store" down the river, at Henderson, Kentucky. Rafinesque reached Henderson in a boat, carrying on his back a bundle of plants which resembled dried clover. He accidentally met Audubon, and asked him where the naturalist lived. The ornithologist introduced himself, and Rafinesque handed him a letter from a friend in the East, commending him to Audubon as an "odd fish, which might not be described in the published treatises." The story of the interview is thus described by Audubon:

"His attire struck me as exceedingly remarkable. A long, loose coat of yellow nankeen, much the worse for the many rubs it had got in its time, hung about him loosely, like a sack. A waistcoat of the same, with enormous pockets and buttoned up to the chin, reached below over a pair of tight pantaloons, the lower part of which was buttoned down over his ankles. His beard was long, and his lank black hair hung loosely over his shoulders. His forehead was broad and prominent, indicating a mind of strong power. His words impressed an assurance of rigid truth; and as he directed the conversation to the natural sciences, I listened to him with great delight.

" That night, after we were all abed, I heard of a sudden a great uproar in the naturalist's room. I got up and opened the door, when to my astonishment I saw my guest running naked, holding the handle of my favourite Cremona, the body 
of which had been battered to pieces in attempting to kill the bats which had entered the open window! I stood amazed; but he continued jumping and running around and around until he was fairly exhausted, when he begged me to procure one of the animals for him, as he felt convinced that they belonged to a new species. Although I was convinced of the contrary, I took up the bow of my demolished violin, and, giving a smart tip to each bat as it came up, we soon had specimens enough."

A part of the story of this visit, which Audubon does not tell, may be briefly related here: Audubon was a great artist, and his paintings of birds and flowers excited the wonder and admiration of Rafinesque, as they have that of generations since his time. But Audubon was something of a wag withal, and some spirit of mischief led him to revenge the loss of his violin on the too ready credulity of his guest. He showed him gravely some ten grotesque drawings of impossible fishes which he had observed "down the river," with notes on their habits, and a list of the names by which they were known by the French and English settlers. These Rafinesque duly copied into his notebooks, and later he published descriptions of them as representatives of new genera, such as Pogostoma, Aplocentrus, Litholepis, Pilodictis, Pomacampis, and the like.

These singular genera, so like and yet so unlike anything yet known, have been a standing puzzle to students of fishes. Various attempts at identification of them have been made, but in no case have satisfactory results been reached. Many of the hard things which have been said of Rafinesque's work rest on these unlucky genera,* "communicated to me by Mr. Audubon." The true story of this practical joke was told me by the venerable Dr. Kirtland, who in turn received it from Dr. Bachman, the brother-in-law and scientific associate of Audubon. In the private notebooks of Rafinesque I have since found his copies of these drawings, and a glance at these is sufficient to show the extent to which science through him has been victimized.

* I am informed by Dr. J. A. Allen that there are also some unidentified genera of herons, similarly described by Rafinesque from drawings kindly shown him by Mr. Audubon. Apparently these also date from the same unlucky practical joke. 
About this time Rafinesque turned his mind again toward invention. He invented the present arrangement of coupon bonds, or, as he called it, "the divitial invention." Savings banks were projected by him, as well as "steam ploughs," "aquatic railroads," "artificial leather," fireproof houses, and other contrivances which he was unable to perfect. He took much delight in the study of the customs and languages of the Indians. In so doing, if the stories are true, he became, in a way, associated with the origin of Mormonism; for it is said that his theory that the Indians came from Asia by way of Siberia, and were perhaps the descendants of the ten lost tribes of Israel, gave the first suggestion to Solomon Spaulding for his book of the prophet Mormon. In any case, whether this be true or not, it is certain that Rafinesque is still cited as high authority by the Latter-Day Saints when the genuineness of the Book of Mormon is questioned.

Rafinesque now returned to Philadelphia, and published The Atlantic Journal and Friend of Knowledge, Annals of Nature, and other serials, of which he was editor, publisher, and usually sole contributor. After a time he became sole subscriber also-a condition of affairs which greatly exasperated him against the Americans and their want of appreciation of science. He published several historical treatises, and contemplated a Complete History of the Globe, with all its contents. An elaborate poem of his, dreary enough, is entitled The World; or, Instability. He made many enemies among the American botanists of his time by his overbearing ways, his scorn of their customs and traditions, and especially by his advocacy of crude and undigested though necessary reforms, so that at last most of them decided to ignore his very existence. In the words of Dr. Baldwin, "these botanists possessed independence enough to reject the wild effusions of a literary madman." In those days, in matters of classification, the rule of Linnæus was supreme, and any effort to recast his artificial groupings was looked at as heretical beyond all toleration. The attempt at a natural classification of plants, which has made the fame of Jussieu, had the full sympathy of Rafinesque; but to his American contemporaries such work could lead only to confusion. Then, again, in some few of its phases, Rafinesque anticipated the modern doctrine of the origin of species. That the related species of 
such genera as Rosa, Quercus, and Trifolium have had a common origin-a view the correctness of which no well-informed botanist of our day can possibly doubt-Rafinesque then maintained against the combined indignation and disgust of all his fellow-workers. "New species and new genera," he said, "are continually produced by derivation from existing forms." His writings on these subjects read better to-day than when, fifty years ago, they were sharply reviewed by one of our then young and promising botanists, Dr. Asa Gray.

But the botanists had good reason to complain of the application of Rafinesque's theories of evolution. To him the production of a new species was a rapid process-a hundred years was time enough-and when he saw tendency in diverging varieties toward the formation of new species, he was eager to anticipate Nature (and his fellow-botanists as well), and give it a new name. He became a monomaniac on the subject of new species. He was uncontrolled in this matter by the influence of other writers-that incredulous conservatism as to another's discoveries which furnishes a salutary balance to enthusiastic workers. Before his death so much had he seen, and so little had he compared, that he had described certainly twice as many fishes, and probably nearly twice as many plants and shells, as really existed in the regions over which he had travelled. He once sent for publication a paper seriously describing, in regular natural history style, twelve new species of thunder and lightning which he had observed near the Falls of the Ohio.

Then, too, Rafinesque studied in the field, collecting and observing in the summer, comparing and writing in the winter. When one is chasing a frog in a canebrake, or climbing a cliff in search of a rare flower, he can not have a library and a museum at his back. The exact work of our modern museums and laboratories was almost unknown in his day. Science cares little for information which is not absolutely exact. Then, again, he depended too much on his memory for facts and details; and, as Prof. Agassiz used to say, "the memory must not be kept too full, or it will spill over." It is, moreover, true that Rafinesque was very severe on other botanists, who repaid his scorn with generous interest. One example will serve, as told by Dr. Meehan. An interesting plant was found on the Wissahickon, near Philadelphia. Dr. Kuhn, a former 
pupil of Linnæus, was giving botanical lectures there. $\mathrm{He}$ sent the plant to his master, who named it Kuhnia. Rafinesque made this comment: "Kuhn was but a poor botanist, and hardly deserved to have so fine a plant named for him. He did not find the plant, but only took it to Linnæus, who was flattered because his students gave the first botanical lectures in America ; but Kuhn has written nothing."

Thus it came about that the name and work of Rafinesque fell into utter neglect. His writings, scattered here and there in small pamphlets, cheap editions published at his own expense, had been sold as paper-rags, or used to kindle fires for those to whom they were sent, and late authors could not find them. His Ichthyologia Ohiensis, once sold for a dollar, is now quoted at fifty dollars, and although it has been my fortune to be reviewer and re-editor of this work and to show its claims for a place in modern science, I have seen but two copies of it. The restoration of Rafinesque to his proper place in ichthyology is a thankless but necessary piece of work which some fourteen years ago fell to my lot. It has been the fortune of Prof. E. L. Greene, of the University of California, to fix Rafinesque's place in American botany. In the absence of means to form a just opinion of his work, it became the habit to pass him by with a sneer, as the "inspired idiot, ... . whose fertile imagination has peopled the waters of the Ohio." Until lately, only Prof. Agassiz * has said a word in mitigation of the harsh verdict passed on Rafinesque by his fellow-workers and their immediate successors. Agassiz says, very justly:

"I am satisfied that Rafinesque was a better man than he appeared. His misfortune was his prurient desire for novelties, and his rashness in publishing them. . . Tracing his course as a naturalist during his residence in this country, it is plain that he alarmed those with whom he had intercourse by his innovations, and that they preferred to lean upon the authority of the great naturalist of the age (Cuvier), who, however, knew little of the special history of the country, rather than to trust a somewhat hasty man who was living among them, and who

* So early as 1844 Prof. Agassiz wrote to Charles Lucien Bonaparte: “I think that there is a justice due Rafinesque. However poor his descriptions, he first recognised the necessity of multiplying genera in ichthyology, and this at a time when the thing was far more difficult than now." 
had collected a vast amount of information from all parts of the States upon a variety of subjects then entirely new to science." *

Prof. Herbert E. Copeland has said :

"To many of our untiring naturalists, who sixty years ago accepted the perils and privations of the far West to collect and describe its animals and plants, we have given the only reward they sought-a grateful remembrance of their work. Audubon died full of riches and honour, with the knowledge that his memory would be cherished as long as birds should sing. Wilson is the 'father of American ornithology,' and his mistakes and faults are forgotten in our admiration of his great achievements. Lesueur is remembered as the "first to explore, the ichthyology of the great American lakes.' Labouring with these, and greatest of them all in respect to the extent and range of his accomplishments, is one whose name has been nearly forgotten, and who is oftenest mentioned in the field of his best labours with pity and contempt."

Dr. Goode, still later, has said: "Perhaps the time has not yet come when full justice can be done to the memory of Constantine Rafinesque, but his name seems yearly to grow more prominent in the history of American zoölogy. He was in many respects the most gifted man who ever stood in our ranks. When in his prime, he far surpassed his American contemporaries in versatility and comprehensiveness of grasp. He lived a century too soon. His spirit was that of the present period. In the latter years of his life, soured by disappointments, he seemed to become unsettled in his mind; but as I read the story of his life his eccentricities seem to me the outcome of a boundless enthusiasm for the study of Nature."

"I have often been discouraged," Rafinesque says, "but I have never despaired long. I have lived to serve mankind, but have often met with ungrateful returns. I have tried to enlarge the limits of knowledge, but have often met with jealous rivals instead of friends. With a greater fortune, I might have imitated Humboldt or Linnæus."

It is doubtless true that while, as Prof. Agassiz has said, Rafinesque "was a better man than he appeared," and while he was undoubtedly a man of great learning and of greater

* Agassiz, American Journal of Science and Arts, I854, p. 354. 
energy, his work does not deserve a high place in the records of science. And his failure seems due to two things: first, his lack of attention to details, a defect which has vitiated all of his work; and, second, his versatility, which led him to attempt work in every field of learning. As to this, he says himself :*

"It is a positive fact that in knowledge I have been a botanist, naturalist, geologist, geographer, historian, poet, philosopher, philologist, economist, philanthropist; by profession a traveller, merchant, manufacturer, brewer, collector, improver, teacher, surveyor, draughtsman, architect, engineer, pulmist, author, editor, bookseller, librarian, secretary, and I hardly know what I may not become as yet, since, whenever I apply myself to anything which I like, I never fail to succeed, if depending on myself alone, unless impeded or prevented by the lack of means, or the hostility of the foes of mankind."

But a traveller Rafinesque chiefly considered himself; and to him all his pursuits, scientific, linguistic, historical, were but episodes in a life of travel. Two lines of doggerel French were his motto:

\footnotetext{
"Un voyageur des le berceau, Je le serai jusqu'au tombeau."

"A traveller from the cradle, I'm a traveller to the tomb."
}

On the medal granted him by the French Geographical Society is another motto, evidently original with him :

$$
\begin{aligned}
& \text { " De Linné } \\
& \text { Le Génie } \\
& \text { Il a choisé pour guide." } \\
& \text { "The spirit of Linnæus he chose as his guide." }
\end{aligned}
$$

From this medal, which he hoped would remain as the pride of his family and successors, long since turned as old gold into the United States Mint, the only known portrait of Rafinesque has been taken.

Long before the invention of railroads and steamboats he had travelled on foot tens of thousands of miles over most of southern Europe and eastern North America, when eastern North America was as new as Zululand is now. Without money, 
except as he earned it, he had gathered shells and plants and fishes on every shore from the Hellespont to the Wabash.

Concerning one element of Rafinesque's character I am able to find no record. If he ever loved man or woman, except as a possible patron and therefore aid to his schemes of travel, he himself gives no record of it. He speaks kindly of Audubon; but Audubon had furnished him with specimens and paintings of flowers and fishes. He speaks generously of Clifford, at Lexington; but Clifford had given him an asylum when he was turned out of the Transylvania University. No woman is mentioned in his Autobiography except his mother and sister, and these but briefly. His own travels, discoveries, and publications filled his whole mind and soul. Were it not for his will, recently discovered and published by Thomas Meehan, nothing would have been known of his family or children. From this will we learn that his son, Charles Linnæus Rafinesque, died in $18 \mathrm{I}_{5}$. His wife, in the same year, married a comedian, who squandered his property, and who was supported by the earnings of the daughter, Emily Rafinesque, who was a singer in the Palermo theatre.

In his will he says, "I leave my immortal soul to the Creator of the Universe, the Supreme Ruler of millions of worlds soaring through space, to be sent to whatever world he may deem fit, according to his wise laws." His body he left to be burned, not to contaminate the earth. "My ashes, if they can be collected," he says, I wish deposited in an urn to be kept with my collections."

His property, consisting of inventions and specimens, was to be divided between his sister, his daughter, and a school for orphan girls on the plan of Girard College.

These plans were not carried out, for his sister died before him; his daughter seems to have entered no claim; the inventory of the sales of his herbarium and books as waste paper, the sale by auction of his black bottles, boxes, and demijohns, clothing, gold medal, and all, shows that after all was paid and the executor and cataloguer had received their percentage, Rafinesque was still indebted to the world in the sum of thirteen dollars and forty-three cents.

Rafinesque died in Philadelphia, in $\mathbf{1 8 4 0}$, at the age of fiftysix. He had lived obscurely in miserable lodgings; for his dried plants, and his books, published at his own expense, 
brought him but a scanty income. His scientific reputation had not reached his fellow-lodgers, and his landlord thought him "a crazy herb doctor." He died alone, and left no visible assets; and his landlord refused to allow his friends-such friends as he had-to enter the house to give him a decent burial. He wished to make good the unpaid rent by selling the body to a medical college. At night, so the story goes, Dr. Bringhurst, who had studied botany with Rafinesque, got a few friends together, broke into the garret in which the body had been locked, and let it down out of the window by a rope. Then they carried it away and buried it in a little churchyard outside the city limits. This place has lately been identified as Ronaldson's Cemetery, on the corner of Ninth and Catharine Streets. Which was his grave we know not, for in the growth of Philadelphia the whole cemetery has been almost obliterated and forgotten.

American naturalists have greater honour now than fifty years ago. Rafinesque died unnoticed, and was buried only by stealth. A whole nation wept for Agassiz. But a difference was in the men as well as the times. Both were great naturalists and learned men. Both had left high reputations in Europe to cast their lot with America. Agassiz's great heart went out toward every one with whom he came in contact; but Rafinesque loved no man or woman, and died, as he lived, alone. If some one who loved him had followed him to the last, it might have been with Rafinesque as with Albrecht Dürer: " 'Emigravit' is the inscription on the headstone where he lies." But there was no one; and there is neither headstone nor inscription, and we know not even the place where he rests after his long journey.

The last recorded words of Rafinesque were these: "Time renders justice to all alike" ; and to the justice of time we may leave him. 


\section{JAMES POLLARD ESPY.}

$$
\text { I 785-r } 860 \text {. }
$$

Meteorology is one of the youngest of the sciences. Most of what is settled and systematized has been developed within the memory of men who are still living. The contributions of Americans to research in this branch have been among the most important. Of the earlier labours in this field none deserve or have received wider recognition than those of Prof. Espy. He may, indeed, be regarded with justice as the founder of the science as at present cultivated in relation to storm predictions.

James P. Espy was born in Westmoreland County, Pa., May 9, 1785 , and died in Cincinnati, Ohio, January 24, r86o. While he was still an infant his father moved to the Blue Grass region of Kentucky; but, on finding the institution of slavery antagonistic to the principles inherited from his Huguenot ancestry, he removed after a few years to the Miami Valley in Ohio. One of his daughters had in the meantime married a Kentuckian of Mount Sterling, and James, remaining with this sister for the sake of the opportunity, became, at eighteen years of age, a student in Transylvania University, at Lexington. Here he was visited in 1805 by an elder brother, who was engaged in the practice of the law in Pennsylvania, who wrote of him: "I met my brother James, whom I had not seen since he was an infant. I found him at the university, where he had made considerable progress in the dead languages and in general science. He shows an ardent desire for knowledge, and promises to be both intelligent and useful." He was graduated in 1808 , and went to Xenia, Ohio, where he taught school and studied law. Of this part of his career, Mrs. L. M. Morehead, his niece, in her Few Incidents * of his life, says that "his

* A Few Incidents in the Life of Prof. James P. Espy, by his Niece, Mrs. L. M. Morehead, Cincinnati, Robert Clarke \& Co. 


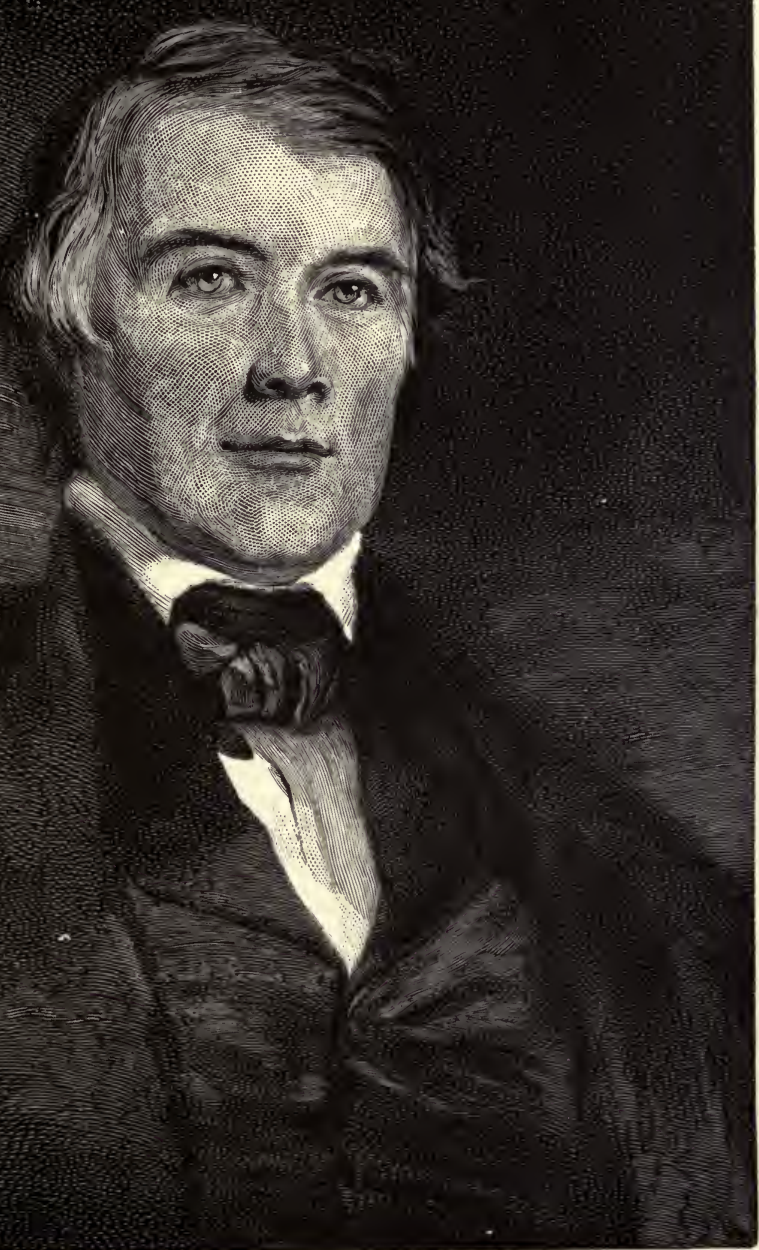

JAMES P. ESPY. 

love for teaching amounted to enthusiasm, and, although he completed his law studies, he finally abandoned the idea of choosing the law as his profession, and determined to follow the bent of his inclination, and become a conscientious instructor of youth." To his latest years " he considered this a noble profession, and even in old age was fond of drawing out young students to talk over their lessons with him, both hearing them and asking them questions." Either before or after this-the authorities differ-he filled creditably and satisfactorily the position of principal of the academy at Cumberland, Md., where he married Miss Margaret Pollard, who afterward gave him her full sympathy and encouragement in his meteorological researches. She was physically delicate and, although younger than her husband, died ten years before him. They had no children.

In I8I $7 \mathrm{Mr}$. Espy became a teacher in the classical department of the Franklin Institute, a position in which, according to Prof. Dallas Bache, he became known as "one of the best classical and mathematical instructors in Philadelphia, which at that day numbered Dr. Wylie, Mr. Sanderson, and Mr. Crawford among its teachers. Impressed by the researches and writings of Dalton and of Daniell on meteorology," Prof. Bache continued, in a eulogy before the Regents of the Smithsonian Institution, "Mr. Espy began to observe the phenomena and then to experiment on the facts which form the groundwork of the science. As he observed, experimented, and studied, his enthusiasm grew, and his desire to devote himself exclusively to the increase and diffusion of the science finally became so strong that he determined to give up his school, and to rely for the means of prosecuting his researches upon his slender savings and the success of his lectures, probably the most original which have ever been delivered on this subject. His first course was given before the Franklin Institute of Pennsylvania, of which he had long been an active member, and where he met kindred spirits, ready to discuss the principles or the applications of science, and prepared to extend their views over the whole horizon of physical and mechanical research. As chairman of the Committee on Meteorology, Mr. Espy had a large share in the organization of the complete system of meteorological observations carried on by the Institute under the auspices and within the limits of the 
State of Pennsylvania." Mrs. Morehead quotes from the account of a friend who visited him in Philadelphia a description of Prof. Espy's method of pursuing his atmospheric calculations, which necessarily had to be carried on out of doors. The high fence inclosing the small yard was of smooth plank, painted white, while the space inclosed was filled with vessels of water and numerous thermometers for determining the dewpoint. The white fence, when last seen by the narrator, was so covered with figures and calculations that not a spot remained for another sum or column. Prof. Espy's theory of storms was first developed in successive memoirs in the Journal of the Franklin Institute, containing discussions of the changes of temperature, pressure, and moisture of the air, and of the direction and force of the wind, and other phenomena attending remarkable storms in the United States and on the ocean adjacent to the Atlantic and Gulf coast. "Assuming great simplicity," says Prof. Bache, "as it was developed, and founded on the established laws of physics, and upon ingenious and well. directed experiments, this theory drew general attention to itself, especially in the United States. A memoir submitted anonymously to the American Philosophical Society of Philadelphia gained for Mr. Espy the award of the Magellanic premium in the year 1836 , after a discussion remarkable for ingenuity and closeness in its progress, and for the almost perfect unanimity of its result."

In 1840 Prof. Espy, by invitation, visited England for the purpose of explaining his theory of storms before the British Association. He presented it, in an elaborate paper, in September, I840, Prof. Forbes being the presiding officer of the meeting, after which it was subjected to a lively discussion, in which some of the most eminent British scientific men of the day took part, some sustaining it and some presenting objections to it. He afterward visited Paris, and presented a communication to the Academy of Sciences. The committee to whom the communication was referred, consisting of MM. Arago, Pouillet, and Babinet, at the conclusion of their report, admitted that the memoir "contains a great number of wellobserved and well-described facts. His theory in the present state of science alone accounts for the phenomena, and when completed, as Mr. Espy intends, by the study of the action of electricity when it intervenes, will leave nothing to be desired. 
In a word, for physical geography, agriculture, navigation, and meteorology, it gives us new explanations, indications useful for ulterior researches, and redresses many accredited errors. The committee expresses, then, the wish that $\mathrm{Mr}$. Espy may be placed by the Government of the United States in a position to continue his important investigations, and to complete his theory, already so remarkable, by means of all the observations and all the experiments which the deductions even of his theory may suggest to him in a vast country, where enlightened men are not wanting to science, and which is, besides, the home of those fearful storms. The work of Mr. Espy causes us to feel the necessity of undertaking a retrospective examination of the numerous documents already collected in Europe, to arrange them, and draw from them deductions which they can furnish, and more especially at the present period, when the diluvial rains which have ravaged the southeast of France have directed attention to all the possible causes of similar phenomena. Consequently, the committee proposes to the Academy to give its approbation to the labours of Mr. Espy, and to solicit him to continue his researches, and especially to try to ascertain the influence which electricity exerts in these great phenomena, of which a complete theory will be one of the most precious acquisitions of modern science."

This report was incorporated in full in the introduction to The Philosophy of Storms-" not merely," as the author says with characteristic independence of opinion, "for the purpose of showing the reader that I have the highest authority on my side-for I do not submit to authority myself_-but to exhibit a beautiful analysis of my theory by three of the most distinguished philosophers in Europe. As a matter of authority, however, I should be justified in bringing forward the report to rebut authority. It had been sneeringly said before a large audience, by a distinguished professor, that I had failed to convince men of science of the truth of my theory, and that I had appealed to the people, who are incapable of judging. It became, therefore, necessary to obtain authority against authority."

The origin of the studies upon which the theory of storms is based is traced in the opening paragraph of the Philosophy to the result described by Dalton, that the quantity of vapour 
in weight, existing at any time in a given place, could be determined by means of a thermometer and a tumbler of water cold enough to condense on its outside a portion of the vapour in the air. "It occurred to me at once," Prof. Espy says, "that this was the lever with which the meteorologist was to move the world. I immediately commenced the study and examination of atmospheric phenomena, determined to discover, if possible, what connection there is between rain and the quantity of vapour in the atmosphere." Prof. Espy prefaced his paper in the British Association by saying that he had found, by examining simultaneous observations in the middle of storms and all round their borders, that the wind blows inward on all sides of a storm toward its central parts; toward a point if the storm is round, and toward a line if the storm is oblong, extending through its longest diameter. The theory is, in brief, that every atmospheric disturbance begins with the ascension of air that has been rarefied by heat. The rising mass dilates, and, as its temperature falls, precipitates vapour in the form of clouds. Owing to the liberation of the latent heat, the dilatation continues with the rising till the moisture of the air forming the upward current is practically exhausted. The heavier air flows in beneath, and, finding a diminished pressure above it, rushes upward with constantly increasing violence. The great quantity of aqueous vapour precipitated during this atmospheric disturbance gives rise to heavy rains. Much of this theory still holds good; but it has been found that the motion of the wind in storms is rotary.

Besides his explanation and proofs of this theory, Prof. Espy presented to the British Association a paper on Four Fluctuations of the Barometer. The theory was more fully elaborated in The Philosophy of Storms, which was published in a large octavo volume by Little, Brown \& Co., Boston, in I84I, and was re-enforced by detailed descriptions of a large number of storms occurring on the land and the ocean, the course of which the author had been able to follow and study with considerable accuracy. It also contained his answers to the criticisms which had been made against his theory in the British Association and elsewhere by prominent men of science and rival meteorologists. In it, furthermore, he defended his theory that storms could be produced by large fires making local disturbances in the equilibrium of temperature, whence 
follow ascending currents, cloud, and rain. He spent much effort in trying to secure an experimental demonstration of this scheme, and made unsuccessful petitions to Congress and the Legislature of Pennsylvania for appropriations to enable him to carry them out on an adequate scale. The scheme was not regarded as practicable, and he became the object of some ridicule for his enthusiasm-to which he replied in his book with the self-possession of a man who believes to the full in his purposes: "Gentlemen have made their puns on this project, and had their laugh: and I am sorry to see, by letters which I have received, that my friends and relations at a distance are much troubled by these innocent laughs; but let them be consoled: I have laughed too, well knowing that those who laughed the most heartily would be most willing to encourage the experiment as soon as they discovered they had nothing to laugh at. As a proof that I was right in this anticipation, I may be permitted to say that I have lately received a letter from a highly distinguished member of the American Legislature,* who laughed as heartily as any one when my petition was presented them, containing many kind expressions, and promising me, by way of amends for his levity, to avail himself of the earliest opportunity of being better informed on the subject of my new philosophy. Such conduct as this is all I want; I fear not the strictest scrutiny." The same confident spirit is exhibited in his letter to his superior in the War Department, suggesting a second year of employment in the official study of storms, and which is given in facsimile on the following page.

In 1843 Prof. Espy was given a position in the War Department, where he could pursue his investigations in atmospheric currents and disturbances, and receive reports from distant points of observation. He instituted a service of daily weather reports, out of which our present Signal-Service system has grown; and, on the basis of this enterprise, as Mrs. Morehead relates in her book, Prof. Henry once remarked to her that there was no question in his mind that "Prof. Espy should be regarded as the father of the present Signal Service of the United States, his Theory of Storms having led the way to its establishment and present success." Prof. Henry added that 
202

PIONEERS OF SCIENCE IN AMERICA.

the charts now used in the service were identical (with some modifications) with those that the "Old Storm King" constructed for use in the Meteorological Bureau of the War Department

washington City Sept 10.

Dear Si:

I was placed in your Bureau, at a time when my discoveries in Meteorology were, by a large majority of the people of the Unites states, supposed to be cither humbug, or the vain imaginings of a wite enthusiast.

I have re as on however to think that a guat chang. has been wrought in nexis minds on this subject since that time. Certain is is, that the great body of facts collates in my Fist Before to you, is calculates to produce a. Change, as soon as that Report becomes genes. ally known." It is not for me to say that all the facts yet collected; and you know whoa at a sn ass we have go uniformly to frown my theory; but I will say. That the mode of investigating, which I have adopted since I have been in your Duncan, is the only one which will ever de monstiate any theory to be true.

If you agree with mme that the sulyict in which I am engage is of high in test an utility, you will 1 as I ruppuetfully ask you to do/ mate an estimate in your annual. Refer for the con inveraner of my labor. I sen. ain very us pe tidally yours. Thomas Law son M.D. surgeon Genera H.S. A.

Lamerosespy

when he was at its head. A similar acknowledgment was made by General Myers. Prof. Espy was for several years a regent of the Smithsonian Institution, and was brought into close relations and friendship with Prof. Henry. On the occasion of 
his death, Prof. Bache pronounced his eulogy in the Board of Regents, and the regents passed memorial resolutions, one of which describes him as "one of the most useful and zealous of the meteorologists co-operating with the Institution, whose labours in both the increase and diffusion of knowledge of meteorology have merited the highest honours of science at home, and have added to the reputation of our country abroad."

Prof. Espy delivered many lectures in the towns, cities, and villages of the United States, explaining his theories and the results of his observations. These efforts were very successful, and, according to Prof. Bache, by their originality attracted more attention to his views than could have been obtained in any other way. "He soon showed remarkable power in explaining his ideas. His simplicity and clearness enabled his hearers to follow him without too great effort, and the earnestness with which he expressed his convictions carried them away in favour of his theory." He was also remarkably successful in gaining the sympathy of public men, and, through them, in obtaining from the Government continued opportunities for study, research, and the comparison of observations. His reports to the Surgeon-General of the Army, to Congress, and to the Secretary of the Navy, are mentioned as among his latest efforts in this direction.

Prof. Espy is charged with the one scientific defect that, with his deep conviction of the truth of his theory, and the enthusiasm it fed in him, he could not pass beyond a certain point in its development, and for the same reasons his deductions were often unsafe. He was not prone to examine and re-examine premises and conclusions, but considered what had once been passed upon by his judgment as finally settled. "Hence his views did not make that impression upon cooler temperaments among men of science to which they were entitled, obtaining more credit among scholars and men of general reading in our country than among scientific men, and making but little progress abroad." But, toward the close of his life, he was-induced, by the Secretary of the Smithsonian Institution, to re-examine the various parts of his theories, and to insert in his Fourth Report, while it was going through the press, an account of his most mature views.

Prof. Espy thought much on subjects of mental and moral 
philosophy, and after his death his relatives in Cincinnati published his short Treatise on the Will, which is described as embodying some original and striking ideas.

Personally, according to Prof. Bache, "Prof. Espy was eminently social, full of bonhomie and enthusiasm, easily kindling into a glow by social mental action. In the meetings and free discussions of a club formed for promoting research, and especially for scrutinizing the labours of its members, and of which Sears C. Walker, Prof. Henry, Henry D. Rogers, and myself were members, Mr. Espy found the mental stimulus that he needed, and the criticism which he courted, the best aids and checks to his observations, speculations, and experiments. But there was one person who had more influence upon him than all others besides, stimulating him to progress, and urging him forward in each step with a zeal which never flaggedthis was his wife." Mrs. Morehead says that "he never seemed impatient or concerned at the slow recognition of his discoveries as means of practical use in commerce or other national needs. He would say, 'I leave all this to the future, sure that its adaptation to the uses of life must one day be seen and acknowledged.'" 



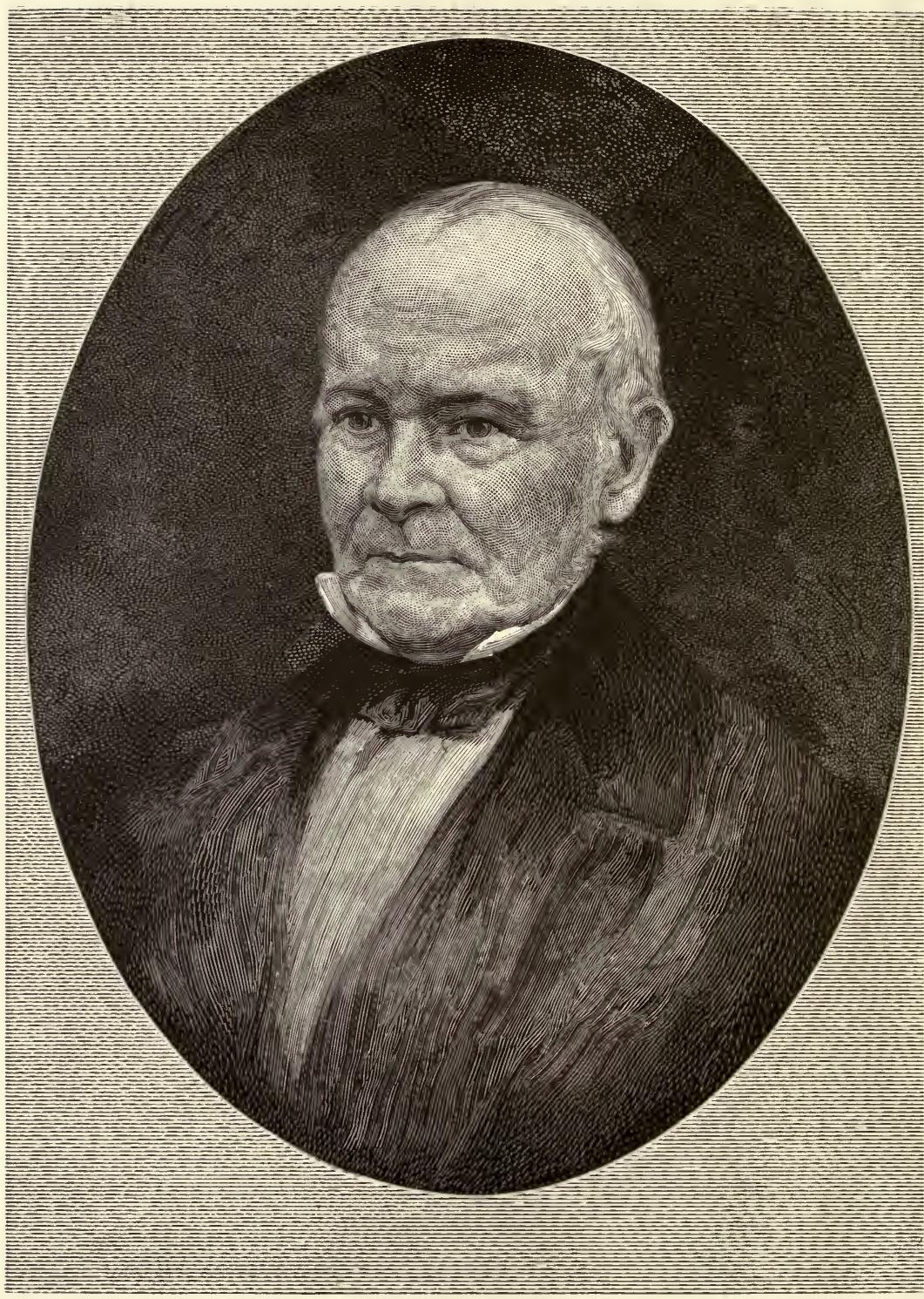

THOMAS NUTTALL. 


\section{THOMAS NUTTALL.}

$$
\text { I 786-I } 859 \text {. }
$$

IT has often happened that a young man who has begun life as a printer has afterward attained to distinction in some more intellectual pursuit. So it was with Benjamin Franklin, and so it was with him whose story is now to be told. Whether this is due to the information which the young printer obtains from the matter constantly passing through his hands, or whether it is because the most intellectual of the young men who learn a mechanical trade take to printing, it would be difficult to say. The fact only need be noted here.

Thomas Nuttall was born in 1786 , in the market town of Settle, in the West Riding of Yorkshire, England. His parents were probably in humble circumstances, for at an early age he was apprenticed to the printer's trade, either in his native town or in Liverpool. In the latter place he had an uncle engaged in this business, for whom he worked as a journeyman several years; then, having had a disagreement with him, young Nuttall went to seek employment in London. He was not fortunate in the metropolis, and sometimes went to bed without knowing where he would get his breakfast the next morning.

When twenty-two years of age he came to America, landing in Philadelphia. He must have devoted a large part of his spare moments to study during his early life, for he has been described on his arrival in this country as a well-informed young man, knowing the history of his country and somewhat familiar with some branches of natural history and even with Latin and Greek. A testimony to his early studious habits came to notice sixteen years later. It is thus recorded in the biographical notice of Nuttall, read by Elias Durand before the American Philosophical Society, which has been taken as the basis of this article: 
"When, in 1824, Prof. Torrey was preparing for publication his Flora of the Northern and Middle States, which he dedicated to his friend Thomas Nuttall, with high compliments, the printer who was engaged upon it asked the professor who was that Nuttall so frequently referred to in his work, adding that he had once worked with a printer of that name, who spent the greatest part of his time reading books, and he would not be surprised if he were the same man. Prcf. Torrey rejoined that 'his surmise was correct; the printer of former times had proved a most arduous labourer in the field of science, and was now a distinguished botanist and an officer of one of the first scientific institutions of the country." "

That Nuttall knew nothing of botany when he landed in the United States is shown by an anecdote that he used to tell of himself. Taking a walk in the outskirts of Philadelphia the morning after his arrival, he noticed a common greenbrier (Smilax rotundifolia). "Egad!" said he to himself, "there is a passion-flower"; and he plucked some branches of it, which he brought home for inquiry. His fellow-boarders could not satisfy him, but referred him to a certain Prof. Barton, a great botanist, whose residence was near. With his treasured branch in his hand, Nuttall called at once upon Prof. Benjamin S. Barton, who received him courteously and pointed out the difference between the genera Smilax and Passiflora. Then, perceiving the intelligence of the young man, Prof. Barton went on to tell him some of the general principles of botany and how much pleasure could be derived from its pursuit. This conversation made Nuttall a botanist, and Barton became his friend and patron. It was then early spring, and throughout the season of flowers he took frequent rambles over the neighbouring fields, eagerly gathering specimens, which he brought to Barton, studying them with him and preparing them for the herbarium. Soon he began to extend his excursions, going first down into the lower part of the peninsula between the Delaware and Chesapeake Bays, and later to the coasts of Virginia and North Carolina. When occupied with his favourite pursuit, serious discomfort could not distract him. At one time, while collecting in the southern swamps, his face and hands became covered with mosquito bites, so that when he approached a human habitation the people of the house would 
not at first admit him, believing that he had the smallpox, and it was with great difficulty that he convinced them of the contrary.

Returning from this trip, he made the acquaintance of $\mathrm{Mr}$. John Bradbury, a Scotch naturalist, who had come to America to collect objects of natural history in the interior. Nuttall eagerly offered to accompany Bradbury, and his proposition was accepted. Proceeding to St. Louis, they set out from that city on the last day of December, I809, crossed the Kansas and Platte Rivers, passed through the Mandan villages, where Lewis and Clarke had spent the winter of 1804-'05, and ascended the Missouri River still higher, returning after an experience full of the greatest fatigues and dangers. They were pursued and robbed by the Indians, and Bradbury, who was captured by them, only saved himself from being killed by taking his watch to pieces and distributing the works among them. Nuttall, overcome by fatigue and hunger in the wilderness, laid himself down to die, but was found by a friendly Indian, who took him in his canoe down the Missouri to the first settlement of white men. In spite of these misadventures, he was able to bring with him on his return, in the beginning of I8Ir, ample treasures of seeds, plants, minerals, and other natural objects.

For the next eight years he remained in Philadelphia, during the winter months studying the collections made by him in summer excursions to various parts of the country east of the Mississippi, from the Great Lakes tôn Florida. Being absorbed in his studies and naturally reserved, Nuttall's social intercourse was limited. The families of the botanists and horticulturists of the time in Philadelphia-Prof. Barton, Zaccheus Collins, Reuben Haines, McMahon, from whom he named his genus Mahonia, William Bartram, and Colonel Carr-were almost his only acquaintances. To these he made visits, of ten of several days, from time to time. In Colonel Carr's house a room was expressly reserved for him. During this period he prepared also the descriptions for his Genera of the North American Plants. Upon this work, which appeared in 1818 , the reputation of Mr. Nuttall as a botanist principally rests. Prof. Torrey, in the preface to his Flora, declared that it had "contributed more than any other work to the advance of the accurate knowledge of the plants of this country." Nuttall 
turned his early trade to account by setting the type for the greater part of his book.

In I8I 7 Mr. Nuttall, already a Fellow of the Linnæan Society of London, was elected a member of the American Philosophical Society at the same meeting with Say and Schweinitz. He was made a corresponding member of the Academy of Natural Sciences of Philadelphia in the same year, and began to publish essays in the journal of the academy. Among his earliest contributions was a description of Collinsia, a new genus of plants, named in honour of his friend and patron, Z. Collins.

Nuttall had long desired to visit the Arkansas country, and soon after his American Plants was published Messrs. Correa de Serra, Z. Collins, William Maclure, and John Vaughan procured him the means of performing this long journey. Starting from Philadelphia on October 2, r818, he reached the mouth of the Arkansas River about the middle of January and Port Bellepoint on April 24th. Thence he made expeditions in several directions, returning with abundant collections. $\mathrm{He}$ was on one of these trips in the middle of August, when, exhausted by long and difficult marches, made under the rays of a burning sun and in constant dread of the Indians, having suffered from thirst, insufficient food, and exposure to the night dews, he was seized with a violent fever among the Osage tribe. The Indians robbed him of his effects and even threatened his life, but he finally reached the garrison at Bellepoint, where he remained sick until the middle of October. $\mathrm{He}$ made one more trip and then set out for home, reaching New Orleans February 18, r820. He had then in sixteen months made a journey of more than five thousand miles, mainly over a country never visited before by scientific explorers, and still in the undisputed possession of the Indians.

Getting back to Philadelphia early in the spring of 1820 , he immediately set about arranging his Arkansas collections and preparing his Journey into the Interior of Arkansas in 1818 and 1819 , which he published in the following year. In the course of the years 1820 to 1822 he contributed several memoirs to the Journal of the Academy of Natural Science, among them being one On the Serpentine Rocks of Hoboken and the Minerals which they Contain, for he was giving some attention to mineralogy at this time. $\mathrm{He}$ also lectured on botany to classes of young men. His lecturing was not re- 
markable for eloquence, but he always communicated to his pupils something of his own passion for his favourite science.

At the end of $1822 \mathrm{Mr}$. Nuttall was called to Harvard College. The fund of the college for a professorship of natural history not being sufficient to support a professor, he was appointed merely Curator of the Botanic Garden, and but light duties of instruction were assigned to him. In consequence the greater part of his time was devoted to the culture of rare plants and to his own studies, in which mineralogy and ornithology were included. In Cambridge, as in Philadelphia, he led a retired life.

In editing the Letters of Asa Gray Mrs. Gray remarks : "The garden was laid out by Dr. Peck in 1808 , and the house built for him was finished in I8ro. Mr. Nuttall, the botanist and ornithologist, who boarded in it while giving instruction in botany, left some curious traces behind him. He was very shy of intercourse with his fellows, and having for his study the southeast room, and the one above for his bedroom, put in a trapdoor in the floor of an upper connecting closet, and so by a ladder could pass between his rooms without the chance of being met in the passage or on the stairs. A flap hinged and buttoned in the door between the lower closet and the kitchen allowed his meals to be set in on a tray without the chance of his being seen. A window he cut down into an outer door, and with a small gate in the board fence surrounding the garden, of which he alone had the key, he could pass in and out safe from encountering any human being."

Aware that he was doing little for science, Mr. Nuttall became dissatisfied with his position at Cambridge; he used to say that he was only vegetating, like his own plants. Congenial occupation was furnished him for a time by the suggestion of Mr. James Brown, who was probably his only intimate friend in Cambridge, that he write a book on ornithology. He had given more or less attention to this science during almost the whole of his residence in America, and readily adopted the suggestion. He set to work with great zeal, and in $183^{2}$ produced his Manual of the Ornithology of the United States and Canada. It was published in two volumes of about six hundred pages each and illustrated with excellent woodcuts. In the course of his residence at Cambridge he contrib- 
uted papers to the various scientific periodicals of the time, and issued a little book entitled An Introduction to Systematic and Physiological Botany.

About the beginning of $1833 \mathrm{Mr}$. Nuttall went to Philadelphia with a collection of plants gathered by Captain Wyeth during a journey overland to the Pacific Ocean. Captain Wyeth was soon to start on a second expedition, to establish posts for the Columbia Fishing and Trading Company, and Nuttall wished to accompany him. Not being able to obtain a sufficiently long leave of absence from Cambridge, he resigned his position at the college and spent the interval before the departure of the expedition in Philadelphia studying the collection already referred to and his own Arkansas plants.

Mr. Nuttall and Mr. John K. Townsend, a young naturalist sent out jointly by the American Philosophical Society and the Academy of Natural Sciences, joined Captain Wyeth's party at Independence, Mo., from which place the start was made April 28, 1834. The details of the journey are given in Townsend's Narrative of a Journey across the Rocky Mountains to the Columbia River, etc. On September 3 d they came to the Columbia, and, descending it, reached Fort Vancouver. Here the two naturalists remained for the rest of the autumn to explore the surrounding region. Then desiring to pass the winter months where inclemency of the season would not interfere with their pursuits, they took passage on a Boston brig for the Sandwich Islands, where they arrived January 5, 1835 .

Here for the first time Mr. Nuttall enjoyed the beauties of a tropical vegetation. He remained two months collecting plants and seashells on the several islands, and then, separating from his companion, sailed for California. He spent a great part of the spring and summer on the Pacific coast, then returned to the Sandwich Islands, where he embarked on a Boston vessel to come home by way of Cape Horn. It happened to be the ship on which Mr. Dana was serving his "two years before the mast," and the latter relates in his book that when rounding Cape Horn Nuttall's passion for flowers was aroused by the near view of land. He entreated the captain to put him ashore, if only for a few hours, that he might become acquainted with the vegetation of this dreary spot, although the wind was blowing furiously and the ship was surrounded 
with icebergs. When his persistent requests were sternly refused he was much disappointed and displeased, being unable to comprehend such indifference to the cause of science.

He arrived in October, 1835 , and again took up his abode in Philadelphia to work up the rich treasures gathered on his long journey. For several years he and Dr. Pickering worked harmoniously together at the Academy of Natural Sciencesthe former on his own collections, the latter on the Schweinitz herbarium. Two important memoirs based upon the fruits of the trip across the continent were published about 1840 in the Transactions of the American Philosophical Society. Conchology was a new subject of study to Nuttall, and he became much absorbed in it. He did not trouble himself much about his meals when at work, and Dr. Pickering would often return after an hour's absence from the academy hall in the middle of the day and find him stooping over a case of shells in the same place and position as when he left him.

Nuttall was a remarkable looking man. His head was very large, bald, and bore the signs of a vigorous intellect; his forehead was expansive, but his features small, and his gray eyes looked out from under fleshy brows. His complexion was fair, and sometimes very pale from close application to study and lack of exercise. $\mathrm{He}$ was above medium height, his person stout, with a slight stoop, and his walk peculiar and mincing, resembling that of an Indian.

He was naturally shy and reserved, but, if silent and perhaps morose in the presence of those toward whom he felt no attraction, yet with congenial companions he was communicative and agreeable. It will readily be surmised that his devotion to science frequently led him into actions that were strangely at variance with the circumstances of the moment. In one of his solitary digressions in the wilderness he got lost. The party he was with resumed its march, sending out some friendly Indians to find him and bring him to rejoin it. The Indians performed their duty faithfully. Looking upon him, however, as a great medicine man, they were afraid to come close to him, so they surrounded him, keeping at a respectful distance. Nuttall soon became aware that he was watched by savages, and, not knowing whether they were friends or foes, became intensely alarmed. From what he had already ex- 
perienced at their hands he had the utmost horror of Indians. Therefore hiding himself, and taking advantage of every ravine, every tree and bush, he succeeded in regaining the track of the caravan, which he followed for three days without food or sleep, when, to his infinite delight, he overtook it and was relieved from his anxieties.

On another occasion he was rambling in the vicinity of the camp when a band of Indians, apparently hostile, made its appearance. The alarm was immediately given, with orders to prepare for an expected attack. Nuttall was nowhere to be seen, and a friend ran in search of him. It was not long before he perceived the naturalist at some distance, quietly examining a specimen. He hailed him with signs to return quickly. "We are going to have a brush with the Indians," said his friend; "is your gun in good order?" Alas! the gun had been freely used to uproot plants, and was filled with earth to the muzzle. Had Nuttall fired it in this condition it would inevitably have burst in his hands and killed or severely wounded him.

On his journey to the Pacific the caravan separated into two parties to cross the Rocky Mountains by different routes. One of the parties had the good fortune to meet with plenty of buffalo cows, upon whose meat they became fat. The other, to which Nuttall belonged, suffered much from fatigue, and found scarcely anything to eat except a few lean grizzly bears. When the parties reunited, Nuttall had lost so much flesh that his old companions could scarcely recognise him. Upon one of these expressing his surprise at the great change in his appearance, he heaved a sigh of inanition and retorted, "Yes, indeed, you would have been just as thin as myself if, like me, you had lived for two weeks upon old Ephraim (grizzly bear), and on short allowance of that too!"

At Christmas, r84r, Nuttall returned to England, where he resided for the remaining seventeen years of his life. An uncle who had prospered in business, having no family of his own, bequeathed to him an estate called Nutgrove, in the neighbourhood of Liverpool. A condition attached to the bequest was that Nuttall should reside in England at least nine months of the year for the rest of his life. He had been thirty-four years in the United States and become much attached to this country, so that, although he had visited England in I8I I 
and 1822 , returning to reside permanently in the land of his birth seemed to him like going into exile. He therefore hesitated for some time to accept the inheritance, but consideration for his sisters and their families finally induced him to take it. Becoming a British landed proprietor did not make Mr. Nuttall wealthy. The Nutgrove estate was encumbered with annuities, besides which there was a heavy income tax to pay. Dr. Pickering and other American friends who visited him found him living in the fashion of a plain farmer, working and eating with his men like one of them. But his interest in botany was not allowed to die out. $\mathrm{He}$ made use of the opportunity which the possession of ample grounds afforded for the cultivation of rare plants, especially rhododendrons, which his nephew, Mr. Thomas J. Booth, brought him from the mountains of Assam and Butan. Various new species of these were described by him in British scientific journals.

Shortly before leaving the United States Nuttall was induced to write a supplement to Michaux's Sylva in three volumes. In the beautifully written preface to the work his own wanderings are vividly sketched. Owing to various delays the edition was not issued till 1846 .

Nuttall returned only once to America. As he could not be absent more than three months in any one year, he took the last three months of 1847 and the first three of 1848 -not a very desirable season for a botanist's outing. Nevertheless, he managed to do some congenial work. He studied at the Philadelphia Academy the plants brought by Dr. William Gamble from the Rocky Mountains and Upper California, and prepared a paper on them which was published in the journal of the academy.

His death occurred on September ro, 1859 . In his eagerness to open a case of plants received shortly before from $\mathrm{Mr}$. Booth he overstrained himself, and from that time steadily declined until he died. Through his love of Nature, joined with untiring industry and great firmness of purpose, he had raised himself from the condition of an unknown artisan to the foremost rank of American men of science. No student begins upon the study of systematic botany without being struck by the frequency with which his name is met. His friends and colleagues, Profs. Torrey and Gray, have testified to their ap- 
preciation by attaching his name to a beautiful genus of the Rosacee. Elias Durand said of him immediately after his death: "No other explorer of the botany of North America has personally made more discoveries; no writer on American plants, except perhaps Prof. Asa Gray, has described more new genera and species." 



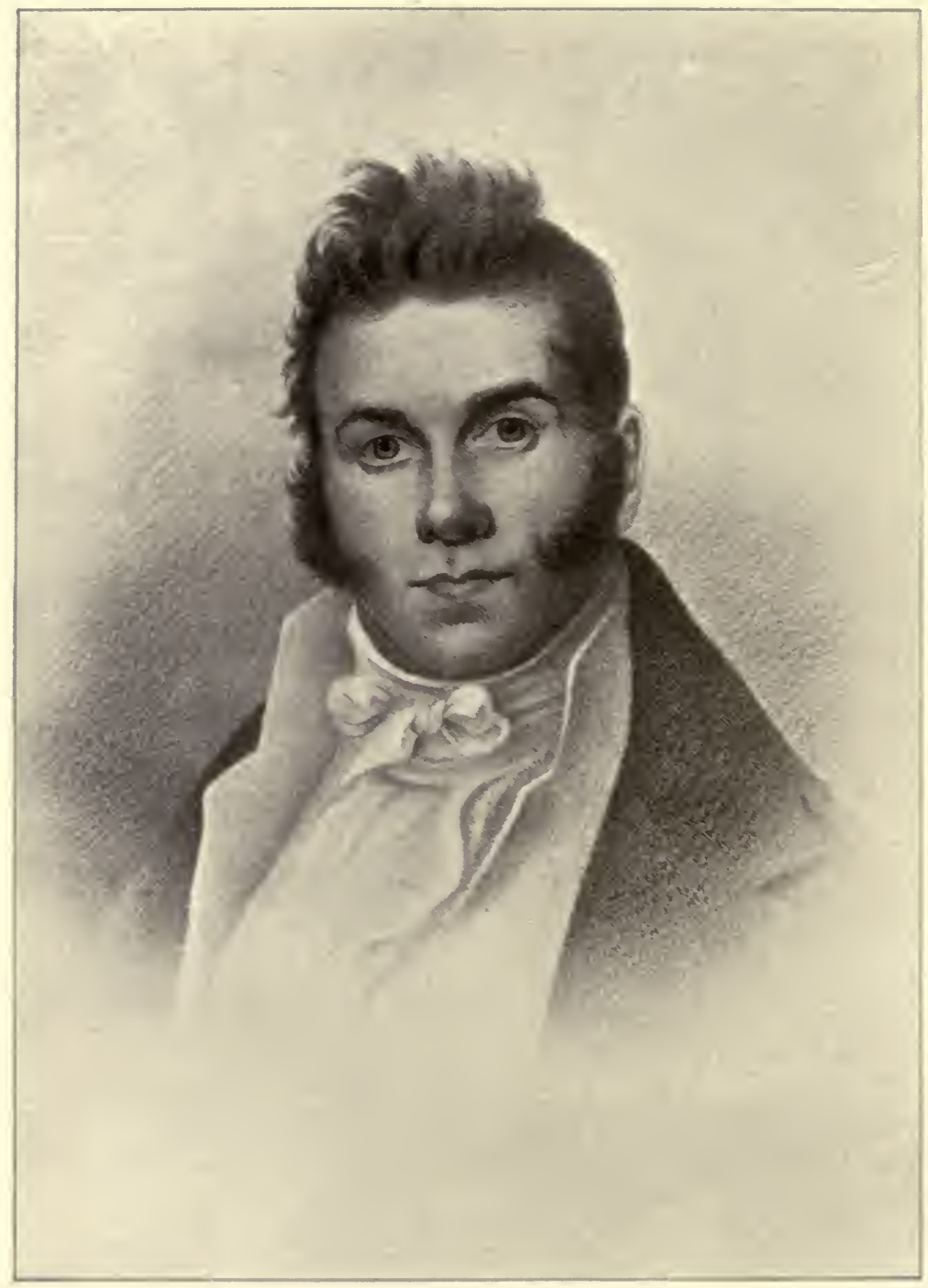

THOMAS SAY 


\title{
THOMAS SAY.
}

\author{
$1787-1834$
}

Agarar we turn toward Pennsylvania and a Quaker family to trace the extraction of an American pioneer of science.

Thomas Say, the father of American entomology, was born in Pbiladelphia, July 27, 178\%. His great-grandfather, William Say, was an early Quaker colonist. His grandfather, who had the same name as the naturalist, followed the calling of an apothecary. He helped to found the Pennsylvania Hospital, and was prominent in other philanthropic undertakings. When a young man he supposed that he visited hearen in a trance. An account of this vision and other matters was published by his son, Dr. Benjamin Say, who succeeded him in the apothecary business. The son was equally public-spirited with his father. In $178 \mathrm{r}$, the year after taking his medical degree, his name is found among those of the "fighting Quakers," who were disowned by the general body of the Friends for their active sympathy with the military operations of the colonists in the Revolution. Dr. Say was a founder of the College of Physicians, of Philadelphia, and its treasurer for eighteen years. He was a contributor to the Pennsylvania Hospital, a founder of the Pennsylvania Prison Society, and for many years President of the Humane Society. He served in Congress from 1808 to $18 \mathrm{r}$.

The naturalist was a son of Dr. Benjamin Say and his wife Anna, daughter of Benjamin Bonsall, of Kingsessing. William Bartram was still living at the famous botanic garden at Kingsessing during Thomas Say's boyhood, and Thomas with other boys was enlisted by a family connection in gathering natural curiosities for Bartram's museum. This pursuit young Say found very congenial.

At an early age the boy was placed in a boarding school under the control of the Friends, but he did not take kindly to 
the instruction there provided, and acquired nothing but a most intense dislike for his teachers and for all ordinary branches of study. We are justified in ascribing this antipathy on his part to the incompetency of the instructors, for in after years Say showed an ability and a desire to learn which only the most repressing circumstances could have checked in his youth. As he had no predilection for any of the learned professions, young Say, after leaving school, was placed for a time behind the counter of his father's shop. After he had acquired some knowledge of the drug business, his father established him in trade with John Speakman. Through Speakman, who was a member of the Academy of Natural Sciences of Philadelphia, Say was induced to join the society, and with this act he began a life of science which has left its impress on every branch of natural history.

The academy was founded early in 1812 , and Say, who was elected to membership in April of that year, was enrolled as one of the founders by a vote of the society. His first attendance at a meeting was on April r6th. What was his surprise, on entering the temple of science, to find the whole collection of specimens consisting of "some half a dozen common insects, a few madrepores and shells, a dried toadfish, and a stuffed monkey!-a display of objects of science calculated rather to excite merriment than to procure respect." In fact, the academy was largely a social organization. This is shown by its first constitution, the preamble of which recites that, " considering that the expense of obtaining and preserving in a suitable place and conveniently for perusal and use the many important periodical publications and scientific papers of the lettered world, with the requisite collections and apparatus for repeating notable experiences and following up in due series experiments for the elucidation of remarkable physical truths, an expense that esocietarily might demand the fortune of a prince, but which in a society where gratuitously many are capable of rendering to the general interest without injury to their professional distribution of time essential services, and many competent to fill indispensable offices without detriment to their private concerns, may be defrayed by a most trifling pecuniary contribution," they had determined to establish this society. With the advent of Say to membership this was soon changed, and the academy took its place among the 
scientific bodies of the world, a place which it has since occupied.

Long before entering the academy, Say had acquired a familiarity with the forms of beetles and butterflies, but without reducing his knowledge to systematic order. Now, on joining a scientific society, he began those investigations on the American fauna which only ceased with his death. In the second year of his membership he gave a series of original lectures on the elements of entomology. His partner, Speakman, fully sympathized with his passion for Nature, and willingly did the labour of both in the shop, so that Say might devote all his time and energies to his favourite studies. However, this comfortable arrangement did not last long.

"Through indorsement for unfortunate friends," says Dr. Ruschenberger, in his Notice of the Academy of Natural Sciences, "the firm and business of Speakman \& Say were at an end; and it is related of these servants of science that they retained scarcely anything for themselves; and that Mr. Say gave to those to whom they had become debtors by indorsement the contents of his pocketbook and even the loose change in his purse. After this he resided in the hall of the academy, where he made his bed under the skeleton of a horse, and fed himself on bread and milk; occasionally he cooked a chop or boiled an egg; but he was wont to regard eating as an inconvenient interruption to scientific pursuits, and often expressed a wish that he had been made with a hole in his side in which he might deposit, from time to time, the quantity of food requisite for his nourishment. He lived in this manner several years, during which time his food did not cost, on an average, more than twelve cents a day." Had he, like Thoreau, given an account of his life at this time, it would have been a highly interesting chapter.

In 18 i 6 he projected a work on American entomology, and in the next year six plates and the accompanying text were printed, but, from a lack of proper pecuniary support, the project for the time fell through, and the work was not properly published until a later date. In I8I 7 William Maclure was elected president of the academy. Through his efforts and those of several other men of influence and property who had joined the society, the Journal of the Academy of Natural Sciences of Philadelphia was started, and Say began his long 
series of contributions to knowledge. No complete list of his papers has been published, but the number aggregates nearly one hundred.

In 1818 Say, in company with William Maclure, George Ord, and Titian R. Peale, visited Georgia and Florida on a collecting expedition, and in the next year Say received an appointment as naturalist on Long's expedition to the Rocky Mountains, with Peale as an assistant. Long's expedition left Pittsburg, Pennsylvania, in May, on a steamboat built for the purpose, and proceeded as far as Council Bluffs, Iowa, where they spent the winter. During the next year they went to the Rocky Mountains, and, returning by another route, broke up at Cape Girardeau, Missouri, in November. Say appears to have been unfortunate on this expedition. At one time he was in charge of a party of five, making a trip on foot, when the packhorse broke loose, and they lost both horse and baggage. Later, in charge of another party, he fell in with a number of Kansas Indians, and again lost horses, baggage, and camp equipments. The narrative of Long's expedition was published in two octavo volumes and folio atlas (Philadelphia, I823), and some of Say's descriptions of the animals and "animal remains found in a concrete state" were given in footnotes scattered through both volumes.

After the disruption of the party, Say, in company with one or two others, went to New Orleans, and soon returned to Philadelphia. His next journey was with Long's second expedition, which explored the sources of the Mississippi River; but, with the exception of this and one or two minor trips, the next few years were spent in Philadelphia. His share in Long's two expeditions included, besides his own specialty, various matters having little or no connection with this. $\mathrm{He}$ was the historian of all classes of facts collected by the detachments under his command; in the second expedition he made the whole of the botanical collection; and, although not a philologist, he obtained the vocabulary of the Killisteno language.

In 1825 Say left his native city, never to return. William Maclure, who was a man of wealth and refinement, but considerably eccentric withal, had an idea that the "community system" was the true way of living, and, unlike some other dreamers, he proceeded to put his plans into execution. $\mathrm{He}$ 
joined Robert Owen in his famous scheme, a large tract of land was purchased at New Harmony, Indiana, and there the community was started. His plan included a college of science in which Say was to be one of the instructors. Numbers of people, influenced by the arguments of the projectors and the glowing accounts of the happy life to be led by a people possessing all things in common and working for a common good, removed themselves and theirs to this modern Utopia. The community, however, did not prosper; internal dissensions, as might have been expected, sprang up, and the aid of the courts was invoked. Maclure, utterly disgusted, went to Mexico, and left Say at New Harmony as his agent, to attend to the settling of the affairs of the community. This was not an agreeable task, but, without other means of support, Say was obliged to accept, and continued in this position until his death. This stay at New Harmony was not a period of scientific idleness on the part of Say, as the numerous contributions which proceeded from his pen attest. Say's maltreatment of his stomach was continued in the West, and doubtless weakened his constitution. In one of Maclure's letters has been found the statement that for a considerable time these two men lived on six cents a day each.

At his death his collections and library came into the possession of the Philadelphia Academy. The insects were submitted to another entomologist for arrangement, but through an unpardonable neglect were allowed to go to complete ruin before their return to the academy, and the types of hundreds of species were thus irrevocably lost. The remainder of his type specimens are as religiously preserved with his own labels as are those of Linné and Fabricius in London, or of Herbst in Berlin. The number of new species which Say described has probably never been exceeded, except in the cases of those two exceedingly careless workers, John Edward Gray and Francis Walker, of the British Museum. There is this in Say's favour, which can not be said of the two just mentioned, that his descriptions are, almost without exception, easily recognised, and almost every form which he described is now well known. Working as he did without books, and without that traditional knowledge which obtains among the Continental workers, it was unavoidable that he should redescribe forms which were known before; but, owing to the clear insight he 
possessed, and the discrimination he exercised in selecting the important features of the form before him, his work has never caused that confusion in synonymy which many in much more favourable circumstances have produced.

Say's work was almost wholly the scientific description of the forms which came under his eye, and there is scarcely anything in his writings concerning the habits of animals, or which appeals in the slightest to the popular taste. Having been intolerant of literary studies in his youth, he never attained to a happy command of language. An extract from his American Entomology will illustrate this: "During the progress of Major Long's expedition up the Missouri, that enterprising and excellent officer intrusted me with the direction of a small party of thirteen persons, destined to explore the country on the south side of that extended river. After encountering many obstacles and privations, which it is unnecessary to enumerate, the party arrived at the village of the Konza Indians, hungry, fatigued, and out of health. Commiserating our situation, these sons of Nature, although suffering under the injustice of white people, received us with their characteristic hospitality, and ameliorated our condition by the luxuries of repletion and repose. Whilst sitting in the large earth-covered dwelling of the principal chief, in presence of several hundred of his people, assembled to view the arms, equipments, and appearance of our party, I enjoyed the additional gratification to see an individual of this fine species of Blaps running toward us from the feet of the crowd. The act of impaling this unlucky fugitive at once conferred upon me the respectful and mystic title of 'medicine man' from the superstitious faith of that simple people."

Say's two principal works, published separately, were his American Entomology in three volumes (Philadelphia, 18241828), with fifty-four coloured plates; and his American Conchology, of which only six parts appeared previous to his death. Two volumes of the former appeared before the author went to New Harmony and a third volume three years after; it was then left uncompleted. The work on entomology was a credit to himself and to the printer, while almost the only merit possessed by the latter work was the fine plates from the pencil of Mrs. Say. Mr. Say's other published papers will be found in the Journal of the Academy of Natural Sciences of Phila- 
delphia, Transactions of the American Philosophical Society, Maclurean Lyceum, Nicholson's Encyclopædia, American Journal of Science and Art, Western Quarterly Reporter, reports of Long's expeditions, and several papers which were published separately at New Harmony. His entomological papers have been collected and reprinted, with annotations, by Dr. John L. Le Conte, in two octavo volumes (New York, r869). He was a foreign member of two English learned societies-the Linnæan and the Zoölogical.

Besides the work which appears in connection with his own name, almost all of the publications of Prince Charles Lucien Bonaparte, while in America, were corrected and arranged for the press by Say. This and other work made such calls upon his time that nearly all of his own work was the product of the midnight hours; and this, in connection with his wicked disregard of the demands of his stomach, so undermined his constitution that, when attacked by a fever in his Western home, he had not the strength to rally, and on October 10, 1834, he passed away.

According to the testimony of all who knew him, Mr. Say was a most pleasant and agreeable companion, a thorough student, and a man of the most unpretentious manner. Always ready to assist a friend, his stores of knowledge were freely opened to those who asked, and information was cheerfully granted to all inquirers. He was tall and spare of habit, somewhat muscular, with a dark complexion, and black hair. Two portraits in oil in the possession of the academy represent a face of more than average attractiveness. While at New Harmony he married Miss Lucy W. Sistare, of New York, who survived him. She was a highly cultured woman and an excellent artist. She had the distinction of being the first woman ever admitted to membership in the Academy of Natural Sciences of Philadelphia, although many have been elected since.

A marked feature of Say's character was his modesty, which was almost excessive. It led to habits of retirement and in some respects unfitted him for the intercourse of general society. His distrust of his own powers was a perpetual barrier to material advancement. He declined a professorship of natural history on the plea that he would not be able to lecture satisfactorily. When Dr. Baldwin, the botanist and 
historian of Major Long's first expedition, died, Say refused the opportunity, which his commander offered him, of continuing the journal of the expedition, alleging that he was incompetent for this responsible employment. His sister and stepmother, who survived him, bore strong testimony to his domestic virtues. The soul of honour himself, he had the strongest aversion to deceit or dishonesty in others, yet he had so little insight into character that the most barefaced impostor would have little difficulty in securing his confidence. 



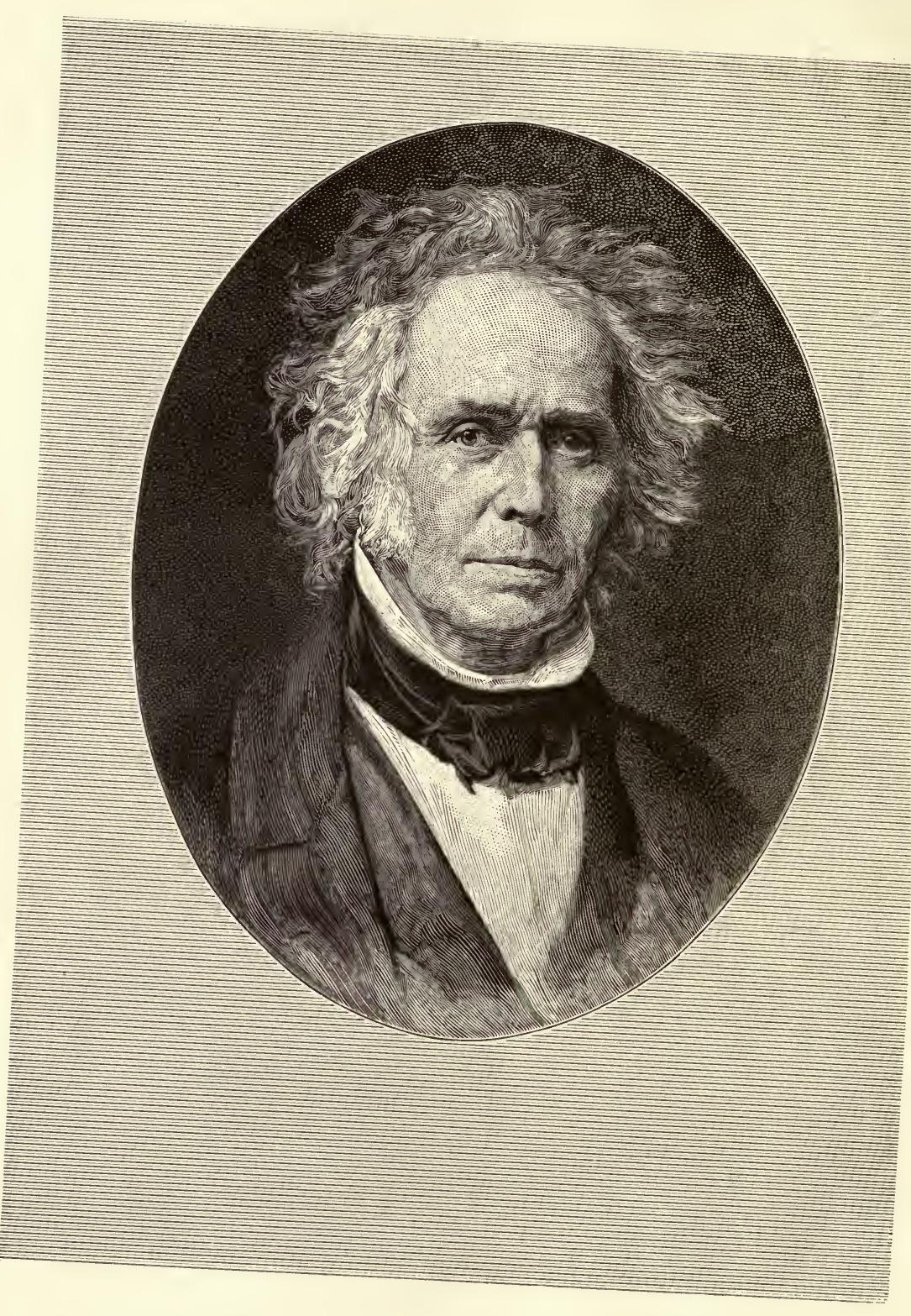

WILLIAM CRANCH BOND. 


\section{WILLIAM CRANCH BOND.}

$$
\text { I 789-r } 859 \text {. }
$$

IN seconding the obituary resolutions of the American Academy of Arts and Sciences on the first director of the Harvard College Observatory, ex-President Quincy used these words: "It is not too much to say that the extent of his knowledge, the winning urbanity of his manners, and his exemplary exactness in life and as an observer, in a great degree effected the attainment of those large means and increased powers which ultimately raised to its present prosperous state the observatory over which through subsequent life he watched, and which he left at death honoured and improved by his labours and genius." Let us briefly trace the career which could deserve such a testimonial.

William Cranch Bond was born in Portland, Me., September 9,1789 , being the youngest son in a family of several children. His parents, Hannah (Cranch) and William Bond, were natives of England and were married there. The Bond family can be traced to the time of William the Conqueror, by whom Brandon Manor is said to have been granted to the contemporary ancestor of that line. William Bond was born in Plymouth, and became a clockmaker and silversmith. Having been induced to emigrate to America, he located at Portland, then called Falmouth, and engaged in cutting ship timber which he sent to England. In a short time he brought over his family, but the timber business not proving successful, he removed to Boston in 1793 and took up again his former occupation. His shop stood on one of the two corners of Milk and Marlboro (now Washington) Streets, the other being occupied by the Old South Church. William C. Bond was then a Boston boy from the age of four years. He had little opportunity to attend school, for the circumstances of the family, as he afterward told Josiah Quincy, "obliged me to become an apprentice to 
my father before I had learned the multiplication table." But, judging from his later achievements, young William must have been the kind of boy that picks up knowledge, so his lack of set schooling was not so great a misfortune as it might seem.

His eldest sister described him as having been, at the age of fourteen, " a slender boy with soft gray eyes and silky brown hair, quick to observe, yet shrinking from notice, and sensitive to excess." She adds, in reference to his early developed tastes: "The first that I remember was his intense anxiety about the expected total eclipse of the sun of June 16, I 806 . He had then no instrument of his own, but watched the event from a house top on Summer Street through a telescope belonging to Mr. Francis Gray, to which somehow he got access. In so doing he injured his eyes, and for a long time was troubled in his vision."

An elder brother writes of him at this early period, " $\mathrm{He}$ was the mildest and best-tempered boy I ever knew, and his remarkable mechanical genius showed itself very early." $\mathrm{He}$ adds that in devising and making bits of apparatus that boys use in their sports, William was chief among his comrades. Before he was fifteen years old he had constructed at odd times a reliable shop chronometer. He had no model to go by, but made it after a description of an instrument used by La Pérouse, the navigator, which he had found in an old French book. Not having a suitable spring to put into it, he contrived to run it by weights. About a year later he made a good working quadrant out of ebony and boxwood, the best materials he had. His son, George Phillips Bond, has thus described this instrument: "It is no rude affair, but every part, especially the graduation, the most difficult of all, shows the neatness, patience, and accuracy of a practised artist. A better witness to the progress he had already made in astronomy could not be desired. It is all that the materials would admit of, and proves that he must have been, even then, irrevocably devoted to astronomy."

About the time he became of age his father took him into partnership, and the clock-making business was expanded to include the rating, repairing, and making of chronometers. The first seagoing chronometer constructed in America was made by him in 1812 . It at once went into service, and satis- 
factorily stood the test of a voyage to and from the East Indies. In 18 ro the Bonds removed their business to Congress Street, and the family took up its abode in Dorchester.

$\mathrm{Mr}$. Bond regarded his watching of the eclipse when he was seventeen years of age as the event that determined his pursuit of astronomy. Certain it is that he never afterward abandoned it. Five years later he came under the notice of older astronomers, and in this way: Prof. John Farrar, of Harvard College, having caught sight of a comet on September 4, I8I I, watched its subsequent progress and published a paper on it in the memoirs of the American Academy. Dr. Nathaniel Bowditch, of Salem, to whom he communicated this discovery, did the same, and the comet was watched also by others. Before presenting his paper to the academy, Prof. Farrar learned that young Bond had seen the comet in the preceding April. $\mathrm{He}$ mentioned this fact in the account of his own observations and added the following notes, with which, he says, Mr. Bond had "obligingly favoured" him:

"I remarked on the 2 Ist of April a faint, whitish light near the constellation Canis Major projecting a tail about one degree in length, and set down its place as follows: right ascension, $106^{\circ}$; declination, $7^{\circ}$ or $8^{\circ}$ south. Its motion and the situation of its tail convinced me that it was a comet. I noticed it several times in May, and supposed that its motion was toward the western part of the constellation Leo."*

These observations on the comet brought the young chronometer-maker the acquaintance of scientific men and facilities for his favourite pursuit. Up to this time his observations had been made with the rudest appliances. The elder brother already quoted says of these early days: "I suppose it would cause the astronomer royal to laugh could he see the first transit instrument used by us at Dorchester-a strip of brass nailed to the east end of the house, with a hole in it to see a fixed star and note its transit; this in 1813 . When we moved into the Hawes house, he procured a good granite block; we dug a deep hole and placed it at the west end of the house,

* Much of the material here employed is derived from a historical sketch of the Harvard College Observatory, prepared by Mr. Daniel W. Baker, which first appeared as a series of newspaper articles, and was afterward reprinted in pamphlet form as one of the official publications of the observatory. 
and got Mr. Alger to cast a stand for the transit instrument, a small one, which I think belonged to Harvard College. From this time he began to live among the stars."

Bond's sister also gives an account of the setting up of the first telescope used by him at Dorchester, and says that through it could be seen the satellites of Jupiter and the rings of Saturn. She adds that in the pursuit of astronomy "he had had no assistance whatever, except from the genial kindness of Hon. Josiah Quincy, who had early recognised the future astronomer in the unpretending boy in the watchmaker's shop on Congress Street, and whose kindness and encouragement never failed throughout the subsequent years."

The obstacles in the path of the young astronomer were now rapidly removed. The leading men of science in Boston and vicinity gave him their aid and counsel. "He has mentioned," writes his son, "the names of Dr. Nathaniel Bowditch, Prof. Farrar, and Tutor Clapp as those from whom he received most encouragement to continue the cultivation of astronomy. Upon his friendly intercourse with the eminent mathematician and astronomer first named he often dwelt with peculiar pleasure and warmth of feeling."

Although instruction in astronomy had been given and astronomical observations had been made by the Professor of Natural Philosophy at Harvard for a century or more, the college had not as yet been able to erect an observatory. In 1805 John Lowell, uncle of the founder of the Lowell Institute, had obtained from Delambre in Paris advice as to a building and its equipment. But nothing further was done at that time. Ten years later the ${ }^{\circ}$ college authorities took up the subject anew and appointed a committee to form a plan for an observatory. Mr. Bond was then about to make a trip to England, and his friends Farrar and Bowditch procured for him a commission as agent of the college to obtain information as to the construction and instrumental equipment of the observatory at Greenwich, and to make such drawings as would be needed in constructing an observatory for the college. He was requested also to obtain from the makers the prices of instruments like the principal ones used at Greenwich. "He performed the service," says the writer of the sketch above referred to, "and reported in detail in the following year. That nothing practical came of it for a quarter of a century was not 
owing to the will but, comparatively speaking, to the poverty of the college.

"This result followed, however, that, upon his return, Mr. Bond constructed the model of an astronomical dome, the operative plan of which was the same as that of the great dome built in 1844 , and which has been in satisfactory use at Cambridge to the present time. The chief peculiarity of its mechanism is in the method of rotation by means of smoothly turned spheres of iron. The dome rests on these at equidistant points, and, being set in motion by suitable gearing, the iron balls sustaining its weight roll along a level, circular track of iron, the circumference of which is equal to that of the dome. The method was unlike that previously in use. It appears to have been original with $\mathrm{Mr}$. Bond, as is perhaps evinced by a remark in his report for 1848 referring to the matter: "If carefully examnied, it will be found that this arrangement is as perfect in theory as it is appropriate and convenient in practice.' Experience has shown that spheres of hard bronze are more serviceable than those of iron, and bronze is now used."

While Mr. Bond was abroad, he married, July 18, I8I9, his cousin, Selina Cranch, of Kingsbridge, in Devonshire. Returning home, he went to live in Dorchester near his father's residence in a house which he bought. On these premises he erected, about 1823 , a small wooden building which he carefully equipped for astronomical observations. This building is the one mentioned in the official reference to the "observatory at Dorchester" found in various publications. Its position, as given by Mr. Bond in 1833 , was $0^{\circ} 3^{\prime} 15^{\prime \prime}$ east of Harvard Hall in Cambridge.

Mr. Bond now advanced rapidly in his favourite pursuit. "As soon as his circumstances permitted," writes his son, "he imported more perfect apparatus from Europe, and continued to add to his collection until it was the best in the country." In his little observatory "no eclipse or occultation escaped him, though occupied in business during the day in Boston." After gathering for several years materials for investigating the comparative rates of chronometers at sea and on shore, he presented a paper to the American Academy in which he effectually disposed of the scientific question involved, so far as it related to the interests of navigation. Mr. G. P. Bond, 
who records this, states that his father investigated also the influence of changes of temperature in the presence of large surfaces of iron upon the performance of chronometers, and, "although the conclusions arrived at were at variance with the opinions of mén high in authority in such matters, they are now known to be correct."

About this time the Navy Department sent out the Wilkes Exploring Expedition, the purpose of which in part was to establish the latitudes and longitudes of uncharted places in distant parts of the world where American commerce was extending, and in part to investigate natural phenomena, including the facts of terrestrial magnetism. In connection with this expedition, Mr. Bond was engaged to make at his private observatory investigations to fix a zero of longitude, whence final reference to Greenwich might be had, and to make a continuous record of magnetic observations at Dorchester for comparison with like records obtained at distant points by the expedition itself. As preliminary to the latter work Mr. Bond tested the magnetic instruments with which the expedition was to be equipped.

Josiah Quincy, who had given Mr. Bond early encouragement, was now President of Harvard College. It occurred to him, to use his own words, "that if Mr. Bond could be induced to transfer his apparatus and residence to Cambridge and pursue his observations there, under the auspices of the university, it would have an important influence in clearing the way for the establishment of an efficient observatory in connection with that seminary."

There was little inducement for Mr. Bond to make the change. His business was prosperous and his home life among friends and neighbours whom he had known for years was very pleasant. The college could offer him no salary-only the use of a house. In his excessive modesty he feared that the arrangement proposed would arouse great expectations that he with the facilities at his command would be unable to satisfy. He made other objections, but all were overcome, and on November 30,1839 , he entered into a contract with the college corporation, agreeing to make the transfer as proposed. A subscription was at once raised for fitting up a dwelling owned by the college to be occupied by Mr. Bond. This building, known as the Dana House, was the first observatory of Har- 
vard College. It still stands upon its original site at the southeast corner of what are distinctively called the college grounds, and is remembered by many Harvard graduates as the residence for a term of years of the Rev. Dr. A. P. Peabody. Its cupola was placed upon it to accommodate one of Mr. Bond's telescopes, and at that time was suitably domed.

Mr. Bond's chief work at Cambridge for the first two or three years was a continuation and extension of his observations for the Navy Department in regard to the earth's mag-

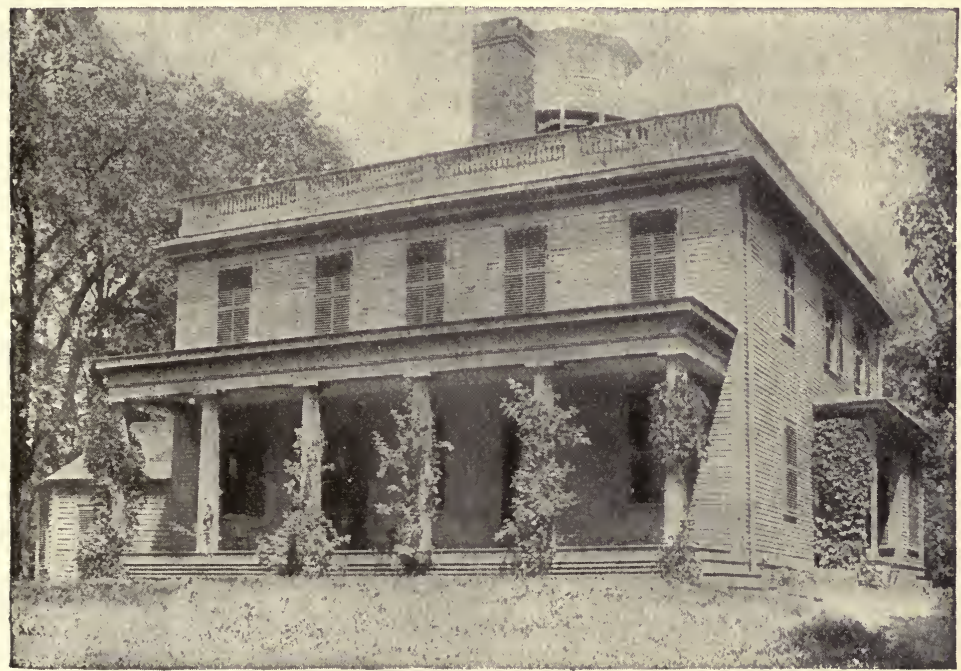

FIg. 4.-The Dana House. First observatory of Harvard College.

netism. He was assisted by his son, W. C. Bond, Jr., whose death in 1842 was regarded as a loss to science. Renewed exertions were now made to secure an adequate observatory and set of instruments. The site was purchased in $184 \mathrm{I}$. A brilliant comet that appeared in 1843 furnished a favourable occasion for raising a subscription. The best telescope that could be produced in Europe, a refractor of fifteen inches aperture, equatorially mounted, was ordered from Merz \& Mahler, of Munich, and ground was broken for a pier for it in the summer of the same year. In September, 1844 , the instruments were removed from the Dana House to the new observatory, and Mr. Bond entered upon a series of observations for determining the latitude and longitude of the new station. 
Mr. Bond's first recorded observation in Cambridge was of date Deceinber 31, 1839, and his appointment as director of the observatory dates from February 12, 1840. During the first eight years of his connection with Harvard College he is to be regarded as a benefactor rather than an employee of the institution. The official report for 1846 states that up to that time the labours of Mr. Bond had been "entirely unrequited, except by the gratification of his love of science and of home," and suggests that this devotion to the institution at Cambridge was the more marked in that during the preceding spring he had declined "the almost unlimited offers made to him by the administration at Washington to induce him to take charge of the observatory there." It is known also that frequent expenditures of his own money were made during this period for current expenses and for things convenient in conducting the observatory-sums small severally, no doubt, but considerable in the total. In 1846 a sum equal to the proposed salaries for the next two years was subscribed by citizens of Boston, and in 1849 the official board was able to report that "through a bequest of one hundred thousand dollars made by Edward Bromfield Phillips they should thereafter be relieved from anxiety as to the payment of salaries and current expenses."

The fifteen-inch equatorial was set up in June, 1847 , and has done splendid service for now nearly half a century. At last the skill of Prof. Bond was furnished with a fitting implement. In reply to an inquiry from Edward Everett, who had become president of the college the year before, Prof. Bond wrote specifying several interesting things that could be seen with it, and ended by saying: "But I must recollect that you require of me only a brief account of our telescope. The objects revealed to us by this excellent instrument are so numerous and interesting that it is difficult to know where to stop." In a subsequent letter he wrote to the president, "You will rejoice with me that the great nebula in Orion has yielded to the powers of our incomparable telescope." Besides this and other nebulæ the planet Saturn was an early subject of investigation. On September 19, r848, Prof. Bond discovered the eighth satellite of this planet, which long remained the only addition to the solar system made on the continent of America.

When Bond was determining the position of the Harvard Observatory, Commodore Owen, of the British navy, was mak- 
ing an official survey in New Brunswick and Nova Scotia. The latter, desiring to use the observatory as his zero point, co-operated with Bond in making a transfer of twelve chronometers to and from Greenwich, England. Afterward other chronometer expeditions were conducted by Bond in co-operation with the United States Coast Survey, the final one being in 1855 . In the summing up of results, seven hundred and twenty-three independent chronometer records were used. The magnitude of this undertaking, as a whole, surpassed anything ever attempted in any other country.

As early as 1848 Prof. Bond mentions, in his report as director of the observatory, some experiments with the daguerreotype and talbotype processes for obtaining pictures of the sun, which, though encouraging, could hardly be called successful. But in his report for $185^{\circ}$ he is able to say: "With the assistance of Mr. J. A. Whipple, daguerreotypist, we have obtained several impressions of the star Vega. We have reason to believe this to be the first successful experiment ever made either in this country or abroad." Some daguerreotypes of the moon and certain stars were exhibited in the World's Fair of the following year at London, and received a council medal.

The inventive skill which won success for Bond as an artisan appears in certain astronomical appliances and methods devised by him. The great telescope is poised thirteen feet above the floor of the observatory's dome. It has a vertical sweep of more than ninety degrees, and can, of course, make a complete revolution about its axis of support. An observer would evidently have to be something of an acrobat to use it successfully, unless a suitable chair could be obtained. There was none in the world that filled all the requirements, so Prof. Bond invented and made one. It is in use unchanged to this day, and by means of its ingeniously combined wheels, cogs, and pulleys the observer can quickly and easily place himself anywhere along the vertical quarter-circle and horizontal fullcircle traversed by the eyepiece of the telescope.

Certain experiments for determining differences of longitude by the aid of the telegraph were undertaken by the Coast Survey in 1848 , Prof. Bond being one of the special assistants whose services were secured for this work. While engaged in these experiments the idea occurred to him, as it had to 


\section{SAMUEL FINLEY BREESE MORSE.}

$$
\text { I 79I-I } 872 \text {. }
$$

THE inventor of the telegraph! From Franklin to Edison no American has won so much honour from scientific achievements as he. Doubtless the wondrous character of the works wrought by these three men is due to the fact that they all dealt with the still mysterious though now familiar force electricity. Morse's life, indeed, seemed a continuation of Franklin's, for he was born but little over a mile from the American philosopher's birthplace and but little over a year after he died.

Samuel Finley Breese Morse was born at the foot of Breed's Hill, in Charlestown, Mass., now a part of Boston, April 27, I79I. His earliest paternal ancestor in this country was Anthony Morse, who came from Wiltshire, England, and settled at Newbury, Mass. In the sixth generation from Anthony was Jedediah Morse, D. D., father of Samuel. He was pastor of the First Congregational Church in Charlestown, author of the American Geography and a Gazetteer of the United States, and was very active in the work of establishing religious and benevolent institutions, such as the Andover Theological Seminary, the American Board of Foreign Missions, the American Bible Society, the American Tract Society, and various religious periodicals. Dr. Eliot said of him, "What an astonishing impetus that man has!" President Dwight declared, "He is as full of resources as an egg is of meat"; and Daniel Webster spoke of him as "always thinking, always writing, always talking, always acting." He married, May 14, I789, Elizabeth Ann Breese, daughter of Rebecca (Finley) and Samuel Breese. Rebecca Finley was a daughter of Dr. Samuel Finley, President of Princeton College. To Dr. and Mrs. Morse eleven children were born, of whom only Samuel and two younger brothers survived infancy. 


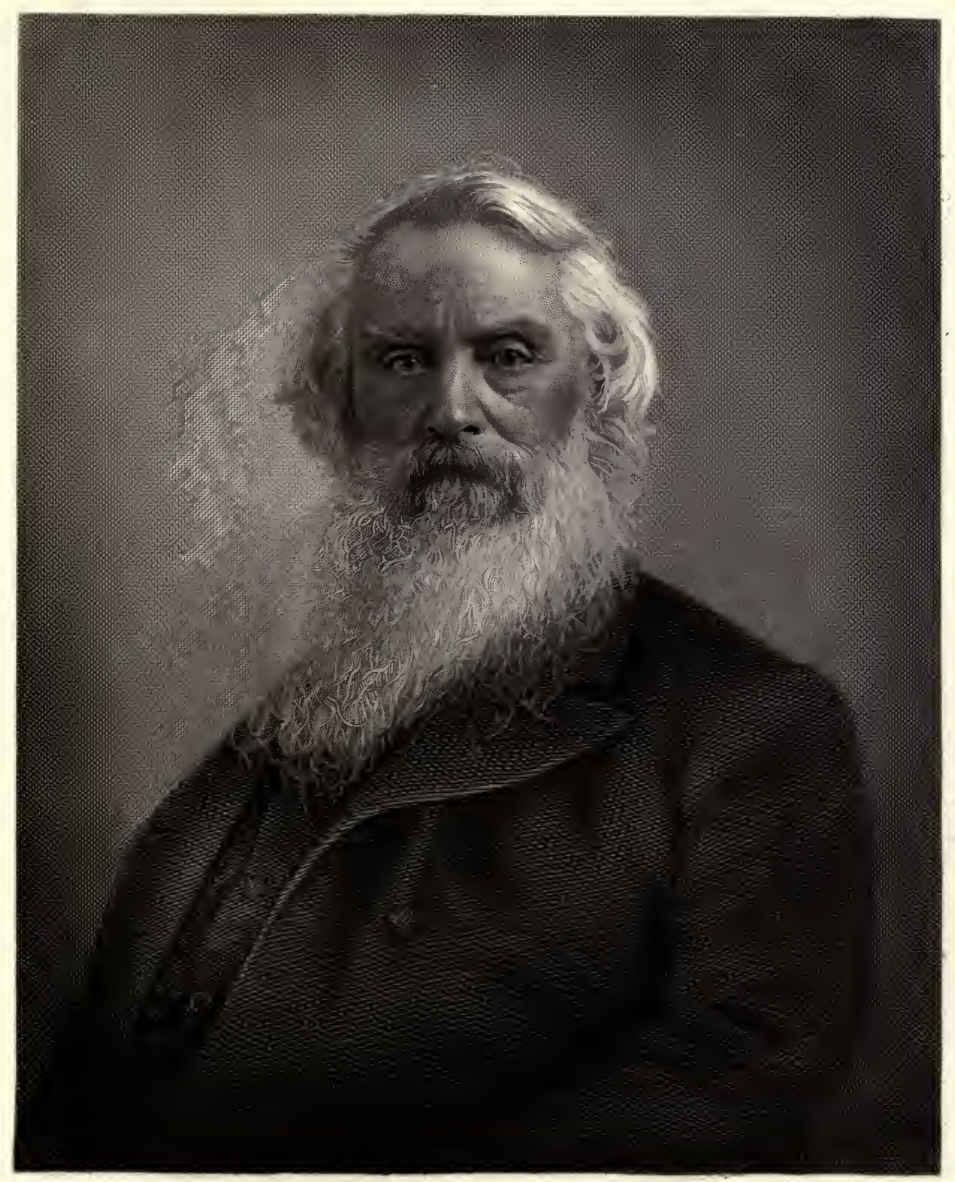

Samptomonse 

When four years old Samuel was sent to a little school kept by an old lady known as "Old Ma'am Rand." The mistress was unable to get about much, and controlled her flock from her chair with the aid of a rattan long enough to reach across her little domain. She also punished her pupils by pinning them to her dress. Young Samuel once incurred the latter penalty for scratching a picture of Ma'am Rand on a chest of drawers with a pin. He was not a quiet prisoner and was soon at the farther side of the room, dragging part of the old lady's gown after him, but not far enough away to escape a smart caning from the rattan.

At seven years of age the boy was sent to the school of a Mr. Foster at Andover, Mass., from which he passed to the Phillips Academy in the same place, to prepare for college. At fourteen he was admitted to Yale College, his father's alma mater, whither his brothers soon followed him. The Rev. Timothy Dwight, D. D., was then president, and being a warm personal friend of their father, took especial interest in the Morse boys. Here under Jeremiah Day, Professor of Natural Philosophy, and the elder Silliman, whose lectures on chemistry included the subject of galvanism, Finley Morse gained his first knowledge of electricity, which he was destined to use to such marvellous advantage. His letters home give abundant evidence of his interest in his studies, with frequent especial references to the electrical experiments exhibited by his instructors.

The picture of "Old Ma'am Rand" scratched by young Finley in her little schoolroom was a real indication of artistic talent, which became plainly manifest during the young man's college course. Although wholly untaught, he was able to produce miniature portraits which his fellow-students (not very critical, perhaps) were willing to pay moderate prices for. Immediately after his graduation, in July, r8ro, he wrote home that he was confirmed in the opinion that he was made for a painter, and asks that arrangements be made for him to study with Washington Allston, who was to return to England the following year. Although Dr. Morse had intended his son's college course as a preparation for a learned profession, he acquiesced in this change of plan.

In July, I8I r, young Morse set sail with Mr. and Mrs. Allston for England. His first letter home contains an ardent 
wish for what his great invention years afterward made possible. His words are :

"I wish that in an instant I could communicate the information, but three thousand miles are not passed over in an instant, and we must wait four long weeks before we can hear from each other."

Allston introduced Morse to Benjamin West, then seventythree years old and President of the Royal Academy. West accepted him as a student, and showed him many favours because he was an American. Allston continued also to act the part of friend and critic. The young student remained in England four years, within which time the War of 1812 took place. The hostilities, however, made no enmity against him. In 1813 he won the gold medal of the Society of Arts for a figure representing the Death of Hercules, and a large painting which he made of the same subject was admitted to the exhibition of the Royal Academy. It was highly praised, one of the British newspapers ranking it among the best nine paintings in a gallery of nearly a thousand.

Returning home in the summer of $1815, \mathrm{Mr}$. Morse opened a studio in Boston, where he exhibited a large painting, The Judgment of Jupiter, and waited for orders for historical pictures. After a year had passed without his obtaining employment he started out as a travelling portrait painter and achieved a moderate success. Within that year of waiting, however, his genius for invention became manifest. In conjunction with his brother Sidney he invented a modification of the common suction pump, which could be adapted to the forcing pump in the fire engine, and secured a patent for it. In his travels as a portrait painter he met Miss Lucretia P. Walker, daughter of Mr. Charles Walker, of Concord, N. H., and married her October I, I8I8. The winter before and that following his marriage he spent at Charleston, S. C., in the pursuit of his profession. In the winter of $1819-20$ he painted a portrait of President Monroe, for which he had received an order from the Common Council of Charleston. His father having resigned his charge and removed to New Haven, Mr. Morse spent the following summer there with his wife and infant daughter. The next winter he executed a great picture of the House of Representatives, in which were eighty portraits of members. 
Several years of struggle-in Albany, New York, and other places-followed. During this period his inventive faculty was not idle. He devised a machine for carving in marble copies of any model, and was revolving other ideas in his mind. In February, I 825, he was in Washington painting a full-length portrait of Lafayette for the city of New York, when his father wrote him that his beloved wife had died of a heart disease on the 7 th of that month. She was only twentyfive years of age, and there is abundant testimony that she was a woman of great loveliness. But little more than a year afterward Morse's father passed away. He was sixty-five years of age, and had long been loved and honoured by a wide circle.

After his wife's death Morse had again repaired to New York and made gradual progress with his brush. His brothers had been there since 1823 , had established the New York Observer, and were steadily building it up. His three children were now in the care of various relatives. Morse was one of the leading spirits in establishing, during the winter of $1825-26$, the National Academy of Design, the prime object of which was to provide art students the facilities that were then churlishly denied them by the American Academy of Arts. $\mathrm{He}$ was its first president, and was continued in the office until I 845 , when he retired from it to give his attention to his telegraphic researches.

In the early part of 1827 Morse attended a course of lectures on electro-magnetism, delivered before the New York Athenæum, by Prof. James Freeman Dana, with whom he was well acquainted. At these lectures experiments were shown to illustrate the power of a straight wire carrying a current of electricity to induce magnetism, and the increased effect of such a wire bent into a ring, into a series of rings forming a spiral, and into a flat spiral or volute. Prof. Dana died soon after giving these lectures, and the subject apparently passed out of Morse's thoughts for a time.

Morse was now at thirty-six years of age a successful artist. He had been honoured by his fellows with repeated elections to the presidency of the National Academy, and had made many warm friends among the wealthy and influential citizens of the metropolis. But the determination to rise yet higher was as strong as when he began his studies. He de- 
termined to go to Italy and study the works of the old masters. Accordingly, he secured commissions amounting to nearly three thousand dollars for pictures to be painted abroad, and sailed from New York, November 8, i829. He was absent three years, spending about two-thirds of his time in Rome and a year in Paris. In the latter city he renewed his acquaintance with Lafayette, and before returning to America crossed over to London, where he met again several of his artist friends of early days, and where he was duly honoured as the President of the American National Academy of Design.

We come now to the masterly application of science by which Morse eclipsed his artistic triumphs. A younger artist, Mr. R. W. Habersham, of Georgia, and James Fenimore Cooper, were both intimate with Morse in Paris. Each of these men has put on record most positive recollections that Morse early in 1832 mentioned to him in conversation the idea of conveying intelligence by means of electricity. The inventor's own recollection did not carry his conception of a telegraph back earlier than October, 1832 , when he was returning to America on board the packet Sully, in company with Hon. William C. Rives, minister to France, Dr. Charles T. Jackson, of Boston, and others. The incident which led up to the invention is thus described by Morse's biographer, Dr. S. Irenæus Prime :

"In the early part of the voyage conversation at the dinner table turned upon recent discoveries in electro-magnetism, and the experiments of Ampère with the electro-magnet. Dr. Jackson spoke of the length of wire in the coil of a magnet, and the question was asked by some one of the company, 'If the velocity of electricity was retarded by the length of the wire?' Dr. Jackson replied that electricity passes instantaneously over any known length of wire. He referred to experiments made by Dr. Franklin, with several miles of wire in circuit, to ascertain the velocity of electricity; the result being that he could observe no difference of time between the touch at one extremity and the spark at the other. At this point Mr. Morse interposed the remark, "If the presence of electricity can be made visible in any part of the circuit, I see no reason why intelligence may not be transmitted instantaneously by electricity.' The conversation went on. But the one new idea had taken complete possession of the mind of 
Mr. Morse. It was as sudden and pervading as if he had received at that moment an electric shock."

The invention was already complete as to its main features - a current of electricity passing through a wire between two places, and signals to be made at one terminus by making and breaking the circuit at various intervals at the other. As soon as opportunity offered Morse set about sketching in his notebook details of apparatus and a scheme of dot-and-dash signals for numbers and words. He showed his drawings to his fellow-passengers and to the captain of the ship, and told them what he hoped to accomplish. Arrived in New York Morse had before him the problem of devising an apparatus to embody his ideas. He could devote but little time or money to the task, as he was dependent on his painting and his pupils for a livelihood. Two or three years passed, during which he experimented as he had opportunity.

In 1835 he was appointed Professor of the Literature of the Arts of Design in the University of the City of New York, and a studio was assigned to him on the third floor in the north wing of the original building in Washington Square. Here he prosecuted his experiments, and here, in order to economize his scanty means, he slept and took his meals, prepared by himself. In January, 1836 , he gave one of his colleagues at the university, Prof. Leonard D. Gale, a private view of his first practicable instrument, represented in Fig. 5. His transmitter is shown in the lower part of the figure. He did not trust his hand to move the key, $\mathrm{O}$, at the proper intervals, but tripped it by toothed "type" set in the rule, $M$, which was carried on a belt of cloth passing over the wheels L, L. The key was hung on an axle at $\mathrm{N}$, and bore a weight at $\mathrm{P}$. The circuit was closed and broken by means of a bent wire attached to one end of the key, by which it was dipped into and raised from two cups of mercury, J, K, connected with the poles of the battery, I. The receiver was a clumsy affair. For framework it had a canvas-stretcher nailed upright against the edge of a table. The paper ribbon was drawn from the roll, A, by means of the clockwork, D, driven by the weight, E. The suspended frame, F, carried an armature at a point opposite the electro-magnet, $h$, and a weighted pencil in the tube, $g$.

Prof. Morse worked on through 1836 and half of 1837 , occupied mainly with trying various modifications of the mark- 
ing apparatus and in devising the relay instrument. In these experiments he was assisted by Prof. Gale. Having set up his telegraph so as to operate through about a third of a mile of

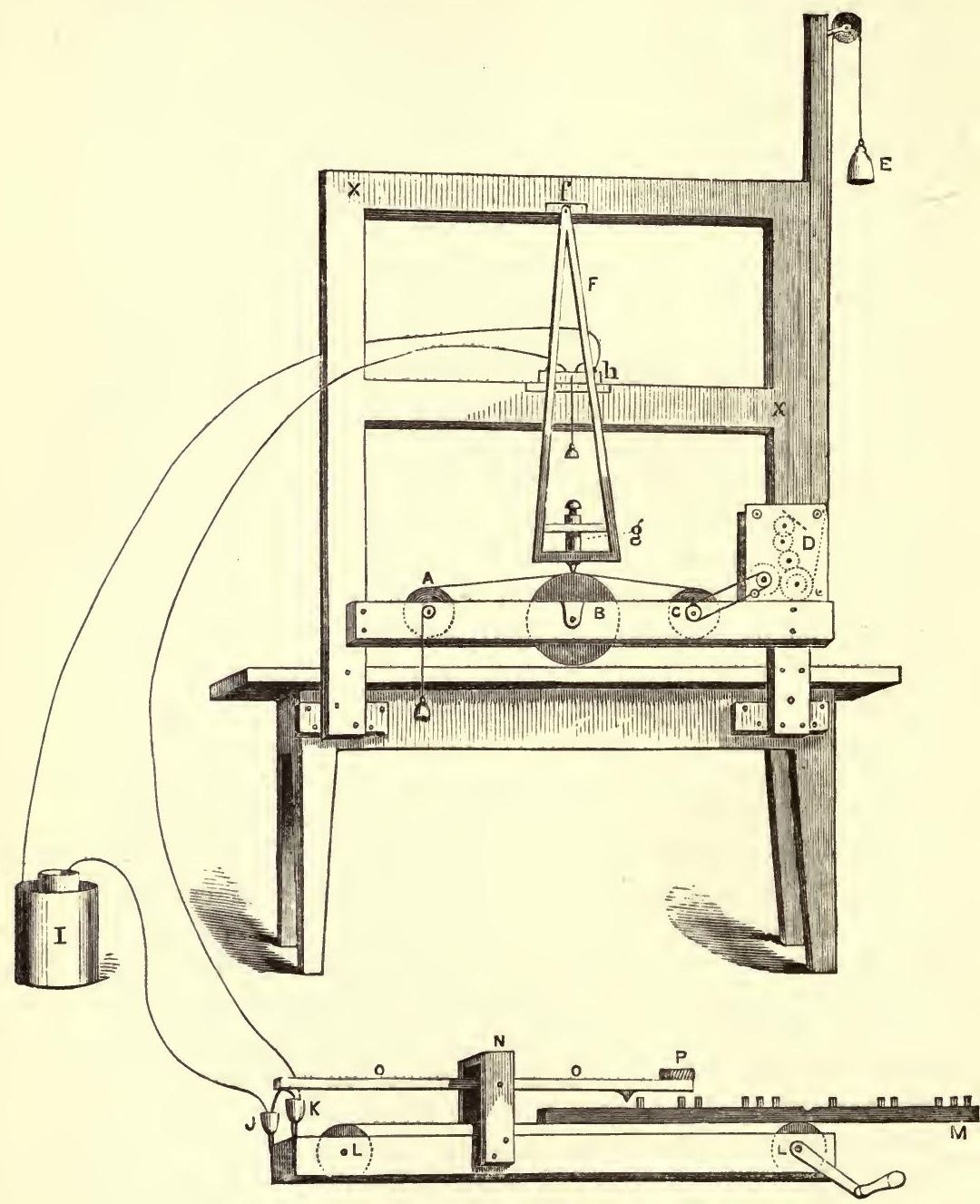

FIG. 5.-Prof. Morse's first telegraph instrument.

wire stretched back and forth in the cabinet of the university, he showed it to parties of visitors in the latter part of the summer of 1837. Among those who saw it was Mr. Alfred 
Vail, a recent graduate of the university. His father, Judge Stephen Vail, and his brother George, were proprietors of large machine works at Speedwell, N. J., where he had himself acquired skill in brass-working before he went to the university. $\mathrm{He}$ inquired further into the matter, and soon entered into a partnership with Prof. Morse, receiving a one-fourth interest in the patent to be secured, in return for providing means and facilities for developing the invention.

Prof. Morse now filed a caveat at the Patent Office, and, together with young Vail and Prof. Gale, who was admitted to the partnership, enthusiastically renewed his exertions. Several valuable modifications of the invention are due to the ingenuity of Mr. Vail. In February, 1838 , he took an improved instrument to Washington, and exhibited the telegraph on a ten-mile circuit to President Van Buren and his cabinet, members of Congress, foreign ministers, and men of science. His petition to Congress for an appropriation of thirty thousand dollars to defray the expense of a specimen line of fifty miles was not acted upon when Congress adjourned in March. The Hon. F. O. J. Smith, of Maine, was now admitted to the partnership. He and Prof. Morse drew the specifications for the American patent and then both sailed for Europe to procure patents there.

In England Morse met with the opposition of Prof. Wheatstone and $\mathrm{Mr}$. Cooke, who had recently patented a telegraph requiring six wires and making signals by deflecting five magnetic needles, but producing no record on paper. His application was rejected by the attorney general on the ground that an account of it had been published in England, although this account gave none of the essential details. He was further told by that official that "America was a large country, and he ought to be satisfied with a patent there"! Proceeding to Paris, he was cordially received by Humboldt, Arago, Gay-Lussac, and other distinguished savants, and readily procured a French patent.

Prof. Morse had met M. Daguerre in Paris, and each had shown the other his invention. As an artist Morse became much interested in the daguerreotype process, and, after it was made public in the summer of 1839 , obtained from the inventor instructions which enabled him to introduce it in America. Morse and John W. Draper soon applied the pro- 
cess to the taking of portraits-for which its inventor had doubted its being applicable. After actively pursuing the art for about six months, Prof. Morse laid it aside to devote his attention to the telegraph more closely, but during several years made occasional experiments and improvements upon the process.

The year 1839 was crowded with discouragements. A provisional arrangement to introduce the telegraph into Russia, which Morse had made with an agent of the Russian Government while he was in Paris, failed to receive the approval of the Czar. A Mr. Chamberlain who had undertaken to exhibit the telegraph to the governments of eastern Europe, lost his life in an excursion on the Danube before he had effected any results of pecuniary value. Meanwhile the rival schemes of Wheatstone in England and Steinheil in Bavaria were making progress.

The years 1840 and $184 \mathrm{I}$ dragged through without any improvement in Morse's prospects. In the spring of 1840 he completed the formalities required, which he had interrupted on departing for Europe in 1838 , and received his patent. Wheatstone had actually secured an American patent for some of his devices at an earlier date, and was urging his scheme upon Congress. Morse's partners had suffered financial reverses and were no longer able to help him. Almost despairing, he worked on constructing improved instruments with his own hands, and obtaining a precarious livelihood by giving lessons in painting. The long session of Congress in $184 \mathrm{I}-\mathbf{A}^{\prime} 2$ wore away without any attention being secured for the telegraph. He had not had the money since 1838 to make another prolonged stay in Washington, but the next winter, determined to stake all upon a last personal appeal to Congress, he proceeded to the capital. Again he carefully strung his wires and set up his instruments; day after day he patiently explained the operation of his invention to members of Congress, officers of the Government departments, and other visitors. He had a few active friends at Washington; one of these was Hon. H. L. Ellsworth, a college classmate, who was now Commissioner of Patents. Hon. Charles G. Ferris, of New York city, undertook to push the bill relating to the telegraph through the House. He secured a favourable report from the Committee on Commerce December 3oth. When the short 
session was within a fortnight of its close, February $23 \mathrm{~d}$, the bill passed the House. There was a great amount of business before the Senate, and the telegraph bill had not been reached when the last day of the session opened. All that day and into the evening Prof. Morse sat in the gallery of the Senate. Then, assured by his friends that there was no longer any hope, he left the Capitol well-nigh broken-hearted. The next morning he was met at breakfast with congratulations. A few minutes before midnight the bill had been taken up and passed!

Prof. Morse's suggestion that the specimen line run between Washington and Baltimore was accepted, and before the month was out preparations for its construction were actively under way. Prof. Morse appointed as his assistants Profs. L. D. Gale and J. C. Fisher. To Mr. Vail he assigned the duty of buying materials and constructing instruments. The wire, carefully insulated, was inclosed in lead pipe, and $\mathrm{Mr}$. Ezra Cornell (afterward the founder of Cornell University) was engaged to lay the pipe underground with a machine which he had invented for the purpose. It was soon found that the insulation of the wire was destroyed by the method employed for inclosing it in the pipe, and the plan of stretching the wire on posts was adopted. Steinheil had discovered that the ground could be used as one half of a galvanic circuit, and Morse found before he had proceeded far with the work that he could get better results by utilizing this discovery than with a complete circuit of wire. After the line had reached a railroad station halfway to Baltimore, Vail would get news from passengers on trains from Baltimore and telegraph it ahead to Morse in Washington. Much interest was aroused in this way, especially when the news of Henry Clay's nomination for the presidency by the Whig Convention held at Baltimore in May was known in Washington before the passengers on the train could bring it.

On May 24, I844, many of the highest officers of the Government assembled with the personal friends of Prof. Morse in Washington to witness the first operation of the telegraph over the completed line. To the daughter of Commissioner Ellsworth, who had been the first to inform him of the passage of the appropriation for the telegraph, Prof. Morse had promised that she should give the first message to be sent over the fin- 
ished line. At the suggestion of her mother she chose the text, "What hath God wrought," which was transmitted by Prof. Morse to Mr. Vail in Baltimore, and by him instantly returned. The toil and struggles of twelve years were now crowned with success, and the inventor received the richly merited congratulations of the assembled company. Two days later the complete line had its first public test. The National Democratic Convention met in Baltimore and nominated James K. Polk for the presidency, and the Hon. Silas Wright, then a senator from New York, for the vice-presidency. Vail promptly secured the news and telegraphed it to Morse, by whom it was communicated to $\mathrm{Mr}$. Wright, who was in Washington. Within a short space of time the convention was astounded at receiving a message from $\mathrm{Mr}$. Wright saying that he respectfully declined the nomination. Most of the members were incredulous as to the genuineness of the message, and the convention accordingly adjourned over to the following day, so that a committee might go to Washington and confirm or disprove it. The committee returned in the morning, and its report fully established the correctness and capacity of the telegraph.

The public was allowed to test the telegraph gratuitously for about a year. On April I, I845, a charge of one cent for each four characters was established by the Postmaster-General, after which the telegraph was used more for business purposes than when the service was free. The proprietors now offered to sell the invention outright to the Government for a hundred thousand dollars, but fortunately for them and the country the offer was declined and the development of the American telegraph was left to private enterprise. They then appointed the Hon. Amos Kendall, ex-Postmaster-General, their agent, and under his management the Magnetic Telegraph Company was organized in May "for the purpose of constructing a line of said telegraph from New York to Washington."

Prof. Morse sailed from New York early in August to present his telegraph again to European nations under much more favourable auspices than before. Accomplishing nothing in England, he visited Hamburg and afterward Paris, but returned to America in November, having received many honours, but nothing more substantial. Meanwhile numerous lines were 
in construction at home, and in the next year the telegraph reached from Washington through Philadelphia and New York to Boston, from New York to Buffalo by way of Albany, and there were many branch lines in operation. Morse's system had been adopted by the Austrian Government early in the year.

That success has its perils was early shown in the case of the telegraph. Unauthorized attempts to use Morse's system, in whole or in part, began soon after its value was demonstrated. They rapidly became numerous and appeared in the most varied forms, and were often accompanied by malicious defamation of the inventor and barefaced denials of his claims to originality and priority. Mr. Kendall was vigilant in defending the legal rights of the Magnetic Telegraph Company and entirely successful. The first suit for infringement was brought against one Henry O'Rielly, who had built a line to the West under license from the company and then attempted to establish a branch line without authority. The suit was tried in the summer of $\mathrm{I} 848$ at Louisville, Ky., and Morse's patent, was sustained. O'Rielly and his associates then made attempts to evade the injunction granted against them and finally carried the matter to the Supreme Court of the United States. All the historical and expert evidence that could be brought to bear on the matter was now passed in review, with the result that on January 30,1854 , Chief Justice Taney delivered an opinion, Justices Daniel, Catron, and McLean concurring, in which Samuel F. B. Morse was declared to be the first and sole inventor of the electro-magnetic recording telegraph, although it was denied that he had the right to the $e x$ clusive use of electro-magnetism for a recording telegraph. The minority opinion differed in the direction of being more favourable to Morse. Other suits were decided in the same way, and the rights and achievements of Morse were impregnably established.

In 1847 Prof. Morse bought a tract of two hundred acres on the Hudson River just below Poughkeepsie. Naming his place Locust Grove, he built a tasteful mansion upon it and gathered his children and grandchildren about him. $\mathrm{He}$ had never been able to enjoy a home since he left his father's roof up to this time, for even when his little family was established at New Haven he could be there but little. The next year he 
married Miss Sarah E. Griswold. Her mother was a cousin of Prof. Morse, and her father was an army officer. The lady was a mute. While Prof. Morse could now enjoy comfort and happiness he was by no means idle. The constant attempts to displace or infringe upon his invention entailed upon him a great amount of labour in correspondence, and in collecting and arranging evidence to combat them. Yet he was able to enjoy considerable compensation for his many years of toil and privation. And his own invention ministered to his pleasure and comfort, for with a telegraphic instrument on his library table he could converse with friends and correspondents in every important place in his own land, and in later years could exchange messages with those on the opposite side of the Atlantic. Several years later he bought for a winter residence a beautiful house in New York, No. 5 West Twenty-second Street: The building is now marked with a tablet bearing this inscription: "In this house S. F. B. Morse lived for many years and died."

Prof. Morse was one of the few great inventors who receive an adequate pecuniary reward for their services to the world, and to whom merited honours come while they are alive. He received the degree of Doctor of Laws from Yale College, and was elected to membership in learned societies of the United States, France, Belgium, Sweden, and Switzerland. Orders and decorations were bestowed upon him between 1848 and 1864 by the sovereigns of Turkey, Prussia, Würtemberg, Austria, France, Denmark, Spain, Portugal, and Italy. This list stands in chronological order. It will be observed that the Sultan of Turkey took precedence in honouring the inventor of the telegraph over the rulers of many more pretentious nations, while England does not appear at all. We may well believe the statement of his biographer that "Prof. Morse re. ceived a greater number of honorary distinctions than were ever bestowed upon any other private citizen."

The idea of laying telegraphic lines under water was conceived by Prof. Morse early in the history of his invention; he was known to have mentioned it in 1837 and 1838 . His first submarine cable was laid by him from a rowboat, between Castle Garden and Governor Island in New York harbour one moonlight night in 1842 , and was picked up on the anchor of a vessel the next morning and broken while Morse was sending 
his first message over it. The matter rested until in 1854 it received an impulse from Newfoundland. Mr. F. N. Gisborne, of that province, had sought to interest Mr. Matthew D. Field, of New York, in a project for connecting the island with the mainland. Several cables connecting Great Britain with Ireland and with the continent of Europe were then in operation. Mr. Field consulted his brother, Cyrus W. Field, to whom this idea suggested the greater undertaking of crossing the Atlantic with a telegraphic line. Strong companies were soon organized on both sides of the ocean to co-operate in the work. The first link in the chain-a sixty-mile cable from Nova Scotia to Newfoundland-was attempted unsuccessfully in I 855, and laid in the next year. In the summer of 1856 Prof. Morse went to England to superintend some of the preparations for the cable across the Atlantic, and in connection with this trip made a tour through France, Germany, Denmark, and Russia. Presentations at royal courts, and honours by men of science and affairs, attended his whole progress. Perhaps the greatest triumph was a public dinner given to him in London, where a very cold shoulder had been his portion eighteen years before. Mr. W. F. Cooke, who had been the partner of his chief English rival, presided at the dinner.

The preparations having been completed, a fleet of British and American vessels left Valentia Bay, Ireland, early in August, I857, laying the cable as they went. When about three hundred miles had been paid out the cable parted. The next June a second attempt was made. This time the two vessels bearing the cable steamed to midocean, and when the two halves of the line had been joined, the vessels set out in opposite directions. Only two hundred miles had been laid when another break occurred. A month later the third attempt was made, and on August 5, I858, both ends of the cable were successfully landed-the American in Trinity Bay, Newfoundland, the European at Valentia. Enthusiastic celebrations followed. Mr. Field and Prof. Morse were the lions of the civilized world. The rejoicings over this success had not ceased when, on September Ist, the cable ceased to work. This last accident caused many persons to lose faith in the project; then the civil war came on and another attempt was not made until the summer of 1865, when the Great Eastern, starting from Valentia, laid twelve hundred miles and then the cable parted. 
The Great Eastern started with another cable on Friday, July I3, I 866 (ominous day!), and on Friday two weeks later the American end was safely landed. From that day to this telegraphic communication across the Atlantic has been uninterrupted.

While the early attempts to lay an Atlantic cable were in progress, Prof. Morse had, by the advice of friends holding high official stations, issued a memorial asking for compensation for the use of his telegraph in the various countries of Europe. He had the best claim on France, for he had actually obtained a patent in that country, but the Government, which had a monopoly of transmitting intelligence, had declined to use his invention for some years and had afterward adopted it without compensation to him. Negotiations followed which resulted in a sum equal to eighty thousand dollars being awarded to him by a conference of representatives of ten European governments-Austria, Belgium, France, the Netherlands, Piedmont, Russia, the Holy See, Sweden, Tuscany, and Turkey. Morse's telegraph had now come into use to the exclusion of its rivals everywhere except to a limited extent in Great Britain.

In I 866 Prof. Morse took some of his younger children to Europe for a course of study, remaining abroad two years. During his stay he accepted a pressing invitation to serve as one of the committee on telegraphic instruments at the Paris Exposition. As on repeated former visits, he was everywhere the recipient of distinguished honours. And marked honours awaited. him from his fellow-citizens at home. Toward the close of December, I868, a splendid banquet, at which two hundred gentlemen of mark in their respective walks in life were present, was given him in New York. It was presided over by Chief Justice Salmon P. Chase, who had been the leading counsel against Prof. Morse in the first lawsuit brought for infringement on the telegraph patent. No small part of the value of Prof. Morse's invention was that it created a new means of gaining a livelihood, which has been an inestimable boon to tens of thousands of men and women throughout the world. In 1869 a movement was started by the operators in Allegheny, City, Pa., to bestow a testimonial upon the inventor for this service. A sum of money was raised, mostly in one-dollar subscriptions, sufficient to erect a bronze statue of Prof. Morse, which was placed in Central Park, New York. It was unveiled on June 10, 1871, with inspiring and enthusiastic exercises. 
When wealth came to him Prof. Morse was not backward in conferring benefactions upon worthy persons and institutions. $\mathrm{He}$ was a man of firm religious convictions, and gave many donations to churches, theological seminaries, and missionary societies. A love for his early art clung to him throughout his life. The honours received for his artistic talents were especially prized by him, and in his later years he encouraged struggling artists of ability by purchasing their pictures, and gave aid to art societies and institutions.

Throughout his long life he had suffered little from sickness. In his latter years he became subject to neuralgia, which in the winter of $187 \mathrm{I}-72$ concentrated its attacks in his head. After weeks of intense pain he fell into a stupor from which he partly aroused at times, and finally passed away April 2, I872. At his funeral and afterward high honours were paid to his memory by the States of New York and Massachusetts, the Congress of the United States, the great telegraphic companies, by many cities, by the societies of which he was a member, and by assemblages of individuals.

"In person," says his biographer, "Prof. Morse was tall, slender, graceful, and attractive. Six feet in stature, he stood erect and firm, even in old age. His blue eyes were expressive of genius and affection. His nature was a rare combination of solid intellect and delicate sensibility. Thoughtful, sober, and quiet, he readily entered into the enjoyments of domestic and social life, indulging in sallies of humour, and readily appreciating and greatly enjoying the wit of others. Dignified in his intercourse with men, courteous and affable with the gentler sex, he was a good husband, a judicious father, a generous and faithful friend. . . He was as gentle as he was great. Many thought him weak because he was simple, childlike, and unworldly. Often he suffered wrong rather than resist, and this disposition to yield was frequently his loss."

What Morse accomplished for the advance of civilization was due chiefly to an unbounded perseverance which enabled him to endure the grievous hardships and triumph over the enormous obstacles that lay in his path. It has been well said that "the genius and labour of such a man reflect glory upon his country, so that his name becomes part of the national heritage and treasure." 


\section{DENISON OLMSTED.}

$$
\text { I 79 I }-1859 \text {. }
$$

Prof. Olmsted, the American Journal of Science said, in its obituary notice of him, "regarded his most appropriate sphere of effort, in the circumstances in which he was placed, not so much to cultivate science as to teach and diffuse it." The circumstances mentioned in this sentence called him to be a teacher, whatever lines of work he may have planned to pursue. Although his mind at different times in his life turned to other occupations and he began to prepare for them, he was as often called back to teaching by agencies outside of himself. He was a successful and superior teacher. But his achievements in independent and original research, for which he seemed to have a natural taste, were not few nor insignificant; and we can not doubt that, if he had been permitted to devote himself to that line, he might have arrived at great distinction in it.

Denison Olmsted was born in East Hartford, Conn., June 18, 1791, and died in New Haven May 13, 1859. His father was descended from James Olmsted, one of the first settlers of the colony of Connecticut, who died about four years after Hartford was founded. His mother was a daughter of Denison Kingsbury, of Andover, Conn., from whom he seems to have received his Christian name. His father was a farmer in moderate circumstances. He died when the son was a year old, and the care of the boy's education devolved upon his mother, who is highly spoken of as having been a lady of native strength of mind, sound judgment, and uncommon piety and benevolence. He was early trained to habits of order, diligence, and perseverance, for which he was distinguished throughout his life.

The neighbourhood school was not all that was desired, and Mrs. Olmsted, in order to give her son better facilities 

for instruction, obtained a place for him, when he was about twelve years old, in the family of Governor Treadwell, as a chore boy, with the understanding that he should attend the district school. He was, according to the Rev. Dr. Porter, of Farmington, Conn., a very lovely, intelligent boy, and soon engaged the affections of the family. Governor Treadwell became interested in him, and took pains to help him along in his studies. Only reading, spelling, and writing were taught in the school. A proposition of Governor Treadwell to teach him arithmetic was readily accepted, and the boy made good progress under this sympathetic attention. Young Olmsted was put into a country store at Farmington, in which Governor Treadwell's son was a partner, and then at Burlington, where he had the same employer. When sixteen years old he became desirous of obtaining a liberal education. He had already acquired a considerable knowledge of English literature, and made creditable progress in the elementary mathematics. With the consent of his guardian and his mother he went to Litchfield South Farms, to attend the school of James Morris. $\mathrm{He}$ undertook the care of a public district school for a short time; completed his fitting for college under the Rev. Dr. Noah Porter at Farmington, and entered Yale College in r8o9 He took rank at once among the best scholars in his class, being apparently nearly equally proficient in all his studies, excelling also in writing, and cultivating a taste for belleslettres and poetry. $\mathrm{He}$ was graduated with the highest honours in 1813 , when he was appointed one of the orators in a class of seventy, of which only ten received that distinction. The subject of his graduation address was the Causes of Intellectual Greatness.

After graduation, Mr. Olmsted obtained a position as a teacher in the "Union School" at New London, Conn., a private institution for boys which had been supported by a few families of the place for several generations. In I 815 he was appointed a tutor in Yale College. Here he joined a small class in theology, instructed by Dr. Dwight, with the intention, which he had formed a short time before-having come under strong religious influence-of entering the ministry. Dr. Dwight died within a year, and Mr. Olmsted published a memoir of him in The Portfolio for November, 1817. The theological studies were terminated in 1817 by Mr. Olmsted's 
appointment to be Professor of Chemistry, Mineralogy, and Geology in the University of North Carolina.

During his tutorship at Yale in $18 \mathrm{r} 6, \mathrm{Mr}$. Olmsted delivered the Master's Oration on the occasion of taking his second degree, taking as his subject The State of Education in Connecticut. In this oration he brought out his plan for a normal school, which, so far as appears, was then a complete novelty, and was wholly original with him. He pointed to "the ignorance and incompetency of schoolmasters" as the primary cause of the low condition of public schools, and appealed to public and private liberality to establish and support institutions of a higher grade, where a better class of teachers might be trained for the lower schools. He has himself, in one of his letters, given an account of the origin of his conception of this scheme of "a school for schoolmasters." It was while engaged in the Union School at New London, where he had pupils of various ages pursuing a great variety of studies; so that, while the number of pupils was small, the classes were many. He discovered a marked difference in intelligence and capacity between those who were studying the languages and mathematics, preparatory to entering college, and who devoted only a small part of the day to the common rudimentary branches, such as English grammar, geography, reading, writing, and spelling, and those who spent all their time in these elementary studies. "I was surprised to find that the former excelled the latter even in a knowledge of those very studies; they read better, spelt better, wrote better, and were better versed in grammar and geography. One inference I drew from the observation was that an extended course of studies, proceeding far beyond the simple rudiments of an English education, is not inconsistent with acquiring a good knowledge of the rudiments, but is highly favourable to it, since, on account of the superior capacity developed by the higher branches of study, the rudiments may be better learned in less time; and a second inference was that nothing was wanted in order to raise all our common schools to a far higher level, so as to embrace the elements of English literature, of the natural sciences, and of the mathematics, but competent teachers and the necessary books. I was hence led to the idea of a seminary for schoolmasters." His plan was outlined in accordance with this thought. Another encouraging feature in his scheme, 
as it appeared to him, was that "no sooner would the superior order of schoolmasters commence their labours, than the schools themselves would begin to furnish teachers of a higher order. The schoolmasters previously employed were for the most part such as had received all their education at the common schools, and could only perpetuate the meagre system of beggarly elements which they had learned; but it was obvious that schools trained in a more extended course of studies would produce teachers of a corresponding character-that is, if we could once start the machine, it would go on by its own momentum." $\mathrm{He}$ was contemplating a series of newspaper articles in advocacy of his plan, and communications concerning it with eminent men interested in education, when he was called to another enterprise. The idea of normal schools was afterward taken up by other men and brought by them before the public under much more favourable circumstances than he could have commanded had he remained in Connecticut and continued his advocacy at that time.

At a later time, as a member of the Board of Commissioners of Common Schools for Connecticut, in 1840 , in drafting the annual report, he observed that "wherever normal schools have been established and are adequately sustained, the experiment has uniformly resulted in supplying teachers of a superior order. As in every other art whose principles are reduced to rule and matured into a system, the learner is not limited to the slow and scanty results of his single unaided experience, but is at once invested with the accumulated treasures of all who have laboured in the same before him."

Preparatory to going to his professorship in North Carolina, Mr. Olmsted engaged in private studies in geology with Prof. Silliman. He found at his new post two of his old friends, Yale men like himself, occupying professorial chairs: Elisha Mitchell, his former classmate, that of Mathematics and Natural Philosophy, and Ethan A. Andrews that of Languages, and here he spent seven happy years.

In 182 I he laid before the Board of Internal Improvements of North Carolina a proposition to undertake a geological survey of the State, offering to perform the entire work himself gratuitously, but suggesting an appropriation of one hundred dollars to defray his necessary expenses in travelling, to be afterward renewed or not at the pleasure of the board. The 
proposition was declined by the Board of Internal Improvements, but the survey was afterward made under the direction of the State Board of Agriculture. To this board Prof. Olmsted addressed his report, which was published in two parts, in 1824 and 1825 , and filled in all about one hundred and forty octavo pages. The American Journal of Science observes of this survey that, regarded especially as the gratuitous vacation work of a single individual, and in view of the state of geological science in this country at the time, it "must certainly be looked upon as creditable in the highest degree both to the enterprise and to the scientific ability of its projector; and it has undoubtedly been of great benefit, not only to the State which authorized it, but to the country and to science generally, by the stimulus which it afforded to similar enterprises in other States." It was the first instance of one of the United States instituting a geological survey. In the course of his work Prof. Olmsted gave the first geological description of the Deep River coal beds and of the new red sandstone accompanying them, and referred the strata correctly to the same age with that of the Richmond coal beds and the Connecticut River sandstones.

Prof. Olmsted began researches to determine the practicability of obtaining illuminating gas from cotton seed, but removed to the North before he had secured definite results.

In $1_{25}$ Prof. Olmsted was appointed Professor of Mathematics and Natural Philosophy in Yale College. In 1836 this chair was divided at his request, and the professorship of Mathematics was assigned to A. D. H. Stanley. As a professor in Yale he performed an unbroken service of thirty-four years, till it was interrupted by his illness. His labours as a teacher during the last twenty years of his life consisted, as described by Dr. Woolsey in The New-Englander, " in teaching astronomy by a text-book, and in three courses of lectures-experimental ones on natural philosophy and optics, historical ones on the progress of astronomical discovery, and theoretical ones on meteorology. His colleagues and friends have regarded him as a born teacher, as possessing a most happy union of several powers-the capacity to convey instruction with clearness and evidence, the capacity to impress the pupil with the importance of the branches taught, the disposition to shrink from no labour necessary in preparing himself for teaching, and to require of 
the student that he master and reproduce the lessons conveyed to him. While many lecturers prepare their lectures once for all, and then cease to improve them, he was constantly revising, elaborating, and almost constructing anew the courses on astronomy and meteorology which he delivered annually to the three upper classes." These lectures were spoken of by Dr. Barnard, in his Journal of Education, as having been characterized "by fulness, clearness of method, and sometimes by eloquence. The course on meteorology was, perhaps, on the whole, the most attractive and useful."

Prof. Olmsted soon became sensible of the deficiency of the text-books on which he had to rely in his department. Enfield's Philosophy was inaccurate and behind the state of science; and the work of Prof. Farrar, of Cambridge, was too extensive and too difficult. He undertook to prepare new books suitable for his classes. His Natural Philosophy appeared in 1831 , and his School Philosophy in 1832. His Astronomy, first published in 1839 , went through forty or fifty editions. An edition of it was printed in raised letters for the blind, it having been selected by Dr. Howe, according to Dr. Barnard, "for its clear, accurate, comprehensive presentation of the science of which it treats." The Rudiments of Natural Philosophy and Astronomy followed, in $\mathbf{1 8 4 2 .}$ The Letters on Astronomy was a work in more familiar style, cast in the form of letters to a lady, and prepared as a reading book for the school libraries established by the Massachusetts Board of Education.

The great meteoric shower of November, 1833 , which was observed over a large part of the American continent and on the ocean, directed Prof. Olmsted's mind to a new and original field of investigation; and several papers upon it were published by him and Prof. A. C. Twining, of West Point, in the American Journal of Science during 1834. The collation of the collected observations brought out the fact that the apparent point of radiation of the meteors was identical with that toward which the earth was tending in space-which indicated a cosmical origin. It was further found that several showers had been observed before within forty years, on the same day of November. In explanation of the phenomenon, Prof. Olmsted supposed, in an article published in the American Journal of Science, that the meteors "consisted of portions of the ex- 
treme parts of a nebulous body, which revolves around the sun in an orbit inferior to that of the earth; but little inclined to the plane of the ecliptic; having its aphelion near to the earth's path ; and having a periodic time of one hundred and eight-two days, nearly." Two of the principal features of this theorythose of the cosmical origin of the meteors and their periodicity -are still maintained; but instead of one periodical shower, astronomers now count several; and instead of a single infraterrestrial nebulous body, they connect the several showers each with a particular comet. Priority in putting forth these conceptions was disputed by Chladni, whose claims, however, do not seem to have been so definitely established as those of Prof. Olmsted. Of course, the suggestion of the cosmical origin of meteors, as a suggestion, was never wholly new, for it had been made in general terms by other philosophers, from Anaxagoras down; but the credit is claimed for Prof. Olmsted of having first embodied it in a definite, coherent theory, accompanied with valid evidence; whether or how far Chladni may have anticipated him, his conclusions, as Prof. Silliman well says, were undoubtedly original with himself, and entirely independent of any results of preceding investigations. His work was, furthermore, spoken of in the most complimentary terms by the most distinguished foreign students in those lines of the day. Humboldt referred, in the first volume of his Cosmos, to the excellent description which Prof. Olmsted had given of the shower in November, 1833 , and to his brilliant confirmation of Chladni's view that the phenomenon was of cosmical origin. Olbers praised him for his circumstantial description and collection of particulars of the shower, and agreed with him in the conclusion that it came from abroad. Biot, in a communication to the French Academy in 1836 , spoke of his "very comprehensive and highly interesting work" in collecting and making known "all the circumstances of position, direction, and periodicity peculiar to the meteors of the $13^{\text {th }}$ of November."

In his first memoir on the shooting stars, Prof. Olmsted suggested that the explanation of the cause of the meteors of November $3^{\text {th }}$ might include that of the zodiacal light. He further published a well-matured theory of the nebulous body represented by the zodiacal light. Biot agreed with him in this view, and recognised his priority in the conception. Astronomy 
has not yet satisfied itself concerning the nature of this phenomenon. $\mathrm{He}$ also studied the aurora borealis, concerning which he contributed articles to the American Journal of Science in 1835 and 1837 , and gave at length a theory of cosmical origin and secular period in the eighth volume of the Smithsonian Contributions to Knowledge. He thus ascribed shooting stars, auroras, and the zodiacal light to substantially the same origin. These views, however, as Prof. Silliman observes, were mostly thrown out only as conjectures, and not as formal theories to be held and defended.

Previous to this, Prof. Olmsted had interested himself in meteorological studies. In 1830 he published in the American Journal of Science a new theory of hailstones, in which he ascribed the origin of those formations to the sudden mingling of large bodies of hot and humid air with air extremely cold, by which the vapour of the former would be rapidly condensed and congealed into hail. These effects, he assumed, would be produced whenever, by means of opposing winds, whirlwinds, or other atmospheric disturbances, hot air should be brought above the line of congelation or cold air brought below it.

$\mathrm{He}$ agreed with Redfield in supposing that ocean gales are progressive whirlwinds; and he believed that he had established their laws or modes of action on an impregnable basis. This view of storms as progressive whirlwinds still holds good as a generalization; but his further ascription of the ultimate causes of atmospheric disturbances to the diurnal and orbital motions of the earth has not found an accepted place in science. Prof. Olmsted had a close friendship and a warm sympathy with Mr. Redfield, with whose views respecting the rotatory motions of storms he agreed; and he read an affectionate memorial of him before the American Association, at Montreal, in 1857 .

Prof. Olmsted and Prof. Loomis, who was then a tutor in the college, were the first persons of all observers to find Halley's comet on its return in 1835 . One of the results of this observation was the awakening of an interest in procuring larger and improved telescopes. It did not bring immediate fruit, it is true. The project already conceived for the estab. lishment of a permanent observatory at Cambridge, to which it gave a new impulse, was not yet to be made real. There were other circumstances, however, than want of interest in astrono- 
my that kept such liberal schemes from being carried out-the country and the universities had not grown up to them, and the needed abundance of money had not yet come-but this was one of the incidents that kept the movement vital and sped it on. Prof. Olmsted also conceived a plan for the establishment of an observatory at Yale College, which should have two departments : one to aid in the instruction of students and the other for the use of scientific observers; but the time had not yet come for this. As another incident of his astronomical work, President Woolsey relates that "for a number of years, until his health forbade it and his eyesight began to fail, he was accustomed to gather his class around him on a bright autumn evening and introduce them to the heavenly bodies. In this way he endeavoured to train up a corps of practical observers, whose labours, when they should be scattered abroad in this vast country, should not be lost to science."

In purely practical lines of enterprise he invented an excellent stove which bore his name, and the patent for which brought him considerable profit; and he devised a preparation of lead and rosin for lubricating machinery.

Of his qualities as a teacher Prof. Silliman mentions especially his uniform kindness and courtesy of demeanour and patience in imparting instruction; the excellent moral influence he always exerted, his consistent Christian example, his personal counsels, the genuine friendliness of his disposition, and the unaffected interest he always manifested in the welfare of his pupils. He was ever ready to encourage and assist any who exhibited special fondness for the studies of his department, and it always gave him pleasure when students passed beyond the bounds of ordinary attainment.

$\mathrm{He}$ laboured to make knowledge more accessible to the people, and science comprehensible and interesting to them. Dr. Barnard, who describes him from the point of view of a teacher, says that he "availed himself at all times of the lyceum and the popular lecture, as well as of the daily press, to apply the principles of science to the explanation of extraordinary phenomena of meteorology and astronomy, as well as to the advancement of domestic comfort and popular improvement generally. In an essay read before the American Association for the Advancement of Education, at New York, in I835, he showed, in a felicitous manner, that the whole tendency and 
drift of science, its inventions and institutions, is democratic."

Besides the works already mentioned, Prof. Olmsted published many articles of a scientific or literary character in the leading periodicals of the day-contributing thus to the American Journal of Science, The Transactions of the American Association, The Smithsonian Contributions, The Christian Spectator, and The New-Englander. He was especially fond of biographical composition, and his memoirs of Dr. Dwight, Sir Humphry Davy, Governor Treadwell, Eli Whitney, and William C. Redfield are mentioned by Prof. Silliman as favourable examples. 


\section{ISAAC LEA.}

I 792-I 886.

FEw naturalists have enjoyed a longer working life, or been able to make it more fruitful in finished achievement, than Isaac Lea. His first paper, being a simple account of the minerals then known to exist in the vicinity of Philadelphia, was published in 1818 . Additions to this contribution were made but slowly for a few years, but as the list swelled they became frequent, giving evidence of indefatigable industry in research; and the last paper, standing as No. 279 on the catalogue, is dated 1876 , closing a record of fifty-eight years of productive activity. During most of this time Dr. Lea was associated in the conduct of a large publishing house, and was able to give only his hours of leisure to science.

Isaac Lea was born in Wilmington, Delaware, March 4, 1792. He was descended from ancestors who came over from Gloucestershire, England, with William Penn, and were described as "a couple of noted and valued preachers." He was the fifth son of James Lea, a wholesale merchant, and Elizabeth, daughter of Thomas Gibson, and was at first put in a course of classical instruction at the academy in Wilmington, in preparation for the medical profession. This purpose was afterward given up, and, when he was fifteen years old, Isaac was sent to Philadelphia to engage in mercantile business in association with his brother. The business panic which followed the peace of 1815 broke up the firm, and in $1820 \mathrm{Mr}$. Lea married Frances Ann, daughter of Mathew Carey, at that time the leading publisher and bookseller in the United States. He entered the house of M. Carey \& Sons, which he continued under the well-known firms of Carey \& Lea and Lea \& Blanchard until $\mathrm{r} 85 \mathrm{I}$, when he retired from business. The children of his marriage were M. Carey Lea, whose researches in chemical physics are widely known; Henry Charles Lea, LL. D., 


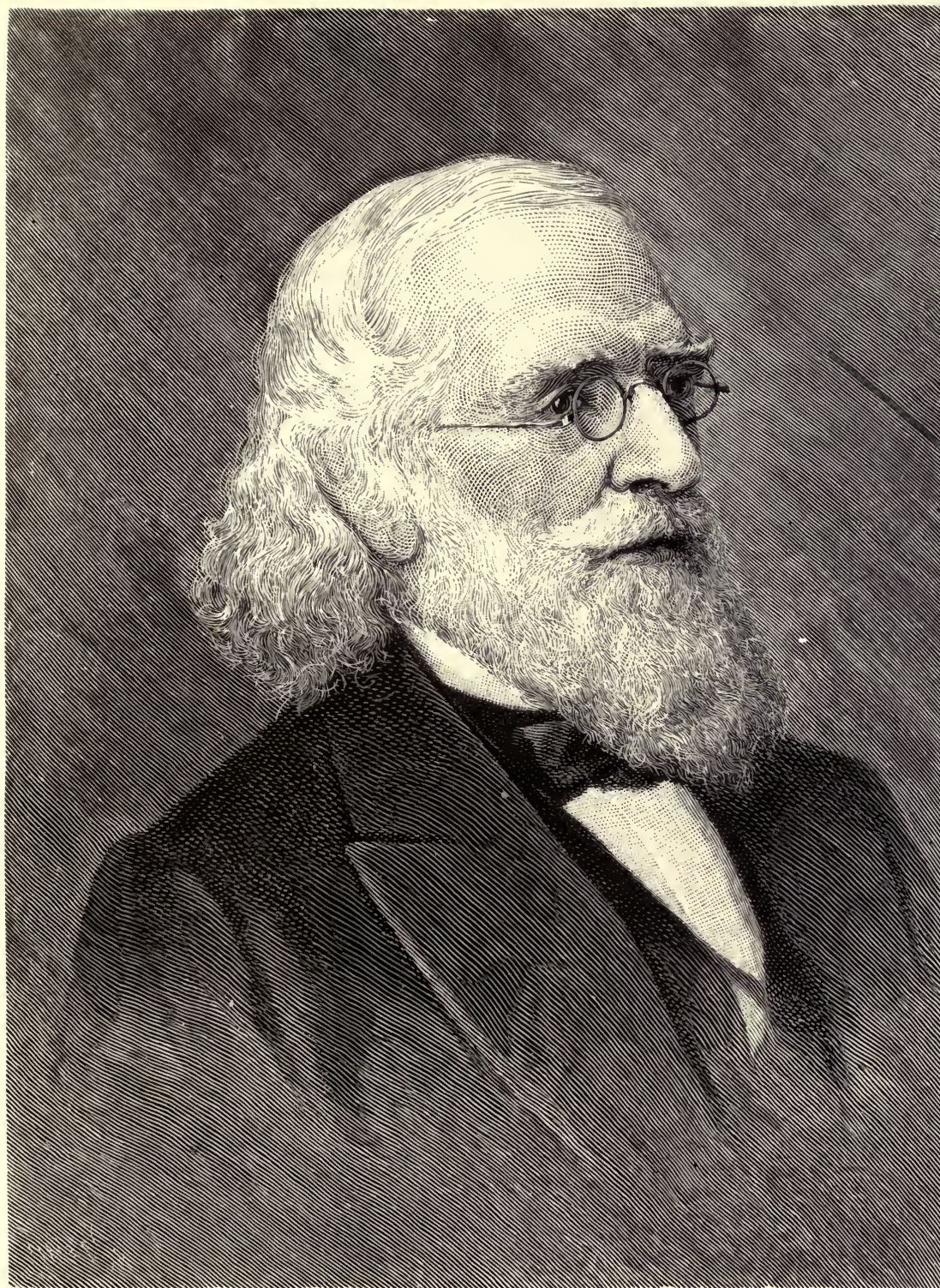

ISAAC LEA. 

the historian of the Inquisition; and Frances Lea, who died in I894. Mr. Lea had inherited a strong taste for Nature from his mother, and found a congenial spirit in Prof. Vanuxem, then also a youth, with whom he formed the habit of making collecting excursions around the city. The two companions were soon led, by what they found and observed, to inquiry into the composition and structure of the rocks; they had to pursue it at first without any guidance, but in a short time became acquainted with the mineralogical collection of Dr. Adam Seybert. A diversion to their pursuits was given by the occurrence of the war with Great Britain in 1812 . They joined a volunteer rifle company, which offered its services to the Governor. Although the company was disbanded without being called into service, young Lea had, by joining it, engaged enough in war to violate the principles of the Society of Friends, and he lost his birthright in it. Among the excursions which the two youths made was one to the coal mines near Wilkesbarre, where they found slates containing mollusca, which Lea described forty years afterward in the Journal of the Academy of Natural Sciences. They walked back, over the Pocono Mountain through the Wind Gap, where Lea found the first trilobite they had ever seen, and down the Delaware River. In 1815 they were both elected members of the Philadelphia Academy of Natural Sciences, and began to take active parts in its proceedings; and in this society Mr. Lea read his first paper, already referred to, embodying the results of many years of close observation which the friends had made upon the rocks during their excursions.

On the publication, in 1818 , of Prof. Silliman's prospectus of the American Journal of Science, Mr. Lea procured the names of fourteen subscribers to the journal-an act which Prof. Silliman afterward declared "was the turning-point of the scheme"; for, receiving such encouragement from a person with whom he had no personal acquaintance, he was sure the journal would be successful. Mr. Lea contributed several papers to the early numbers of this journal, at the editor's request; but the article of this period which is perhaps most worthy of special mention is one that he published in 1828 in the American Quarterly Review, on the Northwest Passage, in which he expressed the opinion that, if the passage were ever made, it must be, as was indicated by the direction of the currents, 
from west to east. This hypothesis was verified in $185^{2}$ by Captain McClure's making the passage in the direction named.

As Mr. Lea advanced in his geological studies, he found that it was necessary to know something of shells. In order to study their genera as described by Lamarck, he imported a large collection of shells from China. He soon became interested in this branch of the science, and ultimately made it the leading object of his researches. A collection of severai species of Unio, including some beautiful and rare specimens, was sent to the Academy of Natural Sciences, in 1825 , by Major Long, of the Engineer Corps, who had obtained them in dredging the channel of the Ohio River below Louisville. At about the same time, Mr. Lea's brother Thomas, having engaged to look after the shells in the vicinity of Cincinnati, where he was living, shipped a barrel of shells of rare beauty, including six new species. The description of these specimens-Description of Six New Specimens of the Genus Unio-presented to the American Philosophical Society in 1827 , formed the first of that long series of papers on the Unio and allied shells which constitute the chief of Mr. Lea's works. Yet, at the time he presented it, he had no thought that he should ever have another word to say on the subject, for at that time no one conceived the infinite variety of species of the family which American waters are now known to contain. As a side result of Mr. Lea's interest in the Unios may be mentioned the conversion of his brother from an indifferent barreller of shells for another to an enthusiastic student of land shells and botany, and to be the author of a monograph on The Plants of Cincinnati.

Dr. Lea spent the travelling season of $183^{2}$ in Europe, where the journal of his excursions is a record of successive introductions to famous scientific men, and interesting conversations with them, in which he was never the only one who received information. In London he attended a meeting of the Geological Society, and met most of the leading geologists of Great Britain. At Oxford, he attended the second meeting of the British Association, over which Dr. Buckland presided. Meeting Dr. Buckland afterward in London, the conversation turned upon the quantity of coal in the United States. Dr. Buckland thought we had very little coal. Dr. Lea pointed 
out on a map the coal fields of the United States as they were then known. After several hours spent in the examination of the matter, Dr. Buckland taking notes all the time, the distinguished geologist remarked, as he took his leave to meet an engagement, that England had enough coal to supply the United States when its supply should fail. Dr. Lea replied that the quantity of anthracite and bituminous coal was almost unlimited in North America, and promised to send him maps and sections that would satisfy him upon the subject. He fulfilled his promise after he returned home, and, upon the evidence thus afforded, Dr. Buckland presented a paper to the next meeting of the British Association on the extent of our coal supply. At the British Museum, by the request of Dr. Gray, Dr. Lea went over the collection of the Unionida, arranged and named them correctly, and added some new species from the United States. He called, in Paris, on Baron Ferussac, the eminent student of terrestrial and fluviatile mollusca, who was then engaged in preparing his great work on the Unionida. During the conversation the baron "complimented Dr. Lea by saying that he could not go on with his work until he (Dr. Lea) had finished his memoirs." Dr. Lea afterward spent several hours in going over the baron's collections, which contained Unionide from Brazil, Syria, Turkey, and Egypt, and rearranging it, cutting down the species and forming numerous synonyms. Afterward, he met Blainville, Ferussac, and others at the Jardin des Plantes, to arrange and name all the Unionida of the collection there, to which he added fourteen species. From Studer, the elder, in Berne, he received the last copy in the author's possession of his work on the land and fresh-water shells of Switzerland, and compliments on the papers he had himself written. At Paris, again, he examined the Unionida in the Duc de Rivoli's collection, which contained all those of Lamarck, and was thereby able to identify all of Lamarck's species in his subsequent memoir. Calling on M. Gay by invitation, he was shown all the mollusca which that naturalist had collected in his travels, and was invited to select a specimen of each. Thus he found the most eminent naturalists everywhere, on the strength of the few papers he had published on American mollusca, ready to welcome him as one of themselves, and to receive instruction from him. Their general message to him was to go on with the investigations 
he had begun, with the assurance that no naturalist in America or Europe had the advantages that he possessed.

On returning home in November, 1832 , he found that he had been anticipated in a work he should have done on the Tertiary shells of Alabama, but, having specimens of the species in his cabinet, he prepared a paper, Contributions to Geology, which he presented to the Academy of Natural Sciences in August, 1833 . It contained two hundred and twentyone species. His Synopsis of the Family Naïades, published in 1836 , and afterward supplemented and expanded, is said to have settled satisfactorily to most conchologists the synonymy of the species. On receiving it, Prince Charles Bonaparte expressed a desire to see all parts of zoölogy treated in the same manner. In 1849 Dr. Lea presented a paper on the footmarks of the reptile Sauropus primavus, found by him in the red shales at Pottsville, Pennsylvania, seventeen hundred feet below the conglomerate, which was of interest on account of the discussion it excited as to the age of the fossil. The footprints were assigned to the old red sandstone, while Prof. Agassiz had declared that he did not believe that any air-breathing animals had existed before the new red sandstone. The discussion was kept up for several years, in the course of which Dr. Lea reiterated and maintained his position that the fossil was what he represented it, and that the formation in which it was found was the one indicated by Rogers as No. XI. Its interest has since been diminished by the discovery and authentication of fossils of air-breathers in still older formations. Another series of papers of peculiar interest was that concerning the fossil saurian of the new red sandstone (Clepsysaurus Pennsylvanicus).

Having retired from business in $185 \mathrm{r}$, Dr. Lea made another visit to Europe in $185_{2}$. Many of the incidents of his previous visit were substantially repeated, but in large part with naturalists of another generation than those whom he had met before. At Paris he arranged and named the Unionide in the cabinets of the eminent conchologists Boivin and Petit. He called upon Dr. Chenu to look for the original specimen of Mulleria of Ferussac, which had never been figured, but simply described as being in Lamarck's collection. "He told Dr. Chenu that he thought it must have been mixed with the Etheria, of which the collection had many specimens. Dr. Chenu declared this 
could not be so, or he would have seen it. As soon as he pulled out the drawer, Dr. Lea saw at a glance the identical specimen which Ferussac had described. He took it up and declared this to be it. Both the naturalists were surprised and delighted. . . . Thus Dr. Lea's theory of the genus Acostea, of D'Orbigny, was complete-it was a Mulleria." At Vienna he showed the Austrian naturalists some features in their species and specimens which had escaped their eyes. At Berlin he found Humboldt and other distinguished men of science much interested in what was going on in geology in the United States. At a dinner with the Philosophical Club in London, Sir Charles Lyell gave him credit for being the first and only one who had yet observed an air-breathing animal in so ancient a rock as that in which the Sauropus primavus occurred, and added that the Clepsysaurus Pennsylvanicus was the first discovery of bones in the new red sandstone, although a jaw of a similar animal had since been found. Colonel Sabine exhibited a bottle which he supposed had come through Behring Strait from Japan, which Dr. Lea was able to claim as a verification of his theory of a west-to-east Arctic current.

On his return home in November, 1853 , Dr. Lea found an accumulation of correspondence and specimens awaiting his attention that hardly diminished, so incessant were the fresh arrivals, during the remainder of his active life, or for twentyfive years. Among his new Southern and Southwestern correspondents was Bishop Elliott, of Georgia, who became greatly interested in the mollusca of that State, and engaged the interest of others in the subject and in collecting shells. The scientific researches of Dr. Lea were continued, with constant publications, until 1877 , when a sudden illness which came upon him in Southern California disabled him from further vigorous work. He still, however, continued to add to his collections and perform such work upon them as his strength would allow. He gave much attention to the microscopic examination of quartz crystals, with drawings and descriptions of the inclusions and markings of each, so that Prof. H. Rosenbusch, in his work on the subject, mentioned him as having been the first in America to enter into microscopic mineralogy. $\mathrm{He}$ had engaged, since his return from Europe, in other branches of natural history than conchology. The elephant folio edition of the account of the fossil footmarks near Potts- 
ville elicited warm commendation for the beauty of its execution and illustration. In 1858 appeared a memoir on the embryology of the Unionida, giving descriptions and figures of thirty-eight species. In all of his papers he described eighteen hundred and seventy-two species of mollusks of various kinds, most of which were from the United States. The series was embodied in a private edition of thirteen volumes, with three indexes, which the author distributed among men of science and learned societies. Richard Owen, acknowledging the receipt of one of the volumes, said, "They represent a kind or class of labours the most genuine and important and lasting, in the hard endeavour to gain a knowledge of Nature." Prof. Haidinger, of Vienna, said, on a similar occasion, that his work would "last as long as natural science shall be cultivated by mankind. The more it is compared and studied, the more appears your power of observation, your efforts in pursuing your object, your steadiness and perseverance." M. A. Boivin wrote, "You render a great service to science in devoting your time to the classification and description of the Unio." About ten thousand individuals were displayed in Dr. Lea's cabinet of Unionide, so arranged that each could be separately examined, and, in many instances, with a sequence from the youngest to the oldest, so as to exhibit the aspects of growth. His other cabinets contained nearly a thousand specimens of quartz crystals, nearly five hundred of corundum, thirty-five drawers of the mica group, and several hundred sections of lamina prepared for the microscope.

In 1884 Dr. Lea was able to receive and entertain about two hundred members of the British Association at his cottage at Long Branch; and in his ninety-fourth year he continued in good health, with his mental and physical faculties unimpaired. His death occurred December 8, 1886. He was President of the Academy of Natural Sciences in Philadelphia from 1853 to 1858 , and was President of the American Association in 1860. The list given in his Bibliography of the society honours conferred upon him numbers twenty-eight titles, and concludes with an etc. He received the degree of LL. D. from Harvard while absent in Europe in $185_{2-53}$. A correspondent, who maintained most intimate and confidential relations with Dr. Lea for more than twenty years, furnishes a sketch of his personal character and social life, from which we quote the following words: 
"Possessing a mind of great vigour and culture, he was a most genial companion to those whose tastes and sympathies accorded with his own. $\mathrm{He}$ was an ardent admirer of the works of Nature; and his cultivated mind enabled him to perceive many qualities and properties in them, the beauties of which are not comprehended by a less gifted observer. Few objects escaped his notice. He possessed, in an eminent degree, a prompt and keen appreciation of the sublime and of the grotesque; and a speedy judgment in detecting merit or fraud, affectation or sincerity.

"Dr. Lea habitually, during a period of nearly half a century, spent many hours of the night in his studies and his writings, seldom relinquishing them before midnight. These night studies were continued, with little intermission, until he was nearly eighty years old; and they were gradually and finally abandoned only in compliance with the warnings of his medical adviser. Until Dr. Lea became enfeebled with age, at a late period in his life, it was a source of great delight to him to collect mineral specimens in Chester and Delaware Counties in Pennsylvania. His most frequent companions, on such occasions, were Mr. William W. Jefferies, formerly of West Chester, and the writer. No ardent schoolboy manifested more enthusiasm in digging than he, when a fair prospect was afforded for obtaining specimens; and his well-trained eye quickly recognised a specimen, though covered with soil. He never permitted any person to clean his specimens excepting himself; and that operation he performed with great patience, in the most complete manner, in order to display all the beauties which the minerals possessed. He was familiar with nearly all the mineral localities in Eastern Pennsylvania. Many years ago the writer described a locality for minerals in Delaware County, which he supposed would be new to Dr. Lea, and received the following reply from him: "I have crawled all over that locality, on my hands and knees, a half-dozen times, with good results every time.'

"Dr. Lea was a strong admirer of gems, and his familiarity with precious stones was so great that he was considered to be one of the best judges of them in this country. He devoted more time than any other mineralogist to the microscopic examination of the precious stones; the results from which were published, at various times, in the proceedings of the 
Academy of Natural Sciences. He possessed a large collection of precious stones from all the important localities in the world; and copious notes, in his own writing, are still attached to all the specimens.

Another friend of Dr. Lea's expresses surprise that, in all the published notices of him, "no one has spoken of his wonderful powers of observation of Nature even in her minutest forms. You will pardon me if I say that I consider it one of his highest qualifications as a man of science. Nothing ever escaped his quick eye in the field or by the roadside when driving. Every tree, shrub, and flower, was full of interest to him, from which he ever imparted knowledge to his friends. In observing crystalline forms I believe he excelled others."

Another friend regards him from a different point of view, and says: "Something of his great-heartedness was revealed to even the casual observer. It found expression in form, and feature, and voice. Yet it was by those who knew him intimately that the social, affectional qualities of his nature were best perceived and most admired. Inheriting a loving spirit, and receiving the gentle impressions of a Christian home, he never lost his priceless dower. The demands of successful, enlarging business, the fondness for scientific study, the passion for scientific discovery, the allurements of fame, were wholly insufficient to make him other than amiable and self-forgetful. His home was the source and centre of his delight. He gratefully acknowledged his indebtedness to those on whom he lavished his regard. During all the years in which he used even the night-watches for his investigations, the early hours of evening were spent, with free and joyous mind, in the midst of his family. He ever took more from himself than from others. Hospitality was the very genius of his house. With gentlest, heartiest courtesy his friends were welcomed to his fireside and his board. To those of scientific turn his rare and extensive scientific collections were opened with genuine delight. For those whose choice was in other directions, provision was made with equal care and gladness. Toward little children, and the young in general, his sympathies went forth with spontaneous freedom. He delighted to show to childish eyes, and to explain to childish comprehension, the beauties and marvels of Nature. Especially did he rejoice in giving encouragement to those who were struggling upward against 
great odds. The sight of such aspiration always awakened his enthusiastic interest. Not a few who to-day occupy positions of honour and usefulness owe their success to his appreciative, generous help. To envy his heart was wholly a stranger, and thus his friendships with men of science, both young and old, and with men great in other walks, were peculiarly tender and strong.

"In truth his kindly interest included whatever affected the welfare of the race. He took pleasure in all honest effort. $\mathrm{He}$ exulted in all honourable achievement. He felt that he was personally indebted to whosoever made man better or more wise. In all social problems he took profound, unflagging interest. $\mathrm{He}$ sought to hold in view the progress of humanity in every land. In the alliance between religion and philanthropy and science he was a firm believer. $\mathrm{He}$ was confident that truth and right would triumph at last. To his perception the laws of Nature were the constancy of God's action, and Nature itself a transcript of the Eternal Mind." 


\section{LARDNER VANUXEM.}

$$
\text { 1 792-1 } 848 \text {. }
$$

LARDNer VanuXem was born in Philadelphia, July 23, 1792, and died at his home near Bristol, Pa., January 25, 1848. His father, James Vanuxem, was a shipping merchant of Philadelphia, formerly of Dunkirk, France-a man eminent in business and highly esteemed as a citizen and in social and domestic life. His name was originally written Van Uxem; the form was changed by him partly for convenience in writing, but largely because he had become a great admirer of his adopted country and wished to remove the foreign stamp from his cognomen. James Vanuxem's wife, Rebecca, was a daughter of Colonel Elijah Clarke, of New Jersey. Of their fifteen children Lardner was the eighth. Seven of these lived to long past middle life, and two of them to ninety and over. His maternal grandmother's name was Lardner.

Of the early educational course of the subject of this sketch there is no record, and no one living has any knowledge. It is thought that he was for a time a student in the Pennsylvania University, but this can not be verified. He entered his father's counting-house as a young man, but business proved very distasteful to him, his mind having been drawn previously to the cultivation of chemistry and mineralogy. $\mathrm{He}$ soon determined to give up all connection with business and devote himself to science. Accordingly, his father gave him the advantage of a three years' residence in Paris, at the School of Mines, where he became the associate of Prof. Alexandre Brongniart, the Abbé Haüy, and other distinguished men then prominent as professors in the schools of that great scientific metropolis. There he formed an intimate acquaintance with the late Prof. Keating, of Philadelphia, who in the same walks was drinking from the same fountain of knowledge. Being graduated in 1819 , after a short tour through some dis- 


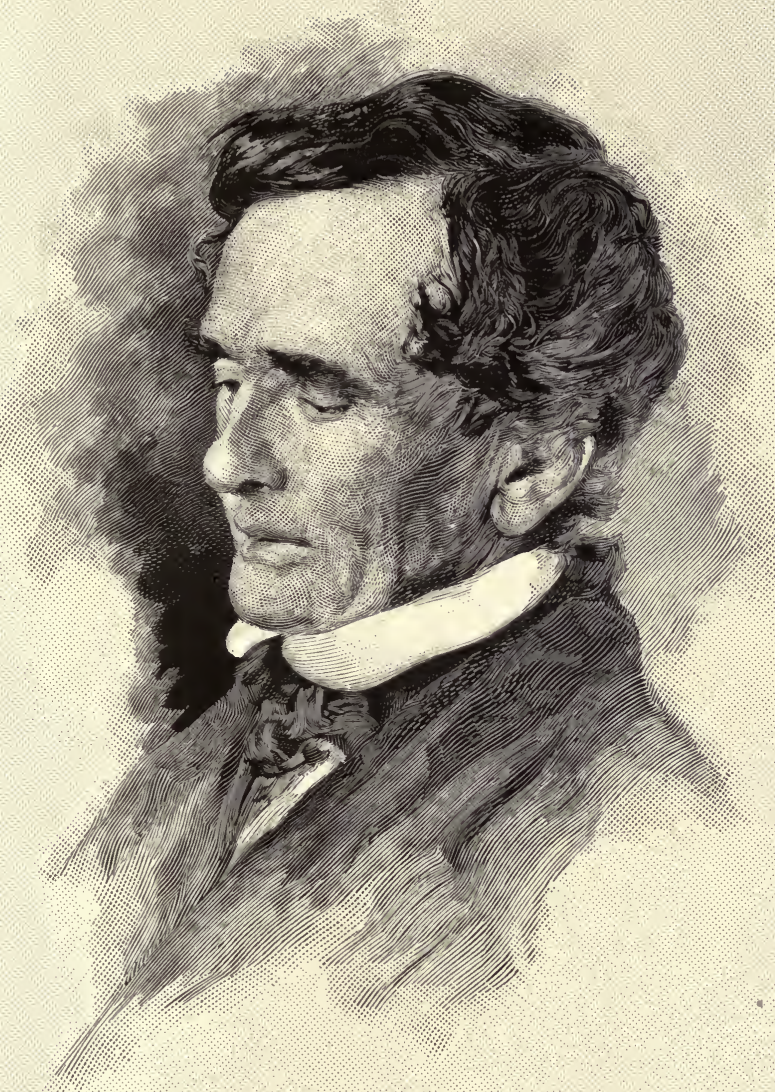

LARDNER VANUXEM. 

tricts of France investigating the rock formations, collecting specimens, etc., he returned to this country and his native city, "charged with all the improvements of recent chemical discoveries, and the advancement in all its kindred arts." But he preferred the more abstract pursuit of his studies to the application of his knowledge to the practical arts.

Almost immediately after his return home, he was invited by President Cooper, of Columbia College, in South Carolina, to take the chair of Chemistry and Mineralogy in that institution. Becoming a member of the president's family, a warm friendship was formed between him and each member thereof, which ended only with their lives.

In 1826 he retired from the college and devoted his attention exclusively to geology as a profession. During that year he published in the newspapers and in Robert Mill's Statistics of South Carolina reports on the geology of the State, of which he made a survey or assisted in making one, having previously made one of North Carolina. "He also made quite a collection of minerals and rocks of the State, which were deposited in the University of South Carolina."

He then visited Mexico to examine gold-mining property, of which he had been solicited to take charge. His inspection soon convinced him that no profitable results could accrue to the owners, and he advised that it be abandoned.

In $1827-28$ he studied the geological features of the States of New York, Ohio, Kentucky, Tennessee, and Virginia, under the auspices of the State of New York, and made his report to its Legislature.

It was either at this time or immediately after his return from France that he spent much time in geological investigations in the vicinity of Philadelphia in company with Dr. Isaac Lea, who was his chosen and most intimate friend and associate from his early days to the end of his life. Subsequently Dr. Lea honoured him by naming after him a class of freshwater shells which he had been the first to discover and make known. It is from Dr. Isaac Lea's record of him that much of the information in connection with science, contained in the first part of this sketch, is derived. He also made at times extensive and careful investigations in the franklinite districts and marl beds of New Jersey.

In 1830 , having returned to Philadelphia, he purchased a 
farm near Bristol, $\mathrm{Pa}$., and soon after married a daughter of his neighbour, John Newbold, Esq., of Bloomsdale. His farm remained the home of himself and family for the remainder of his life, about seventeen years. "While he often assisted with his own hands," says Dr. Lea, "in the cultivation of the farm, he never at any moment ceased to cultivate his already extensive acquirements in geology, mineralogy, and chemistry, nor to add to a collection of specimens of great extent and rareness."

In 1836 , at the solicitation of Governor Marcy, he entered upon what has been pronounced "one of the most magnificent investigations ever made in the geological developments of any country or by any government "- the geological survey of the State of New York. The results are given in Geology of New York, Third District, Albany, I842. The Third District, of which he had charge, comprised fourteen counties in the central part of the State. The scope of the work performed by Prof. Vanuxem and his colleagues is thus indicated by Prof. James Hall: * "During the few years of field work the New York geologists had harmonized the conflicting views before entertained regarding the relations of the geology of the eastern and western parts of the State; they had traced the boundaries of the successive geological formations, had shown the extent and limits of the iron-bearing strata, and had rectified the erroneous views which had been held till some time after the commencement of the survey regarding the boundaries and distribution of the salt-bearing formation of the State. They had also shown the limits of the granitic formations and their associated mineral products, the thickness and extent of all the limestone, sandstone, and shale formations of the State, and had definitely settled the relations of the rocks of New York to the coal measures of Pennsylvania and the geological formations of the Western States."

The important service rendered to geological science in the matter of nomenclature by the members of this survey is also described by Prof. Hall, as follows: "Since there was no possibility of identifying the individual rocks and groups of strata with those of Europe, as described, the New York geologists were compelled to give names to the different members of the

* In The Public Service of the State of New York. 
series; and since the sandstones, limestones, slates, and shales are so similar in different and successive groups, it was impossible to give descriptive names which would discriminate the one from the other. Therefore local names were proposed and adopted-as, for example, Potsdam sandstone, Trenton limestone, Niagara limestone, and Niagara shale (the two latter, with subordinate beds making the Niagara group), the Medina sandstone, the Onondaga salt group, the Hamilton, Portage, and Chemung groups, thus giving typical localities of the rock instead of descriptive names. This method or system of nomenclature leaves no possibility of mistake or confusion which might arise from a different appreciation of descriptive terms. The typical locality always remains for study, comparison, and reference, and there need be no difference of opinion or discussion as to what was intended by the use of any one of the terms. The progress of geological science in the country is greatly indebted to this system of nomenclature, and to the absolute working out of the succession of the groups, and the members of the same, to which this system of nomenclature has been applied."

At the close of the survey he spent some months in Albany (associated with Prof. Hall) in arranging the State geological cabinet, the specimens of which he had assisted in collecting, and out of which has grown the New York State Museum. His name was given by his colleagues to several species of the fossils discovered in the course of the survey, and in $185^{8} \mathrm{Mr}$. Elkenah Billings named a genus (discovered in Canada) in his honour.

Prof. Vanuxem's private collection of minerals and geological specimens was considered at the time of his death as "the largest, best arranged, and most valuable private collection in this country." The shell and mineral specimens were fine and many of them very beautiful, but it was the geological department, with its numerous specimens of rock and fossil and the perfect arrangement of the whole, giving to the investigator, in the best manner possible, the information sought, and all arranged by his own hands and methods, that constituted its chief value. It was constantly visited by eminent scientists both of this country and from abroad. Prof. Agassiz, Sir Charles Lyell, and Dr. Nicolay were drawn to it on more than one occasion. Those who were in the habit of visiting it most frequently, both from interest in it and its possessor, seemed to 
be filled with enthusiasm, of whom were Dr. Emmons, Dr. Beck, Prof. Timothy Conrad, Dr. Locke, of Cincinnati, and many others. On one occasion, while engaged on the United States Coast Survey, Dr. Locke brought all his paraphernalia of work and his assistants, pitching his tents in a field on the Vanuxem farm near the house; there he remained for some weeks, continuing his work, at the same time availing himself of the opportunity of study in and examination of the cabinet, making numerous casts of the specimens, especially the rare fossils.

After his death, Prof. Vanuxem's collection was purchased by W. M. Stewart, President of Masonic College at Clarksville, Tenn. It was reported that during the civil war the collection was dissipated and destroyed, but this rumour could not have been wholly true, for part if not all of the specimens are still there. In May, 1892 , one of Prof. Vanuxem's daughters was applied to by a geologist for information as to the whereabouts of this collection, as it contained, he said, the only known specimen of a certain South Carolina fossil, which he very much desired to examine.

Prof. Vanuxem was a member of and assisted in the organization and establishment of the Philadelphia Academy of Natural Sciences and other scientific associations.

"It was the habit of those connected with the New York survey to meet at Albany at the end of each field season, for the purpose of comparing observations and becoming acquainted with each other. In the autumn of 1838 Prof. Vanuxem suggested that an invitation be extended to the geologists of Pennsylvania and Virginia for the purpose of devising and adopting a geological nomenclature that might be acceptable to all those who were then engaged in the State surveys, and thus become the nomenclature of American geology. This meeting was finally held in 1840 , and then the Association of American Geologists was organized, which is now succeeded by the American Association for the Advancement of Science."

Some few years after the close of the New York survey, Prof. Vanuxem was solicited by Prof. Henry, of the Smithsonian Institution, at Washington, to become his associate in charge of that institution. Although it would have been a work in many ways congenial, the offer was declined, for various reasons that he deemed good ones.

In addition to the report that has been mentioned, and nu- 
merous papers on scientific subjects published in the American Journal of Science, he published An Essay on the Ultimate Principles of Chemistry, Natural Philosophy, and Physiology (Philadelphia, 1827 ); but it is his Report of the New York Survey which it is said "will remain his monument, and on which the reputation of his scientific attainments is based."

It would seem as though a man as devoted to science as the subject of this sketch would have his time and thoughts completely absorbed thereby, but not so in this case. The investigating turn of his mind prompted the examination of abstruse subjects, and to him the Scriptures presented an unlimited field. His careful scrutiny of the sacred writings and close study of all the extant commentators upon them resulted in an immense pile of manuscript books which he left as a monument of his interest in the subject, untiring industry, perseverance, and love of research, if nothing more. Although trained in the Presbyterian faith by his mother, Prof. Vanuxem had adopted, and expressed in these writings, views which were too broad and too far in advance of the time to be considered "orthodox."

Every attempt to extend the bounds of human knowledge or to give the benefit of enlightened direction to the activities of mankind aroused his interest. His attention was thus drawn to the so-called new religions, Mormonism and Millerism, as they arose; to the religious teachings of Channing and Emerson; and to the study of Egyptian antiquities. He studied phrenology, and became a believer in its theories. At a time when the subject had hardly been thought of he was a strong advocate of the emancipation of woman from the narrow sphere of activity to which she had been confined. General literature did not have the absorbing interest for him that scientific subjects did. As for music, it appeared to have no charms in his eyes; he declared that far too much time was wasted over it. This fact seems rather unaccountable, as all his brothers and sisters were devoted to the art, and some of them proficient in it.

For Benjamin Franklin's character and achievements he had the highest admiration; honouring himself and his place by naming it after him "Franklin Farm," and the entrance hall of the house was adorned for many years by a bust of the great man; attention often being called to it as "the presiding genius of the place." 
To complete the picture, even of a man of science, the social and domestic side of his character and life as well as daily occupations must not be omitted. He was kind and gentle in manner and speech, his somewhat quick temper being under complete control. Though his children stood rather in awe of him, as did many others (of his subordinates), he ruled them by affection and "treated them as intelligent beings," as he said, the result being the most implicit obedience.

His active mind was engaged frequently upon subjects requiring deep thought while his hands were executing works of minor importance. On being asked why he did not plow his own fields, he would reply that he never liked to engage in any manual labour that absorbed the whole attention, as he desired to keep his mind free for other matters. His knowledge of chemistry was brought into use in the cultivation of his farmmuch to the amusement of his less enlightened neighbours, who did not believe in "book farming." He had learned the use of carpenter's tools when a boy, for his father, in order to keep his sons off the street, had wisely provided them interesting occupation at home by fitting up a shop for their use. Prof. Vanuxem turned his skill to account in making the cases and chests of drawers in his cabinet-a room measuring about fifteen by twenty-five or thirty feet-and otherwise as occasion required.

"Always cheerful, intelligent, bright, and full of anecdote," it has been said of him, "he was gladly welcomed into every social circle." Both frugality and generosity were prominent traits of his character. More than once did he take into his household, for indefinite periods, young relatives who needed assistance. His table was abundantly supplied and his house was well furnished with comforts, but extravagance in anything he strongly deprecated, especially in dress. "Love of dress," he used to say, "had caused more sin than anything else in the world."

Careful and neat to an extreme himself in his habits and arrangements, he exacted the same from those around him as far as possible. Of the courtesies and conventionalties he was most scrupulously observant, and was greatly annoyed by any breach thereof, as when any of his Quaker neighbours, coming in, would sit with hat on in the house. Obedience to the "golden rule" appeared to be the guide of his life, as he was 
wont frequently to hold it up to his children, that they should make it theirs.

He had the reputation of being visionary and full of untenable theories. This may have been true to some extent, and it would certainly have appeared to be the case even if not so, for it was often said by his scientific contemporaries that "he lived too soon, being many years in advance of his times; people were not prepared for his discoveries and theories, and therefore not able to appreciate them, even the scientific world." He was considered also "a very peculiar man," which was not surprising, in view of his independence of general opinion, in following out what he considered the right or best course in any matter. As an illustration might be given a description of his equipment for the New York survey. It consisted of a four-wheeled wagon with buggy top, covered with white canvas for coolness, with a box at the back large enough to hold his requirements for the season, and working implements. This was drawn by a large, rusty-brown mule, very far from handsome, but strong, trusty, faithful, with powers of endurance much beyond those of a horse. He was often not a little amused at the comments and ridicule that this equipage provoked, but it was the thing that best answered his purpose, so he went on his way and let them laugh.

The necessity for turning his acquirements to some pecuniary advantage, was one of the inducements for Prof. Vanuxem to engage in the New York survey. The working for "pay" was one of the things for which he had a great aversion, "a feeling," as he writes, "he never could conquer." $\mathrm{He}$ wanted to be able to work for the public without charge and not feel that his time belonged to some one who had a right to its control; he was too conscientious to feel any freedom when under bonds of this sort.

Physically Prof. Vanuxem was below the average in height, rather slightly built, active, energetic, with great powers of endurance, and persevering in whatever he undertook. He was always in good health, being "temperate in all things," and, though often furnishing wine for his guests, declining the use of it himself, as he said he wished to keep his head always perfectly clear. To tobacco in all its forms he had a great aversion. One of his theories was that human life was much too short, either because of too much luxury and self-indulgence 
on the one hand, or lack of proper sustenance on the other. By striking the happy medium, he believed life might be indefinitely prolonged. His last illness was of about three weeks' duration, and caused by a carbuncle on the upper lip. After a time the brain became affected and unconsciousness ensued, which continued uninterruptedly until he passed away, having seen but fifty-five and a half years. This early ending of his life seems like the irony of Fate! The many letters received by the family after his death, from those with whom he had been associated in his scientific career, filled with such heartfelt expressions of sorrow and regret for the personal loss and the loss to science, attest the estimation in which he was held by them all.

The original of the likeness accompanying this sketch was a daguerreotype-the only portrait of any kind ever made of Prof. Vanuxem. This was taken in a group in 1846 , in the early days of the art, when the arrangement of dress and pose was not understood so well as afterward. Hence the eyes, said to have been his best features, are unfortunately cast down, as he was told to look at the child seated on his knee. The portrait is like him, but has not the pleasing aspect his countenance always wore. 



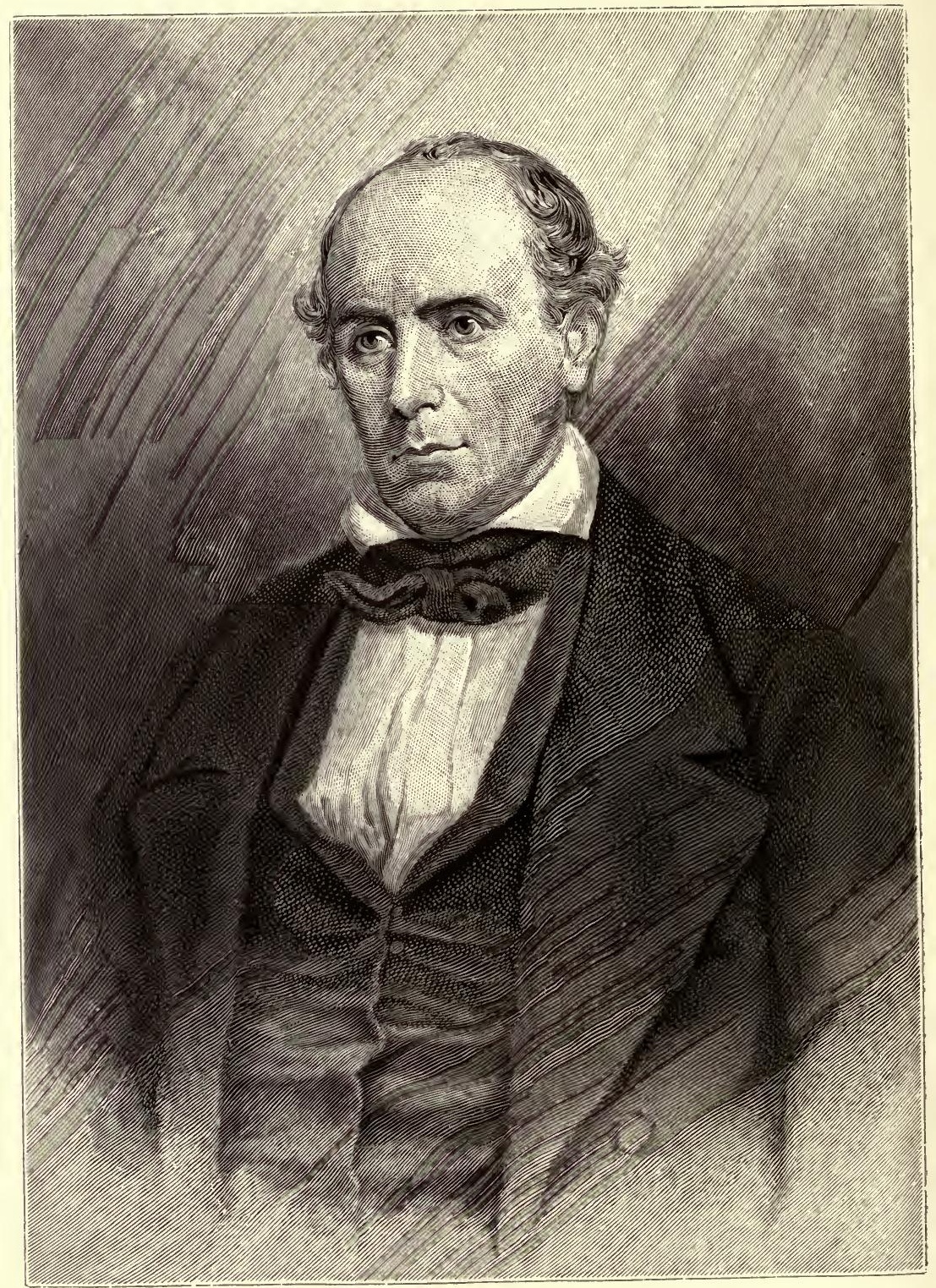

ELISHA MITCHELL. 


\section{ELISHA MITCHELL.}

$$
\text { I 793-1 } 857 \text {. }
$$

A monument of modest size and style, standing in Yancey County, North Carolina, on the highest point of land in the eastern United States, marks the grave of the man who first determined, by measurement, the culminating point of the Appalachian range-a man, too, whose local fame as a student of natural history, a hardy explorer, and a teacher, was pre-eminent. Not the little obelisk of bronze-that only shows the exact spot where his body lies-but the mountain on which it stands, whose supremacy over all the peaks east of the Rocky Mountains he established, and in the exploration of which he lost his life, is the true monument of Prof. Elisha Mitchell.

Elisha Mitchell was born in Washington, Conn., August 19, 1793. His father, Abner Mitchell, was a farmer; and his mother, Phebe Eliot, was a descendant, in the fifth generation, from John Eliot, the Apostle to the Indians. His great-grandfather, the Rev. Jared Eliot, M. D. and D. D., for many years minister at Killingworth, Conn., was distinguished for his knowledge of history, natural philosophy, botany, and mineralogy, no less than as a sturdily orthodox theologian; was a correspondent of Dr. Franklin and Bishop Berkeley, and was awarded a gold medal by the Royal Society for a discovery in the manufacture of iron. Young Mitchell inherited many of the qualities of the Eliots, and particularly of this ancestor. At four years of age he acquitted himself with credit in a school exhibition. At a little latter age he was" fond of collecting his playmates in a group and telling them what he had read in his books, or explaining the pictures to them. He was prepared for college at the classical school, in Bethlehem, of the Rev. Azel Backus, D. D., afterward President of Hamilton College. He was graduated from Yale College in 1813 , in the same class with Denison Olmsted, afterward his associate in 
the University of North Carolina, and with other persons who subsequently became conspicuously known. He was then engaged as a teacher in Dr. Eigenbrodt's boys' school at Jamaica, L. I.; in the spring of $18 \mathrm{I}_{5}$ he took charge of a school for girls at New London, Conn., where he became acquainted with the lady who was afterward his wife; and in 1816 he was appointed a tutor in Yale College. While thus engaged, he and Prof. Olmsted were recommended by the Rev. Sereno E. Dwight, son of President Dwight, Chaplain of the United States Senate, to Judge Gaston, member of the House of Representatives from North Carolina, who appears to have been looking around for candidates as suitable persons for professorships in the University of North Carolina, at Chapel Hill. Mr. Mitchell was chosen Professor of Mathematics, and Mr. Olmsted Professor of Chemistry, to which a chair was then for the first time assigned. Having studied for a short time at Andover Theological Seminary and received a license to preach, Mr. Mitchell removed to North Carolina, and reaching Chapel Hill on the last day of January, r8I8, immediately began his work as a professor. Here he remained, continuing at his post without intermission of considerable length, for thirty-nine years, or till the end of his life.

In the fall of the next year Prof. Mitchell returned to Connecticut to be married to Miss Maria S. North, daughter of Elisha North, M. D., of New London. The bride's letters describing her journey to North Carolina give some sidelights on the life and methods of travel of the time. The marriage took place on Friday, the choice of the day having been partly made as a demonstration against a popular superstition, and partly determined by circumstances. The journey of eight hundred and fifteen miles to Chapel Hill occupied ten days. On the removal of Prof. Olmsted in 1825 to accept a professorship in Yale College, Prof. Mitchell was transferred to the chair he had filled, and became, and continued till the end of his life, Professor of Chemistry, Mineralogy, and Geology.

Dr. Albert R. Ledoux, in a historical sketch of the University of North Carolina, published in the University Magazine for October, 1890 , speaking of the intellectual giants in its faculty who have given reputation to the institution, and whose contributions to letters and science made them prominent among the learned men of their day, observes that Prof. Mitch- 
ell was the most noted of them all. During his occupation of the chair of Mathematics, the doctrine of fluxions, or the calculus, was introduced into the course, and the standard of attainment was raised in other branches of the department. His transfer to the chair of Natural Science was welcome to him. Even while a Professor of Mathematics, according to Prof. Charles Phillips, he had made frequent botanical excursions in the country round Chapel $\mathrm{Hill}$; and after settling himself in his new chair he extended and multiplied these excursions; "so that when he died he was known in almost every part of North Carolina, and he left no one behind him better acquainted with its mountains, valleys, and plains ; its birds, beasts, bugs, fishes, and shells; its trees, flowers, vines, and mosses; its rocks, stones, sands, clays, and marls. Although in Silliman's Journal, and in other periodicals less prominent, but circulating more widely nearer home, he published many of his discoveries concerning North Carolina, yet it is to be regretted that he did not print more and in a more permanent form. It would doubtless have thus appeared that he knew, and perhaps justly estimated the worth of, many facts which much later investigators have proclaimed as their own remarkable discoveries. But the information that he gathered was for his own enjoyment and for the instruction of his pupils. On these he lavished, to their utmost capacity for reception, the knowledge that he had gathered by his widely extended observations, and had stored up mainly in the recesses of his own singularly retentive memory." The notes of his excursions, which are recorded in a series of blank books kept for the purpose, give revelations of the habits of the author's mind; they chronicle his walks over farms which he names, and observations of individual plants and other objects in specified localities. "By such a rock," writes Mrs. C. P. Spencer, in an article of reminiscences, "in such a field, is a plant that he must identify. By Scott's Hole, near the willow is a Carex that he must watch. March 29, 182r, he finds yellow jessamine in bloom in Mrs. Hooper's garden, and 'in great abundance on the creek below Merritt's mill.' ... May 30, I82 I, occurs this note, that he had that day found the last of the twelve varieties of oak that are within two miles of the university; then follows a list of the oaks and notes of their situation. ... In the third week of April, 1824, he began a new 
Diary of Mosses, and hunts the Liskea hypnum through a dozen authorities, to be sure of it. He had the true scholar's disdain of taking anything at second hand. Such pages are diversified with 'Hints for the good instruction of the class'; or, 'Points to be meditated respecting the nature of light." " In the preface to one of these notebooks-written in French-a plan of study was laid down for each week. So many hours were to be given to mathematics, so many to Latin and Greek, so many to history, so many to the Spanish language and to botany; and the resolution appears that, till such an hour, "I will not touch one book of belles-lettres." $\mathrm{He}$ thus visited the plants and rocks of the State in their own homes, and became one of the best authorities in the country respecting them. The expeditions which he conducted into all parts of North Carolina, examining the flora and rocks and strata, made him the best physical geographer the State had ever had. The information he gathered in this way was used profusely in the instruction of his classes, and they always reaped greater benefits from his acquisitions than any other part of the community. While he wrote occasionally for the scientific papers, "he read more than he observed, and observed more than he wrote." Among the articles contributed by him to Silliman's Journal are named, in a memoir published in the local paper at the time of his death, those on the low country of North Carolina, 1828; on the Geology of the Gold Regions of North Carolina, r 829; on Welther's tube of safety, with notices of other subjects, I830; on the causes of winds and storms, 1831 ; Analysis of the Protogæa of Leibnitz, I83 $\mathrm{I}$; and notices of the high mountains in North Carolina, 1839. Such articles were contributed at intervals till the time of his death. $\mathrm{He}$ also prepared for use in his classes a Manual of Chemistry, the second edition of which was passing through the press when he died; a Manual of Geology, illustrated by a geological map of North Carolina; and Facts and Dates respecting the History, Geography, etc., of Palestine.

Prof. Mitchell was an industrious reader, particularly on all subjects that were directly or indirectly connected with his professorship, and had a knowledge of geography that was regarded as wonderful. At a time when students were more isolated from one another than they are now, and facilities for exchange of news were not so abundant, he was at great pains 
to keep up with the advance on every side. With all this he was of conservative tendency, and not disposed to accept the new too hastily. As a teacher, Prof. Phillips says, "he took great pains in inculcating the first principles of science. These he set forth distinctly in the very beginning of his instructions, and he never let his pupils lose sight of them. When brilliant and complicated phenomena were presented for their contemplation, he sought not to. excite their wonder or magnify himself in their eyes as a man of surprising acquirements, or as a most dexterous manipulator, but to exhibit such instances as most clearly set forth fundamental laws, and demanded the exercise of a skilful analysis. Naturally of a cautious disposition, such had been his own experience, and so large was his acquaintance with the experience of others, that he was not easily excited when others announced unexpected discoveries among the laws and the phenomena which he had been studying for years as they appeared. While others were busy in prophesying revolutions in social or political economy, he was quietly awaiting the decisions of experience. He constantly taught his pupils that there were things wherein they must turn from the voice of the charmer, charm he ever so sweetly. His influence on the developments of science was eminently conservative, for he loved the old landmarks."

Prof. Mitchell's general fame rests chiefly on his work in the exploration of the Black Mountain of North Carolina, a spur which, standing between the main mountain ridges, had been regarded by persons best acquainted with the region, without knowing its exact height, as the culminating point of the Appalachian system. The two Michauxes had remarked, about the beginning of the century-the elder in I799, and the younger in 1802 - the presence of Alpine plants there that were not found again south of Canada, and inferred that the peak must therefore surpass all its fellows in height. John C. Calhoun had come to a similar conclusion, from the observation of the streams that had their source on the mountain. Meeting the Hon. David L. Swain, who was afterward President of the university, in $1825, \mathrm{Mr}$. Calhoun congratulated him on being of the same height with Washington and himself, and on their both residing in the neighbourhood of the highest mountain on the continent east of the Rocky Mountains. When asked the meaning of his remark, Mr. Calhoun referred to the map as 
showing that in this group were to be found the highest sources of one of the great tributaries of the Mississippi, the Tennessee; of the Kanawha, flowing northward into the Ohio; and of the Santee and Pedee, which run directly to the Atlantic-all considerable rivers finding their way to the sea in opposite directions. The story was told by Governor Swain to Prof. Mitchell in 1830 , during an excursion on the Cape Fear River. Although Mr. Calhoun's reasoning was defective, his observation, coupled with the opinion expressed on other grounds by the Michauxes, impressed Prof. Mitchell, and aroused a desire in him to know more of the Black Mountain, and to determine its height. The opportunity came in 1835 . The memorandumbook in which the notes of his visit in that year are recorded contains such entries as "Objects of Attention-Geology; Botany; Height of the Mountains; Positions by Trigonometry; Woods, as the Fir, Spruce, Magnolia, Birch; Fish, especially Trout; Springs; Biography," etc. He was accompanied by his daughter, and carried "two barometers, a quadrant, a vasculum for plants, and a hammer for rocks." The incidents of this expedition, the details of which became important in the case of a controversy that afterward arose, have been summarized and confirmed by the testimony of witnesses in an article which Prof. Charles Phillips contributed to the North Carolina University Magazine for March, I858. Having made some observations of the geological formations of the Grandfather Mountain, and measured some heights near Morgantown, Prof. Mitchell crossed the Blue Ridge and fixed his headquarters at Bakersville, in Yancey County, near the foot of Roan Mountain. From here he made several excursions in a country which was then nearly in the condition of the primitive wilderness. Being told that Yeates's Mountain was the highest of the group, he climbed it, accompanied by two guides, on the 27 th of July, I 835-a day so clear and serene "that all the main eminences of the Black were clearly visible." He found that this mountain was overtopped by several of the peaks around it, the most of which confronted him in an arc so curved that it was easy to decide which of them was the highest. He made the entry: "Top of Yeates's knob; N. E. knob of Black bore N. $46^{3 / 4}$ E. Counting from Young's knob: one low one; one low one; two in one, the southernmost pointed; a round knob, same height; a double knob; then the highest; then a long, low place with a 
knob in it; then a round three-knobby knob, equal to the highest, after which the ridge descends." This verbal account tallies exactly with a profile of the range drawn by Prof. Guyot when standing on the same Yeates's Peak in 1856 . On the next day, July 28th, Prof. Mitchell and his guides visited the peak which had been determined by the Yeates's Mountain observation to be the highest; according to the testimony of the guide, William Wilson, they "came to the top at a small glade, not more than a quarter of an acre in extent, and, turning to the right, not more than one hundred and fifty yards, we arrived on the top of the main highest peak, being the same one as we thought that we had selected from Yeates's knob the day before. Then Dr. Mitchell climbed into the highest balsam he could find, and took his observations. After consulting his barometer, he said that it was the highest point that he had found yet."

Some of the immediate results of the excursions from $\mathrm{Ba}$ kersville, including geological and botanical observations, were published in the Raleigh Register of November 3, I835. The height of the mountain was calculated as compared with that of Morganton, which was then supposed to be 968 feet above the sea. The mountain being found to be 5,508 feet above that point, its height was given as 6,476 feet, or 200 feet less than the real height. The discrepancy became afterward a source of confusion, and has been used to support the allegation that the peak Dr. Mitchell climbed that day was not the real highest peak. But it was explained and vanished when the railroad surveys showed that Morganton depot is really $\mathrm{r}, \mathrm{I} 69$ feet high. This would make Prof. Mitchell's real measurement 6,677 feet, nearly what he obtained $(6,672$ feet) in 1844 . Prof. Guyot, in 1856 , obtained a height of 6,701 feet.

Doubts afterward rose in Prof. Mitchell's mind whether the peak he climbed in 1835 was the true summit of the mountain. A new measurement of Mount Washington had been made, which seemed to add to its reported height and lift it above Mitchell's Peak. Dr. Mitchell revisited the mountain in 1838 , and determined in 1844 to make a new survey and measurement. He obtained a Gay Lussac mountain barometer from Paris, took William Riddle as his guide, and, making Asheville his base for comparison, found the height 6,672 feet. The identity of the peak visited this time was afterward called in 
question by other parties, but Prof. Mitchell himself never doubted that he had been on the right spot. He wrote in the summer of 1856 : "I stood upon the highest peak some days since, and could then distinguish the ridges over which my guide, William Riddle, taking as nearly as he could a straight, or, as it happened, a diagonal direction across them from the neighbourhood of the Green Ponds, led me directly to the peak we were in search of."

After the survey of 1844 , the Hon. Thomas L. Clingman put forth a claim to having been the first to measure the real culminating point of the Black Mountain, and undertook to prove that Prof. Mitchell had been mistaken in the mountain which he measured. The question thus raised was the subject of an active controversy for several years. The highest mountain was called Clingman's Peak, and Prof. Mitchell's name was transferred to the peak which was described in his diary of I835 as "a round three-knobby knob, equal to the highest," which he had never assumed to climb or to measure. It was as much to settle this dispute as for the sake of more accurate measurement that Prof. Mitchell made his fifth visit to the mountain in 1857 , in which he lost his life. The question was investigated by his friends after his death, when all the accessible evidence was collected and compared, and his priority in measuring the peak, and the identity of the mountain he measured in 1835 with the real highest point, seem to have been satisfactorily established. In evidence to support his claim, Prof. Phillips brought forward the notes in his diary of 1835 and their exact correspondence with Prof. Guyot's profile; the testimony of William Wilson, one of the guides who went up with him, and who gave in his certificate a correct description of the topography of the summit, and of Nathaniel Allen, son of Adoniram Allen, the other guide, deceased, who said that his father had always spoken of that peak as the one which he ascended with Prof. Mitchell; the certificate of four citizens who accompanied William Wilson in September, 1857 , while he retraced the steps of the ascent of 1835 ; the testimony of numerous citizens respecting the landmarks and the geographical features, particularly of the streams, by which the true highest peak is located and identified; and the testimony of the same citizens that this peak was generally known through the country as Mount Mitchell or Mitchell's High Peak, while the other 
mountain (Party Knob) to which Prof. Mitchell's name has been attached was not so known till after the visit of 1844 .

Prof. Mitchell's fifth visit to the Black Mountain, in 1857 , was made in view of the controversy with Dr. Clingman for the sake of obtaining more careful and accurate measurements than he had been able to secure before, and for the purpose of investigating the value of the number which is used in calculating heights by barometrical observations. To this end he had provided himself with four of Green's Smithsonian barometers, and sent one of them to Savannah to be employed in contemporaneous observations by Dr. Posey at the level of the ocean and nearly on the same meridian as the Black Mountain. $\mathrm{He}$ further intended to connect the beach-mark on the North Carolina Western Railroad survey by a line determined by a spirit-level with the top of Mitchell's Peak. After marking off points differing in height by five hundred or a thousand feet, he designed to continue contemporaneous barometrical and thermometrical observations for several days at each of these points, and thus obtain reliable data for a full discussion of questions concerning measurements by barometer in the latitude of the region. He began to survey about the middle of June. On the $27^{\text {th }}$ of that month, when his work was about half completed, he separated from his son, with the intention of going across the mountain to the Caney River settlement to visit the Wilsons and Mr. Riddle, his former guides, and securing their assistance in identifying points which they had visited together. He was never seen alive afterward. A storm arose that evening, in which he probably perished. When it was found that he had neither reached Mr. Wilson's nor returned to his lodgings, parties started in search of him. As the search continued, and the news spread that he was missing, the parties grew, and soon included a considerable part of the mountain population of Yancey and Buncombe Counties; for the people were all warmly attached to him. His trail was found and followed to a point where the guides declared, from its irregularities and the evidences that the wanderer had become no longer able to pick his course, that darkness had overtaken him; thence along a small creek to a place now called Mitchell's Falls; and there, on the 7 th of July, the body was found in the pool below the falls. The marks on the bank showed that Prof. Mitchell had slipped forty-five feet down the slope and 
then fallen fifteen feet into the pool. The body was borne by the Yancey men, after the coroner's inquest, a distance of about three miles, to the top of the mountain. Then word came that it was to be taken to Asheville; and the men of Buncombe took it up and carried it there.

Not quite a year afterward, in June, $185^{8}$, the body was exhumed from the graveyard of the Presbyterian church in Asheville, and was carried again, this time with formal ceremonies, and a procession of citizens, large considering the character of the march, to the top of the mountain, where it was laid in the earth, within a few feet of the famous balsam tree. A funeral discourse was pronounced by Bishop James H. Otey, D. D., of Tennessee, one of Prof. Mitchell's first pupils, and an address in vindication of Prof. Mitchell's claims to have the mountain named after him was delivered by President Swain. It is worthy of remark that the first class taught by Prof. Mitchell in the university was represented at the ceremonies, in the persons of Bishop Otey and Dr. Thomas H. Wright, of Wilmington, and the last class by Mr. J. W. Graham and his own son. A monument, twelve feet high, in the material known as white bronze, was erected over the grave in 1888 .

The question of the name of the mountain appears to have been decided by the United States Geological Survey in I $88 \mathrm{I}-$ '82, which, adopting the final designations for the peaks of this range, gave Prof. Mitchell's name to this one.

Prof. Mitchell was a Presbyterian minister of the Presbytery of Orange, Synod of North Carolina, and was styled, in the memorial resolutions passed by the synod, probably the most learned man that had ever lived in the State; was a regular preacher in the college chapel and the village church; and was the college bursar, a justice of the peace, a farmer, a commissioner for the village of Chapel Hill, and at times its magistrate of police. He was known as a skilful and conscientious professor, and vigilant, long-suffering, firm, and mild as a disciplinarian. Believing that prevention of the ills of a college life was better than having to cure them, he was watchful to guard the students against falling into error. When offences were committed, he would try to present the nature of his conduct to the culprit in its true light, and, when punishment had to be inflicted, to select such a method as would appeal to his better feelings and open the way to a return to sound views. 
He was extensively known among the mountaineers, who all had a remarkably warm affection for him, and the interest that was aroused among them by the circumstances of his disappearance was still "warmly alive," and the event was still a topic of conversation as late as the end of r889. 


\section{EDWARD HITCHCOCK.}

$$
\text { I 793-1864. }
$$

Born at Deerfield, Mass., May 23, I793; died at Amherst, Mass., February 27, 1864.

The first of this family emigrated to this country in 1635 , coming probably from Warwickshire in England. He was one of the original members of the New Haven, Conn., Colony. Two or three generations of the family resided in New Haven; the fourth in the line emigrated to western Massachusetts, and was an officer in the Revolutionary War. His son, Justin, the father of Edward, was a soldier in the army of General Gates when Burgoyne's army was captured. Justin married one of the Hoyts, who was descended from the sufferers at Deerfield at the French-Indian raid of 1704. He settled at Deerfield, and was a hatter. Becoming embarrassed financially by obligations incurred in the continental currency, he suffered from poverty all his life, and was unable to give his children more education than was afforded by the common school and the local academy. Edward was therefore compelled to educate himself, and that under the drawback of ill health, caused by overwork and carelessness. Six particulars may be mentioned, going to show that by improving his opportunities he was well educated in many respects: I. For several years he was a leading member of a debating society. This afforded the opportunity to practise extempore speaking, composition, and acquire facility in philosophical reasoning. A few short poems showed that he essayed the higher type of composition. One of these was a tragedy entitled The Downfall of Bonaparte, written at the age of twenty-two, just after the battle of Waterloo, and acted by himself and friends before the people of the village. 2. For four years-from twenty-two to twenty-sixhe was the principal of the academy in his native town. As there were always in this school a number who were fitting for 


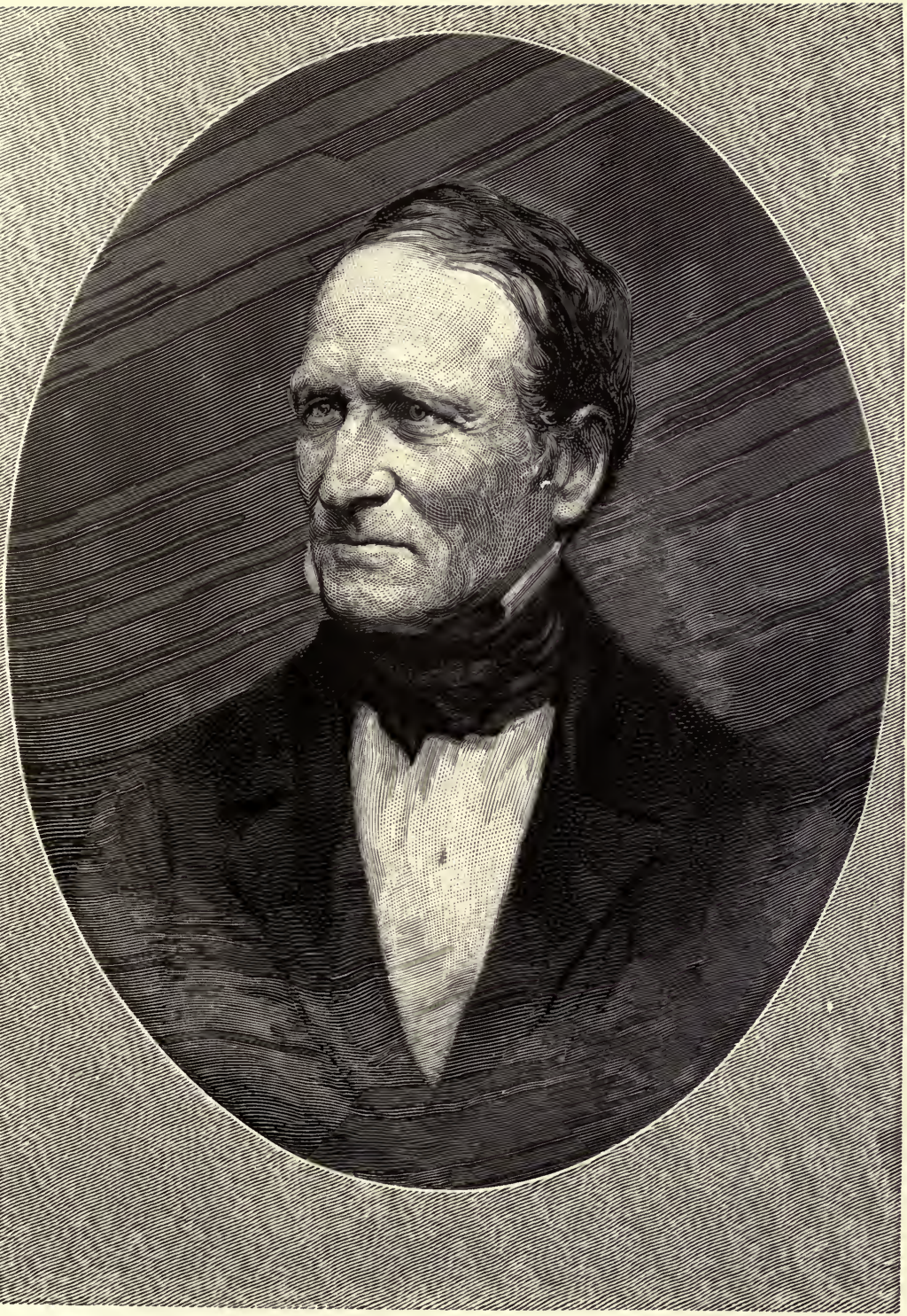

EDWARD HITCHCOCK. 

college, he found it necessary to review all his classical studies-not once merely, but several times. The same was true of scientific studies also, so that quite a large number of subjects were gone over very thoroughly, and the details were fixed in his memory. It was a better discipline than if he had simply taken these studies as a college student. The academy owned a very good philosophical outfit and young Hitchcock prepared a number of lectures on physics, which were delivered with experiments both before his classes and in the evening to people of the village. 3. Perhaps the best mental discipline came from the use of the astronomical instruments belonging to the academy. He observed first the comet of I8I I. From September 7 th to December 17 th, during the presence of the celestial visitor, he noted the distance of the comet from various stars, determined the latitude and longitude by lunar distances and eclipses of the sun and moon, occurring about the same time, and the variation of the magnetic needle. Several months of study were required to reduce these observations; and, as tables were wanting, he was compelled to calculate elements that the modern astronomer finds ready to his hand. The results of this work were published by the American Academy of Arts and Sciences in a paper by General Epaphras Hoyt, the conclusions of the uncle and nephew being combined in a longitude determination. 4. In these calculations use was made of the Nautical Almanac, then published by Edmund M. Blunt, of New York (reprinted from the standard English publication). Errors would hardly be looked for in such a work, but beneath the opening page for every month was this sentence: "Ten dollars will be paid on the discovery of an error in the figures." Young Hitchcock soon discovered a long list of errors, both in the figures and the text, and sent it to Mr. Blunt, who answered evasively. The list was then published in the American Monthly Magazine, which called out Mr. Blunt in a statement commencing, "Noticing an attack on my Nautical Almanac from one Edward Hitchcock, a few remarks only are necessary to explain the man's drift." He represented the errors as occurring in a part of the work used chiefly by astronomers, and added, "I would rather ten errors should escape me there than one by which the mariner should be deceived." Before this answer had been seen, Hitchcock had forwarded to 
the magazine a list of twenty errors in the tables of lunar distances, which were serious, because of their magnitude and their use by sailors. Six months later another list of thirtyfive errors from these almanacs for $1815,1816,1817$, and 1818 made its appearance. This led $\mathrm{Mr}$. Blunt to employ a mathematician to recalculate the almanac for 1819 , and in his preface to state that "it will afford much satisfaction and promote commercial advantages if, on discovery of an error in any nautical work, publicity should immediately be made." A copy was sent to Hitchcock, who soon made out a list of thirty-five errors, and forwarded them to the magazine. Mr. Blunt did not send the pecuniary reward promised, but published the statement that "the communication of Mr. Hitchcock deserves notice, and he is entitled to much credit for his perseverance." It was a great triumph for a young man to sustain himself against these standard astronomical tables. The most rigid accuracy was indispensable, and the discipline fully equal to that acquired by years of scholastic training. 5. A related discipline came from the publication of a Country Almanac from 1814 to $18 \mathrm{I} 8$, whose calculations were original. Here also accuracy was essential to success. No complaint was ever made, except in the assignment of Easter to an unusual date. Both clergymen and people denounced the almanac because of this supposed misstatement. Defence was made that the ordinary rules for determining this festival were useless for that year, as it was a peculiar case, occurring only once in several hundred years. Soon afterward the bishop of the diocese issued a circular sustaining the almanac. 6. Classical training came in connection with teaching. First came the ordinary labour of making translations and grammatical construction. Then he kept a notebook for putting down the most striking sentiments of an author, such as would answer for mottoes and quotations. To obtain the choicest sentiments he carefully looked up all the references made from rare authors. Thus he became familiar with the best thoughts of the classical authors, and by fixing them in his memory obtained a fair substitute for the more extended college training.

During his connection with Deerfield Academy, Hitchcock became interested in botany and mineralogy, through the influence of Prof. Amos Eaton. With two associates, the list of plants and minerals of the neighbourhood was soon made ex- 
haustive. He had correspondence with the elder Prof. Silliman, of Yale College, respecting difficult questions, and the two maintained for each other a lifelong friendship. It was probably this correspondence which led Hitchcock to join the newly opened theological department at New Haven. He furnished contributions to the first volume of Silliman's American Journal of Science and Art, and to many later issues. In all, his name is prefixed to fifty-two papers, notices, and reviews on topics relating to geology, mineralogy, ichnology, surface geology, physics, meteorology, and botany, in this journal.

Hitchcock chose the ministry for his profession. He was settled as a pastor over the Congregational Church in Conway, Mass., from 1821 to 1825 . While in this office he studied natural history to some extent, for the benefit of his health. It was at this time that he discovered and described that small but widely distributed fern, Botrychium simplex. In 1825 he was appointed Professor of Chemistry and Natural History in Amherst College. Twenty years afterward he became president of the same institution, and continued in the office for nearly ten years. For the remainder of his life-nearly ten years-he taught geology and natural theology in the same institution.

Like scientific men of his time, Dr. Hitchcock was familiar with several departments of learning-being an author, educator, theologian, and explorer. His career as a geologist is the best known. Starting as a student of the rocks of the Connecticut Valley, his home, he is soon found at both extremities of the State-at Martha's Vineyard and Berkshire County. With larger opportunities for travel, he was impressed with the importance of interesting legislatures in geological surveys, and he took measures to enlist the government of Massachusetts in such work. With this aim in mind he published a lengthy review of Olmsted's survey of North Carolina in the American Journal of Science, in 1828 . Near the close he says: "We wish now to ask the intelligent legislator whether such a development of internal resources as this report exhibits does not amply remunerate the State of North Carolina for the comparatively trifling expense of this survey; and whether so great success ... does not strongly recommend that this example be followed by other States of the Union?" 
As a result of this and other efforts, the State of Massachusetts commissioned him to make a geological survey of her territory in 1830 . Three years were spent in the explorations, and the work was of such a high character that other States were induced to follow the example of Massachusetts, and similar surveys were organized in Tennessee, Maryland, New Jersey, New York, Virginia, Maine, Rhode Island, New Hampshire, Connecticut, Pennsylvania, Ohio, Delaware, Michigan, Indiana, Kentucky, and Georgia. The State of New York sought his advice in the organization of a survey, and followed his suggestions, particularly in the division of the territory into four parts, and appointed him as the geologist of the first district. He entered upon the work, but after a few days of labour he found that he must necessarily be separated from his family, much to his disinclination. He also conceived the idea of urging a more thorough survey of his own State; hence he resigned his commission and returned home. The effort for a resurvey of Massachusetts was successful, and he was recommissioned to do the work. The results appeared in $184 \mathrm{I}$ and I844-the first a quarto report and the last the geological coloration of a map based upon Borden's Trigonometrical Survey.

Independently of the survey came the discovery of fossil footmarks. As far back as 1800 Pliny Moody had observed trifid markings upon sandstone which he called the tracks of birds. In $1835 \mathrm{Mr}$. W. W. Draper, of Greenfield, Mass., noticed similar impressions, and drew the same conclusions. $\mathrm{Mr}$. Draper remarked upon them to Dexter Marsh and Colonel William Wilson, who in turn consulted Dr. James Deane, who wrote to Professors Silliman and Hitchcock. All agreed to refer the investigation to Prof. Hitchcock, who propounded the fundamental principles of ichnology in the January number of the American Journal of Sciences for 1836 . The announcement was not favourably received by many geologists, while the general public gave expression to their views by the employment of ridicule. The subject was referred to a committee of the American Association of Geologists, consisting of H. D. Rogers, L. Vanuxem, R. C. Taylor, E. Emmons, and T. A. Conrad, in order, if possible, to produce a unanimity of opinion. Those who had most earnestly opposed the new doctrine were upon the committee, but all were convinced; as 
their report, issued in $184 \mathrm{r}$, states, "From a comparative examination of the facts on both sides, your committee unanimously believe that the evidence entirely favours the views of Prof. Hitchcock, and should regret that a difference had existed, if they did not feel assured it would lead to greater stability of opinion."

The publications upon the subject of these Triassic footmarks by Prof. Hitchcock have been quite numerous. The most important were that in the final report upon the geology of Massachusetts in $184 \mathrm{I}$, a paper in the Transactions of the American Academy of Arts and Sciences in I 848, in the Ichnology of New England, published by the State of Massachusetts in 1859 and its supplement in 1865. The total number of species described, as finally revised, amounted to one hundred and fifty. They were referred to several groups: a few marsupialoids, thick and narrow-toed birds, ornithoid lizards or batrachians, lizards, batrachians, chelonians, fish, crustacea, myriapods, insects, and worms. At first the trifid impressions were referred to birds; and it was considered a remarkable confirmation of this view that in 1838 or 1839 there should have been found in New Zealand the bones of true birds having the same dimensions as the largest Brontozoum. Prof. Owen has stated that his belief in the ornithic character of the Deinornis was strongly fortified by the fact of the existence of the Brontozoum. Very soon after the earliest publications about these ornithichnites specimens were exhumed which became very puzzling because of the presence of quadrupedal characters. It became very clear that there must be an intermediate class of beings between birds and reptiles, and accordingly this conclusion was embodied in the assignment of a large number of these Ichnozoa to the designation of "ornithoid lizards or batrachians." As time has progressed the order of Deinosaur has been proposed, to include such animals as have been made known to us by their bones; and now it is doubtful whether any of the impressions were made by birds. Prof. O. C. Marsh has obtained entire skeletons of Deinosaurs from the Connecticut sandstones, which he calls Anchisaurus. They seem to be allied to the Plesiornis rather than the Anomopus or Brontozoum of Hitchcock.

The specimens from which the opinions and descriptions of the ichnology were derived are preserved in the Hitchcock 
Ichnological Cabinet at Amherst College, and completely fill a room one hundred by forty feet, besides two smaller apartments. The number of distinct impressions studied and labelled exceeds twenty thousand. It is likely that some of the suggestions of the Ichnology may not be verified. It would be strange if the following thirty years of discovery should not enable paleontologists to declare positively whether the Batrachoides impressions are really the mud nests of tadpoles, or whether the "insects" are properly larval or adult hexapods, or simply crustacea, as urged by Dana and Agassiz.

In 1857 Prof. Hitchcock accepted the appointment of State Geologist of Vermont. Though the appropriation was very small the work was energetically prosecuted, and conclusions presented in five years' time in two quarto volumes of nearly one thousand pages. Not many speculations were indulged in, though opportunity was afforded for propounding new and startling theories of the metamorphosis of rocks. The report was issued just at the time when Barrande had discharged his artillery at the opponents of the Taconic system, and compelled American paleontologists to assign the Olenellus to the primordial zone instead of the Hudson River slates. The report had been written to accord with the American view, but the authors were enabled to omit everything that did not illustrate the reference of the slates to the Cambrian terrane. The Vermont report suggested two general principles which have been of great service in the further discussion of the nature of metamorphism and the age of the New England rocks. The first point relates to the distortion and alteration of pebbles in conglomerates. As far back as $183_{2}$ Prof. Hitchcock had noticed the singular alterations in the shapes of pebbles constituting conglomerates in Rhode Island. Not till I86I was he able to present satisfactory considerations concerning their distortion and alteration. $\mathrm{He}$ argued that pressure and metamorphism could totally obliterate the shapes of pebbly constituents and convert them into crystalline schists. Very few of his contemporaries followed him in this generalization. The large geological manuals of Dana and Le Conte conspicuously avoided any mention of this view. To-day the skilled petrographers of the country unanimously indorse the doctrine of the distortion and alteration of the fragmental constituents of sediments.

So long as our paleontologists referred the Cambrian fossils 
to the Hudson River group, their associates, as represented by Sir William E. Logan, insisted that the quartzite in western Vermont overlaid the slates, and was of Medina age. Logan also claimed a synclinal structure for the Green Mountains. Before accepting any conclusion as to their structure, Prof. Hitchcock directed that this mountain range should be carefully studied stratigraphically. A dozen sections were made at equal distances apart across the State, and it was discovered that the structure was anticlinal when not monoclinal; and hence comes the certainty that the axis of the Green Mountain chain is older than lower Cambrian. The latest workers in this field accept this conclusion.

Perhaps the favourite subject of Prof. Hitchcock was the study of the "Drift." He began to study the icemarks, even before the discovery of the footprints, and soon found himself far beyond the comprehension of his literary and scientific associates. Neither the iceberg nor glacier theory was original with him; but no one up to the time of his death had published so much upon the subject. His views are developed in the treatise on Surface Geology published by the Smithsonian Institution in 1857 . His general theory refers the phenomena to both icebergs and glaciers; and their setting forth was generically like the most recent deliverances of Sir William Dawson, who acknowledges the presence of glaciers upon the mountains from which the icebergs were derived that flooded the submerged valleys. His papers are of special interest concerning river terraces, local glaciers in western New England, trains of boulders, and frozen deposits of drift gravel. It is an interesting fact that he argued against the admissibility of Agassiz's glacial theory because of the absence of a grand terminal moraine at the outer margin of the ice sheet. It was less than five years after his death that geologists began to appreciate the true significance of the backbone of Long Island -that it was part of a gigantic moraine more than a thousand miles long. It is easy to see where Hitchcock would have stood had these facts been known in his day.

The first written suggestion in regard to the formation of the American Association of Geologists came from Prof. Hitchcock, and he was chosen its first president in 1840 . This was the parent of the later organization known as the American Association for the Advancement of Science. He was present 
at nearly every meeting of both organizations until the gap in the later history induced by the war.

As President of Amherst College he was called upon to exercise unwonted judgment. The institution had almost broken down because of heavy indebtedness. The historian of the college declares that it was saved from destruction by the skill and wisdom of President Hitchcock. As an instructor and guide no one was more loved and honoured. The number of students doubled during his administration. It was while he was president that his Religion of Geology appeared, in which he expounded the applications of science to theology. Most of the positions there maintained are accepted by the advanced Christian thinkers of to-day. The work appeared before the advent of Darwinism, but its principle was discussed as creation by law. While not accepting any development hypothesis, Prof. Hitchcock took pains to insist that its adoption would not be at variance with any fundamental principle of theology. During his lifetime the doctrine of creation was the prevalent fashion of thought, just as now everybody is an evolutionist, and as in the Mesozoic age every vertebrate animal assumed some reptilian feature.

Prof. Hitchcock devoted much thought to the relations between science and theology. He believed that his suggestions -original with him-would tend to bring together truths often divorced, but which only man puts asunder. The following are topics upon which he made important suggestions: r. Proof of the general benevolence of God from geology. 2. Evidence from the same, of special divine interpositions in $\mathrm{Na}$ ture. 3. Evidence from the same, of special providence. 4. Mode of answering objections to the doctrine of the resurrection of the body by the nature of bodily identity. 5. The religious bearing of man's creation. 6. The adaptedness of the world for the redemptive work. 7. The Mosaic days properly interpreted by vmbolism. These and related views were taught by him to his classes under the title of natural theology. Through his efforts the chair of Geology and Natural Theology was endowed in Amherst College, with the understanding that the science should always be taught from a religious standpoint.

A list of Prof. Hitchcock's published writings shows a total of twenty-six distinct volumes, thirty-five separate pamphlets, 
ninety-four papers in periodicals, and eighty newspaper articles -a total of 8,453 pages, with $25^{6}$ plates and $\mathrm{r}, \mathrm{r} 34$ woodcuts. Half of these were scientific papers; of the others, most were religious books, essays, sermons, and tracts. He published also biographies, reviews, poetry, and temperance documents.

In I82 I Mr. Hitchcock married Miss Orra White, daughter of Jarib White, of Amherst, Mass., and they lived together for forty-two years. Mrs. Hitchcock was an artist, and prepared many of the illustrations of her husband's reports. Six of their children, two sons and four daughters, reached maturity. The oldest son is the Professor of Hygiene and Physical Education at Amherst College; the youngest is the Professor of Geology at Dartmouth College. Three of the daughters were married - the first to Rev. Dr. H. M. Storrs, lately of Orange, N. J.; the second to G. B. Putnam, of the Franklin Grammar School, Boston, Mass. ; the third to the late Rev. C. M. Terry, of Minneapolis, Minn. The oldest daughter is known as an amateur botanist, residing at Hanover, N. H. 


\section{HENRY ROWE SCHOOLCRAFT.}

$$
\text { I 793-1 } 864 \text {. }
$$

Mr. Schoolcraft was a conspicuous figure in the scientific life of the early part of the century. A pioneer in some fields, the immediate follower of the pioneers in others, he was, in all the branches of research to which he gave attention, earnest, ready, diligent, sagacious, original, and modest. As among his titles to be remembered, the biographer who prefaces his Personal Memoirs names the early period at which he entered the field of observation in the United States as a naturalist; the enterprise he manifested in exploring the geography and geology of the great West; and his subsequent researches as an ethnologist in investigating the Indian languages and history. "To him we are indebted for our first accounts of the geological constitution and the mineral wealth and resources of the great valley beyond the Alleghanies, and he is the discoverer of the actual source of the Mississippi River in Itasca Lake. For many years, beginning with 1817 , he stirred up a zeal for natural history from one end of the land to the other, and, after his settlement in the West, he was a point of approach for correspondents "-on these topics and for all the Indian tribes.

Henry Rowe Schoolcraft was born in Albany County, N. Y., March 28, I793, and died in Washington, D. C., December ro, 1864 . He was the descendant, in the third generation, of an Englishman, James Calcraft, who, having served with credit in the armies of the Duke of Marlborough, came to America in the reign of George II, in the military service, and was present at operations connected with the building of Forts Anne, Edward, and William Henry. After these campaigns he settled in Albany County as a land-surveyor, married, and in his old age, conducted a large school-the first English school that was taught in that frontier region. In connec- 


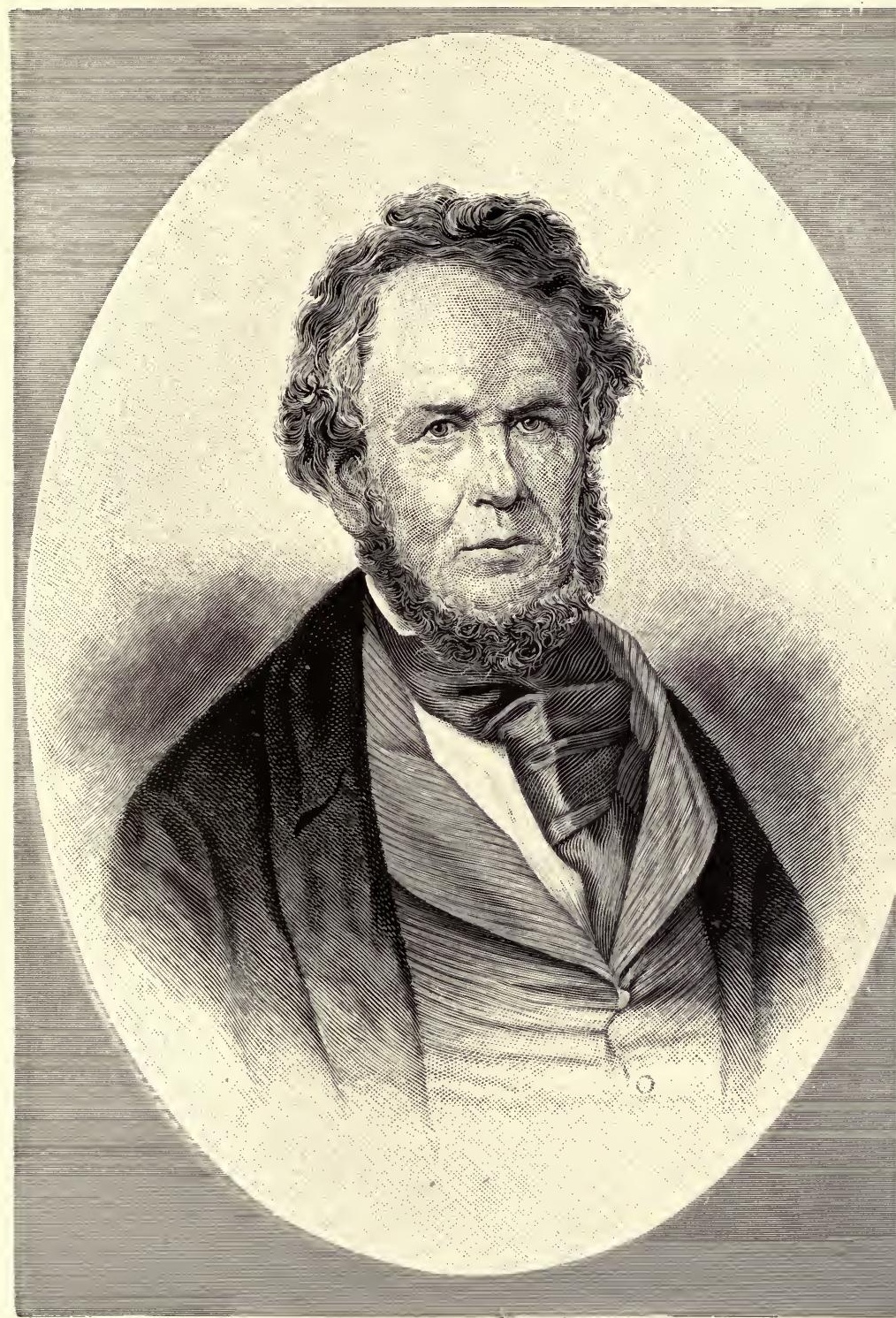

HENRY ROWE SCHOOLCRAFT. 

tion with this incident his name became changed to Schoolcraft. He died at the age of one hundred and two years. John, his third son, was a soldier under Sir William Johnson. Lawrence, John's son, distinguished himself during the siege of Fort Stanwix. He was afterward director of the glassworks of the Hon. Jeremiah Van Rensselaer, at Hamilton, near Albany; and established the manufacture of glass in Western New York.

Henry Schoolcraft spent his childhood and youth in Hamilton, cultivated poetry, and maintained an excellent standing in scholarship. At an early age he manifested a taste for natural science, which was then (about i 808 ) little known outside our seats of learning; formed the beginnings of collections; and organized an association for mental improvement. He investigated the drift stratum of Albany County as seen in the bed of Norman's Kill; and afterward, while living at Lake Dunmore, Vt., put himself under the teaching of Prof. Hall, of Middlebury College; added chemistry, natural philosophy, and medicine to his studies; erected a chemical furnace, and went into experimenting; and picked up a knowledge of Hebrew, German, and French. He began writing for books and periodicals in 1808-contributing, among other things, papers on the Burning Springs of Western New York, and on archæological discoveries that had been made in Hamburg, Erie County. In the last paper, which was published at Utica in 1817 , he pointed out the necessity of discriminating between the period of early European occupancy, and that of aboriginal. American antiquity. $\mathrm{He}$ was engaged for a time in directing the building of works connected with his father's glass-making enterprises in Vermont, New Hampshire, and western New York. The ideas and knowledge gained in these operations supplied the material for his proposed work on Vitreology, or the application of chemistry to glass-making, the publication of which was begun in 1817 . The supervision of these works required the making of considerable journeys, and these created in him the desire to travel through the wilds of the "Far West," which then hardly extended beyond the Missouri River.

He made some "preliminary explorations" to his contemplated journey, in Western New York in 1816 and 1817 , and 
started from Olean on the Alleghany River for a journey down the Ohio and up the Mississippi in 1818. A large company of intending emigrants had gathered there waiting for the season to open, and Schoolcraft took passage in the first ark. Arrived at Pittsburg, he stopped to explore the geology of the Monongahela Valley, and was greatly interested in the rich coal and iron beds. He stopped to visit the Grave Creek mound and the ancient works at Marietta. At Louisville he found "organic remains" of several species in the limestone rocks of the falls, and published anonymously in the paper some notices of its mineralogy. At the mouth of the Cumberland River he exchanged the ark for a keel-boat or barge, with which, propelled by poles pushing on the bottom, he made from three to ten miles a day against the swift current of the Mississippi to Herculaneum, Mo. On this voyage he travelled over a large part of the west bank on foot, and gleaned several facts in its mineralogy and geology which made it an initial point in his future observations. He spent three months in examining the lead mines, personally visiting every mine or digging of consequence in the Missouri country and tracing its geological relations into Arkansas. Hearing of syenite suitable for millstones on the St. Francis, he visited that stream and discovered the primitive tract; and he pushed his examinations west beyond the line of settlement into the Ozark Mountains. He now determined to call the attention of the Government to the importance of its taking care of its domain in the mines, and with this purpose packed his collections and took passage in the new steamer St. Louis for New Orleans. Hence, having inquired into the formation of the delta of the Mississippi, he sailed by brig for New York. He opened his collections and invited examination of them, published a book on the mines and physical geography of the West and a letter on its resources, and went to Washingtón to present his views on the care of the mines to the officers of the Government. While he was looking for a secretary within whose purview the matter fell, Mr. Calhoun invited him to accompany General Cass, Governor of Michigan, as naturalist and mineralogist on an expedition to explore the sources of the Mississippi and to inquire into the supposed value of the Lake Superior copper mines. $\mathrm{He}$ accepted the position, though the compensation was small, because, he says, "it 
seemed to be the bottom step of a ladder which I ought to climb."

Mr. Schoolcraft left New York in March, 1820, reached Niagara Falls on the Ist of May, and Detroit by steamer a week later. While waiting for the completion of arrangements for embarkation, he attended to the correspondence which had been provoked by the publication of his work on the mines and the resultant awakening of interest in the varied resources of the Mississippi Valley and the subject of geographical and geological explorations. He determined to reply to all letters that appeared to be honest inquiries for geographical facts, "which I only, and not books, could communicate." The route of the expedition "lay up the Detroit and St. Clair Rivers and around the southern shores of Lakes Huron and Superior to Fond du Lac, thence up the St. Louis River in its rugged passage through the Cabotian Mountains to the Savannah summit which divides the Great Lakes from the Mississippi Valley. The latter was entered through the Cantaguma or Sandy Lake River. From this point the source of the Mississippi was sought up rapids and falls and through lakes and savannahs, in which the channel winds. We passed the inlet of Leech Lake, which was fixed upon by Lieutenant Pike as its probable source, and traced it through Little Lake Winnipeg to the inlet of Turtle Lake in upper Red Cedar or Cass Lake in latitude $47^{\circ}$. On reaching this point the waters were found unfavourable to proceeding higher. The river was then descended to the falls of St. Anthony, St. Peter's, and Prairie du Chien. From the latter point we ascended the Wisconsin to the portage into Fox River, and descended the latter to Green Bay." At this point the expedition was divided. The party to which Mr. Schoolcraft was attached proceeded to Chicago, thence traced the eastern coast of Michigan, and rejoined the other party, which had gone north to trace the shores to Michilimackinack. About four thousand miles were traversed. Reports were made to the Government by $\mathrm{Mr}$. Schoolcraft on the mineralogy and geology of the region; on the copper deposits of Lake Superior; on the botany, freshwater.conchology, zoölogy, and ichthyology ; soil, productions, and climate received attention; and the Indian tribes were subjects of observation by General Cass. "In short, no exploration had before been made which so completely revealed 
the features and physical geography of so large a portion of the public domain." A new interest in mineralogy and geology was awakened by this expedition, and Mr. Schoolcraft's narrative of it was hurried into press under the pressure of the public clamour for its results. The book was published in May, I821.

Mr. Schoolcraft shortly afterward embarked, with General Cass, on another expedition. The route lay from the present site of Toledo, up the Maumee, down the Wabash and Ohio to Shawneetown, overland across the "knobs" and prairies, taking a famous locality of fluor-spar on the way, to St. Louis; thence up the Illinois to the rapids and on horseback to Chicago, stopping to find the fossil tree in the bed of the Des Plaines. In Chicago, a treaty was made with the Pottawattamies for the surrender of about five million acres of land. to which Mr. Schoolcraft should have given his signature among the others, but he was too ill_-"did not, indeed, ever expect to make another entry in a human journal." The incidents and observations of the journey have been published as Travels in the Central Portions of the Mississippi Valley. In the next year (1822) Mr. Schoolcraft was appointed Indian agent at Sault Ste. Marie, of which he says, giving his reasons for accepting it: "I had now attained a fixed position; not such as I desired in the outset and had striven for, but one that offered an interesting class of duties, in the performance of which there was a wide field for honourable exertion, and, if it was embraced, also of historical inquiry and research. The taste for natural history might certainly be transferred to that point, where the opportunity for discovery was the greatest.". The position afforded him excellent opportunities for studying the Chippewa language and Indian mythology and superstition, characteristics and customs, of which he made the best use. He determined to be a labourer in the new field of Indian studies. His diary during the whole term of his office shows him leading a busy and varied life. We find in it notes on his subjects of study, of his readings on various general topics, observations on the natural features of the region, remarks on mineralogical specimens and incidents of official work.

Mr. Schoolcraft spent the winter of 1824-'25, on leave of absence, in New York, where he superintended the printing of 
his Travels in the Central Portions of the Mississippi Valley. "Society" was much interested in Mrs. Schoolcraft, the "Northern Pocahontas," a lady of aristocratic Irish descent on one side, and tracing her ancestors on the other side to the royal house of the Chippewas, who was withal, having been educated abroad, highly accomplished and refined in her manners. She was the daughter of Mr. John Johnston, of Sault Ste. Marie, who had married the daughter of Wabojeeg, a distinguished Chippewa chieftain. In r825 Mr. Schoolcraft attended a convocation of the Indian tribes at Prairie du Chien, where a treaty was signed, through which it was hoped internal disputes between the tribes might be settled by fixing the boundaries to their respective territories. In the next year he attended a similar gathering of the Chippewa tribes at Fond du Lac, where the principles of the treaty of Prairie du Chien were reaffirmed, and a new treaty was made, under which the Indians acknowledged the sovereign authority of the United States; ceded the right to explore and take away the native copper and copper ores, and to work the mines and minerals in the country; and provision was made for the education of the Indians and their advancement in the arts. The system of Indian boundaries established by these treaties was completed by the treaty of Butte des Morts, August, r827. The three treaties embodied a new course and policy for keeping the tribes in peace, and were founded " on the most enlarged consideration of the aboriginal right of fee simple to the soil." In 1827 he was elected a member of the Legislative Council of the newly organized Territory of Michigan-an office which was not solicited, and was not declined. As a member of this body during four sessions, he directed his attention to the incorporation of a historical society; to the preparation of a system of township names derived from the aboriginal languages; and to some efforts for bettering the condition of the natives.

A proposition was made to $\mathrm{Mr}$. Schoolcraft in 1828 to go as one of the scientific corps of an exploring expedition which the Government contemplated sending to the south seas, under the direction of the Secretary of the Navy. In his reflections on the prospects of this expedition and the acquisitions to knowledge that might be expected to accrue from it, he regarded the experiments of Dr. Maskelyn, denoting a 
greater specific gravity in the central portion of the globe than in its crust, as opposed to a theory that was then advocated of an interior void. Yet he thought "we are advertised, by the phenomena of earthquakes, that this interior abounds with oxygen, hydrogen gas, caloric, and sulphur, and that extraordinary geological changes are affected by their action. It does seem improbable that the proposed expedition will trace any open connection with such an interior world; but it may accumulate facts of the highest importance." There was something, however, about the getting up and organization of the expedition which he did not like, and an apprehension whether Congress would not cripple it by voting meagre supplies and outfits. He declined to go.

A note from Mr. G. W. Featherstonaugh, giving a disparaging view of American scientific achievement, and inclosing the prospectus of a journal designed to correct these things, gave Mr. Schoolcraft opportunity for bearing strong tribute to the genuineness of real American scientific research. The critic's remarks might be true as to a certain class, who had not made science a study; but, if applied to the power and determination of the American mind devoted to natural history, it was " not only unjust in a high degree, but an evidence of an overweening self-complaisance, imprecision of thought, or arrogance. No trait of the American scientific character has been more uniformly and highly approbated by the foreign journals of England, France, and Germany than its capacity to accumulate, discriminate, and describe facts. For fourteen years past, Silliman's Journal of Science, though not exclusively devoted to natural sciences, has kept both the scientific and the popular intelligent mind of the public well and accurately advised of the state of natural science the world over. Before it, Bruce's Mineralogical Journal, though continued but for a few years, was eminently scientific; and Cleaveland's Mineralogy has had the effect to diffuse scientific knowledge not only among men of science, but other classes of readers. In ornithology, in conchology, and especially in botany, geology, and mineralogy, American mind has proved itself eminently fitted for the highest tasks."

The Michigan Historical Society was founded, chiefly through Mr. Schoolcraft's instrumentality, in 1828 , and the Algic Society on February 28,1832 . The latter organization 
had in view the reclamation of the Indians, and, connected with this, the collection and dissemination of information respecting their language, history, traditions, customs, and character; their numbers and conditions; the geological features of their country, and its natural history and productions. It also proposed some definite means of action for furthering the moral instruction of the Indians, and for helping the missionaries in all work for their benefit. As president of this society, Mr. Schoolcraft was asked to lecture on the grammatical construction of the Algonquin languages as spoken by the Northwestern tribes, and to procure a lexicon of it; also to deliver a poem on the Indian character at the annual meeting of 1833 . Other literary efforts of this period were, an address before the Historical Society of Michigan in 1830 , and an address, in $183 \mathrm{I}$, before the Detroit Lyceum, on the natural history of the Territory. In the summer of $188_{2}$ Mr. Schoolcraft, under a commission from the Government, organized and commanded an expedition to the country about the sources of the Mississippi River. The primary object of the expedition was to extend to the Indians living north of St. Anthony's Falls the measures previously taken with those south of that point, to effect a pacification; also, to endeavour to ascertain the actual source of the river. He ascended the St. Louis from Lake Superior to Sandy Lake summit, and passed thence direct to the Mississippi six degrees below the central island in Cass Lake, which was till then the ultimate point of geographical discovery. Thence he went up the river and its lakes, avoiding too long circuits of the stream by portages, to the junction of the two branches, where by the advice of his Indian guide he took the left-hand, or Plantagenian branch, to Lake Assawa, its source. Thence he went by portage, a distance of "twelve resting-places," to Itasca Lake, which he struck within a mile of its southern extremity. The lake was judged to be about seven miles in length, by one or two broad; "a bay, near its eastern end, gave it somewhat the shape of the letter $y$." The discoverer returned, through the stream and its lakes, to St. Peter's.

The narrative of this expedition was published in 1834 ; and was republished, with the account of the expedition of I 820 , in 1853, under the title, Narrative of an Exploratory Expedition to the Sources of the Mississippi River in 1820 , 
completed by the Discovery of its Origin in Itasca Lake in 1832. The whole of Mr. Schoolcraft's earlier life and work up to this time is recorded, mostly from day to day, in his Personal Memoirs of a Residence of Thirty Years with the Inaian Tribes on the American Frontiers, etc., 1812 to 1842 , a book having "the flavour of the time, with its motley incident on the frontier, with Indian chiefs, trappers, government employees, chance travelers, rising legislators, farmers, ministers of the gospel, all standing out with more or less of individuality in the formative period of the country." This book abounds with evidence of Mr. Schoolcraft's scientific and literary activity, as well as of his efficiency in work in whatever field. As early as 1820 we find a letter from Amos Eaton, asking him for information for the second edition of his Index to Geology, respecting the secondary and alluvial formations and the strata of the Rocky Mountains. Dr. Samuel Mitchell writes him, in $182 \mathrm{I}$, about the shells and other specimens he has sent, including a "sandy fungus," and inviting specimens for the cabinet of the Emperor of Austria. Profs. Silliman and Hall acknowledge the value of his examination of the mining regions of Missouri; Prof. Silliman asks for articles for his journal; and Sir Humphry Davy thinks his book would sell well in England. Prof. Cleaveland writes him, in 1827 , that he is about preparing a new edition of his work on mineralogy, and solicits the communication of new localities. In the same year Mr. Schoolcraft himself writes that the collection he made in Missouri, etc., in I8I9, appears to have had an effect on the prevalent taste for those subjects, "and at least it has fixed the eyes of naturalists on my position on the frontiers." Mr. Peter S. Duponceau addresses him, in 1834 , on the structure of the Indian languages, "in terms which are very complimentary, coming, as they do, as a voluntary tribute from a person whom I never saw, and who has taken the lead in investigations on this abstruse topic in America." He pronounces Mr. Schoolcraft's book on the Chippewa languages one of the most philosophical works on the Indian languages which he has ever read. In another letter Mr. Duponceau acknowledges having used Mr. Schoolcraft's grammar, giving due credit, in preparing a prize essay for the Institute of France, on the grammatical structure of Indian languages. Dr. Thomas H. Webb, of 
Providence, in 1835 , notifies him of his election as an honorary member of the Rhode Island Historical Society, and asks about aboriginal inscriptions on rocks. The Massachusetts Historical Society, in 1836 , asks him to proceed with his work on the Ojibway language, complete it, and let the society publish it. John J. Audubon asks for aid in preparing his work on American quadrupeds. There are numerous notices of specimens that have been sent to Mr. Schoolcraft to pass upon, and solicitations from persons representing the principal magazines, to contribute of the results of his researches.

A new disposition of official posts having been made, $\mathrm{Mr}$. Schoolcraft transferred his residence in 1837 to Michilimackinac or Mackinaw. Thence he removed, in I84I, to New York, where he expected to find the surroundings more favourable to the collation and publication of the results of his observations on the red race, whom he "had found in many traits a subject of deep interest; in some things wholly misunderstood and misrepresented; and altogether an object of the highest humanitarian interest." But the publishers were not yet prepared in their views to undertake anything corresponding to his ideas. In the next year he carried out a longdeferred purpose of visiting England and continental Europe, attending the British Association at Manchester. On his return he made a tour through western Virginia, Ohio, and Canada. In 1845 he was appointed by the Legislature of New York as a commissioner to take the census of the Indians of the State, and collect information concerning the Six Nations. The results of this investigation were embodied in his Notes on the Iroquois, a second enlarged edition of which was published in 1847. The latter part of his life was spent in the preparation-under an act passed by Congress in 1847 - of an elaborate work on all the Indian tribes of the country, based upon information obtained through the reports of the Indian Bureau. This work-which was published in six quarto volumes-is described in Duyckink's Cyclopædia of American Literature as covering a wide range of subjects in the general history of the race; their traditions and associations with the whites; their special antiquities in the several departments of archæology in relation to the arts; their government, manners, and customs ; their physiological and ethnological peculiarities as individuals and nations; their intellectual and moral 
cultivation; their statistics of population; and their geographical position, past and present.

His Indian wife having died in $185^{2}, \mathrm{Mr}$. Schoolcraft married, in 1857 , Miss Mary Howard, of Beaufort, S. C. Being highly educated she was able to render him great assistance in the preparation of his last work when he was helpless from paralysis.

Mr. Schoolcraft became interested in religion at an early period in his career, and his journals show him ever more earnestly co-operating in local religious movements; furthering the progress of missionary effort among the Indians, by whatever denomination; labouring for the promotion of temperance among them; and taking the lead in whatever might contribute to their well-being or to the repression of wrong against them. His literary activity was prolific, and appears to have been nearly evenly divided between poetry, Indian lore and ethnology, and the objects of his explorations and scientific investigation. Besides books of poems and the narratives already named, he published Algic Researches, a collection of Indian allegories and legends (1839); Oneota, or the Characteristics of the Red Race in America (I844-'45), republished in 1848 as The Indian and his Wigwam; Report on Aboriginal Names and the Geographical Terminology of New York (1845); Plan for investigating American Ethnology (1846); The Red Race of America (1847); A Bibliography of the Indian Tongues of the United States (1849); and American Indians, their History. Condition, and Prospects ( $185^{\circ}$ ). He received the degree of L.L. D. from the University of Geneva in 1846 ; and was a member of many learned societies. 



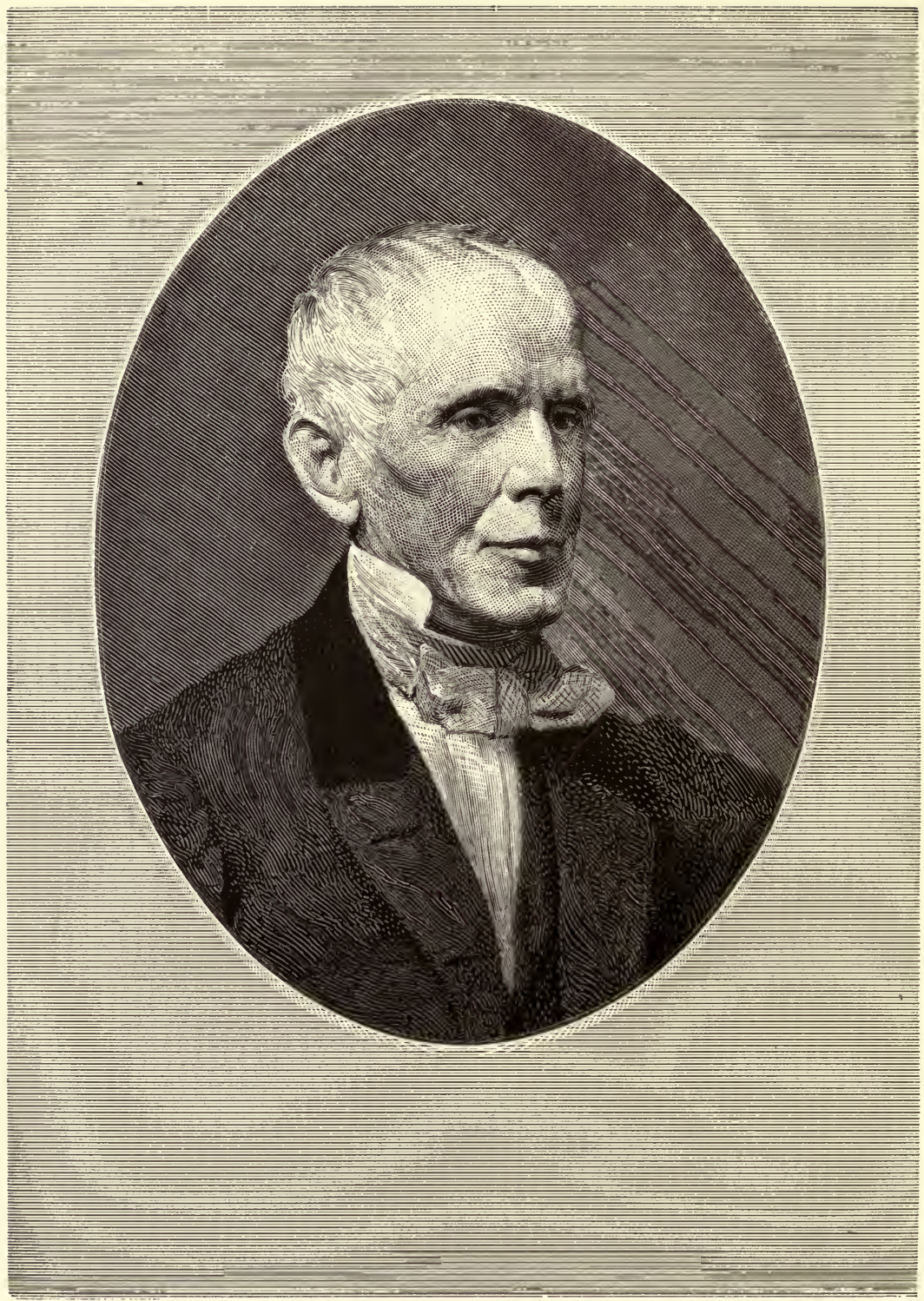

SAMUEL LUTHER DANA. 


\section{SAMUEL LUTHER DANA.}

$$
\text { I 795-1868. }
$$

Samuel Luther Dana, the second son of Lucy (Giddings) and Captain Luther Dana, was born July Ir, I795, in the town of Amherst, not far from Nashua, N. H. He was descended from Richard Dana who came to this country and settled in Cambridge about r640. His father was a native of Groton, Mass., and in the latter part of the Revolutionary War entered the navy of the United States as a midshipman, he being then seventeen years of age. Soon after his marriage in $\mathbf{7}_{7} 88$, he took up his residence at Amherst, and engaged in mercantile business. This not proving successful he took to the sea again, becoming a shipmaster in the merchant service. $\mathrm{He}$ followed the sea until a few years before his death, in I832, and made about seventy voyages to ports in Europe, Asia, and America. Captain Dana was fond of knowledge and took pleasure in collecting objects of natural history, many valuable specimens being given by him to the Marine Museum at Salem, Mass. He had no faith in the superstitions with which seafaring men are haunted, and rather preferred to go out of port on Friday. On one of his most successful voyages he left Salem on a Friday, called at two European ports, reaching and leaving both on Fridays, and it was on a Friday that he finally reached home. His daughter-in-law, Mrs. James Freeman Dana, has described him as "tall and well formed, with a sensible, frank, cheerful countenance. He had clear blue eyes, dark-brown hair, which became silvery white at an early period of life, and a fair complexion, somewhat embrowned by exposure." She also speaks of him as ever ready to assist any who might require aid-one whom the weakest or lowliest might appeal to with the certainty of receiving a kind response. Lucy Giddings was married to him when she was sixteen years of age. She was very handsome and viva- 


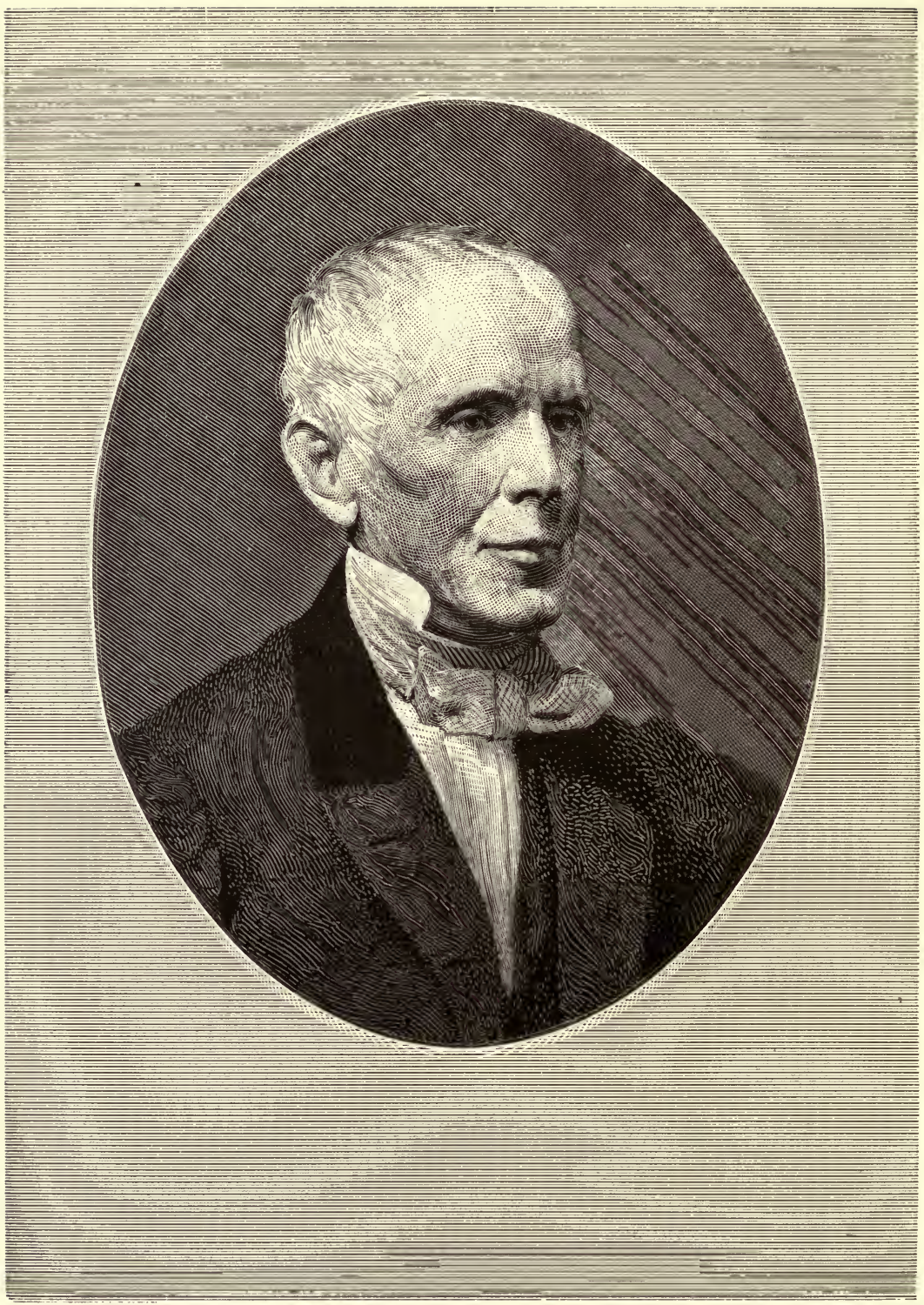

SAMUEL LUTHER DANA. 


\section{SAMUEL LUTHER DANA.}

$$
\text { r 795-1868. }
$$

Samuel Luther Dana, the second son of Lucy (Giddings) and Captain Luther Dana, was born July Ir, I795, in the town of Amherst, not far from Nashua, N. H. He was descended from Richard Dana who came to this country and settled in Cambridge about r640. His father was a native of Groton, Mass., and in the latter part of the Revolutionary War entered the navy of the United States as a midshipman, he being then seventeen years of age. Soon after his marriage in $\mathbf{1} 788$, he took up his residence at Amherst, and engaged in mercantile business. This not proving successful he took to the sea again, becoming a shipmaster in the merchant service. $\mathrm{He}$ followed the sea until a few years before his death, in $183^{2}$, and made about seventy voyages to ports in Europe, Asia, and America. Captain Dana was fond of knowledge and took pleasure in collecting objects of natural history, many valuable specimens being given by him to the Marine Museum at Salem, Mass. He had no faith in the superstitions with which seafaring men are haunted, and rather preferred to go out of port on Friday. On one of his most successful voyages he left Salem on a Friday, called at two European ports, reaching and leaving both on Fridays, and it was on a Friday that he finally reached home. His daughter-in-law, Mrs. James Freeman Dana, has described him as "tall and well formed, with a sensible, frank, cheerful countenance. He had clear blue eyes, dark-brown hair, which became silvery white at an early period of life, and a fair complexion, somewhat embrowned by exposure." She also speaks of him as ever ready to assist any who might require aid-one whom the weakest or lowliest might appeal to with the certainty of receiving a kind response. Lucy Giddings was married to him when she was sixteen years of age. She was very handsome and viva- 
cious, and managed the affairs of her home and family during her husband's long absences at sea with rare judgment and tact.

As Captain Dana's residence was not confined by his calling to any particular place, he changed it twice for the benefit of his boys. In 1804 he removed to Exeter, N. H., in order to give them the educational advantages of Phillips Academy, and five years later, when the two oldest had been prepared to enter Harvard College, the family removed to Cambridge. Samuel passed through college in the same class with his older brother, graduating in $18 \mathrm{r}_{3}$. From a pamphlet privately printed, containing memoirs of several members of the Dana family, it is learned that the two brothers were endowed with the same love for natural science, and entered upon the study of certain branches of it with great enthusiasm. They often made excursions together on foot through the country lying within thirty miles around Boston, for the purpose of examining its geological structure and collecting mineralogical specimens. The result of these researches was a volume on the Mineralogy and Geology of Boston and its Vicinity, published by the brothers about the time they completed their medical studies.

The younger brother also employed himself upon these excursions in searching for entomological specimens, and formed quite a large collection of beautifully prepared insects. This was afterward given to the Linnæan Society of New England, of which the brothers, if not the founders, were among the earliest members. Another taste which formed a strong bond of union between them was their love of music. In college they belonged to the same musical societies.

On graduating from college Samuel began reading law with his uncle, Judge Samuel Dana, then residing in Charlestown, Mass. The War of 1812 was in progress, and young Dana caught the prevailing military spirit. $\mathrm{He}$ applied for a cadetship at West Point, but received instead a commission as first lieutenant in the First U. S. Artillery, with which corps he served in New York and Virginia until the close of the war. In June, 1815 , the army was disbanded and Dana resigned his commission.

A younger brother, Nathaniel G. Dana, was a cadet at 
West Point during the War of 1812 , graduating in $1814 . \mathrm{He}$ remained in military life until his death in 1833 .

Samuel did not return to the law, but took up the study of medicine under Dr. Bancroft, of Groton. Receiving his medical degree in 1818 , he began the practise of his profession in Gloucester, Mass. The next year he married Ann Theodora, daughter of Rev. Joseph Willard, D. D., who had been President of Harvard College from $178 \mathrm{I}$ till his death in 1804 .

Dr. Dana now took up his abode in Waltham, Mass., where he practised medicine until 1826 . Toward the close of this period he established a laboratory for the production of sulphuric acid and bleaching salts. This enterprise soon developed into the Newton Chemical Company, of which he was chemist till r834. His friend Dr. A. A. Hayes, in the memorial pamphlet of the Dana family, has testified to his wide knowledge of the properties of substances and his great fertility in original devices for general and technological work. In his manufacture of acids and other chemicals improved plans and processes were early employed, and Dr. Hayes mentions especially Dana's device for deoxidizing manganic oxide by heating it with sulphur, in order to form from it (with pyroligneous acid) a crude manganous acetate, then largely used in dyeing a fast brown.

The second of Dr. Dana's published writings was issued in 1833, while he was on a visit to England. It was a clear exposition of the chemical changes occurring in the manufacture of sulphuric acid.

In the following year Dr. Dana became resident and consulting chemist to the Merrimac Manufacturing Company, at Lowell, Mass., in which position he remained for the rest of his life-a period of thirty-four years. The improvements which he introduced into the processes carried on in the mills of this company were many and important. Dr. Hayes gives an outline of these. He undertook systematic researches on the action of the dung of beeves-then used for removing the excess of mordant in printing calicoes with madder-which resulted in the discovery that crude phosphates in a bath with bran are a complete substitute for the expensive and disgusting material before deemed indispensable. Arseniates, which are cheaper than phosphates, were 
afterward substituted for them on the suggestion of Mercer, and are the worldwide reliance of print manufacturers at the present day.

Of the same systematic character was his study of the chemical changes involved in the process of bleaching cotton fabrics preparatory to printing them. This inquiry resulted in his inventing a method which not only received high commendation as scientific work but was universally adopted in practice. As most of Dr. Dana's researches were made for the exclusive benefit of the company with which he was connected, their results were not always published promptly, and hence the abilities that might have won a high meed of fame remained known to only a small circle. His discoveries with respect to bleaching cotton, however, were published in the Bulletin de la Société Industrielle de Mulhouse in 1838 . The principles therein established have led to the American method of bleaching, of which Persez, in his Traité de l'Impression des Tissues, says that "it realizes the perfection of chemical operations."

The Merrimac Mills were at first run by water power alone, but when the works were extended this was supplemented by the use of steam. Dr. Dana was now called to the new field of engineering, in addition to his other duties. His development of the whole subject of the evaporative power of coal and the economical disposition of the heat in steam and in water of condensation is a masterly effort, embracing every detail, and was in advance of any published results of the time.

For several years before he became a resident of Lowell, Dr. Dana was frequently called to that city as a consulting chemist. He was also one of the chemists consulted by the water commissioners of both Boston and New York prior to the introduction of the Cochituate and Croton water respectively.

"While these varied applications of science to most useful purposes were daily occupations," says Dr. Hayes, "he was pursuing in his laboratory the great study of his life-madder, its products and its application to dyeing-year after year. $\mathrm{He}$ deemed the subject exhaustless, and while following the published results of other labourers in the same field as test trials, I happen to know that the most important discoveries, 
from time to time, were made by him, and often applied, before their publication by others.

"The laboratory, in most busy moments, was exceptionally neat; the deft handling of the apparatus and order of experiments expressed the system of thought."

Soon after removing to Lowell, Dr. Dana became interested in the action of lead upon water, and made a report to the City Council of that city on the danger arising from the use of lead water pipes. His translation and systematic arrangement of the treatise of Tanquerel on Lead Diseases was considered an important contribution to medical knowledge. The discussion of the lead-pipe question gave rise to several pamphlets from Dr. Dana's pen.

Another division of chemistry in which Dr. Dana did valuable work was in its applications to agriculture. As the outcome of a comprehensive series of experiments and observations, he published, in 1842 , The Farmer's Muck Manual of Manures, which was the sheet anchor of libraries in the rural districts of New England for many years. The next year an Essay on Manures submitted by him won the prize offered by the Massachusetts Agricultural Society. He carried into his agricultural investigations the same scientific methods that he had found so important to success in other technical inquiries, and added an overflowing love for the pursuit in all its varied bearings. The younger Silliman wrote of him: "In point of time, originality, and ability, Dr. Dana stood deservedly first among scientific writers on agriculture in the United States."

The fourth edition of the Muck Manual was published in 1855. Its preface states that "The author is not an agriculturist; he does not assume the name even of agricultural chemist," and mentions his position at the works of the Merrimac Company. "While pursuing there," it continues, "during the years 1835,1836 , and 1837 , researches on the action of cowdung in calico dyeing, he pushed his inquiries, as a recreation, during his few leisure hours, into the nature and action of manures and of soil. Conversation on these matters with the geological surveyor, and with the agricultural commissioner of Massachusetts, led to a correspondence between the parties, which partly appeared in the published reports on the geology and agriculture of 
Massachusetts. This induced some zealous and active citizens of Lowell to ask me to deliver a course of lectures on agricultural chemistry."

From the notes of these lectures the Muck Manual was prepared. "The work," Dr. Dana states further, "was favourably received at home and abroad, where a considerable portion was reprinted. It has passed through several editions, each being enlarged by the addition of new matter, to keep pace with the times. To the present edition is added an entire new chapter on bones and superphosphates of lime and alkalies. ... .

"One word respecting the title of my book. It is my own. I have neither begged, borrowed, or stolen it. That last has been done by an English author, who seems to be ashamed, not of the act, but of the name he has filched from me, and so eases his conscience by apologizing for his 'homely title.' I shall not discredit my child by being ashamed of his name. It was good at the christening, and I trust will be thought respectable in manhood."

This edition of the Manual consists of nine chapters. In the first three the author tells the origin and nature of the inorganic ingredients of soil, and in the fourth he describes similarly the organic constituents. Dr. Dana vigorously combats the idea that the kind of rock underlying a district has anything to do with the character of the soil in that district, showing that the soil at any place is a mixture of materials, most of which have been brought from a distance. His full explanations of the several topics that he takes up are summarized in brief statements in a conspicuous type, which he puts forth as the first, second, third, etc., principles of agricultural chemistry. Among these are, "Rocks do not affect the vegetation which covers them"; "Soils contain enough of all the mineral elements to grow any crop" (but it is otherwise with organic constituents); "One base may be substituted for another in an equivalent proportion."

After describing the mutual action of these two classes of substances, he takes up the subject of manure. His chapter opens characteristically :

"The true farmer, no less a sage than the ancient orator who gave to action the first, second, and third place in eloquence, will answer, if it is asked him what is his first requisite, 
Manure. What second? Manure. What third? Manure. These answers are to be united. Action and manure are the first and last requisites in agriculture; and in the attempt to show what is the last, and how it acts, will be offered every inducement to action."

In the seventy-five pages of this chapter he describes the action of the manures of all domestic animals, also poudrette and certain waste materials valuable as fertilizers-wool washings, soot, bones, and spent lye from soapworks-and gives the chemical composition of nearly all.

In a chapter on artificial manures and irrigation, he deals with the use of swamp muck or peat, and tells how to make it a first-class fertilizer by the addition of soda ash or potash. There are a few pages on the physical properties of soils, and then the use of bones as a fertilizer is discussed. An appendix contains the results obtained by Dr. Andrew Nichols and others with the methods suggested by Dr. Dana.

Dr. Dana's geological knowledge was kept bright and increased by constant additions from the best and latest authorities. It aided him greatly in his agricultural researches. One of his courteous attentions to scientific visitors was an excursion to a travelling sand, in an outlying part of the city of Lowell, which was slowly and steadily advancing over arable land, converting it into a desert place. His long-sustained and minute observations threw strong light on the formation of sedimentary rock deposits, where currents of air rather than currents of water were the active agent, and made this field his own.

Dr. Dana died at his residence in Lowell, March I I, I868, in consequence of a fall upon the ice at his own doorstep. In person he was tall and slender, with blue eyes, dark-brown hair, and a fair complexion. The expression of his countenance was intellectual and sympathetic. He was extremely witty, and, in his hours of relaxation from study, he entered with great zest into the pleasures of society, contributing his full share to the enjoyment of others. Even in his scientific writings his humour had some scope, and added a charm and zest to his descriptions that made them highly enjoyable and utterly inimitable.

Dr. Dana's first wife died in 1828 and he afterward 
married her sister, Miss Augusta Willard. James Jackson, the only son of Dr. Dana who survived childhood, when arrived at a suitable age received a commission in the United States army, and was afterward promoted to the rank of brigadier general. Dr. Dana also left three daughters. 



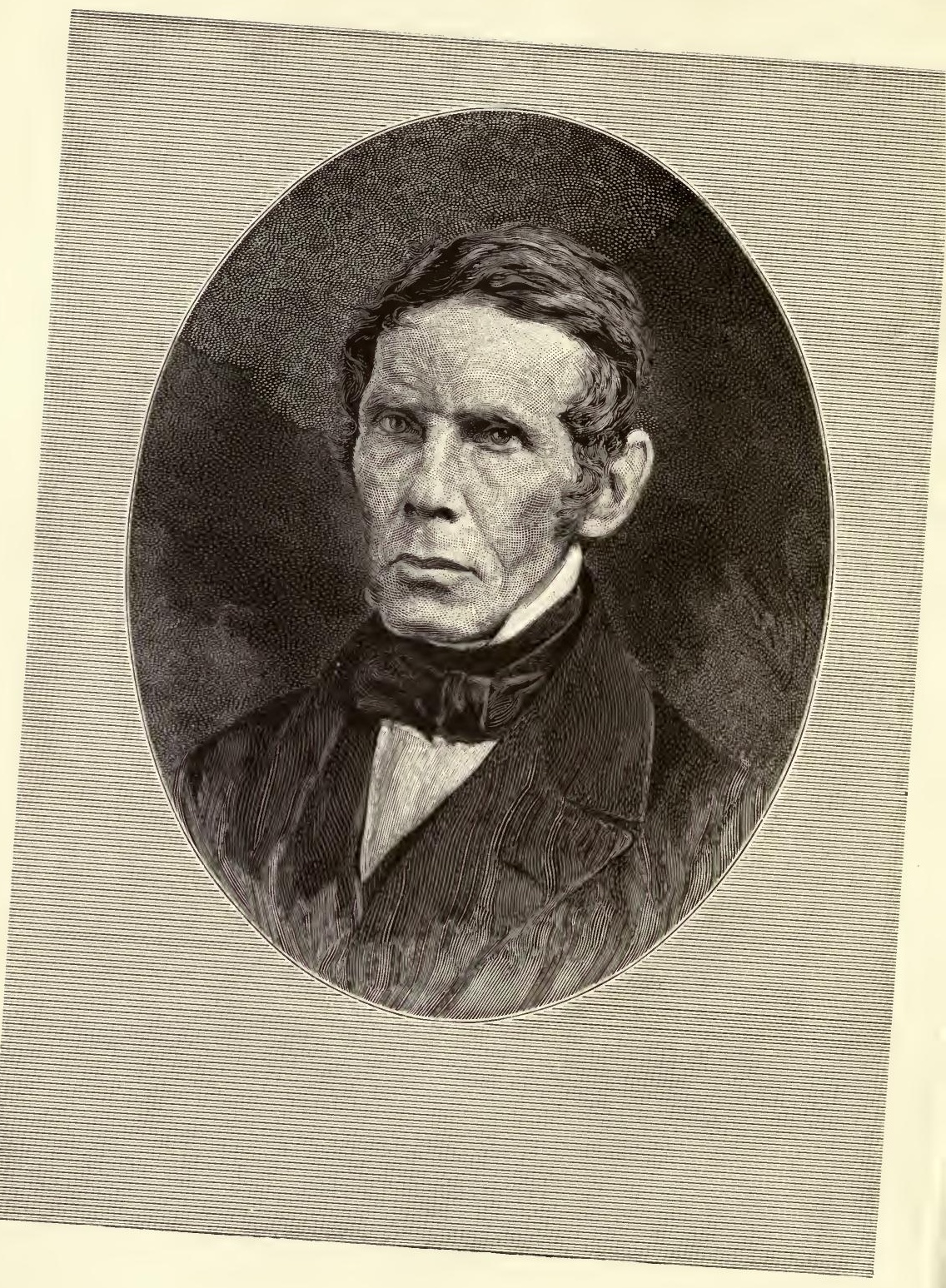

ZADOC THOMPSON. 


\section{ZADOC THOMPSON.}

$1796-1856$.

THE slopes and intervales of the Green Mountains have ever been a home of sterling worth. Much of it has lain modestly hidden unless some compelling occasion called it forth, as the Revolution brought out Ethan Allen and Stark of Bennington. This region has had its workers in science, who, with more generous facilities or a more assertive spirit, could have equalled in prominence many whom the world calls famous. The subject of the present sketch is an example, for he became known in his lifetime only so far as the patient performance of valuable labours of necessity brought him into notice.

Zadoc Thompson was born in Bridgewater, Windsor County, Vt., May 23, I 796. He was the second son of Barnabas Thompson, whose father was one of the early settlers in that part of the country.

His early life was a continual struggle with poverty. Having from childhood a passion for writing and publishing books, he earned part of the expenses of his education in this way. His first publications were almanacs, which he sold travelling about the State on foot. Thompson's Almanac became as famous in Vermont as Robert B. Thomas's in Massachusetts, and shared the honours with the latter publication in adjoining States. Its success was to a large extent due, it is said by those who should know, to a chance remark-it can hardly be called a prediction-which came one day when a clerk, who was at work upon the almanac, found that no weather forecast had been given for July. Prof. Thompson was at the time much absorbed in some investigations, and when interrupted by the printer's inquiry as to the July weather, hastily replied, "Say, Snow about this time." The printer took him at his word and printed snow as a part of the probable weather for 
July. Contrary to all expectations or precedent, in July of that year there was in Vermont a fall of snow! This apparently remarkable knowledge of the probabilities of the weather made Prof. Thompson famous as a weather prophet, and greatly increased the sale of his almanacs. It should be added that Prof. Thompson made constant use of such meteorological instruments as he could obtain, and that he was one of the first in his State to study the weather in a careful and scientific manner.

Mr. Thompson was graduated from the University of Vermont in 1823 , at the advanced age of twenty-seven years, and immediately turned his attention to making known the natural and civil features and history of his native State to its own inhabitants and to the world beyond its borders, which was the chief occupation of his life. Within a year his first publication in this field, a Gazetteer of Vermont, appeared at Montpelier. His first bound volume was an arithmetic, published in 1826 , which had a general sale through the State. While serving as principal of an academy in Canada, he issued a geography and map of Canada for schools, which passed through several editions. In $183_{2} \mathrm{Mr}$. Thompson edited and was the chief contributor to the Green Mountain Repository, a monthly magazine published for about a year at Burlington. In the following year appeared his History of Vermont from its earliest settlement to the close of the year 1832 .

Taking up the study of theology and supporting himself in part by teaching in the Vermont Episcopal Institute and elsewhere, he was prepared for orders, and became a deacon in the Protestant Episcopal Church in 1836 . He preached from time to time in various parishes of northern Vermont and New York, and usually supplied the pulpit of St. Paul's Church, Burlington, during the illness or absence of the rector. His health not being good enough to allow of his undertaking the labours of a parish, and being a man of "deep and unconquerable modesty of spirit," he never advanced to the priesthood.

His earlier works aroused in him a desire to issue something larger and fuller in the same line, and for many years he industriously collected from various "oldest inhabitants" and scattered records facts relating to the history, geography, and natural resources of Vermont. From 1838 to 1842 he devoted 
most of his time to putting together these materials and publishing the resulting Natural, Civil, and Statistical History of Vermont. His attainments in natural history were at that time limited, and he obtained considerable assistance in preparing the accounts of the plants and several classes of animals for this book from other New England naturalists. Having made the mammalia quite a specialty, he described these himself.

The undertaking was most thoroughly and conscientiously carried out, and by the time the book was ready for the press all his savings had been expended. At this juncture the Burlington publisher, Mr. Chauncey Goodrich, who was a neighbour and friend of Mr. Thompson, offered to get out the book for him at the usual prices for the labour and materials without any contingent share in the profit, and to wait for payment from the sales of the work. This generous offer was promptly accepted, and the volume, consisting of six hundred and fifty-six closely printed octavo pages, was duly issued. There were three parts to the work, each of which, if printed less compactly, would have made a fair-sized volume. The first was devoted to the natural features and productions of the State; the second was the civil history; and the third was Mr. Thompson's Gazetteer, revised and enlarged. When Mr. Goodrich several times urged him to issue it in three volumes at six dollars instead of one volume at two dollars and fifty cents, and thereby get twice as much profit from each copy, he steadily declined. Having felt the inconvenience of limited means himself, his sympathies were with those in the same position, and he did not deem it right that those who could not afford the higher price should be deprived of a benefit that their richer neighbours enjoyed, even though the lower price would give him but scant return for the labour, time, and money he had expended. On its appearance the General Assembly of Vermont, regarding the work as a benefit to the State, subscribed for a hundred copies and voted five hundred dollars to the author. By this means and the proceeds of other sales he was enabled to cancel his debt to his publisher in little more than a year.

At about this time Mr. Thompson issued a text-book on the Geology and Geography of Vermont, in which his power of clear and concise statement is well exemplified. He found 
time also to prepare annual astronomical calculations for the Messrs. Waltons, of Montpelier. In 1845 he issued a pamphlet Guide to Lake George and Lake Champlain, with a map and other illustrations.

A State Geological Survey having been authorized by the General Assembly, the Governor in 1845 appointed Prof. Charles B. Adams State Geologist. Prof. Adams chose Mr. Thompson and the Rev. S. R. Hall as his assistants. In one season these two men explored together one hundred and ten townships. The analyses required by the survey were made at New Haven by Denison Olmsted, Jr., until his death in 1846 , afterward by Thomas Sterry Hunt. The survey came to an untimely end by the refusal of the General Assembly of I 847-'48 to make an appropriation for preparing its final report. The notes, specimens, and other materials gathered were allowed to lie in boxes at Burlington and Montpelier for about a year. Then, having had a partial sense of the value of these materials impressed upon it, the General Assembly authorized the Governor to appoint some suitable person to get them together and deposit them in the State House. Governor Coolidge appointed Prof. Thompson, and the latter reported the execution of his commission in October, 1849. Many of the field notes were in a peculiarly abbreviated shorthand used by Prof. Adams, and, on his death in 1853 , became almost wholly useless.

In 1847 Governor Eaton had appointed Prof. Thompson to carry out a resolution of the General Assembly in regard to international literary and scientific exchanges. He wrote a report of proceedings and instructions, presenting the advantages of the exchange system so clearly as to reflect great credit upon himself and upon his State.

From an address which he delivered in Boston, in 1850 , on the invitation of the Boston Society of Natural History, we learn something of the difficulties under which his knowledge of natural science was obtained. "What I have accomplished in the business of natural history," he said, "I have done without any associates engaged in like pursuits, without having any access to collections of specimens, and almost without books." In this address, while showing the difficulties, he at the same time insisted upon the importance of the cultivation of natural history in country places. A habit of observation and com- 
parison of objects, he said, could be acquired quite as readily in the country as in the city. He urged that the study of natural history should be introduced more generally into our colleges and common schools, for the reason that such a study "would refine and improve the moral sensibilities of our people, and sharpen and invigorate their intellectual powers." Prof. Thompson's love for natural history was inborn, and throughout his life amounted to absolute devotion. It was the supreme force in his life. From early childhood until the end, his diligent study of Nature and zeal in collecting facts, and objects to illustrate them, never faltered. He was not only a student of Nature but her ardent and most constant lover. $\mathrm{He}$ also enjoyed mathematical studies and was fond of statistics, and these qualities rendered his work in all departments of science more accurate and orderly than it might otherwise have been.

Certain of his friends (his modest worth had made him many of these), knowing his great desire to see the Exhibition of $185 \mathrm{I}$ at London, furnished him the means of making the trip. After an absence of three months, during which he had spent some time in Paris, he returned to his home in Burlington much benefited in spirit and in health. Yielding to repeated solicitation, he published soon after his Journal of a Trip to London, Paris, and the Great Exhibition in $185 \mathrm{I}$, which gave a most realizing impression of what he had seen to those who had not made the trip.

In the ten years following the publication of his History of Vermont, railroads and telegraphs were introduced into the State, and various discoveries in its natural history were made, all of which furnished him material for a valuable supplement of sixty-four pages, issued early in $\mathrm{r}_{533}$. The General Assembly of this year discovered what a blunder had been made in strangling the geological survey, and passed a bill appointing Prof. Thompson State Naturalist, " to enter upon a thorough prosecution and completion of the geological survey of the State, embracing therein a full and scientific examination and description of its rocks, soils, metals, and minerals ; make careful and complete assays and analyses of the same, and prepare the results of his labours for publication under the three following titles, to wit: first, Physical Geography, Scientific Geology and Mineralogy; second, Economical Geology, embracing Bot- 
any and Agriculture; third, General Zoölogy of the State." At first he planned to do no more than collate and arrange such material as had been accumulated by his predecessors; but he soon found this very unsatisfactory, and, abandoning this plan, he undertook to go over the whole ground anew. He had for years been unknowingly preparing for just this task, and he threw himself into it with his accustomed energy and devotion, and suspended all other work; but ere long his overtaxed strength gave way, and his last illness was upon him. At first he seemed unwilling to lay aside a task so congenial, and which he so greatly desired to finish; but soon his naturally quiet and trustful disposition overcame all discontent, and in full acquiescence in the will of the God in whom he had always trusted and whom he had tried to serve, he came to the end in peace, on January 19,1856 . At this time he also held the professorship of Natural History in the University of Vermont, to which he had been appointed in $185^{2}$.

His friend for over a score of years, Dr. Thomas M. Brewer, editor of the Boston Atlas, and himself a naturalist of no small ability, thus referred to Prof. Thompson's death: "His loss, both as a citizen and a public man-he has not left his superior in science behind him in his own State-is one of no ordinary character. We have known him long and well; and in speaking of such a loss we know not which most to sympathize with, the family from whom has been taken the upright, devoted, and kind-hearted head, or that larger family of science who have lost an honoured and most valuable member. Modest and unassuming, diligent and indefatigable in his scientific pursuits, attentive to all, whether about him or at a distance, and whether friends or strangers, no man will be more missed, not merely in his immediate circle of family and friends, but in that larger sphere of the lovers of natural science, than Zadoc Thompson."

When his death was announced to the Boston Society of Natural History, of which he was a member, Prof. William B. Rogers took occasion to express the high respect in which he had held him as a thorough and persevering worker in geology, saying that he possessed a larger amount of accurate practical knowledge than would have been supposed from his modest and retiring manners, and exhibited a great natural sagacity in those departments of science which he loved. 
No account of the life and labours of Prof. Thompson is at all complete without some mention of his wife, for without her aid and sympathy he never could have accomplished what he did. In childhood they roamed the fields together in search of interesting objects, and later, as husband and wife, they pursued with increased enthusiasm the same study of Nature; and long after Mr. Thompson's death his wife continued her observations of animals and plants. Moreover, being a very shrewd and efficient manager in all household matters, she was able to carry the family through financial difficulties which otherwise would have frustrated many of her husband's scientific undertakings. Their house was not only a home, but it was also a museum and a laboratory. It was a very modest little white cottage, surrounded by a profusion of flowers when the season permitted, and inside, every available shelf or stand was crowded with specimens which either had been or were to be carefully studied, while not seldom there were in or about the house pens, cages, or tubs in which were kept many living animals, whose daily life was under closest scrutiny. Mrs. Thompson not only tolerated these inroads upon her housekeeping, but delighted to assist her husband in his work, and really deserves to be considered a colleague in many of his labours.

Personally, Prof. Thompson was tall, angular, of a very quiet and sedate yet very pleasant manner, a man of most amiable and sweet temper, loved by all who knew him, and respected for his sound sense and accurate judgment. Though retiring by nature, he was fond of long chats around the winter hearth with such neighbours as were congenial. Prof. Joseph Torrey was his most intimate friend, being an excellent botanist, and with him Mr. Thompson's intercourse was most delightful. He was simple, almost childlike in his tastes. Naturally somewhat conservative, his training in science had given him an open mind to all new truth. It is not improbable that the sober manner which he usually maintained came from the shadow of death which had long rested upon him. He was affected by organic disease of the heart, which finally ended his life, and for many years, knowing the possibility of sudden death, he did not trust himself far from home alone. Most often his companion was a Mr. Hills, who was draughtsman and engraver of nearly if not quite all the cuts used in his publications. 
The museum in the Vermont State House contains about three thousand specimens collected by Prof. Thompson. $\mathrm{He}$ was one of the most reliable correspondents of the Smithsonian Institution, and corresponded also with many of the leading naturalists both at home and abroad. His achievements won him a medal from the French Exposition of 1855 . 



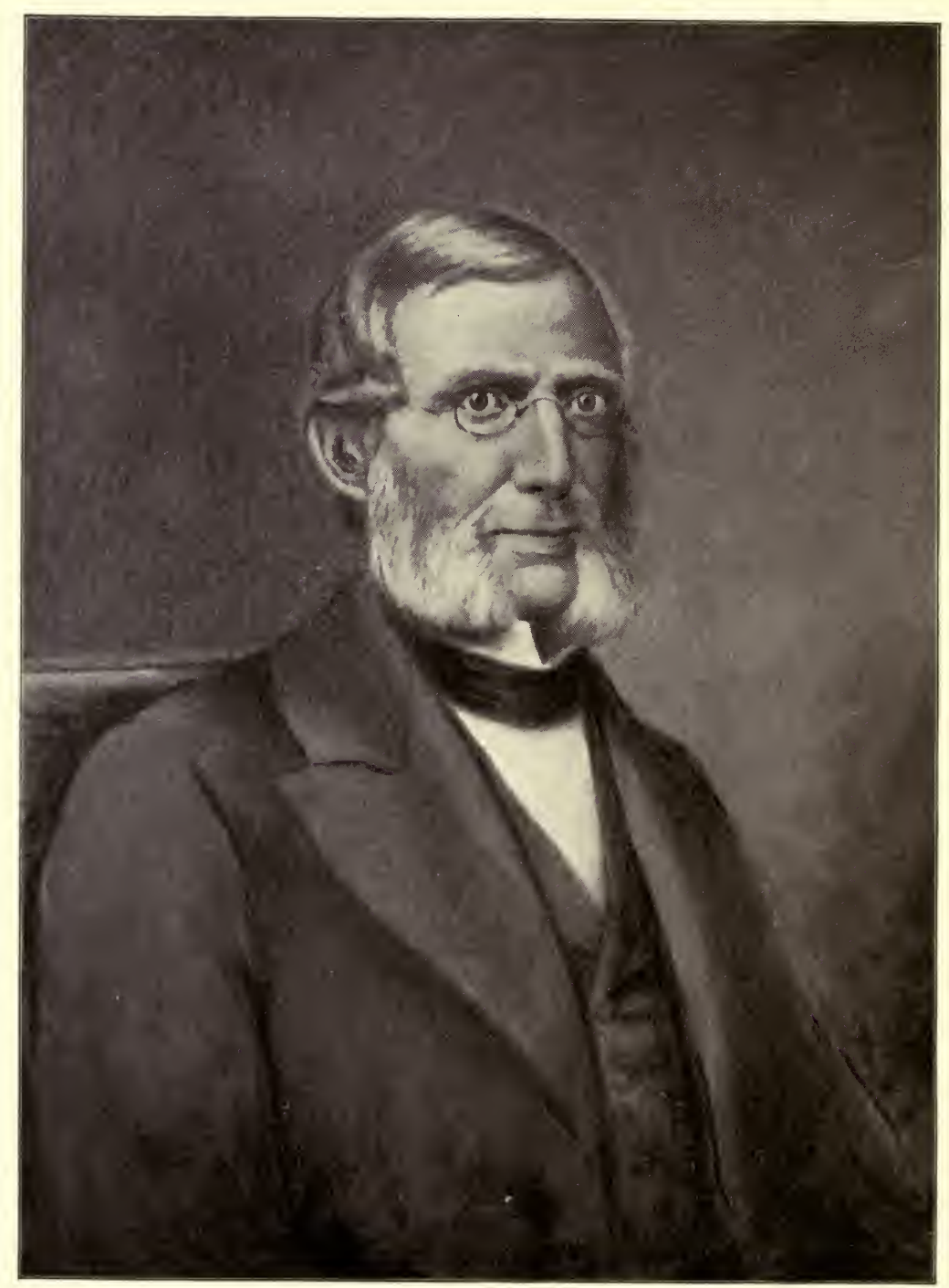

JOHN TORREY. 


\section{JOHN TORREY.}

$$
\text { r 796-1 } 873 \text {. }
$$

Although never noted as a scientific centre, the city of New York has had several men of science of eminent abilities. Among the foremost of these was the subject of the present article.

John Torrey was born in New York, August 15, 1796. He lived most of his life in that city and died there March ro, r873. He is believed to have been descended from William Torrey, who emigrated from Somersetshire, in England, and settled at Weymouth, Mass., about 1640. His grandfather, John Torrey, and his father, William, removed from Boston to Montreal when the Boston Port Bill came into force. William, then a boy of seventeen, soon ran away to New York and joined a Continental regiment of which his uncle was major. He was made an ensign, served throughout the war, and received his discharge as a captain. His father also came down from Canada and served as quartermaster of the same regiment.

Captain Torrey married Margaret Nichols, of New York, in r79r. John was their second child and the first that reached adult age. His birthplace was in John Street, a locality long since given over to trade. He has been heard to tell that when a boy of some twelve years of age he was sent on an errand one evening as far as Canal Street, and that he considered it a great hardship to be obliged to go so far into the country after dark. When he was fifteen or sixteen years old his father was appointed fiscal agent of the State prison at Greenwich, whither the family removed. Canal Street is now considered to be away down town, while Greenwich, although a suburban village in $18 \mathrm{r} 2$, is also a down-town district, being below Fourteenth Street.

Young Torrey received his education in the public schools 827 
of his native city, with the addition of one year at a school in Boston. He had in youth a strong liking for machinery, and at one time had the intention of becoming a machinist, but chemistry offered still greater attractions, and he finally concluded to study medicine. His mechanical talent was in after years of great service to Dr. Torrey, as it enabled him to devise and construct various ingenious forms of apparatus for the illustration of his lectures. While in his teens he came under the influence of that famous teacher of science, Amos Eaton, who explained to him the structure of flowers and thus kindled a zeal for botanical study that persisted to the end of his pupil's life. Torrey's interest in natural science soon extended to mineralogy and chemistry, probably determining his choice of a profession. In I $\mathrm{I}_{5}$ he entered the office of Dr. Wright Post, then one of the leading physicians of the city. At that day physicians dispensed their own medicines, and it was the duty of the office students to prepare the various powders, tinctures, etc., and put up the prescriptions for the patients. The writer has frequently heard Prof. Torrey refer to the great value this experience was to him in after-life, as it gave him an early training in chemical manipulation such as the medical students of the present day rarely acquire.

Dr. Torrey took his degree in 1818 at the College of Physicians and Surgeons, in New York, where Drs. Mitchill and Hosack, then among the leaders of science in America, were professors. He opened an office in New York city, but he never liked the practice of medicine, and did not try very earnestly to become established in it, and we find him, in I824, entering upon the duties of Professor of Chemistry at the United States Military Academy at West Point. At this time he married Miss Eliza Robinson Shaw, of New York. We may here remark that Dr. Torrey's scientific life was twofold. While he is best known to the world as a botanist, it was as a chemist that he found his remunerative occupation. From the time of his acceptance of the chair at West Point, up to the day of his death, he was engaged either in teaching chemistry or in some position to which his profound chemical knowledge adapted him.

In early life Prof. Torrey was an enthusiastic mineralogist, and the first and following volumes of the American Journal of Science contain important contributions made by him to this 
science. His botanical career commenced while he was yet a student of medicine. In 1817 he aided in founding the New York Lyceum of Natural History, and was one of the eleven corporators named in the charter of that institution. The early volumes of the Annals of the Lyceum are enriched by some of his most important contributions to science. His first botanical publication was A Catalogue of Plants growing spontaneously within Thirty Miles of the City of New York. This was presented to the Lyceum in 1817 , but was not published until 18 rg. It contains roo pages, is now exceedingly rare, and chance copies offered at sales of libraries bring fabulous prices. We find quoted in this catalogue the names of those who were distinguished botanists half a century ago, the author acknowledging aid from Mitchill, Nuttall, Rafinesque, Eaton, Eddy, Le Conte, Cooper, and others. When we consider the youth of the author, barely twenty-one, we must regard this catalogue as a remarkable performance. Only those who have undertaken similar works can appreciate the amount of labour necessary to its production, and botanists who go over the same ground at the present day wonder at the completeness of the list. It gives us some idea of the astonishing growth of the city to read in this catalogue of some of the author's favourite localities, such as "Love Lane," "Bogs near Greenwich," and "Swamp behind the Botanic Garden," places that have long been covered by paved streets and brick and brown-stone blocks.

This catalogue, was the precursor of a considerable number of most valuable botanical publications. One of the earliest of these was A Flora of the Northern and Middle United States, or a Systematic Arrangement and Description of all the Plants heretofore discovered in the United States north of Virginia. Elliott's Botany of South Carolina and Georgia was being published in numbers at the time Dr. Torrey commenced this Flora, which, as he says in his preface, was intended as a "counterpart" to Elliott's work. Like the latter, his was issued in numbers, and the first volume was completed in 1824 . But one volume of this work was published, and, as a portion of the edition was destroyed by fire, it is now only rarely to be met with. It contains over five hundred pages, and includes the first twelve classes of the Linnæan system, the species being described with a clearness and minuteness and the synon- 
ymy elaborated with a care not heretofore displayed in any work upon American botany. It was the first work in which our Northern grasses were treated in a thorough manner, and students of the Graminacea at the present day find it a most useful book of reference. At an early day the author foresaw that the Linnæan system must be superseded by the natural system of Jussieu. This consideration, together with the loss of a large part of the first volume, led him to abandon the undertaking. In order to supply the immediate wants of students, he prepared a compendium, which gave brief descriptions of the plants contained in the first volume of the Flora and of those which would have been included in the second volume.

In the same year he published, jointly with Schweinitz, A Monograph of the North American Species of Carex. Two years later his paper entitled Some Account of a Collection of Plants made during a Journey to and from the Rocky Mountains in the Summer of 1820 , by Edwin P. James, M. D., Assistant-Surgeon United States Army, was read before the Lyceum, but it was not published until 1828 . It is a memoir of some eighty pages, and enumerates four hundred and eighty-one plants, many of which were new species. This was, up to the date of its publication, the author's most important contribution to science, and is even now frequently referred to by the student of our Western plants. Besides, it has an especial interest, as it was the first American work of any importance in which the arrangement was according to the natural system, the only earlier publication in which this system was followed being a list by Abbé Correa, of the genera in Muhlenberg's catalogue, arranged according to the natural orders of Jussieu.

In 1838 The Flora of North America, by John Torrey and Asa Gray, was commenced. It was published in numbers, and at irregular intervals, until the year 1843 . Dr. Asa Gray, then a young physician in Western New York, who had already shown great acuteness in his investigations of the flora of the part of the State in which he resided, was happily associated with Dr. Torrey in this great undertaking of publishing a Flora of North America. The work was suspended with the completion of the Compositæ, and for sufficient reasons. Just at this time our Government began to explore its Western territory, soon greatly enlarged by the annexation of Texas and the acquisi- 
tions by the war with Mexico. New botanical material accumulated at an astonishing rate, and our chief botanists had to choose between continuing the Flora, and allowing these botanical treasures to pass into other hands. They wisely determined to devote themselves to elaborating the new material, knowing that this work would be contributing to the future flora of North America, which, from the enlarged possessions and more thorough exploration of the older territory, must be taken up anew. Both authors industriously worked at the collections brought home by the various Government and private explorers; those wholly or in large part examined by Dr. 'Torrey were those of Nicollet's expedition, Frémont's expeditions to the Rocky Mountains and to Oregon and North California, Emory's reconnaissance, Captain Stansbury's expedition to the Great Salt Lake, Captain Marcy's exploration of the Red River of Louisiana, Captain Sitgreaves's expedition to the Zuñi and Colorado Rivers, the Mexican Boundary Survey, and Lieutenant Ives's Colorado exploring expedition.

When the New York State geological survey of $183_{3} 6$ was organized, Dr. Torrey was commissioned State botanist. $\mathrm{He}$ prepared for the survey The Flora of the State of New York, being a portion of The Natural History of New York, and issued in 1843 . This work is in two large quarto volumes, of over five hundred pages each, and illustrated with one hundred and sixty-one plates. The descriptions are all redrawn, elaborate, and in a somewhat popular style. It is a most striking testimony to the industry of the author, who, while engaged upon this work, and making important explorations incidental to it, was at the same time discharging his professorial duties at the College of Physicians and Surgeons, and at Princeton.

The years r855-'60 saw the publication of the Reports of the Pacific Railroad Survey, to the several volumes of which Dr. Torrey made the following contributions: Vol. II, Botany of Captain Pope's Expedition, Botany of Lieutenant Beckwith's Expedition, Botany of Captain Gunnison's Survey (in these three memoirs Prof. Asa Gray was joint author); Vol. IV, Botany of Whipple's Expedition; Vol. V, Botany of Lieutenant Williamson's Report; Vol. VIII, Botany of Lieutenant Parke's Expedition.

We do not include here the contributions of Dr. Torrey to the memoirs of Prof. Gray and others, for which he frequently 
elaborated genera and families; nor do we enumerate his minor contributions to the sciences.

Nearly all of these memoirs are illustrated by engravings, and some of them profusely. Dr. Torrey rarely attempted to give the portrait of a plant, leaving that to the professional draughtsman; but in all the sketches showing minute structure - that which gave the illustrations their greatest value to the botanist-his ready pencil found frequent employment. He drew with great neatness and rapidity, and it was his custom to record his observations by means of sketches of remarkable distinctness and accuracy.

For several years subsequent to $186 \mathrm{x}$ he was engaged in herbarium work. His removal to Columbia College, and the disposal of his most valuable collection to that institution, rendered it necessary that the accumulations of years, including numerous typical specimens, should be put in complete order. He entered into the drudgery of assorting, determining, labelling, and mounting in the herbarium the mass of unarranged material, with the same industry and zeal that he brought to more congenial work. No other hands than his could have completed this important task, and botanists have reason to be grateful that he was spared long enough to put it, in some respects, the most important herbarium in the country, in proper condition for study and reference.

This work being completed, we find him, though advanced in life, again contributing to his favourite science, and, in 1870 , The Revision of the Eriogonex, the joint production of himself and Prof. Asa Gray, was published in the Proceedings of the American Academy of Arts and Sciences. On the return of Wilkes's exploring expedition, the botanical collections were divided between Drs. Torrey and Gray, except the Cryptogamia, which were given to specialists. In the division Dr. Gray took the extra-American share, while those collected on our Pacific coast were elaborated by Dr. Torrey. Before his memoir could be published, the civil war came on, and stopped all appropriations for such work. A few months before his death the proposition to publish was revived, and the last botanical work of Dr. Torrey was to take up, during a rally from his fatal illness, this long-delayed manuscript of the botany of Wilkes's expedition, and prepare it for the press. Although his mind was as clear and his perceptions as acute as 
ever, his strength was unequal to the task. For several years his health had been so delicate as to cause anxiety to his family and friends, and each succeeding winter he seemed to be more susceptible to atmospheric changes. In the winter of $1872-73$ he had a severe attack of pneumonia, which left him so weak that he was unable to rally, and his death, which was in a measure sudden, soon followed. He left one son and three daughters, also a grandson, Gray Torrey.

Speaking of his list of works his pupil and associate, Prof. Asa Gray, says: * "There would have been more to add, perhaps of equal importance, if Dr. Torrey had been as ready to complete and publish as he was to investigate, annotate, and sketch. Through undue diffidence and a constant desire for a greater perfection than was at the time attainable, many interesting observations have from time to time been anticipated by other botanists." Throughout all his botanical labours the flora of North America was constantly kept in view, and each special monograph that he wrought out was regarded as a piece of material for that grand edifice-a complete system of American botany-which he hoped would some day be completed.

"In the estimate of Dr. Torrey's botanical work," Prof. Gray continues, "it must not be forgotten that it was nearly all done in the intervals of a busy professional life." In 1827 he gave up his professorship of chemistry at West Point, already alluded to, and took a similar chair in the College of Physicians and Surgeons, where he had received his own medical degree. For twenty-seven years he held this position, and for part of this time he was also Professor of Chemistry at Princeton, where he was associated with Prof. Henry. Then, in 1854 , a United States Assay Office was established at New York, in which Prof. Torrey became the assayer, and so remained until his death. "The Secretary of the Treasury," says Prof. Gray, "selected Dr. Torrey to be its superintendent, which would have given to the establishment the advantage of a scientific head. But Dr. Torrey resolutely declined the less laborious and better paid post, and took in preference one the emoluments of which were much below his worth and the valuable extraneous services he rendered to the Government, simply because he was

* In a memoir read before the Amcrican Academy of Arts and Sciences, 1873. 
unwilling to accept the care and responsibility of treasure." Difficult problems relating to counterfeiting and other coinage matters, also various delicate and confidential commissions, were frequently intrusted to Prof. Torrey by the head of the Treasury Department, the utmost reliance being placed upon his skill, wisdom, and probity. Two of these commissions took him to California-once by way of Panama and once across the continent-and were especially gratifying to Dr. Torrey, as they enabled him to gather from its native soil many a plant that he had himself described and named from the dried specimens of some other collector. Dr. Torrey's chemical skill made his advice sought for by various industrial establishments, among them being the Manhattan Gas Company, whose consulting chemist he was for a number of years. In his position as United States assayer he was succeeded by his son, Herbert G. Torrey.

This enumeration of his scientific labours would be incomplete without reference to his great work in educating others in science. In the various professorships he held he was always to the students a loved instructor, and many now eminent in science can trace the commencement of their careers to the teachings of Dr. Torrey. His greatest service in this field was in teaching Asa Gray, who came to him with a letter of introduction when nineteen years of age, was invited to a correspondence, and soon became an assistant and associate. Not only in the class-room, but out of it, was his influence constantly exerted, and he was always surrounded by a circle of young men who never came to him in vain for sympathy and encouragement. He gave to such what was better than pecuniary aid, comfort, hope, and help in its best sense. There is many a chemist, now standing high in his profession, who owes much to his kindly aid, and scarcely a botanist in the country who has not been a recipient of favours from his ever-open hand.

As trustee of Columbia College and of Princeton he was largely influential in giving scientific studies their proper prominence in these institutions. It was through his influence, more than to that of any other one person, that the School of Mines was established. $\mathrm{He}$ always took the liveliest interest in its progress, and its ultimate success was to him a source of great gratification. 
Dr. Torrey was a member of many scientific organizations, domestic and foreign. He had presided over the American Association for the Advancement of Science, and was twice, for considerable periods, President of the New York Lyceum of Natural History. It has been said of him that the sole distinction on which he prided himself was his membership in the order of the Cincinnati-which came to him through his father and grandfather. An association formed by the botanists of New York and vicinity, to which they gave the name of the Torrey Botanical Club, grew rapidly from small beginnings to a considerable size. An act of incorporation was obtained for it in $187 \mathrm{I}$ and Dr. Torrey was elected the first president under the charter. This election took place when he was too ill to attend the meeting of the club, and he never assumed the office.

Two attempts, by Sprengel and Rafinesque, to render to Torrey the customary testimonial that a botanist receives from his fellows having failed, it was fortunately possible to give his name to a remarkable ever-green tree discovered in our own Southern States. Three other species have since been found respectively in California, Japan, and China. All four have been introduced into Europe, and are greatly prized there as ornamental trees; so that all round the world Torreya taxifolia, Torreya Californica, Torreya nucifera, and Torreya grandis, by their perpetual verdure, give aid to his own achievements in keeping green the memory of one of America's foremost botanists.

Of Dr. Torrey as a man, aside from his scientific work, a friend who had known him long and well has remarked: " $\mathrm{He}$ is the only man I ever knew of whom it could be said he was truly lovable." However distinguished his position as a man of science, there was something beyond and beneath this, a personal charm that was the admiration of all his friends. A devoted Christian, he never obtruded his Christianity, but let it appear in his every relation in life. Belonging to a denomination that is by some considered exceedingly strict, he was most charitable for the opinions of those who believed differently. Knowing that all truths are compatible, he was never disturbed by the results of scientific.research, being confident, on the other hand, that they would be found in final agreement with all that is truest and best in man's religious beliefs. 


\section{GEORGE CATLIN.}

$$
\text { I796-is? } 2 \text {. }
$$

Grokgs Caturs's work was tendertaken act from a scientiff, but rather an artistic impulse. It became, aevertheless, traly scientific in spirit; and it bas resulted ir learing to the world the fullest and most rarious records that it bas in picture and written description, of the aboriginal tribes of both Americas as ther were before their customs and icleas were modiffed by civiliastien, or they were contamimated by white intureaces-a most precious collection of original material for anthropologists to study.

George Catlia was bora ia Wilkesbarse, Pa, July 26 , 1796 . and died in Jersey City. N. I, December 23,1821 . He was descended from a family who "came over with the Conqueror," bis ancestor of that peried having been recorded in Domesdar Book as poscessing in rost two knights" fees of land io Kent. The Catlias have been seated ever since at Newington, Kent; and various members of the family have been bonourabiy emploved in the service of the kings of England and other powers. Thomas Catlin, the first ancester in the Uaited States, with two brothers came from England or Wrales sometime before 1643 , when be is mentioned as having been settled in Hartford, Coun Putman Catlin, the artist's fatber, served in the colcuial forces for sir years durieg the Revelutionary Wat. He then studied law, was admitsed to the bar, and went to Wilkesbarre, Pa, to gractise his profession. Here, in $17 \&$ g, he married Polly Sutton. She was the danghter of an early settler of Wroming Valler, who was engaged in the battles with the Iadians at the time of the mascacres; and she back been berself captured by the Incians at the surtender of Forty Fort.

Mas Catlin was a Methodist and a derout Christian, wbile the fatber was "a phillosopher, professing wo particular creed. 


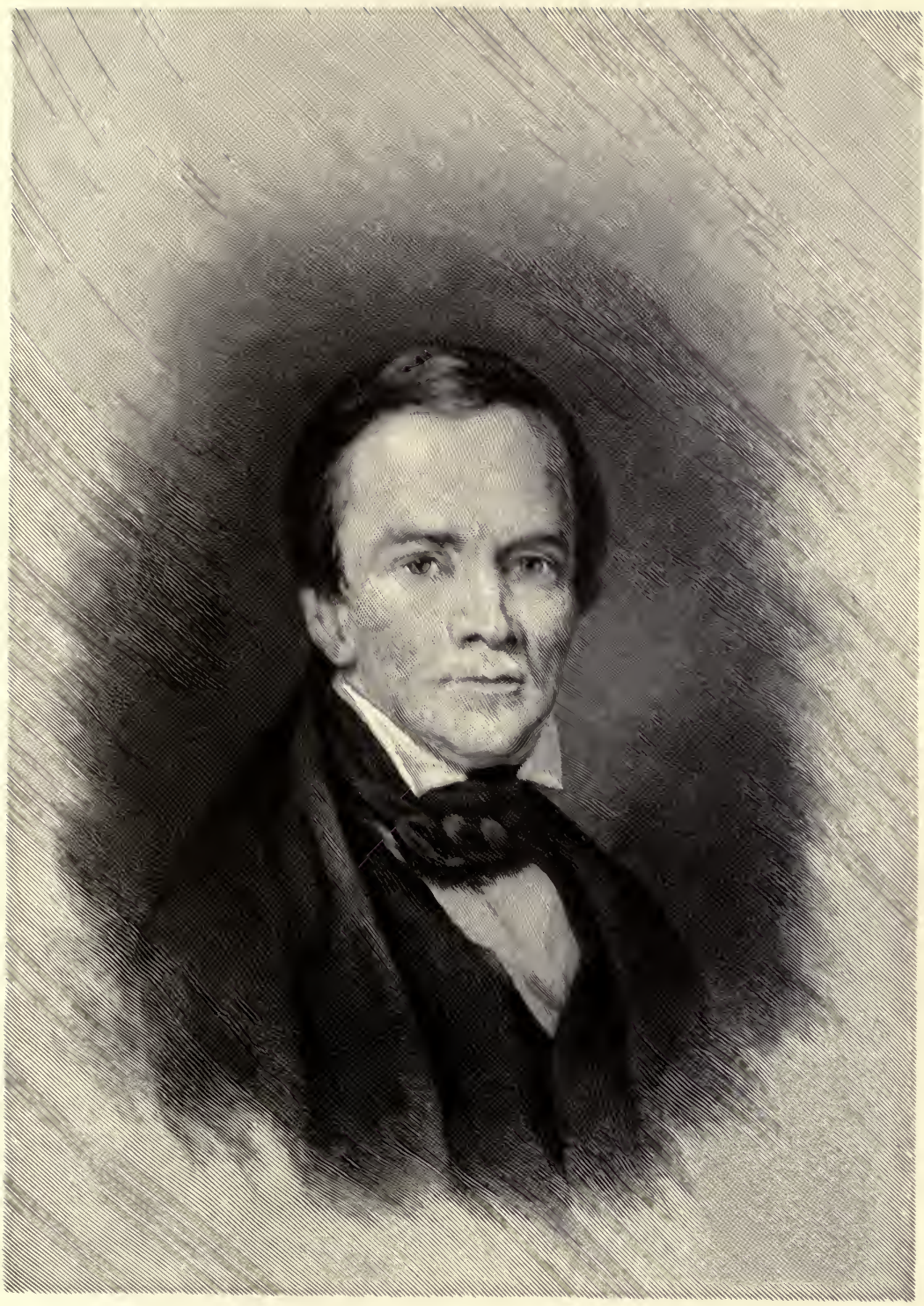

GEORGE CATLIN. 

but keeping and teaching the commandments." In 1797 the family removed to Ona-qua-gua Valley, Broome County, N. Y., travelling on horseback over an Indian trail, the baby George being carried in his mother's arms. They afterward removed, at different times, to Hop Bottom, Montrose, and Great Bend, $\mathrm{Pa}$.

George was the fifth of fourteen children. Until he was about fifteen years old the boy lived much with Nature, and became an accomplished hunter and fisherman-occupations for which he had an inveterate propensity, and from which his father and mother had great difficulty in turning his attention to books. By virtue of his associations his mind and imagination were filled with stories of Indians and Indian life. His parents had vivid recollections of the terrible adventures in which they had participated; his father's generous hospitality caused the place to be frequented by Revolutionary soldiers, Indian fighters, hunters, trappers, and explorers, for whose stories he had an always ready ear; even the noonday rests in the farm fields were enlivened by the relation of incidents of the early settlement; and the very valley where he lived had been the rendezvous of Brant and his army during the frontier war.

His early training, which was that usual for the sons of persons of means in the colonies, was carefully attended to by his father and his mother. In $18 \mathrm{I} 7$ and $18 \mathrm{I} 8$ he attended the law school of Reeves \& Gould, at Litchfield, Conn. $\mathrm{He}$ continued his law studies in Pennsylvania, and entered upon the practice of the profession in the courts of Luzerne and the adjoining counties. But during the time of his practice, from 1820 to 1823 , the passion for painting, in which he had already in Connecticut become noted as an amateur, was getting the advantage of him, and soon all his love of pleading gave way to it ; and, he says, "After having covered nearly every inch of the lawyer's table (and even encroached upon the judge's bench) with penknife, pen and ink, and pencil sketches of judges, juries, and culprits, I very deliberately resolved to convert my law library into paint pots and brushes, and to pursue painting as my future and apparently more agreeable profession."

He settled in Philadelphia in 1823 , and was at once admitted to the fraternity of artists there, which included Thomas 
Sully, John Nagle, Charles Wilson, and Rembrandt Peale. In the next year he was admitted as an academician of the Pennsylvania Academy of Fine Arts. He was most successful as a miniature painter in water colours on ivory. Among his more famous paintings were one of Mrs. Madison in a turban; the Virginia Constitutional Convention of 1839 ; the portrait of De Witt Clinton, which hangs in the Governor's Room of the New York City Hall, and of which the Franklin Institute, of Rochester, N. Y., has a copy from his hand; and portraits of members of the Legislature and other prominent men of New York. While at Albany painting the portraits of Clinton and others, Mr. Catlin met Miss Clara B. Gregory, and was married to her, May Io, I828.

He visited New York, Buffalo, Norfolk, and other cities in the exercise of his art, and often saw the delegations of Indians that were in the habit of visiting Washington at that period of our history. While in Philadelphia, he writes, his mind was continually reaching for some branch or enterprise of the art "on which to devote a whole lifetime of enthusiasm,.... a delegation of some ten or fifteen noble and dignified looking Indians from the wilds of the far West suddenly arrived in the city, arrayed and equipped in all of their classic beauty, with shield and helmet, with tunic and manteau, tinted and tasselled off exactly for the painter's palette." Having an eye for nature rather than for the conventionalities of civilization, he had long been of the opinion that the wilderness of our country afforded models equal to those from which the Grecian sculptors transferred inimitable grace and beauty to marble; and a short experience in the woods among Indians confirmed him in this view. In the midst of his success as a painter, he wrote in $\mathrm{r} 86 \mathrm{I}$, " $\mathrm{I}$ again resolved to use my art, and so much of the labours of my future life as might be required, in rescuing from oblivion the looks and customs of the vanishing races of native man in America, to which I plainly saw they were hastening before the approach and certain progress of civilization." If he should live to accomplish his design, he thought, "the result of my labours will doubtless be interesting to future eyes, who will have little else left from which to judge of the original inhabitants of this simple race of beings." So he set out alone unaided and unadvised, to collect his portraits 
and illustrations of primitive looks and customs, to set them up "in a gallery, unique and imperishable, for the use and benefit of future ages." $\mathrm{He}$ was never even comfortably off in money matters, says his biographer, Mrs. Clara Catlin Clarke, "relying for his livelihood upon his brush or his pen. He lived poor and died the same. He received no pecuniary aid, governmental or individual, in the prosecution of his work." He accomplished it with remarkable thoroughness.

He followed this work for forty-two years-from 1829 to r $87 \mathrm{I}$-and during that time travelled through the wildernesses of North and South America, and visited Europe, making his name known everywhere. During eight years, from 1829 till $\mathbf{r} 838$, he lived among the Indians, traders, trappers, and hunters of the West.

In 1830 and 183 i he accompanied Governor Clark, Superintendent of Indian Affairs, to treaties held with the Winnebagoes and Menomonees, the Shawnees and Sacs and Foxes, and in these interviews began the series of his Indian paintings. In r $_{3}$ I he visited, with Governor Clark, the Kansas, and returned to St. Louis. In $\mathrm{r}_{32}$ he painted the portraits of Black Hawk and his warriors, prisoners of war. In the same year, on his second journey, he ascended the Missouri, by steamer, to Fort Union, mouth of the Yellowstone, and returned to St. Louis in a canoe with two men, steering his frail craft the whole distance of two thousand miles with his own paddle, visiting and painting ten tribes. Of these tribes the most important were the Mandans, to whom he devoted more time and labour than any other in North America. The red pipestone is now classified at the Smithsonian Institution as Catlinite, being considered his discovery. While on the way to gather specimens in $183_{2}$ he stopped at the point where Chicago now stands, and made a sketch of Fort Dearborn, then one of the few landmarks. The sketch is still extant. In 1833 he ascended the Platte to Fort Laramie, visiting villages of the Pawnees, Omahas, and Otoes, and seeing many Arapahoes and Cheyennes, and rode to the shores of the Great Salt Lake, while the Mormons were yet building their temple at Nauvoo. In 1834 he accompanied a regiment of mounted dragoons to the Comanches and other Southwestern tribes, making an extensive journey and seeing many Indians of various tribes; 
then from Fort Gibson, Ark., on his horse "Charley," without a road or a track, rode to St. Louis, a distance of five hundred and fifty miles, guided by his pocket compass, and swimming the rivers as he met them. In 1835 he ascended the Mississippi to the Falls of St. Anthony, saw the Mississippi Sioux, the Ojibways and Saukees or Sacs, and descended the river again to St. Louis in a bark canoe with one man, steering with his own paddle. In 1836 he made a second visit to the Falls of St. Anthony, steaming from Buffalo to Green Bay, ascending the Fox and descending the Wisconsin Rivers, six hundred miles in a bark canoe to Prairie du Chien, and thence by canoe four hundred and fifty miles to the Falls of St. Anthony. Thence he ascended the St. Peter's to the "Pipestone Quarry" on the Côteau des Prairies, and descended the St. Peter's in a canoe, with a companion, to the Falls of St. Anthony, and from them a second time to St. Louis in a bark canoe, nine hundred miles. In 1837 he went to the coast of Florida to see the Seminoles and Euchees, and in the same year made a voyage from New York to Charleston to paint Osceola and the other Seminole chiefs, then prisoners of war. The letters embodying the observations made during these journeys-to which thirty-eight tribes sat to him for their portraits-on the tribes and country furnished the text for the book, Illustrations of the Manners, Customs, and Condition of the North American Indians, which passed in England through more than twenty-five editions, and of which more than sixty thousand copies were sold.

Mr. Catlin's chief object on these journeys was to observe the Indian as a man, and to perpetuate the representation of the kind of a man he was. He watched him in every aspect, caught him in every mood, studied him in every relation, and put him down, on canvas or in his notes, as he found him. He enjoyed and improved, to the full extent of his power, opportunities which have occurred to few so ready to make a record of them, and will never occur again to any one, of becoming familiar with the red man in his natural, unsophisticated state, with the intention of making mankind, as far as possible, a sharer in his privileges.

Most of the places he visited, the names of many of which have become familiar to us, and which now seem commonplace, were then away out beyond the bounds of civilization, and visited by the ordinary tourist, if visited by him at all, with 
an apprehension not unlike that with which he would now start out for Central Africa. The Indians knew little of the white man, and his inventions were strange and mysterious to them. Thus, the people on the Yellowstone had never seen or heard of a steamboat, and at some places were at a loss what to do or how to act at the sight of one.

The art of portrait painting was new to the savages, and the strange, whimsical, and superstitious notions which they conceived of Mr. Catlin's operations were the source of many curious incidents. The portraits produced great excitement in the villages, with intense interest in the personality of the artist. The people pronounced him the greatest medicine man in the world, for he made living beings; they said "they could see their chiefs alive in two places; those that he had made were a little alive; they could see their eyes move, could see them smile and laugh, and if they could laugh they could certainly speak, if they should try, and they must therefore have some life in them." The squaws generally agreed that "they had discovered life enough in them to render my medicine too great for the Mandans; saying that such an operation could not be performed without taking from the original something which I put in the picture, and they could see it move, could see it stir." Then the cry went around that the artist was a dangerous man; "one who could make living persons by looking at them, and at the same time could, as a matter of course, destroy life in the same way, if I chose." When a movement was made to expel him from a village, and a council was held about the matter, which sat for several days, he got admittance to their council, and assured them, he says, "that I was but a man like themselves; that my art had no medicine or mystery about it, but could be learned by any of them if they would practise it as long as I had; and that in the country where I lived brave men never allowed their squaws to frighten them with foolish whims and stories. They all immediately arose, shook me by the hand, and dressed themselves for their pictures. After this there was no further difficulty about sitting-all were ready to be painted; the squaws were silent, and my painting room a continual resort for the chiefs and medicine men." But Mr. Catlin always noticed that, when a picture was going on, the braves who were assisting kept passing the pipe around, smoking for the success of the 
picture and the preservation of the sitter. Then he was feasted, a doctor's rattle was presented to him, and a magical wand, or doctor's staff, "strung with claws of the grizzly bear, with hoofs of the antelope, with ermine, with wild sage and bats' wings-and perfumed with the choice and savoury odour of the polecat; a dog was sacrificed and hung by the legs over my wigwam, and I was therefore and thereby initiated into the arcana of "medicine or mystery."

Mr. Catlin was called by the Iowa Indians Chip-pe-ho-la; by the Mandans, Te-ho-pe-nee Wash-ee, or Great Medicine White Man; and by the Sioux at Fort Pierre, Ee-cha-zoo-kah-ga-zea-kou, the Medicine Painter, and also We-chash-a-wa-kou, the Painter. Associating with the Indians almost constantly, and seeing their best side, Mr. Catlin's sympathies were wholly enlisted for them; and we find much in his observations appreciative of their character and revealing an anxious interest in their future. He often speaks as one who felt that a doom of extermination which they did not deserve had been pronounced against them. He wrote an "Indian creed" in 1868 , pertinently to his being called the "Indian-loving Catlin," in which he described those people as having always loved him and made him welcome to the best they had; as being honest without laws, having no jails or poorhouses, keeping the commandments without ever having read them or heard them preached from the pulpit, having never taken the name of God in vain, loving their neighbours as themselves, worshipping God without a Bible and believing that God loved them also, and-" I love all people who do the best they can, and oh, how I love a people who don't live for the love of money!" He asserted, in his North American Indians, that the Indian "is everywhere, in his native state, a highly moral and religious being, endowed by his Maker with an intuitive knowledge of some great author of his being and the universe; in dread of whose displeasure he constantly lives, with the apprehension before him of a future state, where he expects to be rewarded or punished, according to the merits he has gained or forfeited in this world." He found him the worshipper of a spiritual God, with no idolatry. He discerned the evil of allowing traders to go among the Indians to corrupt them, and thought that, if they were obliged to come to the settlements to do their trading, they would enjoy the advantages of competition, and see the 
better features of our civilization. His theories respecting the origin of the Indians do not seem to have taken settled shape. He believed that the primary race did not come here from abroad, but originated here on the soil independently of other races, although wanderers from other lands may have mingled with it. He found reasons for supposing that there may have been a Jewish element in the race, but not that the race was derived from the Jews; and he speculated upon the possible derivation of the Mandans from a Welsh colony under Prince Madoc in the early part of the fourteenth century. There are not many scientific observations in his itineraries. His journal at Fort Gibson, in 1834 , contains a notice of the death of $\mathrm{Mr}$. Beyrich, a Prussian botanist, who had made an immense collection of plants, and died at Fort Gibson while engaged in changing and drying them.

Mr. Catlin supported himself in his journeys by painting portraits and by the sale of his books. It was his custom to leave the Indian country in the fall and go in his canoe down to St. Louis or New Orleans. There he would select some place promising good custom and settle himself as a portrait painter for the winter. His collections having become large enough to form a gallery and museum, he exhibited them in the chief Eastern cities from 1837 to 1839 . He then offered them for sale to the Government, and their purchase was advocated in Congress by such men as Clay and Webster. But the bill making the appropriation was lost, the casting vote being given by Jefferson Davis, then in the House. Bitterly disappointed at the want of appreciation of his work by his own country, Mr. Catlin then took his collections to Europe, and exhibited them in London and Paris. He gave his exhibition and lectured upon the Indians, with the aid of men and boys in costume, for three years in succession, in London. Then in order to help a stranded party of nine Chippewas that a Canadian had been exploiting in England he associated them with his exhibition for several months. A party of Iowas, among them being several whose portraits he had painted, and still another party of Chippewas enjoyed his protection under similar circumstances in London and Paris. Mr. Catlin never took any Indians abroad for exhibition himself, and was very indignant that any one should speculate with them in this way. The support of those who came under his care fell 
largely on him; many died on his hands; some were buried from his own house; and their expenses and the responsibilities of their affairs forced upon him, helped to bring on his financial ruin. Richly he repaid the hospitalities that the Indian at home had extended to him.

Mrs. Catlin accompanied her husband on his expeditions of r 834 and the three following years, and aided him enthusiastically in his researches and work. She joined him with two of their children in London in 1840 , was with him during his English travels, and proceeded with him to Paris, where she died in 1845 . She had borne him three daughters, Elizabeth Wing, Clara Gregory, and Louise Victoria ; also a son, George, who died at the age of three years.

His visit to France, from 1845 to 1848 , led to pecuniary disaster, and was saddened by the loss of his wife and son; and in $185^{2}$ he suffered a financial wreck in London, from which he never recovered. His collection was seized for debt, but Mr. Joseph Harrison, Jr., of Philadelphia, advanced the funds necessary to release it, and took it as security himself. It was brought back to this country and stored until 1879 , when so much of it as had escaped the ravages of time was presented by Mr. Harrison's widow to the Smithsonian Institution.

Mr. Catlin then started anew. Between $185^{2}$ and 1857 he made three voyages from Paris to South and Central America. $\mathrm{He}$ found great difficulty in getting the Indians of the Amazon to sit for their pictures, but by catching them unawares and sketching from his boat while they were detained on the shore by some pretext of entertainment, he was able to make sketches among thirty different tribes, on the Amazon, the Uruguay, the Yucayali, and in the open air of the pampas and llanos, containing many thousand people, in their canoes, at their fishing occupations, and in groups on the river's shore. These voyages had also another object, having been suggested by his friend von Humboldt, who wished him to pursue some of the questions relative to the origin of the Gulf Stream which the great geographer was then too old to investigate personally.

After he returned from his South American campaigns, Mr. Catlin lived in Brussels for about ten years upon the proceeds of his brush, and working at the same time upon a new gallery of paintings to be known as his "cartoon collection." This was not a replica of the other collection. Instead of being 
portraits the pictures consist of costumes in groups, hunting scenes, views illustrating customs, etc. A price was offered for this in Europe, but Mr. Catlin, always loyal to his country, thought he could join it to the collection still in the hands of Mr. Harrison and sell both to the Government. Subsequent to his death this was attempted by his daughters. Frelinghuysen introduced the bill; Prof. Joseph Henry spoke before the Senate Library Committee in its favour; it was backed by letters from all the college faculties of the United States, but again the motion was lost, and the cartoon collection still remains in the possession of his daughters. In $187 \mathrm{I}$, after an absence of thirty-two years, he returned to the United States, and exhibited his cartoon collection in New York and Washington until his death. Mr. Catlin's last illness was contracted from an exposure which he suffered in Washington, in October, 1872 . He was removed thence to Jersey City, where his daughters and his brother-in-law, the Hon. Dudley S. Gregory, were living, and died there in December.

The George Catlin Indian Gallery of the United States National Museum consists of his first collection of pictures and other articles given to the Smithsonian Institution by Mrs. Harrison, as above stated. A full description of this collection, with notes and statistics, a memoir of Catlin, extracts from his works, and other related matter, was prepared by $\mathrm{Mr}$. Thomas Donaldson and published in the Smithsonian Report for 1885 . This description, upon which the present account is based, occupies 947 pages and is illustrated with 144 plates, most of which are engravings from Catlin's paintings. In his pictorial work he sought to represent the truth, and invented nothing. He regarded the domestic and everyday customs, habits, and manners of the Indians as the essentials to the proper study of their origin and descent, and aimed to reproduce them thoroughly. His principal book was Letters and Notes on the Manners, Customs, and Condition of the North American Indians; written during eight years of travel among the wildest tribes of Indians in North America, first published in I84I, and reproduced in several editions, in English and German, with divers variations of title. He wrote also Catlin's Notes in Europe, two volumes; Life amongst the Indians, a book for youth, I867, which was translated into French. The list also includes works on the O-kee-pa, a religious cere- 
mony of the Mandans; catalogues of his gallery; a pamphlet on breathing, entitled Shut your Mouth, giving the results of observations made during his life among the Indians, 1865 ; a pamphlet concerning a Steam Raft suggested as a Means of Security to Human Life on the Ocean, 1850; Last Rambles amongst the Indians of the Rocky Mountains and the Andes, I868; The Lifted and Subsided Rocks of America, with their Influence on the Oceanic, Atmospheric, and Land Currents, and the Distribution of Races, 1870 ; a Letter to William Blackman, concerning his life among the aboriginal races of America ; and newspaper, review, and magazine notes and articles.

He put forward in $183_{2}$ a suggestion for forming a large reservation of public lands to be a nation's park, containing man and beast in all the wildness and freshness of their natural beauty, saying that he would want no better monument than the reputation of having been the founder of such an institution. More than this: He was the man who picked out the Yellowstone region for a park, and it is time that the credit of the Yellowstone Park should be given to George Catlin and some part of it named after him. In 1845 he published a plan for disengaging and floating quarterdecks on steamers and other vessels for the purpose of saving human lives at sea, and proceeded to take out a patent for it, but found afterward that he had been anticipated. In 1842 he was invited to lecture at the Royal Institution in London, and took advantage of the occasion to introduce a subject on which he had long meditated-that of forming a museum to contain and perpetuate the looks and manners and history of all the declining and vanishing races of mankind.

Attention may properly be called to the extraordinary energy and industry of this man, who produced over twelve hundred oil paintings, besides endless numbers of etchings, penand-ink drawings, manugraphs of his own works resembling the perfection of the ancient manuscripts, miniatures, etc., and at the same time travelled and wrote and left few subjects unexamined. His conversational abilities were sought for at the best houses in London. At seventy-six he retained his natural sight, his own teeth, his uprightness of carriage, and could walk for miles without fatigue. 



\section{EBENEZER EMMONS.}

$$
\text { I 799-1863. }
$$

Authorities differ as to the year in which Ebenezer Em. mons was born. The first General Catalogue of Williams College, published in 1880 , puts " at. 65," after the year of his death. In Durfee's Williams Biographical Annals the year of his birth is given as I799, while, according to Prof. Jules Marcou, in Science, Prof. Emmons always stated to his children that he was born in 1800 . His sister has informed the writer that 1799 is the correct year. The month and day were May I6th, and the place was Middlefield, Mass. He was an only son, but had two sisters older and two younger than he. Prof. Emmons's father, who also bore the name of Ebenezer, was a farmer. His mother's maiden name was Mary Mack. The Rev. Dr. Nathaniel Emmons, who was quite a noted preacher in his day, was an uncle. The first ancestor in America of this branch of the family came from England, and settled at East Haddam on the Connecticut River. A brother who came with him settled in Boston.

Young Eben's interest in nature appeared at an early age. The doors in his room were covered with bugs and butterflies pinned on when he was a small boy. His mother often used to say: " $\mathrm{Eb}$, why do you always have your pockets filled with stones? I have to mend them every week." His birthplace and the adjoining town of Chester were noted for rare minerals. When he came home for a vacation from school or college he generally brought some fellow-student with him. $\mathrm{He}$ and his friend would set off for the mineral localities and be gone all day, coming back tired and hungry, but were always ready to go again the next morning.

He was fitted for college under the instruction of the Rev. Moses Halleck, of Plainfield, Mass., a well known educator of 
his time, and was graduated from Williams College in due course. Prof. Marcou gives 1820 as the year of his graduation, but the General Catalogue has him in the class of 1818 , which seems to be conclusive. As a college student his interest in the sciences was quickened by the instruction of Professors Amos Eaton and Chester Dewey, and he subsequently had a large share in introducing the study of these subjects among the young men of the country. After completing his college course Mr. Emmons continued his favourite studies at the Rensselaer School, graduating there with the class of 1826 . In the same year he published his Manual of Mineralogy and Geology for the use of the students of that institution. $\mathrm{He}$ also studied medicine at the Berkshire Medical School, and established himself as a practising physician in Chester, Mass.

In 1818 , at the age of nineteen, Mr. Emmons married Miss Maria Cone, of Williamstown, and at the age of thirty-seven became a grandfather by the birth of a son to his eldest daughter.

In 1828 Dr. Emmons removed to Williamstown, where he continued to practise medicine, and in the same year was appointed lecturer on chemistry in Williams College. A cabinet of mineralogical and geological specimens which he began to collect here was presented by him to the college after it had received the valuable accretions of twenty years. He resided in Williamstown until 1838 , becoming the most eminent practitioner in Berkshire County. In 1830 he was appointed junior professor in the Rensselaer School and held the position till 1839. He was also a lecturer in the Medical School of Castleton in the days of its renown. His chair in Williams College was enlarged in $1833 *$ to a professorship of Natural History, which he held till 1859, when the department was divided, he retaining the mineralogy and geology till his death.

Having been appointed upon the Geological Survey of New York in 1836 and Professor of Chemistry in the Albany Medical College in 1838 , Dr. Emmons removed in the latter year to Al-

* The History of Williams College, another book by the Rev. Calvin Durfee, D. D., above quoted, gives $I 848$ as the year of his election to the professorship of Natural History. 
bany. He was afterward transferred to the professorship of $\mathrm{Ob}$ stetrics, and remained on the faculty of the Medical College till I852. During this period he used to go to Williamstown each year to deliver the course of lectures belonging to his professorship there. His position on the New York survey enabled him to make the valuable present of a suite of the minerals of that State to his alma mater in 1842 . One of his Williams College students-now himself a venerable though young-hearted professor-well remembers the strong face and beetling brows of Dr. Emmons, and his manner of giving instruction. His disposition was kindly. Being a non-resident, not much was seen of him by the students; he would appear at the lecture room, give his lecture, and disappear. There was not much of the pedagogue about him. Students who had a special liking and capacity for his subject profited much from his instruction; but his enthusiasm in telling the wonders of the rocks carried him along at a rate which left the indifferent student far behind. If only a fraction of his class appeared at the lecture, or if he projected a question at Brown and a response came from Jones or Robinson, he seemed not to notice the difference. Williamstown is in the heart of the Berkshire Hills. One of the summits of East Mountain, a neighbouring eminence, is the only place in that region where gneiss crops out, and here Prof. Emmons used to bring his students to display to them as best he could the relations of his much disputed Taconic System to the other and then better known geological formations. Very likely only a couple of the class would reach the summit with him, yet he would discourse just as earnestly to these as to the whole party that set out with him. This height, says Prof. Arthur L. Perry, in his Origins in Williamstown, "has been justly designated Mount Emmons, by one who was once a pupil and later a colleague and always an admirer of the distinguished Professor of Natural History in the college, Ebenezer Emmons."

It is related of Prof. Emmons, as illustrating his enthusiasm, that once when on a journey with President Hopkins, of Williams, and the president's brother, he asked his friends to turn aside with him to visit a certain cave. They consented to the delay, although the brother was on his way to be married, and waited just.within the entrance of the cavern while Emmons penetrated to its inmost depths. After'a time they 
heard the excited cry, "I've got it!' I've got it!" and out rushed the geologist, bearing triumphantly a muddy fragment of rock. He had secured a piece of evidence in support of his Taconic System.

In 1836 a law was passed providing for a geological survey of the State of New York, and in the organization of the staff for carrying on that work Dr. Emmons was appointed by Governor Marcy to the charge of the second district, which included the northeastern counties of the State. This district was chosen by Dr. Emmons as a field more especially interesting to him on account of its mineral localities and minerals, and giving him a field more congenial to his tastes and experience. He made the public acquainted with the Adirondack region and named its principal mountains. In 1837 he named, described, and classified the celebrated Potsdam sandstone. Among the other rocks and divisions to which he gave a name or a place in geology are the Chazy limestone, black marble of Isle la Motte, Lorrain shales, Champlain group, Ontario group, Helderberg series, and Erie group. During the progress of this survey, also, he made the important discovery that is most closely associated with his name. In 1842 he pointed out a great system of stratified rocks under the Potsdam, which he called the Taconic System. This announcement brought upon him a storm of contradiction and ridicule, and for a time he was scientifically ostracized. Subsequent discoveries by the Canada survey, and by Barrande, in Bohemia, however, as well as the investigations of later eminent geologists, have completely sustained him. In propounding the term Taconic* System Prof. Emmons was following the instruction and views of his teacher, Prof. Amos Eaton, who promulgated his opinions regarding the age of these rocks in his lectures at Williams College from 1817 onward; and subsequently in his lectures at the Rensselaer School to the end of his life, although never having published any satisfactory account of the relations of these rocks to the formations above or below them.

Two years later Dr. Emmons described the primordial fauna, thus preceding the celebrated discoveries of Barrande,

* From the Taghkanic Mountains. 
who recognised the priority of Emmons in the following courteous language:

"In comparing these dates it is clear that Dr. Emmons was the first to announce the existence of a fauna anterior to that which had been established in the Silurian System as characterizing the Lower Silurian Division, and which I have named the Second Fauna. It is, then, just to recognise the priority, and I think it all the more fitting to state it at this time, that it has not hitherto been claimed."

Prof. Emmons's Report on the Second District of the New York Geological Survey was published in $\mathbf{1 8 4 2}$. In the autumn of that year his colleagues presented his name to Governor Seward as a proper person to act as custodian of the collections of the geological survey, then arranged, and in progress of arrangement, in the old State Hall on State Street, which building had been assigned for that purpose by the Legislature of 1840. He was appointed to this position by Governor Seward and assumed charge of the collections the latter part of 1842 . On the same occasion on which this recommendation was made it was also recommended by the staff that the work in agriculture and in paleontology which had been left unfinished should be assigned to Dr. Emmons and Prof. Hall.

In the spring of 1843 Governor Bouck directed Dr. Emmons to investigate the agricultural resources of the State; and the paleontology was placed under the charge of Prof. Hall, while Dr. Emmons still retained his position as custodian of the collections of the survey until 1845 . The five volumes of his report on the Agriculture of New York appeared in 1846,1849 , I $85 \mathrm{I}$, and $\mathrm{r} 854$. The first was devoted to a "topographical sketch of the State, climate, and temperature; agricultural geology, the Taconic System, and the soils of New York"; the second to analyses of grains and other vegetable products; the third and fourth, one consisting of text, the other of plates, to cultivated fruits; and the fifth to injurious insects. This fifth volume has been severely criticised, but it should be remembered that the writer to whom its preparation was intrusted not being versed in entomology, could only compile from the best sources at his command, at a time when the science was in its infancy and comparatively little was known of the insects of the State. The many illustrations, which are well coloured in the larger portion of the edition, were mainly 
drawn from nature, and in some of the orders, as in Coleoptera and Hemiptera, have a degree of excellence which is rarely surpassed even at the present day.

About the time the third volume came from the press he was appointed State geologist of North Carolina. In his new field he made further important contributions to the advance of American geology. In the coal measures of the Deep and Dan rivers he discovered a grand Triassic flora, and a fauna that included among many ancient vertebrates the Dromatherium sylvestre, the oldest mammal yet found anywhere in the world. His description of the new red sandstone flora of North Carolina proved so valuable that twenty years after his death the United States Geological Survey reproduced all the plates and descriptions given by him in the sixth part of his American Geology. Three volumes of North Carolina reports were published by him. One on the Geology of the Midland Counties was issued in 1856 ; a volume devoted to the Agriculture of the Eastern Counties, with descriptions of the fossils of the marl beds, in $185^{8}$; and a second part of his report on the agriculture of the State, "containing a statement of the principles of the science upon which the practices of agriculture as an art are founded," appeared in I86o. The Civil War interrupted his labours. The anxieties and separation from friends occasioned by it probably hastened his death, which took place at his residence in Brunswick County, N. C., October I, 1863. His wife, a son, and two daughters, survived him.

Besides the works already mentioned, Prof. Emmons published an account of the Taconic System (Albany, 1844). Having been commissioned by Governor Edward Everett to report upon the Zoölogy of Massachusetts, he prepared a volume, devoted to the quadrupeds, which was printed at Cambridge in 1840. His American Geology, which appeared in 1855, was supplemented by a Manual of Geology in 1859 .

A clear-sighted and energetic worker, Dr. Emmons was a living force for the advancement of his chosen science. The Rev. Mark Hopkins, President of Williams College from $18{ }_{3} 6$ to 1872 , said of him: "Emmons was a man of remarkable power and great accuracy of observation. He seemed to have an intuitive perception of the differences in natural objects. He possessed an intense enthusiasm in his work, but in his 
manner was remarkably quiet. I have never seen the two things combined to the same extent. His perseverance knew no limit. It ought to be added, that, in connection with his science, he was deeply religious. Williams College is greatly indebted to him for its collections in natural history." 


\section{JOSEPH HENRY.}

$$
\text { I 799-I } 878 \text {. }
$$

THE popular mind often fails to distinguish between the scientist and the inventor-between one who discovers new truths and one who applies truths already known to a useful purpose. Sometimes the two functions are united in the same person, but more often he who is intent on enlarging the bounds of knowledge feels that he has no time for tilling the field that he has won. On the other hand a chance to make a rough way smooth or to save a waste of energy or material, is what appeals most strongly to the mind of the inventor. While the inventor, like Atlas, takes the world upon his shoulders, it is the discoverer who furnishes a support for Atlas. The subject of the present sketch belonged to the latter class.

Joseph Henry was born in Albany, N. Y. There is good authority for Dec. 17, 1799, as the date, but owing to the entry in the family Bible not being distinct, the year is sometimes given as 1797 . One of his daughters writes "I have always thought he numbered his years with those of the century," meaning that he was born in 1800 , but her impression is not inconsistent with the date here adopted. His grandparents on both sides came from Scotland in the same vessel, reaching America on June 16,1775 . His mother's family, whose name was Alexander, settled in Saratoga County, while the Henrys, whose name had been Hendrie, took up their abode in Scotland, in Delaware County, N. Y. When Joseph was seven years old he was sent, for what reason is not known, to live with his grandmother Alexander at Galway, Saratoga County, where he attended the village school. Of William Henry, his father, little is known. He died when Joseph was eight or nine years of age. When he was ten years old Joseph was put to work in the store kept by a Mr. Broderick at Galway, but having his afternoons to attend school. He showed no marked fondness for books until 

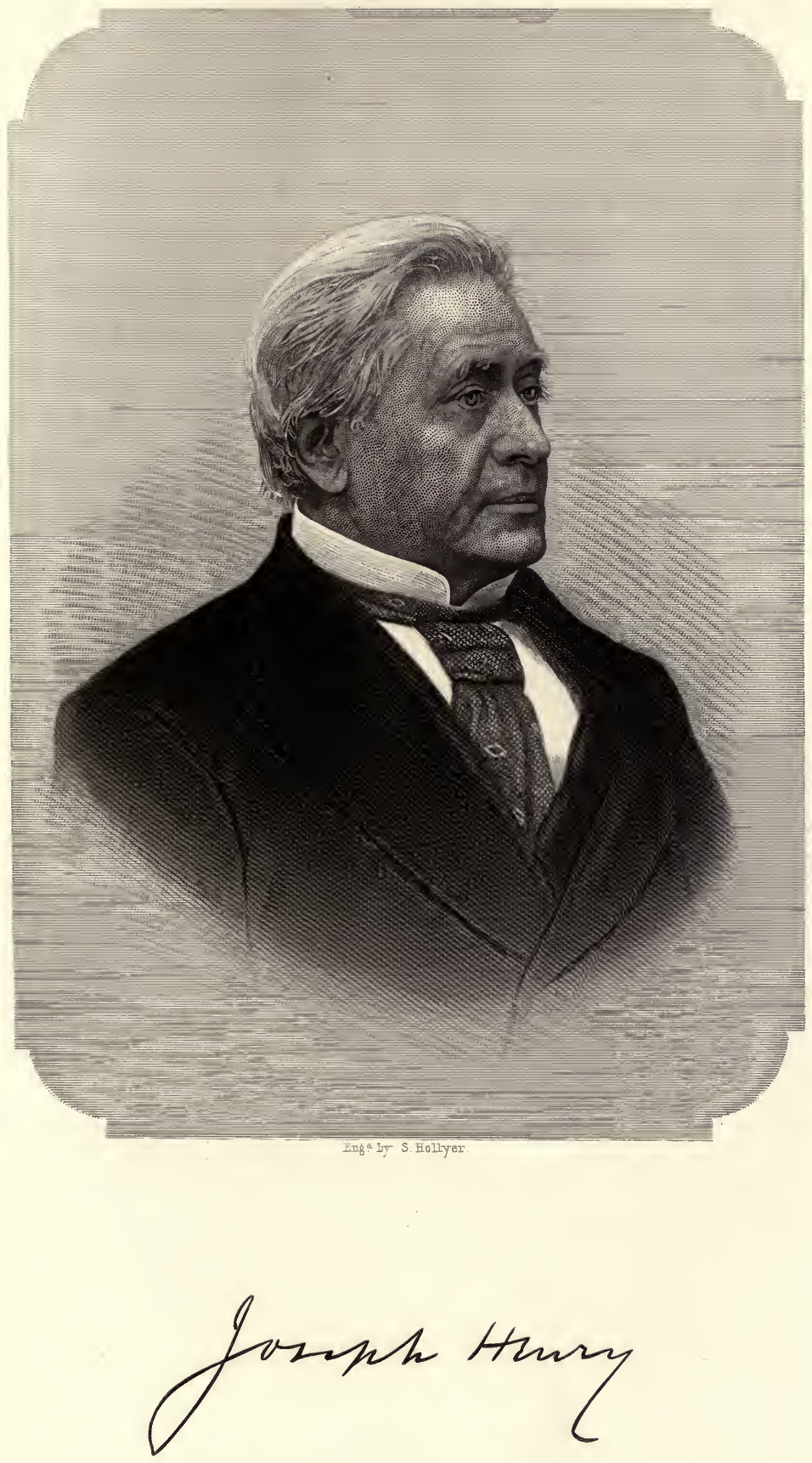

D. Appleton \& Co. 

one day, in chasing a runaway rabbit, he crawled through the broken foundation wall of the village church, and then, attracted by a glimmer of light, made his way up into the vestibule of the building. Here stood a bookcase containing the village library. The boy took down a volume, which happened to be Brooks's Fool of Quality, a novel with a moral purpose, and soon became deeply interested in the story. He afterward spoke of this as the first book he ever opened voluntarily. Returning again and again by the underground passage, young Joseph regaled himself at will upon the fiction in the library. After a time access to the books in the legitimate way was procured for him by Mr. Broderick, who seems to have been a kind employer.

When about fourteen years of age young Henry returned to his mother's house in Albany. As at this time he manifested little inclination for learning, temporary employment was found for him by his uncle with a silversmith, but this arrangement soon came to an end by the failure of his employer. $\mathrm{He}$ now developed a great fondness for the theatre. Besides seeing all the plays he could, he obtained entrance behind the scenes and learned the methods of producing stage effects. Joining a society for debating and amateur theatricals, called the Rostrum, he soon distinguished himself by his ingenuity in stage management, and became president of the society. Having from lack of employment plenty of time on his hands, he wrote a comedy for the Rostrum and dramatized a tale of more serious character. While occupied with such matters, his active mind struck the trail that led it to the road it was destined to pursue. He was kept at home a few days by a slight illness, and chanced to take up an elementary book of science belonging to a Scotchman who lodged in his mother's house. It was Lectures on Experimental Philosophy, Astronomy, and Chemistry, intended chiefly for the use of Young Persons, by G. Gregory. The style of the booksuggesting queries about common things and afterward giving the answers to them-was stimulating to a vigorous mind. This volume was preserved in Henry's library until his death, and the effect it had upon him is attested by the following inscription which he put upon its fly leaf: "This book, although by no means a profound work, has, under Providence, exerted a remarkable influence upon my life. It accidentally 
fell into my hands when I was about sixteen years old, and was the first work I ever read with attention. It opened to me a new world of thought and enjoyment; invested things before almost unnoticed with the highest interest; fixed my mind on the study of Nature, and caused me to resolve at the time of reading it that I would immediately commence to devote my life to the acquisition of knowledge." In accordance with that resolve he resigned from the dramatic society and betook himself to study. At first he attended a night school and after a time entered Albany Academy, paying his way by teaching a country district school and later serving as assistant in the academy. On leaving this institution he obtained the position of tutor in the family of the patroon, General Stephen Van Rensselaer, of Albany, occupying his leisure hours in studies preparatory to the medical profession, to which he added the higher mathematics. General Van Rensselaer was an old friend of the family. He regarded Henry in the light of a son, and Henry was wont to say that the general taught him what it was to have a father, and what were the feelings of a son. Later he made a survey for a road across the southern part of the State, from West Point to Lake Erie. In 1826 he returned to the Albany Academy as an assistant, and in 1828 was made Professor of Mathematics.

Mr. Henry had now become interested in the subject of electro-magnetism, which had recently been much advanced by the discoveries of Oersted and Ampère. In 1827 he read before the Albany Institute a paper entitled On Some Modifications of the Electro-magnetic Apparatus. "By his skilful experimental investigations," says Mr. William B. Taylor, in speaking of this paper, "Henry was enabled to exhibit all the class illustrations, attempted by Sturgeon, not only on a still larger and more conspicuous scale, with the use of feeble magnets (where required), but with a still further reduction of the battery power . . . by the simple expedient of adopting, in every case where single circuits had hitherto been employed, the manifold coil of fine wire which Schweigger had employed to increase the sensibility of the galvanometer." This was Henry's first contribution to electrical science. "Should any one be disposed to conclude that this simple extension of Schweigger's multiple coil was unimportant and unmeritorious, the ready answer occurs that talented and skilful electricians labouring to 
attain the result had for six years failed to make such an extension. Nor was the result by any means made antecedently assured by Schweigger's success with the galvanometer. If Sturgeon's improvement of economizing the battery size and consumption by increasing the magnet factor (in those few cases where available) was well deserving of reward,* surely Henry's improvement of a far greater economy, by increasing the circuit factor (entirely neglected by Sturgeon), deserved a still higher applause."

In describing Henry's work during the next few years $\mathrm{Mr}$. Taylor continues: "To Henry belongs the exclusive credit of having first constructed the magnetic spool or bobbin, that form of coil since universally employed for every application of electro-magnetism, of induction, or of magneto-electrics. ... By means of the Henry 'spool' the magnet, almost at a bound, was developed from a feeble childhood to a vigorous manhood, and so rapidly and generally was the new form introduced abroad among experimenters, few of whom had ever seen the papers of Henry, that probably very few indeed have been aware to whom they were really indebted for this familiar and powerful instrumentality. ...

"But, in addition to this large gift to science, Henry has the pre-eminent claim to popular gratitude, of having first worked out the differing functions of two entirely different kinds of electro-magnet: the one surrounded with numerous coils of no great length, designated by him the 'quantity' magnet; the other surrounded with a continuous coil of very great length, designated by him the 'intensity' magnet. The former and more powerful system was shown to be most responsive to a single galvanic element (a 'quantity battery'); the latter and feebler system was shown to be excited by a battery of numerous elements ('an intensity battery'); but at the same time was shown to have the singular capability, never before suspected or imagined, of subtile excitation from a distant source.

"But this was not all. In this distinction between the two magnets Henry discovered the law that there must be a proportion between the aggregate internal resistance of the bat-

* Sturgeon for this received, in 1825 , the silver medal of the Society for the Encouragement of Arts. 
tery and the whole external resistance of the conjunctive wire or conducting circuit; with the very important practical consequence that by combining with an 'intensity' magnet of a single extended fine coil an intensity battery of many small pairs, its electro-motive force enables a very long conductor to be employed with no sensible diminution of effect. 'It takes nothing from Henry's discovery that $\mathrm{Ohm}$ had conceived a mathematical theory of the same law in r827. Except to a few in Germany this theory was unknown, and did not affect science in England, France, or America until much later. It was unknown to Faraday and Wheatstone in 1837 ; to Bain in I 845. , "

In $183 \mathrm{I}$, Henry made an apparatus by which he caused a steel bar, suspended between the poles of an electro-magnet, to swing and give signals by its strokes on a bell. He operated this through more than a mile of wire. Here was a device which might readily have been developed into an electric telegraph.

Mr. Taylor says of this memorable arrangement:

"In the first place, it was the first electro-magnetic telegraph employing an intensity magnet capable of being excited at very great distances from a suitable intensity battery. . . .

"In the second place, it was the first electro-magnetic telegraph employing the armature as a signalling device; or employing the attractive power of the intermittent magnet as distinguished from the directive action of the galvanic circuit; that is to say, it was, strictly speaking, the first magnetic telegraph.

"In the third place, it was the first acoustic telegraph."

This is the language of a eulogist, but it is a fact that Morse did not succeed in making his telegraph operate through any considerable length of wire until he adopted the intensity magnet of Henry. To quote Henry's words in his Statement in Relation to the History of the Electro-magnetic Telegraph, published by the Regents of the Smithsonian Institution in I 857, "The principles I had developed were applied by Dr. Gale to render Morse's machine effective at a distance." That is Henry's connection with the Morse telegraph in a nutshell.

The discoveries which he announced in 1831 attracted wide attention among men of science, and were the cause of his 
being called the next year to be Professor of Natural Philosophy in the College of New Jersey, now Princeton University.

His researches were interrupted for a year or more when he removed to Princeton. At first he had his new course of lectures to prepare, and in 1833 he supplied the place of the Professor of Chemistry and Geology, Dr. Torrey, during the absence of the latter in Europe. When he was able to resume his experiments, Faraday was running neck and neck with him on the same course. Several important discoveries were made by both men independently. In August, I829, Henry had made in Albany the discovery of electrical self-induction in a long helical wire-the extra current as it is called-in advance of Faraday, who made independently the same discovery in 1834. He also made independently of Faraday the great discovery of magneto-electricity. In Princeton, with some coils of insulated copper ribbon-these coils are known in electrical text-books as "Henry's coils" - he pursued the subject, until he discovered that one induced current can produce another, the second current a third, the third a fourth, the fourth a fifth; also that a current of quantity may be produced by one of intensity, and the converse; also that currents can be induced at a distance, and from obtaining currents in one room induced from primary currents in another room, with no connection merely by the disturbance of the electrical plenum, he passed to the accomplishment of the same result between an upper room of the Philosophical Hall and the cellar of the same building; then between two parallel wires stretched perpendicularly, several hundred feet apart, and then, connecting the tinned roof of his house with the ground, he magnetized needles in his library, by induction, from a thunder cloud eight miles away. The practical applications of these discoveries are numerous. In I836, when in these experiments a Leyden jar was substituted for galvanism, these coils led Henry to the discovery of the oscillatory character of the electric discharge. They were also used to investigate electric screening, which Henry attributed to the neutralizing action of a current induced in the interposed body. These discoveries were announced in the years $1834,1835,1836$, and 1838 . Before leaving Albany Henry had been employed to make one of his powerful magnets for the laboratory of Yale College, then under the direction of Prof. 
Silliman. It consisted of an octagonal bar three inches thick and thirty inches long, bent in the form of a horseshoe, and was able to lift more than a ton. For his own laboratory at Princeton be constructed one to surpass it. This lifted more than three thousand pounds. One other contribution Henry here made to the telegraph. He used the intensity spool and battery, working through long distances, to open and close the circuit of the quantity spool and battery, ... thus making the powerful magnet at short range the servant of the weak one at long range. This device of opening one circuit by means of another is used in the relay to call into play another intensity circuit.

When he had been four years at Princeton he was given a year's leave of absence on full salary, in which he made a very enjoyable visit to Europe. He and his friend Dallas Bache arrived in England in February, 1837 . He received an enthusiastic welcome from the scientists of the old world, especially from Faraday. The importance of his visit to London to the telegraph in England should not be overlooked. Wheatstone was then busy with his form of the invention. He had discarded the electro-magnet, because, to use his own words, "sufficient attractive power could not be imparted to an electro-magnet interposed in a long circuit," and had substituted for it a secondary galvanic circuit. Henry at this time explained to him his discovery of the intensity magnet. Wheatstone never acknowledged any indebtedness to Henry, but it is a significant fact that before Henry's arrival in England the electro-magnet was discarded as inefficient by Wheatstone, and after two weeks of daily intercourse with Henry it was restored to his telegraph, and the success of the English system secured. Crossing over to Paris Henry made the acquaintance of Arago, Becquerel, De la Rive, Biot, and Gay Lussac. A visit to Edinburgh brought him into contact with other congenial minds, and in September he attended the meeting of the British Association, which he addressed, by invitation, giving some of his recent observations on the "lateral discharge" from the Leyden jar or a conducting wire. He also gave the section of Mechanics an account of the great extension of the railway and canal systems in the United States. Returning home in November, greatly invigorated by his tour, Prof. Henry plunged again into his fruitful labours. 
Electricity was not the only subject of Henry's investigations during his years as a college professor. For several years in Albany he was associated with Dr. T. Romeyn Beck, Principal of the Albany Academy, and the Hon. Simeon De Witt, Chancellor of the Board of Regents of the State University, in making annual tabulations of temperature and rainfall obtained at stations in various parts of the State. During the same period he made a series of observations for Prof. Renwick, of Columbia College, to determine the magnetic intensity at Albany, by which he was led to researches upon the aurora borealis. His interest in meteorology continued throughout his residence at Princeton, and prompted several communications to the Philosophical Society. In 1839 he and Prof. Bache induced the society to memorialize the Government to establish stations for magnetic and meteorological observations. This application was only in part successful.

In the field of physics outside of electricity he investigated the capillary movement of liquid metals in solid metals, the cohesion of liquids as seen in the soap bubble, on phosphorescence, on the radiation from sun spots, etc.

We come now to Prof. Henry's connection with the Smithsonian Institution. The origin of this great scientific bureau was admirably described by Prof. Simon Newcomb in his memorial address on Henry. He says: "James Smithson, a private English gentleman of fortune and scientific tastes, a chemist of sufficient note to be elected a Fellow of the Royal Society, led a comparatively. retired life, and died, unmarried, in 1829. He does not seem to have left any near relatives except a nephew. On opening his will it was found to be short and simple. Except an annuity to his servant, he left the nephew, for his life, the whole income from the property, and the property itself to the nephew's children, should he leave any. In case of the death of the nephew without leaving a child or children, the whole property was bequeathed 'to the United States of America, to found at Washington, under the name of the Smithsonian Institution, an establishment for the increase and diffusion of knowledge among men.' . . .

"We thus have the curious spectacle of a retired English gentleman, probably unacquainted with a single American citizen, bequeathing the whole of his large fortune to our Government to found an establishment which was described 
in ten words, without a memorandum of any kind by which his intentions could be divined or the recipient of the gift guided in applying it.

"Hungerford [the nephew] died in 1835 . An amicable suit in Chancery was instituted by our Government, through the Hon. Richard Rush as its agent, the defendant being the Messrs. Drummond, executors of Smithson. Although there was no contest at any point, the suit occupied three years. On May 9, 1838 , the property was adjudged to the United States, and during the next few months disposed of by $\mathrm{Mr}$. Rush for about $£$ 105,000. The money was deposited in the treasury in the following autumn."

The absence of details in Smithson's bequest imposed upon Congress the difficult task of making up its collective mind as to what kind of an institution it would found. It took nearly eight years to do this. "The act under which the Institution was at last organized became a law in August, I846. This law provided that the business of the Institution should be conducted by a Board of Regents, who should choose a suitable person as Secretary of the Institution. It also provided for the erection of a suitable building of plain and durable materials and structure, without unnecessary ornament, for the reception of objects of natural history, a chemical laboratory, a library and gallery of art, and the necessary lecture rooms."

The Regents took expert advice as to how the act of Congress should be carried out, among those whom they consulted being Prof. Henry. He responded with a statement which showed such a comprehensive grasp of the subject that, on Dec. 3,1846 , he was elected Secretary of the Institution. The choice between continuing a career of successful and highly gratifying research and entering upon a course whose direction was largely problematical now had to be made. His decision was quickly reached, being largely influenced by the plea of Prof. Bache that Henry's efforts were needed to secure the proper administration of Smithson's munificent bequest, and before the month was out he entered upon the duties of the office. His suggestions above mentioned, recast to conform to the positive commands of Congress, were adopted a year later by the Regents as a programme of organization. He found himself hampered by the appropriation of a large sum for a building, 
and by the requirement that the fund should support a museum, a library, an art gallery, and courses of lectures. Not one of these institutions, because of their purely local influence, were, in his judgment, consistent with the purposes of the founder, which were to "increase" and to "diffuse" knowledge. By pursuing an unbending but judicious policy, somewhat aided by subsequent events, Henry succeeded in turning most of the resources of the Institution upon the encouragement of original research by prizes and subsidies, and the publication of reports and treatises setting forth the progress made in the different branches of knowledge. This result was not attained without a long continued struggle against narrow prejudice, selfish interests, and misguided schemes of philanthropy, involving some sharp conflicts. As obstacles did not turn the secretary from his course, neither did allurements draw him away. He declined the professorship resigned by Dr. Hare in 1847 , which was tendered to him by the Trustees of the University of Pennsylvania, although its income was more than double his salary at the Smithsonian, and six years later he refused his consent to a movement to make him president of the college at Princeton.

Under Prof. Henry's able management the Smithsonian Institution quickly became a power for the advancement of science. In his first report he announced the acceptance for publication of the famous work of Squier and Davis on Ancient Monuments of the Mississippi Valley. At the same time he proposed "an extensive system of meteorological observations, particularly with reference to American storms," for which Prof. Loomis had suggested that the telegraph, then in its infancy, could render valuable service. This work was undertaken in 1849 and steadily grew in importance and value, so that in 1870 the Government was induced to establish the Signal Office as a bureau of the War Department.

American anthropology was a subject early taken up and energetically promoted by the Institution. Special explorations were conducted, a splendid collection of objects was gathered, and numerous valuable publications in this field were issued. Very early in his administration Prof. Henry organized the Smithsonian system of exchanges by which the scientific memoirs of societies or individuals in any part of the United States are transmitted to foreign countries without ex- 
pense to the senders, and similar publications from abroad are distributed to their intended recipients. From this system of exchanges, not only in publications but in objects of interest, the great National Museum has sprung-a child grown larger, in buildings at least, than its mother. The Library of Congress has been increased from the same source, so that, while at Henry's death the original sum of the bequest remained intact, the objects desired by the opponents of his policy, have been secured. A general index of memoirs on scientific subjects from I 800 was one of Henry's ideas which could not be carried out with the part of the income of the Institution available, but it has been fortunately given form in the great Royal Society's Catalogue of Scientific Papers, due credit for the suggestion being given in the preface to that monumental work. The publications actually issued by the Smithsonian in the course of Henry's administration comprise, first, over one hundred important original memoirs, forming twenty-one large quarto volumes of the Smithsonian Contributions to Knowledge, most of them universally recognised as authorities on their respective topics; and, second, fifteen octavo volumes of Smithsonian Miscellaneous Collections, more technical than the Contributions, to which should be added the thirty octavo volumes of annual Reports, in which the secretary gave an account of his stewardship. In 1870 the Regents testified to their appreciation of his service by giving him a leave of absence, with an allowance for expenses, in order that he might take a European trip. $\mathrm{He}$ spent four and a half months abroad, being everywhere received with consideration, and hearing abundant commendations of the institution which he represented.

Although no part of his duty as director of the Smithsonian, Prof. Henry was frequently called upon to use his scientific knowledge and ability in the service of the Government. On the establishment of the Lighthouse Board, in $185^{2}$, he was appointed one of its members, and in $187 \mathrm{I}$ became its chairman. The advancing cost of whale oil soon made a more economical illuminant necessary. By a series of thorough tests he demonstrated that lard oil, which had been pronounced unsuitable, was really superior to the colza or rape-seed oil used in France, and the sperm oil heretofore used. Kerosene had not yet become a reliable commercial article. Prof. Henry also investigated the comparative advantages of the steam 
whistle, trumpet, and siren for fog signals, deciding in favour of the last named. This problem, however, had many perplexing sides, and occupied a large share of his attention for the last twelve years of his life.

"The value of Henry's services to the various executive departments of our Government, faithfully and unostentatiously performed through a long series of years and a succession of presidential administrations, can not be estimated," says W. B. Taylor, in the admirable discourse prepared for the Philosophical Society of Washington, from which much of the material of the present account has been taken. "Whenever in any important case a scientific adviser could be useful to the proper conduct of a bureau, Henry's reputation generally pointed him out as the most suitable expert and arbiter. On the outbreak of the great Civil War, the number of such references was naturally very considerably increased. The departments of War, of the Navy, and of the Treasury were besieged by projectors with every imaginable and impossible scheme for saving the country and demolishing the enemy. Torpedo balloons, electric-light balloons, wonderful compounds destined to supersede gunpowder and revolutionize the art of war; cheap methods for the manufacture of Government bonds and paper money; multitudinous expedients for the prevention of counterfeiting by devices in the engraving, by secret markings, by anti-photographic inks, by peculiar textures of paper (applicable to coupons, to circulating notes, to revenue stamps), each warranted to be infallible-such were among the agencies by which patriotic patentees and adroit adventurers were willing to serve their country, and to reap their reward by the moderate royalty or percentage due to the magnificence of the public benefit." When it was proposed that the pay of an expert should be given for these services Henry refused, preferring to make them a free gift to the country.

With so many exacting duties is it to be supposed that Henry would find any opportunity to use his splendid talents for original research? He had no expectation of it when he left Princeton, yet in spite of the improbability he made some valuable advances in directions of his own choice. He so improved the thermo-galvanic multiplicator of Nobili and Melloni as to produce his wonderfully sensitive "thermal telescope" 
with which he tested the radiation of the atmosphere and the clouds. He also made other researches in radiation; he investigated the expansion of a bar of iron at the moment of magnetization by a galvanic current, and many minor questions. In 1868 he was elected President of the National Academy of Sciences to succeed his friend Prof. Bache, who had died in the preceding year.

"After an almost uninterrupted period of excellent health for fifty years," to quote his own words, Prof. Henry was attacked early in December, 1877 , with what seemed to be paralysis, but in a few days proved to be nephritis. The disease was already far advanced and steadily progressed, with occasional alternations of more favourable symptoms, to the inevitable result. On May $13, \mathrm{I} 878$, calmly and with unimpaired intellect, Joseph Henry passed away.

Prof. Henry was above the middle height, finely proportioned, and of dignified bearing. In his character earnestness was his most conspicuous trait. This was evinced in his pursuit of knowledge, which was so earnest that he never thought about securing personal glory in connection with it, and had no time for arguing when his hypothesis was assailed. His friends early learned that the way to get him to take any desired action was not to point out the honour or other benefit that it would secure for him, but to show that it would promote the interests of science. The same trait explains his intense antipathy to scientific or other hoaxes, and the fact that in working for any desired end he never concealed his purpose. Thus, when he took charge of the Smithsonian he made no secret of his wish to secure important changes in the act of Congress which prescribed its scope, and he worked for this end with the inflexibility of purpose, which was another of his characteristics, until the soundness of his views was acknowledged. He was also remarkably considerate of the feelings of others, as was shown conspicuously in his dealings with those who differed from him, and with the visionaries that afflict every one in a conspicuous scientific station.

Prof. Henry married in May, 1830 , Miss Alexander, of Schenectady, the sister of Prof. Alexander, of Princeton, and from the ardent devotion of his wife, and the fraternal sympathy of her brother in his pursuits, he received assistance and support beyond that which usually fall to the lot of men. The most 
peaceful, and to himself the most profitable, part of his life was that spent in Princeton, for which place, and the college located there, he ever retained the warmest attachment. Mrs. Henry survived him three years. His first born, a son, died in early manhood and three children in early infancy; his remaining children, three daughters, are still living.

Prof. Henry was the recipient of many well-deserved honours. He was elected to membership in many learned societies at home and abroad. Several institutions of learning, including Harvard College, conferred upon him the degree of LL. D. A year after his death a memorial meeting was held in his honour in the House of Representatives, and later Congress erected a statue to his memory in the grounds of the Smithsonian Institution. Fifteen years after his death the electrical congress, held at the time of the Columbian Exposition in Chicago, gave his name to one of the electrical units. The "henry" is "the induction in a circuit when the electro-motive force induced is one volt, while the inducing current varies at the rate of one ampere per second." When, in 1895 , the subjects of statues to stand in the new Library of Congress were chosen, Henry was selected as one of the two for the scientific alcove. 


\section{JAMES BLYTHE ROGERS.}

$$
1802-185^{2} \text {. }
$$

SCIENCE has need of all manner of men among its votaries. He whose career will be traced in this memoir devoted to its service a warm sympathy, an inspiring utterance, a high degree of constructive faculty, and a conscientiousness which caused him ever to give his best efforts to the duty before him.

James Blythe Rogers was born in Philadelphia, Feb. II, I 802 , being the first child of Hannah (Blythe) and Patrick Kerr Rogers. His grandfather, Robert Rogers, was one of the gentry of County Tyrone, Ireland. At the age of twentyone he married Sarah Kerr, daughter of a gentleman living near, whose family, like his own, were adherents of the Presbyterian Church. Mr. Rogers was owner of the Edergole or Knockbrack estate, lying between Omagh and Fintano, forty miles from Londonderry, and held on lease a piece of land adjoining it. Dr. W. S. W. Ruschenberger, whose excellent memoir on The Brothers Rogers * is the chief available source of information concerning this family, mentions as additional evidence of his social standing that he inherited the large central pew in the neighbouring Presbyterian Church, which he rebuilt and furnished anew when the church was reconstructed. Robert Rogers was twice married; his first wife bore him twelve children, and the second five. Patrick Kerr Rogers was his eldest child. "The rudiments of Patrick's education," says Dr. Ruschenberger, "were received in a schoolhouse built upon the estate. It is described as having clay walls, a thatched roof, clay seats covered with bits of carpet, and being warmed by a turf fire. The teacher was a lame rustic boy, whom Patrick's aunt, Margaret Rogers, a lady of notable in-

* Proceedings of the American Philosophical Society, vol. xxiii, pp. I04-I46. 


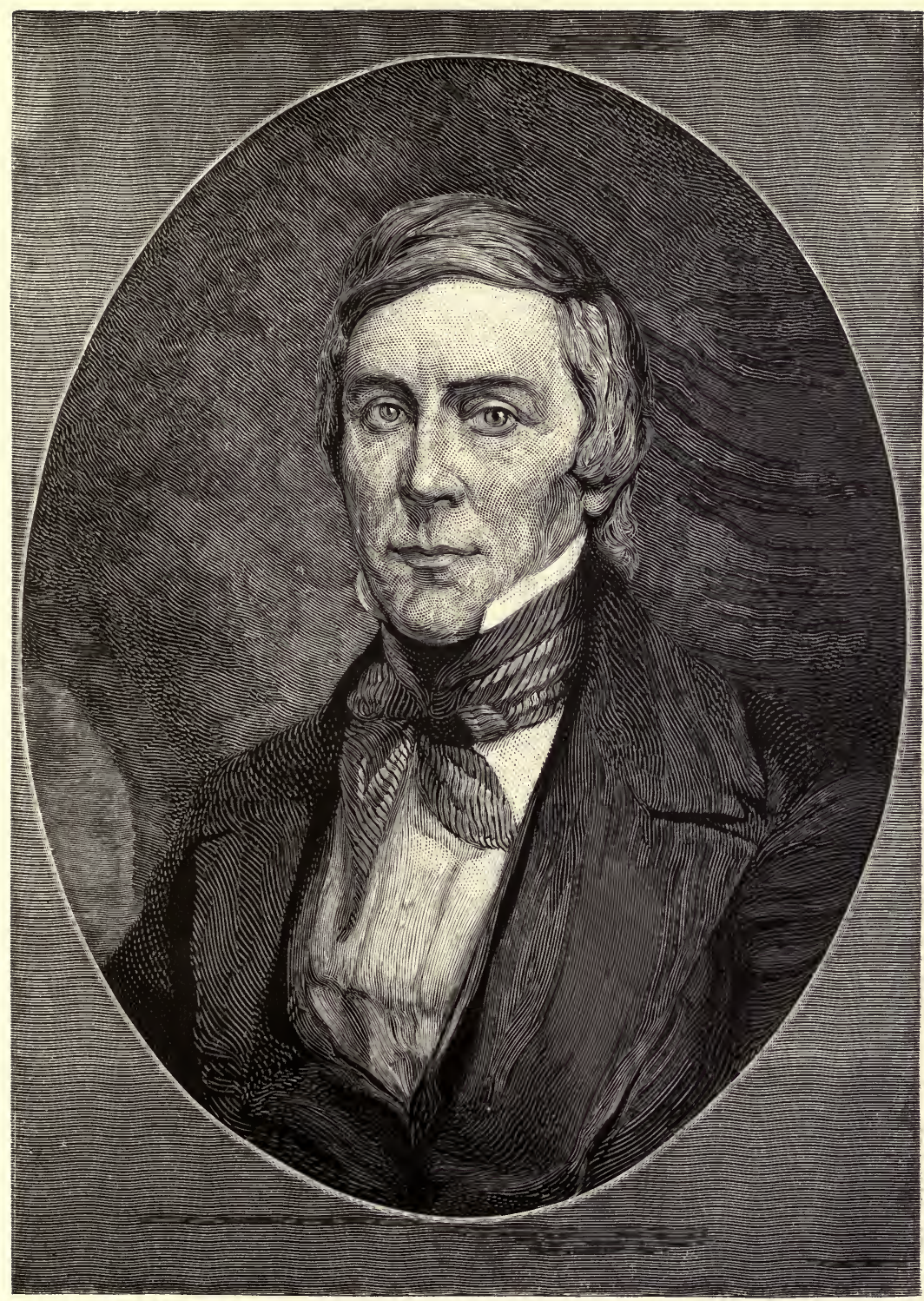

JAMES BLYTHE ROGERS. 

telligence, had trained for the office. It is conjectured that he acquired his classical learning from a private tutor at the house of a kinsman." The father of Sarah Kerr evidently did not believe in the law of primogeniture, for he had exacted, as a condition of his daughter's marriage to Robert Rogers, a settlement of all the latter's lands upon the children of this union, share and share alike. Accordingly Patrick, although the eldest child, could expect only one twelfth of his father's landed estate, and must prepare himself for some other occupation than that of a landlord. "Entertaining opinions not rigidly orthodox, he was unwilling to enter the clerical profession, though he had the example of two uncles who were clergymen." All things considered, a commercial career seemed best, and he therefore entered a counting house in Dublin. When the Irish rebellion broke out, in the spring of 1798 , he contributed to Dublin newspapers certain articles inimical to the Government, on account of which he was obliged to leave the country. At that period ships plied directly between Ireland and Philadelphia, and on one of these he embarked, landing at his destination in August, after a passage of eighty-four days.

In the following May Mr. Rogers obtained an appointment as a tutor in the University of Pennsylvania, and soon afterward began to study medicine under the famous Dr. Benjamin S. Barton. Mr. Rogers was married January 2, I80r, his wife being the youngest of the three orphan daughters of a Scotch father and an English mother. Their father, James Blythe, had been a stationer and newspaper publisher in Londonderry, whither he had gone from Glasgow. After the death of both parents the three sisters had come to America, where they were received by a cousin, Mrs. Thomas Moore. At the time of his marriage Mr. Rogers was described as "a tall, erect man, of grave deportment, having dark hair well sprinkled with gray, and soft sleepy eyes. He played the violin and sang well, but never in company or in the presence of strangers, because such performance or display seemed to him inconsistent with the dignity of a gentleman."

After receiving his medical degree from the University of Pennsylvania, in June, 1802 , Dr. Rogers began the practise of his profession in Philadelphia. $\mathrm{He}$ also took private pupils and lectured to classes in botany, chemistry, and other sciences. He was called to Ireland in 1803 to settle the 
estate of his father who died in that year. This business disposed of, he returned to Philadelphia, bringing with him two brothers and a sister.

The next five years of effort did not bring him a satisfactory income and he removed to Baltimore, where he was more prosperous until he became involved in a controversy on methods of vaccination, which injured his practice. When Dr. Robert Hare resigned the professorship of Natural Philosophy and Mathematics in the ancient College of William and Mary, at Williamsburg, Va., Dr. Rogers was elected to succeed him. In this congenial position he remained, a competent and forceful instructor, until he died of malarial fever in 1828 . His wife had succumbed to the same disease eight years before.

James B. Rogers received his elementary education in Baltimore during the residence of his parents in that city, and, after attending the college of William and Mary, took up the study of medicine in the office of Dr. Thomas E. Bond. In 1822 he received the degree of Doctor of Medicine from the University of Maryland. It is said that while a student he assisted his brothers William and Henry in teaching their school at Baltimore. After graduating he taught for a time a class of girls in conjunction with a Dr. McClellan, of Baltimore. This enterprise proving unsatisfactory, was given up. Being now in need of employment, he thought of seeking the post of surgeon to a colony of free negroes which it was proposed to establish at Cape Mesurado. He consulted his father on this matter, and must have written a rather querulous letter, for he got this chunk of paternal hard sense in reply: "What is the use of your complaining of mankind? The world as yet owes you nothing. Up to this time you have been simply a recipient of its benefits. Make yourself worthy of a place here and you will find one." The project of going to Africa was abandoned.

Dr. Rogers now joined an intimate friend and fellowstudent, Dr. Henry Webster, in a partnership to practise medicine at Little Britain, Pa., about two miles north of the Maryland line. But after a few years' experience he abandoned the profession, having found it repugnant to his mental habits and sensitive nature. He returned to Baltimore, and was soon appointed superintendent of the extensive chemical manufactory of Messrs. Tyson and Ellicott. 
From this time on Dr. Rogers made pure and applied chemistry his chief concern. The professorship of Chemistry in the Washington Medical College being offered to him, he hesitated to accept it, thinking he was not sufficiently ready of speech for a lecturer. He finally undertook the work, and, although it was not remunerative, it served to discover the fact that he shared the gift of eloquence which distinguished his brothers. The ice being thus broken, he found it easy to give chemical lectures before the Mechanics' Institute, in Baltimore, and later he lectured also on physics.

Dr. Joseph Carson states in his memoir of Dr. Rogers that it was William B. Rogers who induced his brother to venture upon the career of a college lecturer, and thus relates how it was accomplished: "To convince him that he had nothing to apprehend on that score [lack of fluency], his brother William prevailed upon him to accompany him to the lecture room, and there, placing the future professor behind the desk, constituted himself the audience. The theme was named, which being instantly taken up and amplified upon, the ease and fullness with which he spoke relieved him of his diffidence and apprehension. This was his first effort to lecture, and, like this, all his future performances were without notes or facilities of recollection, except those incident to the arrangement of the topic."

In September, I830, being then twenty-eight years of age, he married Rachel Smith, of Baltimore, a birthright member of the Society of Friends.

Cincinnati was the residence of Dr. J. B. Rogers from 1835 to 1839 , this period being the whole term of existence of the Medical Department of Cincinnati College, in which he had accepted the professorship of Chemistry. The summer vacations of these four years he spent as an assistant to his brother William in fieldwork and chemical investigations on the Geological Survey of Virginia. While in Cincinnati he declined the office of melter and refiner in the branch mint at New Orleans, offered to him by the President of the United States.

Dr. Rogers now, 1840 , removed to Philadelphia and became an assistant to his brother Henry, who was the State geologist of Pennsylvania. He also turned his knowledge of chemistry to account in various other occupations. He was 
appointed in $184 \mathrm{I}$ lecturer on chemistry in the Philadelphia Medical Institute, then a flourishing summer school, which had been founded by Dr. Nathaniel Chapman. From I 844 to 1847 he was Professor of General Chemistry in the Franklin Institute, of which institution he had become a member when he went to live in Philadelphia. In this period he and his brother Robert compiled a text-book on Chemistry from the Inorganic Chemistry of Dr. Edward Turner and the Organic Chemistry of Dr. William Gregory. It was published in 1846 . $\mathrm{He}$ also conducted quiz classes of medical students. He was for a time Professor of Chemistry in the Franklin Medical College, and represented this institution in the National Medical Convention, held at Philadelphia in 1847 , which organized the American Medical Association.

In 1847 he succeeded the celebrated Dr. Robert Hare as Professor of Chemistry in the University of Pennsylvania - a curious coincidence in connection with his father's succeeding Dr. Hare at Williamsburg. In this position he remained until his death, five years later. $\mathrm{He}$ was also one of the representatives of the university in the National Convention of $185^{\circ}$ for revising the Pharmacopœia of the United States.

In 1846 he was elected to membership in the American Philosophical Society, and the following year joined the Academy of Natural Sciences of Philadelphia.

Dr. Rogers was of slight frame and never enjoyed robust health. In his latter years he suffered at times from nervous exhaustion and defective nutrition, probably induced by unremitting labour. He died June $\mathbf{1 5}, \mathbf{1} 852$, leaving a widow, two sons, William B. and Henry A., also a daughter, Mary V. Rogers.

Never favoured by prosperity, Dr. Rogers was particularly straitened in circumstances during the first part of his residence in Philadelphia. It was not until he entered upon his last professorship that he received a comfortable salary. The institutions with which he had been connected before were small and weak or came to grief in some way that could not be anticipated. While lack of shrewdness and assertiveness on his own part may have contributed to hinder his advancement, his worth as a teacher is beyond question. $\mathrm{He}$ was everywhere esteemed by his colleagues and popular 
among his students. Dr. Carson said of him, "Disinterested and generous in his relations with the world, mild and conciliating in deportment, open and affable when approached, urbane to every one, his virtues shone conspicuously within the circle of his friends. With his pupils he was sympathizing; he errtered cheerfully into their discouragements and difficulties; and those who confided to him received that encouragement and counsel so grateful to the student's feelings. He was emphatically the student's friend." 


\section{JOHN ERICSSON.}

$$
\text { r 803-r } 889 \text {. }
$$

THE arts of marine engineering and naval construction have been revolutionized through the inventions of Captain Ericsson. As is remarked in Mr. W. C. Church's biography of him, "in the closing years of his life he could look back upon 'a change in the physical relations of man to the planet on which he dwells, greater than any which can be distinctly measured in any known period of historic time,' and this he had no small part in creating."

John Ericsson was born at Langbanshyttan, in the province of Wermland, Sweden, July 3r, 1803, and died in the city of New York, March 8, r889. His ancestry is traced back to the family of Leif Ericsson, the son of Eric the Red, the Norse discoverer of America. He was also related to Thorwaldsen, the sculptor, who was descended, according to Mr. John Fiske, from the son of Thorfinn Karlsefne, the first white child born on American soil. His father, Olaf Ericsson, was a proprietor of mines; his mother was a daughter of an ironmaster, and was possessed of gifts which, according to Mr. Church, she transmitted to her sons Nils and John. She used to relate that an old man had prophesied to her father that two boys would be born in the family who would become famous. John manifested an aptitude for constructive work at an early age. As a child he amused himself with drawing, boring, and cutting. A little older, he watched the engines at the mines, copied their models in his drawings, and studied their motions. He traced the first suggestion of his future career to the day when, in his seventh year, he dug a mine a foot deep and made a ladder for the use of imaginary miners. When nine years old he had learned the use of drawing instruments and the art of preparing constructive plans. 


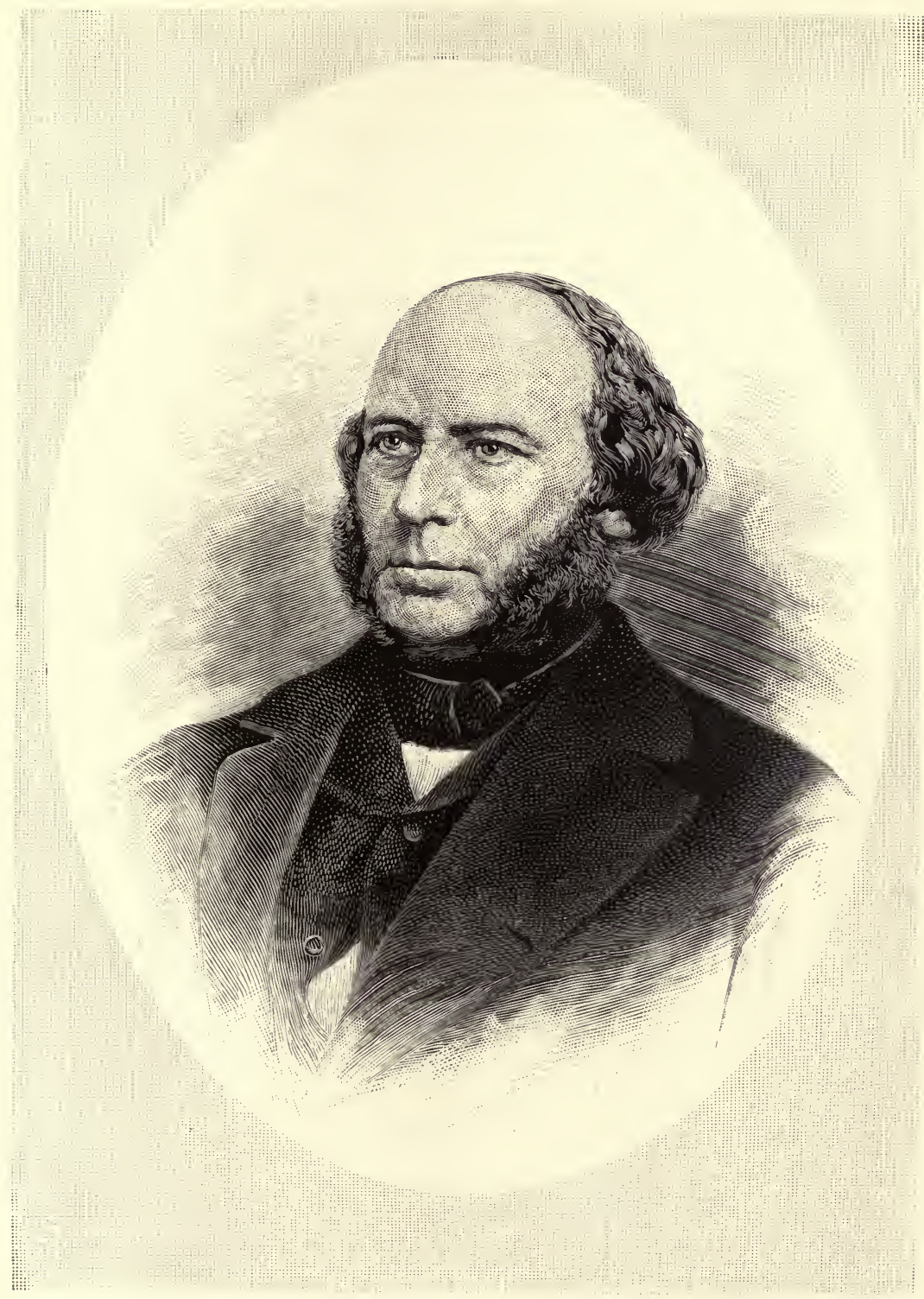

JOHN ERICSSON. 

In the industrial disturbances occasioned by the war with Russia Ericsson's father lost all his property and was thrown out of business. In 18 I 1 he obtained a responsible position in connection with the construction of the Götha Canal, in which he gradually rose. John in the meantime was improving in the exercise of his rare talents. In the deep forests, to which his father had removed, drawing tools were hard to get. $\mathrm{He}$ had a pen and pencil. He made compasses of wood with needles for the points; contrived a drawing pen out of a pair of tweezers; and made brushes of the hairs of his mother's sable cloak. With these home-made instruments he executed the drawings for a pumping engine to be operated by a windmill.

The best use was made for the Ericsson boys of the limited educational advantages which the region afforded. A governess was furnished them in the years 1811 and 1812 . A draughtsman, connected with the work on the canal, taught them how to finish their drawings in a style which rivalled that of engraving. They were given access to the draughtsman's office of the canal company. John exhibited his first drawing to the scale when eight years old, and he learned to sketch maps. One of the superintending constructors of the canal was engaged to teach the boys algebra and architectural drawing. Another tutor " plagued them with lessons in Latin grammar," from whom also John learned "chemistry and many other things," he says, "of great use to me; for instance, how to make and mix colours for my drawings out of materials bought at the druggists for a few cents." The curate at Fredsberg on the Lefsäng was engaged to teach them French. The most distinguished mechanical draughtsman in the country gave them further perfection in his art; and other instructors, drawn also from the professional men engaged on the canal, taught them algebra, field drawing, geometry, and English. While John was naturally disposed to think and act for himself, these lessons tended to promote and encourage his intellectual self-reliance. When a friend spoke to him with regret of his not having been graduated from some technological institute, he answered that the fact, on the other hand, was very fortunate. If he had taken a course at such an institution, he would have acquired such a belief in authorities that he would never have been able to 
develop originality and make his own way in physics and mechanics.

When John was eleven years old he and his brother became pupils in engineering of Captain Edström, who had been sent to England to study the most approved methods in canal construction. $\mathrm{He}$ was so pleased with their work that he recommended them to Count Platen, President of the Götha Ship Canal. This officer had been shown specimens of what John had done, and, receiving him, predicted that if he continued as he had begun, he would some day produce something extraordinary. When twelve years old John was employed, under the direction of his chief, in drawing profile maps and plans for use on the canal, and to be filed in the archives of the company; in the next year he was assistant to the niveleur (or leveler) in charge of the station of Riddarhagen; and in another year, when only fourteen years old, and obliged to stand on a stool to reach the eyepiece of his surveyor's level, he was put in charge of the Rottkilms station, where he had to give directions daily to six hundred men. About this time he became assistant to the chief of the work. While engaged as leveler he made drawings of the Sunderland iron bridge, which Count Platen admired very much. He drew for his private use maps and sketches of important parts of the canal and of the machinery used in its construction, which he began to publish several years afterward, inventing an engraving machine to enable the work to be more speedily done. He found, however, that the machinery illustrated by his drawings was being superseded in the rapid progress of improvement in mechanical construction, and discontinued this enterprise.

In 1820 , when Ericsson was seventeen years old, after his father had died, he entered the military service of Sweden, and was appointed an ensign in the Royal Field Chasseurs of Jämtland, and stationed at Frösön, near Ostersund. The step was taken against the protest of Count Platen, and was the occasion of a breach between them. Soon after joining his regiment he was recommended for promotion, but his colonel was out of favour at court, and the recommendation would not have been heeded, had not the Duke of Upland, son of King Bernadotte, pleaded for him. The Duke showed his Majesty one of Ericsson's military maps, whereby the promotion was secured, and the king's attention was directed to 
Ericsson's skill as an engineer. Ericsson was subsequently commissioned to draw maps to illustrate the campaigns of Bernadotte as marshal of Napoleon. He passed the examination for and obtained an appointment on the survey of northern Sweden, and in connection with that work made detailed drawings of fifty square miles of the country.

On the advice of friends, including the king, who considered his abilities greater than could be adequately rewarded in Sweden, and himself, no doubt, willing to seek a larger field of usefulness, Ericsson in 1826 secured a leave of absence from the service and went to England. He took with him plans, including a flame engine which he had experimented on successfully with wood as fuel, but which was not available when coal was used; and a still undeveloped idea in his mind of a vessel which "it was possible for Sweden to build, and which would render the wooden walls of England of no avail against her." $\mathrm{He}$ had intended to resign his lieutenancy, but, overstaying his leave of absence without obtaining an acceptance of his resignation, he was placed in an embarrassing position, from which he was extricated by the intercession of the crown prince; and in October, 1827 , he received a promotion to a captaincy and an acceptance of his resignation. The title of captain thus obtained, and a degree of LL. D. from an American university, were the only honours he cared to display to the public, though he had many others equally high.

In the two years 1828 and 1829 , after he went to England, Captain Ericsson completed seven inventions. One of these, a machine for compressing air, was used in clearing one of the Cornish mines of water; another involved the use of artificial draught for steam-boiler furnaces. Sir John Ross was preparing for his second arctic expedition, but not wishing his purpose known, concealed it in ordering the engines of his vessel; and the contractors, Braithwaite and Ericsson, supposing that the voyage was to be of an ordinary character, put in one of these engines with other appendages not adapted to arctic navigation. When Captain Ericsson learned the destination of the vessel, he warned Captain Ross that the engine had not been built for that kind of work and would be useless. His prediction was fulfilled as soon as the vessel entered arctic waters, and the engine was thrown overboard. The principle 
was, however, retained for ordinary steam vessels, with results quite satisfactory. The third invention was a steam fire engine. The first, an experimental engine, was followed by four others, completed, one of which, sent to Prussia, proved so efficient that the designer received, in recognition of its value, an honorary membership in the Berlin Institute. Another engine, employed in London, "extinguished the fires, but was objected to and rejected on account of the quantity of water it required; and it was nearly thirty years before London would have another steam fire engine, inferior to Ericsson's.

In 1829 , while it was still undecided whether stationary or locomotive traction should be adopted for the railway between Liverpool and Manchester, a prize of five hundred pounds was offered for the best locomotive. Although five months were given to the competitors in which to prepare themselves, Ericsson did not learn of the offer till within seven weeks of the day of trial. Stephenson brought out his "Rocket" engine, with every appointment perfect and tested. Ericsson produced his " Novelty," graceful in design and structure, and with every part planned on sound principles, but built in haste and untested. It suffered two breakdowns in the trial, caused by undetected faults in workmanship; but not before it had passed the "Rocket" and reached a speed of thirty-two miles an hour. Ericsson withdrew it in disgust, and the prize went to Stephenson. But every one admired the beauty of the "Novelty"; the judges spoke of its appearance as being very much in its favour, and commended the ingenuity with which the machinery was so contrived as to work out of sight, and the compactness of its form; and John Scott Russell, the eminent English engineer, wrote in the Encyclopædia Britannica in 1840 that " the 'Novelty' had to be withdrawn through a series of unfortunate accidents which had no reference to the character or capabilities of the engine. And we well recollect that it made a profound impression on the public mind at the time. On the first day of the trial it went twenty-eight miles an hour (without any attached load), and did one mile in seven seconds under two minutes." Two other elegant locomotives were built by Ericsson, but they failed to give entire satisfaction in the working, and this field of construction was left to Stephenson.

In $x 830$ Captain Ericsson devised the centrifugal fan blower 
which afterward came into general use on our river steamers; in 1834 he took out a patent for a deep-sea lead, on a principle similar to the one employed in a lead designed by Sir William Thomson. He received a prize from the London Society of Arts for a hydrostatic weighing machine. He exhibited at the International Exhibition in $185^{2}$, and received a medal for them, an instrument to measure distances at sea; an alarm barometer which sounded a gong in warning of approaching storms; and a pyrometer which measured temperatures up to the boiling point of iron. He invented an instrument for measuring the compressibility of water; methods of propelling boats on canals, one of which has been applied to the heavy grades of Swiss mountain railroads; a water meter, a centrifugal pump, a file-cutting machine, an apparatus for making salt from brine, and numerous applications to the steam engine, many of which came into use, while others were abandoned. $\mathrm{He}$ experimented with superheated steam; and Mr. Church says that he designed more than five hundred steam engines.

While he was making all these machines he was also experimenting with designs for a caloric engine. His researches in this direction were begun with the "flame engine" already mentioned. He contributed a paper on the subject to the English Institution of Civil Engineers in 1826 ; built three engines in 1827 based on the principle of the expansion of air; brought out a completed caloric engine in 1833 , to which he applied improvements as his investigations continued; received the Rumford medal in 1856 for his researches into the nature of heat; and, according to Mr. Church, spent in thirty years, including the engines for his caloric ship, more than a quarter of a million of dollars in building twenty-seven experimental engines. The caloric system was not successful when applied to the propulsion of large vessels like the Ericsson, although that vessel registered a speed of eight and attained at one time a speed of eleven miles an hour, but for lighter work it has proved very practicable and efficient; the smaller machines have been extensively used, and the inventor derived large profits from them.

The first experiment with the screw propeller was made in I 836 by Captain Ericsson, in con junction with his friend Francis B. Ogden, of New Jersey, United States consul at Liverpool. A model of the apparatus was built and tested in a public bath. 
Then a boat forty feet long, propelled by a double screw, attained a speed of ten miles an hour on the Thames. The Lords of the Admiralty were passengers on the trial trip; but seeing was not believing with them, and, while they witnessed the successful performance of the craft, they declared that no vessel could be steered if the power was applied at the stern, and would have nothing to do with it. Captain Robert J. Stockton, of New Jersey, afterward United States Senator, was visiting England at the time on business connected with the Delaware and Raritan Canal, and, witnessing the performance of the propeller vessel, ordered one built for himself and named after him. It was sent across the Atlantic, and when it reached New York the freedom of the city was given to its captain. This vessel was employed for many years in the waters of the United States, and, passing into the possession of the Messrs. Stevens, of Hoboken, N: J., was known as the tug New Jersey till 1866, when, or about that time, it was broken up.

On the invitation of Captain Stockton, Captain Ericsson resigned, in 1839, the position of Superintending Engineer of the Eastern Counties Railroad in England, and removed to the United States. By the aid of Captain Stockton's influence he obtained a commission to build a steam-propeller frigate, the Princeton, for the United States Navy. Before this vessel was finished, in 1844 , his screw had been placed in forty-one commercial vessels of the United States. Another new and valuable principle was introduced in the Princeton-that of applying the power directly to the shaft turning the screw. Ericsson's propellers with direct-acting engines below the water line were also applied in the French frigate Pomona in 1843 , and in the British frigate Amphion in 1844. The Princeton was fitted with a twelve-inch wrought-iron gun, forged after Ericsson's designs, and strengthened with bands, which had been tested; and with a heavier gun ordered by Captain Stockton, called the Peacemaker. This gun, when fired-Ericsson's friends claim, against his advice-during a visit of President Tyler and members of his Cabinet to the Princeton, February 28, 1844, burst, killing the Secretaries of State and the Navy, and Colonel Gardiner, of New York.

From the year 1826 Ericsson had entertained the idea of contriving an "impregnable and partially submerged instrument 
for destroying ships of war," and had a plan matured for it in I 835 ; and the idea of protecting war engines for naval purposes was as old with him, he wrote, as his recollection. He had become satisfied also that armour plates that a vessel could carry could not be forged which a gun could not be constructed to penetrate if fired directly at them. From these ideas was developed the plan of the submerged vessel carrying a turret, which was embodied in the Monitor. In August, I86r, he proposed to President Lincoln to build a vessel for the destruction of the Confederate war craft, declaring that his purpose was not private profit but only to serve his country. No settled purpose or idea of what was to be done seems to have existed in Washington; but Ericsson, after presenting his plans, was directed to construct the Monitor according to them, within a hundred days. The result of the first experiment with this vessel constitutes one of the sensational incidents of history. The Monitor's guns were not allowed to be charged in that action as heavily as Ericsson desired-they would have borne, in fact, a charge three times as great as was given them-consequently the Merrimac was not destroyed, as it probably might have been. Nine other monitors were built for the Government by Ericsson and his business associates, of which the Dictator was completed, as he reported to the Navy Department, with a displacement of a fraction of an inch less than he had calculated.

In 1869 Captain Ericsson contracted to furnish the Spanish Government with thirty gunboats after his own designs, for use against Cuban insurgent blockade runners. They were all afloat within four months, two months before the time they were to be called for by the contract, and half of them had their engines and boilers on board. Several novel features were introduced upon them; they proved admirably adapted to their purpose; and in recognition of his service the Spanish Government conferred upon Ericsson the decoration of Isabel la Católica.

Captain Ericsson's ideas of a war vessel for submarine work more seaworthy than the monitors were embodied in the Destroyer, which was launched in 1878 . "It is an iron vessel, one hundred and thirty feet long, seventeen feet wide, and eleven feet deep, protected by a wrought-iron breastwork of great strength near the bow," carrying a submarine sixteen- 
inch gun thirty feet long, the muzzle of which projects through an opening in the stem near the bottom, and which is intended to carry a fifteen-hundred-pound projectile charged with three hundred pounds of guncotton. The vessel is intended to attack "bow on," and to discharge its projectile from within three hundred feet of the object of assault. The bill for the purchase of this vessel by the United States, although it passed the Senate in 1885 , failed to become a law.

"Three distinct purposes," says Mr. Church, " are apparent in Ericsson's labours: first, to improve the steam engine and extend the scope of its application; next to discover some more economical and efficient method for changing the mode of motion we call heat into the mode of motion we call power; third, to force the great maritime nations to declare the ocean neutral ground, by making naval warfare too destructive a pastime to be indulged in." We have seen how he worked out the first of these ideas in his numerous adaptations of the steam engine, and the third in the monitors and the Destroyer. In trying to make the second idea practical he devised the caloric engine and devoted many of the later years of his life to the investigation of the solar heat and of methods of converting it into a direct source of mechanical power. He devised and constructed a solar engine in 1883 , which was described and illustrated in Nature (Vol. XXIX, p. 217), and laboured until within two years of his death to improve and perfect it. In his description of this engine he showed that with reflecting plates of one hundred and thirty by one hundred and eighty inches and a steam cylinder of six by eight inches he could obtain a speed of one hundred and twenty turns per minute, with an absolute pressure on the working piston of thirty-five pounds per square inch.

He devoted himself regularly and, except for the daily walk and gymnastics for his health, unremittingly to his work. Fitting up his office and workshop in Beach Street, New York, he occupied his whole time in investigation, experiment, and construction, refusing to be interrupted, and shutting himself out from general visitors. The callers who, in spite of his well-known habits, came to congratulate him on his eightieth birthday were not received. He was a man of great physical strength, and some remarkable stories are told of his feats in lifting. In one of them, when in youth he raised a weight of six 
hundred pounds, he thought he overstrained himself, and he ascribed to it certain pains in his back from which he suffered.

He participated eagerly in physical sports, was expert in Swedish gymnastics, was one of the best shots, the best leaper, and the champion wrestler in his regiment, and was famed as an athlete, skater, and swimmer. Mr. E. H. Stoughton, formerly minister to Russia, is said to have surprised him once at sixty years of age standing on his head, to prove that he had not lost his agility. He was a man of unbounded benevolence, and never refused the petitions of those who came to him in need.

Domestic life was not for him, but his passion for work so absorbed him that he did not regret this. In the course of his brief service in the Swedish army he contracted a union with a Jemtland girl of good family, by whom he had a child. The union was dissolved, and for forty-eight years Ericsson held no communication with his only son, for whom, nevertheless, he seems to have made provision as soon as his circumstances permitted. In 1833 he made a second matrimonial venture, marrying an English lady named Amelia Byam. She came to America with him, but not liking the country, and having little companionship with her husband, she soon returned to England, and died without ever seeing Ericsson again. There was probably no ill feeling between them, for when the Monitor made Ericsson famous the wife wrote him of her gratification at his triumph.

It was a notable coincidence that Ericsson died on the anniversary of the Monitor's famous fight. In the year following his death, on August 23, 1890, his body was taken on board the United States ship Baltimore and conveyed to Sweden. All the United States naval vessels available were assembled in New York harbour and took part in the ceremonies attending the shipment of the remains, each firing a national salute as the Baltimore passed it on the way out to sea. Arrived in his native land, Ericsson's body was placed in a chapel that had been erected for it in the cemetery at Filipstad.

A bronze statue, of Ericsson, eight feet high, standing on a granite pedestal of the same height, was placed in Battery Park, by the city of New York, in April, 1893. The unveiling, which took place on the 26 th day of the month, was accom- 
panied by a parade of Swedish societies and appropriate exercises. No more fitting time could have been chosen to do honour to the inventor of the screw propeller and the Monitor, for the harbour was filled with picked vessels from the navies of the world, assembled for the Columbian naval parade of the following day.

While his literary works were not numerous, Captain Ericsson was a writer of force and ability, with imaginative faculties that might have been developed under cultivation. In his youth, and while engaged in his surveying work, he sometimes, he says, "wrote poetry to the wonderful and enchanting midnight light of Norrland. Connoisseurs often doubted that it came from the second lieutenant and surveyor among the mountains." His communications to the periodical press on the subjects in which he was interested were clear and vigorous, and always acceptable.

He was a man of intense patriotism, which he manifested equally toward his native land, although he never returned to it, and the United States, the country of his adoption. In his studies and inventions he had always in view the protection of Sweden against the aggressive stronger powers; and he gave the fruits of them ungrudgingly to the United Statesnot always insisting upon his reward as persistently as he had a right to do, and too often not receiving it, or receiving it at the expense of delay and trouble not creditable to our Government. His gif ts to Sweden, after he became prosperous, were numerous and beautiful, and included contributions for the relief of sufferers from famine and from a fire at Carlstad, and for a benevolent fund for the aged miners and miners' widows of his native province; a subscription to the Royal Library of Stockholm; the guns for the first Swedish monitor ; and a gunboat for coast defence. In 1867 the miners of his native region erected in front of the house in which he was born, at their own expense, a large granite monument, bearing the inscription, in Swedish, "John Ericsson was born here in $1803 . "$

We are very largely indebted for the detail of the facts concerning Captain Ericsson's inventions to the excellent biography of him by Mr. William C. Church, in two volumes, which was published in $189^{\circ}$. 



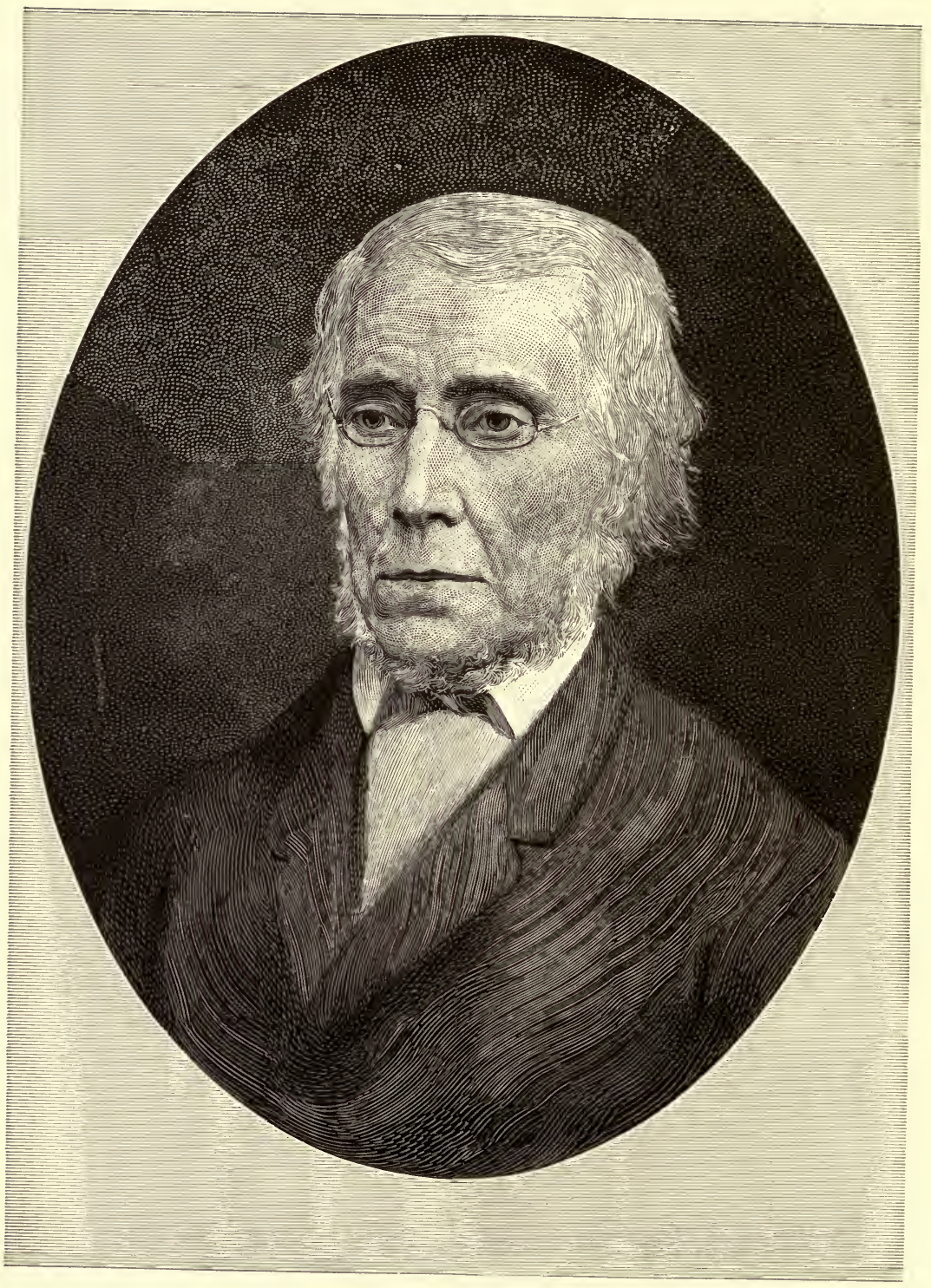

TIMOTHY ABBOTT CONRAD. 


\section{TIMOTHY ABBOT CONRAD.}

$$
\text { 1803-1877. }
$$

In Philadelphia, early in the present century, there was a strongly developed taste for natural history pursuits, and eager collectors of the local fauna naturally became so acquainted and thrown together that the formation of a club and then the organization of the Academy of Natural Sciences were the logical outcome. Previous to this, local zoölogy had not been overlooked, as the quartos of the American Philosophical Society show, and Peale's Museum was also an incentive to natural history studies; but all was more or less chaotic until the academy came into existence. Then fresh enthusiasm was roused and every member became a collector, and every collector a describer of new species. To-day these old naturalists would irreverently be called "species mongers"; but if possibly there was a little less "science" in their labours, all credit is due them for excellent intentions, and every evidence of careful, correct, and valuable work, which has not had to be done over. Looking back to the time when Say, Nuttall, Rafinesque, Lesueur, Vanuxem, Troost, Harlan, Morton, and Conrad filled the pages of the academy's journal, we get a glimpse of a remarkable company, who collected eagerly and studied carefully their "finds" and spicily defended their positions when the great question of "priority of publication" came up. These men were not given to theorizing; evolution was not in their vocabularies, although we see at times some evidence of looking beyond a species to its real significance. De Maillet's strange book had been translated and informally discussed, but, as a general thing, no one troubled himself with Lamarck, or all accepted Cuvier without question. In short, these Philadelphia naturalists gathered specimens all day, and when they had the material sat up all night describing new species. And among 
them all there was no one more eager in the quest and more popular with his fellows than Solomon White Conrad, the father of the subject of the present sketch. That the elder Conrad was a remarkable man all who remember him assert without reserve. That he was a popular one, the fact that his house was a favourite gathering place for all the scientific notables of the city clearly proves. His was the first natural history salon opened in Philadelphia, and, being a matter of six days in the week, instead of at stated intervals, was fully as popular as the celebrated Wistar parties.

A descendant of Thones Kunders (subsequently anglicized to Dennis Conrad), who left Crefeld, Germany, July 24, 1683 , and settled at Germantown, then nine miles from Philadelphia, but now in the city limits, like his American ancestry, Solomon W. Conrad was a strict Quaker and an approved minister of that faith. His father was John Conrad, a blacksmith, and Solomon was born July 31 , I779, and died October 2, I831. Of his early life nothing is positively known, but it is probable that he was apprenticed to a printer or bookseller. It is known that a strong fancy for scientific study was early developed, and the fears of his friends were realized that he would not be successful in business, because of attention divided between his shop and his cherished specimens at home. His partner ruined him financially. His herbarium is now in the possession of the Philadelphia Academy of Natural Sciences. As evidence that the country was more attractive than the shop on Market Street, I quote the following from the manuscript journal of a nephew: "My father, . . . with Solomon Conrad, would take long walks in search of new specimens. I went with them once on a stroll along the banks of the Schuylkill, when they saw at the same time, in the shallow bed of the river, a fine lot of mussels. Both rushed to the spot, regardless of the rough stones and splashing of the muddy water, the broad tails of their plain coats standing out behind and their arms reaching out in front, eager to secure the prize." In the spring of 1829 Solomon Conrad, who at that time had acquired a wide reputation as a mineralogist and botanist, was elected Professor of Botany in the University of Pennsylvania, and delivered, May ist, his introductory address. In The Friend of fifth month, 9, 1829 , the late Roberts Vaux, of Philadelphia, gives the following es- 
timate of the lecture: "With a succinct review of the history of botany he very happily blended some biographical notices of the distinguished men to whom the science owed its origin and illustration. He traced with great acuteness and perspicuity the analogy of vegetable and animal life, admitting the limit of human knowledge. Every view that he furnished of the subject, upon which he is so well qualified to impart instruction in all its details, was just and forcible, while the simplicity of his manner and chasteness of his style were by no means the least interesting traits of the lecturer." The venerable Frederick Fraley, Esq., of Philadelphia, recently informed me that he was present at the introductory lecture referred to, and that Mr. Vaux had in nowise allowed his enthusiasm to outrun his discretion.

On June 2I, I803, when his father was but twenty-four years old, Timothy Abbott Conrad was born. His mother was then staying at the home of her father, four miles from Trenton, in Burlington County, New Jersey. To this birthplace young Conrad became so strongly attached that he yearly made pilgrimage thereto, even when no representative of the family lived there. In his purely literary writings he so frequently refers to the place that he was once twitted about it, but without effect.

"Timothy," remarked an old Friend, "was thy grandfather the only man who ever lived in the country?"

"Other men exist in the country, but no one else lived like my grandfather," he replied.

Brought up, when with his parents, in so scientific an atmosphere, and when at his birthplace so delightfully surrounded not only by congenial kinsfolk, but Nature in her most attractive guise, it is little wonder that Conrad became a naturalist. Mr. Fraley tells me that, when a youth in early teens, Conrad was the "president" of an "Academy of Science" of which he, Mr. Fraley, was "secretary," and that it was conducted with all the decorum and good faith of the institution after which it was modelled.

Conrad was educated at select schools under the superintendence of Friends, but really educated himself, so far as the "higher branches" were concerned, acquiring without a teacher a thorough knowledge of Latin, Greek, and French. His skill in drawing was remarkable and early developed. He not only 
made all his own illustrations, but did considerable for others, as the shells, seaweed, and other small objects on some of Audubon's plates of birds. Before seriously taking up the special studies that subsequently made him famous, he wrote many sketches of a popular character, and occasionally drifted into verse. His father being a publisher and printer, Conrad entered the establishment as a clerk, reluctantly probably, and there learned the printer's art, and when his father died, in I83 $\mathrm{I}$, he continued the business for a short time, but the love of natural history was too strong to be overcome, and he gave up the shop and its belongings. Because of a preference for walking afield to attending religious services, a committee of Friends called upon Conrad, and, not accepting his explanation, they directed his name to be stricken off their roll of membership. Conrad did not like their action, and probably it is due to this that he seldom afterward attended any religious gathering, occasionally dropping into some country Quaker meeting, but always, as he said, for old times' sake and not spiritual profit.

In $183 \mathrm{I}$ he was elected a member of the Academy of Natural Sciences, and, some years after, of the American Philosophical Society. Of many foreign learned societies he was a correspondent, but, keeping no record of such elections, the names and dates of election have been lost.

Conrad's first volume bears date of 1831 , and has the following title: American Marine Conchology, or Descriptions and Coloured Figures of the Shells of the Atlantic Coast. Of this little volume, printed for the author, Conrad says in his preface, "it is designed to supply a deficiency which has long been felt by the cultivators of American natural history." The work contains seventeen plates, all drawn by the author, and coloured by hand by his sister. In I 834 Conrad published New Fresh-water Shells of the United States, with Lithographic Illustrations and a Monograph of the Genus Anculotus of Say. Also, A Synopsis of the American Naiades; Philadelphia, Judah Dobson, 108 Chestnut Street, May 3, r834. The full title of this little volume, with precise date of publication (not much larger than the title is long) is given, because even then questions of priority had arisen, and others laid claim to some of Conrad's species. This unhappy wran- 
gling was kept up for many years. Prof. Dall refers to this, as we shall see further on, as "numerous controversies, which are now ancient history." Conrad's own version should be given. He claimed that the editions of his publications were largely bought up and destroyed by a worker in the same field, and this explains the rarity of some of his writings. In the preface of the little volume above mentioned the author says: "While residing in the mansion of my kind and hospitable friend, Judge Tait, of Claiborne, Alabama, where I was employed in collecting the organic remains of the vicinity, I occasionally made excursions up and down the Alabama for the purpose of procuring fresh-water shells. I have succeeded in obtaining some species which I believe to be new, and hope to fix by accurate delineations and descriptions." The result was the little book, which is dedicated to the late Charles A. Poulson, of Philadelphia, a prominent conchologist in his day, and one of Conrad's financial backers in his several expeditions south in search of both recent and fossil shells. In 1834 , in the Journal (old series) of the Philadelphia Academy of Natural Sciences, Volume VII, Conrad published Observations on the Tertiary and More Recent Formations of a Portion of the United States, which appears to have been his first communication to that body. In $184 \mathrm{I}$ the Proceedings of the Academy were commenced, and a new series of the Journal in quarto. In the former, from Volume I to Volume XXXVI, Conrad's contributions appear in every year, the articles varying from two to a dozen in number. In the first four volumes of the new Journal he has eleven contributions, all of which are profusely illustrated. In $18{ }_{3} 6$ Conrad published Monography of the Family Unionidx, or Naiades of Lamarck (fresh-water bivalve shells), of North America. Illustrated by Figures drawn on Stone from Nature. Philadelphia: J. Dobson, I836. This work, like the Marine Conchology, was never finished. It would seem as if the magnitude of the work had not occurred to him at the time, or that he was soon tired of any subject that he took up, but the real difficulty was a want of financial support. There were never enough subscribers to meet the expense of publication. At this time, too, his health was very bad, and he seemed to lose all interest in every undertaking. "A period of moping would usually end in his writing some verses which nobody would 
praise, and this seemed sufficiently to nettle him, to rouse him thoroughly, and he would become again enthusiastic in the matter of shells and fossils."

In 1837 Conrad was appointed geologist of the State of New York, and after resigning the position remained as paleontologist of the survey until $\mathbf{1 8 4 2}$. "He prepared official reports on the fossils collected by the United States exploring expedition under Wilkes; by Lieutenant Lynch's expedition to the Dead Sea; by the Mexican Boundary Survey, and some of the surveys for a railroad route to the Pacific undertaken under the supervision of the War Department. Many papers were written by him on the Tertiary and Cretaceous geology and paleontology of the eastern United States, and published in the American Journal of Science, the Bulletin of the National Institution, the American Journal of Conchology, Kerr's Geological Report on North America, and other publications. A list of Conrad's papers, which covers most of those bearing on paleontological topics, may be found in Miscellaneous Publications of the United States Geological Survey of the Territories, No. Io; Bibliography of North American Invertebrate Paleontology, by Drs. C. A. White and H. Alleyne Nicholson -Washington, Interior Department, 1878 . It contains a hundred and twelve titles" (Dall).

In $183_{2}$ Conrad published Fossil Shells of the Tertiary Formations of North America. Illustrated by Figures drawn on Stone from Nature. Vol. I. Philadelphia, $183^{2}$. It is dedicated to Samuel George Morton, M. D. In 1838 Conrad published Fossils of the Tertiary Formations of the United States. Illustrated by Figures drawn from Nature. Philadelphia: J. Dobson. These are known generally as the Eocene and Miocene volumes, and both, as original editions, are extremely rare. They have recently been reprinted in facsimile, the former by Mr. G. D. Harris, of the Smithsonian Institution, Washington, D. C., and the latter by the Wagner Free Institute, under the editorial supervision of William $H$. Dall, of the National Museum. In his introduction Prof. Dall says: "Students of the American Miocene and the later Tertiary deposits of the New World are well aware of the importance to them of Conrad's work, usually referred to by the title of The Medial Tertiary. There can be little doubt that the scarcity of this work and its predecessor, the Eocene volume, is the chief 
cause of the delay in investigating our rich and interesting Tertiary beds."

Prof. Dall, in considering Conrad as a paleontologist, remarks as follows: "Mr. Conrad had several peculiarities; he wrote his letters and labels frequently on all sorts of scraps of paper, generally without date or location. He was naturally careless or unmethodical, and his citations of other authors' works can not safely be trusted without verification, and are usually incomplete. He had a very poor memory, and on several occasions had redescribed his own species. This defect increased with age, and, while no question of wilful misstatement need arise, made it impossible to place implicit confidence in his own recollections of such matters as dates of publication. He himself says in a characteristic letter to F. B. Meek, written in July, I863: 'I go on Monday to help $\mathrm{H}$ ferret out my skulking species of Palæozoic shells. May the recording angel help me! God and I knew them once, and the Almighty may know still. A man's memory is no part of his soul.'

"In spite of this constitutional defect, Conrad had an acute and observant eye, and an excellent, if sometimes hasty, judgment on matters of geology and classification. He was in advance of his time in discriminating genera, and in field researches and work on the specimens showed more than ordinary capacity. In those branches of his work which required knowledge of literature and systematic research he took less interest and pains.

"Like many shy people he was brought rather than ventured into numerous controversies, which are now ancient history, and need not be further alluded to. But the sketch just given will enable readers to understand the origin of much that is irritating to those who are obliged to rely upon Conrad's work and find in it slips and errors so obvious that they seem unpardonable. He had the defects of his qualities, but whether for good or evil he was the principal worker in the field of Tertiary geology in America for many years. $\mathrm{He}$ has left a voluminous literature, and neither his faults nor his virtues can by any method be ignored."

When Darwin's Origin of Species was published, Conrad became intensely interested in the discussions that wonderful book provoked. He did not take the theory up as subject- 
matter for an essay, but contented himself with innumerable notes and memoranda that I found on loose slips of paper after his death. He was bitterly opposed to evolution; considered Agassiz the world's greatest naturalist, and predicted that Darwin's “wild speculations" would soon be forgotten. Every geological age came, Conrad held, to a complete close, and the life of the succeeding one was a wholly new creation. These utterly crude and untenable views he held to the last.

It would be unjust to the memory of the subject of this sketch to pass over without notice his characteristics as a man and author. Conrad was something besides a profound paleontologist. This his friends well knew. He was of small stature, thin and homely, yet he had, as an intimate friend recently said, a refined countenance. There was a kindly light in his eyes that words can not describe nor the cunning of the artist depict. I have said "homely"; this on his own authority, for in his poem The Watermelon he declares:

"The poet may sing of the Orient spices,

Or Barbary's dates in their palmy array, But the huge rosy melon in cold juicy slices,

Is the Helicon font of a hot summer day,

"Where I bathe the dry wings of the spirit, and sprinkling

Sweet drops on the pathway of dusty old Care,

I hold Father Time from his villainous wrinkling

Of features that never had graces to spare."

As a conversationist Conrad had few superiors, but a weakness of his voice made it difficult for him to be heard, and it was only when.with two or three intimate friends that this quality shone out. He avoided large gatherings and never spoke in public. He had a keen sense of humour and was an inveterate punster. His memory was "very bad" scientifically, says Prof. Dall, but it was remarkably good so far as poetry was concerned, and when walking alone in the country he would repeat aloud long passages from the works of his favourite authors. His fondness for poetry led him to writing verses, some of which were printed in the Philadelphia papers as early as 1828 , and his latest effort bears date of 1874 . In I 848 Conrad published The New Diogenes, a Cynical Poem. This is well described in the subtitle. It consists of some twenty-five hundred lines of fault-finding. The edition was 
very small and is not yet exhausted. In $187 \mathrm{I}$ his nephew, Dr. C. C. Abbott, undertook to bring together the scattered short poems, and found thirty-two of these, mostly in the corners of newspapers and two in manuscript. The little volume was "privately printed." It bears the title, A Geological Vision and Other Poems. Trenton, N. J., I87 I.

In his nonscientific writings Conrad invites a comparison with Thoreau, but, while loving the outdoor world as devotedly, he always had an eye to physical comfort, and preferred at the end of a long tramp, a good bed at a tavern to sleeping out of doors. So too, probably, did Thoreau, but then to say so does not sound so prettily in a book.

Timothy Abbott Conrad died in Trenton, N. J., August 9, 1877 , the last of the prominent group of early Philadelphia naturalists, who paved the way for the more philosophical biologists of the present day. 


\section{WILLIAM STARLING SULLIVANT.}

$$
\text { 1803-1873. }
$$

"IN him we lose the most accomplished bryologist which this country has produced, and it can hardly be said that he leaves behind anywhere a superior." This is high praise and its value is enhanced by its coming from Prof. Asa Gray, who certainly knew whereof he spoke.

William Starling Sullivant was born Jan. 15, I803, at the little village of Franklinton, then a frontier settlement in the midst of primitive forest, near the site of the present city of Columbus. He was the eldest of the four children of Lucas Sullivant, a Virginian, and Sarah (Starling), his wife. His father had been commissioned by the Government to survey a district in the Northwestern Territory lying in the centre of what is now the State of Ohio, where he early purchased a large tract of land, bordering on the Scioto River, and near by if not including the site afterward chosen for the capital of the State.

The early life of William Sullivant was therefore that of the frontier, with its mixture of hardships and opportunities. At a time when the hominy mortar and the hand-grater served to furnish coarse meal for bread, and grist mills were few and far apart, young William, mounted astride of a bag of wheat on one horse and leading another on which also was strapped a well-filled bag, was often sent on a journey along the blazed bridle-path through the forest to procure flour for the family. These expeditions frequently occupied two or three days waiting for the grist, and necessitated sleeping in the mill wrapped in a blanket, where he was fortunate who had a pile of corn or wheat for his couch, instead of the hard floor. But all this, together with the athletic sports of the frontier settlement, served to give him the fine physical development which was often remarked in his adult years. He was also one of the party on some of his father's shorter surveying expeditions, 


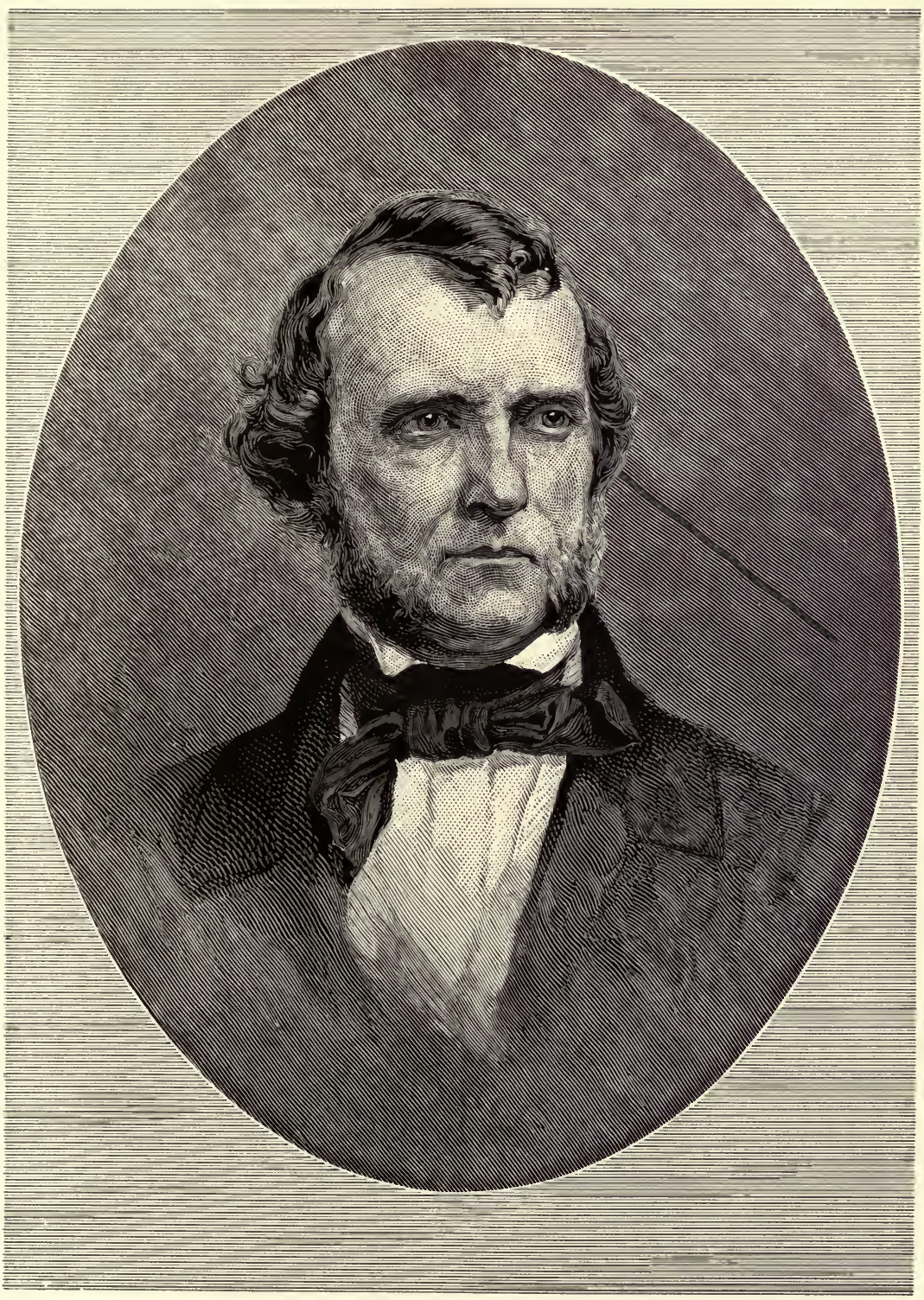

WILLIAM STARLING SULLIVANT. 

thus gaining knowledge that he was soon destined to put in practice.

He was sent to a private school in Kentucky, and entering the Ohio University when that institution opened, received there the rudiments of a collegiate education. He was then transferred to Yale College, from which he was graduated in r823. His father dying in the same year, he was obliged to give up the idea of studying a profession in order to take charge of the large family estate. The property consisted of lands, mills, etc., and required much and varied attention. The care of it required him to become a surveyor and a practical engineer, and to be much engaged in business for the greater part of his life. He became a member of the Ohio Stage Company, whose operations covered a wide field, and before the introduction of railroads afforded the best accommodations and facilities to the travelling public. He was one of the original stockholders and directors of the Clinton Bank, and for a time its president.

Mr. Sullivant was not one of those whose predilection for science appeared at an early age. He was nearly thirty years old and his youngest brother, Joseph, was already somewhat proficient in botany, conchology, and ornithology before his interest in natural history was aroused. He had married Miss Jane, daughter of Alexander K. Marshall, of Kentucky, and niece of Chief Justice Marshall, and was living in his suburban residence in a rich floral district. His wife had died within a year after marriage, leaving him an infant daughter.

His first scientific observations were upon the birds. When his attention was directed to botany, by his brother Joseph, he took up the subject with the determination to acquire a thorough knowledge of it. "He collected and carefully studied," says Prof. Gray in the memoir already quoted from, * "the plants of the central part of Ohio, made neat sketches of the minuter parts of many of them, especially of the grasses and sedges, entered into communication with the leading botanists of the country, and in 1840 he published A Catalogue of Plants, Native or Naturalized, in the Vicinity of Columbus, Ohio (63 pages), to which he added a few pages of valuable notes. His only other direct publication in phanerog-

* Read before the National Academy of Sciences, April 22, I875. 
amous botany is a short article upon three new plants which he had discovered in that district, contributed to the American Journal of Science and Arts in the year 1842 . The observations which he continued to make were communicated to his correspondents and friends, the authors of the Flora of North America, then in progress.

"As soon as the flowering plants of his district had ceased to afford him novelty, he turned to the mosses, in which he found abundant scientific occupation, of a kind well suited to his bent for patient and close observation, scrupulous accuracy, and nice discrimination. His first publication in his chosen department, the Musci Alleghanienses, was accompanied by the specimens themselves of mosses and hepaticæ collected in a botanical expedition through the Alleghany Mountains from Maryland to Georgia, in the summer of $x 843$, the writer of this notice being his companion. The specimens were not only critically determined, but exquisitely prepared and mounted, and with letterpress of great perfection; the whole forming two quarto volumes, which well deserve the encomium bestowed by Pritzel in his Thesaurus. It was not put on sale, but fifty copies were distributed with a free hand among bryologists and others who would appreciate it.

"In $1846 \mathrm{Mr}$. Sullivant communicated to the American Academy the first part, and in 1849 the second part, of his Contributions to the Bryology and Hepaticology of North America, which appeared one in the third, the other in the fourth volume (new series) of the academy's Memoirs, each with five plates from the author's own admirable drawings. These plates were engraved at his own expense, and were generously given to the academy.

"When the second edition of Gray's Manual of the Botany of the Northern United States was in preparation, Mr. Sullivant was asked to contribute to it a compendious account of the musci and hepatica of the region, which he did, in the space of about one hundred pages, generously adding, at his sole charge, eight copperplates crowded with illustrations of the details of the genera; thus enhancing vastly the value of his friend's work, and laying a foundation for the general study of bryology in the United States, which then and thus began. So excellent are these illustrations, both in plan and execution, that Schimper, then the leading bryologist of the Old World, 
and a most competent judge, since he has published hundreds of figures in his Bryologia Europaa, not only adopted the same plan in his Synopsis of the European Mosses, but also the very figures themselves (a few of which were, however, originally his own), whenever they would serve his purpose, as was the case with most of them.

"A separate edition was published of this portion of the Manual under the title of The Musci and Hepaticæ of the United States East of the Mississippi River (New York, I856, imperial octavo), upon thick paper, and with proof impressions directly from the copperplates. This exquisite volume was placed on sale at far less than its cost, and copies are now of great rarity and value. It was with regret that the author of the Manual omitted this cryptogamic portion from the ensuing editions, and only with the understanding that a separate Species Muscorum, or Manual for the Mosses of the whole United States, should replace it." This work Mr. Sullivant was about to prepare at the time of his death.

Mr. Sullivant married Miss Eliza G. Wheeler, of New York, a lady of rare accomplishments, who became a zealous and acute bryologist, and ably assisted her husband in his scientific work until her death, of cholera, in $185^{\circ}$ or $185 \mathrm{I}$. Her botanical services were commemorated by Schimper in the name of the Ohio moss, Hypnum Sullivantic. Two daughters and a son were the fruit of this marriage.

In $1848 \mathrm{Mr}$. Sullivant secured the co-operation of the accomplished botanist Leo Lesquereux, by whose labours his undertakings were substantially promoted. A characteristic feature of his scientific work was the issuing of sets of specimens, mounted on leaves with printed labels, and bound into a volume having a title-page, index, etc. Specimens had accompanied Mr. Sullivant's text in the Musci Alleghanienses, and now, from the ample stores collected by him and Lesquereux, cr otherwise acquired, fifty-six sets of about three hundred and sixty species each were made up, and all, except a few copies for gratuitous distribution, were placed on sale at less than cost, for the benefit of his esteemed associate. The title of the volume was Musci Boreali Americani quorum specimina exsiccati ediderunt $W$. S. Sullivant et L. Lesquereux; 1856. The value of the work ensured the speedy sale of the edition. A similar but larger collection, containing between five and six 
hundred species, many of them recently gathered in California by Dr. Bolander, was issued in 1865 . The sets were disposed of with the same unequalled liberality as before displayed. Still later, Mr. Sullivant aided his friend Mr. Austin both in the study of his material and in the publication of his Musci Appalachiani.

In his Musci Cubenses, which appeared in 1861, Mr. Sullivant named the species of Charles Wright's earlier acquisitions in Cuba and described the new ones. These mosses were also distributed in sets by the collector. His researches upon later and more extensive collections by Mr. Wright, in which many new species were indicated, were left in the form of notes and pencil sketches at his death. The same is true of an earlier collection, made by Fendler in Venezuela.

Mr. Sullivant was several times called upon to work up the mosses gathered by Government exploring expeditions. Thus the Bryology of Rodgers' United States North Pacific Exploring Expedition was early prepared for publication by him in the most elaborate manner. But, from causes over which he had no control, it has never been published, although brief characters of the principal new species have seen the light. The fact that Sullivant's exquisite drawings of these species were not promptly engraved and given to the scientific world is especially to be regretted.

In the case of the South Pacific Exploring Expedition, under Commodore Wilkes, the volume on the mosses was not published in his lifetime, but Mr. Sullivant issued a separate edition of his portion of it in 1859 . It forms a sumptuous imperial folio, the letterpress having been made up into large pages, and printed on paper matching that used for the twentysix plates. The fourth volume of the Pacific Railroad Reports contains Sullivant's descriptions of the mosses collected in Whipple's Exploration, occupying about a dozen pages, and accompanied by ten admirable plates of new species.

The Icones Muscorum, however, is Mr. Sullivant's crowning work. It was issued in 1864 , and consists of "Figures and Descriptions of most of those Mosses peculiar to Eastern North America which have not been heretofore figured," forming an imperial octavo volume with one hundred and twentynine copperplates. "The letterpress and the plates," says Prof. Gray, "(upon which last alone several thousand dollars 
and immense pains were expended) are simply exquisite and wholly unrivalled; and the scientific character is acknowledged to be worthy of the setting." Most of the time which Mr. Sullivant could devote to science in the last few years of his life was given to the preparation of a second or supplementary volume of the Icones. The plates were finished, the descriptions partly written out, and it was to have been printed in the spring in which he died.

Mr. Sullivant was attacked with pneumonia in January, I 873, about the time of his seventieth birthday, and, although making a partial recovery, died from the effects of the disease April 3०. He had married Caroline E. Sutton, who survived him. Four sons and two daughters were born to them.

He bequeathed all his bryological books and his exceedingly rich and important collections and preparations of mosses to the Gray Herbarium at Harvard University. The rest of his botanical library, his choice microscopes, and other collections, were left to the State Scientific and Agricultural College, then recently established at Columbus, and to the Starling Medical College, founded by his uncle, of which he was himself the senior trustee.

The American Academy of Arts and Sciences elected Mr. Sullivant to membership in 1845 ; he was also an associate of the other chief scientific societies of this country and of several in Europe. The honorary degree of Doctor of Laws was conferred upon him by Gambier College, while Torrey and Gray honoured him early by bestowing the name Sullivantia Ohionis upon a rare and modest plant discovered by him in his native State, and belonging to the same order (saxifrages) with the currant, syringa, and hydrangea.

For nearly forty years Sullivant corresponded with Asa Gray, also collecting with him and co-operating in research whenever practicable. He is often mentioned in Gray's Letters. When Lesquereux, who had been Gray's curator at Cambridge, left him to go and assist the Western bryologist, Gray wrote in a letter to Torrey: "They will do up bryology at a great rate. Lesquereux says that the collection and library of Sullivant in muscology are 'magnifique, superbe, the best he ever saw." " Under date of December 6, I857, Gray writes to W. J. Hooker: "Your first letter is now gone to Sullivant, because you speak of him so handsomely, and say that 
Mitten is instructed to prepare a set of mosses for him. A noble fellow is Sullivant, and deserves all you say of him and his works. The more you get to know of him the better you will like him." And when, in 1877 , he gave to Mr. Burgess, since famous as a designer of yachts, a note of introduction to Charles Darwin,Gray wrote: " $\mathrm{He}$ has just married the daughter of my dear old friend, the late Mr. Sullivant, who did for muscology in this country more than one man is likely ever to do again."

Prof. Gray said of him in the memoir already quoted, and which has supplied the facts for a large part of this article: "In personal appearance and carriage, no less than in all the traits of an unselfish and well-balanced character, Mr. Sullivant was a fine specimen of a man. $\mathrm{He}$ had excellent business talents, and was an exemplary citizen; he had a refined and sure taste, and was an accomplished draughtsman. But after having illustrated his earlier productions with his own pencil, he found that valuable time was to be gained by employing a trained artist. He discovered in Mr. A. Schrader a hopeful draughtsman, and he educated him to the work, with what excellent results the plates of the Icones and of his other works abundantly show. As an investigator he worked deliberately, slowly indeed and not continuously, but perseveringly. Having chosen his particular department, he gave himself undeviatingly to its advancement. His works have laid such a broad and complete foundation for the study of bryology in this country, and are of such recognised importance everywhere, that they must always be of classical authority; in fact, they are likely to remain for a long time unrivalled. Wherever mosses are studied his name will be honourably remembered; in this country it should long be remembered with peculiar gratitude."

The following extract from a letter written immediately after Sullivant's death to Mr. Joseph Sullivant by Leo Lesquereux will be interesting:

"In everything, as well you know, W. S. S. was most accurate. He was superficial in nothing. He worked his mosses slowly, coming again and again to a doubtful species, comparng authorities, repeating the most difficult anatomical preparations, till fully satisfied that his conclusions were warranted as far as botanical science could warrant them. The numer- 
ous species to which he has given his authority have therefore been admitted and recognised by the most eminent botanists of our time-Schimper, Müller, Lindberg, etc. More than ten years ago a very honourable account of his works as a bryologist was published in the Botanische Zeitung of Leipsic, which, for botany, is the highest European authority.

"Another remarkable trait of" the character of your lamented brother was his perhaps too liberal disposition to work in science for the benefit of others, without credit for himself. Not only did he give his time to the determination of an immense number of specimens which were sent to him by students, or by so-called authors, etc., but often, without claiming his right of authority, he determined the species, prepared descriptions of the new ones, when he well knew that they would be published under the names of his applicants. $\mathrm{He}$ has thus fixed a far larger number than those which were published in his name. Even lately he examined a large collection of mosses in which his opinion was requested, prepared descriptions of new species, remarks on interesting ones, etc., and from this work a catalogue was made by the same applicant, the notes copied as well as his remarks, and thus the authorship was literally taken from him, and not even a word of credit was given for his work. Such absence of scientific honesty was not even resented by your brother, who merely alluded to it as a poor reward for hard work. A character as was his, without trace of envious or jealous feeling, marked by true kindness for everybody, by a ready disposition to acknowledge and help every effort for the advancement of his science of predilection, to recognise errors and to correct them without the slightest word of depreciation, could but excite admiration and love; and, indeed, your brother was truly and sincerely loved by the few who knew him well; for he was not open to everybody. A man of few words, he never talked of himself or his doings, and thus only those who had the privilege of being intimate with him would recognise his noble nature." 


\section{WILLIAM WILLIAMS MATHER.}

$$
\text { I 804-1859. }
$$

AMERICA will never cease to benefit from the influence of its Puritan stock. Although the former preponderance in national affairs of New England as a section has disappeared with the widening of our territory, the vigour, the intellect, and the conscience of the settlers at Plymouth and at Boston have been diffused by their restless descendants through every State in the Union. They are seen in the capacity of the people of the United States for accomplishing great undertakings, for bearing heavy burdens, and more than all in their power of self-government and self-control.

William Williams Mather came from one of the most celebrated of the Puritan families in America. He was descended from Rev. Richard Mather, who fled to Massachusetts in 1635 to escape persecution for nonconformity. Richard Mather brought four sons to America, from the second of whom, Timothy, was descended the subject of this article. Two other sons, Eleazer and Increase, were born to Richard in this country, and the latter of these was the president of Harvard College from r688-r7or. Cotton Mather, the eminent divine and author, whose misguided zeal was such a strong support to the "witchcraft delusion," was a son of Increase. The paternal grandfather of William, Eleazer Mather, and his grand-uncle, Elisha, were officers of the Connecticut troops in the Revolutionary War. The eldest son of this Eleazer, who bore the same name, was the father of William. He learned the hatter's trade in Norwich and set up a business for himself at Brooklyn, in Windham County, Conn., which he carried on successfully for a number of years. He then travelled for a time in Canada, and returning to Brooklyn married Miss Fanny Williams, daughter of Nathan Williams, who was also a soldier of the Revolution. After his marriage he ceased to 402 


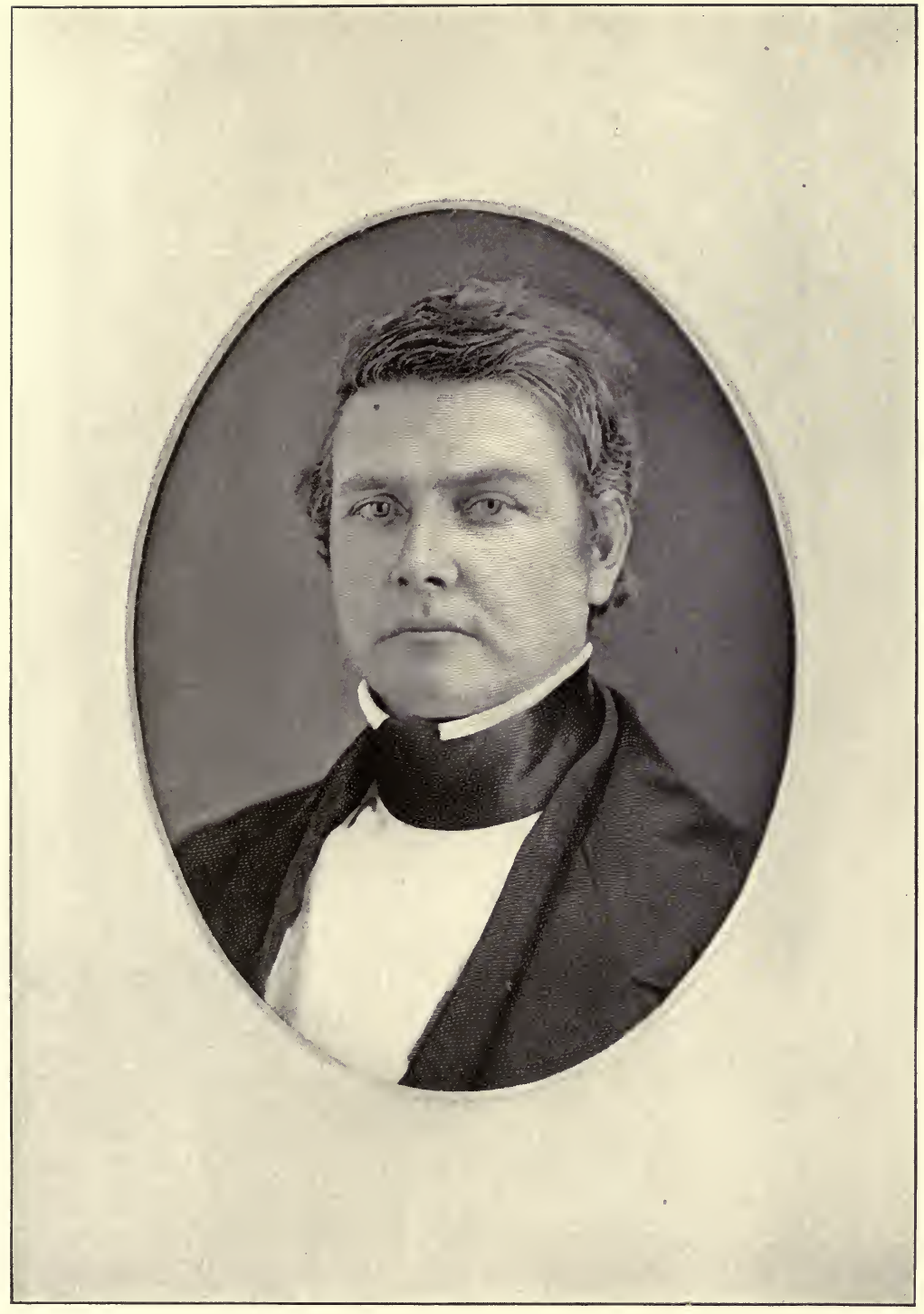

WILLIAM WILLIAMS MATHER. 

follow his trade, and kept a temperance hotel, also giving considerable attention to the improvement of worn-out lands. His son William W. was born in Brooklyn on May 24, 1804 .

The Hon. Ivers J. Austin, who wrote the memorial sketch of William Mather for the New England Historic Genealogical Society, ${ }^{*}$ was unable to find any information concerning William's childhood and very little in regard to his early youth. While still in his teens William formed the purpose of becoming a physician, and went to Providence, R. I., to take up medical studies. There he became much interested in chemistry, and on the occasion of a visit home he brought with him an elaborate piece of chemical apparatus, the cost of which rather astonished and displeased his father. But he so amused and instructed his family by his chemical experiments and explanations that his father became entirely reconciled to this outlay. In 1822 the young man applied for a warrant as a cadet at West Point, which he obtained in the following year. For this appointment he had recommendations of the highest character. Twelve well-known men, living in seven towns, certified to his ability and worth. The chief judge of Windham County, wrote: " $\mathrm{He}$ is about eighteen years of age, possessed of much more than common talents and literature. $\mathrm{He}$ understands the Latin language, and some of the higher branches of mathematical science, which he acquires with much facility. His moral character is, I think, very fair and unexceptionable."

He entered the academy in the summer of 1823 , and, in common with eight or nine other members of his class, spent one year more than the usual period there, being graduated in 1828 . Young Mather was proficient in chemical analysis, especially of ores and minerals, before going to West Point, and in 1826 , when Webster's Chemistry was passing through the press, the proof-sheets of a part if not of the whole of the work were sent to him by the author for suggestions and corrections. These were furnished by him and were adopted, but Mather's name was not mentioned in the preface of the book among those who had contributed to it, and he expressed to his classmate and memoirist, Austin, his disappointment at the

\footnotetext{
* It is from this memorial that most of the facts in the present article are derived.
} 
omission. In the fall of that year he entered the second class, thus coming to the studies of chemistry and mineralogy in the curriculum of the academy, Webster's book being used. Cadet Mather at once took the head of the class in these subjects, and easily kept his place to the end of the course. When off duty he explored the hills of the vicinity to collect minerals for his private cabinet and that of the lyceum. The chemical laboratory of the institution was also a place of resort for his leisure hours. During the last year of the course he was an assistant in the laboratory. He seemed to have a special aptitude for science and took great delight in experimenting. Mr. Austin illustrates this tendency by the following account:

"The winter of 1826-'27 was very cold. The ice, floating down to the narrow gorge between the precipitous shores of West Point and the opposite bank, became wedged there and was exceedingly thick. It occurred to Mather that a favourable opportunity was thus offered to ascertain the temperature of the water at the bottom of the river while the surface was covered with ice. After several attempts he succeeded in making a self-registering thermometer, and an apparatus for bringing up a specimen of the water of the lowest depth. A hole was cut through the ice about the middle of the river, and the apparatus, attached to a strong cord was let down into the water, but the current was so strong that it failed to reach the bottom. With a heavier weight it sank far enough, but the pressure forced the cork into the bottle. The next attempt was successful; water was drawn from below, and its temperature ascertained from the self-registering, compared with that indicated by a detached, thermometer. The result of this experiment, in which the writer assisted him, is not remembered, but Mather declared that he was satisfied with it. Such was his occupation, on one of the coldest days in winter, during the whole of the Saturday afternoon allowed to the corps for recreation."

On graduating he was assigned to the Seventh Infantry with the customary rank of second lieutenant. He remained at West Point as acting assistant instructor of artillery during the summer encampment of 1828 , and was then ordered to the School of Practice at Jefferson barracks, where he remained until April, 1829. From April to the end of June he was on 
frontier duty at Fort Jessup, La. He was then detailed to serve as acting assistant Professor of Chemistry, Mineralogy, and Geology in the Military Academy, which duty he performed until the summer of 1835 . The assistant professors at the academy at that time were usually detailed from recent graduates, and their terms of service rarely exceeded two years. The fact that Lieutenant Mather was retained in that capacity for six years indicates that he was an unusually successful instructor. During the recess of his course of instruction in I 833 he acted as Professor of Geology, with the permission of the War Department, at Wesleyan University, Middletown, Conn., and the following year received the honorary degree of A. M. from this university. In the summer of 1834 he made a geological survey of Windham County, Conn., and drew up a report, which was published.

Within the first year after his graduation Lieutenant Mather published in the American Journal of Science a paper entitled On the Nonconducting Power of Water with Regard to Heat. While serving as assistant professor at the academy he contributed other papers to the same journal, and wrote a small text-book, Elements of Geology, which was afterward enlarged and passed through several editions. $\mathrm{He}$ wrote also an account of the dilivium for the use of the cadets in their study of geology.

On being relieved from duty at the academy he was assigned to topographical service as an assistant to G. W. Featherstonhaugh in a geological examination of the country from Green Bay to Coteaus de Prairies. This work occupied him during the latter half of $\mathrm{I} 835$. He made a topographical map of the St. Peter's (Minnesota) River Valley and a report, which his later associate Whittlesey says he refused to present to the "pretentious English geologist in charge of the expedition," but transmitted direct to the United States Government. When this survey was completed he was promoted to a first lieutenancy and sent to join his regiment on frontier duty at Fort Gibson, in Idaho Territory. The following summer he marched into the Choctaw country in command of his company. Feeling that he could now safely adopt the pursuit of science as a profession, he resigned his commission in the army at the end of August, 1836 .

When he had been one year at West Point as assistant 
professor, Lieutenant Mather married his cousin, Miss Emily Maria Baker. By this marriage he had three sons and three daughters. Mrs. Mather died in $185^{\circ}$.

After leaving the army Mr. Mather was for a short time Professor of Chemistry, Mineralogy, and Geology in the University of Louisiana, but before the close of 1836 Governor Marcy, of New York, appointed him, together with Ebenezer Emmons, T. A. Conrad, and Lardner Vanuxem to make a geological survey of that State. Each of these principal geologists was assigned to one of four districts into which the State was divided for the purpose. Mather had the first district, which comprised Washington, Saratoga, Schenectady, Schoharie, and Delaware Counties, and all that part of the State to the southeast of them. What this survey accomplished has been told by Dr. James Hall, in the Popular Science Monthly, for April, I883. Among other things, he says that "Their labours had in a great degree quieted the feverish anxiety regarding the discovery of coal within the limits of New York, for which frequent explorations had been made in the black slates of the Hudson River Valley and elsewhere, involving the expenditure of much money and loss of time. ... Professor Mather has estimated, from what he regarded as reliable data, that the fruitless coal-mining enterprises which had been undertaken in the Hudson Valley alone, during the fifty years preceding 1840 , had cost more than a quarter of a million of dollars. The sums thus expended in other parts of the State, though doubtless much less, must, nevertheless, have been very large." The work of the survey lasted about seven years. During this time Prof. Mather made five periodical reports and a final report. This last forms a quarto volume of six hundred and fifty-three pages, with fortysix coloured plates, being one of the set of volumes embodying the results of the survey and published by the State. This report has been highly commended.

In 1837 a State Geological Survey of Ohio was projected and Prof. Mather was made chief geologist. This ill-fated project was killed after an existence of little more than two years by a spasm of economy which attacked the Ohio Legislature of 1839. Two annual reports had been presented, and were printed as State documents, and a report on the collections was made afterward, but there was no final report, and 
no provision was made for preserving papers, field-notes, and maps. A geological reconnaissance of Kentucky, authorized by the Legislature of that State, was made by Prof. Mather in $1838-39$, his report being issued as a State document. Both his appointment in Ohio and that in Kentucky had been accepted with the condition that they should not prevent the completion of his work in New York.

Colonel Charles Whittlesey has stated, in an article on the Personnel of the First Geological Survey of Ohio, that after the suspension of the Ohio survey, Mather bought a tract of several hundred acres, including the Pigeon Roost, north of the court-house in Jackson County, and became a citizen of Ohio. He cleared a part of this land for a farm and built him a comfortable house on it. Afterward he and Prof. James Hall entered a large tract of Government land in the southern part of the same county, on which they erected an iron furnace.

When Mr. Mather settled in Jackson County, in $184 \mathrm{I}$, it was impossible to obtain sperm oil there for domestic lighting. The only recourse of the family was to mould tallow candles, which was very unsatisfactory. In the following winter $\mathrm{Mr}$. Mather began experimenting on the preparation of oil from lard. He placed the lard in a canvas bag and suspended it in a warm room, thus obtaining by the slow process of dripping an oil that the family used in lamps. An account of these experiments was published, and is believed to have been the starting-point of the production of lard oil, which has since become so extensive.

About the time the field work of the New York survey was finished, Prof. Mather became Professor of Natural Science in the Ohio University at Athens. He held this position from 1842 to $\mathrm{r} 845$ and from $\mathrm{I} 847$ to $\mathrm{I} 850$, being vice-president and acting president in $r 845$. The period from $r 845$ to $r 847$ was occupied in examining mineral lands for mining companies, mainly about Lake Superior, but also in New Jersey, Virginia, and Massachusetts. During the first quarter of 1846 he was acting Professor of Chemistry and Geology in Marietta College, his other engagements making him unwilling to accept the professorship. In the winter of 1845 he began a series of experiments on the extraction of bromine from the bitter waters of the salt works near Athens, Ohio. At that time bro- 
mine, which can now be had for sixty cents a pound, was selling at sixteen dollars an ounce. The results of his investigations were published in the American Journal of Science. They showed that bromine could be obtained from these waters for much less than it was then costing, and resulted in the establishment of a plant at Pomeroy, Ohio, which produces the greater part of the world's present supply of this substance.

In similar public and private employments the rest of his life was passed. He was Agricultural Chemist for the State of Ohio, and secretary of the State Board of Agriculture from $185^{\circ}$ to 1854 . During part of this time he edited the Western Agriculturist, and during the last year was member for Ohio of the U.S. Board of Agriculture. He also continued to make examinations of mineral lands. His first wife having died, he married in $185 \mathrm{I}$ Mrs. Mary (Harries) Curtis, who survived him. By this marriage he had one son. The person of Prof. Mather was large and robust, and he had a great capacity for physical and mental labour, all of which promised a long life. This expectation, however, was not realized. $\mathrm{He}$ died Feb. 26, x859, in Columbus, Ohio, at the age of fifty-four. His death was sudden and was ascribed to a complication of dropsy and paralysis.

In addition to his writings already mentioned, Prof. Mather contributed frequent papers to the American Journal of Science and other scientific periodicals, and he wrote many reports on the explorations made in the course of his professional work. He received the degree of LL. D. from Brown University in 1855 , was a member of twenty-five scientific and literary organizations, a life-member of many religious associations, and for fifteen years a trustee of Granville College.

In his various expeditions he collected large numbers of minerals and geological specimens. His collection was much increased by exchanges with American and foreign geologists, and at his death contained about twenty-six thousand specimens. At present it is owned by his son, Richard, of Ironton, Ohio.

Mr. Austin thus describes his character: "Equable in his disposition and gentle in his manners, considerate of others and just in his judgment of them, modest, but manly and selfreliant, thoroughly versed in the branches of science to which he devoted himself, he had neither dogmatism nor ostentation. 
As he observed in a letter to a personal friend, who differed from him in regard to a geological question: 'I am not wedded to any theory, but seek the truth-and when found adopt it." "He was not inclined to court popularity, neither was his manner forbidding. Letters preserved by his family and friends give abundant evidence of the gentleness of his disposition, the firmness of his principles, and his high sense of honour.

The supremacy of his will-power over physical pain is illustrated in the following anecdote: "While making an examination of coal lands near Pomeroy in Ohio, he was wounded in the second finger of his right hand. This wound induced a partial paralysis, and required an amputation of the finger. The cause of it was supposed to be a snake bite. As soon as he was convinced by the examination that amputation was inevitable, he directed the surgeon to procure a block, a chisel, and a mallet, and, placing his finger on the block, told him to sever the finger at one blow. This was attempted, but proved a sad failure. The chisel was too thin and highly tempered, and the edge crumbled. Nevertheless he directed the surgeon to go on, and several blows were required before a complete severance could be made; although in this painful operation the bone was crushed instead of being cut, he bore it without flinching."

The substantial national reputation as a geologist won by William W. Mather was the result of the steady and conscientious application of a natural aptitude. "Not possessing the genius which dazzles," says his friend Austin, "he had the intellect which, continually improved by exercise, achieved valuable results by patient and conscientious industry. What duty demanded, that he performed regardless of consequences, either to himself or others. Not indifferent to fame, he never. sought it by doubtful or devious courses. His object was not to enhance his reputation, but faithfully to do the work before him. Through the whole of his active and laborious life of thirty years in the cause of science, in all the various and important public positions which he occupied, no breath of censure assailed his integrity, which was a law of nature with him, rather than a choice or a principle." 


\section{WILLIAM BARTON ROGERS.}

$$
\text { 1804-1 } 882 \text {. }
$$

THE second in age of four brothers eminent in science, William Barton Rogers was born in Philadelphia, Dec. 7 , 1804. His ancestry will be found in the sketch of his elder brother included in the present volume. The middle name given to him is a loving memorial of his father's respect and friendship for his medical preceptor, Dr. Benjamin S. Barton. William was eight years old when his parents removed to Baltimore and fifteen when they went to Williamsburg. Hence his early education was mostly obtained in these two places. Dr. Ruschenberger mentions that William, while a youth, "was employed in Baltimore by a dealer in crockeryware, and acquired such facility in wrapping packages that he subsequently reckoned it among his accomplishments." *

He graduated in 1822 from the College of William and Mary, where his father was then Professor of Natural Philosophy and Mathematics, and soon after this he and his brother Henry started a private school in the suburbs of Baltimore. How long the enterprise endured or what was its success have not been ascertained.

When twenty-two years of age William gave his first lectures on science in the Maryland Institute, Baltimore, and the following year was appointed to the professorship in William and Mary College, left vacant by the death of his father, where he remained until 1835 . He was then appointed to the chair of Natural Philosophy in the University of Virginia, and there extended his instructions by adding the subjects of mineralogy and geology to his course. The same year he organized

* A Sketch of the Life of Robert E. Rogers, M. D., LL. D., with Biographical Notices of his Father and Brothers. By W. S. W. Ruschenberger, M. D. Read before the American Philosophical Society, Nov. 6, I885. 


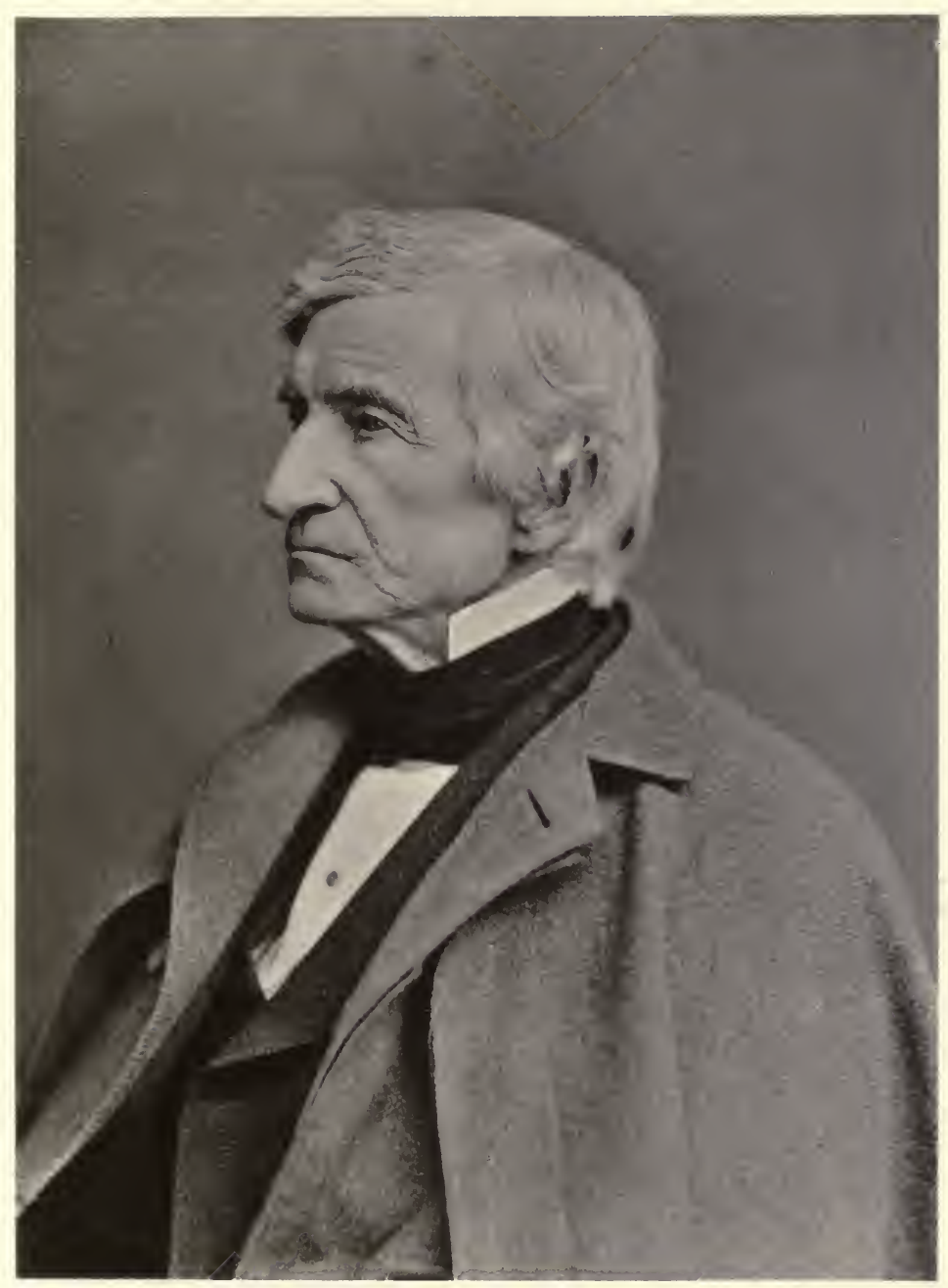

WILLIAM BARTON ROGERS. 


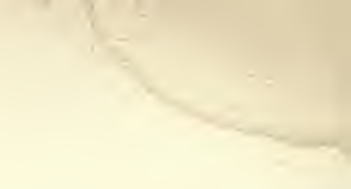


the geological survey of the State, having, while a professor at William and Mary, begun his geological labours with an exa nination of the Tertiary formation of this region, of which he published, in conjunction with his brother Henry D. Rogers, two memoirs in the Transactions of the American Philosophical Society. In June, I834, and May, I835, he had published also, in the Farmers' Register, three papers on the Green Sand and Marl of Eastern Virginia, pointing out their value as fertilizers. At this time, besides other chemical researches, he made an analysis of the waters of the Virginia mineral springs, the results of which have appeared in various publications.

He remained at the head of the geological survey until it was discontinued in $\mathbf{r} 842$, having published a series of annual reports and collected further materials, for the completion and publication of which, however, no provision was made by the State. All his brothers were from time to time among his assistants in field and laboratory work. While at the university he published for the use of his students a short treatise on the Strength of Materials (Charlottesville, 1838), and a volume on The Elements of Mechanical Philosophy (Boston, I852). During this period of his life, besides the cares of his professorship and of the survey, he occupied himself with original researches in various departments of science, partly geological, in connection with his field work, and, after the survey ended, chiefly in chemistry and physics.

In 1840 the "Association of American Geologists and Naturalists" was organized. In this society, embracing Hitchcock, Hale, Vanuxem, the four brothers Rogers, Conrad, Emmons, and others engaged in active scientific research, Prof. Rogers took a leading part, as will be seen by referring to its Transactions.

One of the more important of his geological researches published at this time concerned the solvent power of water, especially when charged with carbonic acid, on various ninerals and rocks, and showed the extent of this action in Nature. In connection with his brother Robert, Prof. Rogers was the first to investigate this subject.

From his examinations of the Virginia coal deposits he discovered that the condition of any coalbed stands in a close genetic relation to the amount of disturbance to which the 
enclosing strata have been submitted, the coal becoming harder and containing less volatile matter as the evidence of disturbance increases.

But the most notable contribution that Prof. Rogers made to the advance of geologic science was the "wave theory" of mountain chains. This was the joint work of William B. and Henry D. Rogers, being founded on their researches in the Appalachian chain, and was presented by them to the Association of Geologists in 1842 in the form of an oral statement, with the title, The Laws of Structure of the more Disturbed Zones of the Earth's Crust. The theory represented the elevation of mountain chains as the result of movements of the earth's surface similar to the movements which raise up waves upon a body of water. The grandeur of the conception, the immense amount of evidence piled up in support of it, and the eloquence with which the whole was presented made a profound impression at the meeting. One who was present, $\mathrm{Mr}$. John L. Hays, of Cambridge, said forty years afterward: "I have frequently read it since. To me it is now comparatively tame in expression. It lacks the inspiration of the scene and the man, the illustrative diagrams, the emphasis of voice and finger pointing out the distinguishing phenomena, and the fervour of spontaneous utterance. The impression I have of this exposition as delivered is that, next to the Phi Beta Kappa oration of Wendell Phillips at Harvard, it is the most lucid and elegant effort of oral statement to which I ever listened." It was the first important contribution to dynamical and structural geology which had been brought forward in this country. The novelty and importance of its generalizations were at once recognised in Europe as well as at home, and gave the authors, the "Gebrüder Rogers," a prominent place among contemporary geologists. This memoir is still regarded as of classical value.

The "wave theory" was further supported by the discoveries of Prof. Rogers in regard to the distribution of those ruptures of the strata called faults. He showed in another paper that they do not occur on gentle waves, but on the sharpest flexures of mountain chains, which have given way at the summit where the strain was greatest. Furthermore, the plane of the fault was usually parallel to, if not coincident with, the plane of the ridge. The evidence for this statement 
was afforded by the observed positions of more than fifty thermal springs in the Appalachian belt, occurring in an area of about fifteen thousand square miles, which were shown to issue from anticlinal axes and faults, or from points very near such lines.

In connection with his brother Robert E. Rogers, now become his colleague as Professor of Chemistry and Materia Medica in the university, he published a number of important chemical contributions, relating chiefly to new or improved methods in chemical analysis and research, in Silliman's Journal, between 1840 and $185^{\circ}$. Among these were papers On a New Process for obtaining Pure Chlorine; A New Process for obtaining Formic Acid, Aldehyde, etc.; On the Oxidation of the Diamond in the Liquid Way; On New Instruments and Processes for the Analysis of the Carbonates; On the Absorption of Carbonic Acid by Liquids, an extended investigation; and On the Decomposition of Rocks by Carbonated and Meteoric Waters, a paper of much interest in its geological bearings.

In the volume of the Transactions of the British Association for 1849 , Prof. Rogers called attention to the existence of true coal measures below the horizon of the Carboniferous limestone in the Appalachian belt as discovered by him in the Virginia survey, and referred to in his annual reports.

Prof. Rogers married June 20, I849, Miss Emma, daughter of Hon. James Savage, of Boston, President of the Massachusetts Historical Society, and author of the Genealogical Dictionary, and, with his bride, sailed the same day for a trip in Europe. He returned in October to resume his duties in Virginia. Mrs. Rogers became, says William C. Rives,* "the promoter of his labours, the ornament and solace of his middle life, and the devoted companion and support of his declining years." Soon after his death she edited very admirably, with the assistance of Major Jed. Hotchkiss, a Reprint of the Annual Reports and other Papers on the Geology of the Virginias. $\dagger$

In 1853 Prof. Rogers resigned his professorship at Charlottesville, after eighteen years of efficient service, and removed

* An address delivered before the Society of the Alumni of the University of Virginia, on Cómmencement Day, June 27, I883.

† D. Appleton \& Co., New York, I884. 
to Boston. Here, although he early identified himself with the educational and public interests of the community, he did not relax his devotion to scientific labours, which were now, however, more largely directed to the department of experimental physics. Among his contributions to physics at this period may be mentioned a series of papers On Binocular Vision, giving an Elaborate Analysis of the Phenomena, with some Important Additions to the Researches on this Subject of Wheatstone and Brewster; Experiments on Sonorous Flames, in which he described an apparatus for making visible the vibrations by rotating the flame; and On the Formation of Rings of Air and Liquids-all of which may be found in Silliman's Journal (1855-1860).

$\mathrm{He}$ also published, in the New Edinburgh Philosophical Journal, the results of continued observations on atmospheric ozone, and on the auroras of August and September, I859 and 1860. As a member of the American Academy of Arts and Sciences, and of the Boston Society of Natural History, Prof. Rogers took an active part in the discussions of the various scientific questions then rising into importance, and made contributions from time to time to their published proceedings. Among the communications to the American Academy we may note papers On the Protozoic Age of Certain Rocks in Eastern Massachusetts; On the Actinism of the Electric Discharge in Vacuum Tubes, of which he exhibited numerous photographs, in connection with his paper on the improvements, by Mr.E.S. Ritchie, of the Ruhmkorff apparatus; and Experiments disproving, by the Binocular Combination of Visual Spectra, Brewster's Theory of Successive Combination of Corresponding Points.

In the Transactions of the Boston Society of Natural History appeared, among other articles by Prof. Rogers, communications On the Growth of Stalactites; Geological Relations of the New Red Sandstone of the Middle States to the CoalRocks of Eastern Virginia and North Carolina; On the Origin and Accumulation of the Protocarbonate of Iron in Coal Measures; On the Natural Coke and Associated Igneous Rocks of Eastern Virginia; and On Pebbles in the Newport Conglomerate.

At the annual meetings of the American Association for the Advancement of Science, Prof. Rogers was a frequent con- 
tributor, as well in the discussions of scientific questions as in the communication of original papers, which, however, in most cases, appear only by title in their Transactions, or are to be found in other publications before mentioned. In 1857 he made another visit to Europe and attended the meeting of the British Association at Dublin.

At the request of his friend Governor Andrew, in $186 \mathrm{r}$, he accepted the office of Inspector of Gas and Gas Meters for the State of Massachusetts, and organized a system of inspection in which he aimed to apply scientific principles more fully than had hitherto been attempted in the United States. Some account of his methods was given by him at the meeting of the British Association in 1864. During this time Prof. Rogers was often called upon for public lectures on scientific subjects in Massachusetts and elsewhere, and gave several courses before the Lowell Institute in Boston.

Prof. Rogers had long felt the need, in our educational system, of giving to the physical sciences a higher place and more practical methods of teaching than had hitherto been allowed them, and he was therefore eager to avail himself of an opportunity for carrying out these views. In 1860 , in behalf of a committee of gentlemen who had become interested in the subject, he drew up a scheme entitled "Object and Plan of an Institute of Technology," embracing a society of arts, a museum of arts, and a school of industrial science; and he subsequently addressed a memorial to the Legislature of Massachusetts, urging the establishment of such an institution. Finally, in 1862 , a charter for the "Massachusetts Institute of Technology" was granted, and Prof. Rogers was placed at its head. A whole square of land on Back Bay was granted for building purposes-one third to the Boston Society of Natural History, the other two thirds to the Institute of Technology. Accompanied by Mrs. Rogers he went to Europe in 1864 to collect models of machinery and apparatus for the use of the school. The detailed plan for the departments of the school, prepared by Prof. Rogers in that year, has been carried out, with but slight modifications. A marked feature of this plan, which has since been adopted in many other institutions, was the introduction of laboratory teaching, not only in the department of chemistry, but in that of physics, mechanics, and mining, a feature which has contributed largely to the reputa- 
tion which the school has acquired for thoroughness of scientific training.

The success of the institute, based upon no sentimental or traditionary regard for its subjects of instruction, but upon the service that it has been able to render to the country, is the best testimonial to the wisdom of its founder. Among the technical schools in the United States there is none higher. Students have resorted to it in constantly increasing numbers, so that department after department has outgrown the accommodations provided for it. Its graduates may be found throughout the length and breadth of the land doing valuable work as civil, mechanical, and mining engineers, chemists, architects, or teachers of these professions, for which the sound training of the institute has excellently qualified them. The considerable endowments which this institution has gradually accumulated testify to the respect which it has won among the promoters of the scientific arts. The institute embodies the general attitude of William Rogers toward science. He always had a strong interest in the economic side of his field of labour. Those investigations had a doubled attraction for his mind which promised to place new resources at the disposal of mankind. Hence in establishing this noble school of applied science he erected his only adequate and most appropriate monument.

After the establishment of the institute the activity of Prof. Rogers was governed by the fluctuations of his health. For the first few years, besides being president of the institution, he filled the chair of Physics and Geology. Ill health caused him to resign the presidency in 1870 , but having partly regained his strength in 1878 he was induced to accept it again. Three years later infirmity compelled him to relinquish it finally.

His death occurred within the walls of the noble institution that he had created. On Commencement Day, May 30, 1882 , the end came while he was delivering an address. "Thus was closed," says Dr. Ruschenberger, "probably without pain, his bright career. He had fairly won and received all the compliments and honours that a votary of science in this country can win; and he was universally esteemed in private life on account of his probity, urbanity, and social accomplishments." 
Prof. Rogers was a member of all the prominent scientific societies in the United States, and had been an officer in many of them. He was chairman of the Association of American Geologists and Naturalists in 1845 , and again in 1847 , when it was expanded into the American Association for the Advancement of Science, at the first meeting of which he presided until it was fully organized. He was also elected president of the American Association for its meeting in 1876 , and was a corresponding member of the British Association. $\mathrm{He}$ was corresponding secretary of the American Academy of Arts and Sciences from 1863 to 1869 . After taking up his residence in Boston he joined the Thursday Evening Scientific Club, of that city, and was its president for a number of years. When Joseph Henry died in 1878 , Prof. Rogers was elected to succeed him as President of the National Academy of Science. He was active in founding the American Social Science Association, and was its first president.

Among the honours paid to him was the degree of LL. D. from Harvard College in 1866 . In the following year he was appointed commissioner to represent the State of Massachusetts at the Paris Exposition, and spent the summer at the French capital.

But this inventory of the life work of Prof. Rogers, extensive and interesting as it is, leaves out a powerful element of the influence he has exerted as a teacher over great numbers of young men who have been brought within the spell of his personality. Prof. Rogers was an orator of the first class, and was long regarded as the most impressive and delightful speaker that appeared before the American Association. It must be remembered that science puts oratory to its highest test; it is a field in which reason is supreme, and where the speaker is not at liberty to throw logic to the winds, and make a fiery appeal to the feelings and passions of listeners. The scientific orator must address intelligent men, habituated to think for themselves, on the alert against tricks that carry the imagination, while the speaker himself is kept under the close restraints of fact. To be able to captivate and enchain an audience in the pure work of exposition, to fascinate in teaching, is a triumph of oratorical ability. Prof. Rogers was marked by the possession of this rare gift, and before his classes in college, whether treating of rocks, physical forces, or rigid 
principles of mathematics, he was always able to kindle the enthusiasm of the students, and make the most vivid and lasting impressions upon their minds. We were not surprised, therefore, to note, in a Virginia newspaper, an exciting description of the way Prof. Rogers was received by his old students at the semi-centennial of the University of Virginia, where he "was the central object, on whom were fixed the eyes and hearts of the great concourse there assembled from all parts of the country. It was difficult to get near enough to speak to him, surrounded as he was by such numbers of those who in years long past had attended his lectures." He made an address, the reception of which was described by the writer with a pardonable warmth: "At the dinner of the alumni, Prof. Rogers addressed them in a speech of half an hour. It was a wonderful specimen of eloquence. The old students beheld before them the same William B. Rogers who, thirty-five years before, had held them spellbound in his class of natural philosophy; and as the great orator warmed up, these men forgot their age; they were again young, and showed their enthusiasm as wildly as in the days of yore, enraptured by his eloquence, they made the lecture room of the university ring with their applause. Such was the effect produced by the off-hand words of this distinguished man of science and unrivalled orator; and those who have heard him in his moments of inspiration will not wonder at the account we have given." 



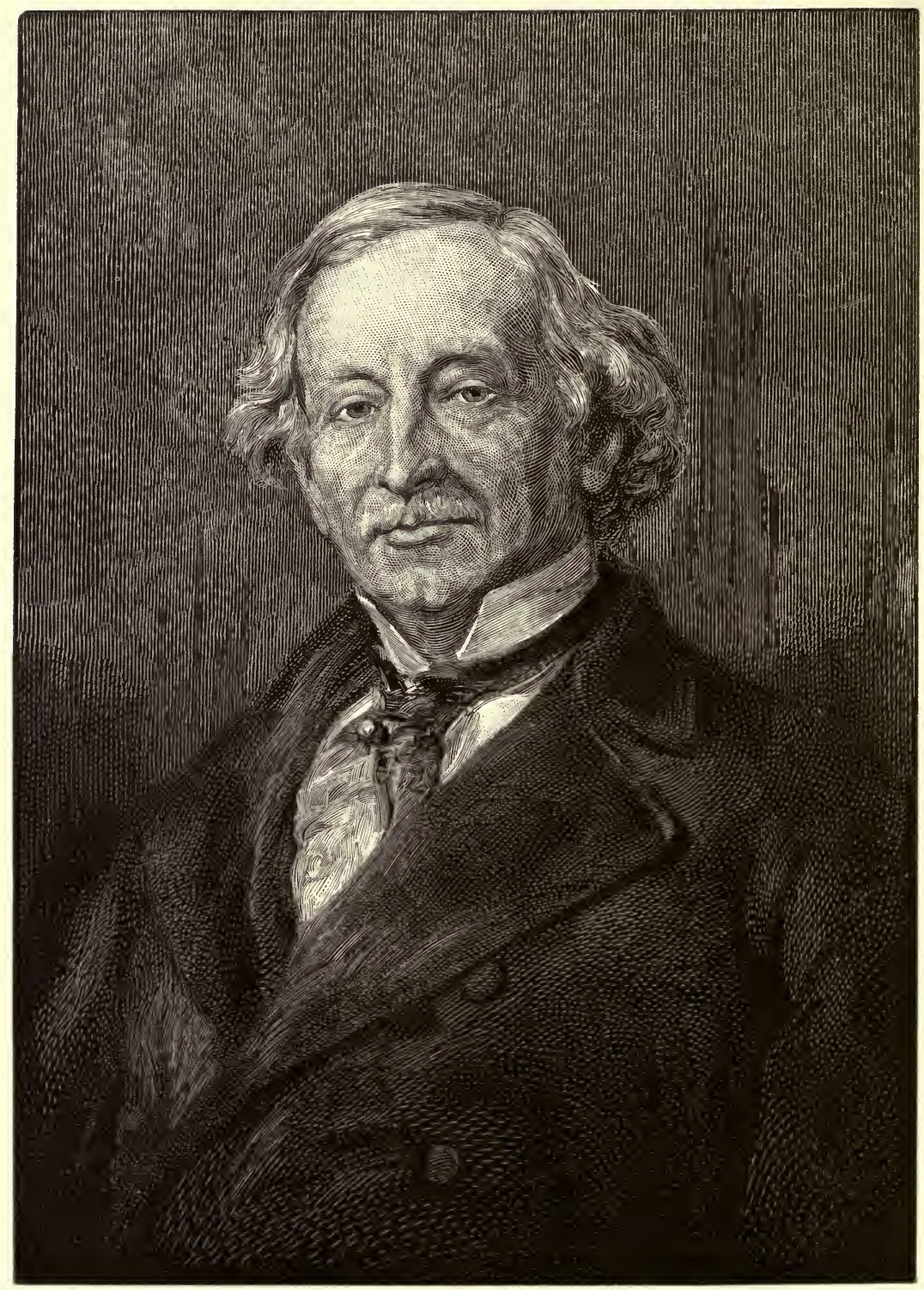

CHARLES UPHAM SHEPARD 


\section{CHARLES UPHAM SHEPARD.}

$$
\text { I 804-1 } 886 \text {. }
$$

Charles Upham Shepard was born at Little Compton, a town in the southeastern corner of Rhode Island, June 29, 1804. His father was the Rev. Mase Shepard, the pastor for thirty-four years of the Congregational Church of that place. His mother, Deborah Haskins, came from a highly intelligent Boston family, from which sprang Ralph Waldo Emerson and other well-known men. It was in the little country home that the love of the beautiful, which so marked the later character of the son, was developed. Of his father he has written: "His manners were attractive and his entire address dignified. In particular, his sense of the proprieties of clerical deportment and appearance was extremely nice. It comprehended all the appointments about his home. My father greatly enjoyed social intercourse, and in turn made himself very agreeable to others. There was an unfailing cheerfulness in his conversation, attended by a remarkable abstention from every approach even to undue criticism or detraction. This praiseworthy trait was equally shared by my mother." Thus were implanted in the boy those traits which endeared him to all and made him not only an agreeable associate, but an example to others.

He was fitted for college in the Providence Grammar School and entered Brown University in 1820 , but left the following year to join the sophomore class of the new college which opened then at Amherst, Mass. He was graduated in due course in the class of 1824 . In a graphic sketch of Amherst College as it was during his student days, contributed to Prof. Tyler's History, Prof. Shepard has said:

"I remember that I was the youngest of my class. Most of my fellows were mature youths who did not appear to me youths at all-seniors in character and manlike in purpose, with an air which seemed to tell of years of yearning for the 
ministry, and of a brave struggle with the poverty which had kept them from their goal." After a description of the village and the mode of life in it, Prof. Shepard continues: "With such surroundings, what now were our interior advantages? Whatever we may have represented them to outsiders, whatever we may have persuaded ourselves concerning them, they were, in my day, extremely meagre. The teachers were few, and in general were not distinguished in their departments. Our library did not surpass the scholarly range of a country clergyman in fair circumstances. Apparatus and collections were unknown in our first year, and they had made but feeble beginnings before our graduation. The only lectures which I remember were the two annual courses of Prof. Amos Eaton, in his day a distinguished botanist and geologist.

"In Dr. Moore, a gentleman of suave manners, of true Christian dignity, and of singular judgment in managing youth, we had an admirable president. I venture to suspect that he was the only college president in the United States who, from the beginning, personally subscribed for the somewhat expensive numbers of the Journal of the Royal Institution of London. From this source, and others similar, he appears to have gained a prevision of the importance of the modern sciences in education, and to him mainly are we indebted for the early foothold which they gained in the institution; to him, at all events, we owed the presence of Prof. Eaton. Rarely has college lecturer been more faithfully and enthusiastically listened to than Prof. Eaton in his course on chemistry and botany, together with his abridged course on zoölogy. To supply the place of a text-book on the last-mentioned branch, he furnished us a highly useful printed syllabus, drawn mainly from the great work of Cuvier, then wholly inaccessible to us. ... There were doubtless deficiencies to be regretted. In the larger and older universities we might have found better teachers and richer stores of libraries and collections, but in some unknown way, perhaps in the enthusiasm of comparatively solitary effort, compensation was made; and on the whole we may doubt whether higher life success would have attended us had we launched from other ports."

For a year after graduation he studied botany and mineralogy with Thomas Nuttall at Cambridge, and during most of this time taught the same branches in Boston. His study of 
mineralogy led to the preparation of papers on that subject which he sent to the American Journal of Science, and in this manner he became acquainted with its editor, the elder Silliman. He was invited in 1827 to become Prof. Silliman's assistant, and continued as such till r83r. For a year of this time he was Curator of Franklin Hall, an institution that was established by James Brewster in New Haven for popular lectures on scientific subjects to mechanics.

In 1830 he was appointed to a lectureship in natural history at Yale, which he held till 1847 . In the winter of $183_{2-}$ r 833 he investigated the culture of sugar cane and the manufacture of sugar in the Southern States, his results being incorporated in Prof. Silliman's report to the Secretary of the Treasury.

His investigation in the sugar States led to his appointment, in 1834 , as Professor of Chemistry in the South Carolina Medical College, at Charleston. This position required his residence in the South for only part of the year, so that he was able to continue his lectures at Yale and to accept; in 1835, an appointment as associate to Dr. James G. Percival on the Geological Survey of Connecticut.

It was in the darkest hours of Amherst College, in December, 1844 , that Prof. Edward Hitchcock was raised to the presidency of that institution, and in order to provide for the partial vacancy thus created in his department, Charles $U$. Shepard, of New Haven, was elected Professor of Chemistry. and Natural History, this election " to take effect provided Prof. Hitchcock accepts the presidency." Both appointments were accepted. Prof. Shepard entered upon his new duties in the following year. Only two years were needed under President Hitchcock's able management to restore prosperity to the college. Prof. Shepard, being then satisfied that Amherst would be able to afford him a permanent field of labour, severed his connection with Yale and offered to bring his valuable collections to Amherst if the college would house them in a fireproof building and consider the purchase of them when it was able. This proposition was gladly accepted.

As an instructor, he at once communicated to his students his own zeal, unless, perhaps, the ground was unfertile, in which case he would plainly but politely suggest the desira- 
bility of their devoting themselves to more congenial studies. His devotion to his subject rendered him averse to calling the roll. As a lecturer his manner was easy and self-forgetful; his success in imparting knowledge was due to his earnestly endeavouring to uplift his listeners' minds, but at the same time neither to discourage nor weary them. Imitating Faraday, his manner was that of a gentleman returned from an interesting travel narrating to his friends some of the delights he had experienced.

His professorship was divided in $185^{2}$, when the college became able to have a separate Professor of Chemistry. Prof. Shepard continued to deliver the lectures on natural history till 1877 , when he was made professor emeritus. After leaving Amherst his northern home was at New Haven for the rest of his life.

The following history of the growth of Prof. Shepard's collections was written by him for the History of Amherst College, at the request of Dr. Tyler :

"My mineralogical cabinet was commenced at the age of fifteen, while a member of the Providence Grammar School, and was brought with me when I left Brown University to join the sophomore class of Amherst institution in 1821 . An early visit after my arrival here to the tourmaline and other localities of Chesterfield and Goshen served to increase my eagerness as a collector, and at the same time placed me in possession of abundant materials for, exchange. In $1823 \mathrm{my}$ identification of the previously supposed white augite of Goshen with the species spodumene, gave me confidence in the study of minerals, while it increased my stock of specimens desirable to mineralogists. The exchange I then carried on with the Austrian consul-general, Baron von Lederer, in behalf of his own collection and that of the Imperial Cabinet of Vienna, rapidly enriched my little museum in foreign minerals. Indeed, from the first it was sufficiently ample to serve a useful purpose in the instruction of beginners, and was the sole resource of Prof. Amos Eaton in the lectures he gave during two seasons before the students of the institution.

"On leaving college I resided a year partly in Cambridge and partly in Boston, during which period I profited much in extending my collections, through visits to new localities in eastern Massachusetts and Rhode Island, and still more by 
exchanges with Prof. Nuttall and other active cultivators of mineralogy in the region. I soon after made a very successful tour into Maine, where, at Paris, I was the fortunate discoverer of the most remarkable green and red tourmalines then known. With some of these I made profitable exchanges with the British Museum and other large collections. My association in 1828 with Prof. Silliman as his assistant, and afterward with the college as a lecturer on natural science for many years, afforded me unusual facilities for the extension of my cabinet. All the best localities of Connecticut were frequently visited, specimens of rare interest secured, and the means of supplying scientific correspondents abundantly obtained. These objects were still further effected by journeys into adjoining States and the Canadas, until 1835 , when $I$ became Professor of Chemistry in the Medical College of the State of South Carolina, where a new and very ample field was opened for the extension of my collections. From that time to the present [ $\mathrm{r} 87 \mathrm{r}]$, with the exception of the period of the civil war, I have passed nearly the half of each year in the South, and been engaged to a considerable extent in scientific and mining explorations, which have resulted in varied and rich contributions to my cabinet. These travels have also embraced the Western or Mississippi States, attended by similar results. But most of all have I gained by frequent excursions to the Old World, having since 1839 twelve times visited Europe, where my exchanges and purchases of specimens have been conducted on a scale, I am led to believe, not surpassed by any of my countrymen. Numbers, however, have never been my aim in these acquisitions. I have rather sought what was characteristic and instructive-not, however, to the neglect of the rare and beautiful."

The foregoing relates to the mineralogical part of Prof. Shepard's collections; his geological cabinet was also important, being especially remarkable for fossil remains. The meteoric collection, begun in 1828 , he stated to be the fourth in extent and value known at the time of writing.

As to the transfer of the combined cabinets to Amherst College, Prof. Shepard continues :

"The removal of these collections from New Haven to Amherst, in 1847 , was the result of an understanding entered into between President Hitchcock and myself, that if the 
college would cause a fireproof building to be erected for their reception, I would deposit them therein, at least for a term of years, and with the hope, through arrangements afterward to be made, of leaving them with the college as a permanent possession. Such a building was provided in the Woods Cabinet; and, more recently, the conditions for the purchase of the collections have been agreed upon." When he wrote the above he was engaged in the more perfect cataloguing and arranging of the three collections.

When Walker Hall was built, the mineralogical cabinet was removed to rooms in that building, and was destroyed when the building was burned, in March, 1882. Although few could be classed as combustibles, a diligent search in the $d \dot{e}$ bris of the building revealed scarcely a trace of the specimens. This was a sad loss. Prof. Shepard valued the collection at seventy-five thousand dollars, and the college had actually paid forty thousand dollars for it. There was only fifteen thousand dollars of insurance on the whole contents of the building.

Dr. Shepard held his professorship at Charleston uninterruptedly until the civil war, and immediately after it closed he went back, at the urgent invitation of his former colleagues, and resumed his lectures. In 1869 he retired from the full discharge of his duties, but continued to give some lectures until shortly before his death. While in Charleston he discovered rich deposits of phosphate of lime in the immediate vicinity of that city. Their great value in agriculture and subsequent use in the manufacture of superphosphate fertilizers proved an important addition to the chemical industries of South Carolina.

The collection that was burned in 1882 was the finest in the United States, and was surpassed abroad only by that in the British Museum. But Dr. Shepard's collecting had not stopped with its formation, and he succeeded before his death in gathering a second cabinet of meteorites and minerals which ranked among the very largest private collections. This he kept in a fireproof cabinet at his private residence in New Haven.

The influence of his early home culture was clearly marked in Prof. Shepard. To such a degree was he distinguished in all the characteristics of a gentleman that he was called upon 
by both Northern and Southern classes to address them on the subject of "manners"; and it may not be amiss to quote from one of these lectures, as presenting a mirror of his own life: "As the dress of a gentleman is quiet and unpretentious, his conversation in public places and among strangers is equally subdued. Good manners, though often favoured by a happy constitution, do not proceed from a single root, much less do they arise spontaneously from any soil. They are complex in their origin, and result to a great degree from the most sedulous culture. He who aspires to be a gentleman has an intricate problem to solve, an up-hill path to tread. An occasional smile however bland, obeisances and salaams be they ever so Oriental, flatteries the most Parisian, the wardrobe of Beau Brummel himself, the nice punctilios and etiquettes of courts, will not of themselves serve the purpose. Other things vastly more weighty are demanded, such as strict honour, selfcommand, forbearance, and refined feelings; a character in which all meanness and peevishness are unknown, and where candour, veracity, moral and physical courage and dignity are never for a moment in abeyance." After noting several matters of conduct, he continues: "The most natural beginning in our work will be an attention to those causes which affect the health. If there is neglect here grievous must be the failure elsewhere; for what superstructure can you erect upon a shattered constitution? The gentleman is required first to know what belongs to complete living in this world. Vigorous health and its accompanying high spirits are larger elements in gentlemanly character and general happiness than any other things whatever."

A most striking feature of his after life was the realization of his boyish dream as portrayed in his thesis entitled The Enthusiasm of the Naturalist, which he read on graduating. The material features of extensive travel, of unusual opportunities for the acquisition of specimens, and the happiness of being able to increase the world's knowledge-these were the minor points. Of greater joy to him and to those who loved him were his youthful enthusiasm and the delights which lingered to the very last; when, after expressing devout gratitude for his joyous life, he yearned to be free from the limitations of earth and time. Mineralogy was beautiful to him. He loved her every perfect specimen; his mind dwelt on its origin and 
occurrence. It was an individuality to him. His keen eye distinguished differences which others could not detect. To his loved specimens he might always turn with relief when sorely pressed by affliction or other misfortune.

Prof. Shepard died, after a short illness, at Charleston, May r, r886. He left two children, a son and a daughter.

In its obituary the Charleston News said of him: " $\mathrm{He}$ chose his profession well. A mind so analytic as his and so keen in the perception of relations could not have failed to see that the field in which he cast his literary fortunes was one which offered an undying reward for those who made it a successful arena of untiring and indomitable labour and energy. ... Prof. Shepard discovered more new species of minerals which have attained permanent recognition than perhaps any other scientist of the present day. He was a member of many American and foreign societies, among which are the Imperial Society of Natural Science of St. Petersburg, the Royal Society of Göttingen, and the Society of Natural Sciences of Vienna. He published a Treatise on Mineralogy ( $183_{2}$ and 1835 ), a report on the Geology of Connecticut, and numerous scientific papers." Many reports on mines made by him have been printed.

He announced in 1835 his discovery of his first new species of microlite, that of warwickite in 1838 , that of danburite in r839, and he afterward described many other new minerals until shortly before his death. His knowledge of minerals was wonderfully extensive, "and he was hence ready," it has been said, "with quick judgments as to new and old; sometimes too quick-but in any case imparting progress to American mineralogy." The honorary degree of M. D. was conferred upon him by Dartmouth in 1836 , and that of LL. D. by Amherst in 1857 .

Prof. Shepard's son, Charles Upham, was born at New Haven, October 4, r842. He was graduated from Yale College in 1863 , and took the degree of M.D. at Göttingen in r867. He succeeded to his father's professorship at Charleston, and has been active in developing the phosphate and other chemical industries of South Carolina. In 1887 he presented the second cabinet of minerals that was formed by his father, numbering more than ten thousand specimens, 
to Amherst College, and his cabinet of representatives of more than two hundred different meteorites has been deposited in the United States National Museum. During the past few years he has devoted himself to the experimental cultivation of tea on his plantation near Summerville, S. C., where he has extensive gardens of the leading varieties. 


\section{SEARS COOK WALKER.}

$$
1805-1853 \text {. }
$$

A FEw years before the middle of the present century the condition of science in America was far from inspiring. Although this country had long since ceased to be a dependency of Great Britain politically, it still seemed unable to rise out of such a position intellectually. In science and letters English authority was paramount. To the generality of American scholars a grudging mention in an English publication outweighed domestic honours of a much higher grade. Scientific treatises emanating from Great Britain were accepted as gospel, while the science of the rest of Europe was known only through British translations. There were a few men of science, however, who were independent in the midst of dependency, and among them one of the most active in promoting this intellectual self-respect, both by his researches and his writings, was the subject of the present sketch.

Sears Cook Walker was born March 28, 1805, in Wilmington, a small town of Massachusetts, about sixteen miles northwest of Boston, where four generations of his ancestors had lived and died. His father's mother was descended in a direct line from the celebrated Elder Brewster, who came over in the Mayflower. Sears was a delicate child and so precocious intellectually that he early became the wonder of the village. His father had died when he was a mere infant, so that his whole care and training devolved upon his mother. She fortunately realized the importance of providing for his physical welfare and checking his too great fondness for books. It was a constant struggle with the boy's natural inclinations to do this, but the effort was successful. He joined heartily in many of the sports of his companions, and gradually gained a good measure of health and strength.

Young Walker took the studies preparatory for college at 


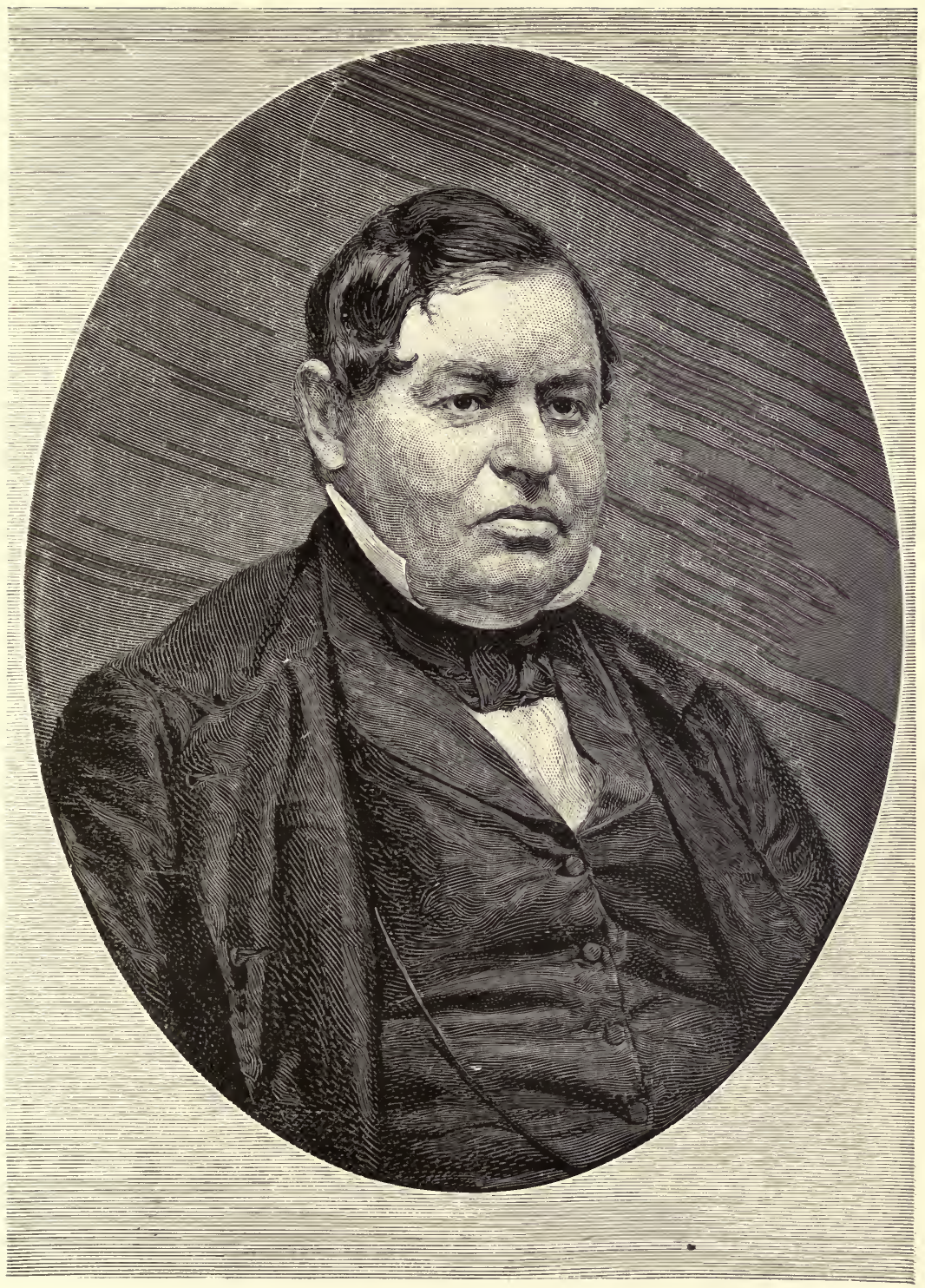

SEARS COOK WALKER. 

the academies of Andover, Tyngsborough, and Billerica; then went to Harvard, where he was graduated in the class of 1825 . Immediately after his graduation he took up teaching as an occupation and followed it for ten years-the first two years in the vicinity of Boston and the rest of the time in Philadelphia. From 1836 to 1845 he was actuary of the Pennsylvania Company for the Insurance of Lives and Granting Annuities. His life in Philadelphia was a period of prosperity and comfort; he, moreover, early took on a corpulent habit of body, so that whatever influence his circumstances exerted was adverse to any strenuous intellectual exertions, and to the obtaining of adequate physical exercise. Yet his mind was one that could not be idle. "While engaged with his school," says Benjamin A. Gould, in his memorial address, " "he studied medicine, and went through the whole course requisite for the attainment of a degree. He devoted his leisure for a period to the study of natural history, and was no mean proficient in geology and mineralogy, as well as in physics and chemistry. He was an active member of the Pennsylvania Geological Society, of the Committee of the Franklin Institute on Science and Art, and one of the most useful members of the American Philosophical Society. By frequent articles upon scientific topics in the various prints, by elaborate reports upon various subjects to the Franklin Institute, and by monthly announcements in its Journal of occultations and other celestial phenomena, he kept awake the interest and sympathy of the community for studies of this character. Among other labours, he prepared, in 1834, an ingenious set of parallactic tables, by which the time required for computing the phases of an occultation was reduced to less than half an hour. These were calculated for the latitude of Philadelphia, and it was his intention to publish them in a more general form adapted to different latitudes. But, as this would have been a work requiring considerable time, he subsequently abandoned the project, believing that he could employ his leisure hours more usefully. He continued the computation of the occultations without interruption for six

* An address in Commemoration of Sears Cook Walker, delivered before the American Association for the Advancement of Science, at its meeting in Washington, April 29, I854. From this address many facts concerning Walker's life and work in addition to the above quotation have been drawn. 
years, and then induced our well-known colleague, Mr. Downes, to undertake the continuance of the work. It has been prosecuted to the present time, with what success we all know, and has of late years been published by the Smithsonian Institution and the Astronomical Ephemeris. Astronomy and geography in America are much indebted to Mr. Walker for these labours, since many already in possession of the necessary means were stimulated by the periodical announcements, and by his personal exertions in still other ways, direct and indirect, to observe these phenomena. An extensive series of such observations was collected by Mr. Walker and published in the Proceedings of the American Philosophical Society."

During most of Walker's residence in Philadelphia he must be regarded as an amateur rather than a scientist. For many years his interest in Nature was spread over several fields, but gradually it concentrated upon astronomy. He had procured an astronomical clock, a twenty-inch transit instrument, and a small Dollond telescope, and from about the time when he gave up his school to become actuary of the insurance company all his leisure was devoted to astronomical observation and study. "In 1837," Dr. Gould's account continues, "he was invited to propose a plan for an observatory in connection with the Philadelphia High School, an invitation which he accepted with eagerness. In accordance with his suggestion, the committee in charge of the school imported from Munich the excellent Fraunhofer equatorial and Ertel meridian circle which, in his hands and those of his accomplished brother, the present director of the observatory, have done so much for astronomy in America-not merely by the number of observations made with them, but also by the incentive which they afforded to the lovers of astronomy in other parts of the country. It is unquestionable that in several instances they induced successful efforts for the procurement of similar and even superior apparatus elsewhere." The results of Walker's researches appeared from time to time in the publications of the American Philosophical Society and various journals. It was in $184 \mathrm{I}$ that he may be said to have "earned his spurs" by a paper on the periodical meteors of August and November, which for many years remained the most important memoir on the subject that had appeared. From that time on he is to be ranked among scientific investigators. 
In $r 845 \mathrm{Mr}$. Walker's affairs underwent a revolution. Certain commercial operations turned out disastrously and entirely bereft him of means. The sense of defeat, the loss of luxuries at a time of life when habits have become fixed, together with anxiety for the future, made the blow a hard one. But it revealed to him, and to the world, the extent of his own scientific ability, and opened the way to higher intellectual gratifications, which he quickly learned to appreciate. The Secretary of the Navy offered him a position in the observatory at Washington, which he at once accepted. Here, for the first time, the facilities which his special gifts required were at his disposal, and he immediately proceeded to make good use of them. After a short time he gave up his position at the observatory to accept the direction of the longitude department of the Coast Survey-an office which he ably filled until his last illness.

Early in 1847 , while engaged in researches upon the then newly discovered planet Neptune, he became convinced that a star observed by Lalande in May, r795, must have been this planet. With the telescope of the Naval Observatory Prof. Hubbard confirmed this conjecture, and astronomers were thus furnished with an observation of Neptune made fiftytwo years before, which afforded means for a most accurate determination of the planet's orbit. The American was none too soon to secure priority, for, quite independently, the same important fact was laboriously hunted down in Europe by Petersen only a few weeks later. Walker now attacked the problem of Neptune's orbit; Benjamin Peirce was at the same time calculating the planet's perturbations. The approximate results of each furthered the computations of the other, so that within eighteen months from the discovery of the planet these two Americans had attained a remarkably accurate statement of its theory.

In conjunction with Prof. A. D. Bache, Superintendent of the Coast Survey, Walker developed the method of determining differences of longitude by telegraph. One feature introduced by Walker was the application of the method of coincidence of beats to the comparison of timekeepers-one indicating mean, the other sidereal time-at the two ends of a telegraphic line. These beats were signalled from one station to the other by taps of an observer upon the telegraph key. 
Such signals are, of course, subject to the errors that always attend the action of human nerves and muscles, so the next problem was to make the clock give its own signals. Two methods had been proposed, but there were fears-groundless they have since been proved-that either of these would injuriously affect the running of the clock. Mr. Walker sought diligently for some apparatus that would not arouse any such fears. He propounded the problem to several astronomers, and two or three contrivances were devised for the purpose.

This mode of observation and the apparatus invented to meet its requirements proved valuable not alone for determinations of longitude, but also for all other astronomical observations requiring minute precision in the determination of time. The mental effort required of the observer being reduced to a minimum, many more transits could be observed at a single meridian passage. Walker immediately modified the transit instrument to suit the new requirements, and, instead of five, seven, or at most nine threads, he provided it with several tallies of five threads each. There remained but one requisite to complete the American method of observation. This was some mechanical contrivance for securing a uniform rotary motion of the record sheet. It had not been attained when Walker died, although some progress toward the solution of the problem had been made.

It is proper for the biographer to point out the share which Walker personally had in this series of inventions, although he was far from making any such claims for himself. With a fine comradeship he was jealous only for the credit of the organization of which he was a member-the United States Coast Survey. Speaking to the American Association for the Advancement of Science, Walker said: "With the single exception of the experıment between Baltimore and Washington, in 1844 , I know of no telegraphic operation for longitude, and of no step in the improvement or perfectionment of the art, in Europe or America, which has not been the work of the officers proper of the Coast Survey, or of commissioned officers and civilians acting temporarily as assistants. ... I will not here allude to the respective claims of Americans for priority or superior excellence of inventions and suggestions, believing that it will be becoming for all of us to look to the great work that has been 
accomplished by our united efforts, rather than to the single share of each."

The transmission of observations by telegraph between Cambridge, New York, Philadelphia, and Washington furnished Walker an opportunity for another important discovery. $\mathrm{He}$ found that an appreciable time was required for the passage of these signals, and that this time was less than one tenth of that required for the passage of light over an equal distance in space. This result was so greatly at variance with the ideas of electricity current at the time that it was not accepted in America until the celebrated velocity experiments between St. Louis and Washington put it beyond question, and even after that some European physicists still refused to be convinced. While the matter was in dispute Walker was generous with aid and encouragement to those who sought to test his discovery, whether their results seemed likely to conflict with or to confirm his own.

The English Nautical Almanac for 1856 (issued in 1853 ) contained a profound discussion, by the astronomer Adams, of the amount of the lunar parallax. In this paper Adams showed that the tables of Burckhardt, which had been the standard ones, contained errors sometimes amounting to $6^{\prime \prime}$, and pointed out the effect that such errors must have upon determinations of longitude from occultations. In the greater part of this discovery Walker had anticipated the renowned Adams by more than four years. In April, I848, he had presented to his chief in the Coast Survey a report on longitudes in the course of which he pointed out the chief errors of Burckhardt's tables, giving four out of the five principal terms with remarkable precision.

Mr. Walker's intellectual labour was intense and unremitting ; it was scarcely interrupted even in summer, when he was accustomed to betake himself to Cambridge, to escape the heat of Washington. During one of these summer sojourns, in August, $185 \mathrm{r}$, he suffered a slight attack of paralysis, which for a few days deprived him of the use of one hand. This warning and the entreaties of his friends were not enough to induce him to relax his exertions. In the following autumn he took charge of the expedition for determining telegraphically the differences of longitude between Halifax, Bangor, and Cambridge. Immediately after his return to Washington, at about 
the end of December, symptoms of mental alienation appeared, and he was taken to the hospital at Mount Hope, near Baltimore. Thence he was removed in the following April to Trenton, N. J., where under the skilful care of Dr. Buttolph, the superintendent of the institution, his disordered brain gradually regained its normal tone. Visits of friends, correspondence on the subjects of his researches, and finally his books and papers were allowed him. While still at Trenton he computed the ephemeris of Neptune for the American Astronomical Ephemeris of 1855 . In the fall of $185^{2} \mathrm{Mr}$. Walker left the asylum apparently cured, although much debilitated by his illness, and went to Cincinnati for a visit to his brother, Hon. Timothy Walker, intending to remain until the following spring. $\mathrm{He}$ took in hand certain labours for the Coast Survey and prepared to resume in full his former sphere of activity. He had fixed a time for returning to Washington and re-engaged his apartments in the city, but he was not destined to make the journey. An attack of fever was followed by other maladies, and Walker soon found himself engaged in a second severe struggle with disease. In this condition Hamlet's problem"To be, or not to be"-forced itself upon his thought with all its puzzling considerations. The sound mind in a sound body can give but one reply to this problem, but coming as it did to Walker at a moment when Reason was not firm in her seat, it elicited the opposite response, and on Jan. $3 \circ, 1853$, he launched himself into the mysterious after-life. His remains were placed in Spring Grove Cemetery, near Cincinnati.

The character of Sears Walker was marked by a childlike simplicity which many persons could hardly realize was not assumed to cover shrewd designs. He was impulsive, but his impulses were always noble and generous. Highly magnanimous, he was always prompt to acknowledge an error, and to overlook not only mistakes but even lapses from honour and justice in others. Intellectually he had the ability of genius. $\mathrm{He}$ was unadapted and disinclined for participation in the world's affairs, and could not refrain sufficiently for his physical welfare from intellectual labour.

Although his fame was won in the abstruse field of mathematics, his linguistic attainments were of a high order. In college he was as conspicuous for his classical as for his mathe- 
matical ability. During his years of teaching his knowledge of the languages was in daily use, and throughout life the literatures of Greece, of Rome, and of Italy were a source of enjoyment to him. His powerfully retentive memory was stored with long passages from the poets of the past, Tasso being his especial favourite. 


\section{ALEXANDER DALLAS BACHE.}

$$
\text { r 806-r } 867 \text {. }
$$

The life of Alexander Dallas Bache lends support to the belief that what a man is to be, or, rather, what he is capable of being, is mainly determined by what his parents and ancestors have been. According to the doctrine of heredity, it is not surprising that Bache, descended from illustrious progenitors on both sides of his family, should himself achieve intellectual eminence. But as he received an education admirably suited to the work he was to perform, his career gives little help in answering the question whether heredity is or is not stronger than training.

His most important work is instructive in another way. It shows how effective efforts for the advancement of knowledge can be made by the power and resources of a great government when the right man is secured to direct them, just as other instances have made plain how wasteful and demoralizing such efforts may become when unwisely directed.

Alexander Dallas Bache was born in Philadelphia, July i 9, 1806. His father, Richard Bache, was a grandson of Benjamin Franklin, being one of the eight children of Richard Bache, Postmaster General from I776 to I782, and Franklin's only daughter, Sarah. His mother, Sophia Burret (Dallas), was a daughter of Alexander J. Dallas, who was Madison's Secretary of the Treasury, and sister of George M. Dallas, Vice-President of the United States in Polk's administration.

Dallas Bache, as he was usually called by his intimates, was placed in a classical school at an early age, and proved to be a remarkably bright pupil. When fifteen years old he was appointed a cadet in the Military Academy at West Point. $\mathrm{He}$ maintained a high stand in scholarship from the beginning to the end of his course, and graduated in 1825 at the head of his class, although its youngest member. This was no small 


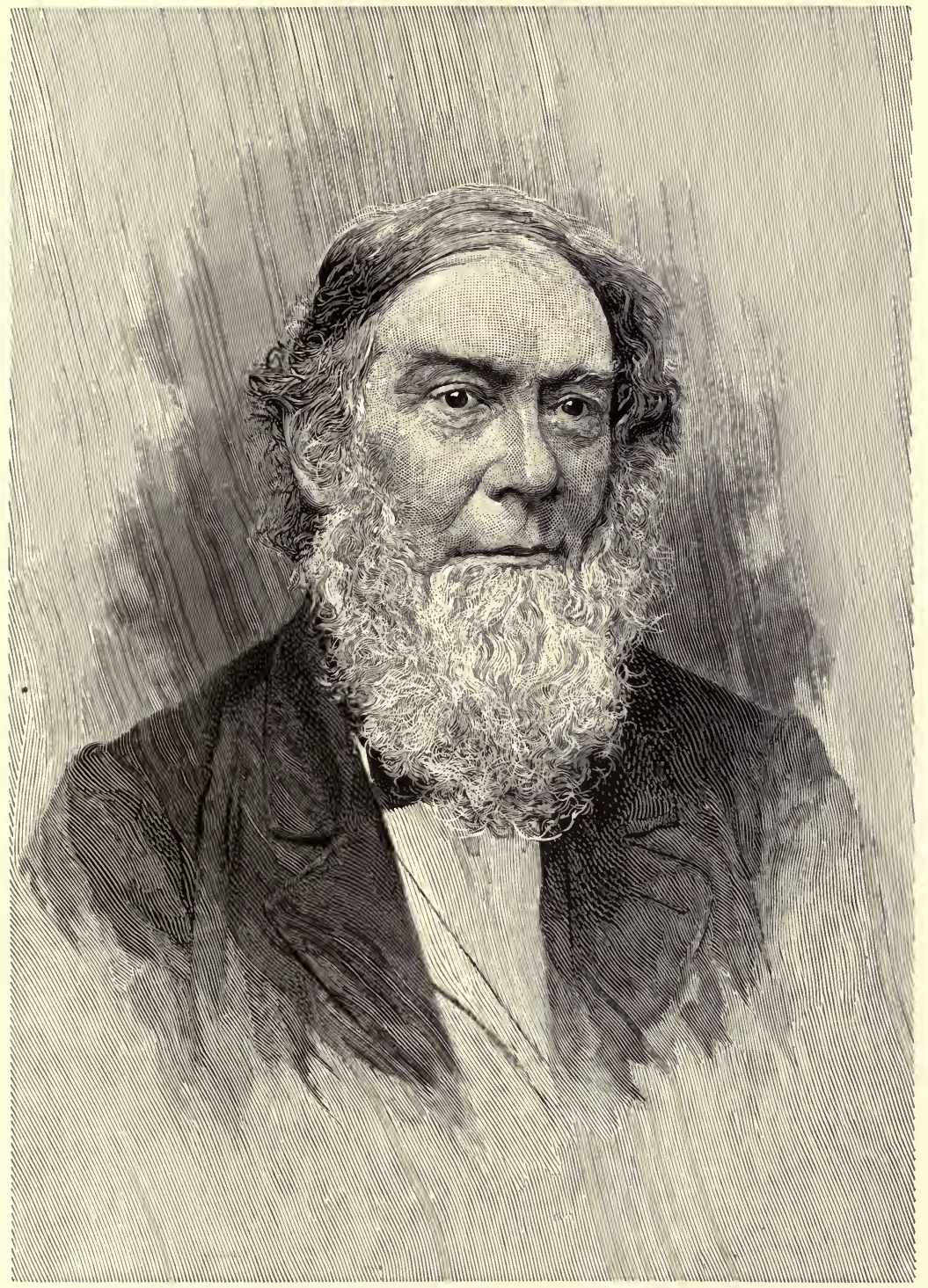

ALEXANDER DALLAS BACHE. 

achievement in a class from which four cadets were assigned to the Engineer Corps, when only one or two members attained this honour in most classes. Moreover, he went through the whole four years without receiving a demerit mark-equally remarkable in view of the rigid discipline of the academy, and the only instance on record. Students are generally none too prone to admire one of their fellows who is noted only for studious habits and correct deportment, but young Bache had the personal qualities that win esteem. Prof. Joseph Henry, in his memoir read before the National Academy of Sciences, relates of cadet Bache that " his superiority in scholarship was freely acknowledged by every member of his class, while his unassuming manner, friendly demeanour, and fidelity to duty secured him the affection as well as the respect not only of his fellowpupils, but also of the officers of the institution. It is also remembered that his classmates, with instinctive deference to his scrupulous sense of propriety, forbore to solicit his participation in any amusement which in the slightest degree conflicted with the rules of the academy. So far from this, they commended his course, and took pride to themselves, as members of his class, in his reputation for high standing and exemplary conduct. His roommate-older by several years than he was, and by no means noted for regularity or studious habits - constituted himself, as it were, his guardian, and sedulously excluded all visitors or other interruptions to study during the prescribed hours. For this self-imposed service, gravely rendered as essential to the honour of the class, he was accustomed jocularly to claim immunity for his own delinquencies or shortcomings.

"But whatever protection others might require on account of youth and inexperience, young Bache needed no guardian to keep him in the line of duty. Impressed beyond his years with a sense of the responsibility which would devolve upon him as the eldest of his mother's family, entertaining a grave appreciation of the obligations involved in his education at the national academy, he resolved from the first to devote his energies to the utmost in qualifying himself for the duties which he might be called upon to discharge, whether in professional or private life. Nor was he uninfluenced in this determination by a consciousness that, as a descendant of Franklin, he was in a certain degree an object of popular interest, and that on 
this account something more than an ordinary responsibility rested upon him."

All of young Bache's predispositions for good were stimulated and sustained by the judicious care of his mother, not only while he was a child at home, but also by means of a ready pen during the whole of his residence at West Point. It should not be inferred that the young man attained perfection in his conduct. "When a child he is said to have been quicktempered, and at later periods of his life, when suddenly provoked beyond his habitual power of endurance, he sometimes gave way to manifestations of temper which might have surprised those who only knew him in his usual state of calm deportment. These ebullitions were, however, of rare occurrence, and always of short duration."

On graduating, Lieutenant Bache was assigned to duty at the academy as assistant professor. A year later he was transferred at his own request to engineering service on the fortifications at Newport, R. I., under Major (afterward General) J. G. Totten. Here he remained two years. One of his recreations during this period was making a collection of shells of molluscs.

In 1828 , being then twenty-two years of age, Lieutenant Bache resigned his commission in the army to accept a call to the chair of Natural Philosophy and Chemistry at the University of Pennsylvania. This change was welcome in more ways than one. He was engaged to Miss Nancy Clarke Fowler, the daughter of an old and highly respected citizen of Newport, but marriage was apparently a remote prospect, for he had only the stinted pay of a lieutenant of engineers, out of which he must contribute to the support of his mother and her younger children. The salary of his new position, however, justified him in hastening the happy event.

His year's experience in teaching at West Point assisted Mr. Bache in taking up his duties at the university. He was a very successful instructor, and popular with his students. But he did not rest content with imparting knowledge obtained by the labours of others. He joined the Franklin Institute, then newly established, and took a prominent part in its investigations for the promotion of the mechanical arts. For a full account of his labours in connection with this society we must here be content with referring to the volumes of its Journal 
from 1828 to 1835 inclusive. One of the most important and fruitful of these was the investigation of the bursting of steam boilers, of which he was the principal director. From inquiries and experiments, the latter not unattended with danger, "the most frequent cause of explosion was found to be the gradual heating of the boiler beyond its power of resistance; and, next to this, the sudden generation of steam by allowing the water to become too low, and its subsequent contact with the overheated metal of the sides and other portions of the boiler. The generation of gas from the decomposition of water as a cause of explosion was disproved, as was also the dispersion of water in the form of spray through superheated steam."

Early in $1829 \mathrm{Mr}$. Bache was elected to membership in the American Philosophical Society, and at once entered upon various researches in pure science in co-operation with his fellowmembers. With the aid of his wife and of his former pupil, John F. Frazer, he determined with accuracy, for the first time in this country, the periods of the daily variations of the magnetic needle, and by another series of observations established the connection between certain perturbations of the terrestrial magnetism and the aurora borealis. With Prof. Courtenay he investigated the magnetic dip at various places in the United States, and with Mr. Espy made a minute survey of part of the track of a tornado which visited New Jersey, June $19,1835$.

After Stephen Girard died, in $183_{2}$, Prof. Bache was elected one of the trustees of the College for Orphans, founded by the will of the childless merchant. Three years later the trustees decided to select a president for the institution, in order that he might go abroad and study European methods of education while other preparations were being made. Prof. Bache, then only thirty years of age, was selected for the position. Although regretting the consequent interruption of his scientific researches, in which he had become much absorbed, he accepted the appointment, and departed on his mission, Sept. 30 , 1836. His own previously published researches combined with the memory of his distinguished ancestor to secure him a cordial welcome by the intellectual class in each country that he visited. Two years were spent agreeably and profitably in Europe, and on his return Prof. Bache made a report to the trustees embodying his observations on the schools of England, France, Prussia, Austria, Switzerland, and Italy, with the many helpful 
conclusions and suggestions that he had derived from these data. The document was printed, making a large octavo volume.

As the preparations for opening the college were not yet complete, Prof. Bache offered his services gratuitously to reorganize the public schools of Philadelphia, and his offer was gladly accepted by the municipal authorities. A year later, finding that the trustees of the college were still unprepared to open the institution, he relinquished the salary of his office and accepted from the city a much smaller compensation for his time. His work on the public schools was completed in $\mathbf{1 8 4 2}$, and resulted in a system that has been taken as a model by other cities in various parts of the United States. So highly were his labours appreciated that the Central High School was frequently called Bache Institute.

Girard College having made very little progress, he now resigned all connection with it, and accepted his former chair at the University of Pennsylvania, with its welcome opportunities for scientific research. The preceding six years had by no means been a blank with respect to his favourite investigations. When he went to Europe he took care to provide himself with a set of portable instruments, with which, as a relief from the labours imposed by the special object of his mission, he made a connected series of observations on the dip and intensity of terrestrial magnetism at important places on the Continent and in Great Britain.

After his return to Philadelphia he co-operated in the undertaking of the British Association to determine by contemporaneous observations at widely separated points the fluctuations of the magnetic and meteorological elements of the globe. $\mathrm{He}$ also made in his summer vacations a magnetic survey of Pennsylvania. Mr. Cramp, afterward the famous shipbuilder, was then a boy in the high school, and assisted Prof. Bache in his observations.

Valuable instruments and methods for performing scientific observations were devised by Bache during this period. $\mathrm{He}$ invented an ingenious instrument for determining the dew point, which is especially valuable where readings must be made by persons without special scientific training. Only much later did he learn that the principle of the device had already been used by Belli, of Milan. He also introduced a 
modification of Osler's anemometer and invented a thermoscope of contact, both of which avoided difficulties involved in the use of previous instruments.

The way in which a man conducts a controversy is always a severe test of his character. Bache had one with Denison Olmsted on the periodical recurrence of meteors. Prof. Gould, in his American Association memoir, thus describes the occurrence: "Mr. Bache maintained that there was no recurrence in I834; Prof. Olmsted, on the other hand, maintained the reverse. Prof. Bache instituted special inquiries at the military posts (where, of course, sentinels were on duty) along all the frontiers of the United States, also among the night police of various cities, and at the universities, and he found but one exception to the statement that no unusual number of meteors was seen. Of this controversy Bache wrote, in 1846 :

" "There is something yet to be found out on this subject which may reconcile our opinions. Neither I nor any of those watching with me, or for me, have seen an unusual number of meteors on the night of the $\mathbf{I} 2$ th of November in any year since the great night at Philadelphia, and we have taken great pains to be sure. Yet I can not doubt the testimony as given for some other places. . . . I had a complimentary letter from the professor in regard to my manner of conducting the controversy, which I valued more highly than if I had gained the victory." "

The year after Prof. Bache resumed his old position at the university he was called to the superintendency of the United States Coast Survey, left vacant by the death of Mr. Hassler. His appointment to this position was first suggested by members of the American Philosophical Society, and the nomination was fully concurred in by the other principal scientific and literary institutions of the country. For the successful prosecution of the work of the survey Dallas Bache was abundantly well qualified by his training at West Point and subsequent experience as an army engineer, by his attainments in pure and applied science, by his knowledge of the world, by his skill in research, his rare executive ability and consummate tact.

Although the Coast Survey had been founded a quarter of a century, the policy of Congress toward it had been changeable and its appropriations limited. It had been suspended 
fifteen years of that time, so that its work was but just begun. The Atlantic coast line had been surveyed only from Point Judith, on the coast of Rhode Island, to Cape Henlopen, at the entrance of Delaware Bay. "The new superintendent," says Prof. Henry in his memoir, "saw the necessity of greatly enlarging the plan, so as to embrace a much broader field of simultaneous labour than it had previously included. $\mathrm{He}$ divided the whole coast line into sections, and organized, under separate parties, the essential operations of the survey simultaneously in each. He commenced the exploration of the Gulf Stream, and at the same time projected a series of observations on the tides, on the magnetism of the earth, and the direction of the winds at different seasons of the year. $\mathrm{He}$ also instituted a succession of researches in regard to the bottom of the ocean within soundings, and the forms of animal life which are found there, thus offering new and unexpected indications to the navigator. He pressed into service, for the determination of longitude, the electric telegraph; for the ready reproduction of charts, photography; and for multiplying copperplate engravings, the new art of electrotyping. In planning and directing the execution of these varied improvements, which exacted so much comprehensiveness in design and minuteness in detail, Prof. Bache was entirely successful. He was equally fortunate, principally through the moral influence of its character, in impressing upon the Government, and especially upon Congress, a more just estimate of what such a survey required for its maintenance and creditable prosecution. Not only was a largely increased appropriation needed to carry out this more comprehensive plan, but also to meet the expenses consequent upon the extension of the shore line itself. Our seacoast, when the survey commenced, already exceeded in length that of any other civilized nation, but in 1845 it was still more extended by the annexation of Texas, and again, in 1848 , by our acquisitions on the Pacific. Prof. Bache was in the habit of answering the question often propounded to him by members of Congress, 'When will this survey be completed?' by asking, 'When will you cease annexing territory ?" "

Prof. Bache's policy of dividing the Atlantic and Gulf coast (we had no Pacific coast in 1843 ) into sections, and carrying on work in all the sections at the same time greatly allayed sectional jealousies in States which the previous operations of the 
survey had not reached and had great influence in winning public favour for the survey. He had a wonderful faculty for enlisting the efforts and talents of others in carrying out his plans. "As rapidly as means allowed, the services of American scientists throughout the land were enlisted in aid of the survey, and the whole intellectual resources of the country thus made tributary to its usefulness and success. Thus Walker, Peirce, Bailey, Agassiz, Barnard, Kendall, Mitchell, Bond, Alexander, and many others, were called on to assist in the advancement of the undertaking; and this large and wise policy prevailed during the whole period of his superintendence." * Many of the ablest officers of the navy and the army were brought into the Coast Survey service, and gained experience of great value in the duties many of them were afterward called upon to perform in the civil war.

The efficiency of the survey was greatly increased by improved instrumental equipment. Antiquated instruments were replaced by those of the most improved type; an apparatus for the measurement of base lines, invented by Prof. Bache, was introduced, and secured a degree of accuracy before unknown. The method of determining longitude by the exchange of star signals were developed through the agency of Sears C. Walker. Prof. Gould has stated that he had received accounts of this important advance in geodetic practice from the lips of both Bache and Walker, and that "their descriptions varied but in one salient point, namely, that each ascribed the chief merit to the other." The determination of latitudes with the zenith telescope, by Talcott's method, first tested in 1845 , was early adopted by the survey. "Thus by the use of the zenith telescope, combined with the determination of longitudes from the adopted meridian by the exchange of star signals, the geographical position of the primary astronomical stations of the survey could claim, ten or fifteen years ago, to be determined with more accuracy than that of any European observatory."

Stations for tidal observation were established all along the Atlantic, Gulf, and Pacific coasts. The character of the Gulf Stream and other currents along our coast were determined.

* Address in commemoration of Alexander Dallas Bache, by Benjamin Apthorp Gould, delivered before the American Association for the Advancement of Science, Aug. 6, 1868. 
Twice was Agassiz sent to study the formation of the coral reefs of Florida, and the causes that promote and restrict their growth. The magnetic constants were determined for every important point possible within reach of the survey. The scientific progress of the nation was promoted by Bache through the agency of the Coast Survey more than by any other man. His work for commerce, for the safety of passengers and seamen, and for national defence was thorough and important-all the more so because he called to his aid the resources of the highest science.

Other duties were assigned to Prof. Bache by the Government from time to time. He was made Superintendent of Weights and Measures, and in the exercise of this function directed a series of investigations relative to the collection of excise duties on distilled spirits, and superintended the construction of a large number of sets of standard weights and measures for distribution to the several States of the Union. $\mathrm{He}$ was appointed on a commission created to examine the lighthouse system of the United States, and was a member of the Lighthouse Board, into which this commission was merged, from its organization till his death. In this work he took a lively interest and rendered important service.

As to the connection of Prof. Bache with the Smithsonian Institution we can not have better testimony than that of him who was identified with the institution for more than thirty years, its first secretary. Prof. Henry says: "In 1846 he had been named in the act of incorporation as one of the regents of the Smithsonian Institution, and by successive re-election was continued by Congress in this office until his death, a period of nearly twenty years. To say that he assisted in shaping the policy of the establishment would not be enough. It was almost exclusively through his predominating influence that the policy which has given the institution its present celebrity was, after much opposition, finally adopted." * Not the least of Bache's services to the institution was securing Henry for its secretary. The latter states, in the place just quoted, that "it was entirely due to the persuasive influence of the professor" that he was induced to take the position.

Although not fond of physical exertion, Prof. Bache had

* Biographical Memoirs of the National Academy of Sciences, i, I97, I98. 
been accustomed to spend part of each summer in a tent at some station of the survey on the top of a mountain, where he took part in the measurement of angles and directed the movements of field parties at other stations. The civil war brought added labours upon him so that his constant presence in Washington was required, and his health no longer obtained the yearly recuperation of this season of outdoor life. During the alarm in Philadelphia which immediately preceded and followed the battle of Gettysburg, the services of Mr. Bache, with a corps of his assistants on the Coast Survey, were accepted by the city and utilized under the direction of General N. J. T. Dana, in reconnaissances and the throwing up of such earthworks near the city as might frustrate a raid of cavalry. Successful defence against a victorious army of the enemy would have been impossible, both from the nature of the ground about the city and the lack of troops to make a stand against such a force. Although overburdened with other public duties, Prof.,Bache personally superintended the construction of some of the works. Unaccustomed for many years to direct exposure to the sun, this undertaking brought on the first indications of the malady that ended his life. He had been subject to attacks of "sick headache"-a tendency which he seems to have inherited-and now various symptoms of softening of the brain came upon him in succession. For several months he was very anxious about the business of the Coast Survey, and with difficulty could be restrained from attempting to perform the duties of his office. As the malady increased, however, his attention was gradually withdrawn from the exterior world, with which he almost ceased to hold active communication. A trip to Europe, covering a period of eighteen months, produced no permanent benefit. He died a short time after his return, at Newport, R. I., February i 7, I867.

The ability and worth of Dallas Bache brought him many and high honours. There were few of our leading learned societies that did not number him among their associates. $\mathrm{He}$ was President of the American Association for the Advancement of Science in $185^{\circ}$ and $\mathrm{r} 85 \mathrm{r}$, of the American Philosophical Society in 1855 and 1856 , and of the National Academy of Sciences from its establishment in $\mathrm{I} 86_{3}$ until his death. He was a member also of the Royal Society of London, the Imperial Academy of Sciences at St. Petersburg, the Institute of 
France, the Royal Society of Edinburgh, the Royal and Imperial Geographical Society of Vienna, the Royal Academy of Turin, the Mathematical Society of Hamburg, the Academy of Sciences in the Institute of Bologna, the Royal Astronomical Society of London, and the Royal Irish Academy of Dublin.

The degree of LL. D. was conferred upon him by the principal American universities, and he received several medals from foreign governments for his distinguished services to science in the course of his labours on the Coast Survey and in other researches.

Mr. Bache was gifted with quick apprehension, and at the same time with deep intelligence, which is not always allied to the former quality. He had also great power of application. When at the head of a body of workers those under him were always nerved to do their best, because they saw that the master did not spare himself. He was always ready to learn from others. He would listen carefully to younger men if he saw that they had ideas which might be developed to good purpose. After arguing vehemently in opposition to the views of his brother on a matter under consideration, he would of ten come out on the same side of the question, and explain that his contention was designed to draw out arguments.

In his home he dropped science, and was a genial companion of old and young. Although not prepossessing in face, he was charming in manner and disposition. He was a very lovable man, and there was always plenty of company at his house in Washington. His favourite relaxation was reading light novels. He had a great appreciation of humour, but failed in trying to contribute humorously to the entertainment of others.

As an evidence of his high appreciation of abstract science derived from original investigation, he left his property in trust to the National Academy of Sciences, the income to be devoted to the prosecution of researches in physical and natural science, by assisting experimenters and observers, and the publication of the results of their investigations.

Appended to the memorial address by Dr. Benjamin A. Gould already cited is a list of the published scientific papers of Prof. Bache, embracing one hundred and twenty-three titles, besides thirty-five annual reports, and twenty-one reports on harbours made jointly with Messrs. Totten and Davis. 



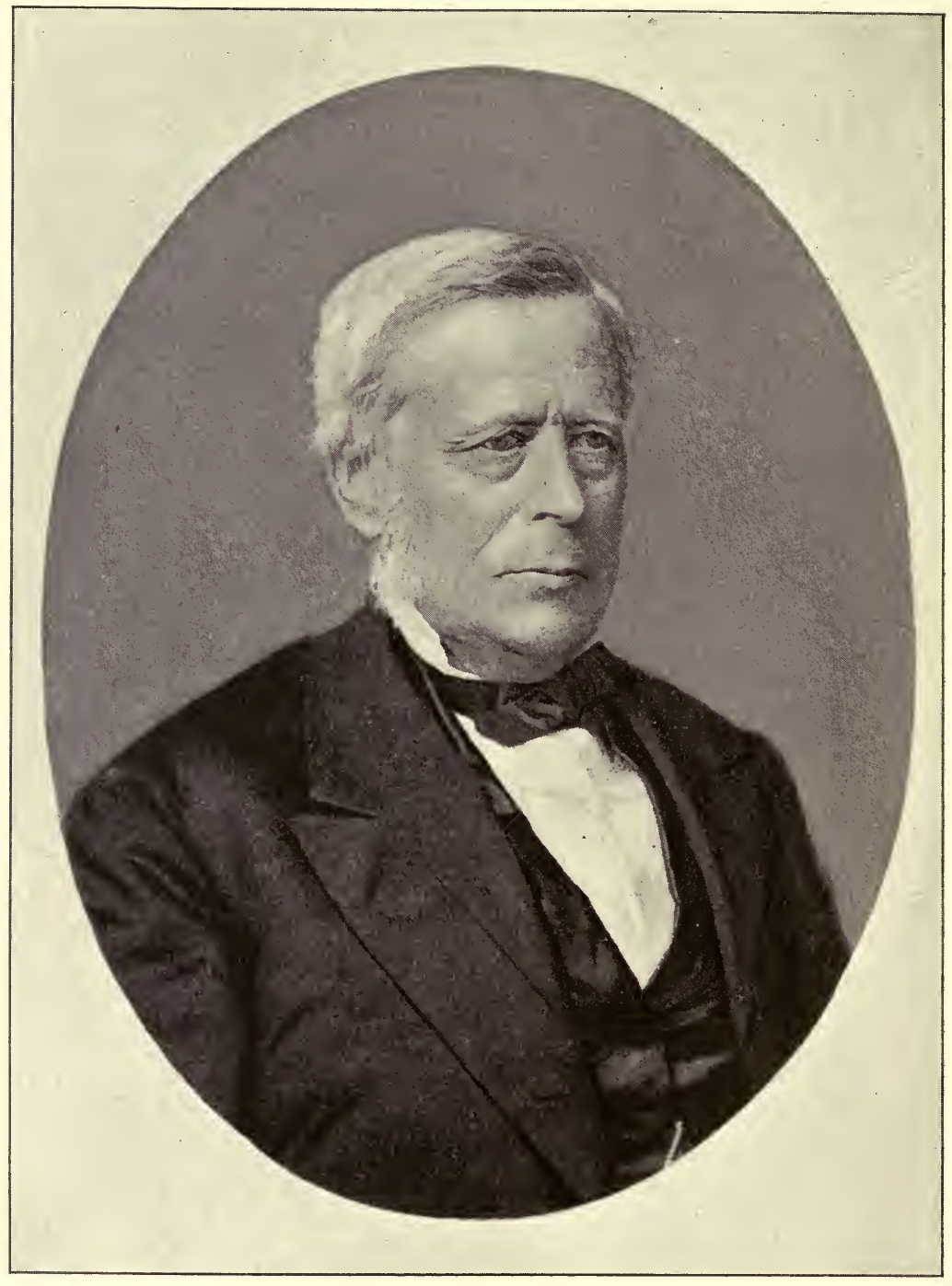

-JAMES HENRY COFFIN. 


\section{JAMES HENRY COFFIN.}

$$
\text { 1806-1 } 873 \text {. }
$$

From Sir Richard Coffin, Knight, who accompanied William the Conqueror to England in 1066, springs the genealogical tree that bears the name of Tristram Coffin, who came to America from Devonshire in 1642. Six years later he erected "the Coffin house," still standing, at Newbury, Mass., and in I660 he, with nine others, bought the island of Nantucket from the Indians. His American descendants have been engaged, to a large extent, in navigation. Of these, and fifth in the line of descent from 'Tristram, is the subject of this sketch.

James Henry Coffin was born in Williamsburg, Mass., on the 6th day of September, 1806 . He was therefore sixty-six years old at the time of his decease, which occurred February 6, I 873, at Lafayette College, Easton, Pa., where he had for over twenty-six years filled the professorship of Mathematics and Astronomy. From the full and faithful Life of Prof. Coffin, by his son-in-law, Rev. John C. Clyde, D. D., we learn that he was the third among the six children of Matthew Coffin and Betsey Allen, both natives of Martha's Vineyard. His father's occupation being that of a country broker, led him to travel in New England, buying the bills of banks and presenting them for redemption in coin at the place of issue. He frequently had occasion to handle large sums of money, but being reputed a superior marksman and well armed, was never molested on his long journeys. He carried his specie in nail kegs. Among the many commercial reverses that marked the close of the second war with England were numerous bank failures. Four banks in western Massachusetts closed in one week, and $\mathrm{Mr}$. Coffin was left with fourteen thousand dollars in the bills of these institutions on his hands, which proved a total loss. $\mathrm{He}$ died in 1820 without having repaired his lost fortunes.

At the death of their father the older children were scat- 
tered among kind relatives. Henry (he was always called by his middle name) was then fourteen years old. He had been a feeble child and his schooling - at various public and private schools-had consequently been much interrupted. It was only in the preceding spring that he hadbecome strong enough to work on his father's farm. The next winter and summer he worked for an uncle. From the age of ten years, he notes in his journal, he had spent most of his leisure "in exercises of mechanical ingenuity, for which I was then more noted than for anything useful." It was this bent which determined his intention, after his father died, to go to the trade of musical instrument and cabinet maker. This plan was not carried out, for in September, r82r, he went to live with another uncle, the Rev. Moses Hallock, of Plainfield, who added to his pastoral duties the preparation of boys for college and the tilling of a farm. The poet William Cullen Bryant was one of his many pupils. For two years Henry worked on the farm in summer and studied at odd times and in winter, going through in this period all the studies required for admission to college. He had no thought of entering for several years at least, having no means of meeting the necessary expenses. But Amherst College was then new and was bidding eagerly for students. His case was made known to its authorities without his knowledge, and such promises of aid were extended to him that he entered in the fall of 1823 .

$\mathrm{He}$ took with him to Amherst seventy-five cents in money and a small chest containing his few belongings. The chest was made by his own hands and was a good specimen of his expertness in the use of tools. It is still in the possession of his family, and as substantial as when it was new. Only part of the promised aid was ever realized, but, mainly with the money earned in teaching during vacations and part of termtime, he was enabled to meet the expenses of his course, except about two hundred dollars that he owed when he graduated. In the first term he had the measles, which affected his eyes so as to cause several interruptions of his studies and teaching in the course of the next six years. Having lost considerable time from his first three years in college he decided to go back a year, and graduated in the class of 1828 .

During part of the year after graduating he was engaged in teaching and a part in an agency in eastern Massachusetts. 
In August, 1829, he opened a private school for boys at Greenfield. Three months later he added a boarding house to the school, and the next spring he annexed a manual labour department. For the latter purpose he hired about two hundred acres of land and a farmer to superintend its cultivation. The students had each a share in whatever profits the business of the year might afford, and in this way were able to pay half their expenses. The enterprise had a rapid growth, and in its third year Mr. Coffin converted it into a joint-stock company, having obtained for it by subscription a capital of eight thousand dollars. It was chartered under the name of the Fellenberg Manual Labour Institution, and the spring term of $183^{2}$ began under the charter. The number of pupils reached one hundred and nine, and frequently applicants for admission had to wait their turn for a vacancy. An ample corps of assistants was provided, and at the close of $\mathrm{s} 833$ the trustees lightened the labours of the principal by appointing a superintendent of the farm and boarding house. An unwise choice of superintendent proved the ruin of the enterprise. The man selected kept no proper accounts, and two years later it was discovered that two or three thousand dollars had been sunk in his department. The institution was reduced to the scope of an ordinary school, and Mr. Coffin left it, carrying away with him perhaps two hundred dollars' worth of household effects as the outcome of eight years of unceasing labour.

While at Greenfield he had taken up the practice of surveying, and part of his time in 1836 was devoted to this employment. The ownership of a plot of land in Deerfield, formed by a river having changed its course, was in litigation, and $\mathrm{Mr}$. Coffin was occupied for about a month, on an order of the Supreme Judicial Court, in surveying, dividing, and computing this formation. He presented a thorough and exhaustive report on riparian ownership that has been frequently referred to in Massachusetts legal practice. The following winter he was induced by certain townspeople of Greenfield to reopen the school there. He soon received a call to take charge of an academy at Ogdensburg, N. Y., on a salary of eight hundred dollars a year, whither he removed in the following spring. He remained at Ogdensburg about two years and a half. The next winter was spent in astronomical and meteorological investigations at Williamstown, Mass., and in the fall of 1840 he 
entered upon an appointment as tutor in Williams College. During his stay at Williamstown he became interested in tracing the early land allotments of the settlement, which were somewhat complicated. He prepared a wall map of the town, which was engraved and published in Boston. It became a saying among the farmers of the vicinity that there was a young man at the college who could tell them more about the boundaries of their lands than their fathers had ever made known to them. He retained his tutorship for three years, but the salary of four hundred dollars, which was all that the college could afford to pay, was too small for the needs of a growing family. Consequently, in October, 1843, Mr. Coffin removed to South Norwalk, Conn., to become the principal of the academy in that flourishing village. Here he prospered; his circle of meteorological correspondence widened, and abundant facts for his researches were gathered from the logbooks of New York sea captains and the library of Yale College. In I 846 he was called to the chair of Mathematics and Astronomy in Lafayette College, which he filled to the time of his death.

Twenty-seven years of untiring labour, carried on in a truly self-sacrificing spirit, amidst circumstances which might have discouraged a less noble nature, his great success as a teacher, his quiet but never-flagging enthusiasm, and the beneficent influence he exerted on his pupils, made him one of the main pillars of that institution during a long period of great depression. He lived, however, to see Lafayette College rise to the honourable position she now occupies among the American seminaries of learning.

Mr. Coffin married, December 5, r833, Aurelia Medici, eldest daughter of the Rev. Ebenezer Jennings, of Dalton, Mass. She had been one of his pupils, when, as a college student, young Coffin taught the winter school in her native town. She proved to him a most devoted helpmate, and years after her death Prof. Coffin said, "If I have accomplished anything worth speaking of, I owe it all to her aid, consideration, and thoughtful carefulness." Three children were the fruit of this happy union. The first, a daughter, died at the age of twenty years. The second is his son, Selden Jennings, who succeeded to his father's professorship at Lafayette. The youngest, another daughter, became the wife of the Rev. John C. Clyde, D. D. Prof. Coffin was a second time married, March I2, I85 I, 
to Mrs. Abby Elizabeth Young, who survived him seven years. The only child of this marriage was a son who died in infancy.

In national affairs Prof. Coffin ever took a deep interest, and his political duties were always performed as matters of conscience. His course was strictly independent, hence he could not become a "party man."

He was quick to seize an opportunity to do a kindness; was fond of little children, and would take much pains to amuse them. He enjoyed music, and having learned to play the flute in his early years, continued the practice into middle life.

In the eulogy pronounced upon him before the National Academy of Sciences, by his intimate friend, Prof. Arnold Guyot, of Princeton, Prof. Coffin was described as "naturally modest, unobtrusive, and absolutely unselfish; he never sought to impose himself or his opinions on others. His kindness of heart, his gentleness, coupled with great firmness, energy, and perseverance, exerted a strong and beneficent influence on his surroundings. His profound love of truth made him the cautious, candid, and persevering observer whom we know, while his inquiring mind kept his eye open to every ray of light, from whatever quarter it might come. He joined the Church while at Amherst, and to the end of his life was a devoted Christian.

His health suffered several severe strains in 1872 , so that when in the following winter he was attacked by erysipelas, from which his wife was suffering at the time, he was unable to withstand the onslaught of the disease.

As a teacher, Prof. Coffin was laborious and enthusiastic, and his success was remarkable. He secured the respect and love of his pupils to a degree seldom equalled; but he was also a zealous student in science, and published several valuable works as the results of his researches. Among these are his Analytical Geometry, and his Conic Sections, which, at one time, were extensively used as text-books in our colleges. While connected with the Fellenberg Institution he published two works on book-keeping, that were adopted by the State schools of Massachusetts. He read many valuable papers before the American Association for the Advancement of Science, of which he was, from its organization, a member; and also before the National Academy of Science, for the meeting of which in 1873 he had in preparation an article on the Storm- 
curve, the object being to show that it was an hyperboloid, the equation of which he had computed. In 1859 he received the degree of LL. D. from Rutgers College.

His chief reputation, in science, was achieved by his researches in the department of meteorology. These were commenced in 1839, while principal of the Ogdensburg (N. Y.) Academy. He took simultaneous and constant observations of the barometric changes connected with the variations of the wind-vane and with the fall of rain. His instruments were self-registering. Each motion of the vane directed a minute but constant stream of dry sand into some one of thirty-two stationary hoppers, corresponding in position to as many points of compass. The weight of sand found in the several receptacles below each hopper showed the length of time that the vane had pointed in that direction. The rain-gauge was an inverted cone, having an horizontal surface of 172.8 square inches: the rain falling into it passed down, through an orifice so small that no appreciable evaporation could occur, into a close-fitting can. One inch of rain in depth would, therefore, make $x / x$ of a cubic foot when collected, the weight of which is one hundred ounces. Each ounce that the can contained after a storm, consequently, represented $\mathrm{x} / \mathrm{x}_{\mathrm{o}}$ of an inch in perpendicular fall. The amount necessary to merely moisten the funnel without precipitation into the can is easily determined as a constant. The results of these observations for the year I $83^{8}$ were published by Prof. Coffin in the Meteorological Register, a monthly journal, of which he issued the first number in January, I839. It was devoted to the discussion of various phenomena connected with physical science. Though the demand for a periodical of this nature was insufficient to sustain it, it brought into correspondence many who were interested in such subjects. The investigation of rainfall and evaporation had present practical value in being made the basis of the report of the committee of the New York Senate, in I 839 to I 840 , appointed to consider the enlargement of the canal system of the State by the construction of the Genesee Valley Canal. These studies were afterward extended to form the chapter on the climate of the State, published in the Natural History of New York, in $\mathrm{r} 845$, in which the inquiries took a wider range; and questions of vegetation, agricultural epochs, the migration of birds, etc., were introduced. A determination 
was also made of the amount of rise in the thermometer per hour, during the prevalence of winds from the northeast by east to south-southwest, and the unequal corresponding decrease of temperature when the winds were from the northwesterly points of compass.

While at Williams College, Prof. Coffin erected, upon the Greylock peak of Saddle Mountain, at a height of nearly four thousand feet above the ocean, an observatory, where continuous observations were taken, even through the winter season, when for three months it was impracticable to ascend the peak. In this interval the clockwork faithfully did its entire duty. The anemometer had been changed by substituting for the stream of sand a series of cards half an inch square, laid consecutively on a moving band that deposited one of them every fifteen minutes. Each card being inscribed with the day and hour it represented, when the receptacle marked "North," for example, was examined, all the cards found in it indicated the exact quarter-hour in the past three months when the wind was from that direction. In 1872 he constructed, for the observatory of the Argentine Confederation, at Cordova, a duplicate of this instrument with improvements similar to the one in use at Lafayette College.

The Results of Meteorological Observations for I 854 to I 859 , in two volumes, quarto, 1,757 pages, prepared under his supervision, under the auspices of the Smithsonian Institution, constitute a vast fund of condensed material from which to study the climate of North America.

But the great work of Prof. Coffin's life was the development of his theory of the winds, under the auspices of the Smithsonian Institution, the following account of which has been given by Prof. Henry, secretary of the institution:

"The results of the scientific labours of Prof. Coffin include contributions to astronomy, mathematics, and especially to meteorology. His labours in regard to the latter branch of science commenced immediately after his graduation, and were continued, almost uninterruptedly, until the time of his death. He was early recognised as one of the meteorologists of the country, and, on the establishment of the Smithsonian Institution, he was invited to become one of its collaborators in that line. All the materials which were collected from the observers of the institution, and from those of the army from 1854 to 
1859 inclusive, were placed in his hands for reduction and discussion. This work was conscientiously and thoroughly performed, and the results published in a quarto volume of upward of twelve hundred pages. In conducting this work, Prof. Coffin engaged the services of some of the students of Lafayette College, and a large number of women. The wages of these computers were paid by an appropriation from Congress, while the services of Prof. Coffin himself, in directing and superintending the whole, were entirely gratuitous."

His treatise on The Winds of the Northern Hemisphere, issued in the Transactions of the Smithsonian Institution, vol. vi, in 1853, was his most important publication, and the one which made him known wherever science is cultivated. This work had been commenced at least ten years before the date of its publication, a communication having been made in relation to it to the American Association for the Advancement of Science, in 1848 .

The materials on which it was based were derived from all accessible sources, including six hundred different stations on land, and numerous positions at sea, extending from the equator to the $83 \mathrm{~d}$ degree of north latitude, the most northerly point then reached by man, and embracing an aggregate period of over twenty-eigh't hundred years.

The design of the work was to ascertain, as far as possible, the mean direction in which the lower stratum of the air moves in different portions of the Northern Hemisphere, its rate of progress, the modification it undergoes in different months of the year, the amount of deflecting forces, and its relative velocity from different points of the compass. The collection of this material involved an amount of correspondence and bibliographical research which but few would undertake, even with the hope of pecuniary reward, and still fewer for the love of truth, and the acquisition of knowledge for its own sake. But the labour of computation, and discussion of the materials, was an almost Herculean task, to which years of silent and unobtrusive labour were devoted. The work consisted mainly of about one hundred and forty quarto page tables of figures, with descriptive deductions, and illustrated by maps. Each of these figures is the result of laborious calculations, since the method of determining the velocity and direction of the wind is the same as that employed by the mariner in determining the dis- 
tance in a straight line, and direction at the end of a given time, from the place of his departure. In this work Prof. Coffin was the first clearly to establish the fact, by accurate comparison of observations, that there are three great zones of winds in the Northern Hemisphere. At a later date he demonstrated the same truth in the case of the Southern Hemisphere. The first belt is that of the region of the easterly trade winds, extending northward in the Western Hemisphere to about the $3^{2} \mathrm{~d}$ degree north latitude, and in Europe to the $42 \mathrm{~d}$ degree. The second is the great belt around the world of the return trades, in which the predominant direction is from the west. This extends northward in America to $56^{\circ}$, and in Europe and Asia to about $66^{\circ}$ north latitude. Beyond this, principally within the Arctic Circle, is a belt of easterly or northeasterly winds. The common pole of these belts or zones has not the same position as that of the geometrical pole of the earth. It appears to be in latitude $84^{\circ}$ and longitude ro5 $5^{\circ}$ west of Greenwich, and has been denominated by Prof. Coffin the meteorological pole.

These results are in general accordance with the mathematical deductions from the theory of the winds of the globe, which considers them as due to the combined action of the movement produced in the air by the greater heat of the equator, and the rotation of the earth on its axis.

The researches of Prof. Coffin also strikingly exhibit the fact of the influence of the seasons in modifying the direction of the wind, or in producing the results denominated monsoons. Thus, along the eastern coast of North America, as is shown on the maps, the tendency during the summer months of the opposing forces is to lessen the dominant westerly wind, and this effect is noticed even beyond the Mississippi, as well as in the Atlantic Ocean along our coast. The effect is, undoubtedly, due to the change of temperature in the land-the temperature of the ocean remaining nearly the same during the year, while that of the land is greatly increased in summer above the mean, and depressed in winter. From this cause the air will tend to flow toward the centre of the continent from the ocean in summer, and from the same centre toward the ocean in winter.

At the meeting of the American Association for the Advancement of Science, held in Cleveland in 1853 , he discussed 
the relation of the prevalent winds to the rise and fall of the barometer, particularly showing that "the line of the wind's approach makes an angle of about sixty-five degrees with the line drawn to the point of maximum pressure." It is this principle that was afterward so emphasized by the director of the Royal Observatory of Holland, that it has since been designated by his name-rather than that of Prof. Coffin-and is referred to in Europe as "Buys-Ballot's law of the winds." The results of the investigations of Prof. Coffin have been referred to in all the treatises on meteorology which have appeared since their publication, and they have been employed with other materials as the basis of the wind-charts of the Atlantic and Pacific Oceans, prepared and published by the English Board of Trade.

In attentively studying the result of Prof. Coffin's labours, we can not but be struck with his conscientious regard for accuracy, and his devotion to truth. In all cases in which the results do not conform to the theory which explains the general phenomena, the discrepancies are fully pointed out; and, where he is unable to suggest an hypothetical cause of the anomaly, he candidly acknowledges his ignorance. In this respect he is an admirable model for an investigator, since errors in science as frequently occur from defects of the heart as from those of the head.

After the publication of the work on the winds, he continued to collect materials, at first with a view to an appendix, and finally extended his investigations to the winds of the entire globe. To aid in this enterprise, the Smithsonian Institution placed in his hands all the observations on the winds, which it had obtained from its numerous observers during the twenty years since the system was commenced, together with the observations made by the officers of the army, as well as the extensive series of materials in the various series of transactions of scientific societies of the Old World, obtained through the exchanges of the institution. Unfortunately, however, he was not spared to complete this work, although he left it in such a condition that it was readily pushed to completion within three years after his decease. The tables of The Winds of the Globe, were completed and the charts for it were drawn by his son. A discussion and analysis of the tables and charts was supplied by Prof. Coffin's long-time correspondent, Dr. Alex- 
ander Woeikof, former secretary of the meteorological committee of the Imperial Geographical Society of Russia, and the work was issued in 1876 as the twentieth volume of the Smithsonian Contributions to Knowledge.

In reviewing what may be called the extra labours of Prof. Coffin, we can not refrain from endeavouring to impress upon the mind of the general public that men of his character, who do honour to humanity, ought not to be suffered to expend their energies in the drilling of youth in the mere elements of knowledge, and with a compensation not more than sufficient to secure the necessaries of life; that they should be consecrated as officiating priests in the temple of knowledge, be furnished with all the appliances and assistance necessary to the accomplishment of their objects, namely, the extension of the bounds of human thought and of human power. 


\section{LEO LESQUEREUX.}

$$
\text { I 806-1 889. }
$$

American science owes an incalculable debt to the Geneva Revolutionary Council of 1848 , that suppressed the Academy of Neuchâtel and sent to our shores Agassiz, Guyot, and Lesquereux. In the heart of Switzerland's mountain grandeur this illustrious trio first saw the light and drank of that love of Nature which, deepening with the years, peculiarly linked their lives. Agassiz had been in America two years, when he was joined by Guyot and Lesquereux, whose friendship had been formed while they were collaborators in the quaint Swiss town.

Leo Lesquereux was born at Fleurier, canton of Neuchâtel, Switzerland, November 18, 1806. His ancestors were French Huguenots. His father was a manufacturer of watch springs, and wished his only son to follow the same trade, as was the custom of the country. The future botanist's health being delicate, however, his mother desired him to study for the ministry. But the grandeur of his mountain home had already sunk deep into the impressible soul of the youth, and circumstances sealed his preference for another pursuit. He has described himself as a boy fond of rocks and flowers and eager for books-" a kind of natural, as they call people of that kind in the South." In order to prepare for the university he was sent to an academy in Neuchattel, and at the age of nineteen had completed his preparations. Among his fellow-pupils at this school were Arnold Guyot and August, a younger brother of Louis Agassiz. To Guyot he became especially attached. Leo's father was in only moderate circumstances, and unable to defray his son's expenses at a university; he had paid only for the youth's board at Neuchâtel, young Leo having met his tuition fees by teaching. Accordingly, the young man took a 


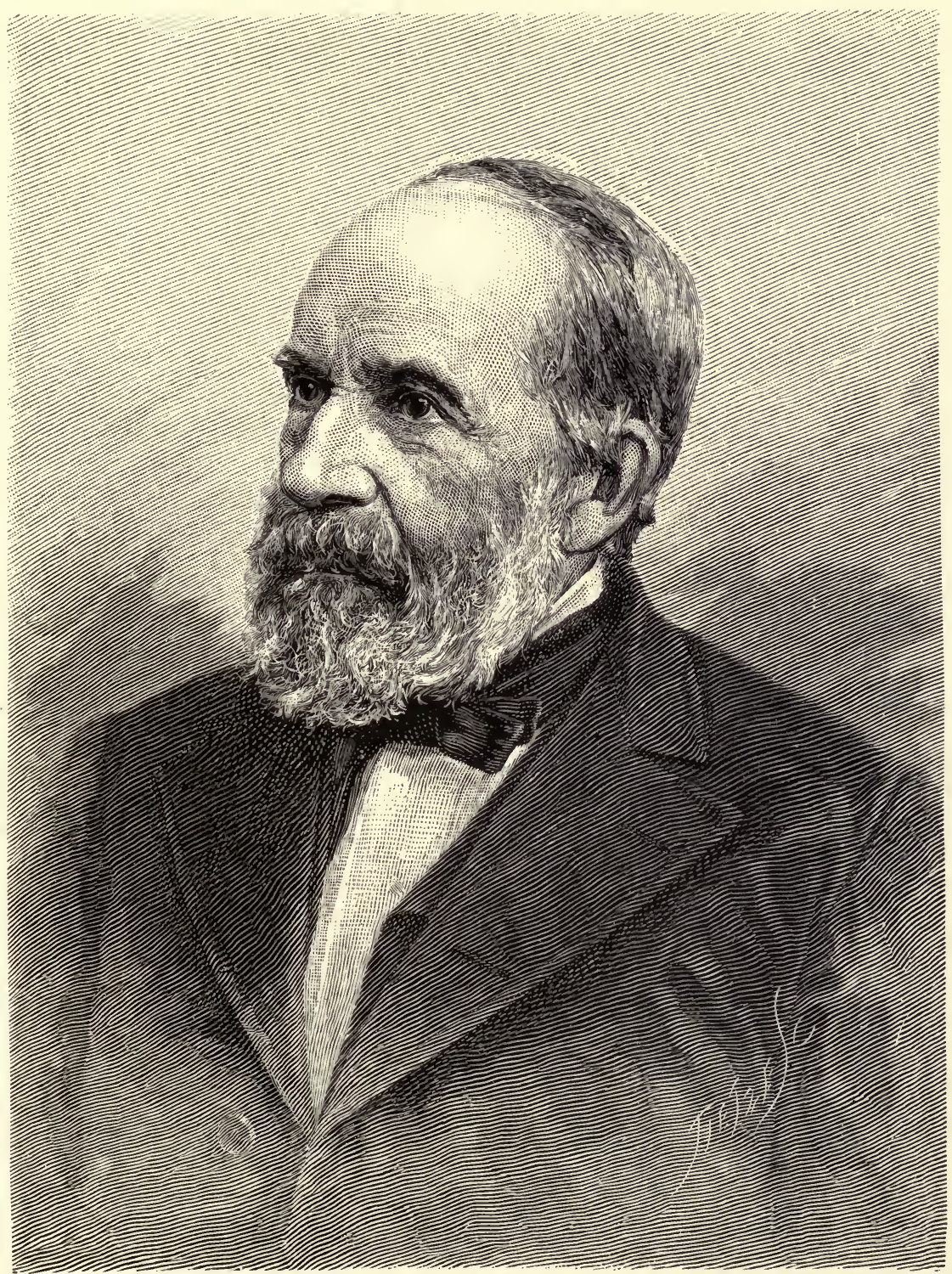

LEO LESQUEREUX. 

position as Professor of French in a young ladies academy at Eisenach, in Saxe-Weimar, hoping to obtain money enough to go later to the university. "They were the happiest days of my life," he has said of this period. "My pupils were from the noble families of Weimar. They were well educated, and came to me for conversation. I remained at Weimar for some time. Then love came and I went back to Switzerland, and I never regretted it." $\mathrm{He}$ had been at Eisenach four years when he became engaged to one of his pupils. The young lady was of small fortune, but of noble family, being the daughter of a distinguished soldier, General Von Wolffskel, an attache of the court of the Duke of Saxe-Weimar. In her earlier years she had received especial notice from Goethe, and the letters of the poet to his child friend were long proudly preserved by her family. When the daughter of the duke was united with Prince William of Prussia, the future Kaiser, Fräulein Von Wolffskel was one of the bridesmaids. Her father was a man of learning, with a strong propensity for science. When young Lesquereux was about to return to his home, the father, who was setting out in the same direction invited him to share his carriage. The marriage was agreed upon during this journey.

After a short period of teaching at Locle, Lesquereux obtained the principalship of an academy at La Chaux de Fonds, which he held for three years. A year after his return to Switzerland he was married, and brought home his bride. At the wedding the groom's best man was a certain Lieutenant Von Moltke. The name has become known in a higher rank since. Lesquereux had been married but a couple of years when a serious misfortune overtook him. A fall down the mountain side overlooking Fleurier when he was about ten years old had injured the hearing of one ear, and now he rapidly became so deaf that he had to give up teaching and resort to a mechanical trade to support his family. He was at this time twenty-six years of age.

At first he took up the engraving of watch cases, but finding this work injurious to his health he accepted a partnership in his father's business, and returned to his old home. "But I could not stick to that work," he wrote many years after to Prof. Lester F. Ward, " and was constantly busy in my hours of rest, that is mostly in the night, with a poor small 
microscope, studying mosses, and on Sundays running in the mountains to gather them."

Lesquereux published some memoirs of his investigations which attracted the attention of Agassiz, then occupying the chair of Natural History in the newly formed Academy of Neuchâtel. Agassiz invited the author to visit him for a consultation upon the theories he had set forth, and this visit was the beginning of a friendship that ceased only with Agassiz's life.

On account of the rapid cutting away of the forests, the subject of fuel for the poor was then becoming a matter of concern in Neuchâtel, and the government of the canton offered a gold medal for the best treatise on the formation of and the possibility of replenishing the peat bogs. Lesquereux competed for this prize and won it; his memoir on the subject gained wide reputation, and is still quoted as one of the best authorities. A committee of eight savants was appointed to explore the peat deposits of the canton, in order to be fully informed as to the value of Lesquereux's researches. Prof. Agassiz, who was a member of this committee, did not at first agree with his theory, but after being out a few daysthe committee was two weeks in the field-he accepted it and became its ardent supporter. Lesquereux was now employed by the canton to write a text-book on peat for the schools, and was made director of operations in the peat bogs bought by the Government. Under the patronage of the King of Prussia he also explored the peat bogs of the countries of northern Europe, and in this way became acquainted with the botany and geology of these districts.

To the New World his labours were now transferred, when, in addition to the misfortune of becoming totally deaf in the prime of life, he also found himself deprived of scientific employment at home by the political changes that followed the revolution of 1847 . He embarked with his wife and five children as steerage passengers, reaching Boston in September, 1848. At the earnest solicitation of that naturalist he became a member of the household of Agassiz. Here he worked upon the botanical part of Agassiz's Journey to Lake Superior, until the eve of Christmas, 1848 , when, at the invitation of the eminent bryologist, W. S. Sullivant, he went to Columbus, Ohio, and, entering his laboratory, continued there the study of 
mosses. At the close of the year 1849 , under the advice and with the co-operation of Mr. Sullivant, he made a tour of exploration among the mountains of the Southern States, for the collection of plant specimens, and secured a great variety of plants, which found a ready sale among students of botany. He was particularly successful in the collection of mosses. The preparation of the specimens, their determination and distribution, gave him employment for two years, and resulted in one of the most valuable contributions to American bryology-the Musci Americani Exsiccati, by W. S. Sullivant and L. Lesquereux. The expense of preparation and publication of this work was defrayed by Mr. Sullivant, who, taking only a few copies for presentation, allowed his colleague the benefit of the sales of the rest. Using that author's library and herbarium Lesquereux lent most valuable assistance to the preparation of Mr. Sullivant's works on the mosses of the Wilkes South Pacific Exploring Expedition, Whipple's Pacific Railroad Exploration, and the Icones Muscorum.

Sullivant had collected materials for a complete account of the North American moss flora, which he hoped to publish. After his death, at the urgent request of Dr. Asa Gray, Lesquereux undertook to complete the task. A large part of the work was done when, in 1869 , his sight became impaired, and Prof. Thomas P. James, of Cambridge, was enlisted in this labour. He made the microscopical examinations that were still to be done, but his death caused another delay, and it was not till 1884 that the Manual of North American Mosses was finally issued.

The publication of Brongniart's Prodrome, and the commencement of the Histoire des Végettaux Fossils, in 1828 , laid the solid basis upon which the science of paleobotany has been erected. Lesquereux began to write on this subject in $\mathbf{r} 845$, and his studies in America have been directed especially in the line of fossil botany. His most valuable researches, beginning in 1850 , lay in the study of the coal formations of Ohio, Pennsylvania, Illinois, Kentucky, and Arkansas, and his reports appear in the geological surveys of all these States. $\mathrm{He}$ had conceived that his theory of the formation of peat could be extended to the coal, and this proved to be the case. Particularly important are his studies of the coal flora of Pennsylvania, published in the report of H. D. Rogers in $185^{8}$, 
together with a Catalogue of the Fossil Plants which have been named or described from the coal measures of North America. Lesquereux also worked up the coal flora in the second geological survey of Pennsylvania. The fruit of this labour was two volumes of text and an atlas, published in 1880 - the most important work on carboniferous plants that has been produced in America. Geological work, especially researches on fossil botany, in connection with the United States Geological Surveys of the Territories, began in 1868 to absorb his attention. He was employed to work up the collections of Dr. F. V. Hayden's surveys of the Territories, and important papers on the subject appeared in the annual reports of the surveys from 1870 to 1874 inclusive. Lesquereux was frequently called to Cambridge to determine the specimens of fossil plants in Prof. Agassiz's museum, where he was a guest in the naturalist's household for weeks and months at a time, and their mutual attachment grew very strong.

Lesquereux, during his long and industrious life, contributed twelve important works to the natural history of North America, besides a large number of memoirs on divers subjects, amounting in all to about fifty publications. He was a member or correspondent of more than twenty scientific societies of Europe and America, and was the first elected member of the National Academy of Sciences. The degree of LL. D. was given him in 1875 by Marietta College. He was in close correspondence with all the leading paleontologists of Europe, Oswald Heer being one of his particular friends.

The characteristic works of the most eminent scientific writers of the age comprised his library. Brongniart, who laid the foundation of paleobotany; Göppert, who built its superstructure ; Schimper, Heer, Dawson, Ettingshausen, Newberry, the Marquis Gaston de Saporta, together with Grande Eury and Renault, who thoroughly studied the carboniferous flora of France; Williamson, who mastered that of England; Nathorst, who opened up the subterranean floral treasures of Sweden; Engelhardt, Hosius, Under Marck and Schenk, who investigated without exhausting the rich plant beds of Germany-all were numbered among Lesquereux's friends and correspondents.

The fraternal bond that binds the scientific world is almost indissoluble. When once asked if his long and intimate associ- 
ations with so many illustrious minds had not stored his memory with anecdote and reminiscence, Lesquereux responded: " The science students' life is absorbed with grave and serious truths; they are naturally serious men. My associations have been almost entirely of a scientific nature. My deafness cut me off from everything that lay outside of science. I have lived with Nature, the rocks, the trees, the flowers. They know me, I know them. All outside are dead to me."

Dr. Lesquereux's death occurred at his modest home in Columbus, Ohio, on October 25, r889. His wife had shortly gone before. He lived and died in the communion of the Lutheran Church, and never felt the essentials of his religious belief disturbed by the advances of science. A visitor described him at the age of eighty as "a middle-sized man with dark eyes that flashed with mirthfulness when he spoke, and a step so brisk, and hair and beard so free from time strokes, that the longcherished patriarchal vision of the botanist's appearance vanished."

Four sons and one daughter lived to adult age. The sons followed in their father's footsteps, not in the pursuit of science, but by becoming watchmakers.

The last work upon which Prof. Lesquereux was engaged was an important treatise on The Flora of the Dakota Group, which was published posthumously under the editorship of $\mathrm{Mr}$. F. H. Knowlton as Monograph 17 of the United States Geological Survey, in $\mathrm{r} 8 \mathrm{~g}$. 


\section{MATTHEW FONTAINE MAURY.}

$$
\text { 1806-ז } 873 \text {. }
$$

Mrs. Corbin, Lieutenant Maury's daughter and biographer, claims for her father the recognition of the whole civilized world; for, she says, "the best part of his life was devoted to the performance of services which conferred benefits on the seafaring class of all countries, while the ideas to which he first gave birth have since borne fruit, and are likely to be useful to the whole human race." She adds that "in Maury we have two characteristics, each valuable in itself, but which almost invariably produce great results when they are combined. He was endowed with extraordinary powers of application and unflagging industry in working out the driest details. But he also possessed a vivid imagination, so that the dry bones of his new science were endowed with life and interest by the magic touch of his descriptive pen. It was Maury who created the science of the physical geography of the sea, and gave that impetus to its study which, in other hands, continues to produce results alike of practical and speculative importance."

Matthew Fontaine Maury was born in Spottsylvania County, Virginia, January $24, \mathbf{1 8 0 6}$, and died in Lexington, Va., February $\mathrm{I}, \mathrm{I} 873$. He was descended on his father's side from two families of Huguenot exiles, connected by marriage before they left France, who settled in Virginia in $17 \mathbf{7}$. His father, Richard Maury, was the sixth son of the Rev. James Maury, an Episcopal clergyman and teacher of Albemarle County, Virginia, who numbered among his pupils three boys who afterward became Presidents of the United States, and five signers of the Declaration of Independence. This scholar appears to have been already interested in the great Northwest, and his speculations respecting the Missouri River, the Western mountains, and the rivers beyond them, then hardly known, greatly impressed his pupil Jefferson, who, when he became 


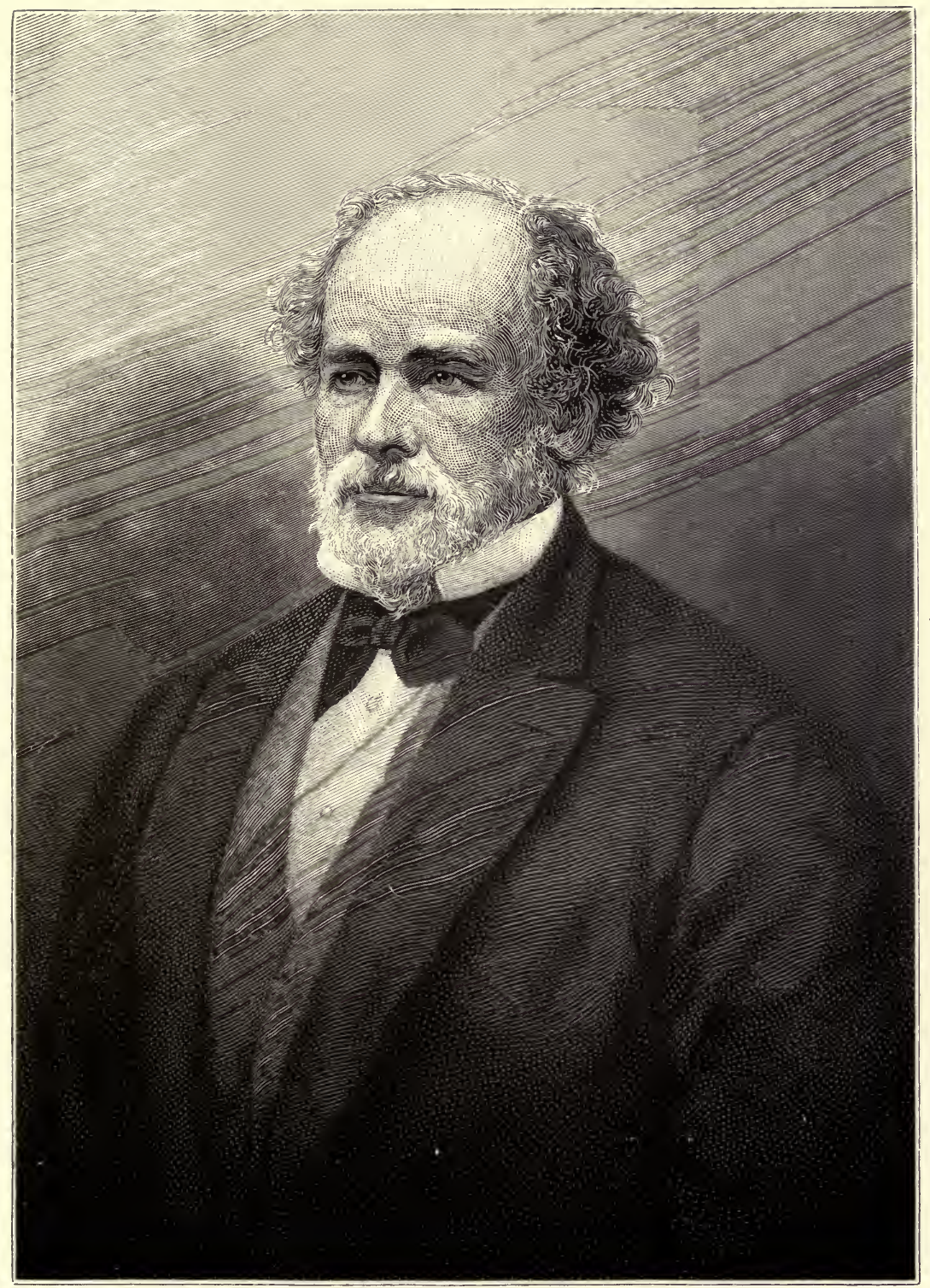

MATTHEW FONTAINE MAURY. 

President, secured the despatch of the expedition of Lewis and Clark. In I790 Richard Maury married Diana, daughter of Major John Minor, of Topping Castle, in Caroline County, and settled in Spottsylvania County, about ten miles west of Fredericksburg. Nine children were the fruit of this marriage, Matthew being the seventh, and the fourth of the five sons.

When young Matthew was in his fifth year the family removed to Tennessee, near Franklin, where they lived the life of early settlers in a new country. The father was very exact in the religious training of his children, assembling them morning and evening to read the Psalter for the day, verse and verse about. Matthew's first ambition to become a mathematician was excited by an old cobbler "who used to send the shoes home to his customers with the soles all scratched over with little $x$ 's and $y$ 's." A fall from a tree in his twelfth year, by which his back was injured, seems to have marked the turning point of his life. His father, thinking him permanently disabled, yielded to his wish and sent him to Harpeth Academy, of which the Rev. J. H. Otey, afterward Protestant Episcopal Bishop of Tennessee, and William C. Hasbrouck, were the teachers.

In 1825 he obtained, through the Hon. Sam Houston, a midshipman's warrant in the United States Navy. His father did not approve the career to which this pointed, for his eldest son, John Minor, had died of yellow fever in the service the year before. Still he did not positively forbid Matthew to accept the appointment, so, having thirty dollars which he had earned by doing tutor's work in the academy, young Maury bought a gray mare, to be paid for when he should sell her at the end of his journey, and started on his own account for the East. After travelling two weeks he came among his Virginian kinsfolk in Albemarle County, where he sold the mare and despatched the money she brought to her former owner. Here he saw little Nannie Herndon, then a girl of twelve or thirteen years, who was afterward to become his wife. She was the eldest child of Elizabeth Hull and Dabney Herndon, of Fredericksburg. There was no naval academy then, and young Maury went on shipboard at once. He soon showed that his mind was set upon mastering the theory and practice of his profession. "It is related by some of his companions of that period," says Mrs. Corbin, "how he would chalk diagrams in 
spherical trigonometry on the round shot in the quarterdeck racks, to enable himself to master problems, while pacing to and fro, passing and repassing the shot racks on his watch." With an old Spanish work on navigation, he pursued the double object of studying the Spanish language and adding to his stock of nautical information. His first voyage was to England, in the Brandywine, which conveyed General Lafayette home to France; his next was in the Vincennes, round the world. On this voyage he constructed a set of lunar tables and prepared himself for examination.

During his next cruise of four years on the Falmouth, Dolphin, and Potomac, beginning in $183 \mathrm{I}$, Maury conceived the idea of his current and wind charts; observed and began to study the curious phenomenon of the low barometer off Cape Horn, concerning which he wrote his first scientific paper-for the American Journal of Science; and began to prepare for the press a work on navigation, for which he had been several years collecting the material. It was published in 1835 , was favourably noticed in England, and was used as a text-book in the United States Navy. Immediately after his return home on the Potomac, in 1834, he married Miss Ann Herndon, to whom he had been engaged since he was last on shore.

Maury next received an appointment as astronomer and hydrographer on the South Sea Exploring Expedition, which was to go out under Commodore Catesby Jones, and, preparatory to it, practised in the use of the telescope, transit instrument, and theodolite; but, Captain Wilkes succeeding to the command, he resigned, in order to permit the new commander to select his own associates. He was then assigned the duty of making surveys of Southern harbours. While travelling on leave of absence from this work, his leg was broken by the overturning of a stagecoach, whereby he was disabled from active service for several years. The misfortune is regarded by his biographer as having been a "blessing in disguise"; for it caused his mind to turn more intently to the scientific side of his work, and thus contributed indirectly to the fruitfulness of thought by which his after-life was distinguished.

A series of articles on naval reform and kindred subjects, entitled Scraps from the Lucky-Bag, published by Maury under the pen-name of Harry Bluff, attracted attention and approval. Among the points discussed in them-most of which were 
brought up for the first time-were the adoption of steam as a motive power; great-circle sailing; the establishment of navy yards and forts at Memphis and Pensacola; the use of blank charts on board public cruisers; the Gulf Stream and its causes; the connection of terrestrial magnetism with the circulation of the atmosphere; and a ship canal from the Illinois River to Lake Michigan. The papers gave their author fame, and secured respect for his opinions on naval questions. Certain journals even urged his appointment as Secretary of the Navy. He was placed in charge of the Depot of Charts and Instruments at Washington, an office which was developed into the Naval Observatory and Hydrographical Department. "No man," said Senator John Bell, "could have been found in the country better fitted than Maury for this difficult duty; and he worked with the zeal and energy that were expected of him."

One of Maury's first enterprises in this office was the compilation of his wind and current charts and sailing directions. $\mathrm{He}$ had already, as sailing master of the Falmouth, in $183 \mathrm{I}$, observed the want of trustworthy information concerning the winds and currents encountered by mariners. He then resolved, if he ever had opportunity, to compile such information from the store of old log books in the Hydrographical Bureau of the Naval Department. This he now did, and his charts and sailing directions were furnished to the masters of vessels bound for foreign ports, who in turn supplied the results of their own observations. The most favourable reports came in of the value of the work, and it was illustrated by some then really wonderful incidents.

The fact was demonstrated in American and English journals that, by the mere shortening of voyages they made possible, these charts effected a very great saving in the expense of commerce between distant ports. Testimony was repeatedly borne to their value in the annual reports of the Navy Department and of congressional committees. Secretary Dobbin reported, in 1855 , that other maritime nations, appreciating the value of this plan of investigation, had united in a common system of observations for its further prosecution; and that it was suggested by Lieutenant Maury that the same system of meteorological research, " if extended to the land, would afford for the agricultural interests of the country, and for science too, results quite as important as those which commerce and 
navigation have already received from it." While analyzing and tabulating these "millions of observations," Maury wrote his Physical Geography of the Sea, which took rank at once as a masterly as well as a charming work. In the preface to it the author attributed such success as he had achieved to the observance of the rule "to keep the mind unbiased by theories and speculations; never to have any wish that an investigation should result in favour of this view in preference to that; and never to attempt by premature speculation to anticipate the results of investigations, but always to trust to the investigations themselves." The book met a large demand at home and abroad, more than twenty editions having been sold in England alone; and it was translated into the French, Dutch, Italian, Swedish, and Spanish languages. Following this came the assembling of the Meteorological Congress at Brussels, in 1853 , of the chief nations interested in commerce, at which a uniform system of observations on land and at sea was resolved upon. Among the incidents of the conference was a letter in 1857 from Humboldt, "at the age of ninety years," relating to its results, and offering "to my illustrious friend and associate ... the tribute of my respectful admiration. . . . It belongs to me, more than to any traveller of the age, to congratulate my illustrious friend upon the course which he has so gloriously opened."

Lieutenant Maury, after returning from the Brussels Conference, pressed the scheme of co-operation in the meteorological observations on land. In addresses delivered at agricultural societies in 1855 he urged farmers to make daily observations of weather conditions and the state and yield of the crops, to be sent to him, as sailors were sending their observations at sea; and he advised them to seek from Congress measures for the establishment of a central office where these reports could be digested and the results sent monthly, weekly, or even daily, to all parts of the country, so that farmers could be "warned of the approach of storms, severe frosts, etc., that might prove injurious to the crops." He defined this proposition in an address before the United States Agricultural Society in January, 1856 , as a concerted plan, the idea of which was to spread the network of instruments and observers in this country and over other parts of the world also, to which he was assured the co-operation of men of science abroad would 
be given. About three years afterward, in an address at Decatur, Ala., as if foreseeing that his services might become forgotten, he said: "Take notice, now, that this plan of crop and weather reports is my thunder; and if you see some one in Washington running away with it, then recollect, if you please, where the lightning came from." The whole record of Maury's meteorological work, and his part in advocating this plan, were reviewed by Senator Harlan, in a committee report to the United States Senate, made in 1857 . His scheme also embraced a system of meteorological observations on the Great Lakes. Records had already been kept for many years by the army, to which, Maury acknowledged, " alone we are indebted for almost all we know concerning the climatology of the country"; but he explained that their value was retrospective; while the observations he proposed were to be used for predictions and warnings of what the weather was to be.

As early as 1848 Maury had concluded, from his investigations of the winds and currents, that a broad and level plateau -the "telegraphic plateau"-existed at the bottom of the ocean between Newfoundland and Ireland. His view was confirmed by the deep-sea soundings that were taken at his instance between 1849 and 1853 ; and early in 1854 he reported to the Secretary of the Navy that, so far as the bottom of the deep sea was concerned, a submarine telegraph between Newfoundland and Ireland was practicable. A plateau seemed to have been placed there especially for holding the wires and keeping them out of harm's way. His views respecting the manner of constructing cables were confirmed, both in the behaviour of the first cable, constructed differently from them, which failed, and the others, made more in harmony with them, which were successful. At the dinner given in celebration of the arrival of the first message across the Atlantic, Mr. Cyrus W. Field said, referring to the enterprise, "Maury furnished the brains, England gave the money, and I did the work."

A painful surprise came to Lieutenant Maury when the Naval Retiring Board, under the act of Congress of February 28,1855 , placed him on the retired list on leave-of-absence pay, but without detaching him from the Naval Observatory. $\mathrm{He}$ regarded the act as an indignity. He wrote to three of the Secretaries of the Navy under whom he had served for expressions concerning his efficiency, particularly inquiring why he 
had been kept at the observatory instead of being sent to sea. Ex-Secretary Graham answered: "I considered your services at the National Observatory of far more importance and value to the country and the navy than any that could be rendered by an officer of your grade at sea in the time of peace. Indeed, I doubt whether the triumphs of navigation and of the knowledge of the sea achieved under your superintendence of the observatory will not contribute as much to an effective naval service and to the national fame as the brilliant trophies of our arms." Mr. John P. Kennedy wrote, "From my knowledge of the nature of your scientific pursuits, their usefulness to the country, and your devotion to them, I can say that nothing but such an emergency as left me no alternative would have induced me to withdraw you from your labours at the observatory by an order to go to sea." Mr. William Ballard Preston wrote to similar effect. In the following winter Maury was, by special act of Congress, reinstated and promoted to the rank of commander, with back pay from the date of his retirement.

Other schemes discussed by Lieutenant Maury in general or special papers included the location of lighthouses on the Florida and Gulf coasts; systematic observations of the rise and fall of the water in the Mississippi River and its tributaries, with gauges at all the principal towns; the redemption of the "drowned lands" of the Mississippi; navigation by great-circle routes; a ship canal and railroad across the Isthmus, which he insisted should be by way of Panama or Nicaragua rather than Tehuantepec; the establishment of a great port at Norfolk, Va.; and the colonization of the surplus black and other population of the South in the valley of the Amazon. The Darien expedition of Lieutenant Strain and Lieutenant Herndon's exploration of the Amazon were connected with two of these schemes. The "lane route," followed by some of the transatlantic steamship lines, originated in the publication by Maury, in 1855 , of a chart on which two lanes were laid down, each twenty-five miles broad, by following which the danger of collisions might be reduced. In acknowledgment of the value of the service rendered by this plan, and by the wind and current charts and sailing directions, the merchants and underwriters of New York presented him with five thousand dollars in gold and a handsome service of silver. 
When the Ordinance of Secession was passed by the Legislature of Virginia, Commander Maury believed that his paramount obligation was to his native State. He accordingly left the service of the United States and identified his fortunes with those of Virginia and the Confederacy. There can be no doubt of his disinterestedness in taking this course. His merits and the value of his services were generally recognised throughout the North, and he had but recently given courses of lectures in the principal towns and cities, which were a series of popular ovations to him. In going into the service of the Confederacy he put himself under the direction, as his immediate superiors, of two men who, as United States Senators, had been prominent in opposition to his reinstatement after he had been put upon the retired list, and who are said to have been hostile to him before the war and through it. Of the manner of his leaving the service of the United States, he said, May I 2, I86I, in a letter to a friend in Newburg, N. Y.: "I only saw last night the remarks of the Boston Traveller about Lieutenant Maury's treachery, his desertion, removal of buoys. It's all a lie! I resigned and left the observatory on Saturday the I 2 th ult. I worked as hard and as faithfully for 'Uncle Sam' up to three o'clock of that day as I ever did, and at three o'clock I turned everything-all the public property and records of the office-regularly over to Lieutenant Whiting, the proper officer in charge. I left in press Nautical Monograph, No. 3 , one of the most valuable contributions I ever made to navigation; and, just as I left it, it is now in course of publication there, though I shall probably not have the privilege of reading the proof. . . . As for the buoys, I touched them not!" The Grand Duke Constantine and Napoleon III offered him positions in Russia and France, respectively, which he declined. He became a member of a Council of Three to assist the Governor of Virginia, and in June, I86I, was appointed Chief of the Seacoast, Harbour, and River Defences of the South. $\mathrm{He}$ assisted in fitting out the Merrimac; invented a torpedo to be used for harbour and land defence; and was engaged, in the summer of 1862 , in mining the James River below all the defences, when he was ordered to go to Europe to purchase torpedo material. During the first and second years of the war he published a series of papers urging the building of a navy, and of protecting the bays and rivers with small floating bat- 
teries. He stayed in England, on Confederate business, till the surrender of Lee, when he despatched a letter to the United States officer commanding the squadron of the Gulf, declaring that he regarded himself in the relation to the United States substantially of a prisoner of war. He then offered his services to Maximilian in Mexico, and accepted the position of Director of the Imperial Observatory. A plan he had conceived for the formation of a colony of Virginians in Mexico was accepied by Maximilian, and he was appointed Imperial Commissioner for Colonization. The scheme was, however, abandoned as soon as Maury left Mexico to return to England. His course in this matter was not approved by his friends, either in Europe or in America. It is claimed that he performed one great service for Mexico during his short career there, in introducing the cultivation of the cinchona tree.

Returning to England in March, 1866, whither most of his family had preceded him, Maury was given a testimonial, by naval and scientific men, in recognition of his scientific worth and service. He was employed in Paris, by Napoleon III, to instruct a board of French officers in his system of defensive sea mining. Returning to London, he opened a school of instruction in electric torpedoes, which was attended-at the expense of their governments-by naval officers of Sweden, Holland, and other nations. At the instance of Mr. C. B. Richardson, a New York publisher, he undertook a series of geographical text-books, saying as he went to his task, "I could not wind up my career more usefully (and usefulness is both honour and glory) than by helping to shape the character and mould the destinies of the rising generation." $\mathrm{He}$ also wrote a popular book on astronomy, which has never been published.

In 1868 Maury received the degree of LL. D. from the University of Cambridge, along with Alfred Tennyson, Max Müller, and Mr. Wright, the Egyptologist. In the same year he declined an invitation from Napoleon III to the directorship of the Imperial Observatory of France. Taking advantage of the general amnesty act to return to the United States, he declined the superintendency of the University of the South at Suwanee, Tenn., to accept the professorship of Meteorology at the Virginia Military Institute. Pending his entrance upon the duties of this position, he considered a scheme for establishing a line of steamers between Norfolk and Flushing in Holland. 
During the last four years of his life he worked at a meteorological survey of Virginia. He engaged actively again in the advocacy of his old scheme for a Telegraphic Meteorological Bureau, in furtherance of which he repeated an address in Boston and Missouri and several places in the South. A paper on this subject, presented to the International Congress, at St. Petersburg, for the Advancement of Geographic Knowledge, etc., was unanimously approved by that body. The exposure incident to travel in fulfilling his lecturing appointments brought on the illness which ended with his death; but he continued, to within a few days of that event, dictating and revising the last edition of his Physical Geography.

Commander Maury is described by his daughter as having been a stout man, about five feet six inches in height, with fresh, ruddy complexion, curling brown hair, and with every feature of his bright countenance bespeaking intellect, kindliness, and force of character. "His fine blue eyes beamed from under his broad forehead with thought and emotion, while his flexible mouth smiled with the pleasure of imparting to others the ideas which were ever welling up in his active brain. . . . His conversation was enjoyed by all who ever met him; he listened and learned while he conversed, and adapted himself to every capacity. He especially delighted in the company of young people, to whom his playful humour and gentle consideration made him very winning." N. P. Willis, speaking of him to a friend, said that he made him subject to his personal magnetism, and, during a trip while they were together, "unconsciously furnished an exquisitely interesting study of character." $\mathrm{He}$ was a firm believer in the Christian religion, but did not join the Church till I867, when he was confirmed with his children in the Episcopal Church.

Maury had eight children, five daughters and three sons. His biographer was his second child, Diana Fontaine, who married Mr. S. W. Corbin, of Farleyvale, Va. He had pet nicknames for all except the eldest, and the children knew that something was wrong if he called them by anything else. $\mathrm{He}$ never found it necessary to shut himself up away from their noise to work, and as they grew old enough they gave him in turn much valuable aid as amanuenses.

Maury's published works, books, pamphlets, and official papers were numerous, and bore reference to the researches 
which have been described in this sketch, concerning which they stand as original authorities. Orders were conferred upon him by the sovereigns of Russia, Denmark, Portugal, Belgium, and France; gold medals by those of Prussia, Austria, Sweden, Holland, Sardinia, France, and the free city of Bremen; and other honours by the Pope and Maximilian. He was a member of ten foreign and four American scientific and historical societies that are named, and of many other learned bodies of which the records were lost during the war. 



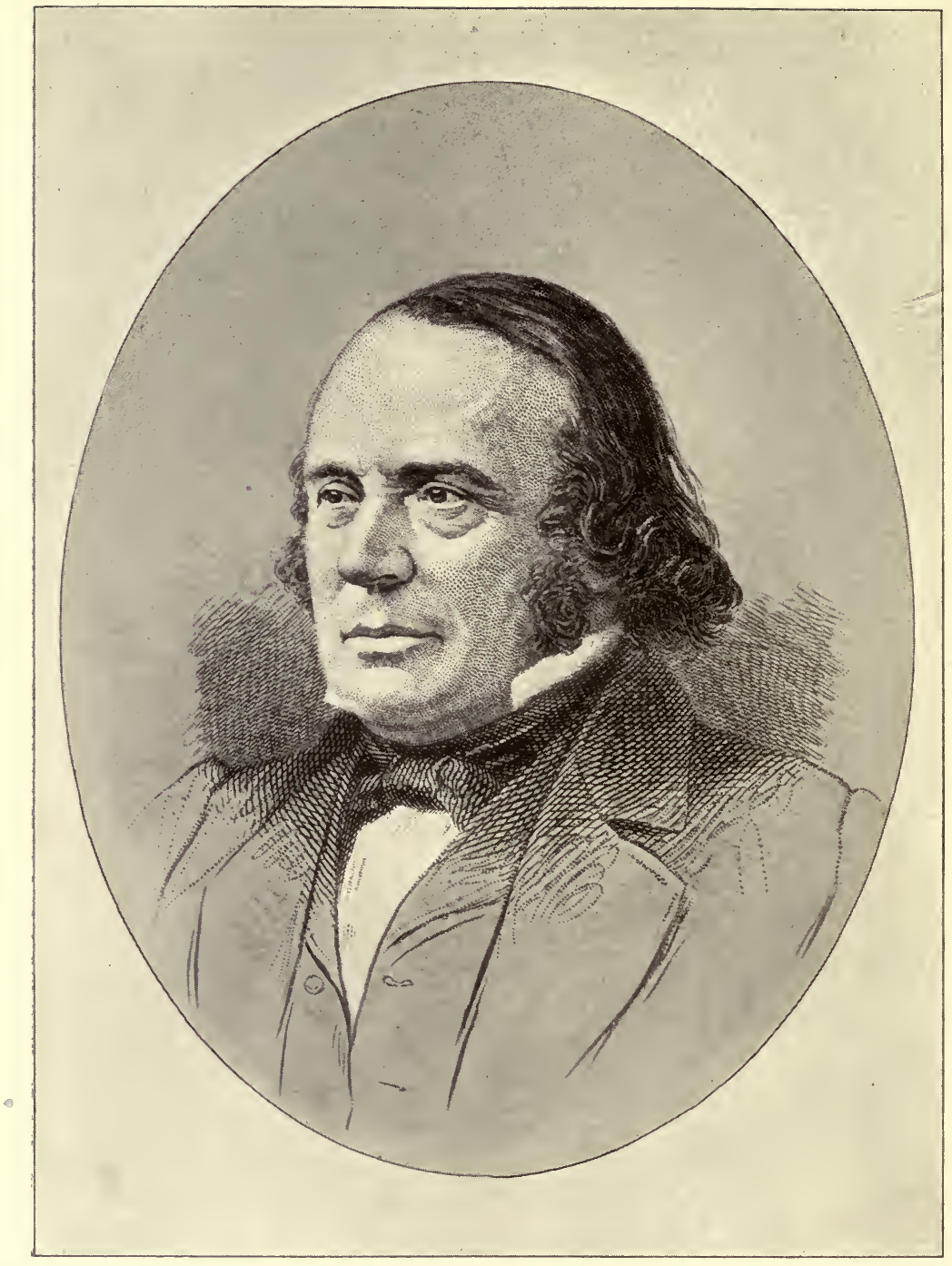

JEAN LOUIS RODOLPHE AGASSIZ. 


\section{JEAN LOUIS RODOLPHE AGASSIZ.}

$$
\text { I } 807-1873 \text {. }
$$

Jean Louis Rodolphe Agassiz was born in the Swiss village of Motier, on the shore of Lake Morat, May 28, 1807. His father, Louis Rodolphe Agassiz, was a clergyman; his mother, Rose Mayor, was the daughter of a physician of Cudrefin, a village on the shore of Lake Neuchâtel, about four miles away. Having lost her first four children in infancy his mother watched anxiously over his early years.

Louis's interest in the animal kingdom appeared at an early age. A great stone basin behind the parsonage house, through which a pure spring of water always flowed, was his first aquarium. He had also a variety of other pets-birds, field-mice, hares, rabbits, guinea-pigs, etc. Although fish are commonly looked upon as among the most intractable of animals, young Louis early gained such a knowledge of their haunts and habits as to have a surprising power over them. He and his brother Auguste, two years younger than Louis, had little need of hook or net for capturing the finny denizens of the lake. "They acquired such dexterity that when bathing they could seize the fish even in the open water, attracting them by little arts to which the fish submitted as to a kind of fascination." Almost every country-bred boy learns more or less of such field and water craft, but in Agassiz it was the foundation of a career. Like many another bright and nimble-fingered lad, too, he imitated the arts of the mechanics who came to his father's house from time to time, " and when a very little fellow, he could cut and put together a well-fitting pair of shoes for his sisters' dolls, was no bad tailor, and could make a miniature barrel that was perfectly water-tight. He remembered these trivial facts as a valuable part of his incidental education. He said he owed much of his dexterity in manipulation 
to the training of eye and hand gained in these childish plays."

When Louis was ten years old he was sent to a school for boys at Bienne. Up to this time his parents had been his only teachers; and he could not have had better. Wherever his father was settled as pastor his influence was felt hardly less in the schools than in the pulpit. At Bienne nine hours of school work a day were required-an amount that would not be borne in American schools, and that doubtless goes far to explain the superior attainments that Americans recognise in men educated in Europe. Yet whether or not from some difference in method, or climate, or mode of life, or temperament, the boys were healthy and happy under these exactions. After four years at this school the time came when it was intended that Louis should enter the business house of an uncle at Neuchâtel, as his parents did not feel able to give him further educational advantages. But the boy had formed the desire to become a man of letters and begged for at least two years in the academy at Lausanne. His request, which was supported by his former teachers, was granted. At Lausanne his taste for everything bearing upon the study of Nature became more pronounced. His mother's brother, Dr. Mathias Mayor, who was a prominent physician in Lausanne, soon perceived the bent of the youth's mind, and advised that his nephew be allowed to study medicine as the calling probably most congenial to him. His parents were persuaded to this view, and Louis at seventeen years of age entered the medical school of Zurich. His brother Auguste, who had entered the school at Bienne a year later than Louis, was still his constant companion. Many an hour did the young students spend in copying books which their scanty means would not permit them to buy. This was largely a labour of love on the part of the younger brother, for the books were more needed in Louis's studies than in his.

After two years at Zurich Louis went, early in I826, to the University of Heidelberg, while Auguste entered upon commercial life in Neuchâtel. At the university the letters that Louis brought from former instructors, together with his diligence and winning disposition, quickly gained the interest of his professors. At the suggestion of one of them he made the acquaintance of a fellow-student, Alexander Braun, who was as enthusiastic a botanist as Agassiz was a zoölogist. They 
became fast friends for life. Karl Schimper was another friend whom he found at Heidelberg. As the distance made it too expensive for Agassiz to spend his vacations with his parents, he soon became accustomed to pass them at the home of Braun at Carlsruhe. Braun's father was much devoted to science, having a rich collection of minerals, and his house afforded abundant facilities for the studies of his sons and their young friends. Here young Braun brought Agassiz in the spring of 1827 to recover from an attack of typhus fever. And when the patient was advised to recruit in his native air, Braun accompanied him all the way to his own home. Braun having become convinced that there were especially good facilities for scientific study at Munich proposed that Agassiz accompany him there in the fall of the same year. To this the latter readily assented, and Schimper soon followed them. Here, under Martius, Oken, Döllinger, and Schelling, he devoted himself eagerly to the pursuit of natural history, though still as at Heidelberg keeping up his medical studies out of deference to the wishes of his parents. At that time Martius was publishing his great work on the Natural History of Brazil, and Spix, who was editing the zoölogical portion, having recently died, Martius intrusted to Agassiz the description of the fishes. In this work, which was admirably well done, Agassiz characterized nine genera, embracing forty-two species new to science.

For some time Agassiz had contemplated a monograph on the Fresh-water Fishes of Central Europe, but pecuniary embarrassment rendered this impossible, till a bookseller by the name of Cotta, to whom Agassiz showed the material he had collected, furnished him the means necessary for its completion. Meanwhile he studied and obtained the degree of Doctor of Philosophy, and soon after obtained that of Doctor of Medicine. After his examination, Agassiz went to Vienna, and applied himself closely to the study of actual and fossil ichthyology. He then spent a year at home continuing his studies and practising medicine, after which, in the fall of 1831 , he went to Paris, where he made the acquaintance of Cuvier and Humboldt, both of whom warmly welcomed this expert young naturalist. Here he lived on the most intimate terms with Cuvier for some months, till the death of that naturalist, when he returned to Switzerland and established himself at Neuchâtel, where he was appointed 
Professor of Natural History. This position he held till his departure for America, although in the meantime invited to Geneva and Lausanne.

Through the aid and influence of Humboldt, between whom and Agassiz there existed the warmest friendship, he was enabled to begin the publication of his Poissons Fossiles, a work evincing such careful and profound research, and such a wonderful power of generalization, as to obtain for him a place among the very first naturalists of the day. Cuvier, who had intended to prepare such a work, generously abandoned his plan after perceiving his young friend's capability, and gave Agassiz the use of his material. This work, which appeared in parts, between the years 1833 and 1845 , comprises five volumes, of about 1,700 quarto pages, with an atlas of 400 folio plates, and contains descriptions of nearly a thousand species of fossil fishes. Aside from the great number of species, genera, and families established, Agassiz adopted an entirely new system of classification. In the classification proposed by Cuvier, fishes were divided into two orders, according to the nature of the skeleton, viz., cartilaginous and osseous. Agassiz-looking upon the external covering of the animal as a reflex of the connection existing between the being and its surroundings, bearing the imprint of all the peculiarities of its existence, and consequently of its organization-deemed that the true principle of the classification of fishes was to be found in the scales. In view of this he proposed a division of the families of fishes into four orders, viz., Placoids, in which the scales are represented by plates of enamel, as in the sharks; Ganoids, in which the scales consist of angular bony plates covered with a thick layer of enamel, as in the garpikes; Ctenoids, or fishes with true scales, in which the posterior edges of the laminæ are toothed; and Cycloids, in which the scales are composed of simple laminæ with smooth posterior edges. Agassiz found that the study of fossil fishes exhibits a remarkable parallelism between the development of the individual and that of the class in geologic time. During part of the embryonic life of fishes, and even in some adult forms, the dorsal cord exists as a simple gelatinous cylinder, surrounded by a fibrous sheath, in which, after a time, there is found a cartilaginous and then an osseous deposit, which goes to form the vertebræ, the ossification taking place first in the apophyses. This embyronic character 
Agassiz found to be peculiar to the fossil fishes of the earlier geologic ages. There is no trace of a vetebra, but the apophyses, usually ossified, rest directly on the spinal cord.

In October, 1833, Agassiz married Cecile, the sister of his life-long friend Alexander Braun. With rare artistic talent she had greatly aided her brother by making drawings of botanical objects, and she now performed a similar service for her husband.

The appearance of the first part of his Fossil Fishes had won for Agassiz the Wollaston prize of the Geological Society of London. In 1834 , and again in 1835, Agassiz visited England and received the kindest attentions from Buckland, Sedgwick, Murchison, Lyell, and others, and much aid in his researches.

Agassiz next turned his attention to the study of Mollusca and Echinoderms, and in 1836 published a prodromus of the Echinoderms, and in 1837 a treatise on the fossil Echinoderms of Switzerland. In 1839 he began a more elaborate work, entitled Monographies d'Échinodermes vivants et fossiles, a most important contribution to modern zoölogy. This work comprises five parts: the first and second, on the Salenies and Scutella, by Agassiz; the third and fourth, on the Galerites and Dysaster, by Desor; and the fifth, Anatomie du genre Echimus, by Valentin. While he was publishing his work on the Echinoderms, this indefatigable naturalist also described and figured a large collection of fossil shells from the Oölite and Cretaceous formations, in a work entitled Études critiques sur les Mollusques du Jura et de la Craie, besides issuing an annotated German translation of Buckland's Geology, and French and German translations of Sowerby's Mineral Conchology.

Notwithstanding the immense amount of work on his hands, Agassiz found time to prosecute his investigation upon the fresh-water fishes of Europe. The first part of his work upon them, issued in 1839, is devoted to the genera Salmo and Thymallus. The second part, which did not appear till 1842, consists of a folio of plates and a volume of text on the Embryology of the Salmons, by Carl Vogt, whom Agassiz had associated with him in his work. This excellent treatise was never completed; Agassiz's departure for the United States shortly after, and his increasing responsibilities, prevented the perfecting of his original plan. 
In 1842 Agassiz began the publication of his Nomenclator Zoologicus, an alphabetical list of every genus, with the name of the author, the work in which it originally appeared, the derivation of the name, and the family to which the genus belongs; the list embracing upward of seventeen thousand names. In the introduction the author discusses at length the rules proposed by the British Association and those of the British Committee, in regard to assigning and changing the names of genera and species, the settlement of priority, the proper terminations of zoölogical names, and other like matters.

The Fossil Fishes was now approaching completion, but, in consequence of additional material, Agassiz determined to publish a supplement; and accordingly there appeared, in 1844 , the Fossil Fishes of the Old Red Sandstone. It was accompanied by an atlas of thirty-nine folio plates illustrative of the seventy-six species described.

Of all Agassiz's investigations, perhaps none made his name more popularly known than his studies on glaciers-studies which were pursued through a long course of years, and conducted with the same painstaking care that had heretofore characterized all his labours.

About the year $1834, M$. Charpentier advanced the theory that the erratic blocks, and certain dikes of peculiar shape found in the Alpine regions, were the result of the action of former glaciers descending from the Alps and reaching even the upper portions of the Jura. This theory Agassiz deemed improbable, till, having visited Charpentier and investigated the phenomena, he not only became convinced of the correctness of Charpentier's views, but deduced from these and other phenomena a theory which, at the time (1837), was startlingly novel. It was that, previous to the elevation of the Alps, the globe experienced a very great reduction of temperature, and that the appearance of those mountains found the surface of the globe, from the north pole to the Mediterranean Sea, covered with an immense sheet of ice. An elevation of temperature, consequent upon the upheaval of the Alps, caused this ice slowly to disappear, remaining longest in the valleys, where it gradually retreated to its present limits, leaving behind it, as a record, the peculiar phenomena which have attracted the attention of so many observers.

Of course a theory so novel at once raised a storm of oppo- 
sition, and it became necessary for Agassiz, if he would prove the correctness of his views, to make the most careful and thorough investigations on living glaciers. For this purpose Agassiz, in company with Desor and several others, made visits in 1838 and 1839 to the glaciers of Mont Blanc and the Bernese Oberland, and in 1840 established himself for the summer on the glacier of the Aar. That year he published his Études sur les Glaciers, giving the results of his investigations up to that time. $\mathrm{He}$ also visited England, Scotland, and Ireland, and studied the evidences of ice action in those countries. He persuaded Arnold Guyot, who had been his friend from boyhood, to join him in this work, and after their first season, 1838 , divided the work with him and Desor.

But his labours were not finished. Doubting the sufficiency of the theory of De Saussure-that the cause of the motion of the glacier depends upon gravity-and inclined to accept the dilatation theory of Scheuchzer, it became necessary for him to examine with care the structure, form, distribution, and rate of motion of the glacier. Thus it was that, in $184 \mathrm{I}$, he began a second series of observations for the purpose of determining these points. He chose, for the theatre of his investigations, the glacier of the Aar, which, by its extent and accessibility, promised the most favourable results. In 1845 he had completed his work, and in 1847 appeared his Systeme Glaciaire, which embodied the final results of his researches upon the structure of glaciers, and their effects upon the soil. The results at which he arrived constitute the chief part of the theory of glaciers as accepted to-day, accounting for their formation, their stratification, their blue bands, their movement, their moraines, the grooved or polished surfaces of the rocks over which they pass, and the erratic blocks left where old glaciers have been. Some important additions have been made by Tyndall, and there are a few points on which these two investigators disagreed.

Charles Bonaparte, Prince of Canino, had for several years been planning a scientific journey in the United States, and had invited Agassiz to accompany him. The latter had agreed to the proposal, and, in order to prolong his stay, obtained, through the influence of Humboldt, a grant of 15,000 francs from the King of Prussia. The Prince was obliged to give up the journey and Agassiz went without him. For the last few 
months before his departure Agassiz was busily engaged in completing several scientific undertakings that he had in hand. Then, leaving his son Alexander at school at Neuchâtel and his wife, with their daughters, in the care of her brother, at Carlsruhe, he sailed for the United States in September, I 846.

Agassiz was thirty-nine years of age when he came to the land that was to be his home for the rest of his life. His reputation had preceded him, and he was most cordially received by American scientists. Before leaving Europe he had made through Lyell an engagement to deliver at the Lowell Institute, Boston, a course of lectures on The Plan of Creation, especially in the Animal Kingdom. His audiences were so well pleased that after the completion of this course he undertook one on glaciers, also in Boston, which was highly successful. The next summer he took a small house at East Boston and gathered around him a corps of naturalists and illustrators, among them being Count François de Pourtales, who had accompanied him to this country, E. Desor, and Jaques Burkhardt. He also made journeys to visit men of science or to explore interesting localities, and the following winter lectured in Boston and other cities. Before this winter was over, in February, I848, came the proclamation of the French republic, and then all Europe was in turmoil. The canton of Neuchâtel had been a dependency of Prussia, which explains why Agassiz was in the pay of the Prussian king. The republican party at once rose up in Neuchâtel and carried the canton into the Swiss confederacy. As a consequence, Agassiz was honourably discharged from his commission. The Lawrence Scientific School was being organized about this time in connection with Harvard College. Mr. Abbott Lawrence, its founder, offered the chair of Natural History in this school to Agassiz, who accepted it, and held the position till his death.

The Swiss naturalist now took up his abode in Cambridge, and became a leading factor in the scientific development of the Western republic. He soon had the pleasure of welcoming to the shores of America Guyot and others of his old friends, who were dislodged by the overturn in Europe. The death of his wife soon broke another of his own ties to the Old World.

Delightful facilities for research were afforded to Agassiz in the course of his first summer in America by excursions on the United States Coast Survey steamer Bibb, then employed in 
the survey of Massachusetts Bay. From this time to the end of his life, under Superintendents Bache and Pierce, courtesies were frequently extended to him by the Survey, to the specific benefit of the latter's work as well as of science in general.

Agassiz had not been two years in this country before he began publishing in English. The first part of Principles of Zoölogy, by L. Agassiz and A. A. Gould, appeared in 1848 . Several editions were disposed of, mainly for school use, but its sale was checked by the lack of a concluding part, which was never issued. The same year, in connection with $\mathrm{H}$. E. Strickland, he began the publication of a Bibliographia Zoologice et Geologice. This work, which comprises a list of all the periodicals devoted to zoölogy and geology, and an alphabetical list of authors and their works in the same departments, was completed in four volumes, the fourth being published in 1854 .

Agassiz's studies on the glaciers of Switzerland led him to expect to find in the United States many traces of former ice action. Nor was he disappointed. He explored the country from the Atlantic to the Rocky Mountains, from the Great Lakes to the Gulf of Mexico, and everywhere, north of the thirty-fifth parallel of latitude, found evidences of glacial action, in erratic blocks, polished and striated rock surfaces, and terminal moraines. Naturally this served to confirm his belief in the universality of the ice period; and, upon his departure for Brazil, in 1865 , he announced his confident expectation of finding records of the former existence of glaciers in that country; for he believed that not only most of the Northern, but also most of the Southern Hemisphere was, during the glacial epoch, encased in ice. The evidences of glacial action in the United States are fully discussed by Agassiz in his Lake Superior, a work on the physical character, vegetation, and animals, of Lake Superior, compared with those of other and similar regions.

Agassiz was a firm believer in the diversity of origin of the human race, and his views on this point are ably presented in the Christian Examiner for July, 1850 , and in an introduction to Nott and Gliddon's Types of Mankind. The geographical distribution of animals shows, he maintained, that distinct zoölogical provinces are each characterized by peculiar fauna, and that therefore animals did not originate from a common centre 
nor from a single pair. The races of men, in their natural distribution, cover the same ground as the zoölogical provinces, and he believes there is every reason to suppose that these races originally appeared as nations in the regions they now occupy.

In the spring of $185^{\circ}$ Agassiz married Elizabeth Cabot Cary, daughter of Thomas Graves Cary, of Boston. This marriage bound him still more closely to America, and enabled him to give his children a home here. $\mathrm{He}$ accordingly sent for his daughters, his son, then thirteen years old, having joined him the summer before.

Being commissioned by Mr. Bache, the Superintendent of the Coast Survey, to investigate the nature of the Florida keys and reefs, and the channels dividing them, as also their relation to the hummocks and everglades of the mainland, he spent about two months in the winter of $185^{\circ}-{ }^{\prime} \mathrm{r}$ in this work. From his report the Coast Survey derived much valuable information concerning the maintenance of channels, and the placing of signals, and of foundations for lighthouses. In the following winter he entered upon an appointment as professor at the Medical College in Charleston, S. C. His course of lectures there occupied the winter months-between his autumn and spring courses in Cambridge-and relieved him from the necessity of travelling about to lecture in different cities, which had already somewhat taxed his health. It was at the end of his first winter in Charleston that news came of the award of the Cuvierian prize to him for his Fossil Fishes. During part of his second winter in Charleston he was dangerously sick with a fever, and in the following spring he resigned his professorship. In the winter of $1854-55$ he resumed his public lectures, but it became evident in the spring that he must give up this practice.

Some other means of supplementing his scanty salary must be found, and at this juncture his wife and daughters proposed to open a girls' school. Agassiz not only approved the plan, but entered into it himself, and was an important factor in the splendid success that it enjoyed for its eight years of existence. The adverse influence of the civil war, added to the fact that the income from it was no longer needed, brought it to a close in 1863 .

Ever since his arrival in America, Agassiz had been collect- 
ing material for a series of Contributions to the Natural History of the United States. In I 857 appeared two volumes of these contributions; the first containing an Essay on Classification and the history of the North American Testudinata; the second on the Embryology of the Turtle, and was illustrated with thirty-four plates.

In the essay on Classification, Agassiz affirms that Nature is but the expression of the thought of the Creator, and that a true classification will be found to be but an unfolding of the plan of creation, as expressed in living realities; that these realities do not exist in consequence of the continued agency of physical causes, but appear successively by the immediate intervention of the Creator. We find in Nature a progressive series, from lower to higher forms; but it is not a uniform progress for the animal kingdom as a whole; neither is it a linear progress for the branches or classes, but a progress in which each type has usually been introduced by the creation of species belonging to one of its higher groups, for the earliest representatives of a class do not always seem to be the lowest. Yet, notwithstanding these downward steps, the progress has continually tended toward the production of higher and higher types, culminating at last in Man.

The third volume of the Contributions appeared in 1860 , and was devoted to the class of Acalepha, the author treating specially of the order Ctenophore. The fourth volume, issued in 1862, concluded the Acalephre. The plan of the work had contemplated ten volumes, but only these four were completed in his lifetime. A fifth volume on North American starfishes appeared after his death.

From his early student days Agassiz's collections were a source of care and solicitude to him. In a letter written from Munich, he values his accumulations at two hundred louis, near one thousand dollars, and calls this a low estimate. His grandfather gave them houseroom for a while, and they, with later additions, were finally disposed of to the Lyceum of Neuchatel when Agassiz entered upon his professorship there. Starting anew after he came to America, he gathered specimens more rapidly than before. During his first years at Cambridge an old boathouse on the bank of the Charles River served as a storehouse for them. By 1850 they had acquired such volume as to make a severe drain upon his income merely to preserve 
them from destruction. In that year a wooden building on the college grounds was provided for their storage, and four hundred dollars was allowed him as an annual grant toward the expense of keeping them. Soon after this certain friends subscribed twelve thousand dollars to purchase his collections, thus relieving him and securing the precious material for Cambridge permanently-provided fire did not seize upon their frail shelter and the jars of alcohol in which many of the specimens were preserved, involving all in ruin.

The creation of a great and systematically arranged zoölogical museum had been the dream of Agassiz's life. $\mathrm{He}$ would have its collections so arranged as to show the relation of each part of the animal kingdom to all others, so that it might be a powerful means for training teachers of science in the common schools, for illuminating the text-books of their pupils, and for educating the general public. He would have, also, in connection with it, laboratories for special students, with abundance of duplicate specimens, and all the appliances needed for their studies and researches. Fortunately, he was able, in great measure, to attain his ideal. In $1858 \mathrm{Mr}$. Francis C. Gray, to whom he had explained his purpose, died, leaving by his will fifty thousand dollars for the establishment of a Museum of Comparative Zoölogy. A grant of lands worth one hundred thousand dollars was obtained from the Legislature of Massachusetts, a private subscription of over seventy thousand dollars was raised, and Harvard College gave an ample site for a building. By these events Agassiz's vacation trip to Europe in the summer that followed them was made doubly happy.

The plan of the museum building provided for a main structure three hundred and sixty-four feet long, with wings two hundred and five feet long, the whole forming three sides of a square. A section of the north wing, about eighty feet in length, was built in $1859-' 60$, being sufficient for the time being. One addition was made before Agassiz's death, and since then the original plan has been filled out by successive additions. As soon as the first portion was ready he set about installing the collections in it. Its laboratories were soon open to students, and from this time on his lectures. were given there. These pursuits, with writing, now occupied him during the college year at Cambridge. Summers he spent at Nahant, a favour- 
ite resort on a rocky peninsula north of Boston Harbour, where his father-in-law, Mr. Cary, had given him a cottage and laboratory. Here he could study the fauna of the seashore to excellent advantage.

When the civil war broke out he worked on in full confidence that the country would weather the storm, and testified to his faith by becoming naturalized in the darkest hour of the struggle. He deeply felt the misrepresentations of the North that appeared in British newspapers, and in his letters to British men of science took pains to convey correct ideas of American affairs. Early in this period he was enabled to begin issuing the illustrated bulletin of the museum, by a grant of ten thousand dollars from the Massachusetts Legislature. While exerting himself to the utmost to advance his own department, Agassiz was deeply interested in the welfare of Harvard as a whole, and faithfully performed his duty as a member of the academic council of the university.

In the spring of 1865 , feeling the need of complete change of scene, and a release from indoor occupations, Prof. Agassiz planned a trip with his wife to Brazil. Meeting Mr. Nathaniel Thayer, of Boston, one day, the latter engaged him in a conversation about the proposed trip, and in the course of it offered to pay the expenses of half a dozen scientific assistants. The expedition was accordingly organized and was gone sixteen months. The Pacific Mail Steamship Company gave his party free transport to Rio de Janeiro, the Secretary of the Navy equipped him with a letter requesting commanders of United States vessels of war in southern waters to give him aid and support, while the Emperor of Brazil, with whom Agassiz had long been in friendly relations, showered aid and attentions upon him. The first three months in Brazil were spent in Rio de Janeiro and vicinity, the next ten on the network of Amazonian waters, and finally two months were devoted to excursions along the coast and in the mountains near Ceara and Rio. It will be remembered that his first scientific work was on Brazilian Fishes, and he now made the fresh-water fauna of Brazil one of his two subjects of inquiry. The other was the glacial history of the southern America, which he found as plainly written as he had expected. He brought home many hundreds of species of new fishes where less than two hundred had been known before. An account of the trip was written by him 
and Mrs. Agassiz and published under the title A Journey in Brazil.

In the autumn of 1869 Agassiz's overtasked brain made an unmistakable demand for rest. $\mathrm{He}$ was withdrawn entirely from mental occupation for the whole of the following winter, and spent a period of convalescence at Deerfield, Mass., in the next spring. Agassiz was then sixty-two years old. He had had his periods of sickness before, but no such peremptory check as this. Late in 1870 he returned to his work, and his recovery of health seemed to be so complete that Prof. Benjamin Pierce, then Superintendent of the Coast Survey, ventured to write him, in the February following, "I am going to send a new iron surveying steamer round to California in the course of the summer. She will probably start at the end of June. Would you go in her and do deep-sea dredging all the way round? If so, what companions will you take?" Agassiz went, taking as companions Count de Pourtalès, who had been associated with him in many such researches, Dr. Franz Steidachner, of the museum staff, and Mr. Blake, a student at the museum. Mrs. Agassiz was also of the party. The steamer was the Hassler. Owing to various delays it did not sail until December $4,187 \mathrm{I}$. The season and defects in the vessel's machinery and equipments compelled a reduction of the contemplated operations, yet the trip was profitable and extremely pleasant. Reaching San Francisco in August, 1872, Agassiz was back in Cambridge two months later.

During his absence some of his younger scientific associates had formed an educational plan which they felt sure needed only Agassiz to be a success. This was for a school of natural history at the seashore during the summer months, in which teachers from our schools and colleges could make their vacations serve both for recreation and for study from the open book of Nature. Although no facilities or means for the undertaking were in sight, Agassiz entered heartily into the scheme. An appeal which he made to the Legislature of Massachusetts in its behalf the following spring was read in a newspaper by Mr. John Anderson, of New York, who had acquired wealth in the tobacco business. Mr. Anderson at once offered as a site for the school the island of Penikese, off the southern shore of Massachusetts, at the entrance of Buzzard's Bay, together with the furnished dwelling and barn upon it. Scarcely 
was this gift accepted when he added an endowment of fifty thousand dollars for the equipment of the school. Early in July the school was opened, and a most profitable summer was spent on the island by the fifty or sixty persons there assembled. The resident professors besides Agassiz were Burt G. Wilder and Alpheus S. Packard. Count de Pourtalès was there in charge of the dredging, for which purpose Mr. Charles G. Galloupe had given the school a yacht. Agassiz's friend from youth, Prof. Guyot, came to deliver a course of lectures and remained some time.

In the fall Agassiz returned to his usual occupations. The care of the summer school had imposed an added strain upon his long over-burdened nervous system, and his health was now a subject of anxiety to his friends. One day in December he went home early from the museum, complaining of great weariness, and, after an illness of eight days, he peacefully passed away December 14, 1873. He was buried at Mount Auburn. A boulder from the glacier of the Aar is his monument, and around it grow pine trees also sent from Switzerland.

As a naturalist, Prof. Agassiz was unwearied in his devotion to his favourite pursuits. He worked early and late, often denying to himself the most necessary rest and recreation; and his remarkably strong constitution sustained him under a strain that would quickly have proved fatal to a man of less vigour. His mind was pre-eminently great; gifted with a wonderfully retentive memory, he combined with it a power of generalization and quick perception that places him next to Cuvier, whose disciple he was, and whom he seemed to imitate. In his methods of investigation he was perfectly honest, and, though many might differ from him in his conclusions, none could deny the absolute integrity of his convictions. His intercourse with his fellow-men was pervaded by his goodness of heart and childlike simplicity With inexperience he was most patient and painstaking, never wearying in his efforts to aid. Tolerant of ignorance where associated with modesty, he had but little patience with arrogance and ignorance combined. His students will all bear witness to the unvarying cheerfulness and ready sympathy in him they had learned to look up to as their master.

Agassiz was a great naturalist, but he was a greater teacher. 
From his student days, when he and Braun and Schimper used to expound to each other what they had learned, down to the summer at Penikese-his last on earth-he took no less pleasure in imparting than in acquiring knowledge. And his teaching was singularly impressive. He made his pupils not only know, but understand. Laboratory work and original research were his chief educational appliances years before other instructors had escaped from the bondage of textbooks. "If you study Nature in books," he said, "when you go out of doors you can not find her." This mode of instruction, then so novel, often induced in his students at first a comical feeling of despair. "Observation and comparison," writes Mrs. Agassiz,* "being in his'opinion the intellectual tools most indispensable to the naturalist, his first lesson was one in looking. He gave no assistance; he simply left his student with the specimen, telling him to use his eyes diligently and report upon what he saw. He returned from time to time to inquire after the beginner's progress, but he never asked him a leading question, never pointed out a single feature of the structure, never prompted an inference or a conclusion. This process lasted sometimes for days, the professor requiring the pupil not only to distinguish the various parts of the animal, but to detect also the relation of these details to more general typical features." Mr. Samuel H. Scudder, in his essay In the Laboratory with Agassiz, gives an amusing account of such a first lesson, entirely devoted to a single fish.

Agassiz never accepted the theory of evolution in the animal kingdom, although Darwin's Origin of Species was before the world during the last fourteen years of his life. On this account he is sometimes spoken of as a naturalist who fell behind the progress of his age. Yet, excepting Darwin, no man of his time did so much to carry the science of zoölogy forward as he. Agassiz was to Darwin as he who lays the firm, level track is to the builder of the locomotive. Without him evolution might still he butting against the ledges of prejudice or floundering in the sloughs of vague knowledge. Prof. Joseph Le Conte says, "I think it can be shown that to Agassiz, more than to any other man, is due the credit of having established the lares of succession of living forms in the geological history

* Louis Agassiz: his Life and Correspondence, p. 566. 
of the earth-laws upon which must rest any true theory of evolution. Also, that to him, more than to any other man, is due the credit of having perfected the method (method of comparison) by the use of which alone biological science has advanced so rapidly in modern times." * He saw clearly that the embryonic development of the higher animals consisted of a series of stages corresponding to an ascending scale of lower animals, and he was the first to show that both corresponded to the succession of forms in geologic time. He also announced the laws by which the geological succession of animal forms proceeds-he refused only to recognise the result that must come from the operation of these principles and laws. To his simply but tenaciously devout mind the derivative origin of species could not be true, for it seemed to eliminate the Creator.

* Evolution and its Relation to Religious Thought, p. 38. 


\section{ARNOLD HENRY GUYOT.}

$$
\text { I } 807-1884 \text {. }
$$

THE political disturbances of $\mathrm{i} 848$, injurious as they were to Switzerland, were a great and direct gain to America, for they gave to this country Agassiz, Guyot, and Lesquereux, for a long time eminent labourers for the advancement of American science and the diffusion of sound learning among the people. The refuge which this country has afforded to the politically, socially, or religiously oppressed of the Old World has been abundantly recompensed by the labours of those who have taken advantage of it, but never more conspicuously than in the above instances.

Much light is thrown upon the character of Prof. Guyot by certain facts of his descent. The Guyot family became Protestants through the preaching of the French reformer Farel, a contemporary of Luther, and, at the revocation of the Edict of Nantes, was one of sixty families that betook themselves from Dauphiny into the principality of Neuchâtel and Valangin. From such conscientious and high-minded stock have the makers of the American republic been largely drawn.

Arnold Henry Guyot was born at Boudevilliers, near Neuchâtel, September 28,1807 , being one of twelve children, and was named after the Swiss patriot Arnold von Winkelreid. He died at Princeton, N. J., February 8, I884. Young Guyot's father, David Pierre, has been described as a man of "prompt intelligence and perfect integrity," and his mother as "a lady of great personal beauty and rare nobility of character." They were married in I796, Madame Guyot having been Mademoiselle Constance Favarger, of Neuchâtel. About I8I8 the family moved to Hauterive, where M. Guyot died the following year.

In his memoir read before the National Academy of Sciences, Prof. James D. Dana gives this account of Guyot's edu- 


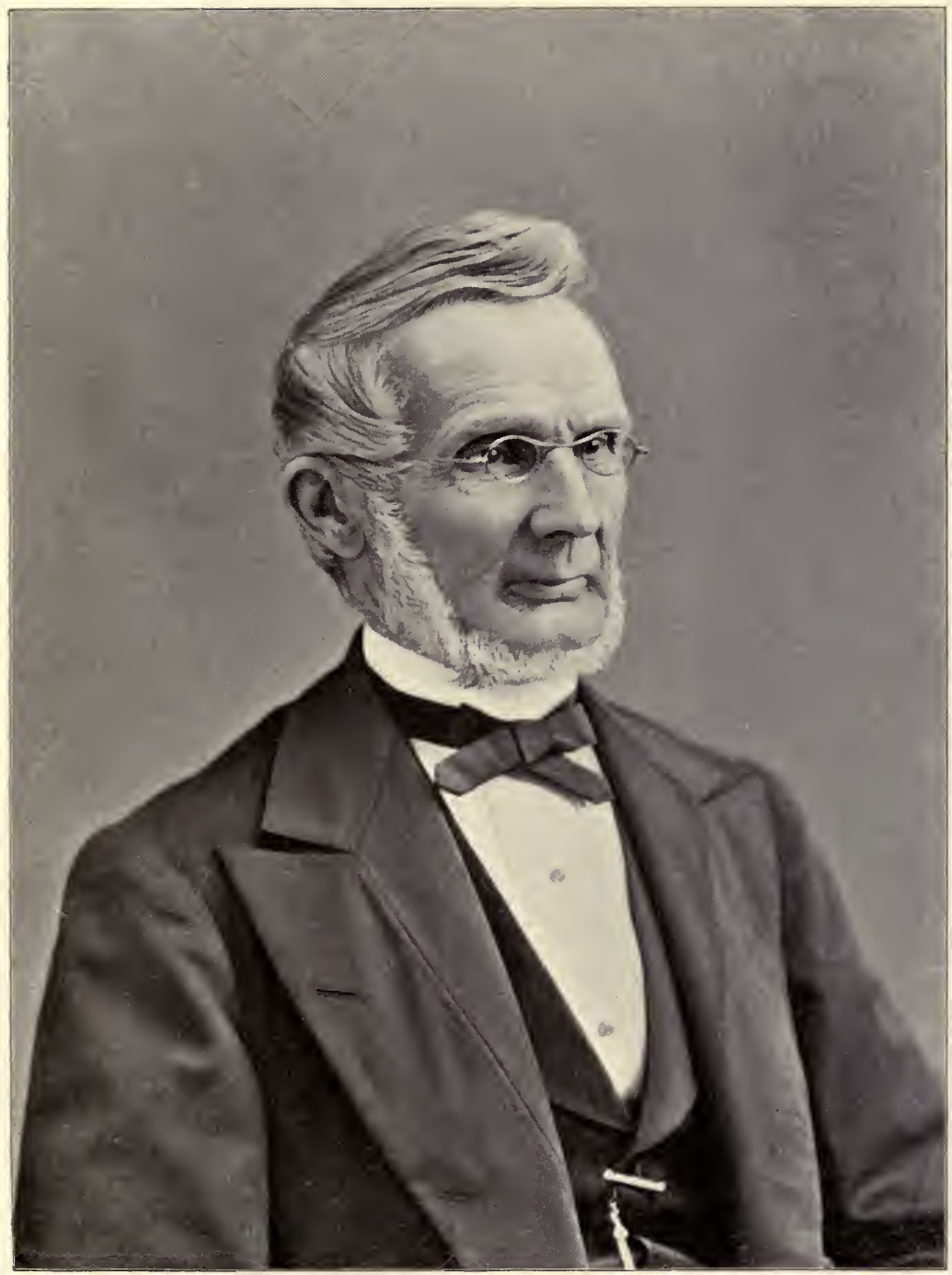

ARNOLD HENRY GUYOT. 

cation, based upon information obtained from Switzerland: "Previous to the year 18r8, and for a while after, Guyot was at school at $\mathrm{La}$ Chaux-de-Fonds, a noted village 'at the foot of a narrow and savage gorge of the Jura,' three thousand and seventy feet above the sea. In $182 \mathrm{r}$, being then fourteen years of age, he entered the College of Neuchâtel, where he was a classmate of Leo Lesquereux, the botanist: 'Guyot and I,' says Lesquereux, 'were for some years brothers in study, working in common and often spending our vacations together, either at Guyot's home at Hauterive, or with my parents at Fleurier; and I owe much in life to the good influences of this friendship.' His studies were classical-Latin, Greek, and philosophy-arranged for preparing a boy for the profession of the law, medicine, or theology, with almost nothing to foster his love of Nature." It is interesting to note that during his school life he was president of the gymnastic club, and one of the best of the school athletes. His slight, wiry frame thus received a training in strength and endurance which afterward stood him in good stead when he undertook the immense labours of glacier study in Switzerland and of mountain surveying in America.

In 1825 he went to complete his studies in Germany, attending successively the gymnasia of Carlsruhe and Stuttgart. At Carlsruhe he resided with a family named Braun, with which several of his relatives had long been intimate. There he met his countryman Agassiz, who, with Imhoff and Carl Schimper, was making a vacation visit to his friend, young Alexander Braun, the discoverer of phyllotaxy. This period was one of the critical points in Guyot's career. There was formed that close and tender friendship with Agassiz which lasted until the latter's death, and found its final expression in the beautiful memoir of Agassiz which Guyot read before the National Academy of Sciences in 1878 . But of still greater importance was the impulse toward the study of science which he received from the enthusiastic group of young naturalists with whom he was thus brought into daily and hourly contact. He says of this period: "My remembrances of these few months of alternate work and play, attended by so much real progress, are among the most delightful of my early days. ... It would be idle to attempt to determine the measure of mutual benefit derived by these young students of Nature 
from their meeting under such favourable circumstances. It certainly was very great, and we need no other proof of the strong impulse they all received from it than the new ardour with which each pursued and subsequently performed his lifework."

From Carlsruhe young Guyot went to Stuttgart, and in 1827 returned to his home in Switzerland. Becoming impressed with a sense of duty to study for the ministry, he began at Neuchâtel a course leading in that direction. In 1829 he repaired to Berlin in order to complete his theological studies; but an obstacle was thrown in his path by an injury to his voice, produced by the severe climate of Berlin, from which he never fully recovered. The love of science was strong within him, and the new field which the lectures of Steffens, Hegel, and Ritter opened up to his view decided him to enter upon the study of Nature as his life-work. Having thus decided, he determined to lay his foundations broad and deep, and with this end in view he attended lectures on nearly all departments of natural science-chemistry, physics, meteorology, zoölogy, geology, and physical geography, alike received attention, and his subsequent career showed the great wisdom of this thorough preparation. In 1835 he received the degree of Doctor of Philosophy, and went to Paris to take charge of the education of the sons of Count de Pourtalès-Gorgier. Here he resided more than four years, occupying his leisure with scientific studies and extending them in vacation tours taken with his pupils through various European countries. He also took up the subject of history under Michelet, and, like everything else which he touched, made it valuable in the great pursuit of his life, the study of earth and man.

In the spring of 1838 Agassiz came to Paris, enthusiastic upon the subject of glaciers, and induced Guyot to turn his attention in the same direction. When the summer came on the latter went to Switzerland and began a study on the glaciers of that country. The rich results of his summer's work were told to Agassiz, and were presented in a paper before the Geological Society of France during the session of 1838 , at Porrentuy. This paper is mentioned in the Proceedings of the society (Bulletin, vol. ix, p. 407), but, owing to a long illness of the author during the following winter, it could not be printed. 
To quote his own statement as to what he had then learned : * "The glacier of the Aar, on which Agassiz began two years later (1840) his regular system of observations, taught me the law of the moraines. The glacier of the Rhône gave me the law of the more rapid advance of the center of the glacier and that of the formation of the crevasses, both transversal and longitudinal. The glacier of Gries showed me the laminated or ribboned (blue bands) structure of the ice deep down in the mass of the glacier, and the law of the more rapid advance of the top over the bottom. On the southern slope of Mont Blanc, the great glacier of La Brenva, with its twin rocks, rising like two dark eyes from the middle of the ice (they are indeed called by the mountaineers the 'eyes of the glacier'), made me understand that the motion of the glacier takes place by a gradual displacement of its molecules under the influence of gravity, giving it a sort of plasticity, and not by simultaneous gliding of its whole mass, as believed by De Saussure. All these laws, deducted from a first but attentive study of the phenomena of the glaciers, were at that time, excepting that of the moraines, new for science."

Agassiz was intensely interested by Guyot's discoveries, and appears to have gone the next year and discovered the same things. Then, with his customary enthusiasm and genius for organizing great enterprises, he proposed a joint research in which Guyot was to have the distribution of erratic rocks in Switzerland as his exclusive province, resigning to Agassiz all that concerned the structure and movement of glaciers, in which the former had made such a brilliant beginning. As part of this plan, in which Guyot modestly accepted the place assigned him, the Porrentuy paper was to remain unpublished. Two years later arose the fierce controversy between Agassiz and Forbes as to priority in certain glacial discoveries. Faithful to the spirit of the above agreement, Guyot took no part in this wordy war, allowing Agassiz to use the work of both as his own. The latter repulsed Forbes's claim as to the blue bands, and secured the credit for Guyot by publishing that part of Guyot's paper describing them, and, in order to have the rest of the paper as ammunition for future use, deposited the manuscript in the archives of the Society of Natural

* Memoir of Louis Agassiz. 
Sciences at Neuchâtel. It was withdrawn by Guyot when he came to America, and was not printed in full until 1883 , when he acceded to the request of the society for permission to do this. Throughout all these years Guyot never claimed the honour due him, contenting himself with a simple statement of the facts after the death of Agassiz.

In I839 Guyot accepted a call to the Academy of Neuchâtel, where Agassiz was already settled, and there he remained till his removal to America in 1848 . His chair was that of History and Physical Geography, and he regarded the years of his work there as the period of his greatest intellectual activity. During this time he gave much attention to his glacial work, taking up the geological side of the question, the erratic blocks and ancient extension of the glaciers, and devoting to this work "absolutely single-handed, seven laborious summers, from 1840 to $1847 . "$ This gigantic undertaking was brought to a successful conclusion, though the results were but partially published, inasmuch as the Système Glaciaire, by Agassiz, Guyot, and Desor, never went further than the first volume (Paris, I 847). Guyot's collection of five thousand specimens chipped from erratic rocks, illustrating eleven erratic basins, now fills a room in the Princeton Museum, a monument of painstaking labour. A duplicate set was deposited in the Museum of the Academy of Neuchâtel.

The political disturbances of 1848 upset the plan for the glacial publication as it did many others. Guyot now followed his friend Agassiz to America, and lived for some time at Cambridge, Massachusetts. After he had got settled in this country he brought over his mother, two sisters, a nephew, and two nieces. During his first winter he delivered in Boston, in the Lowell Institute course, the remarkable series of lectures afterward published in the well-known book Earth and Man. They were delivered in French and translated for publication by Prof. Felton. These lectures were the starting-point of a great reform in the historical and geographical teaching of this country. For six years he was engaged by the Board of Education of Massachusetts as a lecturer to the normal schools on geography and the methods of teaching it, and after leaving the service of that State he followed up the work there commenced by preparing a series of geographical text-books and large maps. To use the words of a writer in Science with 
regard to these books: "It is not too much to say that they revolutionized the methods of teaching geography. Every series of geographies which has since appeared shows the influence of Guyot." He threw aside the old routine methods, and brought his pupil face to face with Nature, showing the bearing of the earth's physical features upon every department of human interest. His geographical works received the medal of progress at the Vienna Exposition of 1873 , and a gold medal, the highest award, at that of Paris, in 1878 .

Another pre-eminent service which Guyot rendered to America was the work he did in meteorology, a science which had received very little attention when he arrived in this country. From 185 I to 1859 he worked at the preparation of the Meteorological and Physical Tables, published by the Smithsonian Institution, and also superintended the construction of accurate meteorological instruments. In connection with Prof. Henry he did much to establish the system of weather observations and reports which has resulted in the Government Weather Bureau.

In 1854 Guyot was elected to the chair of Geology and Physical Geography at Princeton, a post which he filled for the thirty remaining years of his life. Until compelled to cease by the increasing infirmities of age, he devoted all his vacations and spare time to his favourite investigations, making elaborate and careful examinations of the mountains from New England to South Carolina. This work involved an immense amount of hardship and fatigue, and he was fond of describing with quaint picturesqueness and humour his experiences in roughing it in the mountains of Pennsylvania and the Carolinas. In r86r he published in the American Journal of Science and Arts the results of his work up to that time, "a memoir which remains to this day the best existing description." Again, in 1880 , he brought out another memoir on the same subject, devoted chiefly to the Catskills, some of the rough work for which was done after he was seventy years old. Many shorter papers on meteorological, physical, and geographical subjects were written at intervals. His work during this period is a noble example of what may be done without appropriations or endowments, for in those days Princeton was very poor, and he had to do as best he could without assistance.

As a friend and teacher Guyot will ever be held in loving 
remembrance till the last of his hundreds of students shall have followed him to the grave. His lectures were wonderfully fascinating, leading his hearers step by step to heights whence they could survey the whole field of his subject. His broad culture, gained by the combination of the humanitarian and scientific studies, had given him an extraordinary power of generalization, stimulating his students by showing them the relations of any subject which he handled to the whole realm of knowledge. He was able to depict these sciences in their true perspective without distortion or exaggeration, a power which unhappily is not very common. Those who had the rare privilege of pursuing advanced courses of study under his supervision will long remember the great stimulus to earnest work which they received from him, and the clear, philosophical views of Nature which he expounded.

For many years Guyot laboured under great disadvantages from the lack of proper appliances, but he never allowed these drawbacks to lower the character of his work. When Princeton's day of prosperity came, he showed that he knew how to apply money wisely, as before he had been able to accomplish a great deal without it. The system of scientific expeditions to the West, which has so greatly stimulated the study of natural science at Princeton, and added so much to the treasures of her museums, was organized under his direction; and the wonderful growth of all the departments of natural science in the college must be in very large measure attributed to the wisdom and foresight of Guyot.

The visible monument of Guyot's work in Princeton will always be the Museum of Geology and Archæology. He expended with consummate skill the sums placed at his disposal by generous friends, and organized an enthusiastic corps of workers, so that a superb series of collections has been gathered. Thus in every department of activity his influence has been of the utmost service to Princeton in particular, and to American science in general.

In addition to the work of his professorship, Guyot gave courses of lectures at the New Jersey State Normal School, in Trenton, at the Princeton Theological Seminary, at Columbia College and the Union Theological Seminary in New York, and at the Smithsonian Institution. He wrote a treatise on physical geography for Johnson's Atlas, and was one of the two 
principal editors of Johnson's Cyclopædia (1874 to 1877 ), the other being President Barnard, of Columbia College. Prof. Guyot was much impressed by the correspondences to be found between the account of creation in Genesis and the progress of evolution contained in the geological record, and his latest publication was devoted to this subject, being entitled Creation, or the Biblical Cosmogony in the Light of Modern Science.

Prof. Guyot received the honorary degree of LL. D. from Union College; he was one of the original members of the National Academy of Sciences, an associate member of the Royal Academy of Turin, honorary correspondent of the Royal Geographical Society of London and of the Geographical Society of Paris, a member of the American Academy of Science, the American Philosophical Society, and other learned bodies.

In 1867 Prof. Guyot married a daughter of the late Governor Haines, of New Jersey, a lady of intelligence and refinement, who made for him the happiest of homes. He left no children.

Prof. Henry C. Cameron, of Princeton, who was intimately associated with him for more than twenty-five years, has described him "as a man of the most cultivated taste in every respect-in music, in painting, in short, in all the fine arts. I have known no man who could generalize as he could. His knowledge of history and philosophy, his acquaintance with theology, and his scientific attainments were wonderful. Everything was assimilated and systematized so that all he had learned seemed always to be at perfect command. A perfect gentleman, a model Christian, a man whose equal I have never seen." 


\section{DAVID DALE OWEN.}

$1807-1860$.

David Dale Owen was born at Braxfield House, near New Lanark, Scotland, June 24, 1807. He was the fourth son and sixth child in a family of eight children. All but the first born, a son, lived to adult age. His father, Robert Owen, the celebrated philanthropist, was a native of North Wales.

Robert Owen, after working in the drapery business in London and elsewhere, entered into partnership with a mechanic, at eighteen years of age, in the manufacture of cottonspinning machines. A year later he took a position as superintendent of a mill employing five hundred hands, and at twenty-two years of age he became a partner in an old-established spinning concern of Manchester. Having become attached to Miss Anne Caroline, the eldest daughter of David Dale, proprietor of large mills at New Lanark, near Glasgow, he arranged with his partners to buy the works of the father, and soon after obtained for himself the hand of the daughter. They were married in 1797 . Undertaking the management of the works ("government" he called it), he steadily improved the condition of the factory hands, which had been there as elsewhere bad to a degree now almost incredible. Some of his measures were opposed by his partners, and led to several dissolutions of partnership through which he retained the management, but he was forced to retire in 1829 , when fifty-eight years of age. In spite of what he spent for the workers, Owen always made the business pay well. , For several years, beginning with $1_{8}$ I $_{5}$, he worked for the passage of acts of Parliament beneficial to factory operatives. Becoming convinced that social reform could be best secured through communism, he bought from an agent of the Harmony Society in 1824 a tract of thirty thousand acres, and the 


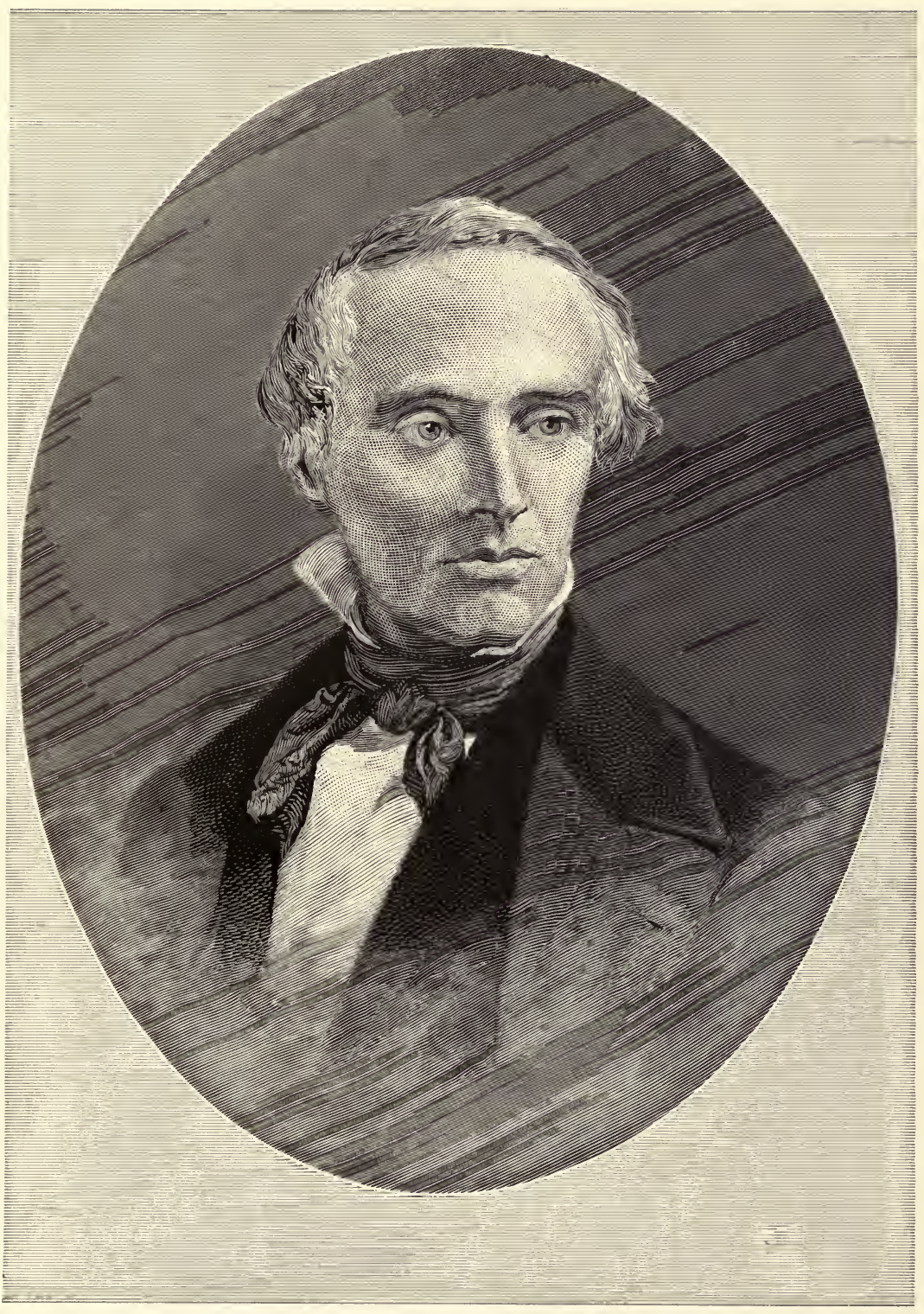

DAVID DALE OWEN. 

buildings of their settlement at New Harmony, Ind. The Harmony Society was prosperous but wished to change its location. Coming to America in the spring of 1825 , he organized a community of about nine hundred persons on a provisional plan, and then returned to Scotland to look after his business, leaving his two oldest sons at New Harmony.

William Maclure, of Philadelphia, a man of means and devoted to philanthropy and the advancement of science, took part in founding the community. He heard of Owen's scheme on returning to the United States after an attempt to found an agricultural labour school in Spain, and believed that it would afford favourable conditions for carrying out his cherished idea of an educational institute founded on rational principles. He accordingly bought a large tract of land in New Harmony and vicinity, and removed thither his library and collection of minerals, which were extensive, and his valuable scientific apparatus. He induced Gerard Troost, C. A. Lesueur, and Thomas Say, also Joseph Neef, the pioneer of Pestallozzian education in America, to come into the community with him, and to act as instructors in the institution proposed. When the society was divided into a manufacturing and educational, and an agricultural branch, Maclure became the leading spirit in the educational division.

Owen visited New Harmony a second time in the winter of 1825-'26. His third visit was made in the spring of 1828 , and by that time so many troubles had arisen that the community was disbanded. The failure of the undertaking was due to the one great cause that makes all communistic enterprises impracticable in the present age-the imperfections of human nature. In the same year Mr. Owen went to Mexico, on the invitation of the Mexican Government, to put his ideas into practice there, but effected nothing because the Government insisted that the state religion of the proposed community should be Roman Catholic. Some experiments were afterward tried by him in Great Britain, and he continued to advocate his views with voice and pen until his death in 1858 . His followers received the name of "Owenites." $\mathrm{He}$ published a considerable number of writings, including an autobiography.

When David Dale Owen was about four or five years of age, Nicholas (afterward Czar of all the Russias) visited Rob- 
ert Owen to make inquiries into the practical workings of $\mathrm{Mr}$. Owen's proposed new social system, as it was then being tried at New Lanark. He was entertained several days in Braxfield House, and took a great fancy to little "Dale," played with him, and begged to be allowed to adopt the child, and take him to Russia for life, but Mr. Owen refused. Years afterward, when Nicholas had ascended the Romanoff throne, and the little white-haired boy had emigrated to the wilds of Posey County, Indiana, and had made a national reputation in geology, he sent to the autocratic Czar a set of his voluminous reports of our Northwest territories. The Czar in his own hand acknowledged the receipt of the volumes, and heartily congratulated his former little favourite whom he had fondled on the hills of Scotland.

David Dale Owen's early education, which was received from a private tutor, included the English branches, the rudiments of Latin, and a course in architectural drawing. $\mathrm{He}$ was also trained in the use of carpenter's tools in the mechanical department connected with his father's mills. $\mathrm{He}$ was for a time a pupil in the grammar school, or academy, at New Lanark. His father, while travelling on the continent of Europe, had visited the celebrated educational institution of Emanuel von Fellenberg, at Hofwyl, Switzerland, and was so much pleased with the system pursued in it-neither moral, physical, nor intellectual development being neglected-that he sent there first his two oldest sons-Robert Dale and William-for a three years' course, and after their return sent David Dale and his younger brother Richard in 1824 , also for three years. The studies of the more advanced classes were partly elective, and David Dale and his brother chose chemistry, drawing, and modern languages in addition to the prescribed mathematical and literary course. Dale Owen's first interest in science was aroused during his school-boy excursions over the mountains of Switzerland, while a pupil at Hofwyl. Robert Dale Owen, the eldest brother of the subject of this sketch, describes in his autobiography, Threading my Way, those excursions down into sunny Italy, over into the Tyrol, France, and Germany, which Fellenberg's pupils most heartily enjoyed.

David Dale and Richard returned to Scotland in September, 1826, the former being then nineteen years old. They entered 
the classes in physics and chemistry conducted by Dr. Andrew Ure, author of the Dictionary of Arts, Manufactures, and Mines, at Glasgow, where their mother then resided. Their father was absent at New Harmony. For that place the two younger sons set out in November, 1827 , going by a ship from Liverpool to New Orleans, thence up the Mississippi by steamer, reaching the settlement on the Wabash early in January, $\mathrm{r} 828$.

During the next three years they kept up and increased their knowledge of chemistry by repeating the experiments of Dr. Ure's course. Desiring to extend his knowledge of chemistry and geology, Dale Owen in $183 x$ returned to Great Britain. He had as a companion Henry D. Rogers, and they both lived at the house of Owen's father in London while attending the lectures of Dr. Turner at the London University.

After about a year abroad Owen came back to the United States. Soon after his return he was stricken with Asiatic cholera, which was epidemic in this country in the summer and fall of 1832 , but was fortunate enough to survive the attack. Wishing to increase his knowledge of anatomy and physiology as an aid in the study of paleontology, he entered the Ohio Medical College, in Cincinnati, and was graduated in the spring of 1836 . He devoted the summer following his graduation to gaining practical experience in field geology. To this end he accompanied at his own expense Dr. Gerard Troost, who was then engaged on the State Survey of Tennessee.

Dr. Owen married, March 23, 1837, Caroline C. Neef, the third daughter of Joseph Neef.

Having been appointed State Geologist of Indiana, Dr. Owen, immediately after his marriage, entered upon the duties of this position. He made a preliminary reconnaissance in I 837 and 1838 , his report upon which was published immediately after its completion and reissued in 1859 . Geological science being little understood in the West when this document first appeared, a brief introductory exposition of the leading formations was given in it, after which the rich deposits of coal, iron, and building stones within the limits of the State were described.

The Hon. James Whitcomb, then Governor of Indiana, was 
soon afterward made Commissioner of the General Land Office, and Congress having ordered a survey of the Dubuque and Mineral Point districts under the direction of his bureau, he selected Dr. Owen, with whose ability he was well acquainted, to conduct this examination. These districts comprised eleven thousand square miles of the Northwest Territory, now included in the States of Wisconsin and Iowa, and the object of the examination was to enable the commissioner to reserve from sale those sections found to contain mineral wealth. But a short time was allowed for the work, hence it became necessary to organize a large force. The difficulties involved in such a rapid prosecution of the survey are indicated in the report presented by Dr. Owen to the commissioner, April 2, 1840. "In one month from the day I received my commission and instructions," he says, "(to wit, on September I 7 th) I had reached the mouth of Rock River; engaged one hundred and thirty-nine subagents and assistants; instructed them in such elementary principles of geology as were necessary to the performance of the duties required of them; supplied them with simple mineralogical tests, with the application of which they were made acquainted; organized twenty-four working corps, furnished each with skeleton maps of the townships assigned to them for examination, and placed the whole at the points where their labours commenced, all along the line of the western half of the territory to be examined. Thence the expedition proceeded northward; each corps required, on the average, to overrun and examine thirty quarter sections daily, and to report to myself on fixed days at regularly appointed stations: to receive which reports and to examine the country in person, I crossed the district under examination, in an oblique direction, eleven times in the course of the survey."

It was in the spring of $x 840$ that William Maclure died. As administrator of his estate, his brother Alexander engaged Dr. Owen to assort the very extensive collection of minerals and fossils which Mr. Maclure had made in the course of his geological exploration of the United States and his travels in this country, Europe, and the West Indies. Specific suites were to be distributed to certain schools and colleges, and the remainder was to be retained by Dr. Owen as the nucleus of a museum. These directions were duly carried out. With regard to the portion remaining in Dr. Owen's hands The Ameri- 
can Geologist* states: "To this latter Dr. Owen subsequently added largely, by purchase from Dr. Krantz, of Germany, illustrative fossils of every period; among others an ichthyosaurus, from the Lias of Würtemberg, larger than the one in the British Museum. Another interesting and valuable specimen was a nearly complete skeleton of a gigantic megatheroid animal (the Megalonyx) which he exhumed near Henderson, Ky. The entire collection some years after Dr. Owen's death was purchased by the Indiana University, and unfortunately nearly all consumed by fire, when the new university building, including the museum, laboratory, and library, was destroyed."

Dr. Owen was again called into the service of the Government in 1847 , being appointed United States Geologist and directed to make a survey of the Chippeway land district. His Preliminary Report, made in the following year to the Hon. R. M. Young, then Commissioner of the Land Office, was a document of one hundred and thirty-four octavo pages, and was accompanied by three hundred and twenty-three lithographs from his own sketches, and numerous maps, diagrams, etc.

The scope of his examination was then enlarged so as to embrace a fuller survey of portions of the Northwest Territory, lying mainly within the present States of Wisconsin, Iowa, and Minnesota. This task required five years of field work and a final year of laboratory and office work, ending with the year $185_{2}$. A large appropriation was made by Congress for illustrating and printing Owen's report, all the details of publication being committed to him. The result was a finely illustrated quarto volume of six hundred and thirty-eight pages, many of the illustrations being from the original drawings of Dr. Owen, who had great facility in sketching. In this volume he applied for the first time the medal-ruling style of engraving to cuts of fossils.

In an article on Geological Surveys in Missouri Mr. Arthur Winslow says of Owen's reports up to this time: "These reports supplied the guiding lines along which later strati-

* Sketch of the Life of David Dale Owen, M. D., August, I889, to which source acknowledgment is due for a large portion of the material entering into the present account. 
graphic work in the Mississippi Valley was done. Without attempting here to present the history of this work, its bearing upon future operations in Missouri calls for brief mention. In the Indiana reports Owen makes a separation of the rocks, in harmony with the English classification, into-r. Bituminous coal formations. 2. Mountain limestone. 3. Grauwacke. 4. Crystalline and inferior stratified rocks. In the succeeding reports, as the results of wider observation and more thorough study, the classification was changed and differentiated until, in the final report, we find a classification which, not only in its general features, but in many of its details, is still adhered to in Missouri."

From 1854 to 1859 Dr. Owen was occupied with the geological survey of Kentucky, having been appointed State Geologist by Governor Powell. The results of his explorations were published as the work progressed, and compose four large octavo volumes. Dr. Robert Peter, of Lexington, Ky., performed the chemical work of the survey and made a special report upon it. Toward the close of his labours in Kentucky, in October, 1857 , Dr. Owen was commissioned to conduct a geological survey of the State of Arkansas. His principal assistant in the Kentucky survey, Mr. Е. ' $\mathrm{C}$. Cox, filled the same position in the new work. The chemical assistant on the latter survey was Dr. Elderhorst, author of a work on the blowpipe.

Various incidents in his surveys prove Dr. Owen to have been a man of indomitable perseverance. Once, while on the Red River of the North with a Canadian voyageur, the fowlingpiece used by the latter for procuring game was discharged in such a way as to lodge a number of shot in Dr. Owen's shoulder. He did not permit the accident to delay him an hour. Again, the summer occupied with the field work of the Arkansas survey, a considerable part of which was necessarily spent in the rich and malarious bottom lands, proved very detrimental to his health, bringing him home in the autumn with a hue denoting serious derangement of the liver. Yet he not only persevered in his explorations, but occupied himself in winter with laboratory work, usually until midnight. He did not desist even when suffering acutely from his last illness, but dictated the closing portions of his report until within forty-eight hours of his death. Between Dr. Owen and Governor Conway, who had given him the Arkansas appointment, there always ex- 
isted the most cordial good feeling, and the latter provided every facility for the prosecution of the survey. Toward the end of 1860 postal communication between the North and South was considerably interrupted, for the breach which culminated in civil war was already opening. Yet the Governor, at considerable pains, succeeded in sending safely to New Harmony several thousand dollars due from the appropriation, and required for the publication of the second volume of the report. Dr. Owen had died, and the issuing of this volume, for which he had left full instructions, fell to his brother and administrator, Prof. Richard Owen. The latter also executed a second survey of Indiana, for which his brother had been appointed in 1859 , with the understanding that Richard should do as much of the work as might be necessary.

The labours above outlined resulted in undermining the originally good constitution with which Dale Owen had been endowed. Malarial fever, complicated with rheumatic attacks which threatened the heart, terminated his career of usefulness November I3, I860. He left a widow, two sons, and two daughters. Mrs. Owen survived her husband for more than thirty years. His sons, Colonel Alfred Dale and William H. Owen, adopted mercantile pursuits. The latter has also taken much interest in astronomy, being considered one of the best authorities in his State on his favourite science. All the children and grandchildren of Dr. Owen show evidence of inheriting a goodly share of the Owen intellect and character.

Like Robert Owen, David Dale was kind, unassuming, industrious, and easily imposed upon, because he thought all as honest as himself. $\mathrm{He}$ often allowed wandering geologists to visit his cabinets, and many valuable specimens were lost in this way. His kindness and liberality were well known, and his scientific work was always conscientiously performed. $\mathrm{He}$ is not known to have given much attention to religious matters, and one relative has stated that he inclined to materialism. His fondness for chemistry and mineralogy led him to build at a cost of ten thousand dollars a laboratory fully equipped, which served as a material evidence of his good taste in architecture. His architectural taste was further evinced in the artistic design which he submitted for the Smithsonian Institution building. He also tested many varieties of building 
stone before the selection of material for that structure was determined.

His artistic skill enabled him, besides richly illustrating his reports, as above noted, to leave good portraits in oil of members of his family. He transmitted to London views of the fossil Sigillaria found erect in situ twelve miles from New Harmony, with a description, which were presented to the British Association for the Advancement of Science by Sir Roderick Murchison. He subsequently conducted Sir Charles Lyell to the locality while the latter was his guest at New Harmony in his second visit to the United States.

In later years Dr. Owen became completely absorbed in his scientific labours, so much so that he frequently failed to eat or sleep. Many stories are told of his complete "marriage to his laboratory," as he was wont to express it. A relative was visiting him once, and at the close of dinner he arose from the table and asked to be excused, by saying that he had told Carrie before marriage that he had married his laboratory first. Yet a better husband or a kinder father was never known. Of the many excellent traits noticeable in common among all the male descendants of Robert Owen, no other is so apparent as their devotion to wife and children.

An added value was given to Dr. Owen's scientific labours by the interest they aroused among the untutored settlers of the West in geology and chemistry. Had it not been for him, much that William Maclure attempted for early science in the West would have been lost. He was the first State Geologist of Indiana, and he also trained the second and third incumbents of that office, namely, Dr. Richard Owen and Prof. E. T. Cox. Indiana owes a great debt to Dr. Owen for his early work in science; Kentucky and Arkansas owe fully as much. Dr. Owen also largely prepared A. H. Worthen for his work later as State Geologist of Illinois. In fact, the whole Mississippi Valley is indebted to this mild-mannered and hard-working scientist for blazing the way for the hosts who have followed. 


\section{APPLETON \& CO.'S PUBLICATIONS.}

HE DAWN OF CIVILIZATION. (Egypt and Chal-
DÆa.) By Prof. Maspero. Edited by the Rev. Prof. Sayce. Translated by M. L. MCCLURE. - With Maps and over 470 Illustrations. 4to. Cloth, $\$ 7.50$.

"The most complete account of ancient Egypt ever published."-Chicago Herald.

"Prof. Maspero's intimate acquaintance with Egypt and its literature, and the opportunities offered him by his position for several years as director of the Bulak Museum give him a unique claim to speak with authority on the history of the Nile Valley."-New York Sun.

\section{POPULAR ASTRONOMY: A General Description of the} Heavens. By Camille Flammarion. Translated from the French by J. Ellard Gore, F. R. A. S. With 3 Plates and 288 Illustrations. 8 vo. Cloth, $\$ 4.50$.

" M. Flammarion has produced a work that charms while it interests. He has classified astronomy so perfectly that any person of ordinary intelligence may learn from this book practically all that the men in the observatories know."-New York Times.

"The fullest and most elaborate compendium of popular astronomy. . . The book might reasonably be pronounced the most desirable of its kind." - New York Sun.

IIFE OF SIR RICHARD OWEN. By Rev. RICHARD OwEN. With an Introduction by T. H. HUXLEY. 2 vols. I2mo. Cloth, $\$ 7.50$.

"The value of these memoirs is that they disclose with great minuteness the daily labors and occupations of one of the foremost men of science in England."-Boston Herald.

"A noteworthy contribution to biographical literature."-Philadelphia Press.

\section{DEAN BUCKLAND. The Life and Correspondence of William BuCKLAND, D. D., F. R.S., sometime Dean of Westminster, twice President of the Theological Society, and first President of the British Association. By his Daughter, Mrs. GoRDON. With Portraits and Illustrations. 8vo. Buck- ram, $\$ 3.50$.}

" Next to Charles Darwin, Dean Buckland is certainly the most interesting personality in the field of natural science that the present century has produced."-London Daily Neres.

"A very readable book, for it gives an excellent account, without any padding or unnecessary detail, of a most original man."-Westminster Gazette.

New York: D. APPLETON \& CO., 72 Fifth Avenue. 


\section{APPLETON \& CO.'S PUBLICATIONS.}

\section{THE PYGMIES. By A. DE Quatrefages, late Professor of Anthropology at the Museum of Natural History, Paris. With numerous Illustrations. I2mo. Cloth, \$1.75.}

In this interesting volume the author has gathered the results of careful studies of the small black races of Africa, and he shows what the pygmies of antiquity really were. The peculiar intellectual, moral, and religious characteristics of these races are also described.

\section{IJOMAN'S SHARE IN PRIMITIVE CULTURE.} By Otis Tufton Mason, A. M., Curator of the Department of Ethnology in the United States National Museum. With numerous Illustrations. I2mo. Cloth, \$1.75.

"A most interesting résumé of the revelations which science has made concerning the habits of human beings in primitive times, and especially as to the place, the duties, and the customs of women."-Philadelphia Inquirer.

"Mr. Mason's volume secures for woman her glory as a civilizer in the past, and by no means denies her a glorious future."-New York Tribune.

\section{SCHOOLS AND MASTERS OF SCULPTURE. By} A. G. RADCLIFFE, author of "Schools and Masters of Painting." With 35 full-page Illustrations. 12mo. Cloth, \$3.00.

"The art lover will find in Miss Radclife's work a book of fascinating interest, and a thoroughly painstaking and valuable addition to the stock of knowledge which he may possess on the history of the noble art of sculpture."-Philadelphia Item.

"It would be difficult to name another work that would be so valuable to the general reader on the same subject as this book."-San Francisco Bulletin.

"The work is free of all needless technicalities, and will be of intense interest to every intelligent reader, while of inestimable value to the student of art."-Boston Home Fournal.

BY THE SAME AUTHOR.

\section{SCHOOLS AND MASTERS OF PAINTING. With} $\int$ numerous Illustrations and an Appendix on the Principal Galleries of Europe. New edition, fully revised, and in part rewritten. I2mo. Cloth, $\$ 3.00$; half calf, $\$ 5.00$.

"The volume is one of great practical utility, and may be used to advantage as an artistic guide-book by persons visiting the collections of Italy, France, and Germany for the first time."-New York Tribune.

New York: D. APPLETON \& CO., 72 Fifth Avenue. 


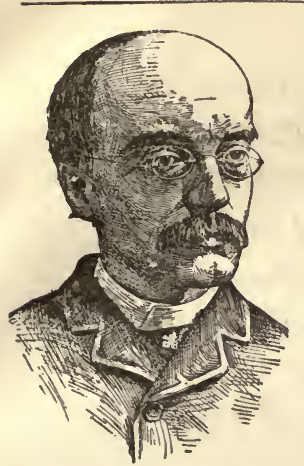

JOHN BACH MC MASTER.

\section{HISTORY OF THE PEOPLE OF THE UNITED STATES, from the} Revolution to the Civil War. By JoHN BaCh MCMaster. To be completed in six volumes. Vols. I, II, III, and IV now ready. 8 vo, cloth, gilt top, $\$ 2.50$ each.

". . Prof. McMaster has told us what no other historians have told. ... The skill, the animation, the brightness, the force, and the charm with which he arrays the facts before us are such that we can hardly conceive of more interesting reading for an American citizen who cares to know the nature of those causes which have made not only him but his environment and the opportunities life has given him what they are."-New York Times.

"Those who can read between the lines may discover in these pages constant evidences of care and skill and faithful labor, of which the old-time superficial essayists, compiling library notes on dates and striking events, had no conception; but to the general reader the fluent narrative gives no hint of the conscientious labors, far-reaching, world-wide, vast and yet microscopically minute, that give the strength and value which are felt rather than seen. This is due to the art of presentation. The author's position as a scientific workman we may accept on the abundant testimony of the experts who know the solid worth of his work; his skill as a literary artist we can all appreciate, the charm of his style being self-evident."-Philadelphia Telegraph.

"The third volume contains the brilliantly written and fascinating story of the progress and doings of the people of this country from the era of the Louisiana purchase to the opening scenes of the second war with Great Britain-say a period of ten years. In every page of the book the reader finds that fascinating flow of narrative, that clear and lucid style, and that penetrating power of thought and judgment which distinguished the previous volumes."-Columbus State Fournal.

"Prof. McMaster has more than fulfilled the promises made in his first volumes, and his work is constantly growing better and more valuable as he brings it nearer to our own time. His style is clear, simple, and idiomatic, and there is just enough of the critical spirit in the narrative to guide the reader."-Boston Herald.

"Take it all in all, the History promises to be the ideal American history. Not so much given to dates and battles and great events as in the fact that it is like a great panorama of the people, revealing their inner life and action. It contains, with all its sober facts, the spice of personalities and incidents, which relieves every page from dullness."-Chicago Inter-Ocean.

"In his first two volumes Prof. McMaster achieved a distinct success. In this (third) volume the reputation thus gained is fully sustained. The same brilliancy of style which characterizes his previous volumes is seen here, and the same excellent arrangement and thorough comprehension of causes and results is apparent."-Boston Advertiser.

" History written in this picturesque style will tempt the most heedless to read. Prof. McMaster is more than a stylist; he is a student, and his History abounds in evidences of research in quarters not before discovered by the historian."-Chicago Tribune.

"A History sui generis which has made and will keep its own place in our literature."-New York Evening Post.

"His style is vigorous and his treatment candid and impartial." $-N$. Y. Tribune.

New York: D. APPLETON \& CO., 72 Fifth Avenue. 




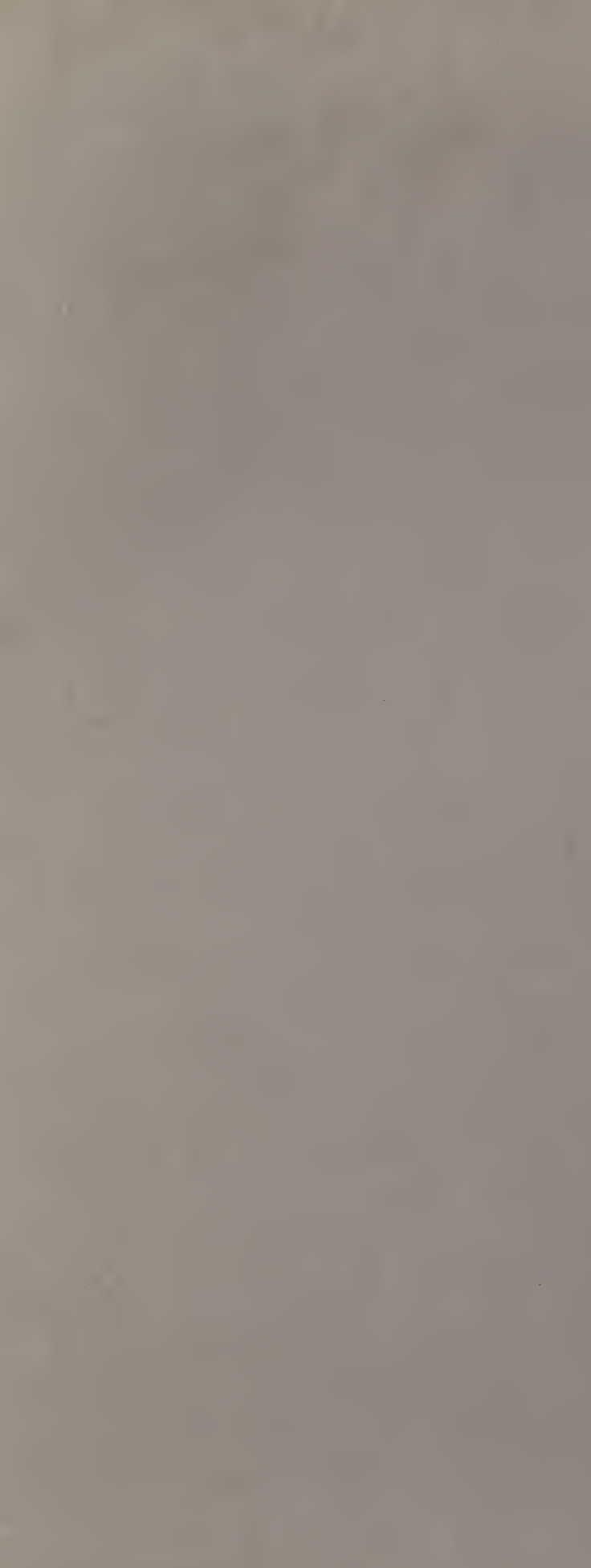




\section{RETURN CIRCULATION DEPARTMENT}

TO $\rightarrow 202$ Main Library

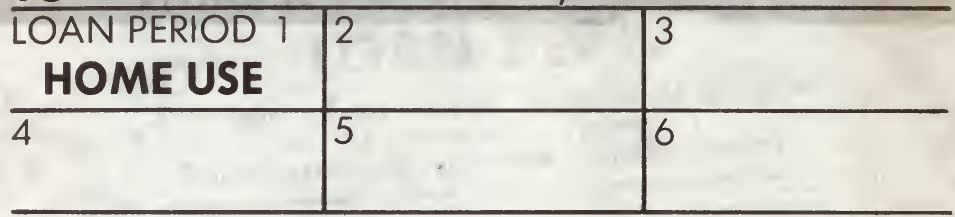

ALL BOOKS MAY BE RECALLED AFTER 7 DAYS

Renewals and Recharges may be made 4 days prior to the due date.

Books may be Renewed by calling 642-3405.

DUE AS STAMPED BELOW

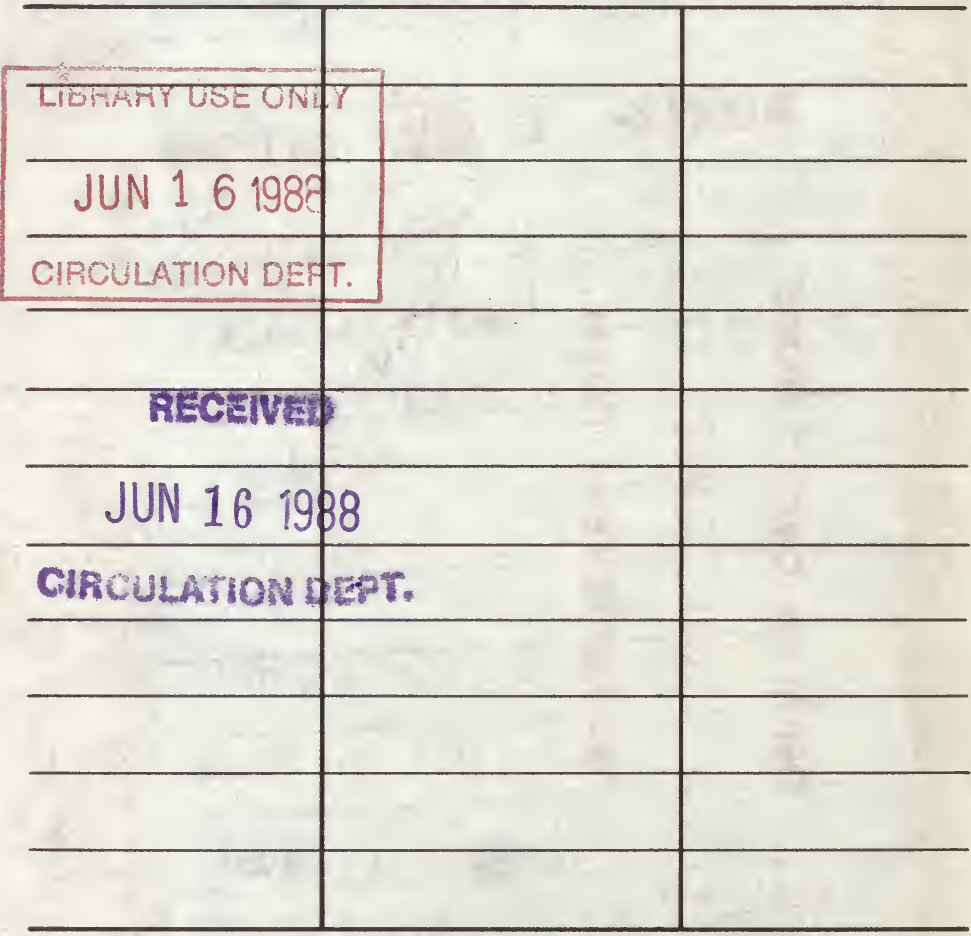

FORM NO. DD6,

UNIVERSITY OF CALIFORNIA, BERKELEY BERKELEY, CA 94720 


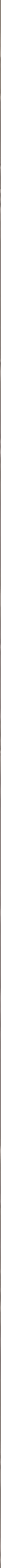


